Ary Fábio Giordani Daniel

\title{
O FANDANGO CAIÇARA NOS TEMPOS DA COMUNICAÇÃO INSTANTÂNEA: MUSICOLOGIA POLÍTICA OU ETNOGRAFIA DO ESTADO DA ARTE?
}

Versão Corrigida

(versão original disponível na Biblioteca da ECA/USP)

Tese apresentado ao Programa de Pós-Graduação em Música da Escola de Comunicação e Artes da Universidade de São Paulo para obtenção do título de doutor em música. Área de concentração: Musicologia/ Etnomusicologia. Orientador: Pedro Paulo Salles

São Paulo 
Autorizo a reprodução e divulgação total ou parcial deste trabalho, por qualquer meio convencional ou eletrônico, para fins de estudo e pesquisa, desde que citada a fonte.

Catalogação na Publicação

Serviço de Biblioteca e Documentação

Escola de Comunicações e Artes da Universidade de São Paulo

Dados inseridos pelo(a) autor(a)

Giordani, Ary

O FANDANGO CAIÇARA NOS TEMPOS DA COMUNICAÇÃO INSTANTÂNEA:

MUSICOLOGIA POLÍTICA OU ETNOGRAFIA DO ESTADO DA ARTE? / Ary

Giordani ; orientador, Pedro Paulo Salles. -- São Paulo,

2019.

358 p.: il.

Tese (Doutorado) - Programa de Pós-Graduação em Música -

Escola de Comunicações e Artes / Universidade de São Paulo.

Bibliografia

Versão corrigida

1. Fandango caiçara 2. Socialidade caiçara 3. Agenciamento

caiçara 4. Luteria caiçara 5. Pulsão de vida I. Salles, Pedro Paulo II. Título.

CDD 21.ed. - 306 
Nome: GIORDANI, Ary

Título: O Fandango Caiçara nos tempos da comunicação instantânea: Musicologia política ou etnografia do estado da arte?

Tese apresentado ao Programa de Pós-Graduação em Música da Escola de Comunicação e Artes da Universidade de São Paulo para obtenção do título de doutor em música.

Aprovado em: 26 de junho de 2019

Banca Examinadora

Prof. Dr. Pedro Paulo Salles (orientador)

Instituição: ECA/USP

Prof. Dr. Alberto Ikeda

Instituição: UNESP

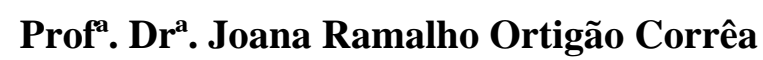

Instituição: Pesquisadora Externa

Prof. Dr. Rogério Budasz

Instituição: University of Califórnia

Prof. Dr. Tiago de Oliveira Pinto

Instituição: Hochschule für Musik Franz Liszt Weimar 
Greice, Mainu e Iyamí: suas lindas. 
Grazie a tutti, buona gente!

Antelmo Giordani - Ilse Angela - Pedro Paulo Salles - Iyamí Barros • André Abujamra • Mainu Giordani $\bullet$ Patrícia Martins $\bullet$ Greice Barros $\bullet$ Rogério Budasz $\bullet$ Aorélio Domingues $\bullet$ Cleiton do Prado - Luis Otávio Almeida • Rivelino Werá Gabriel • Alberto Ikeda • Janaina Moscal • Mariana Zanette - Poro de Jesus • Nélio Spréa • Leandro Diegues • José Muniz • Darci de Castro • Flávio Rocha • Jandaira Moscal • Jorge Cristino da Silva (in memorian) • Mauricy Pereira • Fernando Oliveira • Fernando Alcântara • Ronaldo Miguez • Aldemir Neves • Ivan Vilela • Joana Corrêa • Jairo Santos • Frederico Teixeira • Karina Coelho • Dauro Prado • Ana Josefina • Graciliano Zambonin • Luma Domingues • Isolina Miuduva Rete • Ana Wegner • Aurélio Gasparini • Juarez Bergmann • Tiago Oliveira Pinto • Ivan Ivanovik • Cassiano Zambonin • Daniella Cunha Gramani • Miguel Mamangava - Nemésio Costa (in memorian) • Waldemar Cordeiro • Jean Carlos Gonçalves • Flora Holderbaum - Benedita Cordeiro • Celeste Fernandez $\bullet$ Waldemir Santos • Fábio Macedo • Fernanda Santos Silva - Cristino Karai da Silva • Isabel Jazinski • Juliana Brittes • Malu Zanette • Guilherme Romanelli • Soraya Sugayama $\bullet$ Edvaldo Oliveira $\bullet$ Aguinaldo dos Santos $\bullet$ Elza Fernandes $\bullet$ Herbert dos Santos - Luiz Aguiar • Leandro Mombach • Carolina Barbosa • Rose Satiko • Itaércio Rocha • Mario Gato • Julia Basso • Juliano Doberstein • Tupã Popygua • Simone Toji • Natália Brayner • Sueli Araujo • Marcia Moraes • Pedro Paulo Köhler • Lydio Roberto • Thauy de Jesus • Lauri dos Santos • Glaí Lopes • Wagner Corrêa • Joelma Estevam • Allan Valenza • Antonia Regina • Rosana Vasques • Cristiane dos Santos Souza • Anderson Prado Vanessa Curty • Pedro Prado • Rafael Leite • Anísio Pereira $\bullet$ Zeca Martins $\bullet$ Helena Meidani $\bullet$ Glaé Lopes $\bullet$ Melina Mulazani $\bullet$ Carolina Iarosz $\bullet$ Luciano Faccini • Leandro Teixeira $•$ Elenice Lopes $\bullet$ Josiane de Barros $\bullet$ Rogério Guiraud $\bullet$ Glaci Lopes • Ivan Cerqueira • Denis Lang • Iê dos Santos • João Luiz Silva • Zé Ronaldo Ribeiro • Miguel Gaissler 


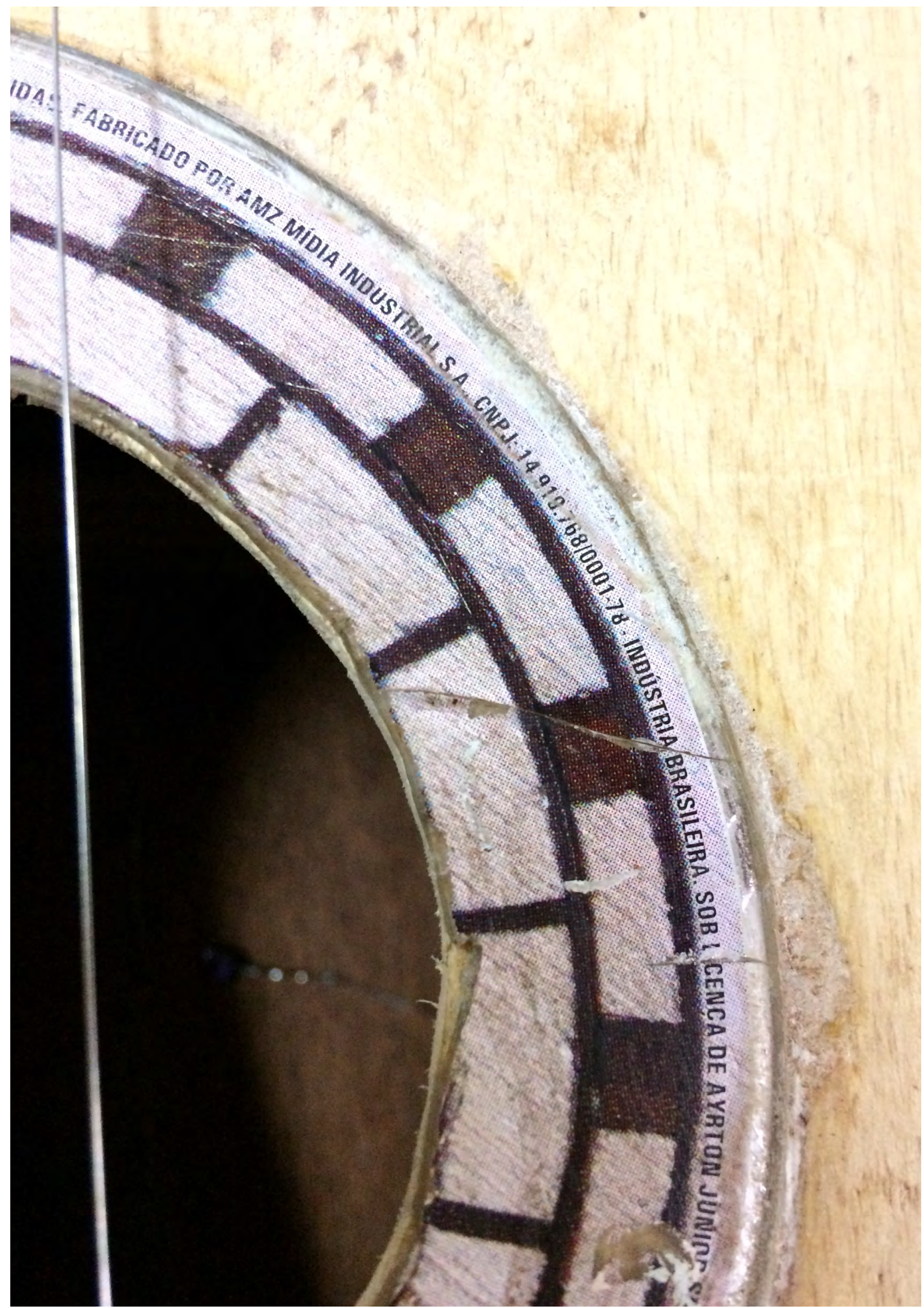




\section{RESUMO}

A tese discute as alterações paradigmáticas que incidem no modo de fazer o fandango caiçara na contemporaneidade refletindo sobre a pulsão de vida e de mundo que move os múltiplos agenciamentos de atores culturais no litoral caiçara. Contempla também os diálogos interétnicos, intergeracionais e interinstitucionais que historicamente fortalecem aspectos macro e micropolíticos inerentes ao fandango e, a partir da consolidação de políticas públicas para as culturas populares e do advento da comunicação instantânea, tomam assento nos modelos culturais e artísticos de que se valem os fandangueiros para manter suas práticas poético-musicais, organológicas e de sociabilidade. Articulamos participativamente nosso engajamento ativo a partir de conceitos musicológicos, etnográficos, cognitivos, filosóficos e performáticos, aproximando-nos ainda da ontologia corpuscular e das humanidades digitais para melhor compreender a alteridade caiçara e suas estratégias de resistência e insurreição frente à distópica conjuntura sociopolítica experimentada globalmente neste recorte sincrônico, lapso temporal dito hipermodernidade.

Palavras-chave: Fandango caiçara. Socialidade caiçara. Agenciamento caiçara. Luteria caiçara. Pulsão de vida. 


\begin{abstract}
This thesis discusses the paradigmatic changes that affect how fandango caiçara is done in contemporary times, reflecting on life and world pulses that move the multiple assemblages of cultural actors in the caiçara coast. It further contemplates the interethnic, intergenerational and interinstitutional dialogues that historically strengthen macro and micropolitics inherent in fandango, and, from the consolidation of public policies for popular cultures and the advent of instantaneous communication, are based on the cultural and artistic models used by fandangueiros to maintain their poetic-musical, organological and sociability practices. We collectively articulated our activist commitment from musicological, ethnographic, cognitive, philosophical and performatic concepts, yet approaching corpuscular ontology and digital humanities in order to better understand the otherness of caiçara and its strategies of resistance and insurrection in the face of the dystopian sociopolitical conjuncture globally experienced in this synchronic cut-off, temporal lapse called hypermodernity.
\end{abstract}

Keywords: Fandango caiçara. Caiçara sociality. Caiçara agency. Caiçara lutherie. Pulses of life. 


\section{RESUMEN}

Tratamos de las alteraciones paradigmáticas que inciden en el modo de hacer el fandango caiçara en la contemporaneidad reflexionando sobre la pulsión de vida y de mundo que mueve los múltiples de actores culturales en el litoral caiçara. También se tratará de los diálogos interétnicos, intergeneracionales e interinstitucionales que históricamente fortalecen aspectos macro y micropolíticos inherentes al fandango y, desde la consolidación de políticas públicas para las culturas populares y la llegada de la comunicación instantánea se consolidan en los modelos culturales y artísticos de que se valen los fandangueiros para mantener sus prácticas poético-musicales, organológicas y de sociabilidad. Articulamos participativamente nuestro compromiso activo a partir de conceptos musicológicos, etnográficos, cognitivos, filosóficos y performáticos, aproximándose a la ontología corpuscular y a las humanidades digitales para comprehender la alteridad caiçara y sus estrategias de resistencia e insurrección delante de la distópica coyuntura sociopolítica vivenciada globalmente en este recorte sincrónico, lapso temporal dicho hipermodernidad

Palabras clave: Fandango caiçara. Socialidad caiçara. Agencias caiçara. Luteria caiçara. Pulsión de vida. 


\section{ÍNDICE DE FIGURAS}

\section{CAPÍTULO 1}

Figura 1.1 - Cone de luz de um ponto no espaço-tempo tridimensional de Minkowski .........28

Figura 1.2 - Brincadeira da hora cheia e outras sincronicidades...........................................29

Figura 1.3 - Capela do Divino, Associação Mandicuera, Ilha dos Valadares...........................30

Figura 1.4 - Fragmento de espectrograma - pássaros na alvorada da capela ..........................31

Figura 1.5 - Melodia de Chamarrita de Mestre Pedro Pereira .................................................37

Figura 1.6 - Melodia de Chamarrita de Mestre André Pires ..................................................37

Figura 1.7 - Melodia de Dom-dom de Mestre Gabriel Martins ................................................38

Figura 1.8 - Montagem das estruturas da Festa do Divino em Superagui, 2017 ....................42

Figura 1.9 - Tabela de posições de Graciliano Zambonin.....................................................47

Figura 1.10 - Cifra da moda Arara, executada pelo grupo Os Sete Unidos da Ilha das Cobras,

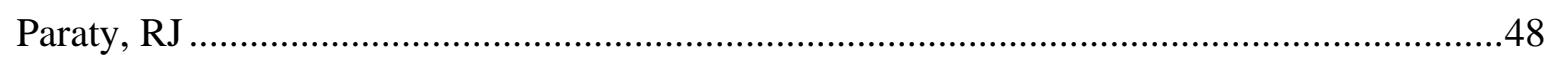

Figura 1.11 - Cifra da moda Noite de Luar, executada pela família Pereira, Guaraqueçaba, PR.

Figura 1.12 - Cifra da moda A Volta que o Mundo dá, executada pelo grupo Manema,

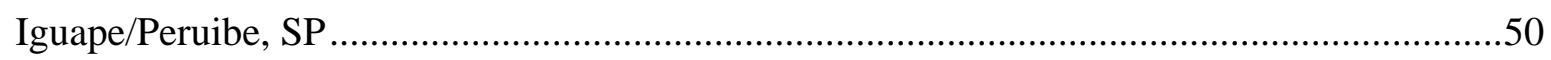

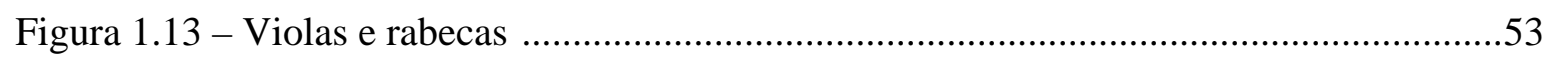

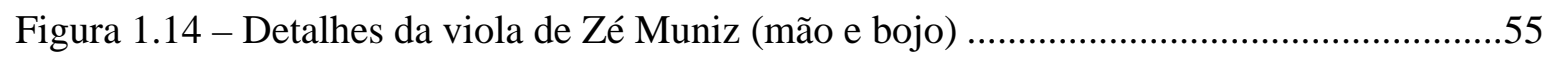

Figura 1.15 - Oficina sobre princípios básicos de áudio - Cananéia, 2018 .............................56

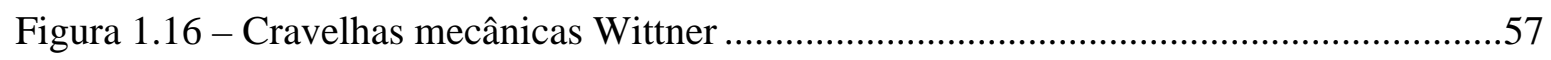

Figura 1.17 - Mesa analógica adquirida via programa de Gestão (TCP) ...............................63

Figura 1.18 - Mistura geral no $1^{\circ}$ Encontro de Fandango do Marujá, 2019...........................65

Figura 1.19 - Efeitos luminosos na festa do Divino em Superagui, 2017 .............................68

Figura 1.20 - Efeitos luminosos em Superagui, 2016 .........................................................68

Figura 1.21 - Efeitos luminosos em Bertioga (Ilha das Peças), 2019 .....................................69

Figura 1.22 - Cifra da moda Menina você tá lembrada, grupo Manema (SP).......................104

Figura 1.23 - Cifra da moda Chora morena, grupo Pés de Ouro (PR) .................................105 


\section{CAPÍTULO 2}

Figura 2.1 - Abertura da II Festa do Fandango de Cananéia, crianças saudando São Gonçalo

Figura 2.2 - Atividade de repasse de toques e versos em Superagui, 2016. 135

Figura 2.3 - Roda de conversa "a presença da mulher no fandango caiçara", Paranaguá, 2017. 137

Figura 2.4 - Malu Domingues na IX Festa do Fandango Caiçara de Paranaguá, 2018 138

Figura 2.5 - Carolina Barbosa Festa do Fandango de Ubatuba em 2017. 143

\section{CAPÍTULO 3}

Figura 3.1 - Atividade de capacitação de monitores - Projeto Fandango na Escola, 2007 ...147 Figura 3.2 - Mbaraká e Ravé de manufatura artesanal, Punta Porã, Campo Nueve (PY) .....151 Figura 3.3 - Visita à comunidade Mbya Guarani de Nueva esperança, no Paraguai, 2006 ...151 Figura 3.4 - Visão geral da opy de Punta Porã, Campo Nueve (PY) ....................................152 Figura 3.5 - Interior da opy na TI Pindoty (Ilha da Cotinga) ..............................................153

Figura 3.6 - Coleta de sumbare, na aldeia Pindoty, dezembro de 2006 ...............................154

Figura 3.7 - Atividade de capacitação e aprimoramento em técnicas artesanais (Mbaraka).155 Figura 3.8 - Ensaio da Orquestra Rabecônica do Brasil, 2011 164

Figura 3.9 - Cena do espetáculo Lendas do Mar de Lá, Centro Cultural Boqueirão, Curitiba, $10 / 2017$ 166

Figura 3.10 - Situação da estrutura do terminal TCP, pós-projetos de ampliação. 174

Figura 3.11 - Distribuição diária de $\left(\mathrm{PM}_{2,5}\right)$ em Paranaguá no ano de 2017. 181

Figura 3.12 - Distribuição dos usos potencialmente causadores de poluição 183

Figura 3.13 - Mapa de distribuições acústicas de Sotalia guianensis (boto cinza) no Complexo Estuarino de Paranaguá. 184

Figura 3.14 - Projetos de Ampliação - Novas Instalações do Porto de Paranaguá 186

\section{CAPÍTULO 4}

Figura 4.1 - Machete cavocado de Zé Pereira (Ariri/SP) 193

Figura 4.2 - Instrumentos produzidos pelo projeto Artesanias Caiçaras. 
Figura 4.3 - Distribuição dos instrumentos durante a VIII Festa do Fandango de Paranaguá (2017) 196

Figura 4.4 - Aula inaugural Projeto Artesanias Caiçaras (2015) 197

Figura 4.5 - Leque de tampo para viola branca produzido pelos participantes do Projeto Artesanias .200

Figura 4.6 - Curvador de aros adaptado ("Seu” Genézio ao fundo) 201

Figura 4.7 - Faquinhas de Cleiton do Prado, Paulo Acosta e Aorélio Domingues .208

Figura 4.8 - O Alegre de Heraldo Pereira e outro produzido durante o Projeto Artesanias Caiçaras .209

Figura 4.9 - Colagem do suporte de fundo abaulado 211

Figura 4.10 - Montagem do fundo abaulado na caixa de ressonância .211

Figura 4.11 - Detalhes da mão e da roseta da viola de abeto 213

Figura 4.12 - Viola branca de abeto, de Filipe Souza .214

Figura 4.13 - Detalhe da boca e do cravelhal (turina) da viola de araucária de Filipe Souza. .216

Figura 4.14 - Suporte para cavoucar fundos e tampos de rabeca 217

Figura 4.15 - Formas com prendedores 217

Figura 4.16 - Formas com prendedores (detalhe) 217

Figura 4.17 - Violona, viola, meia viola (ou machetão) e machete .217

Figura 4.18 - Viola de abeto de Filipe Souza e Rabeca de Cleiton do Prado 218

\section{CAPÍtULO 5}

Figura 5.1 - Fonoautógrafo de Édouard-Léon Scott de Martinville. .222

Figura 5.2 - Altar preparado para a chegada das bandeiras com as medalhas dos foliões, casa de "Dona" Iolanda, Barra do Ararapira, 2018 225

Figura 5.3 - Tripulação da romaria parnanguara (Pontal, Ilha do Cardoso, 2018) .226

Figura 5.4 - Trajeto dos locais visitados pelos foliões da Bandeira do Divino Espírito Santo em 2018. .227

Figura 5.5 - Equipamento de som e teclado na casa de Márcio e Nica (Barra do Ararapira, 2016) .228

Figura 5.6 - Devotas levando as bandeiras (Pontal do Leste, Ilha do Cardoso, 2017)...........232

Figura 5.7 - Manuscrito do Benedito da Paixão, de “Seu” Antônio Muniz, 2017. .236

Figura 5.8 - Sonograma de fragmento do Bendito da Paixão executado a duas vozes por 
Antônio Muniz (Barra do Ararapira, 2017)

Figura 5.9 - Superespaço vetorial de $\mathrm{R}_{1}{ }^{\mathrm{n}+1}$ 238

\section{CAPÍTULO 6}

Figura 6.1A - Partitura da moda Cirindi - grupo Manema (Iguape/Peruíbe-SP) 246

Figura 6.1B - Partitura da moda Cirindi - grupo Manema (Iguape/Peruíbe-SP) .247

Figura 6.2 - Partitura da moda Ciranda - grupo Os Sete Unidos da Ilha das Cobras (Paraty$\mathrm{RJ})$. 248

Figura 6.3 - Zeca Martins e Aorélio Domingues em sessão de gravação do disco Amanhece. 255

Figura 6.4 - Jairo de Souza na capa do disco Amanhece. 256

Figura 6.5 - Curva de Fletcher e Munson. 261

Figura 6.6 - Periféricos utilizados na masterização do disco Amanhece 262

Figura 6.7 - Periféricos utilizados na masterização do disco Amanhece 262

Figura 6.8 - Sonograma comparativo entre Mantiquira e Marinheiro 265

Figura 6.9 - Indicação de frequências fundamentais - 1968 265

Figura 6.10 - Indicação de frequências fundamentais - 2017 265

\section{CAPÍtULO 7}

Figura 7.1 - Gráfico da busca no Google pelo verbete FANDANGO CAIÇARA 268

Figura 7.2 - Gráfico da busca no Facebook (https://www.facebook.com/) pelos verbetes FANDANGO CAIÇARA e CAIÇARA 269

Figura 7.3 - Gráfico de expansão da telefonia móvel e da banda larga no Brasil 269

Figura 7.4 - Criançada na sala de Márcio e Nica na boca da noite 270

Figura 7.5 - Modelo padrão da Física de Partículas 284

Figura 7.6 - ERP alinhado ao surgimento de rajadas de ruído 286

Figura 7.7 - Diagramas de tempo-frequência (média do índice de bloqueio de fase) dos eletrodos frontais para líder (Leader) e seguidor (Folower) durante a configuração do andamento preparatório e em torno de ataques coordenados. .288 


\section{ÍNDICE DE LÂMINAS FOTOGRÁFICAS}

LÂMINA 0 - Roseta da viola de Genézio, aproveitando o rótulo do CD "Pixé de Manema" vi

LÂMINA 1 - Encontro de Bandeiras na Barra do Ararapira, 2016, na Ilha de Superagui, 2017 e em Pontal do Leste (Ilha do Cardoso), 2018.

LÂMINA 2 - Efeitos luminosos na Barra do Ararapira, 2016

LÂMINA 3 - Testes de verniz, por Aurélio Gasparini: Goma-laca (superior esquerda), Cera líquida automotiva (superior direita), Verniz spray (centro esquerda), Cera de abelha (centro direita), Cera de carnaúba (abaixo) 158

LÂMINA 4 - Cartaz da $1^{\circ}$ Festa do Fandango de Paranaguá, 2002 161

LÂMINA 5 - Mapa geral de localização das terras indígenas e de Aldeias e das referências da prática fandangueira na área de interesse. 175

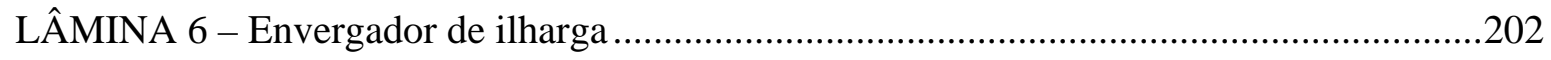

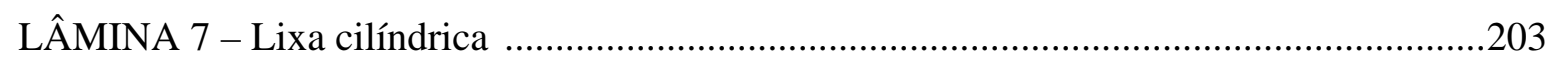

LÂMINA 8 - Detalhes de marchetaria (rabeca, violas e machetes).....................................204

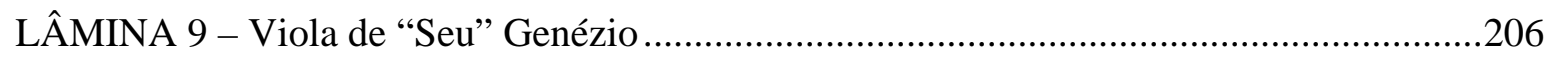

LÂMINA 10 - Romaria caminhando na Barra do Ararapira em 2018 ..................................229

LÂMINA 11 - Fitas das bandeiras na capela do Divino ......................................................23

LÂMINA 12 - Set de gravação do disco Amanhece, Curitiba, 2017 ....................................252

\section{LISTA DE SIGLAS}

IPHAN - Instituto do Patrimônio Histórico e Artístico Nacional

APPA - Administração dos Portos de Paranaguá e Antonina

IAP - Instituto Ambiental do Paraná

UFPR - Universidade Federal do Paraná

IFPR - Instituto Federal de Educação

TCP - Terminal de Contêineres de Paranaguá

MDA - Ministério do Desenvolvimento Agrário

WWW - World Wide Web

FOSPAR - Fertilizantes Fosfatados do Paraná

FBPF - Federação Brasileira para o Progresso Feminino

FUNASA - Fundação Nacional de Saúde 
OMS - Organização Mundial da Saúde

INCRA - Instituto Nacional de Colonização e Reforma Agrária

MOPEAR - Movimento dos Pescadores e Pescadoras do Litoral do Paraná

MPP - Movimento dos Pescadores e Pescadoras Artesanais do Brasil

FBPF - Federação Brasileira para o Progresso Feminino,

SESC - Serviço Social do Comércio

INRC - Inventário Nacional de Referências Culturais (INRC)

GIZ (GTZ) - Agência de Cooperação Internacional do Governo da Alemanha (nova denominação da GTZ)

KFW - Kreditanstalt für Wiederaufbau (banco de desenvolvimento estatal alemão, com sede em Frankfurt)

MINC - Ministério da Cultura

CONAMA - Conselho Nacional do Meio Ambiente

RAIPI - Relatório de Avaliação de Impactos aos Bens Registrados

SEED - Secretaria do estado da Educação do Paraná

INRC - Inventário Nacional de Referências Culturais

CGM - Consumer Generated Media

MEC - Ministério da Educação e Cultura

ONU - Organização das Nações Unidas

PNS - Parque Nacional do Superagui

ICMBio - Instituto Chico Mendes de Conservação da Biodiversidade

SNUC - Sistema Nacional de Unidades de Conservação da Natureza

OIT - Organização Internacional do Trabalho

GDPR - General Data Protection Regulation

EIA - Estudos de Impacto Ambiental

RIMA - Relatório de Impacto Ambiental

ORCCIP CURIM - Organização de Resgate Crítico da Cultura Indígena de Curitiba e Região Metropolitana

COHAB - Companhia de Habitação Popular de Curitiba 


\section{SUMÁRIO}

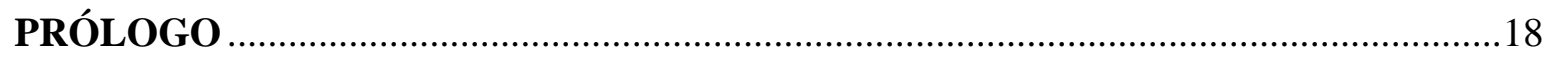

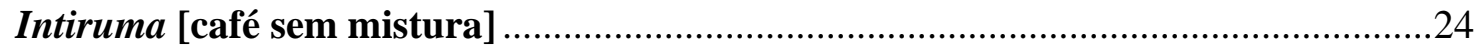

1 REMINISCÊNCIAS, COGNIÇÃO E SOCIABILIDADE .............................................25

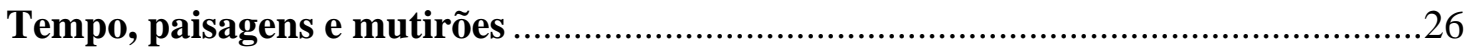

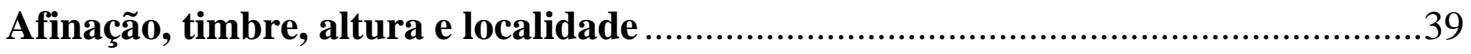

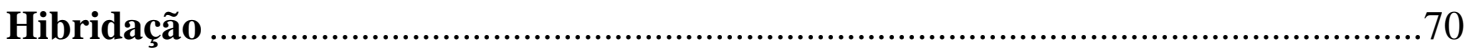

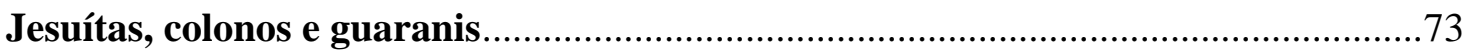

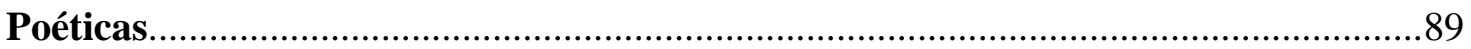

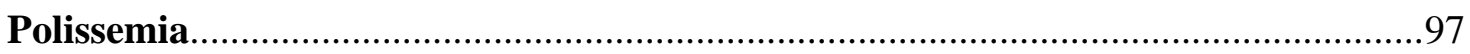

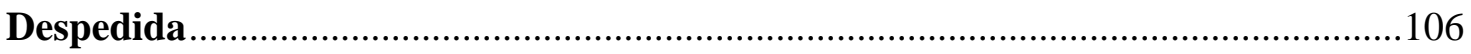

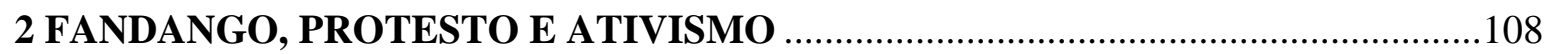

Proibição e cerceamento, o futuro não é mais como era antigamente ......................120

Masculan feminan, a novidade é o máximo do paradoxo …....................................127

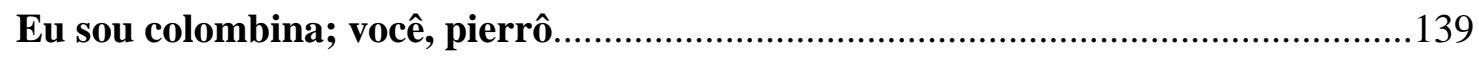

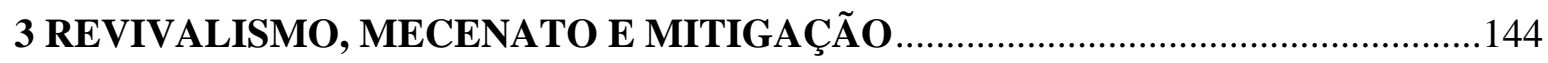

Engajamento, educação patrimonial, violas e mbarakas ..........................................145

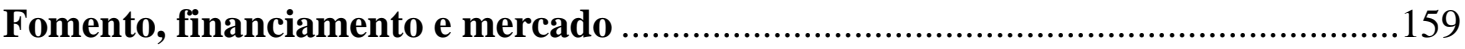

Espetacularização e Associativismo: o fandango como pessoa jurídica ...................167

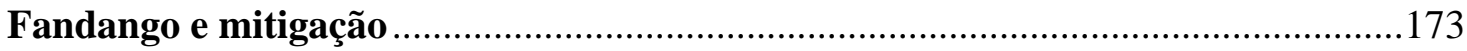

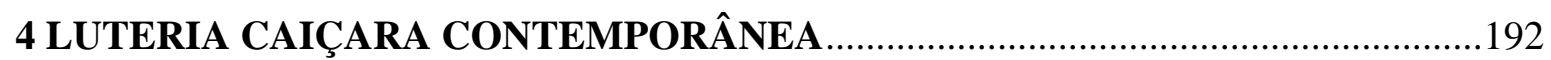

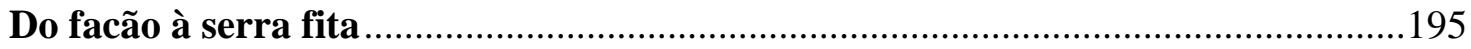

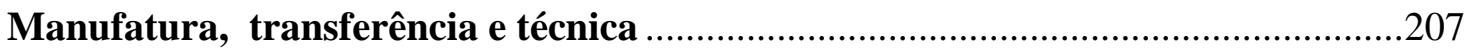

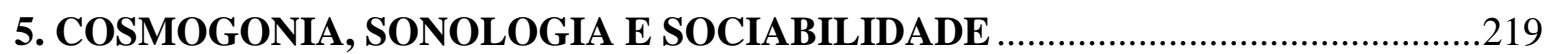

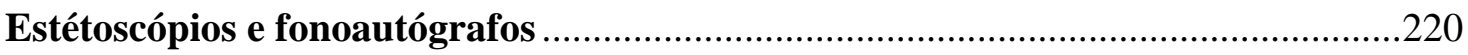

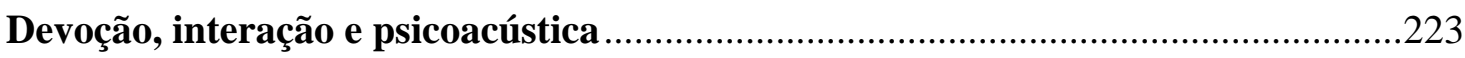




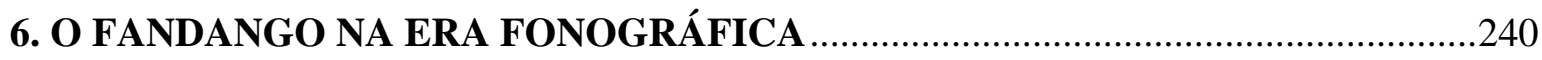

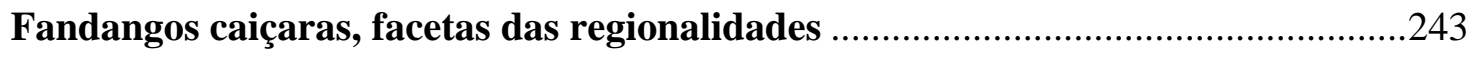

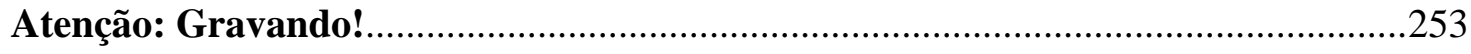

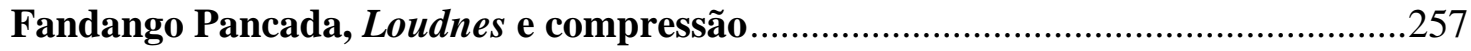

7. CIBERESPAÇO, FANDANGO CAIÇARA E REDES SOCIAIS ............................266

Comunicação instantânea, bolhas ideológicas e fake news ......................................271

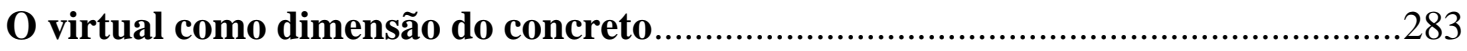

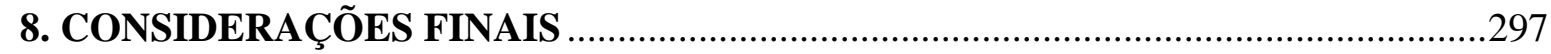

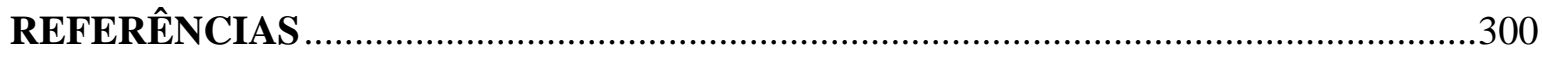

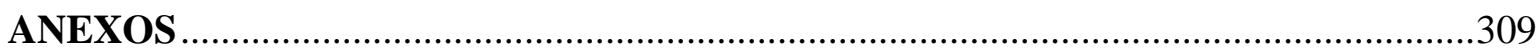

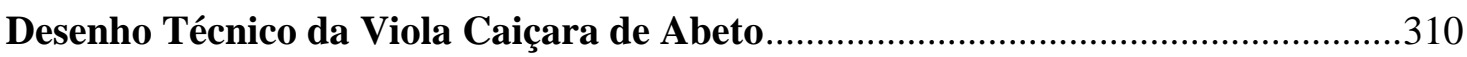

Apostila de Luteria Caiçara (Cleiton do Prado Carneiro).........................................311

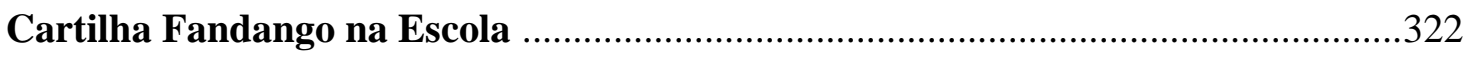




\section{PRÓLOGO}

Passarinho preso canta

Em vez de preso chorar

Como é preso sem culpa

Canta para aliviar

Domínio Público

O foco desta pesquisa é o sentido da experiência humana atravessada pela globalização, em que o virtual se firma como dimensão de interação, e a implementação das novas tecnologias e suas derivações ao campo inter-relacional se estabelecem, pari passu, como processos dinâmicos de afirmação identitária. Nesa perspectiva, debruçamo-nos sobre o território caiçara para melhor entender como o componente humano, nomeadamente detentores e artífices do bem cultural fandango caiçara, agencia suas pulsões de vida e de mundo, delineando trajetórias para as quais a consolidação de políticas públicas para as culturas populares favorece a interação comunicativa e cujo fim se resume à preservação de suas práticas e ao bem-estar de seus atores.

Tratamos da crise existencial crônica que assola as individualidades com a pós-verdade hipermoderna e da dificuldade de expressar ideias, problema ligado à tradução da língua, do gesto e da fala e a dualidades tão caras à teorização antropológica, sociológica e psicofísica. Transitamos entre complementaridade e simetria, imersos num universo interacional em que polarizações político-ideológicas movem montanhas - literalmente, nos casos do nióbio, do minério de ferro, dos combustíveis fósseis, do xisto e de outros bens extraíveis e economicamente valorizados.

Nesse rumo, tomamos parte na temporalidade recente, mais especificamente perto de meu entorno, resultado direto de minhas redes de interação e, em última análise, das localidades e glocalidades que compõem esse mosaico de deslocamentos, agenciamentos e pulsões que nos movem e consolidam sociabilidades.

Mais que existencial, essa crise tem cunho epistemológico, entre o mangue e o concreto, em contínuo exercício reflexivo sobre a inquietação posta. Ao ler trabalhos de colegas ou de desconhecidos cuja pesquisa e cujo objeto de estudo se aproximam dos meus, tenho uma estranha sensação, misto de desdém e euforia. Euforia porque percebo não estar sozinho, 
entendendo a alteridade como basilar na construção metodológica e teórica que subsidia os gritos de resistência frente a uma conjuntura ímpar, na qual domínios do capital econômico monetizado ignoram ideais de equidade social. Desdém, quando deparo com o lado sombrio, onde a antropologia de gabinete e a sociologia de pasquim tomam contornos mercantilistas, como um retorno aos cronistas e navegadores renascentistas que, salvo raras exceções, queriam conhecer melhor as populações nativas com a única finalidade de melhor explorá-las. Felizmente, estas últimas considerações não devem ser generalizadas.

Mais que observador ativo, insiro-me nesses ditos articuladores culturais, mediadores, militantes ou ativistas, em que a ideia de objeto de pesquisa se dilui nos laços de afeto, emotividade e agenciamentos consolidados pelo tempo, lugar onde a interlocução beira o compadrio.

Não vejo outra alternativa a não ser compartilhar vivências, ora como narrador, ora como personagem, ora como pessoa que sou, e transitar por entre singularidades, percepções e premissas há pouco intangíveis, ontologias corpusculares de nossa indeterminada realidade material, cognitiva e afetiva. Seriam os eventos regionais da cultura caiçara Zonas Autônomas Temporárias? Fendas no espaço-tempo propiciadas pela ação conjunta e direcionada de atores diversos? Claraboia festiva em contraponto às mazelas de nosso tempo?

A fissura entre física e filosofia, ainda em fluxo até meados do século passado, perde força frente a experiências concretas levadas a cabo a partir da teorização quântica. A compreensão de um mundo tetradimensional, evidenciado por grandezas de comprimento, massa e tempo, expande-se a novos sistemas de mensuração, em que comprimento, aceleração e energia formulam seus postulados. Seja em Heráclito de Éfeso seja em Max Planck, "A energia pode ser transmutada em movimento, calor, luz e tensão". (HEISENBERG, 1981, p. 31), energia que emana das conexões neurais, transita pelas fibras óticas, sustenta as emissões sonoras e lança luz à percepção das cores e às interações humanas.

Para dar corpo a esses trânsitos, buscarei, a partir de experiências vivenciadas junto a comunidades no litoral, firmar pontos de intersecção de maneira que tecnologia, cultura, política e ecologia nos auxiliem para o entendimento do atual estado da arte inerente ao componente caiçara e suas singularidades.

Antes de concatenar quaisquer dramas de inter-relacionamento que cercam a mim e aos meus interlocutores cotidianamente, por um instante, volto-me às questões individuais que, imagino, possam auxiliar na leitura deste escrito.

Assim como em seu auge, o cinema e o rádio converteram, em seus respectivos procedimentos de transmissão e expressão, objeto em imagem e som em modulação 
(SCHAEFFER, 2010). Seus desenvolvimentos ulteriores nos apresentam cenários da transmissão e compartilhamento de dados informacionais via satélite e por meio de emaranhados quânticos (já tidos como viáveis ao teletransporte de pacotes de informação) que se fazem presentes na atualidade. Assim, o novo paradigma da reprodutibilidade técnica, tornado clássico pela caneta de Walter Benjamin na década de 1930, pode ser revisitado somando-se ao componente mecânico newtoniano, os aspectos multidimensionais inerentes aos avanços do método probabilístico e, ao que se segue, à ontologia corpuscular dos campos quânticos.

A interação humana é algo de complexo e, particularmente, os lugares ocupados pelos indivíduos alocados no espaço-tempo a complexificam exponencialmente, sobretudo depois das atuais constatações empíricas que faíscam dos aceleradores de partículas. Tendo em vista que toda teoria do conhecimento humano reverbera elementos quadridimensionais de interação, inter-relação, coexistência sociabilidade e socialidade, de que maneira poderíamos realocar nosso entendimento quando os emaranhados quânticos, as ondas gravitacionais e o campo de Higgs se deslocam ao patamar de realidade experimental e não mais de elucubração físico filosófica, requalificando a própria ideia de matéria? Qual seria o novo paradigma etnomusicológico quando o fenômeno sonoro vibracional - o fonôn - se redimensiona de onda mecânica a subpartícula antigravitacional?

O ciberespaço toma lugar nos mais diversos campos sociais e políticos, inclusive nas comunidades tradicionais que se valem de ferramentas virtuais na construção de alteridades, identidades, luta por direitos ou simplesmente pela interação entre pares, ampliando concretamente redes de atuação, divulgando, difundindo e produzindo conteúdos, imagens e agenciamentos capazes de visibilizar a cultura caiçara de um modo sem precedentes.

O declínio do sensível na perspectiva da homogeneização das massas, e a busca incessante de capital financeiro em suas mais variadas vertentes sociopolíticas são de fato elementos a serem sondados em busca de realidades socioculturais e socioambientais menos sórdidas. Concordamos com Guattari e Rolnik quando reconceituam o termo cultura à luz de princípios como o da sujeição das subjetividades:

O conceito de cultura é profundamente reacionário. É uma maneira de separar atividades semióticas (atividades de orientação no mundo social e cósmico) em esferas, as quais os homens são remetidos. Tais atividades, assim isoladas, são padronizadas, instituídas potencial ou realmente e capitalizadas para o modo de semiotização dominante - ou seja, simplesmente cortadas de suas realidades políticas. (GUATTARI e ROLNIK, 1996, p. 15) 
Nesse contexto, nossos agenciamentos tangenciam a realidade na qual estamos inseridos e o exercício de autocompreensão parece viável à melhor afecção $^{1}$ de alteridades, sejam elas caiçaras, catalãs ou inuits. Às voltas com conceitos da antropologia compartilhada, da musicologia histórica e da etnomusicologia, seguimos com os mesmos dilemas: afinal, que lugar ocupamos nesse ínterim?

As apropriações e atualizações derivadas da inserção de novas tecnologias, o ativismo presencial e nas redes sociais, a intensificação das mediações junto aos poderes público e privado e a institucionalização associativista de grupos artísticos e agremiações culturais marcam aspectos relevantes do papel dessas transformações para a manutenção de práticas culturais tradicionais, confluindo à autoafirmação da identidade e da sociabilidade caiçara.

A compreensão de individualidades históricas, na qual a ação social pressupõe que seu sujeito, ao mentalizar um sentido seja atravessado pela conduta de outros e movido a levá-la em conta em suas ações ulteriores, remete-nos aos epílogos batesonianos escritos em 1936 e 1958, indicando que, strictu sensu, a partir dos aspectos afetivos e cognitivos, "não chegamos a retratos do indivíduo, mas a retratos dos eventos em que o indivíduo está envolvido”. Bateson sugere que poderíamos sanar tal inconsistência quando entendermos que o termo personalidade não se refere ao indivíduo isolado, mas ao indivíduo no mundo. (2008, p. 305)

Tendo isso em mente, nossa escrita se dará a partir das descrições leves, mas não deixando de ser heteróclita como sugerido por José Jorge Carvalho (1991, p.03), alternando "forçosamente descrição e análise com princípios filosóficos e propostas de atuação", vivenciando e refletindo sobre o cotidiano atravessado de historicidade. A narrativa etnográfica contrasta, modela-se e se relaciona com os apontamentos conceituais e teóricos, tendo por opção a identificação e o afecto, as pulsões de vida e os agenciamentos múltiplos, meus, de meus interlocutores, compadres e camaradas. A transcrição de conversas informais realizadas via WhatsApp, o aplicativo, e de postagens no Facebook também apresentarão ocorrências de relevância no texto, assim como a utilização do gravador de voz como ferramenta complementar aos cadernos de campo. Sem perdermos de vista o fato de que mesmo que a tecnologia nos permita perceber de modo mais próximo aquilo que nossos interlocutores

\footnotetext{
${ }^{1}$ Deleuze (1978) alertava para a "catástrofe" de se traduzir affectio e affectus para afecção, lembrando que em francês há os termos affect (afeto) e affection (afecção), mais próximos da forma utilizada por Espinosa. Há uma distinção entre afeto e afecção que o emprego de um só termo acaba por olvidar. (...) as afecções, embora aconteçam de uma só vez, são efeitos de um corpo sobre outro no espaço; os afetos são os efeitos de um determinado corpo sobre uma duração - variações de potência. Afeto corresponde, portanto, ao modo como problematizamos nossas afecções, nossas dores e prazeres; afecção é tudo aquilo que o corpo absorve no encontro com outros corpos.
} 
percebem, o que qualquer um de nós realmente vê - e como vê - é muito mais do que o que é refratado pela mecânica de um globo ocular, pela lente de uma câmera ou pelos dispositivos tecnológicos dos quais dispomos. (JACKSON, 2013, p. 15) Por essa razão, as transcrições serão longas o suficiente para que tomemos pé de suas particularidades e detalhes, e para que o lugar de fala dos interlocutores se apresente com toda sua intensidade na escrita desta pesquisa.

Em itálico, serão marcados alguns termos nativos, estrangeiros e outros comentários que nos pareçam merecedores de destaque para o melhor entendimento da narrativa que, via de regra, valer-se-á do universo sonoro e das musicalidades caiçaras, como principais eixos condutores.

Na percepção sonora dos Wauja, por exemplo, a base da escuta é construída pela horizontalidade e se relaciona a um monitoramento espacial da natureza, "algo imprescindível não apenas no aferimento de 'distâncias temporais' de objetos sonoros como também em atividades como caminhadas no mato e caça”. (MELLO, 1999, p.95). No caso caiçara, o nativo percebe o cardume de paratis pelo movimento dos peixes e pela textura da água, diferencia e identifica se a buia [ruído] do mato se deu pela queda de um toco ou pelo bicho que caminha, sabe quando a tambarutaca [estomatópode] tá estralando, se a maré está vazia e em qual momento do dia o porvinha [Culicoides $s p$ ] vai comer sua canela. Mais recentemente, manipula seu aparelho de telefonia móvel, percebe e opina sobre a configuração de um sistema de áudio que sonoriza um baile e participa ativamente da consolidação de políticas públicas em defesa de sua cultura e de seu território, aspectos perceptivos de universos sonoros, culturais e sociais, transduzidos em memória.

Assim como Roederer (2002, p. 229), entendemos que a maior e mais importante diferença entre a abordagem do processamento de informação sensorial feita pela "inteligência artificial" dos robôs e as "operações cognitivas reais" do cérebro se localiza justamente no fato de que a última tem um propósito primordial diferente: "otimizar as condições para sobrevivência”.

Nossa análise da conjuntura sociopolítica do Fandango Caiçara e seus detentores pretende atinar para os paradigmas que norteiam estas práticas, a partir da participação observante e de relatos etnográficos da concatenação sincrônica. Essa reflexão gravita entre uma tradicional sociologia da música e uma etnomusicologia aplicada (com vistas à sustentabilidade e aos ecossistemas musicais) que flertam com a teoria da performance, pesquisas em humanidades digitais e postulados da indeterminação probabilística.

Observamos traços al-andaluzos, açorianos, neobrasileiros e contemporâneos, presentes na hibridação e no interculturalismo compondo as dinâmicas das atualizações, apropriações e 
desusos inerentes às manifestações artísticas e culturais. Traços estes que tomam novos contornos a partir de demandas, tais como a desterritorialização, a luta por direitos, a criação de mercado de trabalho no campo cultural, as inovações tecnológicas (na difusão, divulgação e reprodução de folguedos tradicionais), as políticas culturais e os modelos de produção, ciclicamente retomando questões-chave vinculadas às distintas ordens de eventos que possibilitam alterações paramétricas na sociabilidade das populações caiçara na atualidade. 


\section{Intiruma [café sem mistura]}

Em uma daquelas lembranças recorrentes, em que a vivacidade da memória parece ter cheiro, gosto e movimento, eu, ainda imberbe, incauto e com pouca lida com a cataia ${ }^{2}$, situome convidando uma das damas da audiência. Tratava-se do grupo Pés de Ouro, referência do fandango da melhor idade parnanguara, em que os integrantes mais jovens, no geral, somavam mais de sessenta anos de idade. Ora, se até então todos estavam dançando juntos, festivamente, com ampla participação dos espectadores, qual seria a problemática da questão?

Talvez influenciado pela literatura folclorista, pelo imaginário romântico reminiscente das aulas de folclore com a professora Maria do Socorro nos tempos de graduação na então Faculdade Artes do Paraná e, sem dúvida, menos atento, entusiasmado pelos efeitos entorpecentes das folhas secas embebidas no mosto destilado, subo no tablado com minha igualmente desprevenida parceira e cavamos um lugar na roda.

Não via grandes problemas em calçar um All-Star® azul já fuzilado até se iniciarem os rufados. Quando me dou conta da gafe, já era tarde. Tento acompanhar a marca batida, passo os "oitos" coreográficos desajeitado. Era evidente a aflição das dançarinas e batedores que iam nos conduzindo pela roda em movimento, evitando maior desastre da performance em curso.

Isso se passou em idos de 2002, quando tocava lundus e emboladas caipiras em uma formação regional com os parceiros musicais do grupo CaxaPrego. O convite para nossa banda integrar a programação da I Festa do Fandango Caiçara de Paranaguá veio de Aorélio Domingues, então jovem mestre fandangueiro do grupo Mandicuera, idealizador da festa.

De lá para cá, não tive mais incidentes dessa natureza, afinal, se vai dançar uma marca batida, melhor que leve seus tamancos!

\footnotetext{
${ }^{2}$ Nome etimologicamente derivado do tupi, cataia significa "folha que queima". Trata-se de uma bebida elaborada a partir de folhas secas de cataia (Drimys brasiliensis Miers), planta nativa da floresta Ombrófila Mista da Mata Atlântica e pertencente à família Winteraceae. O preparo consiste na imersão das folhas da cataia em mosto de cana destilado (pinga ou cachaça), assim, as propriedades da planta reduzem drasticamente a acidez do destilado, suavizando seu gosto e aroma.
} 


\title{
1 REMINISCÊNCIAS, COGNIÇÃO E SOCIABILIDADE
}

\author{
Eu saí da aventura! Eu fugi da ventura! \\ Nós não estamos na cidade nem no mato. \\ Nós rolamos na ânsia dos fabulosos aeroplanos, \\ E vos garanto que agora não acabaremos mais! \\ Mário de Andrade, Remate de Males
}

A inter-relação entre detentores de bens imateriais e o meio ambiente no qual se encontram inseridos modela não apenas as dinâmicas cotidianas de subsistência, mas de modo mais amplo, constroem também os traços de alteridade próprios das populações caiçara ${ }^{3}$, sua musicalidade, cultura e sociabilidade.

A performance musical possui aspectos fisiológicos, emocionais, estéticos e cosmológicos, como bem argumenta Antony Segeer (2008, p. 256). Isso indica que algumas análises etnomusicológicas se concentram na influência fisiológica, outras na tensão emocional liberada através da música, e ainda outras tratam da correlação social e outras dos efeitos das crenças cósmicas no interior da tradição. Para o autor, todas essas qualidades estão imbricadas, seja qual for a tradição, e devem permear a etnografia da música, consequentemente, compondo um mosaico de reciprocidades entre o meio e seus atores. Essas epistemologias são firmadas no intento de nutrir e manter a vivacidade de tais manifestações.

Tradicionalmente vinculada a mutirões, atividades de plantio, colheita e construção de edificações, em que o convite ao trabalho é recompensado por um baile de Fandango, a manifestação vem modificando seu modus operandi, sendo corriqueiramente vinculada a apresentações artísticas, bailes e sessões em teatros e em eventos culturais. Os novos contextos indicam novas formas de fazer o fandango, em que a amplificação das vozes e instrumentos, o pagamento de cachês e a aproximação a fontes alternativas de financiamento, sejam públicas ou privadas, têm delineado concretamente sua manutenção, destacando-se os contextos e a relevância dessas performances.

\footnotetext{
${ }^{3}$ Entende-se por caiçaras as comunidades formadas pela mescla da contribuição étnico-cultural dos indígenas, dos colonizadores portugueses e, em menor grau, dos escravos africanos. Os caiçaras apresentam uma forma de vida baseada em atividades de agricultura itinerante, da pequena pesca, do extrativismo vegetal e do artesanato. Diegues (2004, p. 9)
} 
O Fandango Caiçara é uma forma de expressão titulada no ano de 2012 como patrimônio imaterial da cultura brasileira e se constitui como um sistema sociocultural amplo e anterior às divisões geopolíticas que o distribuem entre porções litorâneas dos estados do Paraná, São Paulo e Rio de Janeiro. Marcado pelo trânsito e pelas visitações de parentesco e compadrio, o fandango caiçara compõe um complexo de conhecimentos tradicionais e é pautado pelo modo de vida que guarda estreita relação com seu território. Da mata atlântica à faixa litorânea, seus detentores permanecem retirando e recompondo, há mais de dois séculos, as matérias-primas necessárias ao sustento de suas práticas, conceitos e definições, já descritos no Dossiê do Fandango Caiçara, documento que norteia a patrimonialização dessa manifestação cultural. (IPHAN, 2011)

A distensão e compactação do tempo podem ser enunciadas como elementos das transformações em curso, e deve-se ter em mente que diferentes modelos de produção, difusão e divulgação seguem em paralelo. A espetacularização mencionada anteriormente não exclui a possibilidade de que mutirões sejam realizados, pelo contrário, análoga à prática vicinal e de compadrio, as redes de interação vêm sendo ampliadas, valendo-se inclusive do conceito de mutirão para realização de eventos de maior envergadura, como os ocorridos no ano de 2018 , na Ilha dos Valadares, Cananéia, Iguape e Ubatuba. Nesse ano, as festas locais anuais acabaram acontecendo de modo participativo e sem aportes financeiros externos (salvo apoios pontuais de ordem estrutural, que, em todos os casos, contaram com módica participação das prefeituras locais). Como sugeriu Bateson (2008, p. 327): "Estamos preocupados com o problema da mudança, e de modo algum com os valores absolutos."

\section{Tempo, paisagens e mutirões}

O tempo medido, cronológico, cotidiano, apresenta variáveis locais. A mobilização de agentes para a realização de um baile ou de uma violada nas redondezas de Superagui, Abacateiro ou na Barra da Jureia ocorre no contexto do bioma; as referências de tempo e espaço são mensuradas por elementos sinergéticos com o meio; o baile tem outro tempo; o agenciamento é atravessado pelo compadrio, pela relação vicinal; a pressa é outra.

Distinta dos horários pré-estabelecidos dos estabelecimentos públicos ou clubes privados, pelo vai e vem urbano que pisa o chão calçado, asfáltico, o tempo no sítio é outro, mais próximo dos ciclos do dia que dos ponteiros do relógio, ultrapassando inclusive o sentido 
sazonal. Tive experiências marcantes que tratam da distensão do tempo junto a comunidades tradicionais: primeiramente, com indígenas Mbyá Guarani - na Ilha da Cotinga, Piraquara e Sambaqui - durante atividades do Projeto Cotinga ${ }^{4}$ em sua versão piloto. A dependência da maré para realizar deslocamentos exteriores às comunidades, a consolidação da chegada refletida no ato de sentar no Apiká (banco de madeira), fumar pytanguá e tomar mate antes de se tratar de qualquer assunto são elementos que nos conduzem à reflexão e a uma qualidade conectiva. O tempo, a presença e a interação apresentam nuances diametralmente opostas àquelas vivenciadas no cotidiano das metrópoles, tecendo malhas, tramas, camadas cumulativas que se sobrepõem continuamente à experiência vivencial de cada indivíduo, nichos de socialidade atrelados à existência do ser no mundo.

Essencialmente, a duração é memória, consciência, liberdade. Ela é consciência e liberdade, porque é memória em primeiro lugar. Ora, essa identidade da memória com a própria duração é sempre apresentada por Bergson de duas maneiras: "conservação e acumulação do passado no presente". Ou então: "seja porque o presente encerra distintamente a imagem sempre crescente do passado, seja sobretudo porque ele, pela sua contínua mudança de qualidade, dá testemunho da carga cada vez mais pesada que alguém carrega em suas costas à medida que vai cada vez mais envelhecendo". Ou ainda, "a memória sob estas duas formas: por recobrir com uma capa de lembranças um fundo de percepção imediata; e por contrair também uma multiplicidade de momentos. (DELEUZE, 1999, p. 39)

Deleuze explicita que, com efeito, devemos exprimir de duas maneiras o modo pelo qual a duração se distingue de uma série descontínua de instantes que se repetiriam idênticos a si mesmos; citando Bergson, atenta que: de uma parte, "o momento seguinte contém sempre, além do precedente, a lembrança do que este lhe deixou"; de outra parte, os dois momentos se contraem ou se condensam um no outro, pois um não desapareceu ainda quando o outro aparece. (ibid., p. 39)

\footnotetext{
${ }^{4}$ Projeto Cotinga - Implantação de Tecnologia em Sistemas Agroflorestais e Revitalização Cultural em Terra Indígena do Paraná, executado entre 2005 e 2010 com aporte do Ministério do Desenvolvimento Agrário.
} 
Figura 1.1 - Cone de luz de um ponto no espaço-tempo tridimensional de Minkowski

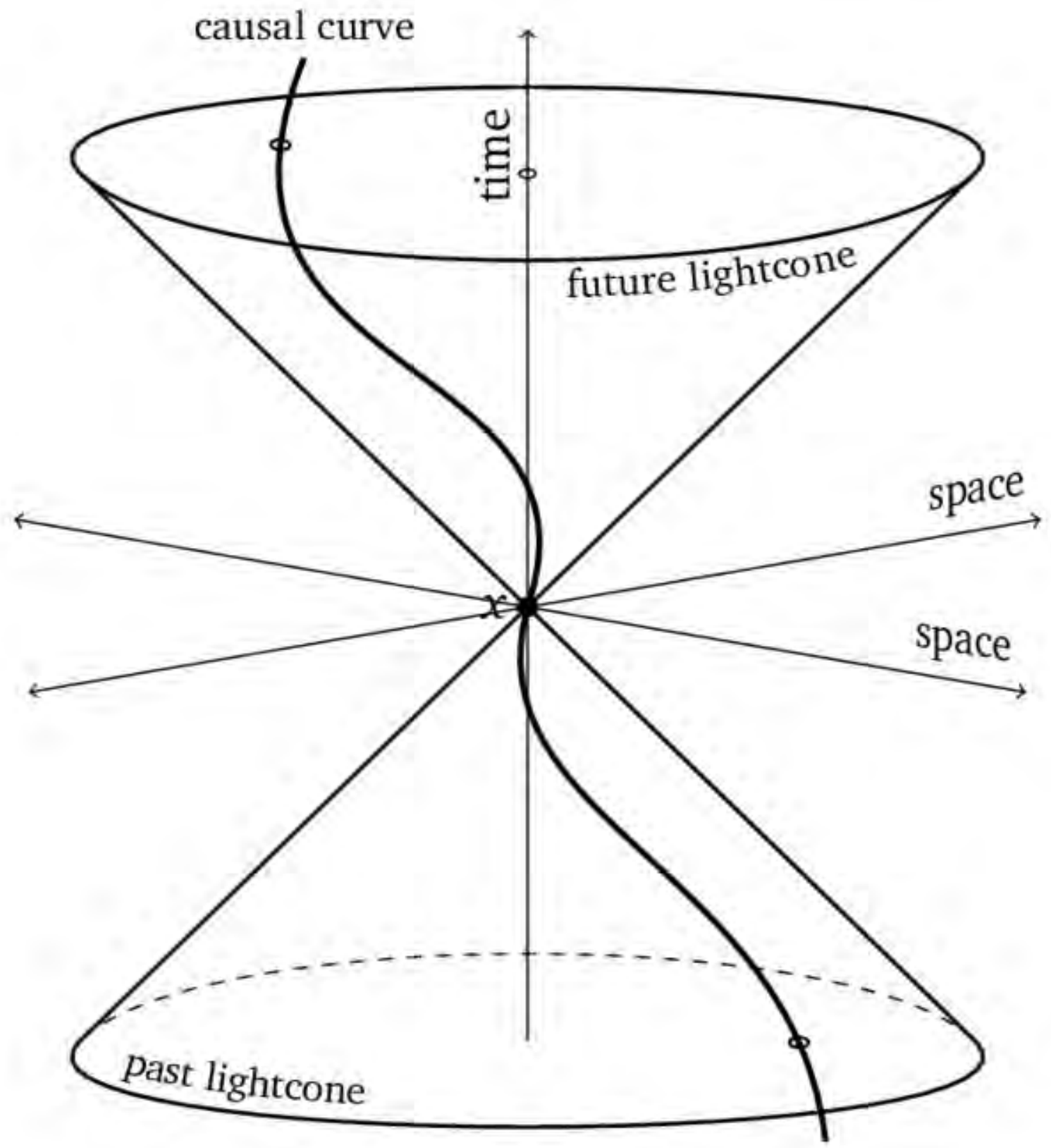

Fonte: (SIEMSSEN, 2015, p. 43)

"Há, portanto, duas memórias, ou dois aspectos da memória, indissoluvelmente ligados, a memória-lembrança e a memória-contração." Deleuze indica que a razão dessa dualidade se encontra na duração, um movimento pelo qual o "presente", que dura e se divide a cada “instante" em duas direções, "uma orientada e dilatada em direção ao passado, a outra contraída, contraindo-se em direção ao futuro.” (DELEUZE, 1999, p. 39)

\footnotetext{
${ }^{5}$ Lightcone of a point in a three-dimensional Minkowski spacetime. A Teoria da Relatividade Restrita é uma teoria geométrica de um espaço tetradimensional plano, o espaço-tempo de Minkowski, cuja métrica, caracterizando-o como um espaço plano, é dada pela distância infinitesimal entre dois eventos localizados em (x, y, z, t). (SOARES, 2013, p.01)
} 
Hoje, primeiro dia do mês de fevereiro de 2019, por um lapso, ponho-me desperto. O calor do verão e a luz ainda acanhada do dia rompem as cortinas do quarto de dormir. De súbito, lembro da noite anterior com acaloradas discussões de WhatsApp com a juventude fandangueira sobre questões de tecnologia de áudio, problemas burocráticos com repasse de verbas a mestres de mais idade (desvios de recursos e outras pendengas vivenciadas em núcleos familiares), modos de comportamento, desconstrução do machismo e da misoginia, tudo isso atrelado aos acontecimentos do $1^{\circ}$ Encontro de Fandangueiros do Marujá, que aconteceu entre os dias 25 e 27 de janeiro deste ano, na comunidade de mesmo nome, localizada na Ilha do Cardoso, município de Cananéia no estado de São Paulo. Piadas, fotos, vídeos e crises geracionais.

Ao despertar, confiro o horário no aparelho celular - 5:55h. Manuseio o Gadget e compartilho o acesso ao lapso de tempo no grupo da tripulação ${ }^{6}$, brincadeira da hora cheia que fazemos com o grupo de foliões da bandeira do Divino.

Figura 1.2 - Brincadeira da hora cheia e outras sincronicidades
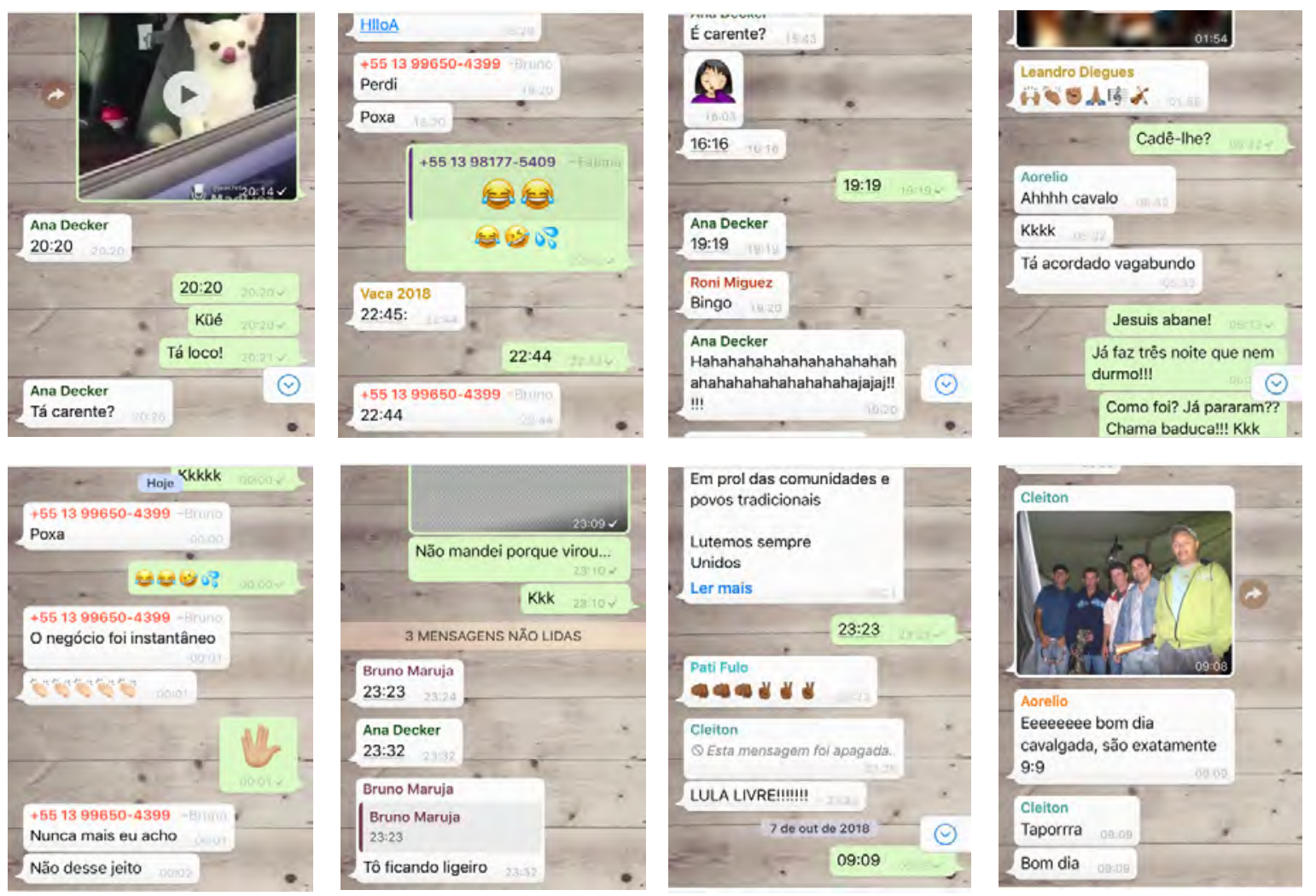

Fonte: Acervo pessoal

\footnotetext{
${ }^{6}$ Termo conferido aos integrantes da romaria do Divino Espírito Santo: instrumentistas, cantores e alferes, por vezes contando também com a presença de pesquisadores, documentaristas e familiares dos foliões. No caso acima mencionado, diz respeito ao grupo de WhatsApp denominado "Tripulação Cósmica", do qual participam os foliões da bandeira parnanguara, no intuito de compartilhar informações sobre a romaria, disponibilidades de agenda e calendários das atividades de peregrinação, entre outros temas diversos.
} 
Figura 1.3 - Capela do Divino, Associação Mandicuera, Ilha dos Valadares

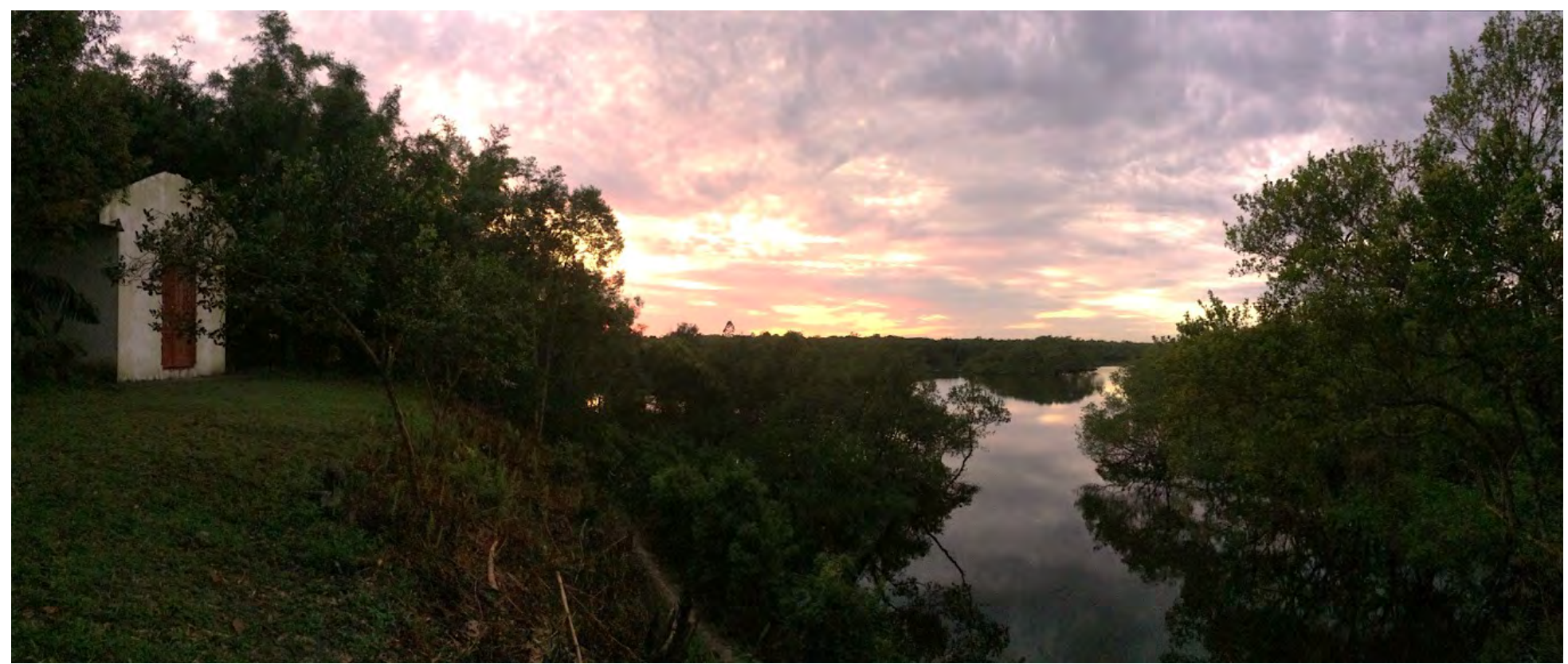

Fonte: Acervo pessoal

Tempo, duração e memória.

Se aproxima a época da romaria, em breve a tripulação estará novamente transitando pelos recônditos recantos do lagamar, levando os sons e as cores da Folia do Divino Espírito Santo àquelas localidades. Reflito sobre A memória como coexistência virtual, sento-me em frente à tela, redijo o presente parágrafo. 
Diferente do cinema, a imagem acima exposta (fig. 1.3) não nos possibilita atentar aos aspectos sônicos inerentes àquele meio. No mesmo local, ainda antes da aurora, coletei em fonograma os sons dos pássaros, da brisa e dos ruídos do despertar do dia, expresso na figura abaixo em sua representação sonográfica.

Figura 1.4 - Fragmento de espectrograma - pássaros na alvorada da capela

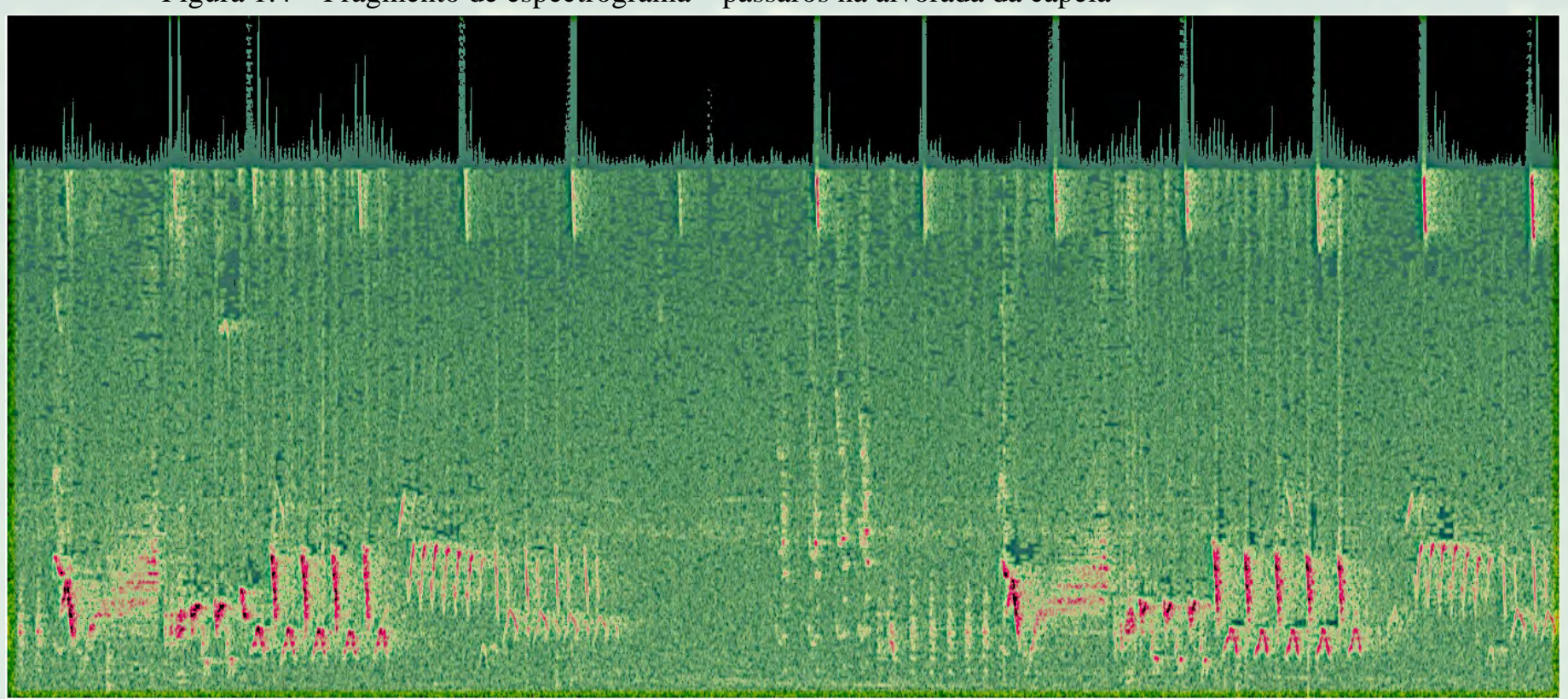

Fonte: Acervo pessoal, gerado pelo aplicativo Sonic Visualizer

Imaginemos ainda que tal representação traz apenas uma parcela da paisagem sonora inerente ao quintal da Associação Mandicuera, no bairro Sete de Setembro, na Ilha dos Valadares (Paranaguá). Caso mergulhássemos na maré, poderíamos também ouvir as frequências graves que emanam do porto, cuja intensidade e ininterrupção as fazem evidentes, mesmo aos ouvidos mais distraídos.

Murray Schafer elucida o fato de que os sons podem ser classificados de muitas maneiras: de acordo com suas características físicas (acústica) ou com o modo como são percebidos (psicoacústica); de acordo com sua função e significado (semiótica e semântica); ou de acordo com suas qualidades emocionais ou afetivas (estética). Schafer (2001 p. 189) propõe que os estudos isolados, vinculados ao hábito de se tratar essas classificações separadamente, acarretam limitações, especialmente no que diz respeito ao conceito de paisagem sonora por ele proposto $^{7}$.

\footnotetext{
7 "Soundscape" (traduzido como paisagem sonora), um neologismo introduzido por Schafer, análogo a "landscape" (paisagem), consiste no ambiente acústico. "Tecnicamente, qualquer porção do ambiente sonoro vista
} 
Schafer enuncia a diferenciação entre objeto sonoro e evento sonoro, demonstrando que o entendimento desses componentes pode auxiliar o trabalho de classificação e análise de dados:

Quando se focalizam sons individuais de modo a considerar seus significados associativos como sinais, símbolos, sons fundamentais ou marcos sonoros, proponho chamá-los de eventos sonoros, para evitar confusão com objetos sonoros, que são espécimes de laboratório. Isso está de acordo com a definição de evento no dicionário, como "alguma coisa que ocorre em algum lugar e dura determinado lapso de tempo" - em outras palavras, implica em um contexto. Assim o mesmo som - por exemplo, um sino de igreja - poderia ser considerado objeto sonoro se fosse gravado e utilizado em laboratório, ou como evento sonoro, se fosse identificado e estudado na comunidade. (SCHAFER, 2001, p. 185)

Propondo alternativas ao entendimento tradicional da percepção, Gibson considera tanto o percebedor quanto o ambiente como um único sistema mutuamente informacional abordagem denominada ecológica (GIBSON, 1979 e TOFFOLO et al, 2003). É sobre esse mutualismo que é encontrada a informação.

Os sistemas perceptuais realizam ativamente uma busca pela informação através da detecção de affordances e invariantes ${ }^{8}$, (categorias ecológicas de alta-ordem). Estas duas noções são aspectos complementares que podem ser entendidas, respectivamente, como informação-para um organismo e informação-sobre um evento do ambiente." (TOFFOLO, OLIVEIRA e ZAMPRONHA, 2003, p.05)

O rompimento do dualismo entre animal e ambiente e, logo, entre percepção e ação, que via de regra predominam na visão científica em vigor na área de comportamento motor, é o ponto de partida para assumir o realismo direto, visão filosófica ontológica do mundo adotada por Gibson, que nega qualquer necessidade de se recriar a realidade através de algum tipo de processamento interno. (FONSECA et al, 2007)

como um campo de estudos. O termo pode referir-se a um ambiente real ou a construções abstratas, como composições musicais e montagens de fitas, em particular quando consideradas como um ambiente". (SCHAFER, 2001, p. 366).

${ }^{8}$ Affordances (lit. 'proporcionantes') são aspectos da informação compatíveis com um determinado percebedor, de acordo com suas características e limites perceptuais e corporais. Essa noção está relacionada diretamente com a relação percepção-ação, informando as possibilidades que um objeto ou evento oferece num determinado contexto. Sendo específica para cada espécie e cada indivíduo, alguns objetos podem gerar affordances para um indivíduo e não para outro, com uma constituição corpórea diferente. A invariante é a informação-sobre as propriedades estruturais tanto do ambiente quanto do evento mecânico que produz um objeto sonoro, permitindo o reconhecimento da fonte sonora e do ambiente (referencialidade). Invariantes são propriedades perceptuais coerentes sobre o fluxo do tempo, permanecendo estáveis enquanto outros aspectos do objeto sonoro estão se modificando. As características do ambiente (medium) e do evento mecânico são ambas especificadas sincronicamente no objeto sonoro através de dois tipos de invariantes: estrutural e transformacional. (TOFFOLO, OLIVEIRA e ZAMPRONHA, 2003, p. 06/07) 
Abandonar o dualismo significa assumir o mutualismo (impossibilidade de separação) entre animal-ambiente e entre percepção-ação, dois princípios básicos da Abordagem Ecológica à Percepção e Ação. (GIBSON, 1986; WITHAGEN \& MICHAELS, 2005; e FONSECA et al 2007). O mutualismo presente na abordagem ecológica de Gibson pode ser correlacionado aos escritos de Bateson, ao afirmar que:

Os elementos mais importantes no ambiente de um organismo individual são (a) outros indivíduos da mesma espécie e (b) plantas e animais de outras espécies com que o indivíduo em questão tem uma intensa relação de interação. $O$ valor de sobrevivência de uma determinada característica provavelmente dependerá em parte do grau em que esta característica é compartilhada por outros membros da espécie; e vis-à-vis outras espécies, devem existir relações - por exemplo, entre predador e presa - comparáveis àqueles sistemas interativos de ataque e defesa que estão se desenvolvendo e são tão dolorosamente familiares nas corridas armamentistas no âmbito internacional. (BATESON, 2008, p. 315)

Para além das sonoridades próprias do deslocamento, do labor da pesca e da plantação, do ruído dos motores, da convolução das ondas e do tilintar das foices e enxadas, das violadas de fim de tarde e dos bailes que alcançam a alvorada, a luteria caiçara, expressa pelo feitio artesanal de instrumentos musicais, nos remete também a tais idiossincrasias.

Os atributos físicos de uma superfície indicam como ela pode suportar certas ações, e a composição de tal estrutura e seu layout constituem o que ela suporta. Uma superfície plana, horizontal, com rigidez aparente, por exemplo, oferece affordance de suporte para um indivíduo, portanto, percebe-se que aquela superfície suporta a circulação desse indivíduo. Um determinado objeto pode especificar a affordance de "pegável”, "manipulável”, dependendo da complementaridade entre as dimensões do objeto e as dimensões da mão do observador (ROCHAT, 1989). A estrutura das ferramentas, a natureza das matérias-primas e as formas moldadas por fabriqueiros ${ }^{9}$ devem também ser entendidas dentro dessa lógica. Nela encontramos distensões temporais na manufatura manual antagônicas àquelas que se valem de maquinário eletrificado. Reflexos do tempo despendido e da capacidade artística criativa de seus artífices, que, via de regra, se apresentam também como exímios instrumentistas e cantadores.

Retomando uma frase de Paul Klee, que reiterava a ideia de que "A arte não é uma reprodução do visível, ela torna visível", Deleuze explora a ideia de que a arte torna sensível o que não é do universo da percepção, e assim ela passa a ser a arte de tornar audíveis as forças não audíveis. O que quer dizer com isso? Ora, o compositor torna audíveis forças como as do tempo, a força

\footnotetext{
${ }^{9}$ Termo que denomina os artífices da luteria caiçara.
} 
de gravidade, as forças de germinação, e tais forças não são audíveis. $\mathrm{O}$ compositor faz com que ouçamos as texturas, ouçamos as estrelas, ouçamos as cores e até mesmo ouçamos as cores do tempo - como o pretende Messiaen em sua Chronochromie. Faz também com que forças audíveis se transformem em outra coisa senão aquela que estávamos ouvindo, e que o metal de uma fundição de aço transforme-se em tempo musical, como o faz Alexander Mossolov em sua obra orquestral A fundição do Aço, de 1927. (FERRAZ, 2010, p. 70)

No universo caiçara, diversos elementos sonoros fazem parte da experiência cotidiana do indivíduo que interage com o meio em que vive. O não audível faz alusão ao tempo da memória-lembrança, da idade, das paixões. Informação recorrente - evidenciada por folcloristas, antropólogos e etnomusicólogos - aproxima a rítmica do tamanqueado à função de debulhar $\mathrm{o}$ arroz ${ }^{10}$, e o próprio folguedo à paga de mutirão. Em última análise, a paga se reverte no divertimento ansiosamente aguardado, enquanto que debulhar o arroz toma novo sentido (independente de possíveis conexões com os bate-pés ibéricos e neobrasileiros, sejam eles açorianos, al-andaluzos ou guaranis): modela o tempo, propõe ritmo e faz emergirem novos mitos de criação.

Diferente do sentido dado do audível - o tempo cotidiano agregado em amálgama multiétnico de intensa hibridação consubstancializa a métrica, a poesia e o movimento, e se manifesta no tempo musical.

Não poderia tomar partido, aqui, nem de Blacking nem de Merriam, apesar de concordar com ambos. Intuo que a narrativa que aqui proponho nos faz pensar tanto na música como cultura, como na música na cultura. Uma possível aproximação das duas conjecturas poderia ser galgada pelo viés das teorias benzonianas, no que diz respeito ao princípio de ISO $^{11}$ ou das

\footnotetext{
${ }^{10}$ Clara conexão aos tempos áureos desta cultura tanto no Paraná como em São Paulo (Paranaguá e Iguape), no caso de Paranaguá, o ouro evidenciado por Gabriel de Lara em 1649 era pouco e logo acabou. Em vista do fraco comércio de gêneros de subsistência, era a farinha de mandioca que possibilitava a importação de produtos básicos como o sal, ferragens e peças de algodão vindos da sede da Capitania. Ainda no século XVII iniciou-se no litoral outra atividade produtiva como o plantio de arroz e cana-de-açúcar.

${ }^{11}$ O princípio é subdividido em quatro estruturas inter-relacionáveis, denominadas da seguinte forma: "1. ISO Universal - estrutura dinâmica sonora que age no inconsciente, caracteriza ou identifica todos os seres humanos, independente de seus contextos sociais, culturais e históricos. Como exemplo desta estrutura, encontramos o ritmo binário, relacionado ao batimento cardíaco, sons da respiração, o sussurro da mãe, o fluxo sanguíneo, o movimento da água (líquido amniótico), a série pentatônica, e o silêncio; 2. ISO Gestáltico - estrutura capaz de potencializar toda força de percepção passada e presente, destacando que a percepção não é a de um conjunto de elementos, mas de um todo unificado, agindo de forma plena no inconsciente, desde o momento da concepção de cada indivíduo, estas energias poderão modificar ou influenciar aquelas que se concentram no ISO Universal; 3. ISO Cultural - é o produto da configuração cultural global da qual o indivíduo e o seu grupo fazem parte; remete a uma identidade sonora própria de uma comunicação de homogeneidade cultural relativa, que corresponde a uma cultura ou subcultura musical e sonora, manifestada e compartilhada; 4.ISO Grupal - estrutura que opera no nível préconsciente, formando a identidade sonora de um grupo humano, produto das afinidades musicais latentes, em cada um de seus membros. " (BENENZON, 2008, p. 73/74).
} 
identidades sonoras, em que enuncia como vivenciamos, armazenamos e construímos nossas identidades sonoras e como o universo sonoro infere no modo como interagimos em sociedade (BENEZON, 2008), conceitos que dialogam com os dois aspectos da memória enunciados por Bergson e Deleuze.

“Toda performance musical é, num sistema de interação social, um evento padronizado cujo significado não pode ser entendido ou analisado isoladamente dos outros eventos no sistema" (BLACKING, 2007, p. 204). Nas mais variadas manifestações etnoculturais dispersas pelo planeta, encontramos resquícios biológicos, sociais e geográficos que atuam em distintos níveis da psique para formação da "Identidade Sonora" dos indivíduos. O conceito é descrito por Benenzon como o "conjunto infinito de energias sonoras, acústicas e de movimento que pertencem a um indivíduo e o caracterizam" (BENENZON, 2008, p. 71). Esse conjunto de movimento e som condensa os arquétipos sonoros que, segundo o autor, são herdados onto e filogeneticamente. De um ponto de vista evolutivo, agregam-se as vivências sonoro-vibratórias e de movimento durante a vida intrauterina, no período gestacional, posteriormente acrescidos das experiências vividas durante o parto, nascimento e no decorrer de sua vida.

Além dos aspectos universais elencados por Benenzon, outras referências sonoras e vibracionais influenciam na formação da personalidade humana, sobretudo aqueles eventos sonoros socialmente engendrados.

Sejam os tamancos a descascar o arroz (num passado histórico ainda recente) ou as buzinas dos trens de carga, que diariamente inundam sonoramente cidades portuárias e seu entorno com o grave e profundo alarido das cargas que se aproximam e são escoadas pelos portos, notamos que essas informações acústicas, eventos e marcos sonoros são impressos na vivência sensorial dessas populações.

Os movimentos coletivos, a participação em bailes e oficinas, os laços de proximidade construídos nas atividades culturais desde tenra idade, ainda com maior ênfase naquelas desenvolvidas nos núcleos familiares de fandangueiros e entusiastas da cultura caiçara, podem ser entendidos como fatores inerentes às vivências sonoras dessas populações, diferentes daqueles de outros folguedos de igual denominação espalhados pelo Brasil ou ainda de seus congêneres espalhados por outras regiões do globo, como o fandango alagoano, o fandango gaúcho, o fandango paulista (do interior), o fandango andaluzo (malaguenho), o fandango e a jarana mexicanos, os jaropos venezuelanos e colombianos e as contradanças e mazurcas caboverdianas. Tal fato caracteriza o fandango caiçara e nos auxilia no entendimento de sua construção como manifestação singular.

A vinculação com o território traz a alteridade endêmica desses modelos de produção e 
difusão. No caso caiçara, apesar de apresentar aspectos razoavelmente homogêneos no que toca à instrumentação, poesia e coreografia, podemos observar distinções evidentes percebidas na modulação das melodias, nos tempos de sustentação em notas de finalização, nos andamentos e em pequenas variações harmônicas. São elementos que identificam cada localidade, com suas marcas registradas e "sotaques", e caracterizam suas respectivas feições musicais: fandango de Paranaguá, de Guaraqueçaba, de Cananéia, de Iguape, da Cachoeira do Guilherme, do Marujá, de Ubatuba ou de Paraty. Mesmo que os fandangueiros dessas localidades executem as mesmas modas, estas soarão de modo diferenciado, inevitavelmente conectadas à construção da identidade sonora de seus detentores.

Uma chamarrita ou um dom-dom ${ }^{12}$ ? Que leque abriremos ao tentar nominar uma moda de estilo bailado, tamanho o universo de variáveis que cerca o termo? Essa variedade e as alteridades resultantes valem também para as marcas batidas. Envólucros da tradição, da ancestralidade discipular e da transmissão oral que reverbera no tampo das violas e rabecas, nos traços da marchetaria, na cadência do toque, na particularidade da rítmica, no contorno melódico, na estrutura métrica e na corporalidade. Foram agentes históricos que ocuparam determinadas localidades e que repassaram seus conhecimentos de modo vivencial aos seus pares e que geraram, por sua vez, novos impulsos de (trans)formação.

Cabe, aqui, trazermos o conceito de localidade, de Appadurai (1996), que nos permite entendermos as localidades como algo que determina e constrói relações sociomusicais e é, ao mesmo tempo, construído e transformado por elas. As marcas dessa produção sociomusical cujo fluxo transformador se dá em duas direções - e seus aspectos distintivos são visíveis nas expressões musicais advindas dos fandangueiros de diferentes sítios.

Um claro exemplo se dá nas três melodias que se seguem. Os distintos toques são singularidades melódicas de três mestres fandangueiros registradas no disco Amanhece, por Aorélio Domingues, que, buscando diversificar as linhas melódicas das chamarritas e domdons contidas no álbum, valeu-se do aprendizado que acumulou junto aos diferentes mestres para inspirar as linhas melódicas executadas pela rabeca: ${ }^{13}$

\footnotetext{
${ }^{12}$ Variedade de marcas bailadas ou valsadas sem a presença de tamanqueado, em que os pares dançam livremente sem coreografia pré-estabelecida.

${ }^{13}$ As transcrições e edições de cifras e partituras contidas neste trabalho contaram com a valiosa e sensível colaboração do meu compadre Luis Otávio Almeida.
} 


\section{Moda da placa solar}

Chamarrita

$$
\int=130
$$
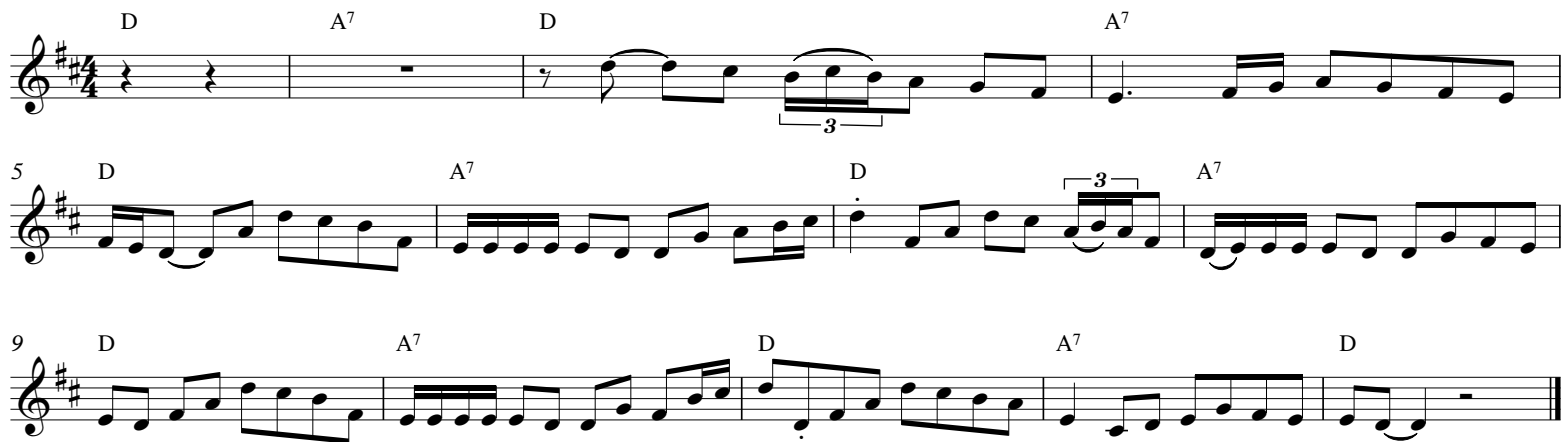

Figura 1.5 - Melodia de Chamarrita de Mestre Pedro Pereira.

Moda da força verde

Chamarrita
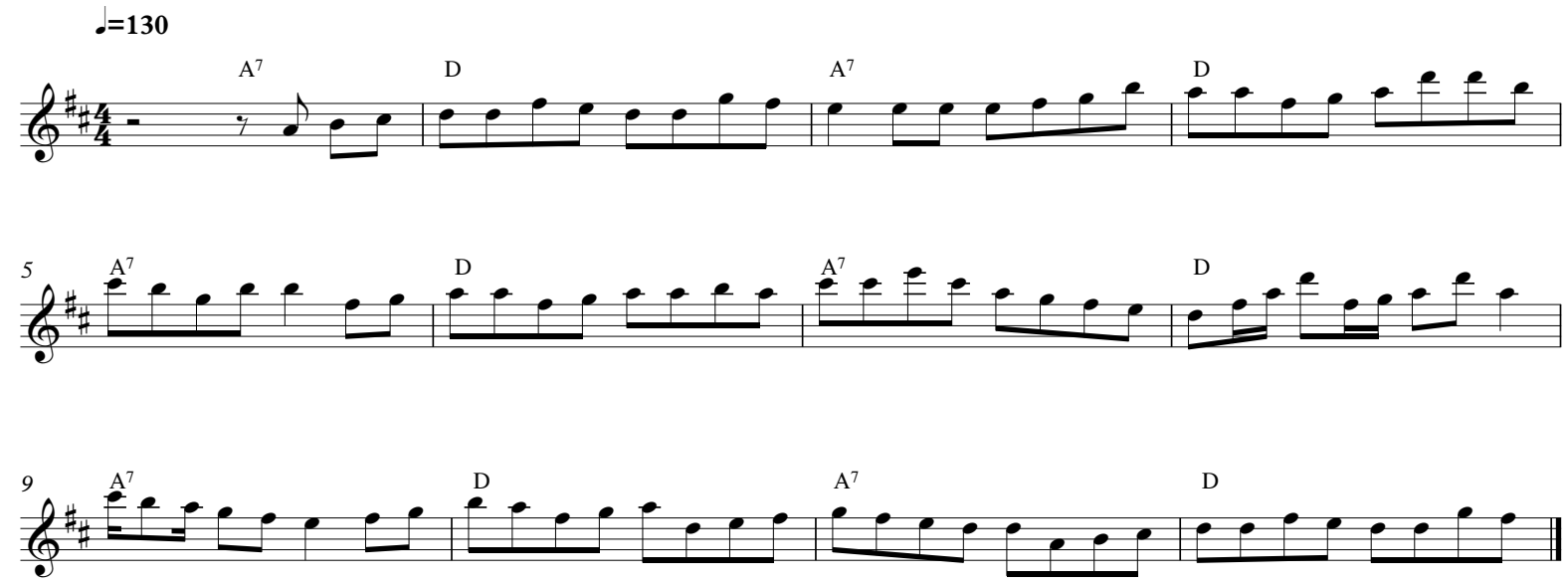

Figura 1.6 - Melodia de Chamarrita de Mestre André Pires 


\section{Moda da Mãe cá Filha}
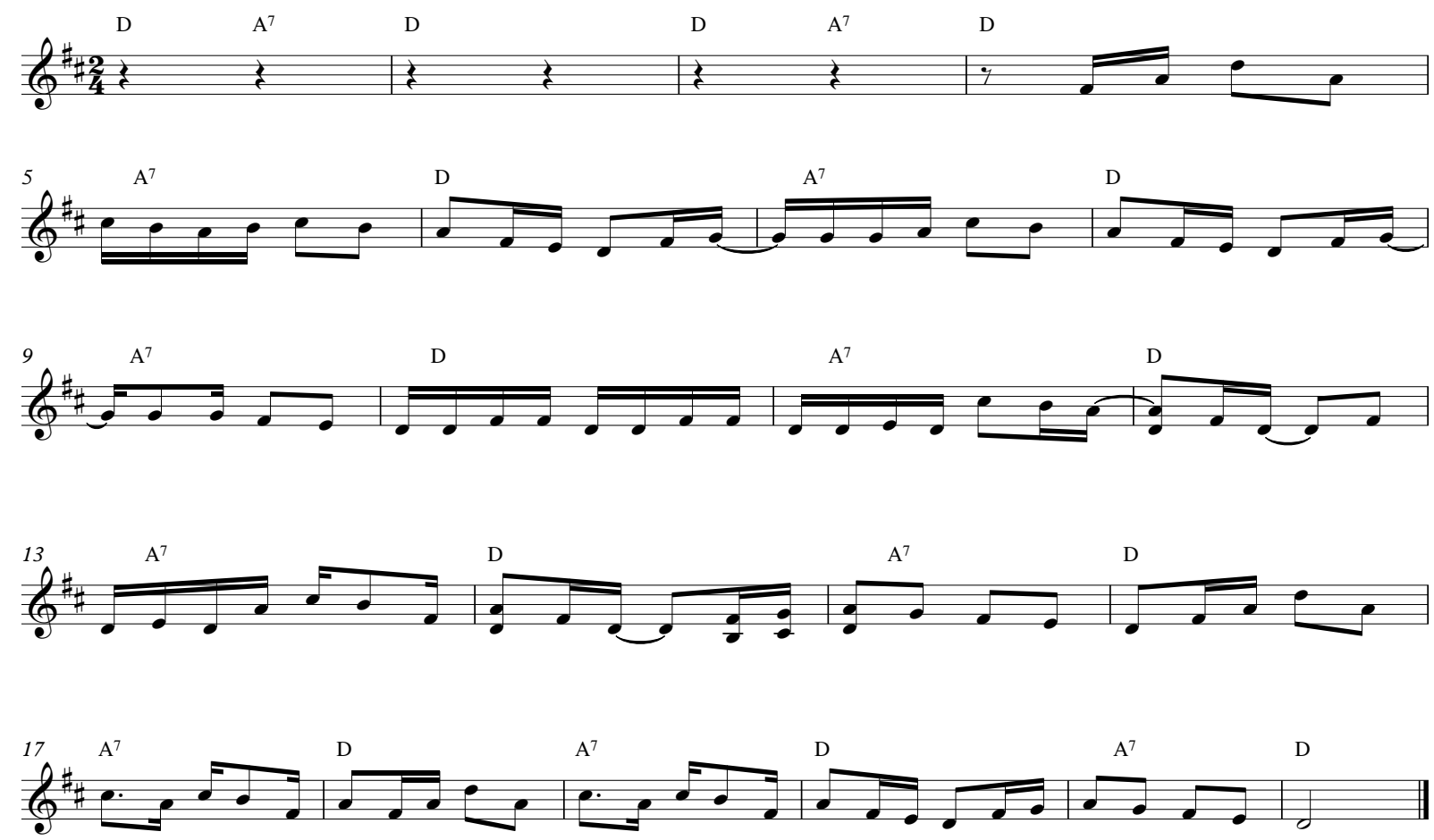

Figura 1.7 - Melodia de Dom-dom de Mestre Gabriel Martins

As melodias personificam seus autores e a bagagem comunicacional e geracional que lhes é intrínseca desde as pagas de mutirão até a contemporaneidade. Mesmo que o modelo de mutirão vicinal já não seja mais o principal responsável pela difusão e divulgação do fandango, as impressões que guardam seguem em dinâmica reprodução.

Análoga às quadrilhas francesas ou às linhas formadas por homens e mulheres na lavra do terreno que antecipa o plantio em atividade de mutirão vicinal são as formações dos pares que podem ser observados em uma apresentação artística de Xiba ou de Ciranda Caiçara ${ }^{14}$. Recria-se coreograficamente uma organização espacial que tem raízes em eventos não mais tão corriqueiros, enquanto outros se construíram a partir de experiências sensoriais de terceiros (como narram cronistas, clérigos e literatos) sobre os costumes culturais da burguesia europeia recriados no Brasil oitocentista. Traços culturais erigidos e consolidados no imaginário dessas

\footnotetext{
${ }^{14}$ Xiba[chiba], ciranda, fandango, função, bate-pé, baile, são aspectos relativos a eventos festivos ou pagas de mutirão relatados por folcloristas e pesquisadores com incidência múltipla no território caiçara, sendo algumas das denominações consolidadas em localidades distintas e assumindo, por essa razão, um caráter local e singular. Na atualidade, Chiba no Litoral norte de São Paulo, Ciranda no Litoral sul do Rio de Janeiro e Fandango nas demais regiões do estado de São Paulo e no Paraná.
} 
populações têm tamanha força, que continuam a ser perpetuados em linhas tangenciais do que podemos definir como suas "origens" ou seus "mitos de criação" mais recentes e ainda vivos na memória de seus artífices, como comenta Leonildo Pereira Pereira em entrevista para o documentário produzido pela equipe do Museu Vivo do Fandango.

O Pagamento era seu divertimento, você garrava dançar e dançar com todo mundo, e anoitecia e amanhecia, daí você ia pra casa contente e descansava. E esse é o contentamento do povo, uma coisa "origem", que eles falam, sei do quê, né? De família... A criar amor por aquela dança! (UNESCO, 2013, 1'48"2’20” - transcrição nossa)

Mesmo que a criação e descendência dos componentes referenciais da musicalidade, coreografia e instrumentação não sejam entendidos de modo consensual por seus principais pesquisadores de meados a fins do século XX, discussões presentes entre a origem espanhola ou portuguesa do folguedo levados a cabo por Inami Custódio Pinto e Roselys Roderjan, por exemplo, parecem úteis para que possamos entender que indiferente a tais "origens", o fandango continua acontecendo de modo dinâmico, fazendo desuso de determinados elementos e se apropriando de outros de modo contínuo. Parafraseando José Muniz em um dos subtítulos de sua dissertação, no que toca à "[des]necessária busca por uma origem europeizada do Fandango", localizando e compilando o que de histórico e etnográfico nos for de interesse, seguimos; e atentamos ao fato de que os estudos das estruturas musicais podem ter um papel proeminente para a compreensão dos processos de subjetivação dessas populações. "A música sempre está acompanhada de um sistema de organização sônica originada na imaginação de humanos" (BLACKING, 1974, p. 11 e 26), aspecto que desenvolvemos a seguir.

\section{Afinação, timbre, altura e localidade}

O campo harmônico e o entendimento das afinações pode, de fato, auxiliar nosso argumento de que determinados padrões e metapadrões sonoros se distribuem de modo razoavelmente uniforme, gerando singularidades resultantes da combinação de tradição e modernidade, aspectos eidológicos ${ }^{15}$ e etológicos, que, no momento presente, expõem a

\footnotetext{
15 O eidos de uma cultura é uma expressão dos aspectos cognitivos padronizados dos indivíduos, enquanto o ethos é uma expressão correspondente de seus aspectos afetivos padronizados. Ambas se baseiam na mesma dupla hipótese fundamental: de que os indivíduos em uma comunidade são padronizados por sua cultura, ao mesmo tempo em que as características gerais que a permeiam, aquelas repetidamente reconhecíveis em seus mais diversos
} 
estrutura cultural $^{16}$ na qual estão imersos os artífices do fandango caiçara.

Discorro, a seguir, sobre uma breve experiência vivenciada na Ilha de Superagui durante a festa do Divino Espírito Santo no ano de 2017:

$\mathrm{Na}$ Festa do Divino, diferentemente do período de romaria, em que os foliões se deslocam pelas ilhas e localidades baía adentro, por várias semanas, entre a Páscoa e Pentecostes, há uma mobilização colaborativa intercomunitária, marcadamente das comunidades anfitriãs. Nos últimos três anos, a festa tem acontecido de modo itinerante, reunindo representantes de todas as comunidades (encontro de bandeiras) onde a romaria passa durante a peregrinação, além de grupos artísticos convidados e turistas que descem de Curitiba e outras cidades para acompanhar as festas. A cada ano é sorteada a localidade que receberá a festividade no ano seguinte.

\author{
LÂMINA 1 \\ Encontro de Bandeiras na Barra do Ararapira, 2016, \\ na Ilha de Superagui, 2017, e em Pontal do Leste (Ilha do Cardoso), 2018 \\ Fonte: Acervo pessoal
}

\begin{abstract}
contextos, são uma expressão dessa padronização. Os conceitos de ethos e eidos sugeridos por Bateson podem ser considerados como subdivisão de um conceito mais geral, o de Configuração. A soma do ethos e do eidos - e aquelas características gerais de uma cultura que podem advir de outros tipos de padronização - compõem a configuração, dupla suposição inspirada no modelo proposto por Ruth Benedict. (BATESON, 2008, p. 95 e 96)

16 "Numa abordagem estrutural, expressões como mãe, metade, linha paterna etc. são consideradas abstrações generalizadas referentes aos aspectos estruturais de grandes massas de elementos culturais, isto é, elementos de comportamento padronizado. Usado nesse sentido, o termo estrutura está intimamente relacionado, em seu significado, com o termo tradição. Mas este último tem suas desvantagens; está evidentemente deslocado em qualquer análise sincrônica, pois, em tal análise, a origem histórica de qualquer detalhe cultural é irrelevante. Apesar disso, a palavra tradição às vezes se insinua nos estudos sincrônicos. Nesses contextos, ela deve ser claramente despojada de toda referência ao passado ou a processos diacrônicos. Assim despojada, a "tradição" só pode significar os fatos dados de uma cultura, fatos que são "dados" como premissas. Assim, por vezes, a palavra tradição é usada na análise sincrônica como um sinônimo para estrutura cultural, tal como aqui definida." (BATESON, 2008, p. 88)
\end{abstract}


$x<5$

t5.

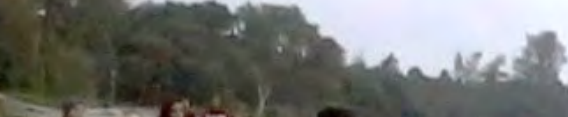

S.

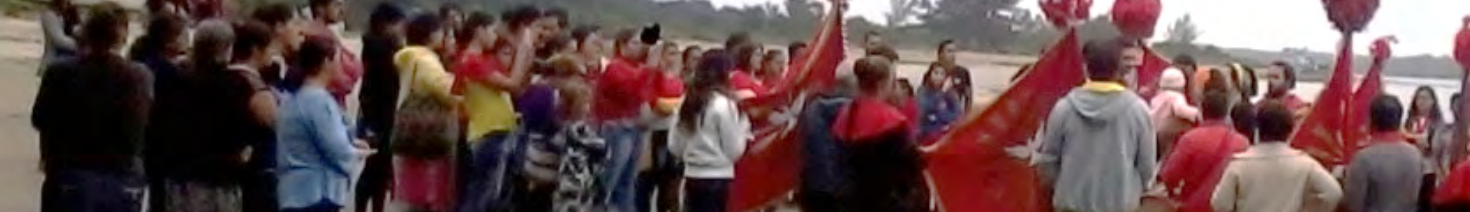

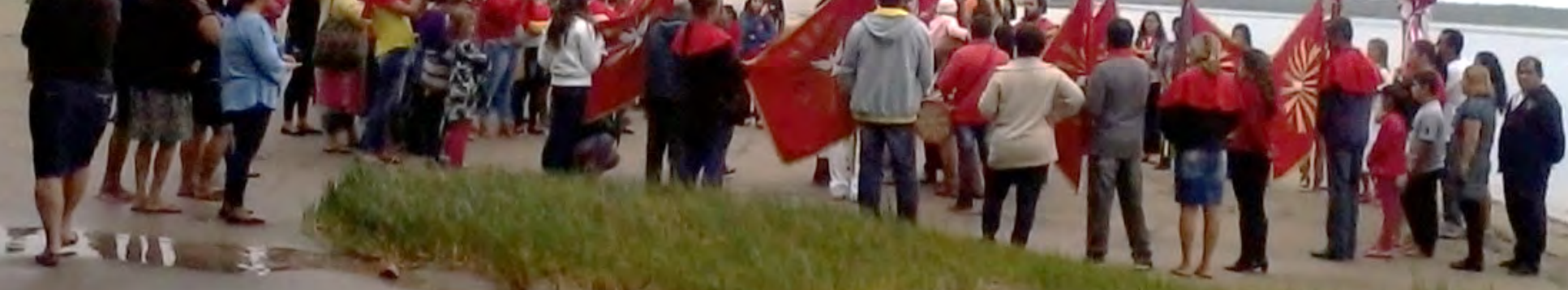

1 tas

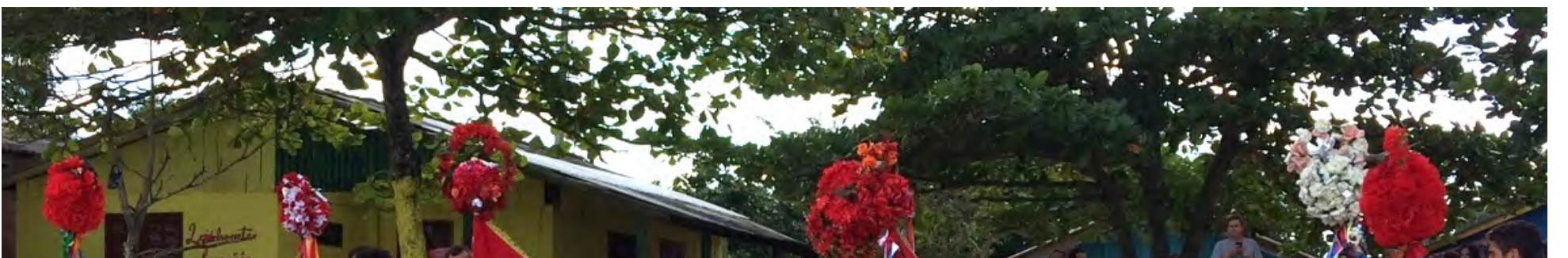

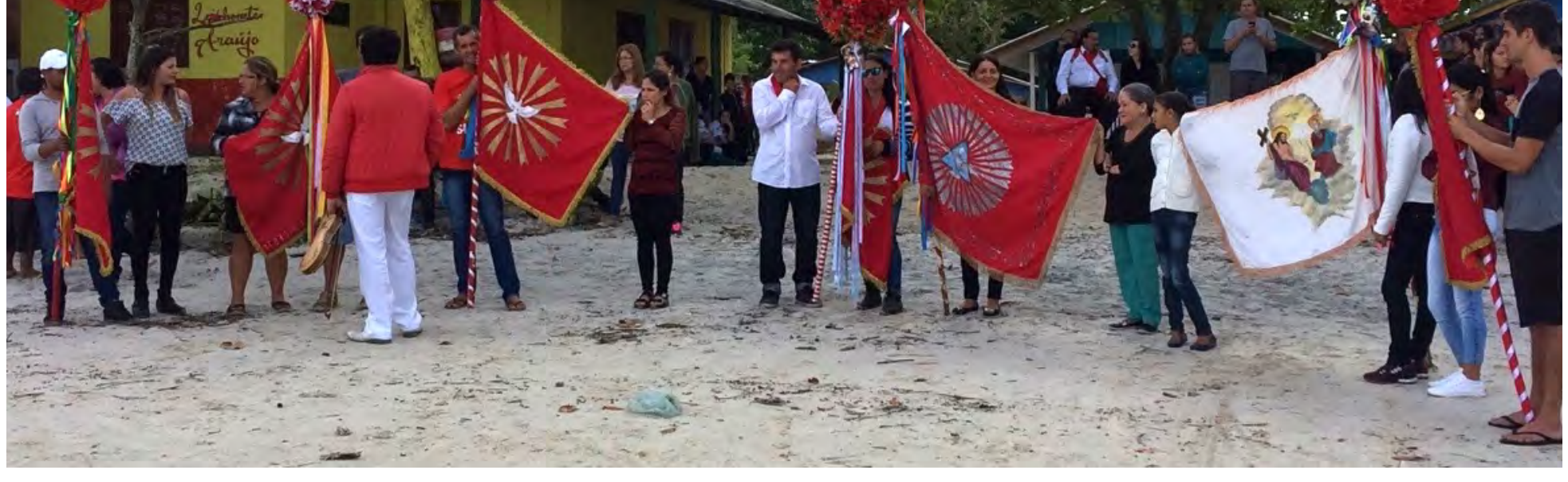

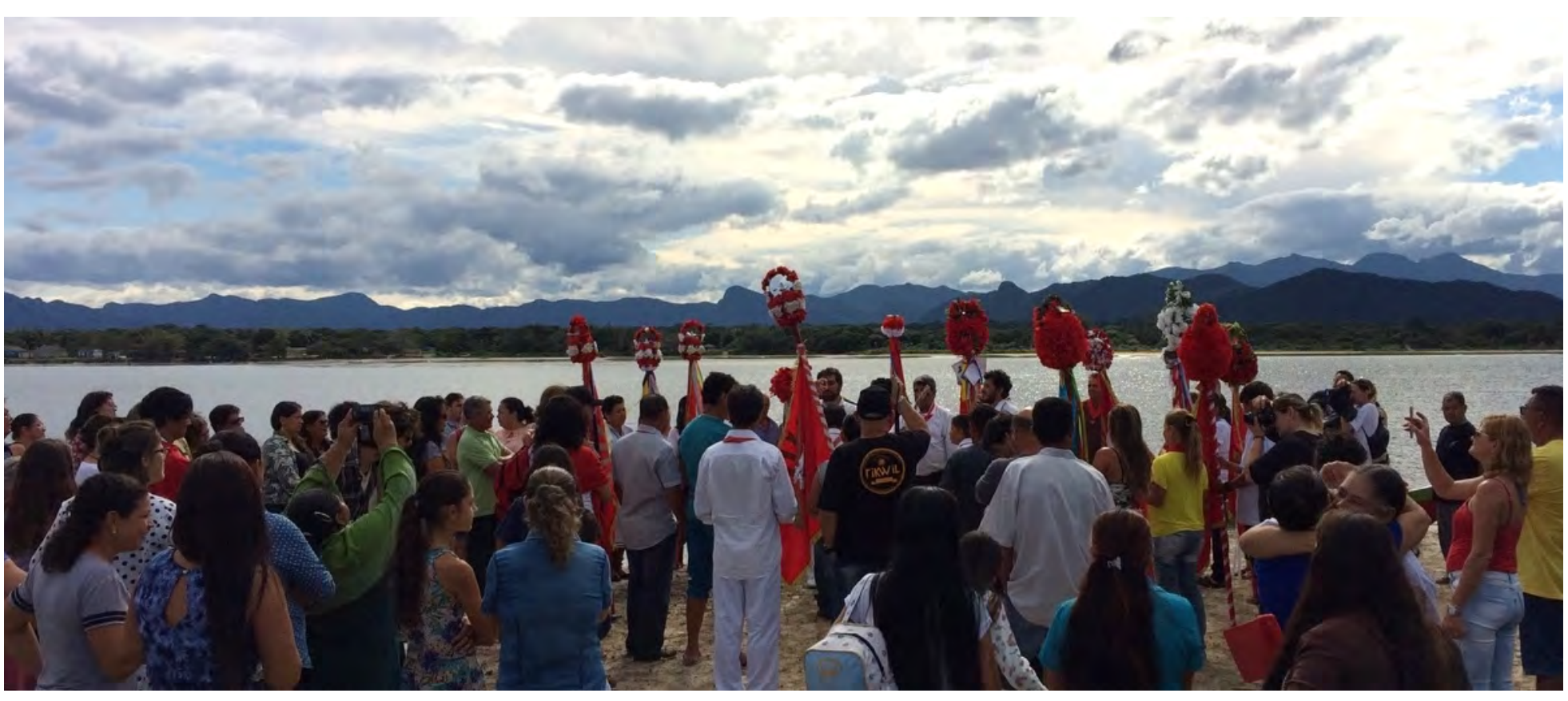


Após nossa chegada na Ilha de Superagui (naquela ocasião estava acompanhado por esposa e filhas), logo nos dirigimos ao pátio onde estava sendo organizado o salão para festa.

Figura 1.8 - Montagem das estruturas para a Festa do Divino, em Superagui, 2017
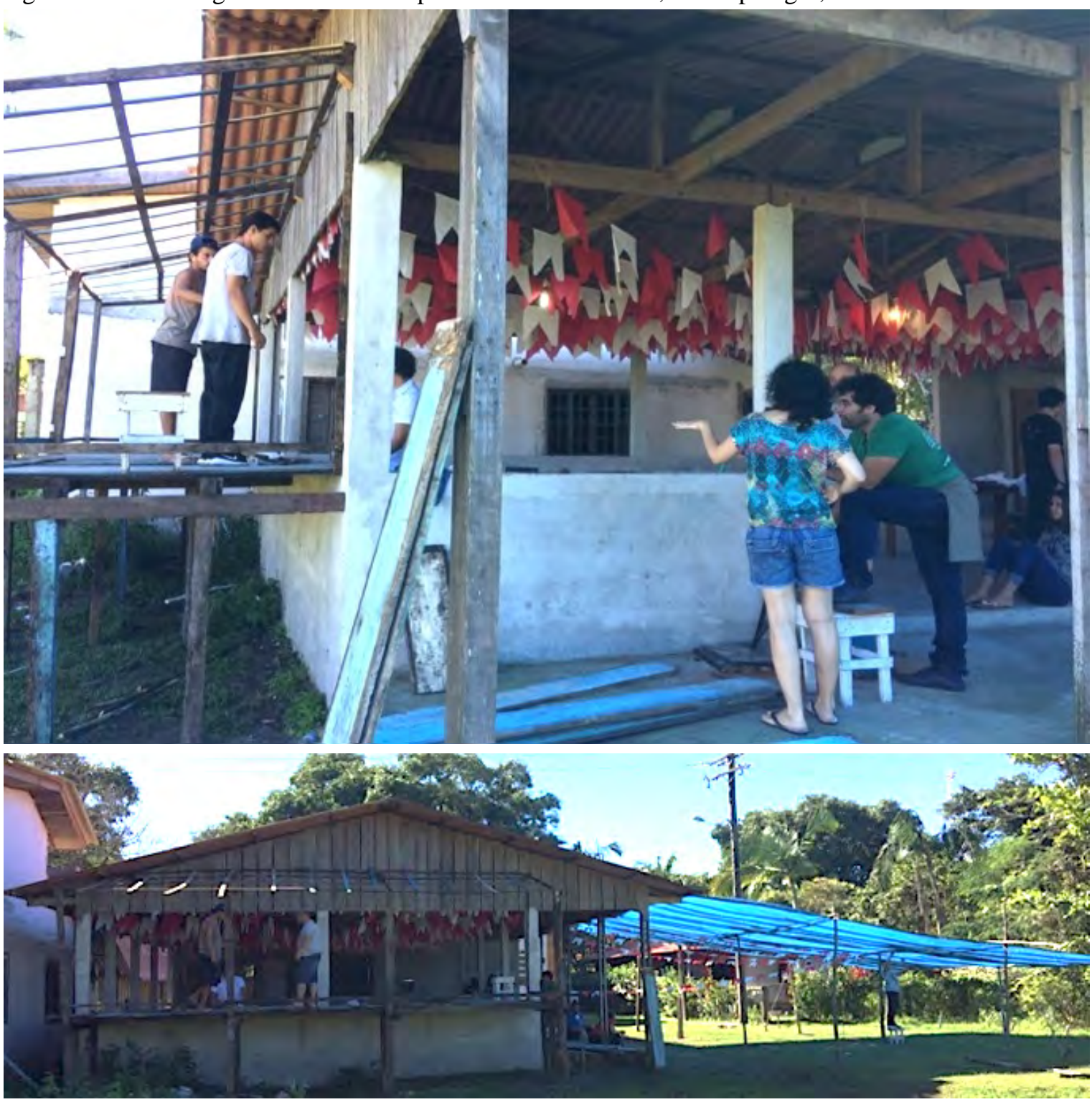

Fonte: Acervo Pessoal

A festa correu por interesse e colaboração coletiva da comunidade católica da Ilha de Superagui e demais comunidades envolvidas, somadas a voluntários, bolsistas de projetos de extensão universitária (UFPR/IFPR), amigos e demais simpatizantes.

O local escolhido para a festa foi o salão paroquial que fica nas redondezas da capela. Anexo ao salão de baile, foram montadas estruturas em madeira, bambu e lona, tanto para acomodar os músicos que iriam tocar na festa como para proteger a audiência das intempéries 
durante a jogatina de bingo ${ }^{17}$ e alocar, de modo confortável, as barracas de alimentação, além das mesas e cadeiras.

Em nosso primeiro dia na comunidade, auxiliamos nos preparativos cortando bambus, esticando lonas, aterrando as depressões no terreno, cortando e colocando bandeirinhas, montando a estrutura do palco, cabos de força, sistema de áudio e iluminação. Nessa atividade pudemos compartilhar com os envolvidos a prática do mutirão: todos estavam participando das atividades com um fim comum, em prol do bom andamento da festa e para melhor atender os convidados das comunidades adjacentes que já começavam a chegar na ilha.

Na programação, estava prevista uma noite de baile, a noite de sábado. O grupo Raízes Fandangueiras abriu os trabalhos com o grupo de crianças, seguido pela apresentação do grupo de jovens e de bailes com os grupos Mandicuera (PR) e Manema (SP). Já tendo passado das três horas da manhã, o baile seguia animado, mas como teríamos que fazer ainda muitas casas com a romaria na manhã seguinte, vários dos músicos já haviam se recolhido. Nesse momento, me animei para auxiliar o grupo Manema, de Iguape, no instrumental, com o intuito de que seguíssemos um pouco mais com o baile. ${ }^{18}$ Por descuido, não havia conferido a afinação do conjunto. Apesar do machete estar afinado (individualmente), ao atacar num dom-dom fiquei estarrecido, soando muito desafinado; mais precisamente, um intervalo tonal de $2^{\mathrm{a}}$ maior abaixo do conjunto! De imediato, conferi a afinação com "Esquerda" (Laercio Alves de Lima, que toca machete com o pessoal do Manema) e percebi que a afinação toda se dá um tom acima do que se utiliza usualmente nas localidades paranaenses.

Depois de afinar meu instrumento com o conjunto, "temperando" a coisa toda, seguimos o baile. Encerradas as funções artísticas, passei rapidamente na casa em que estávamos hospedados, tomei um banho e nos deslocamos para a alvorada ${ }^{19}$, por volta da 5:30 da manhã,

\footnotetext{
${ }^{17}$ O bingo ocupa um lugar importante nas festas comunitárias, momento de confraternização e lazer muito apreciado nas comunidades litorâneas, e também um componente constitutivo da sociabilidade inerente ao universo fandangueiro.

${ }^{18}$ Venho acompanhando há mais de cinco anos as festas e peregrinações do Divino Espírito Santo no litoral do estado do Paraná, nos últimos dois anos como folião aprendiz, tocando viola ou machete e, ocasionalmente, fazendo a voz de tenor (que aliada à voz de mestre e de tipe, formam a estrutura vocal da manifestação). "O mestre que puxa os versos, o contralto ou tenor realiza uma segunda voz e o tipe faz a voz mais alta." (MIGUEZ, 2017, p. 106). Nesse sentido, Miguez se vale de comentários de Kilza Setti, indicando a evidente reminiscência medieval na conformação das práticas vocais na romaria: "Um dos sintomas da permanência das práticas medievais na nossa música de tradição oral transparece através do uso de palavras como, por exemplo, tipe ou tripe. O motetus francês do século XIII utilizava a voz principal (tenor), que propunha o canto. O contralto, medius cantus ou duplum se sobrepunha ao tenor, com canto possivelmente de origem profana. $\mathrm{O}$ tertius cantus discantus ou triplum se sobrepunha aos dois outros com melodia diferente." (SETTI, 1985, p. 181).

19 “A Folia acontece diariamente durante o período de Ave Maria, iniciando às 6h da manhã, com a alvorada, e terminando às $18 \mathrm{~h}$ com o encerro ou fechamento das bandeiras. Se, ao longo do trajeto passamos por uma casa perto das $18 \mathrm{hs}$, é lá que as bandeiras vão passar a noite, pois não se faz cantoria depois desse horário. Se as bandeiras dormem nessa casa, a alvorada no dia seguinte, às 6hs, é realizada lá. O que os romeiros pedem é que a
} 
seguindo de casa em casa no intuito de finalizar as visitas da peregrinação das bandeiras naquela comunidade.

Romaria, cafés, encontro de bandeiras: o percurso do Divino. No dia de domingo, mastro derrubado e funções religiosas encerradas, houve um alvoroço por parte da comunidade. Sabendo que muitos fandangueiros haviam permanecido na ilha, alguns solicitaram veementemente que acontecesse novo baile, pois poderiam, assim, desfrutar de mais uma noite de confraternização e fazer novo bingo com as prendas ainda não distribuídas. A princípio, mantive-me agregado à audiência, vendo tudo acontecer; novamente as crianças começaram a função acompanhadas por músicos de Paranaguá e Superagui. Ao ouvir os primeiros ataques das violas, percebi que um dos violeiros de Superagui estava demasiado fora do contexto harmônico, e tentei acompanhar visualmente as posições executadas na viola, apenas sentindo a desafinação. A manifestação dos demais músicos quanto ao problema (olhares e expressões faciais) foi comedida, controlada. Sendo assim, tomei lugar na mesa de som sem maiores transtornos.

Passada a apresentação das crianças, o baile seguiu. Quando estávamos novamente nos preparando para tocar, reunindo músicos presentes de diferentes localidades, aproximei-me de Herbert dos Santos (o violeiro em questão), que havia se deslocado até a escadaria da capela no intuito de afinar seu instrumento, valendo-se de um aplicativo de celular. Neste momento entendi o problema: ao questionar Herbert sobre como utilizava o afinador virtual, constatei que ele afinava o conjunto de cordas quase meio tom abaixo do usual (digo quase meio tom, pois a referência visual no aplicativo apontava a nota dó sustenido acrescida de 30 cents $^{20}$ ). Ele discorreu então que, quando aprendeu, não sabia afinar o instrumento e, sempre muito atento aos velhos mestres da família Pereira, em especial "Seu" Leonildo, teve o cuidado de anotar corda por corda de acordo com o modo com que o mestre afinava sua viola.

Como pode ser constatado em toda produção discográfica e, de maneira geral, nos bailes onde toca a família Pereira, esse coletivo utiliza a afinação mais baixa que a dos grupos de Paranaguá.

Ciente do problema, expliquei a ele como utilizar o afinador de modo a calibrar o instrumento em $440 \mathrm{~Hz}$, o que facilitaria a interação com os demais grupos, que, nesse caso, se

\footnotetext{
família onde a bandeira pernoitar abra a casa às $5: 30,5: 40 \mathrm{hs}$, do dia seguinte para que os foliões cheguem a tempo de afinar os instrumentos e tomar o intiruma, um café preto. O café gordo deve ser servido apenas depois de feita a alvorada." (COELHO, 2018, p. 6)

${ }^{20}$ Unidade de medida relacionada à percepção humana cujas respostas se dão de modo logarítimico. Equivalente a fração de 1/100 de um meio tom da escala temperada. A distinção de tais intervalos no ouvido humano é de aproximadamente 2 ou 3 cents.
} 
valiam deliberadamente de afinadores digitais e celulares para temperar os instrumentos. Afinamos viola e machete e nos juntamos ao novo grupo que se formava naquele momento. Aorélio na rabeca, Gilvan na caixa, Hely no baixo, eu no machete, Herbert na viola, Poro e Magrinho revezando no adufe!

Esse pequeno relato demonstra de que maneira os padrões de percepção da altura (frequência) e os métodos empregados na afinação apresentam variantes de interesse: 1. O respeito e atenção dos mais jovens quanto ao modo tradicional de utilizar os instrumentos, pois, no caso da família Pereira, a afinação instrumental se dá em temperamento próprio, não necessariamente utilizando o padrão de afinação em $440 \mathrm{~Hz}$; 2. Não temperar os instrumentos nessa faixa de frequência não quer dizer que tais grupos instrumentais executem sua performance de modo desafinado, pelo contrário, temperar os instrumentos individual e coletivamente é característica básica de bons violeiros e dos grupos de fandango de modo geral; 3. A utilização de ferramentas tecnológicas nem sempre cumpre sua função a contento, sendo necessário o entendimento dessas ferramentas para melhor lhes tirar proveito.

No tocante às reminiscências organológicas replicadas ainda na atualidade, o modo de afinar os instrumentos, as ordens das violas e as formas utilizadas como referência ao trabalho de luteria se fundem à prática fandangueira como padrões a serem seguidos, que, se relacionados a outros padrões de uso corrente em outras localidades do território caiçara, mostram-se como metapadrões que constituem uma rica diversidade, construída também pelos cruzamentos, trocas e trânsitos, consolidando a configuração organológica contemporânea do fandango.

Indiferente da altura em questão, o aparato mecânico organológico dos instrumentos, por si só, indica quais os harmônicos que devem soar, havendo casos, inclusive, em que os músicos temperam seus instrumentos com as cordas presas nas posições de execução (na $5^{\mathrm{a}}$ casa da viola), prezando pela melhor relação de intervalos de frequência e sua audibilidade.

As variações locais das violas brancas ${ }^{21}$, utilizadas pelas populações caiçaras, acarretam, por exemplo, o uso de diferentes formas de acordes e afinações, intaivada, pelo meio e pelas três, no uso de cordas com diferentes bitolas e em distintos métodos de confecção (cavoucado e com aros). Ronaldo Tinoco Miguez (2014, p. 39) e Daniella Gramani (2009, p. 30) fazem comentários a esse respeito: "O fandango se toca com formações de acorde a partir da quinta casa e, na Folia do Divino e no Boi-de-mamão, são usadas posições abertas." Nesse

\footnotetext{
${ }^{21}$ Instrumento central do fandango caiçara, também conhecida por viola fandangueira, viola de fandango ou viola caiçara.
} 
sentido, entendem a diversidade da musicalidade caiçara e os pormenores e particularidades inerentes à afinação dos instrumentos: "para o violeiro tocar uma moda de fandango e depois tocar uma da Folia do Divino, ele tem que acertar detalhes da afinação, que irão fazer com que ela afine em um ponto ou outro do braço." (DIEGUES, 2006, p. 320). Esse fator também é observado na rabeca, cuja terceira corda ${ }^{22}$ é diminuída em um tom durante as atividades da romaria do Divino Espírito Santo, configuração que aproveita a corda solta que se converte em frequência tônica do campo harmônico utilizado pelos foliões. Das distintas afinações e das particularidades na formação de acordes usuais no fandango caiçara, uma conversa com mestre Waldemar Cordeiro, saindo de um baile realizado na casa do fandango de Mestre Eugênio, na Ilha dos Valadares, pode nos ser esclarecedora.

Waldemar: A minha viola é pelo meio!

Mas eu toco pelas três também, só que pelas três a gente não tá acostumado, sabe?

Eu aprendi pelo meio, toda vida. O nosso lugar aqui [Valadares], não tocava inativado, tocava só pelo meio, só.

Ary Giordani: - O senhor é nascido aqui mesmo [em Valadares]?

W: - É!

A.G.: - "Seu" Eugênio tocava pelo meio?

W: - É "Seu" Eugênio tocava pelo meio.

A.G.: - Ué, porque Aorélio não toca pelo meio, será?

W: - Ele já aprendeu assim. Em Guaraqueçaba a turma toca só inativado. O Zeca toca inativado também.

A.G: Agora eles fizeram essa viola menor [meia viola], e Aorélio comentou que, nessa, iria ficar melhor se afinar ou pelo meio ou pelas três, diferente a bitola da corda, toca com ela mais "aberta", [cordas soltas]. Isso?

W: - Pelas três é difícil, rapaz, faz tempo que não toco pelas três, antes até tocava.

A.G.: - Tudo bem, também...

W: - O importante é o tal ritmo, né?

A.G.: - Eu aprendi esse intaivado ${ }^{23}$ no machete, mas ali em Cananéia e Iguape, eles já usam diferente, eles afinam mais alta a primeira corda, ali, em baixo[aguda], mas não dei conta de trocar, não. Tava indo bem, assim.

W: - Ó, tá, tá. Tá ótimo, rapaz, pô!

- A pessoa acompanha bem com a viola.

\footnotetext{
${ }^{22}$ Há variabilidade do número de cordas na rabeca caiçara, sendo comum a utilização de instrumentos com três ou quatro cordas. No caso mencionado anteriormente, a alteração se dá na corda mais grave do conjunto, a terceira ou quarta corda, dependendo da característica do instrumento.

${ }^{23}$ De uso corrente em Paranaguá, na afinação intaivada, os instrumentos apresentam a seguinte configuração (por convenção do agudo ao grave): Viola Branca - $1^{\mathrm{a}}$ corda Lá $2,2^{\mathrm{a}}$ Mi 3, $3^{\mathrm{a}}$ Dó $3,4^{\mathrm{a}}$ Sol 1, $5^{\mathrm{a}}$ Ré $1,6^{\mathrm{a}}$ (meia corda, turina) Lá 3; Rabeca - $1^{\text {a }}$ Lá 4, $2^{\text {a }}$ Ré 4, $3^{\text {a }}$ Lá 3; Machete $-1^{\text {a }}$ Lá 4, $2^{\text {a }}$ Fá\# 4, $3^{\text {a }}$ Ré 4 e $4^{\text {a }}$ Lá 3 . Devido ao constante trânsito e interação com fandangueiros de Iguape, nos últimos bailes que toquei com o grupo Mandicuera houve experimentações no intuito de subir a afinação em um tom. Aorélio Domingues alega que tal alteração dá mais brilho na voz, além de facilitar as trocas artísticas com o pessoal de São Paulo. Salvo a experimentação citada, com o Mandicuera, seguimos utilizando o Ré Maior como centro tonal, já com o Herbert e o pessoal de Guaraqueçaba, com quem temos tocado frequentemente em Curitiba, é usual afinarmos em Dó\# (Db).
} 
"Dona" Ditinha: Porque você não vem um dia ali em casa? Aí, ele toca e você aprende. (risos)

W: - Eu aprendi a tocar no machete, depois foi a meia viola, viola $3 / 4$ e aí a viola grande.

- 3/4 é pequena, um pouquinho maior que o machete.

- Eu gosto de tocar viola com a pessoa que me entenda, sabe? Eu gosto de arrepiar, sabe? Não gosto de ficar mamando na viola, eu gosto de chegar e dálhe! (Conversa com mestre Waldemar em 12/01/2019 - transcrição nossa)

Graciliano Zambonim foi assertivo ao concatenar os processos de afinação de violas e rabecas que constam na cartilha elaborada pela equipe do projeto Fandango na Escola:

A afinação da rabeca é uma relação de quinta do acorde (corda mais grossa), tônica (corda do meio) e a corda fina é a quinta, porém oitava acima da corda grossa. As Violas e as rabecas têm alturas relativas, registramos afinações com alturas em lá, outras até em ré sustenido. Sabemos que a altura varia de acordo com a voz e com o tipo da viola. Frequentemente, as violas pelo meio estão entre lá e dó, e as entaivadas [intaivadas], entre dó e ré sustenido. Como a altura depende da ocasião, catalogamos os acordes e os nomeamos como: t para tônica, t 2 tônica com $9^{\mathrm{a}}$ maior, t 4 tônica com quarta justa, t6 tônica com $6^{\mathrm{a}}$ maior, d para dominante, d2 uma variação da dominante. (FANDANGO NA ESCOLA, 2010 [2007], p.33)

Figura 1.9 - Tabela de posições pelo meio e intaivada, de Graciliano Zambonin

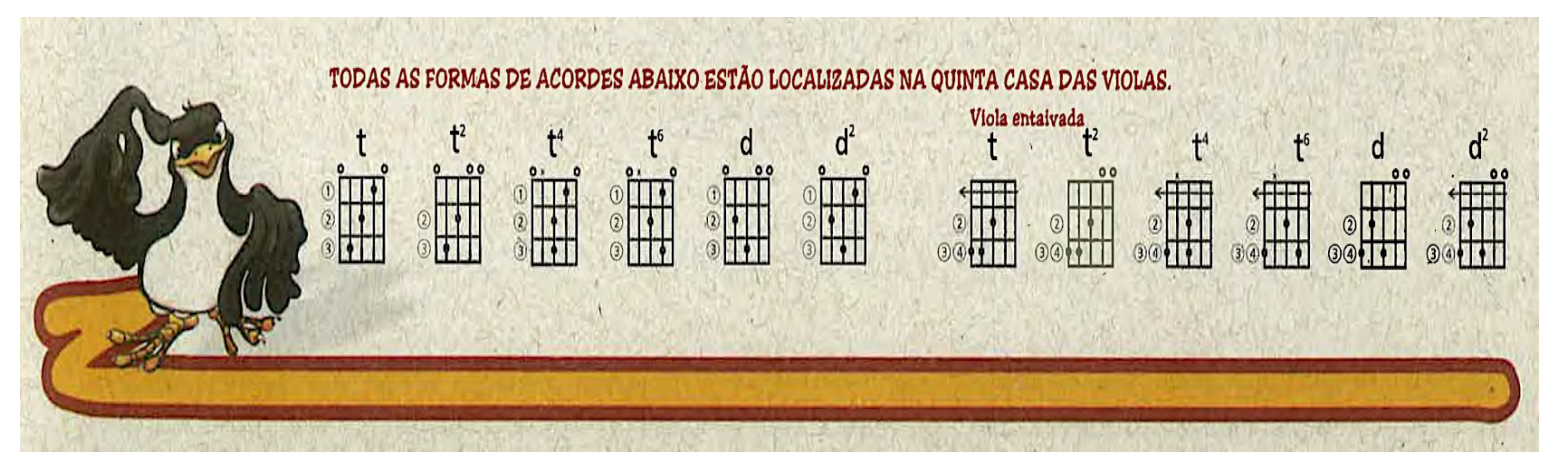

Fonte: (FANDANGO NA ESCOLA, 2010 [2007], p.33)

Cabe ressaltar que ambas as afinações [pelo meio e enativada] se valem dos mesmos intervalos em sua configuração, atentando ao fato da utilização de cordas mais finas no $5^{\circ}$ par, como me esclareceu mestre Zeca Martins: "Muda a bitola da corda que eles [que tocam pelo meio] usam. Só muda o dedo ali, que você dexa uma corda bamba [ $5^{\circ}$ par]. Colocam a $5^{\mathrm{a}}$ e a $6^{\mathrm{a}}$ da viola; já nós usamos mais grossa". (Cadernos de campo - 27/04/2019 - transcrição nossa)

Entendendo a música como evento que modela o tempo, como propõe Deleuze, poderíamos aventar que as gamas de frequências mais baixas utilizadas pela família Pereira, por exemplo, fazem alusão ao tempo vivenciado cotidianamente por seus atores, não apenas em relação ao diapasão, mas também ao andamento. O Fandango da família Pereira é marcantemente mais lento, entre 110 e 118 bpm, em relação às performances de grupos de 
Paranaguá, Iguape e Paraty, sobretudo daquelas formações mais jovens em que os andamentos geralmente são superiores à 120 bpm, alcançando picos de 140 bpm ou mais, dependendo da animação no baile. Como pode ser elucidado nas cifras que se seguem.

\section{Arara}

Grupo Os Sete Unidos da Ilha das Cobras

Domínio Público
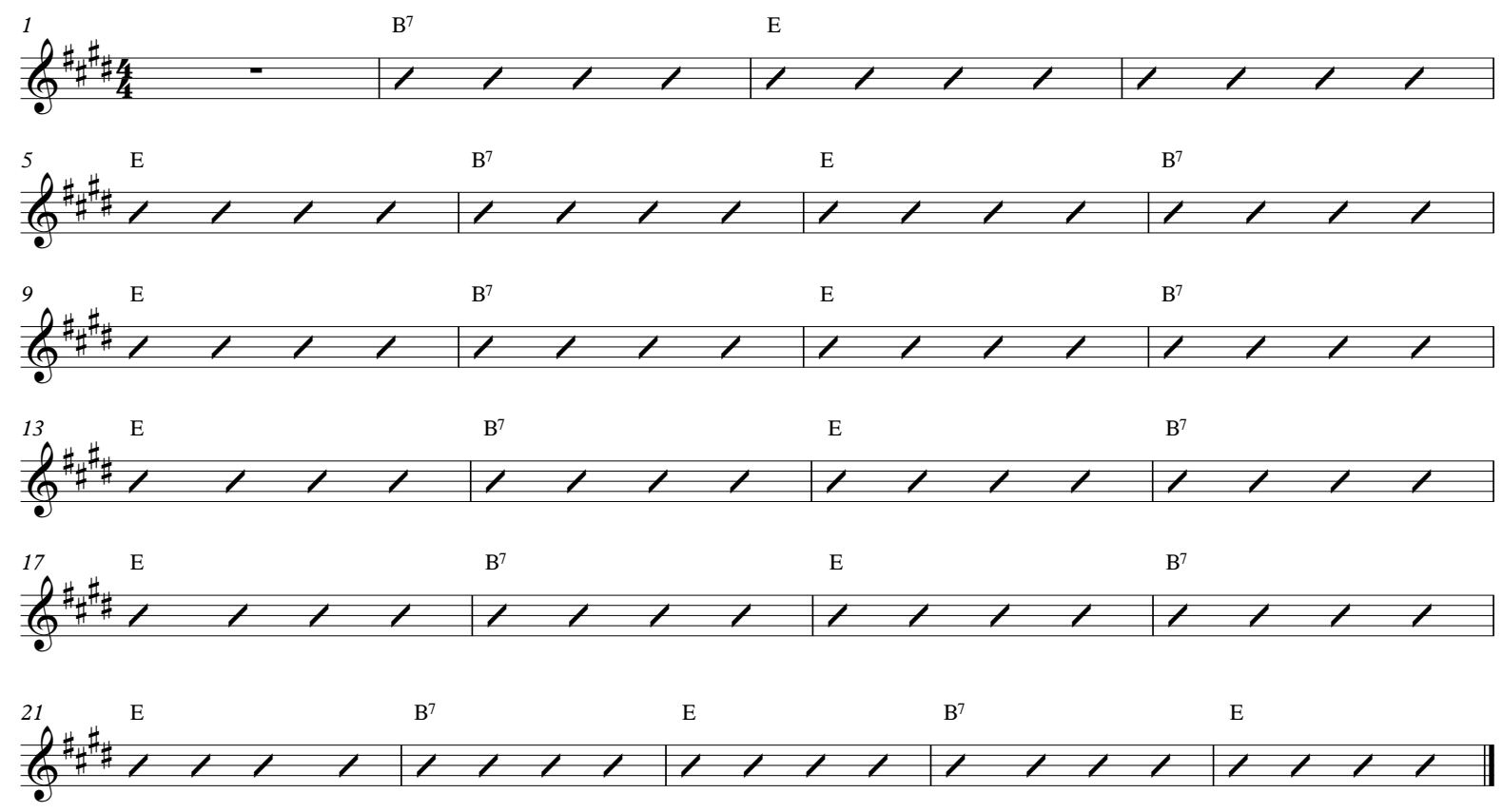

Figura 1.10 - Cifra da moda Arara, executada pelo grupo Os Sete Unidos da Ilha das Cobras, Paraty, RJ. 
Noite de luar

Família Pereira

Domínio público .$=112$

${ }^{\mathrm{A} b^{7}} \mathrm{Db}^{\mathrm{b}}$ (n) $a_{b}^{b}$ (3) (ab) $a^{b} b_{b}$

$A b^{7}$ (25) (29) $33 \quad \mathrm{D} b \quad \mathrm{~A} b^{7} \quad \mathrm{D} b \quad \mathrm{Ab} b^{7}$ $\begin{array}{llll}2 . & \mathrm{A} b^{7} & \mathrm{D} b & \mathrm{~A} \mathrm{~b}^{7}\end{array}$ G (2) (c) (n) $\begin{array}{lllll}\mathrm{D} b & \mathrm{~A} b^{7} & \mathrm{D} b & \mathrm{~A} b^{7} & \mathrm{D} b\end{array}$

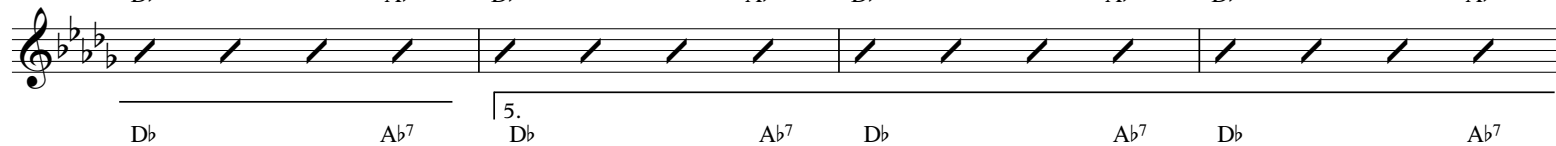
G $\frac{a_{b}}{2 / 2}$

$\mathrm{D} b$

$\mathrm{A} b^{7}$ $\mathrm{D} b$

$\mathrm{Gb}$

Figura 1.11 - Cifra da moda Noite de Luar, executada pela família Pereira, Guaraqueçaba, PR. 
A volta que o mundo dá

Grupo Manema
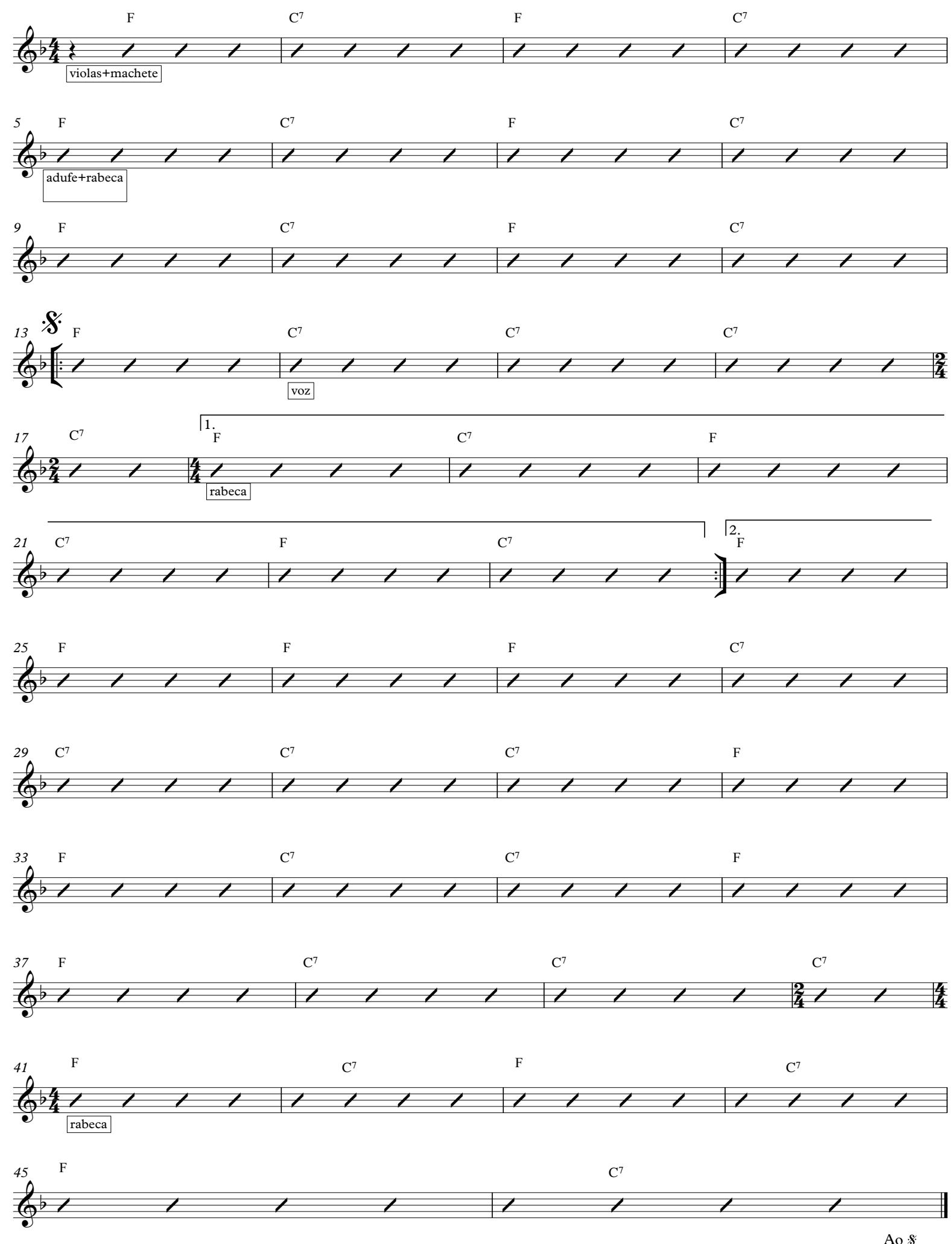

Figura 1.12 - Cifra da moda A Volta que o Mundo dá, executada pelo grupo Manema, Iguape/Peruíbe, SP. 
O aumento da velocidade das modas parece acompanhar os fluxos de urbanização, nos quais a distribuição do tempo, cada vez mais compactado às necessidades individuais, em um cenário de constante embate entre tempo e produtividade, dá-se em consequência daquilo que o regime presentista impõe à vida das organizações e das pessoas, denominado por Lipovetski como "conflitos de tempo e crono-reflexividade". Lipovetsky argumenta que a sociedade hipermoderna se apresenta como "a sociedade em que o tempo é cada vez mais vivido como preocupação maior; a sociedade em que se exerce e se generaliza uma pressão temporal crescente." (2004, p. 75)

Sob uma ótica conservacionista, a reclusão de atores em determinadas áreas geográficas poderia garantir a continuidade de tais modelos sonoros. Podemos conceber tal assertiva como plausível, apenas em parte. A interação é contínua e se modela a cada novo passo, a eletricidade a motor ou a energia fotoelétrica "inventa" novos modelos de sociabilidade, nos quais, por exemplo, a oferta de gelo, torna-se crucial ao cotidiano mercantil da pesca artesanal. Assim, detentores dessa materialidade [gelo] tomam espaços privilegiados na estratificação que se dá nos domínios das localidades de maior isolamento, como na Barra do Ararapira e Vila Fátima (Superagui) ou no Marujá (Ilha do Cardoso).

Cabe mencionar que mesmo essas localidades de maior isolamento vêm interagindo cada vez mais com as novas tecnologias, nomeadamente pelos avanços da telefonia celular móvel e pela interatividade virtual fomentada pelas redes sociais virtuais e por aplicativos multiplataforma (nomeadamente via Facebook e WhatsApp). A imagem e o som têm valor efetivo na construção de narrativas, do local ao global, desde as mais singelas felicitações por datas comemorativas às mais obscuras técnicas de manipulação social e psicológica a partir do acesso não autorizado e do cruzamento de dados pessoais coletados na rede (firehosing, spam e phishing). Por ora, iremos nos ater ao fato de que tais tecnologias têm possibilitado, cada vez mais, a proximidade entre atores culturais no litoral, não apenas no âmbito virtual, como também em ações concretas concatenadas remotamente, como no caso da organização das festas, grupos de trabalho para elaboração e execução de projetos, acompanhamento e fiscalização de políticas públicas entre outros.

O intenso intercâmbio entre atores de duas localidades do litoral caiçara - Iguape e Paranaguá - pode nos servir de exemplo no que se refere às dinâmicas de tempo na musicalidade caiçara.

A emergência do fandango pancada como estilo não apenas insere o componente eletrificado ao instrumental (baixo elétrico), como também propõe aceleração no pulso das modas. A evidência das frequências graves e subgraves se dá não somente pela presença do 
baixo elétrico nas modas bailadas, mas também por encorpar o bufo (os graves das violas), graves esses que, como veremos adiante, também têm sido buscados nos processos de manufatura dos instrumentos.

Tais aspectos são vistos com desconfiança por parte dos fandangueiros de mais idade, que defendem o modo "tradicional” de divulgação e difusão da cultura caiçara em suas práticas. É corriqueiro o desdém às "novidades" em comentários alegando que esse tipo de baile "não é fandango", e são escutados reiteradas vezes, sejam vindos de integrantes de grupos de maior idade, sejam por atores como "Seu" Laurentino, proprietário do Akidov, um dos redutos de encontro de fandangueiros na Ilha de Superagui. Em tom de revolta, repetia considerações semelhantes nos dias de baile na festa do Divino, quando também foi realizado o prélançamento do disco Amanhece, de Aorélio Domingues ${ }^{24}$ concomitante à festa.

$\mathrm{Na}$ atual conjuntura, a resistência quanto à inserção de novos instrumentos, inclusive os elétricos (no caso do baixo), já começa a se diluir em meio à transição geracional. Sendo válido mencionar que a utilização de instrumentos cujas histórias e descendências guarda na forma, na imagem e na relevância sígnica e simbólica, outros capitais para além da manufatura propriamente dita.

Assim, por exemplo, o processo de formação de um violeiro ou rabequista também diz sobre a trajetória de vida destas pessoas. Questões como onde se aprendeu, quem ensinou, de que modo acessou esses conhecimentos, são balizas importantes para compreendermos os modos pelos quais suas violas e rabecas serão tocadas, além dos repertórios possíveis e das redes acionadas para se chegar a tais aprendizados. (MARTINS, 2018, p. 147)

\footnotetext{
${ }^{24}$ Ver Capítulo 6 - O Fandango na Era Fonográfica.
} 
Figura 1.13 - Violas e rabecas

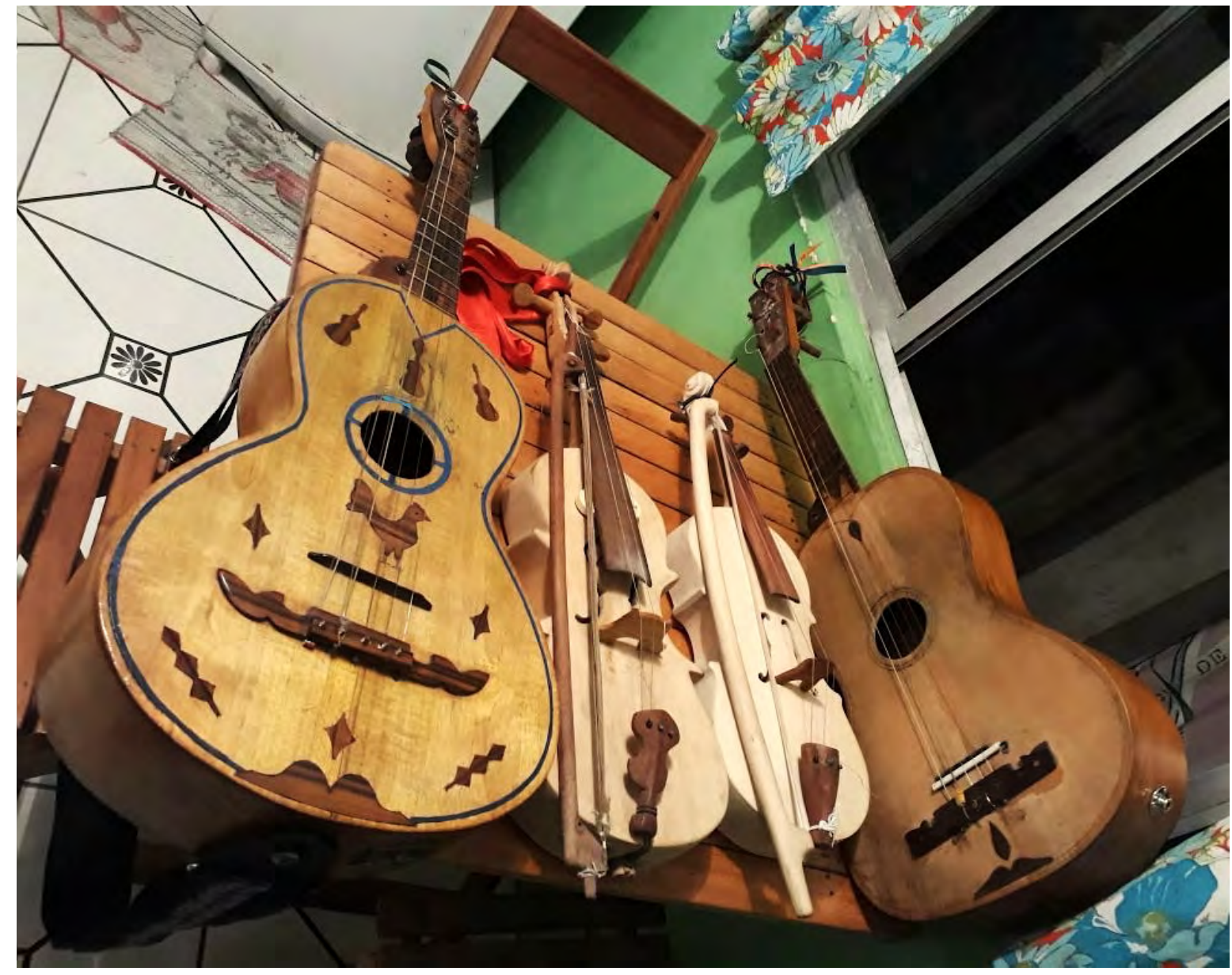

Fonte: Foto de Aurério Gasparini Júnior - Acervo pessoal.

Nesse sentido, há uma movimentação por parte dos detentores mais jovens, no intuito de atualizar os antigos modelos de construção, de maneira que o "melhoramento" dos instrumentos mais antigos se dá na retificação de partes como pestanas, espelhos, contrabraços, trastes ou cravelhas, ou ainda em sua eletrificação.

No barco, voltando do $1^{\circ}$ Encontro de Fandangueiros do Marujá, na Ilha do Cardoso (município de Cananéia), realizado em janeiro deste ano de 2019, Babico (Aurélio Gasparini Junior) comentava o dia em que Zé Muniz pediu para que ele eletrificasse a viola que pertenceu ao avô de Marcelinho, de Guaraqueçaba. Mesmo sendo "só um furinho", Babico conta haver levado um beliscão de Zé Muniz no momento da perfuração. Na figura 1.13, a viola da esquerda é a de Marcelo, a qual pertencia a "Seu" Faustino, e a da direita, é a viola de Zé Muniz, que pertencia a "Seu" Alziro da Utinga, a última, feita em Cananéia. As duas rabecas na imagem foram fabricadas por Nilo Pereira, no município de Guaraqueçaba. 
Na viola que atualmente pertence a Zé Muniz, chama-nos a atenção a cabeça de besouro no interior do bojo, assim como as fitas, ex-votos e a medalha do Divino Espírito Santo incrustada na mão do instrumento, detalhes descritos por Muniz:

Conforme Araújo (1967) "é inegável o poder que ela [viola] possui”, pois ela tem "função medicinal" de "cura as doenças, mata a saudade, elimina a tristeza, realiza a psicoterapia profunda melo-medicinal" (p. 449), porém, o antropomorfismo (características humanas) dado ao instrumento - cabeça, braço, costas, boca, orelha, pestana - faz com que "a viola padece de muitas doenças que atormentam o ser humano", assim, ela "resfria, 'constipa', apanha 'quebranto', fica rouca ou fanhosa, se 'destempera' e chega até a ficar reumática”.

Para evitar esse mal, cada violeiro traz consigo rezas e simpatias com intuito de resguardar seu instrumento contra o mau olhado, podendo oferecêlo a São Gonçalo, quando amarram uma fita branca no braço das violas ao tocar a moda dedicada a este santo, ou mesmo fitas brancas e vermelhas retiradas da Bandeira do Divino Espírito Santo.

Ainda contra a inveja de outros supostos violeiros, que podem arruinar seu instrumento apenas jogando um cabelo dentro d'ele ou também colocando um dente de cobra dentro de sua própria viola, colocam-na um pedaço de algodão [sic], acreditando este limpá-lo; nesse mesmo intuito, serve a cabeça de besouro (Coleópteros), conforme viola de Alziro Pedro, que em certa feita, apostou com três violeiros que vieram de Cananéia/SP a um Fandango em Utinga, para ver qual instrumento tocava mais; ao amanhecer do dia, os três amarraram suas violas a reboque no carro, levando-as de volta, cumprindo o combinado acaso suas violas perdessem.

Para que, com sua companheira viola, possam tocar e cantar melhor, alguns violeiros colocam dentro do seu instrumento o ovo do inseto Mamangava (Xilocopa Spp), ou uma Cigarra (Cicadidae), seca, podendo passar sobre os próprios peitos, assim, ficar como "a cigarra, que cantando vai ao dia", ou mesmo o guizo da cobra Cascavel (Crotalus durissus). (MUNIZ, 2017, p. 99/100)

Muniz detalha, em uma nota de seu texto, que o besouro deve ser macho e morto na lua minguante, deixando sua cabeça cair [espontaneamente] e envolvendo-a em algodão para então ser colocada dentro da viola. Com relação ao ovo de mamangava, vi em violas na Ilha de Superagui e na Ilha dos Valadares, sendo que a utilização de tais simpatias parece ser prática ainda corrente.

O emprego de ovos de mamangava (Xylocopini), partes de insetos e de animais que emitem determinadas sonoridades demonstra, em boa medida, a intrincada relação de escuta e simbiose com outros seres que compartilham o mesmo ambiente. A interação com o bioma suscita prerrogativas de construção de identidades sonoras, de modo que habilidades musicais e impasses de ordem organológica podem ser potencializados, exacerbados ou dissolvidos pela presença destes elementos na viola. 
Figura 1.14 - Detalhes da viola de Zé Muniz (mão e bojo)

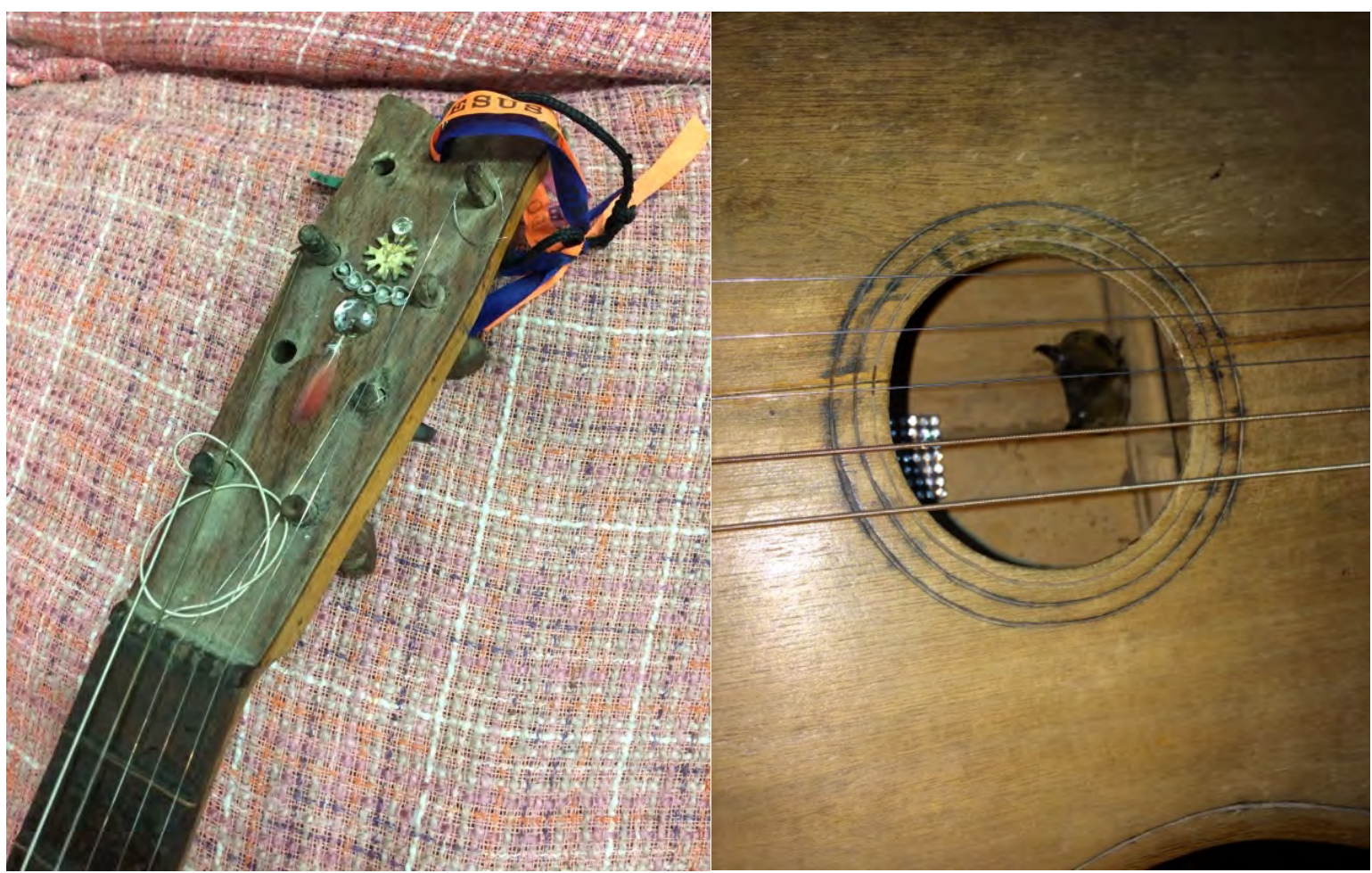

Fonte: Acervo Pessoal

No Encontro realizado no Marujá, tais singularidades podiam ser observadas durante as performances de diferentes vertentes do fandango caiçara que integravam a programação. Depois das apresentações dos grupos, que mantêm presentes suas idiossincrasias e peculiaridades, no fim das noites de baile, tanto na sexta quanto no sábado, houve a junção indistinta de componentes dos vários grupos, "mistura geral", que animou os bailes até o amanhecer e, depois, transbordando até depois das oito horas da manhã.

$\mathrm{Na}$ primeira noite, participei das apresentações auxiliando na técnica e tocando com o grupo Mandicuera. Em meu entendimento, a proximidade com os gostos particulares dos integrantes quanto à equalização dos instrumentos e a preocupação em afiná-los da melhor maneira possível são elementos marcantes na sonoridade do conjunto, características evidenciadas pelo som amplificado. Sem dúvidas, a presença de Cleiton do Prado no grupo vem alterando consideravelmente tais parâmetros, por exemplo no cuidado em regular a tensão da pele da caixa, no intuito de que melhor se tire proveito de seus harmônicos no conjunto (seja na tônica ou na dominante do acorde). Cuidados com os timbres e com a afinação tem sido temas recorrentes, inclusive nos grupos de WhatsApp. Pela riqueza da discussão que se deu nos dias que se seguiram à festa realizada no Marujá em um dos grupos de que participo, onde estão em diálogo fandangueiros de diferentes grupos, linhagens fandangueiras e estados do litoral 
caiçara, e pela absoluta pertinência com as questões desta pesquisa, tomei a liberdade de transcrever integralmente a conversa, que reproduzo abaixo com consentimento dos interlocutores e respeitando sua grafia original.

Cleiton do Prado [Iguape]: Na verdade tem que mudar mesmo esse formato do evento do fandango, acho que teria que dar uma repensada aí principalmente quando se trata de evento de grande porte para o fandango caiçara, igual aí [no Marujá] que tinha bastante grupo, tem que pensar num modo mais organizado pra dar uma agilizada já. Tem que esperar muito, tem umas coisas que teriam que ser mais rápidas, eu tavo conversando com o Ary, sobre a passagem de som, o modo de descrever os instrumentos ali, tem que mudar! A melhor coisa é dividir por números mesmo, nos cabos, colocar a numeração, isso é fundamental para agilizar a passagem de som.

Leandro Diegues [Guaraqueçaba]: Verdade Cleiton, concordo plenamente contigo, esse tempo de passagem de som também dispersa bastante gente. A gente perde um tempão na hora do baile fazendo passagem de som de cada grupo. Aquela mesa que o Mandicuera tem agora, muito sensacional aquela mesa, um parque de diversão para quem mexe, pra quem opera ela. Mas o ideal seria uma digital, o Ary mostrou pra nós uma digital lá na festa de Cananéia ${ }^{25}$. Configura, salva a configuração de cada grupo, cada grupo uma configuração. Aí na hora de tocar já tá tudo certinho e preparado lá.

Figura 1.15 - Oficina sobre princípios básicos de áudio - Cananéia, 2018

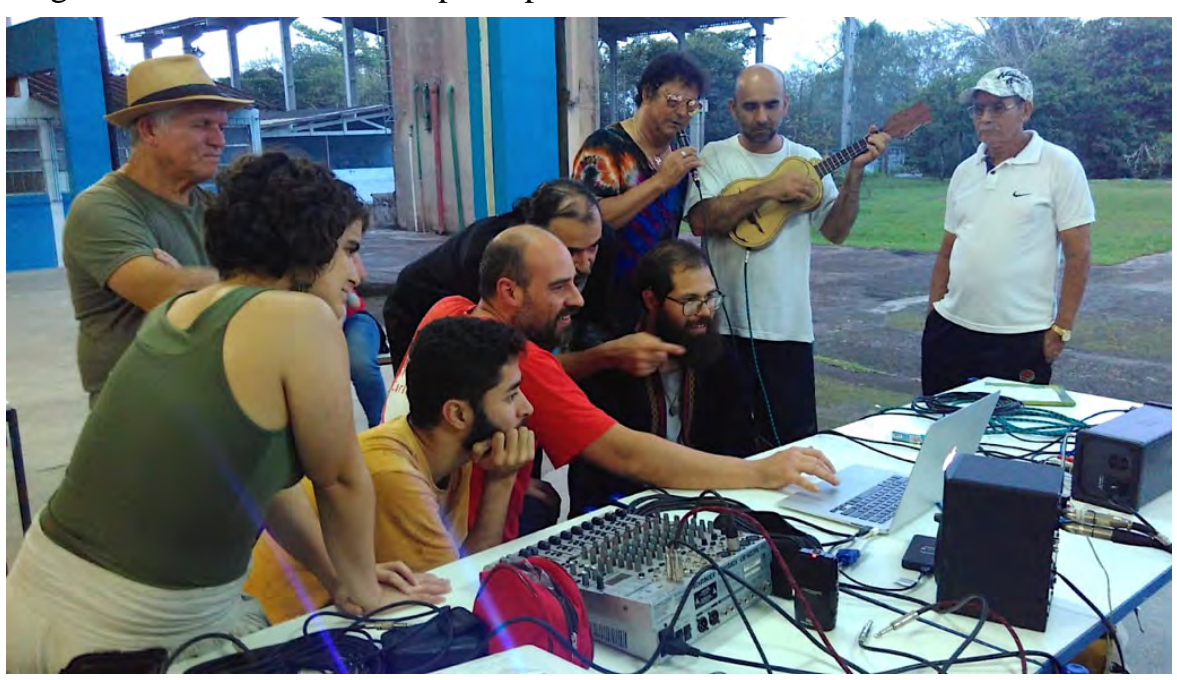

Fonte: Foto de Leandro Diegues - Acervo pessoal

Aorélio Domingues[Paranaguá]: Uma digital seria lindo, como diz Cleiton daquelas que regula até pelo celular em cima do palco, seria bom demais. Então, quando eu falei de ter uma mistura geral no fandango era justamente por isso, pra não ficar tendo que passar o som, e trocar demais os instrumentos. A questão é a seguinte: tem captador que pega melhor, tem captador que pega menos. Tipo o de Taquinha que deu problema, foi inclusive

\footnotetext{
${ }^{25}$ O comentário diz respeito ao console X Air XR-18 - BEHRINGER/MIDAS, que tive a oportunidade de apresentar durante uma oficina que ministrei a convite da organização da III Festa do fandango de Cananéia no ano de 2018. Voltada aos princípios básicos de áudio, a atividade ocorreu nas dependências na Escola Estadual Yolanda Araujo Silva Paiva e contou com a participação de integrantes de grupos de Fandango de Paranaguá, Ubatuba, Guaraqueçaba, Paraty e Cananéia, além de interessados e colaboradores.
} 
um que a gente montou aqui [cristal piezoelétrico]. Não sei o que aconteceu com o captador que não pegou, e o captador do baixolão também não deu certo, acho que por causa do tróculo. A questão é ter o baixo já passado e quando o baile pegar fogo a coisa vai. Instrumento tudo ajeitadinho, a gente tem que ter instrumento bom, captador bom, tudo bom. Por exemplo, se a gente for tocar num palco, num som super profissional, se a gente tiver com captador ruim, ou cabo ruim, ou com instrumento ruim, vai aparecer tudo entendeu? Isso que eu falo da profissionalização! A questão dos instrumentos, uma coisa que aprendi muito com Cleiton, foi que é isso de deixar o instrumento perfeito, para que tenha um som bom. Aprendi com ele que não se deve ter medo, tem que fazer instrumento bom mesmo. Veja os instrumentos do Manema, o som sai! Captador tem que ser captador bom. Agora tô mandando vir as cravelhas lá da Alemanha, umas cravelhas com mecanismo dentro [fig. 1.16 Wittner ${ }^{\circledR}$ finetune-peg], para o instrumento não desafinar, vai desafinar o mínimo. Baduca foi tocar no final do baile, a viola desafina mesmo, porque é muita porrada (risos), coitada da viola. A gente tem que profissionalizar, o momento é esse. O momento da transição é esse. A gente tá chegando, os jovens estão chegando, as crianças estão começando a tocar. O momento é esse, o momento de arrumar o negócio [fandango]. Não que o fandango seja desarrumado, mas o fandango acontecia num determinado contexto e agora se faz em outro.

Figura 1.16 - Cravelhas mecânicas Wittner
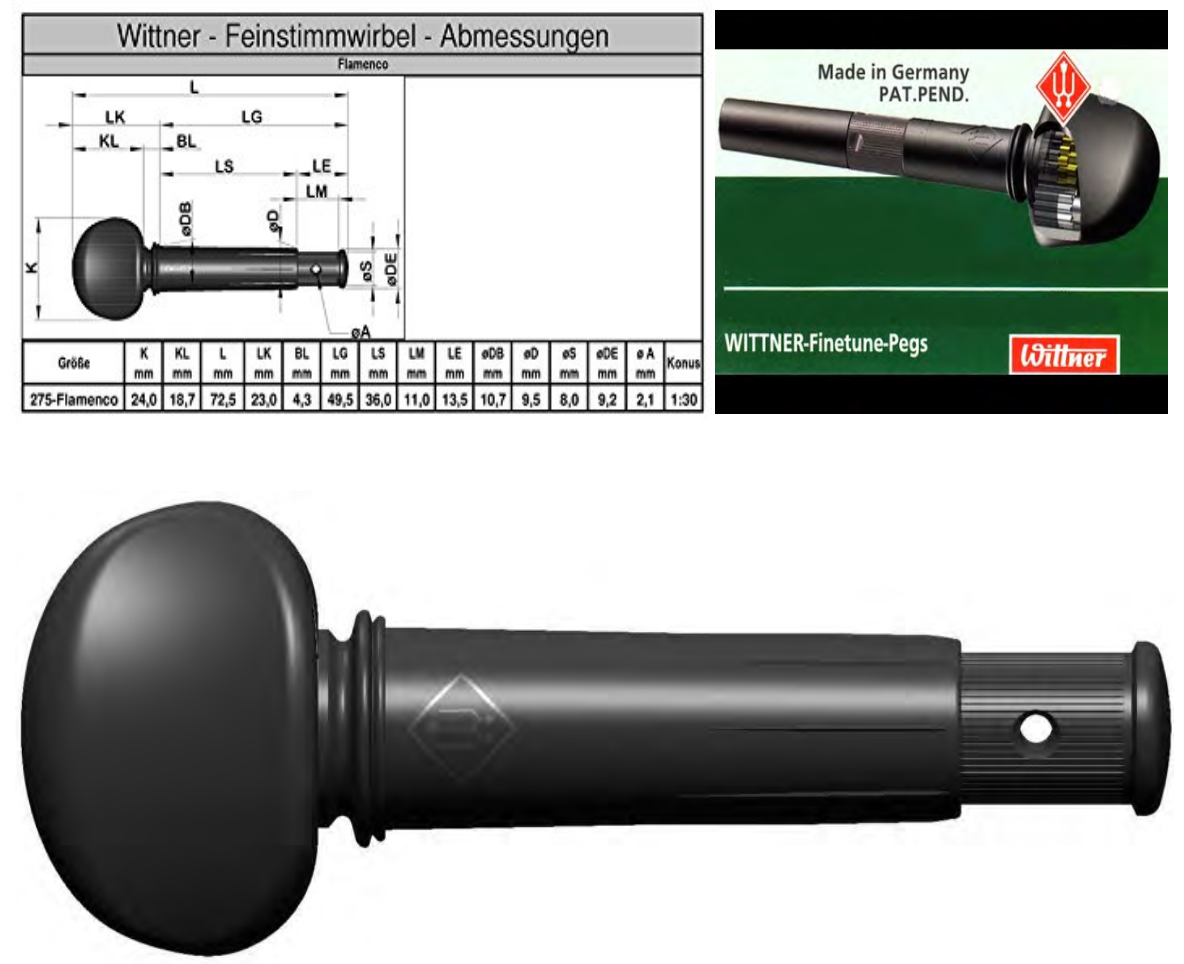

Fonte: WITTNER® GmbH \& Co.KG, 2018

Leandro Diegues [Guaraqueçaba]: Exatamente Aorélio! Vi vocês regulando os timbres dos instrumentos, captação, som, etc. Tudo influencia no som!

Ostinho Garcez (Washington Garcez) [Ubatuba]: Que beleza gente, esses comentários são muito importantes. Vendo os mestres aí fazendo suas colocações, eu tô gostando muito desses encontros, aos poucos estou 
conhecendo as pessoas, vejo muitos fandangueiros e fandangueiras boas, com boas musicalidades, com boas sacadas, versos maravilhosos, músicas bonitas. Então, eu venho fazendo um trabalho com o fandango desde a primeira formação do grupo aqui em Ubatuba em 2005. Recentemente fiz um trabalho com o pessoal do Prumirim, onde as crianças estão voltando a dançar, e formamos esse grupo de ciranda caiçara em novembro do ano passado. Nosso grupo é novo, é pequeno, estamos trabalhando musicalidade. Muito importante esta questão dos timbres, das sonoridades, das afinações e do que é apresentação mais ajustada e do que é apresentação de rodas de fandango. Pra mim o fandango começa a hora que a gente começa a ver o transporte. Na sequência de que você entra no transporte e começa a produzir o fandango, chega na festa, conhece as pessoas, tem o dia a dia, tem a apresentação, tem roda de fandango, diálogo! Você conhece as pessoas, de onde elas vêm, suas histórias, isso é emocionante. O forte do fandango pra mim tá sendo isso! Agora, tocar e cantar é um dom que deus nos dá e nós temos que aprimorar. Essa sacada aí de vocês todos é muito importante e eu já tenho observado isso. Nós tivemos um pequeno problema na nossa apresentação, porque nós cantamos com uma voz feminina na primeira [voz] e ainda estamos ajustando estas coisas, tanto é que na terceira, quarta música foi ficando legal, foi ficando harmonioso e conseguimos dar uma parte do nosso recado. (...) Nosso grupo é um grupo pequeno, nós estamos vendo um novo modelo para apresentar, sem perder as características principais de como fazer o fandango. Mas eu acho que a mulher tem que estar mais presente também, por isso mudamos a tonalidade para sol maior, eu faço a segunda voz, e minha companheira está se firmando na primeira. Então o resultado pra ciranda caiçara ainda vai ser bem mais lá pra frente.

Cleiton: Também acho, é uma dessas que eu tô querendo comprar, pra esses eventos mesmo, você coloca ele no palco, já usa como medusa, vai todos os cabos alí no palco junto com o retorno, o Ary falou pra mim, ou você liga pelo wi-fi, ou pra ficar mais rápida a informação da mesa para o notebook ou para o tablet você coloca um cabo de rede, esse de arrasto, o chumbeiro arrastando bem, Meu Senhor! (risos)

Aurélio Gasparini Jr. [Guaraqueçaba]: Vou colocar um pouquinho da questão técnica de som e sonoplastia, tenho um pouco de conhecimento nessa área, já fui dj, já trabalhei em sonoplastia de igreja, e de palco também. A mesa, excelente, apesar de ter sido pego de surpresa, mesmo tendo sido voluntário já antes de ir pra festa, mas sem tempo nenhum de se familiarizar com o equipamento antes do baile. Ótimo equipamento, mas por não ser digital você não consegue salvar as cenas de cada grupo, a ponto daquele grupo chegar e você já abre a cena daquele grupo todo regulado. Mas acho que isso não é um problema tão grande, a gente conseguiria por exemplo, para evitar esse tipo de problema, quando a mesa não for digital, passar o som de qualquer maneira, durante o dia. E hoje a gente tem um recurso simples que é o celular e até mesmo etiquetar os canais e tirar uma foto por exemplo, você ajusta ali os volumes de cada equipamento, cada instrumento e faz uma foto, e quando entra aquele grupo, você já deixa uma foto com o nome do grupo, e aí você coloca todos os canais de acordo com a foto que você fez e aí depois só faz um ajuste fino, o grupo já pode entrar tocando, sem o atraso que a gente teve em alguns casos, pois você já vai estar sabendo se o captador daquele grupo tem baixa impedância ou alta impedância, maior ganho ou menor ganho. Friso também a importância em se ter um auxiliar de mesa, como Cleiton falou, regulando, ouvindo na frente, ouvindo atrás também. Por que às vezes tá perfeito na saída de frente, mas no fundo tá chegando sem médio ou sem grave ou sem agudo, ou mesmo sem o volume de um ou outro 
instrumento ou voz, que tem que se destacar mais. Então nos encontros tem sempre que levar a sério a questão dos voluntários para operação da mesa...

Outro ponto que acho que resolve muito, por exemplo, na apresentação da Família Pereira, parou de funcionar o captador da rabeca do rabequeiro ali, "Seu" Zé! Complicado às vezes, ah, que recurso vou utilizar, vou utilizar o microfone, às vezes o rabequeiro se mexe muito, o fandangueiro em geral se mexe muito no palco, às vezes ele está perto do microfone, às vezes ele tá longe, leva o sonoplasta [operador de áudio] à loucura, entendeu? Tem que ficar subindo e baixando o volume o tempo inteiro e ficar ouvindo um monte de leigos no assunto falar no teu ouvido que tem que dar mais grave, que tem que dar mais agudo, que tem que erguer mais o volume. Isso é complicado. Então um recurso bom e que eu utilizei desse recurso, foi ter um microfone de captação lapela ou parecido com lapela, específico para instrumento, de grampo, que resolveu, salvou ali umas três ou quatro situações que a rabeca não tinha captação, ou que deu problema na captação, adufeiros que às vezes tem essa questão e se mexem muito, aí você coloca o [microfone de] lapela no adufo e não perde a continuidade do volume do som, então isso é importante, ter um ou dois lapelas para fazer essa correção no caso.

Leandro Diegues: Boas análises aí Babico, verdade cara, é interessante porque a gente que manja um pouquinho dos equipamentos e coisa e tal, é interessante que fiquem sempre por perto ali, dando um suporte, tava você, tava Ary, Cleiton também. Eu coloquei ali falando da mesa digital, seria o ideal, mas a gente não tem pernas para isso ainda, mas seria o ideal pela praticidade, coisa e tal. Mas a gente consegue fazer, da forma como a gente tá se organizando aqui, dando opiniões e tal, a gente consegue fazer uma coisa legal, bem estruturadinha para não prejudicar ninguém. E aí vamo que vamo.

Aurélio Gasparini Jr.: Só colocando mais uma questão técnica, não quero fazer nenhuma crítica a quem montou e disponibilizou a posição do equipamento, acho que todos estamos aprendendo todos os dias, e essas conversas são um jeito da gente desenvolver uma maneira de disposição de caixas de som e tudo mais, para que fique cada vez melhor, pra cada tipo de ambiente vai colocar um desafio diferenciado pra você fazer o som, ambientes mais altos tem muito eco, ambientes mais baixos vão ter pouca propagação, o que dificulta com a questão da microfonia. Ambientes totalmente abertos em áreas externas vão ter déficit de som, tem que fazer compensação por proximidade de caixa, e assim vai, essas coisas são de suma importância. Uma coisa que eu Ary e Cleiton estávamos conversando antes da apresentação do Manema era essa questão, de que a mesa de som deve estar sempre atrás, nunca no meio, e nunca na frente [próxima], numa disposição que se escute tudo que todos estão ouvindo, no centro do salão. Tinha uma situação que a caixa estava depois da mesa, e tínhamos o áudio de palco de uma maneira e a caixa do lado com uma perspectiva diferente de quem estava no fundo [do salão], justamente pela mesa não estar atrás de todas as caixas, estava no meio, isso também é muito importante, na disposição do equipamento, também para que tenha melhor qualidade e que fique mais fácil ter o controle do som.

Cleiton do Prado [Iguape]: Bem isso mesmo Aurélio [Babico], o que você falou é uma realidade, cada lugar que a gente vai tocar é uma coisa, local aberto, local fechado, com a saída, lugar fechado onde o som fica preso dentro, igual foi ali no Marujá, o palco é do lado da porta pra você ter uma ideia. Na verdade, aquele palco deveria ser lá no fundo onde é a lanchonete. Falando na questão da sonoridade, teria que ser lá o palco. Não é uma coisa que foi pensada na hora, faz muito tempo que tem esse centro comunitário. A intenção era o primeiro lugar a vista ser a lanchonete, pois é um modo de ganhar dinheiro também, e o palco ficou atrás da porta. Aí não tem como você fazer uma disposição das caixas e um alinhamento de som perfeito. Ou sei lá, o 
certo seria colocar a caixa lá no final, digo nesse caso ali, e aumentar o retorno pra gente, que a sonoridade de lá não chegasse até ali, pra não dar delay, até é pequeno o espaço, mas ainda dá um pouco de delay, acho que teria que fazer isso. Mas a gente vai aprendendo com o tempo também, experiências. Uma coisa que eu falo para o pessoal sempre: uma coisa é passar som para um grupo de música comercial, guitarra, contrabaixo, bateria, sei lá, e violão, outra coisa é você passar som para o fandango que tem duas violas tocando no mesmo ritmo fazendo base e tem o machete que tá fazendo base também, e alguns grupos ponteiam, e a única coisa que tem de solo é rabeca e machete, mas sempre fazendo solo junto com os instrumentos, não para de fazer solo, dá uma embolada na situação. Ainda bem que hoje em dia está sendo incluído o grave do baixo que dá uma condição pra gente saber que nota que tá, alguma coisa assim, de longe pra gente ouvir, saber que nota está tocando e não se perder, às vezes, até na passagem de som. Porque quando está só as duas violas tocando não dá para perceber. Ainda bem que hoje em dia a gente se liga nesse problema. Nessa situação de conseguir ver a timbragem do instrumento, a questão da melhoria da sonoridade. Acho que isso tem que existir, a timbragem da voz, equalização certinha do instrumento. Isso é super importante, super importante pra gente ter uma apresentação legal, para as pessoas entenderem o que a gente tá tocando e o que a gente tá cantando, eu acho que isso é o básico, as pessoas que não entendem começarem a entender, a gente vai se arrumando, se conversando e melhorando nessa questão, tudo se moderniza, e o fandango, como é uma cultura viva, tem que acontecer melhorias, a intenção não é modificar tanto, mas é melhorar, para gente conseguir ouvir e para as pessoas conseguirem entender o que é fandango e aprenderem a gostar do fandango como ele é, eu acho que não existe muita modificação, existem melhorias, o que é totalmente diferente ${ }^{26}$.

Leandro, Aorélio, Aurélio Jr. e Zé Muniz, eu acho que é importante a gente conversar muito, conversar muito sobre a captação do instrumento, não adianta a gente ter um instrumento bom, um equipamento sonoro bom, top de linha, sendo que a captação do instrumento ainda desfavorece isso, é diferente você ouvir um fandango na roda de fandango ali, com os instrumentos falando do jeito que eles têm que falar, soltando sua sonoridade natural, é muito diferente, é melhor do que você escutar o instrumento ligado, o instrumento amplificado. Porque às vezes a captação do instrumento não condiz com o que ele tem que passar, a captação não condiz com a qualidade do instrumento, não condiz com o timbre da própria madeira. Tem que ter cuidado com esta questão, a captação tem que ser uma captação boa, que capte principalmente a sonoridade natural do instrumento. Tenho ouvido muito a captação metálica, principalmente da rabeca, fica muito metálico, fica muito agudo. Na viola, a gente tem que procurar o lugar, o local pra colocar a captação da viola, é um instrumento médio, que já tem a sonoridade do médio, frequências de médio muito forte. A gente acaba perdendo qualidade pra caramba às vezes, com captação de baixa qualidade. Na hora da instalação do captador, colocar no lugar errado. A gente tem que testar muito na hora que vai colocar o captador. Testar mesmo, vai colocar o captador, coloca provisório, testa num lugar, testa

\footnotetext{
${ }^{26}$ A esse respeito, Bateson elucida que: “As afirmações sobre mudança deverão sempre se formular em uma linguagem de nível de abstração superior em um grau ao da linguagem, que seria suficiente para descrever o estado de equilíbrio estável. Assim, com as afirmações sobre aceleração devem ser sempre um tipo lógico mais elevado do que as afirmações sobre velocidade, também as afirmações sobre mudança cultural devem ser de um tipo mais elevado do que as afirmações sincrônicas sobre a cultura. Essa regra aplica-se a todo o campo da aprendizagem e da evolução. A linguagem usada para descrição da mudança de caráter; a linguagem usada para descrever a etiologia psiquiátrica ou a psicoterapia, ambas implicando mudança, deve ser sempre mais abstrata do que a linguagem do diagnóstico. E assim por diante.” (BATESON, 2008, p. 326)
} 
no outro, tem que ter uma caixa pra testar, um equipamento com qualidade boa para testar a instalação da captação, isso é muito importante pra gente não perder qualidade, para as pessoas ouvirem o que tem que ouvir do instrumento caiçara, acho que isso é muito importante.

Zé Muniz [Guaraqueçaba]: Quanto aos intervalos de grupo... São coisas "normais"... Atrapalha um pouco o andamento, porém momentos de risada, piada, conversa, namorico... insubstituíveis no fandango caiçara... e ninguém vai embora por esperar uns 5 ou 10 minutinhos de um grupo para outro... Estamos vendo esses intervalos como algo ruim, mas são decisivos $e$ importantes em nosso fandango... Com todo respeito à comparação que faço, na Romaria do Divino há intervalo entre Chegada e Despedida, porque são momentos de reza, conversa, promessas... no Fandango são momentos assim também, conversa, namoros etc...

Leandro Diegues: Isso também é um assunto que precisamos mesmo sentar e debater! Acho muito importante a captação dos instrumentos por que elas influenciam significativamente nas apresentações e bailes.

Aurélio Gasparini Jr.: Então Cleiton, eu entendo que isso vai ser sempre um desafio, qual seria hoje o melhor recurso de captação para instrumento de fandango. Eu sou uma pessoa que até já expus pra vocês testes com acabamentos, eu testo muito também a questão da captação, hoje eu tenho viola com captador de rastilho, captador de rastilho disposto no cavalete, captador de rastilho disposto depois do cavalete, cápsula de captação interna, cápsula de captação externa, tipo pastilha, como Aorélio usa bastante, cada uma delas vai ter uma captação diferenciada, além de cada uma ter uma captação diferenciada para cada tipo de instrumento, que ela vai ficar diferente também. Então por exemplo: eu tenho uma viola que tem equalizador, onde a captação pode ser balanceada entre rastilho e cápsula, que seria um microfone interno, é a melhor captação que eu consegui chegar até hoje, onde você consegue regular entre a captação de rastilho e da caixa acústica da viola, e consegue melhorar grave e agudo. Mas daí, como você vai conseguir cobrar isso de cada músico? É complicado. Não é uma coisa tão cara assim, mas você depende também de quem faça, e por aí a conversa se estende. Então, o captador de cápsula, tem uma captação muito boa, mas ele não tem diafragma, é um captador seco, ele não faz o vibrato da ressonância da caixa acústica da viola, então ele vai soar metálico por que não tem vibrato para fazer soar o grave. O captador através de cápsula [microfone] vai captar muito o grave, vai captar bem o agudo também, só que aí tem o problema da microfonia, o que fica dentro da caixa acústica acaba soando muito forte e vai acabar dando microfonia. Então esse tipo de cápsula tem que ter filtro, se não tiver filtro já não dá certo. É bem complicadinho mesmo, é uma questão que a gente tem que conversar muito, mas também tem que entender essa dificuldade, por exemplo, dos violeiros mais velhos. Uma é a aceitação quanto a isso, e outra é: “ah, não vou modificar minha viola" só porque alguém quer que fique melhor ou pior, pra ele tá bom, a gente tem que respeitar esse ponto também.

Cleiton do Prado: Aorélio Jr, isso que estou falando pra você, a gente tem que ver qual é a captação melhor para cada instrumento. Não existe uma captação boa para a viola, existe uma captação certa para a viola certa. Eu tenho duas violas exatamente iguais, todas feitas no mesmo tamanho, com a mesma forma, com a mesma espessura de madeira, tudo igual, só que em uma não deu certo a captação de contato. Uma ficou excelente, nessa que eu toco, captação passiva de contato, excelente, adoro a captação dela. Dá pra equalizar, o importante é isso, dá pra equalizar! Pra você deixar na sonoridade que a viola pede, para deixar o mais próximo possível da sonoridade de uma viola. Agora, a outra não aceitou a captação de contato. Aí eu fiz a mesma coisa que você, tive que comprar uma captação com equalizador e colocar 
nela. A cápsula ficou uma porcaria, como era com equalizador (cápsula e rastilho), a cápsula eu tirei, porque toda hora que ia pro lado da cápsula, dava microfonia. Mas microfonia feia assim, aí eu tirei a cápsula, e hoje em dia só uso a captação de rastilho nela que dá pra equalizar. Os captadores têm que ser de qualidade boa, que alcance frequência de equalização, tem que alcançar frequência de equalização, não adianta colocar um captador que só pegue o metálico do instrumento ou que só pegue o grave, não adianta! Tem que alcançar na frequência da equalização, esse é o mais importante, para você chegar na conclusão de que você quer para o instrumento, o que o instrumento está pedindo.

Aorélio Domingues: Isso, e tem uma coisa da gente estar atento, porque você vê, a captação dos instrumentos deles [Pereiras] não existe né, e de repente a gente não deixar os caras no vácuo. A situação é assim, chama os Pereiras, mas ter uns fandangueiros pra fazer uma "cozinha" para os caras. O mestre Zé Pereira vai fazer uma participação! Aí tem uma cozinha ali pra gente emoldurar o cara entendeu? Não dá pra largar ele sozinho, ou o grupo ali. Não sei o que aconteceu ali... Enfim, tem que emoldurar os caras. A dupla Zé Pereira e Leonildo! A gente vai fazer uma cozinha pra eles, pra deixar legal, ter um técnico na hora, mais atento pra passar o som bem certinho, se a captação não pega, sabendo disso arrumar um microfone, um captador mais potente, um captador externo. Posso montar um captador externo aqui, pra na hora chegar e fazer um clic! Agora a gente já sabe, a gente teve essa experiência, o que não dá é pra deixar os caras ali, ninguém fez isso, mas é uma experiência que a gente teve, eles foram lá e se bateram, a gente também se bateu porque não estávamos sabendo regular o som, o Ary depois me falou que não tava conseguindo melhorar o som, enfim, estudar como seria isso! Se de repente a gente entrava junto pra fazer a abertura, dar uma engrandecida! São ícones, essa é a verdade, os caras são ícones.

Ary Giordani: Acho tudo que foi posto interessante. Mas lembro, na hora de montar a bagaça, fiquei sozinho, fora o Caio que deu uma força e depois apareceu Fernando [Cananéia]! Em qualquer posição teria dado treta, paredes lisas e paralelas reforçam as frequências graves e atrapalham de qualquer jeito! Tanto na sexta quanto no sábado usamos apenas $60 \%$ da potência do equipamento pois qualquer coisa a mais realimentava, causando microfonias...

Achei maravilhoso o Babico e o Leandro dando uma força [na operação do som]! Cada um tem um jeito de trabalhar, e confesso, na hora do Manema, como os meninos estavam por ali, deixei a coisa andar e quando percebi que tava confuso a maneira como tinham sido ligados os instrumentos, foi tarde demais e demorou pra entender o que estava acontecendo! Quanto à posição do som, teve a ver justamente com o fato de geralmente assumir a bronca tendo que tocar também e regular o áudio, estar próximo [da mesa de som]. Se fosse apenas a distribuição o problema, não teríamos conseguido a qualidade, por exemplo, que tivemos com o Mandicuera na sexta-feira (tem a ver também com conhecer os instrumentos e características que cada músico gosta), ruim mesmo foi não ter levado um fone de ouvido bacana!

Fora os Pereiras, que gosto demais, mas já foram enumerados os problemas quanto à captação, outro exemplo: na viola do Marcelo [captação de rastilho], tivemos que colocar o ganho no máximo puxando todas as frequências. Além da captação não dar conta, a afinação variava demais... tem algumas coisas que o equipamento (por melhor que seja) não dá conta!

Pela primeira vez, percebo que exista uma preocupação técnica e acho que quando esta preocupação for melhor discutida, teremos um salto de qualidade nos bailes. Sempre a coisa técnica parecia ser um troço chato e distanciado da prática fandangueira! Sinto às vezes que esta discussão tem que ser ampliada, por mais de uma vez escutei o pessoal falando "toca de qualquer jeito", no 
meu entendimento, não serve! O pessoal sempre chega em cima do laço. Seria o básico passar o som antes, à tarde, como sugeriu Babico [Aurélio Gasparini], por exemplo, como em qualquer evento, mas sabemos que esta prática não é corrente no universo do fandango, espero venha a ser!

Quanto ao equipamento analógico, friso que foi uma aquisição via Programa de Gestão da TCP e que [a opção] prezou pela operação mais simples possível junto a grupos de Paranaguá (incluso aí aqueles que têm menos familiaridade com este tipo de atividade técnica), e que tivemos que brigar muito para conseguir o que estava lá, refizeram toda a lista substituindo o que foi solicitado por equipamentos similares (mas tá bom) já ajuda bastante...

Figura 1.17 - Mesa analógica adquirida via programa de Gestão (TCP)

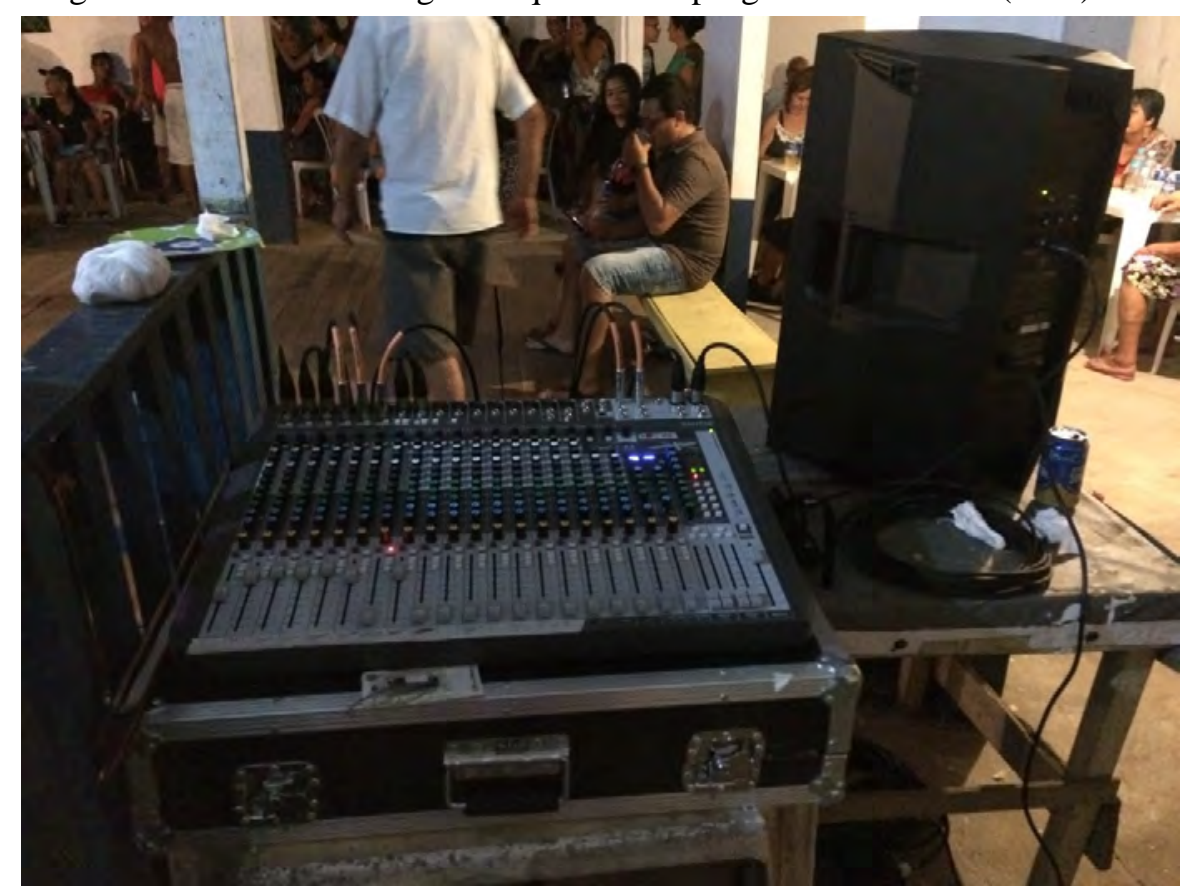

Fonte: Acervo pessoal

No mais é isso, vai que vai! Vamos aprendendo! Ideal mesmo seria que cada grupo tivesse um responsável técnico, mesmo que fosse um dos músicos, para melhorar essa comunicação com o operador.

Herbert dos Santos [Superagui]: Adorei o "Babico"!

Ary Giordani: Viu, o "não serve", é da coisa técnica! Como não poder dar ganho no master por conta de um canal que mesmo clipando não responde, prejudica o conjunto... aí fudeu a paca! Por exemplo, isso do mic lapela condenser nessa situação e pedindo ganho, foi também um lance delicado! Melhor dinâmico de contato, ou piezo mesmo!

O figura lá de Ubatuba tava com tampão na boca do instrumento, pra quem usa piezo ou rastilho, isso é uma coisa que ajuda muito!

Pedro Prado [Iguape]: Boa tarde turma! Não sou muito de expressar no grupo, mas essa fala do Ary e de todos é importante pro alinhamento de como o fandango vai se portar com a sonorização. Também trabalho com isso e sinto falta às vezes de uma pessoa que conheça o grupo pra ajudar a fazer o melhor pra apresentação, pro fandango, pra quem quer dançar. Replicando a fala, o "vai de qualquer jeito" com coisas sobrando, não serve. Fica horrível! Cada um tem que estar no seu devido lugar, depois tudo flui! Haaa na próxima eu vou se Deus quiser! 
Aorélio Domingues: Eu como tinha falado, não entendo nada de montagem, nada, nada, nada! Então eu quero ver se aprendo alguma coisa, até pra dar uma força e coisa e tal. Eu tive ali, levei o som, na hora de desmontar, limpei tudo, o Ary tava junto e coisa tal, na desmontagem, mas eu queria muito aprender. Vou tentar fazer um curso, alguma coisa, aprender. E é bem isso, Ary, cada grupo teria que ter um técnico também pra estar ali ajudando. Mas vamos... Essa coisa do formato do baile também ajuda muito, porque é como eu falo, se a gente tivesse ali uma cozinha, um baixista, uma rabequista, sei lá! A gente precisava sentar uma hora pra discutir isso.

Leandro Diegues: Agora que tô conseguindo ouvir os áudios e ler os textos da tarde kkkk Boa explanação Ary, a parte técnica é tensa!!! Quando cito a questão da mesa digital é somente pra exemplificar algumas situações... Pudemos conversar um pouco naquele dia na Mandicuera sobre esses equipos que ganharam [mitigação] (que pra nós ainda é um sonho kkkk). Mas acho de suma importância o interesse da galera, ou como diz "um representante de cada grupo" que seja para acompanhar na hora da passagem... e no mais Vamo que Vamo!!!!

Aorélio Domingues: Com relação ao que o Ary falou: vai de qualquer jeito! Cara, não dá! Tenho conversado tanto com Cleiton sobre instrumento, a gente tem desenvolvido tanto a coisa, e eu ainda pretendo buscar muitas coisas pra melhorar os instrumentos, melhorar a captação, vamos conversar muito sobre isso. Então não dá pra fazer de qualquer jeito sabe. Não dá! Eu acho que quando estiver desafinado, quando alguém está desafinado, às vezes a gente não está escutando mesmo. Ontem eu tava no barco, o motor ligado, eu não conseguia afinar. Aí eu falei pra Babico: - Porra cara, não tô escutando, não tô conseguindo afinar. Ele falou: - Me dê aqui essa porra aqui, seja humilde! (risos) $\mathrm{E}$ afinou o instrumento. Mas é isso, a gente tem que se cuidar, a gente tem que dar a mão um pro outro, a gente não é perfeito, tem uma hora que a gente toca desafinado, tem uma hora que não, tem uma hora sabe? Então não dá! O fandango tem que estar bom pra gente captar, pra gente pegar a nova geração, o fandango tem que estar bom! A gente não pode falar: - $A h, o$ fandango tem que ser igual antigamente coisa e tal. A gente não vai mudar o fandango, mas a gente vai ajustar para o contexto de agora, se a gurizada, as novas gerações forem lá, esses que não conhecem fandango, e chegarem lá e estar desafinado, eles nunca mais voltam. Mas se estiver afinado, bonito, tudo bem tocadinho, eles vão dançar, vão gostar e vão trazer mais gente, entende? E esse público mais velho está acabando, infelizmente eles estão morrendo, as pessoas estão morrendo. $\mathrm{O}$ público de três, quatro anos atrás aqui [Paranaguá], já tá mudando bastante, as pessoas estão indo, pessoas velhas, com 70, 80, 90 anos, esse pessoal, eles estão indo embora. Então o que que gente precisa? A gente precisa formar novos públicos. A gente já tem garantido aquele público que vem no fandango, mas o povo tá indo, gerações passam, e se a gente não se atualizar, entende? Nós temos que fazer algo que cative as novas gerações. - Ah não, porque o fandango não era assim e coisa e tal... Daí fica complicado. A gente tá aí! A gente está tocando para vários públicos! (mensagens de áudio e texto via WhatsApp, 28/01/2019 transcrições e grifos nossos)

No decorrer do texto, retomaremos alguns dos pontos mencionados na conversa. Voltando ao relato da festa: No baile de sábado para domingo, por volta das quatro horas da manhã, iniciaram-se novamente as "misturas gerais". Baduca tomou seu lugar na primeira voz, com viola em punho e os demais músicos foram revezando. Comecei a tocar por volta das 5 
horas, ainda com o pessoal do Canutilho Temperado, dispostos na foto (fig. 1.18), da esquerda para direita: Vaca [Edvaldo Oliveira] (Mandicuera), Rodrigo Domingues (Família Domingues), eu e Aorélio Domingues (Mandicuera), Zeco [José Carlos Constantino] de peruca loira e Babico [Aurélio Jr.] (Canutilho Temperado), Baduca (Família Neves), Marcelinho (Canutilho Temperado), "Seu" Nilton (Paranaguá) e Eliel Alves (Família Neves). Nessa "mitstura", seguimos até às oito horas da manhã.

Figura 1.18 - Mistura geral no $1^{\circ}$ Encontro de Fandango do Marujá, 2019

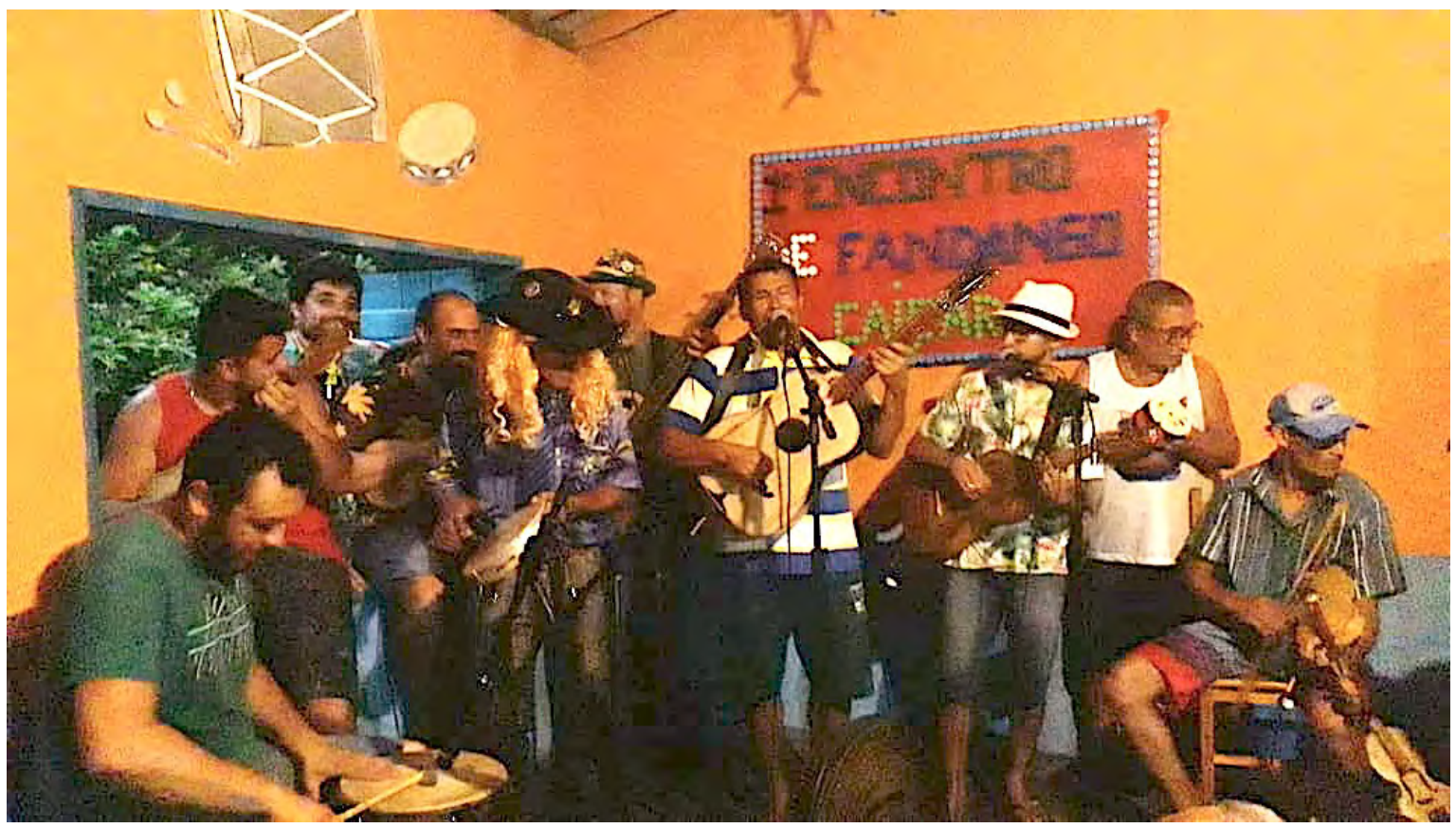

Fonte: Foto de Elyson Domingues - Acervo pessoal

A experiência foi reveladora. Nesse horário, as coisas todas já soam de outra maneira; a expectativa de que o baile amanheça dá, ao ânimo dos envolvidos e seus ímpetos, contornos de um transe catártico. Nesse momento, a preocupação com a afinação me pareceu tomar novo sentido. Sem afinador ${ }^{27}$, tive o cuidado de localizar uma possível referência da tônica e, assim, afinar o instrumento antes de amplificá-lo. Em formações menores, e dispostas a perder algum

\footnotetext{
${ }^{27}$ Utilizo um afinador (D’Addário Ns Micro Pw-cto-12). Por sinal, foram poucas vezes em que não estive com ele. Por acaso, havia emprestado meu machete para o pessoal de uma das apresentações anteriores, e acabou que ele foi junto com outra viola por engano. Indiferente se os conjuntos que acompanho estão no diapasão ou não, de modo geral, utilizo o dispositivo como referência na calibragem da afinação, seja trinta cents abaixo ou meio tom acima de uma tônica qualquer (geralmente, algo entre dó sustenido e mi). Muitos dos violeiros de mais idade, como seu Nemésio Costa e Zeca Martins, fazem questão de mencionar que não utilizam afinadores. Percebo um certo orgulho nisso, como se o fato de utilizar essas ferramentas enfraquecesse seu prestígio por diminuir, por assim dizer, suas competências musicais, mais atreladas à percepção das vibrações do instrumento e de sua própria tessitura vocal. De todo modo, entre os mais jovens o uso dessas ferramentas é corriqueiro.
} 
tempo com a questão, isso não seria um problema. Mas naquela situação, preciosismos desta natureza, em um primeiro momento, pareciam irrelevantes.

Já nos primeiros ataques, Baduca olha para nosso lado [eu e Rodrigo] com certa reprovação e comenta alguma coisa que não entendi. Seguimos adiante. As modas mais curtas duravam entre 7 e 10 minutos. Mesmo em meio às modas, ou nos curtos intervalos, auscultei meu instrumento, e a coisa soava. Na terceira moda, houve uma intervenção mais enérgica do violeiro; uma das cordas de meu colega soava fora. $\mathrm{O}$ encordoamento de metal e o ganho considerável nos monitores de palco, deliberadamente causavam a fissura da interação. Nosso camarada, que já estava tocando há mais tempo, não se animou em temperar o machete e declinou do pleito. Retirou-se. Mais duas modas, e Gilvan assumiu a caixa, e Aorélio Domingues, a Rabeca.

Nesse momento, percebi que, mesmo que a referência tonal estivesse oscilando entre os instrumentos harmônicos, o mais importante parecia ser o fato de que, individualmente, os instrumentos soassem afinados e criassem, a partir do ataque das violas, múltiplas camadas que, embora apresentassem pequenas defasagens harmônicas, atendiam às demandas da presença e da interação entre os envolvidos na performance, sabendo que a esta altura nossa plateia já se reduzia aos mais chegados.

Na noite anterior, ainda no início do baile na sexta-feira, Baduca, nosso querido anfitrião, tomou parte de um pequeno contratempo que surgiu a partir da colocação de um efeito luminoso de LEDs, cuja luminosidade incidia no teto do pequeno palco localizado atrás da porta principal. Quando observou o dito refletor em funcionamento, Baduca veio de imediato nos questionar.

Efeitos luminosos têm sido corriqueiros nos bailes realizados nas ilhas, inclusive em algumas localidades, como na Barra do Ararapira, na vila de Superagui, ou de Bertioga (baía de Pinheiros), os bares e os agitadores culturais dessas localidades possuem esse tipo de equipamento.

\section{LÂMINA 2}

Efeitos luminosos na Barra do Ararapira, 2016

Fonte: Acervo pessoal 


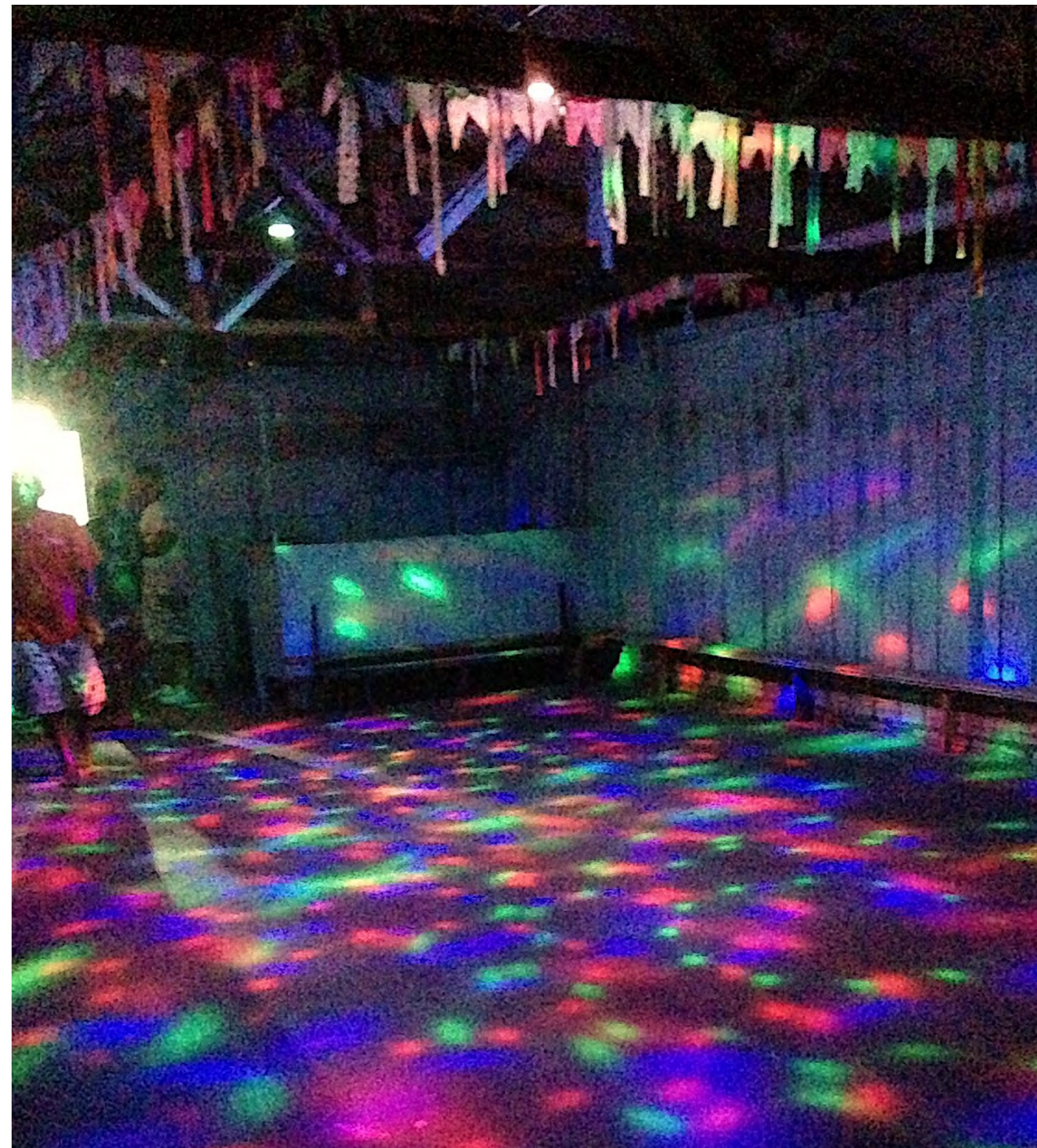


Figura 1.19 - Efeitos luminosos na festa do Divino em Superagui, 2017.

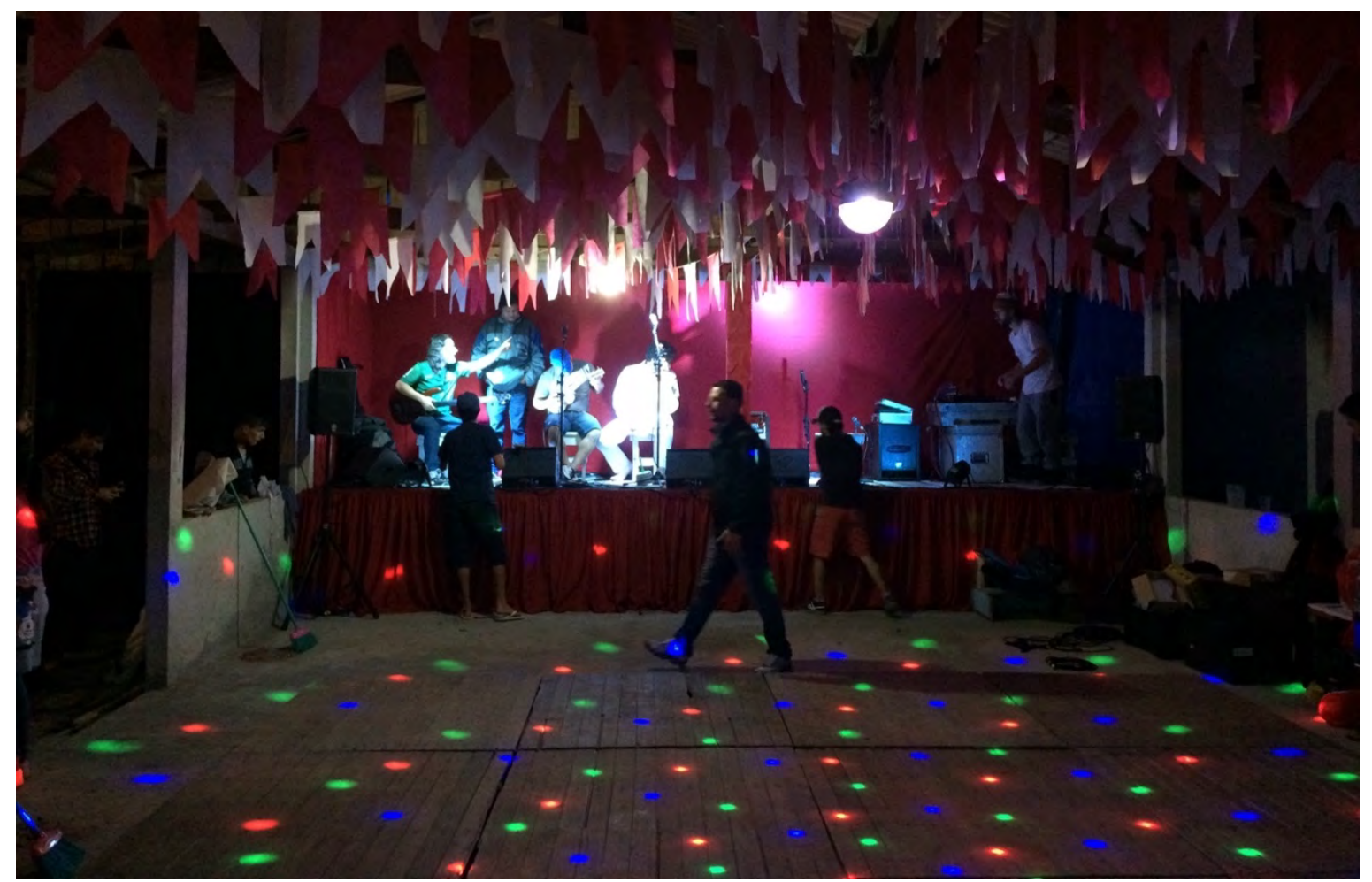

Fonte: Acervo pessoal

Figura 1.20 - Efeitos luminosos em Superagui, 2016

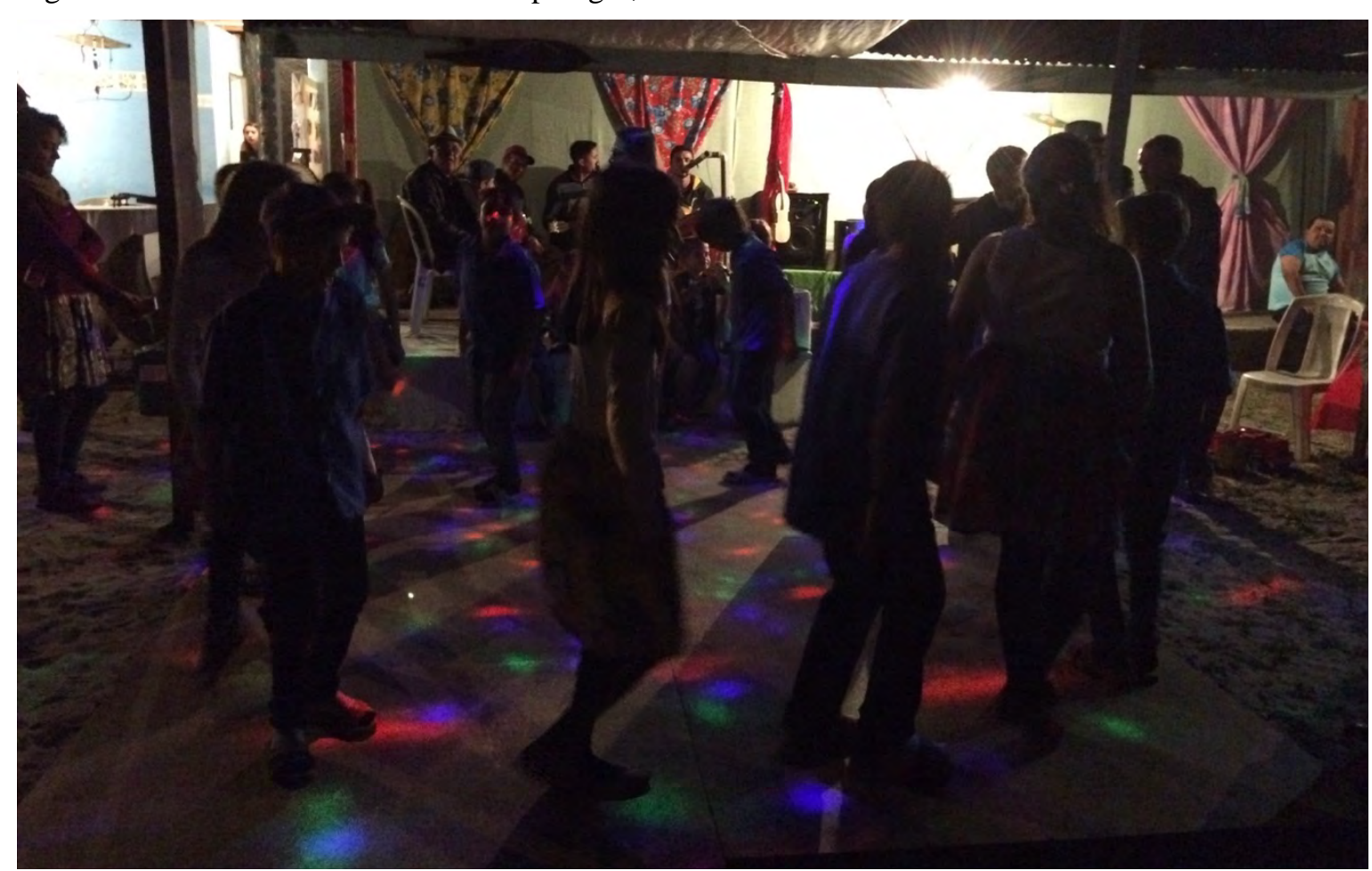


Figura 1.21 - Efeitos luminosos em Bertioga (Ilha das Peças), 2019

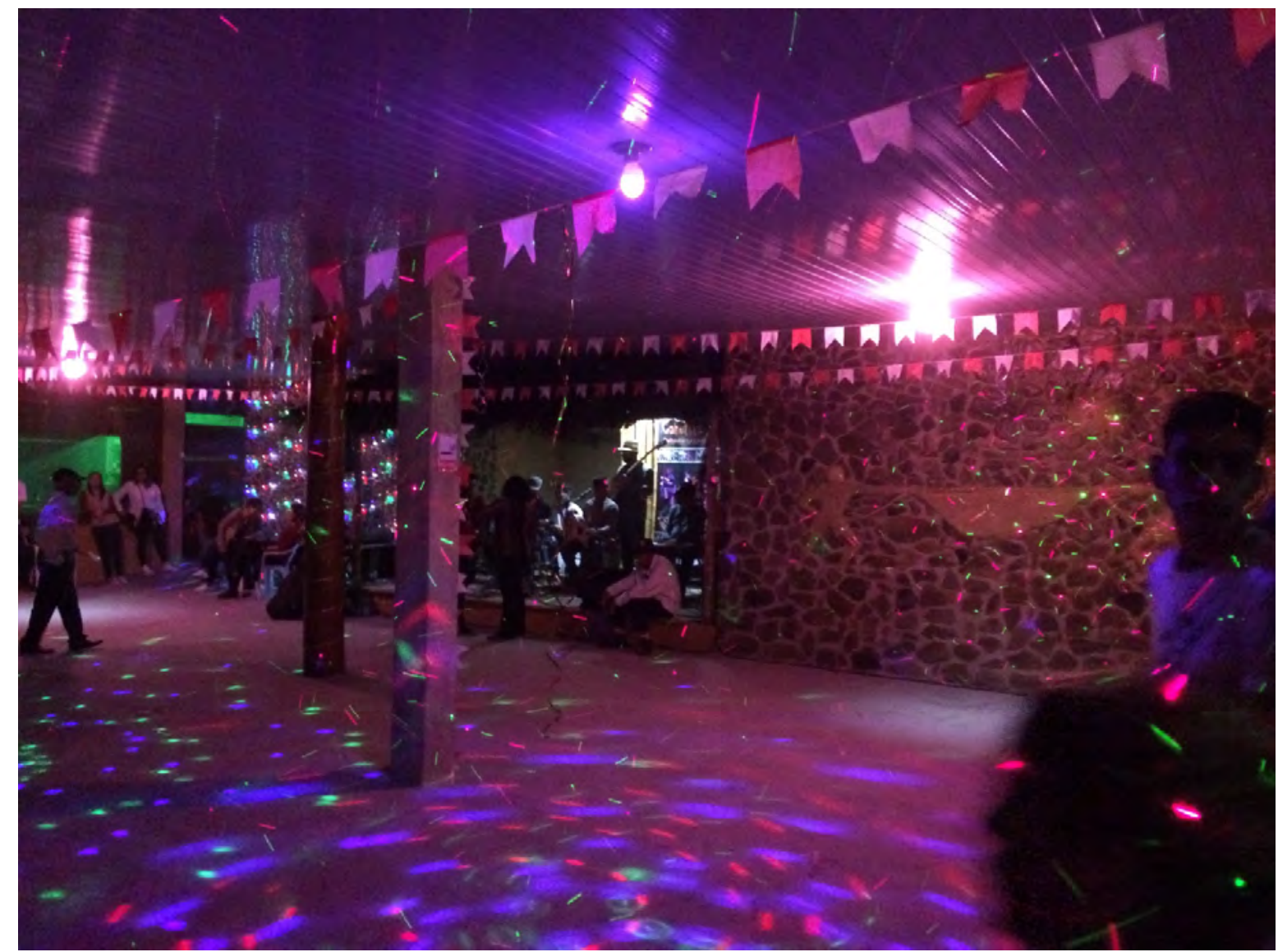

Fonte: Acervo Pessoal

Baduca foi irredutível. Primeiro se dirigiu a mim, questionando-me sobre o dito efeito luminoso. Por estar auxiliando em uma das trocas de grupo (participaram da festa mais de 10 grupos de fandango, vindos de Ubatuba, Peruíbe, Iguape, Cananéia, Guaraqueçaba e Paranaguá), não pude dar maior atenção naquele momento, apenas comentando que não havia sido eu o responsável pela instalação de tal equipamento. Na sequência, dirigiu-se a Aorélio Domingues, sendo enfático ao questioná-lo. Aorélio, por sua vez, lembrando-se de como seu avô tocava, respondeu, usando como argumento reverso o equipamento de som que estava sendo usado: "Na época de vovô era tudo acústico... Desligamos o som também?"

O equipamento não foi desligado; já o efeito LED, foi. Nessa "mistura geral”, por outro lado, o baixo elétrico, ainda considerado como instrumento exótico em determinados contextos fandangueiros, não pareceu gerar qualquer problema. O baile seguiu em frente, até que os primeiros raios de sol oferecessem outras alternativas à iluminação. 


\section{Hibridação}

A complexidade dos processos de imigração e miscigenação em território brasileiro, iniciados no período colonial, guardam em si processos de invasão e dominação, sejam elas econômicas ou culturais. Por sujeição, colonizam-se as subjetividades. O efervescente período de ocupação árabe na península ibérica e a reconquista dessa região pelos cristãos singra os mares no mesmo período da expansão colonial portuguesa e espanhola no Novo Mundo, alcançando outras terras. Segundo Canclini:

Hibridação designa um conjunto de processos de intercâmbios e mesclas de culturas, ou entre formas culturais. Pode incluir a mestiçagem - racial ou étnica -, o sincretismo religioso e outras formas de fusão de culturas, como a fusão musical. Historicamente, sempre ocorreu hibridação, na medida em que há contato entre culturas e uma toma emprestados elementos das outras. No mundo contemporâneo, o incremento de viagens, de relações entre as culturas e as indústrias audiovisuais, as migrações e outros processos fomentam o maior acesso de certas culturas aos repertórios de outras. Em muitos casos essa relação não é só de enriquecimento, ou de apropriação pacífica, mas conflitiva. Fala-se muito, nos últimos anos, de "choque" entre as culturas. Em todo esse contexto vemos que os processos de hibridação são uma das modalidades de interculturalidade, mas a noção de interculturalidade é mais abrangente, inclui outras relações entre as culturas, intercâmbios às vezes conflitivos. (DAMAZIO, s/d)

Nominações de marcas, ainda de uso corrente nos cancioneiros caiçaras, podem ser visualizadas no códice manuscrito por Antonio Vieira dos Santos, Cifras de música para saltério, que data de 1805 (BUDASZ, 1996). O documento parece ter sido escrito em Paranaguá ou Morretes, encontrando-se atualmente sob a guarda do Círculo de Estudos Bandeirantes, em Curitiba. Os códices contêm grande número de peças musicais, de gêneros variados, em tablatura para saltério. "Constitui-se esta obra na mais antiga coleção de música não religiosa encontrada no Estado do Paraná e, em nível nacional, na maior e mais variada da primeira metade do século XIX.” (BUDASZ, 1996) Tal documento é valioso para o estudo da música popular e de salão no Brasil e em Portugal, de fins do século XVIII a meados do XIX, "um verdadeiro catálogo do que se fazia em matéria de música nos salões da colônia”. Entre as peças que constam no códice encontramos um total de 171 músicas, divididas pelo autor em dois grupos principais: 
a) Formas e gêneros musicais europeus: adágios, amáveis, contradanças, cotilhões, hinos, marchas, minuetes, repiques, retiradas, tocatas e valsas.

b)Formas e gêneros musicais de origem nacional ou nacionalizados: baianas, batuques, cantigas, chulas, miudinhos, modinhas, lundus e várias marcas de fandango como anu, chico, recortado, tirana, tonta e vilão. (ibid., - grifos nossos)

O autor ainda tece um quadro comparativo em três distintas categorias: 1) presença maciça no manuscrito de músicas de origem portuguesa, com a possibilidade de consulta direta a fontes primárias em Portugal; 2) comparação com peças de mesmo gênero e com fortes elementos de identificação, como estruturas melódicas semelhantes; e 3) comparação com peças de mesmo gênero, sem maiores elementos de identificação.

À guisa de conclusão, Budasz considera que, através das comparações acima mencionadas, percebe-se certo processo de simplificação em algumas músicas. "Reduzidas às vezes a uma linha melódica em terças paralelas, algumas destas peças lembram certas práticas musicais características da música popular, como o canto em fabordão, ou alguns toques de viola." (ibid.) São modelos poéticos, métricos, melódicos e organológicos que aportam em terras sul-americanas junto com os invasores europeus.

O entendimento histórico dos processos envolvidos nos é útil para entendermos como tais aspectos são vivificados pelos fazedores de fandango na atualidade:

Outra coisa: A nossa viola é da beiroa, daquela que tem a turina, entendeu? Que eles chamam beiroa, que tem o mesmo nome lá [Portugal]. Segundo o Saraiva, que eu falei pra vc, ele falou que a viola caiu na mão dos populares em Portugal nessa época: de mil quatrocentos e tanto até mil quinhentos e tanto, viola que todo mundo queria na época. Então imagina: se todos os populares queriam essa viola na época, que era pra bailes e para coisas assim, o que veio pra cá?

Eu acho que o movimento mais forte hoje em dia é nos Açores. O Rafael Carvalho, lá, é uma cara importante, que tem divulgado muito a viola da terra. Agora são vários grupos, orquestra de viola da terra. Eles criaram método; tudo isso aí que eu quero fazer, eles já fizeram, entende? A viola fez isso aqui ó! "Vum"! Eles tocam, a juventude toca viola da terra! Em Portugal, no Alentejo, Pedro Mestre com a viola campaniça, que é aquela bem acinturada, hoje lá tem construtores que fazem viola campaniça!

Bem acinturadinha, e daí eles já tem viola da terra e campaniça para vender na loja! Você vai lá e compra. Até vi o Pedro Mestre: faltou uma viola, ele foi lá na loja e comprou uma viola campaniça para o espetáculo. Outro grau, viola campaniça profissional! Profissional! Aí rola, meu camarada! Aí rola!

Aí, você olha na televisão, tem gente tocando viola campaniça! Aí rola! (Aorélio Domingues - Cadernos de campo 05/08/2015 - transcrição nossa)

As constantes atualizações em curso demonstram o crescente interesse por instrumentos com melhores qualidades técnicas, capazes de executar não apenas as marcas de fandango, mas 
com a possibilidade de que sejam inseridas em outros nichos de atuação. De qualquer modo, fica clara a referência aos modelos europeus difundidos no Novo Mundo.

Os padrões organológicos replicados desde o período colonial, no qual a convivência entre europeus e indígenas se deu de modos complexos e enviesados, devem ser também atribuídos à presença jesuítica inaciana nos modelos de catequização levados a cabo em terra brasilis. "Não somente as orações, mas as "cantigas de Nosso Senhor polla lingoa" eram fáceis de aprender e quase sempre bem recebidas pelos meninos da terra, já que a música era elemento tão comum na cultura dos indígenas da costa brasileira." (CASTAGNA, 1994, p.03)

A citação de Paulo Castagna diz respeito também aos claros exemplos das contrafacções de inversão ideológica, em que releituras eclesiásticas, visando à substituição das letras (impregnadas de conteúdo moral e ideológico) de determinadas canções ibéricas, conferiam novas conotações aos romances de época, trocando temáticas amorosas, lascivas e libidinosas por poemas devocionais religiosos ${ }^{28}$. Esse aspecto é pormenorizado por Rogério Budasz, que aponta o uso das técnicas do "contrafactun, ou contrafacção ao divino de poesias seculares" como um dos recursos composicionais utilizados por José de Anchieta em sua labuta catequizadora. (BUDASZ, 1994, 1996 e BUDASZ, 2008 p.62)

Se, por um lado, pesquisadores como Fernando Corrêa de Azevedo (1978), Inami Custodio Pinto (1983, 1992, 2003 e 2004), Rozelise Roderjam (1979, 1980 e 1981), e, mais recentemente, Gabriel Bertolo (2015), Patrícia Martins (2018), Cintia Bisconsin Ferrero (2007), Joana Ortigão Corrêa (2016), José Muniz (2017) concordem com a reminiscência ibérica no alicerce organológico, poético e coreográfico do fandango caiçara, por outro, pouco interesse foi destinado às características al-Andaluzas presentes nesse bem imaterial, assim como ao importante papel da presença cosmopolita jesuítica nestes ínterins, perdendo-se de vista importantes dados históricos do período colonial.

\footnotetext{
28 "O Processo consistia em se introduzir determinadas modificações no texto original a fim de transformar seu sentido profano em espiritual. Isto se realizava geralmente com grande facilidade: Algumas palavras são trocadas e o texto adquire um novo sentido religioso. O motivo pelo qual as fontes preferidas para divinização eram as canções populares é simples: já que todos as cantavam, seria um ótimo meio de propagação do sentimento religioso.” (BUDASZ, 1994, p. 63)
} 


\section{Jesuítas, colonos e guaranis}

Aorélio Domingues, que acabou por se converter em um de meus principais interlocutores no universo caiçara, fez comentários e reflexões inspirados em sua última visita a Portugal, os quais podem nos aproximar da concatenação nativa sobre o tema:

Às vezes as mulheres perguntam: porque mulher não bate tamanco? Por quê? Se no flamenco a mulher bate, né! O Rafael Carvalho, que é lá do Açores, me mandou umas danças que são de lá, igual ao fandango, e as mulheres dançam igual aos homens, só que não batem tamanco, mas a coreografia é igual, tem rabeca, viola, caixa, adufo, só que a mulher é "foda", faz tudo que o homem faz. Eu comecei a "pescar" as coisas, era bem o que falei mesmo. Fomos lá pra Penha Garcia; lá é mulher que toca adufo, é mulher que canta. Aí, a rabeca, ela tem o braço curto, pra pegar naquela posição, pra tocar estridente mesmo, para acompanhar melodias tocadas por mulheres. A rabeca acompanhava mulheres, por isto ela tem o braço curto. Poxa, pra gente tocar fandango aqui (Paranaguá), o fandango é alto (agudo).

O que acontece com o machete? Eu conversando com um pesquisador lá, o Thiago Pereira, ele falou:

- Cara, mas que salada é essa que vocês estão. Aí eu falei:

- A gente tem o machete!

- O machete é lá de Braga.

- E a nossa viola, a Viola Beiroa?

- A Viola Beiroa é de Castelo Branco!

- E o fandango?

- Do Minho.

- O Adufe?

- Do norte, de Trás dos Montes.

Cara que loucura, cada coisa de um lugar! Aí o que acontece? Eu ainda acho que, quando os portugueses chegaram aqui, mais importante, eu penso o seguinte: a questão que é anterior, quando aconteceu o fandango, eles tocaram uma matriz de alguma coisa... [elucubrando um diálogo imaginário]

- O que você tem aí?

- Ah, eu tenho uma rabeca!

- Então acompanha, eu tenho um Machete.

- Adufo?

- Traga!

- Viola? Vem todo mundo (e tocaram alguma coisa).

- Vamos dançar, o quê?

- Aquele Fandango lá, Fandango! Fandango! (risos)

E começaram a bater o pé! E o que aconteceu? Não tinha mulher portuguesa, para dançar. Provavelmente colocaram índias para dançar, pessoal que matavam, que amarravam. Você acha que as índias iriam dançar igual nos Açores? Claro que não! Elas estavam ali, submissas, assustadas. E eles ali: festa, vinho, terra de ninguém...

Mas tem uma coisa interessante nessa tristeza toda: é a gente observar que não tinha mulher portuguesa. E que época era essa, que não tinha mulher 
portuguesa? Muito antes de 1750, e da chegada dos açorianos e desta história toda. Foi neste contexto que a coisa aconteceu, com esta mistura toda! (Cadernos de campo, 12/2016 - transcrição nossa)

"Muito antes de 1750, e da chegada dos açorianos e desta história toda", não há dúvidas de que a sólida presença açoriana teve impacto na construção da miscigenada conjuntura neobrasileira que aflorava no Brasil colonial. Fato é que, tanto pelo viés poético quanto organológico, referências clássicas entre os que pesquisam cultura Guarani podem corroborar o fundamento do comentário de Aorélio Domingues. Montoya, por exemplo, na publicação madrilena de seu léxico guaraní, descreve o termo mbaraka ${ }^{29}$ da seguinte maneira:

Cabaça com contas dentro, que serve de instrumento para cantar, e a partir daí põe nome a todo instrumento musical. Ambopu mbaracá. 1. Ambaracaá mbopu, tocar instrumentos. Mbaracá ca, cordas.

Ambaracaá moa tyrõ, ymboio îabo, temperar [afinar]. Ô̂ô̂a catu mbaracaá, estão destemperados [dasafinados] os instrumentos (...) Nimôatyrõhabi, estão destemperados [desafinados] (...) Mbaracá mēndá, ponte de [viola]. Mbaracai cúáquâ hába, trastes. Aîapı̌ pı̌mbaracaca, pôr os dedos nas cordas. Anatôi mbaracaca, tocar rasgado, Ayquǐrĭ mbaracaca, tocar rabecas com um arco. Mbaracá revica, a corda de que pendem todas as cordas das rabecas. ${ }^{30}$ (MONTOYA, 1639 , p. 212)

Podemos concordar com BUDASZ, (2004, p.20) quando nos indica que os "Fandangos parecem ter sido introduzidos no litoral sul do Brasil em meados do século XVIII, época do auge do fandango espanhol em Portugal”, tendo assumido, em nossas terras, o sentido generalizado de festa ou reunião, "compreendendo várias danças". A consolidação epistemológica do termo fandango e, consequentemente, a ampliação de seu uso se dão em um meio propício, um pano de fundo, informado pelo vocabulário musical e organológico disponível na época, no qual já estavam impressas características sonoras e musicais emblemáticas daquilo que, mais tarde, seria entendido como manifestação autêntica das populações caiçara.

Ainda no tocante às populações guarani, conforme afirma Montoya, observamos que o termo mbaraka passa a designar outros instrumentos musicais além do chocalho globular há

\footnotetext{
${ }^{29} \mathrm{Na}$ atualidade, o termo se refere ao instrumento cordofone de cinco cordas utilizado ritualmente pelo subgrupo Mbya Guarani, em suas áreas de incidência (sul e sudeste brasileiro, Paraguai, Argentina e sul da Bolívia) incluídas aí as localidades entendidas como território caiçara, como em Paranaguá e Guaraqueçaba no estado do Paraná, Cananéia, Iguape e Ubatuba no estado de São Paulo e Paraty no estado do Rio de Janeiro.

30 "Calabaço com cuentas dentro, que firue de inftrumento para cantar, y de ahi ponen nombre a todo inftrumento mufico. Ambopú mbaracá. 1. ambaraca mbopú, tocar inftrumentos. Mbaraca çã, cuerdas. Ambaracaçã moa tÿrõ, ymboîo îabo, templar. Oîoîa catu mbaracá, eftàn deftemplados los inftrumentos. (...) Nimôatŷrõhábi, están deftemplados. (...) Mbaracaçâ mēndá, puente de guitarra. Mbaracãī cúáquâ hába, traftes. Aîap̌ pǐmbaracaça, poner los dedos en las cuerdas. Añatôi mbaracaçã, tocar rasgado, Ayquǐrǐ mbaracaçã, tocar rabeles com um arco. Mbaraca reviçã, la cuerda de que pēden todas las cueras de los rabeles."
} 
pelo menos quatrocentos anos, inclusive aqueles munidos de corda - çã. Além do uso corrente desta "nova instrumentação", já se haviam consolidado termos linguísticos capazes de pormenorizar a prática de sua execução: tocar rasgado, tocar rabeles com um arco. Além de chamar a atenção para os aspectos ibéricos da incorporação da viola de cinco ordens - mbaraka - pelos Mbyá Guarani, vale ressaltar quão antiga ela é, em vista do modo com que foi engendrada por essas populações, tanto em termos etológicos quanto cosmogônicos.

Sobre o uso do mbaraka, Kilza Setti aponta a relevância dessa apropriação (muitas vezes considerada como fator de "aculturação"), reservando-lhe sensível interesse, seja a partir dos critérios seletivos adotados pelos indígenas ao "pinçar e adotar" elementos da cultura englobante, seja pelos artifícios utilizados na reinterpretação e na redefinição de usos de artefatos culturais múltiplos.

Sobre a época de adoção do violão nas rezas, Irma Ruiz supõe ter sido adotado entre 1650 e 1750 entre os Mbya do Paraguai e conforme Strelnikov, transmitida pelos Xiripá cristianizados. Ela lembra também o interesse da sobrevivência entre os Mbya da guitarra de 5 cordas e do rabel de 3 cordas, coexistindo com o popular violão ou guitarra de 6 cordas e com o violino de 4 cordas. (SETTI, 1993, p. 9).

Como já aventado em outra oportunidade, as evidências indicam ter sido a viola de cinco ordens, e não o violão, o objeto inicial desse processo, mais tarde substituído por instrumentos manufaturados industrialmente. A retirada da sexta corda é atribuída à simbologia referente às cinco ordens que já havia sido consolidada pelo uso da viola entre os Mbyá ${ }^{31}$. Vale salientar que o chocalho globular, generalizadamente chamado de maracá ou mbaraka entre os falantes de língua tupi, é denominado mbaraka-miri entre os Mbyá Guarani. "A transformação metonímica do mbaraka em mbaraka miri e da viola em mbaraka vai além da simples apropriação de um objeto cultural; neste caso, dá-se a consubstancialização do instrumento, que é agregado a significações múltiplas em uma intrincada rede de signos rituais." (GIORDANI, 2009, p.77)

A partir do mbaraka, nos aproximamos dos estudos sobre as trocas na constituição do mundo social Mbyá-Guarani. Valéria de Assis (2006) acena à perspectiva de que aquilo que é feito configura-se em imitação; associa-se a concepção de que a produção - de objetos, de pessoas e da sociabilidade - é resultado de processos de incorporação, apresentando os objetos

\footnotetext{
${ }^{31}$ Pude constatar, em 2006, nos municípios de Punta Porã e Nueva Esperanza no Paraguai a utilização de mbarakas manufaturados artesanalmente. Em território brasileiro é comum a incidência de violões industrializados produzidos em série, subtraída a sexta corda e mantidos os trastes, mesmo que via de regra, tais trastes não sejam utilizados durante os cânticos na casa de reza. O uso ritual do mbaraka ocupa papel de destaque na morfologia sonora do jeroky mbya.
} 
e sua estética como expressões dessa perspectiva. Sob essa ótica, Assis dialoga com Nancy Munn (1971), que "tematiza o estabelecimento de uma relação entre pessoas e coisas, [...] nas relações sociais, as pessoas trocam-se ao efetuarem trocas de objetos, pois as coisas também têm agência, estão imbuídas também com a noção de pessoa." Ambas concordam que as pessoas podem estar expressas nos objetos e estes formam partes de sua personalidade. (ASSIS 2006, p.141)

As trocas na constituição do mundo social parecem reverberar no universo caiçara de modo similar, como podemos perceber nos relatos compilados por José Muniz, jovem fandangueiro de Guaraqueçaba, que recentemente concluiu seu mestrado junto ao Programa de Pós-Graduação em Desenvolvimento Territorial Sustentável, da Universidade Federal do Paraná (UFPR):

\footnotetext{
"Quase nasci em cima de uma viola", dizia Leonildo Pereira (2009), demonstrando os fortes vínculos do violeiro de Fandango Caiçara com seu instrumento, desde a mais tenra infância quando apenas observava os familiares mais velhos, mais tarde também como violeiro, afamado, portanto, figura esperada a cada Fandango; Antônio Alves Pires (2004) enfatizava que "eu era muito doido por uma viola" (2005). (MUNIZ, 2017, p.98)
} na discussão:

O depoimento de "Dona” Narcinda Lopes, viúva de Pedro Lopes, também nos auxilia

Ele [o falecido marido Pedro Lopes] começô a tocá de idade de 8 anos. [anos mais tarde] Quando a filha comprô pra ele, era todo dia. Aí ele falô até que amava mais a viola do que o próprio filho. Antes de falecê, ele pediu que colocasse a viola no caixão com ele. Mas naquela hora, a gente não lembro né, esquecero. Pois não é que ele veio no sonho do filho, falá da viola. Então o filho sonhô co pai que vinha pedi a viola. (MUNIZ, 2017, p.99)

Em nota de rodapé, Muniz tece considerações sobre esse relato, que podem ser entendidas como confluências históricas às quais se vinculam caiçaras e guaranis: "Logo após o falecimento do dono, o instrumento perde a função de uso e algumas famílias passam a guardar o instrumento como recordação do ente querido". Muniz nos narra haver encontrado, na Barra de Ararapira, violas e rabecas guardadas com esse intuito, narrando ainda que, na comunidade de Rio Verde, nas proximidades de Guaraqueçaba, “costumava-se queimar a viola logo após o falecimento de seu dono". Sobre a queima ritual de pertences e habitações que pertenciam aos mortos Mbyá, tive por duas vezes a oportunidade de presenciar fatos semelhantes, relatados em Mbaraka: Metonímia Musical Mbya (GIORDANI, 2009, p. 49). No primeiro caso, fui testemunha ocular dos entulhos de madeira queimada remanescentes da antiga habitação do Senhor Faustino, na Ilha da Cotinga, que na época se mudara para a aldeia 
de Cerco Grande, em Guaraqueçaba. No segundo caso, narro o comentário de "Seu" Cristino, liderança política e religiosa Mbyá, que comentou o fato de haver ateado fogo em sua antiga residência motivado pela morte de sua esposa. No caso Mbya, a morte pode ser associada à perda, ao descontentamento ou ao deslocamento.

Retomando o tema da dispersão de elementos culturais (inclusive aqueles de origem ibérica) a partir de práticas guarani, ao proceder um conjunto de associações "enquadrando os deslocamentos dentro do conceito da espacialidade que, junto com a tradição, formaria um dos grandes eixos do modo de ser Guarani”, nota-se a ligação entre a constante procura de terras novas para aldeias e roças e a migração de fundo profético. São movimentos que sugerem a busca de um espaço não apenas geográfico, mas também espiritual, que propicie a recriação do modo de vida próprio dos Guarani, "quer pela renovação do local de assentamento, quer pelo reencontro com uma terra mítica" (MONTEIRO, 1992, p. 482).

No estudo linguístico de Ruiz de Montoya (1876), a tradução de yvy mara e’y se apresenta no sentido de "solo intacto, não edificado"; Bartolome Melià (1981, p. 10/11) desloca o foco da discussão às implicações econômico-ecológicas implícitas nos deslocamentos de grupos Guarani. Dessa maneira, o mito estaria vinculado a noções e práticas econômicas caracterizadas pelo teko Guarani, "modo de ser", entendendo a estada terrena de modo cíclico, permeada pela dualidade abundância/carência. A abordagem proposta por Melià encontra motivação múltipla no fenômeno da movimentação desses grupos, não perdendo de vista o caráter mítico-religioso estabelecido em sua base, fundamentalmente de cunho "espiritual", tendências que podem ser percebidas em trabalhos posteriores, como os de Garlet (1997), Ladeira (2001), Chamorro (1995, 1998), Mello (2001) entre outros. Ivori Garlet (1997) defende a ideia de ampliação territorial relativa a eventos do contato, utilizando-se de noções de "desterritorialização e reterritorialização", explicando a reorganização territorial e sua utilização de maneira "circular", "território aberto, descontínuo e sem fronteiras definidas, razão pela qual pode ser continuamente ampliado a partir da incorporação de novos espaços".

Os movimentos de trocas e dinâmicas de mobilidade se dão em vias de muitas mãos, nas movimentações de correligionários das ordens religiosas, bandeirantes, colonos, aventureiros, indígenas, do movimento do tropeirismo e da inserção do componente africano escravizado, em todos os casos estabelecendo relação com os embrionários centros urbanos que, via de regra, centralizavam o ambiente político e cultural do Brasil colonial.

$\mathrm{Na}$ efusiva dinâmica de apropriações e desuso, a fala de Aorélio Domingues vai ao encontro das considerações de Darcy Ribeiro sobre a conformação humana inerente à área cultural por ele denominada sulina, abrangendo gaúchos, matutos e gringos. (RIBEIRO, 2006, 
p. 374). Os brasis sulinos, cuja configuração histórica se assemelha à dos gaúchos platinos, surge a "partir da transconfiguração étnica das populações mestiças de varões espanhóis e lusitanos com mulheres Guaranis". As práticas de entretenimento e diversão levadas a cabo por estas populações se desdobravam em uma complexa rede de apropriações, aculturação e reinvenção de estruturas poéticas e festivas medievais disseminadas pelos lusitanos e espanhóis, absorvidas e difundidas pelas populações neobrasileiras em períodos anteriores ao traslado de açorianos ao Brasil, que foi impulsionado pela coroa portuguesa no século XVIII.

Nesse sentido, também são plausíveis os argumentos tanto de Roselys Roderjan quanto de Inami Custódio Pinto, que refutam veementemente a possibilidade de que o "fandango teria sido trazido ao litoral paranaense pelos açorianos de Santa Catarina". Para reforçar tal argumento, Roselys vale-se de Barbosa Lesa e Paixão Cortes, afirmando que "Da conjunção do fandango vicentista (São Vicente, SP), dança masculina estritamente sapateada, com cantigas trazidas por açorianos e luso-brasileiros, povoadores do Sul, surgiu o primitivo fandango gaúcho.” (BOLETIM DA COMISSÃO PARANAENSE DE FOLCLORE, 1980, p. 14)

\footnotetext{
Queremos lembrar que o vicentino, citado pelos autores acima, é referido por vários autores rio-grandenses em seus estudos sobre a formação cultural dos gaúchos, generalizando todo o contingente humano que desceu povoando Santa Catarina e Rio Grande do Sul nos séculos XVII e XVIII. Eles referemse como povoadores do rio grande a lagunenses, catarinenses, paulistas mamelucos, índios, etc., sem citar nem uma vez o natural de Curitiba ou de Paranaguá, o paranaense que levou para lá a cultura de mais de um século, desenvolvida no Paraná, abrindo os caminhos para o Rio Grande, defendendoo contra-ataques espanhóis, fundando futuras cidades e povoando o sul, a mando do governo português, ou através do tropeirismo. Antes de qualquer referência que se faça à influência do fandango gaúcho sobre as sobrevivências dessa forma de música popular no Paraná, é necessário lembrar que essa influência partiu há três séculos, do Paraná para o sul. (ibid., p. 14)
}

Em outro volume, publicado em 1981, Roderjan cita ainda o fato de que os primeiros caminhos abertos do Rio Grande do Sul até Curitiba, de 1720 em diante, tiveram supervisão da Câmara de Curitiba, havendo reunido curitibanos para dar cabo dessa empreitada. "Como tropeiro, ele vai trazer o gado solto, remanescente dos antigos rebanhos das Missões jesuíticas, que prolifera aos milhares nos campos do Sul”. (RODERJAN, 1981, p. 7)

A presença de missionários entre os Guaranis antecedeu em muito a fundação das primeiras reduções, que se deu apenas em 1610. Ainda na década de 1550, os jesuítas portugueses de São Vicente se interessavam pelos Carijós, uma vez que possuíam a informação de que estes eram mais numerosos e mais propícios à conversão do que os Tupiniquins, que apresentavam toda sorte de resistência ao projeto inaciano. (MONTEIRO, 1992, p. 487) 
Na verdade, à altura da principal invasão do Guairá pelos paulistas, as missões em sua maioria eram comunidades recém-formadas, precárias e isoladas, debatendo-se em busca de uma base económica viável para sua sobrevivência. Em 1628, quando os paulistas já se encontravam instalados nas margens do Tibagi, o padre António Ruiz de Montoya, então superior das missões do Guairá, retratou, em sua carta ânua, outros obstáculos para o êxito missioneiro. Além das atividades predatórias de paulistas e espanhóis, Montoya acrescentava as doenças, a fome, as rivalidades faccionais e a guerra intertribal como as principais atribulações da população aldeada em oito das reduções da província[...]. Por outro lado, os portugueses interessavam-se pelos Guarani de longa data, desenrolando-se relações de troca e de aliança, seguindo o padrão em formação ao longo do litoral brasileiro. Desde meados do século XVI os primeiros povoadores da capitania de São Vicente percorriam os caminhos do sul e sudoeste, acumulando um considerável conhecimento das terras e populações situadas na zona intermediária entre as colônias ibéricas. Do mesmo modo, freqüentavam o litoral ao sul da capitania, travando um intenso intercâmbio com os grupos Guarani da região, sobretudo na chamada laguna dos Patos. Portanto, bem antes do estabelecimento das primeiras reduções, os paulistas realizavam "resgates" tanto ao longo do caminho terrestre que atravessava a "província" guairenha quanto no litoral. Estas relações revestiam-se de uma complexidade que não transparece facilmente na bibliografia, que tende a retratar a situação em termos de bandeirantes versus jesuítas (...). Os paulistas favoreciam esta forma de recrutamento de mão-de-obra até a década de 1630, quando expedições maiores passaram a transformar estas relações na região dos Patos. Mesmo nessa conjuntura, alguns paulistas reivindicavam a preservação do velho escambo diante do avanço do sertanismo de apresamento. Assim, em 1635, a Câmara Municipal de São Paulo enviou uma carta ao capitão-mor de São Vicente em protesto contra uma expedição vicentina aos Patos, armada por Luís Dias Leme, pois esta ameaçava as boas relações entre paulistas e Carijó[s] dos Patos. Ressaltando que o "resgate que levam não é mais que pólvora e chumbo e pelouros e correntes", a Câmara buscava impedir a escravização dos "índios [...] que há mais de cem anos são nossos amigos e compadres de nossos antepassados pois era remédio desta capitania" (MONTEIRO, 2005, p. 70/71).

As implicações do contato e da conquista modificaram fortemente a constituição da organização das populações guarani. Monteiro (1992) nos apresenta dois fatores no intuito de exemplificar essa situação: por um lado, o abrupto declínio populacional em função do fator epidemiológico e, por outro, o recuo estratégico dessas populações para áreas de acesso mais difícil.

A "docilidade" com a qual as populações guarani são muitas vezes apresentadas frente à labuta serviçal aos missionários europeus, ou ainda como vítimas que foram dos famigerados bandeirantes, os Guarani, longe dessa visão, “desenvolveram estratégias próprias que visavam não apenas a mera sobrevivência, mas, também, a permanente recriação de sua identidade e de seu modo de ser frente às condições progressivas adversas.” (MONTEIRO, 1992, p. 475)

A desesperança missionária toma voz nos apelos de Manoel da Nóbrega, Luís da Grã e 
Ambrósio Pires que, frustrados com as experiências iniciais antes inundadas de otimismo missionário, acabam por adotar a subjugação social e política dos "gentios" como estratégia alternativa, na qual "o projeto catequético e conquista colonial soldaram-se num só movimento". (MAESTRI FILHO, 1997, p. 226)

Já nesse período, a dita docilidade atribuída aos Guarani da costa já era conhecida pelas diferentes regiões do imaturo projeto colonial. No ano de 1555, na capitania da Baía, anotava o padre Ambrósio Pires:

Parece que não é chegada a hora em que estas gentes hão-de entrar no curral de Cristo. E parecia duvidar que os Carijós [Guaranis] fossem, como acreditava-se, mais pré-dispostos ao evangelho. "Em algumas partes dizem que há mais disposição [...]. O Senhor faça que não sejam as mostras que estes [Nóbrega e os primeiros jesuítas] tiveram nos princípios. (ibid., p. 224)

Monteiro também nos esclarece que, no século XVI, o território ocupado pelos Guarani situava-se do Chaco até o Atlântico, "das capitanias do sul até o Rio da Prata, neste vasto território que atualmente constitui os estados do Rio Grande do Sul, Santa Catarina, Paraná, São Paulo e Mato Grosso do Sul, além de partes de países vizinhos como a Argentina, Uruguai e Paraguai." A distribuição demográfica heterogênica destas populações nesses territórios devese ao fato de que elas se encontravam principalmente nas florestas tropicais e subtropicais, "ao longo do litoral e entre os principais rios do sistema Paraná-Paraguai." (MONTEIRO, 1992, p. 476/477)

Um recuo inicial destas parcialidades étnicas e a construção social modelada pelas reduções jesuíticas têm um papel - pouco explorado pelos estudiosos das musicalidades das populações caiçara - tanto na qualificação de mão de obra para manufatura dos instrumentos quanto na importação de instrumentos ibéricos, belgas, franceses e alemães que serviriam de modelos a serem replicados. Este elemento também se pode conectar, em certa medida, à formação musical de "gentios" cujas qualidades musicais são exaltadas por diversos relatos de missionários jesuítas e autoridades coloniais, no Brasil, Paraguai e Argentina.

Ponto pacífico na ocupação dos territórios do Brasil meridional, a mobilidade Guarani expressa o trânsito em territórios antes contíguos, acentuado tanto pela dissolução da ordem jesuítica e pela expulsão de seus correligionários destes territórios no século XVIII, como pelas migrações massivas dessas populações para o leste. Movimentos opostos ao distanciamento estratégico inicial fomentados tanto por levantes messiânicos quanto por crenças no paraíso mítico, cuja orientação cardeal acena o sol nascente como marco de evolução espiritual na cosmologia Guarani, rumo à Yvy Mara e’y, movimento também conhecido como “marcha para 
o leste".

Na biblioteca do virtual do IBGE, consta que no início do século XII começaram as atividades de mineração no Brasil a partir da descoberta de ouro nos rios Ribeira, Açungui e Serra Negra; locais onde se fixaram os portugueses na região. "Em 1614, Diogo de Unhatte, tabelião da ouvidoria de São Vicente, obteve de Pero Cubas a sesmaria denominada Paranaguá, localizada entre os rios Ararapira e Superagui, atual município de Guaraqueçaba." (IBGE, 2017), sabendo-se que a efetiva povoação da região foi alavancada pelo capitão-mor Gabriel de Lara, responsável pela fundação da Capitania de Paranaguá.

Com a descoberta, inúmeros mineiros e aventureiros dirigiram-se para a região, explorando as terras e os rios em busca do ouro. Os missionários jesuítas, vindos de Cananéa fundaram no porto de Superagui, um estabelecimento agrícola e ao mesmo tempo religioso, para facilitar a catequese, visto que a população estava disseminada ao longo dos rios. (IBGE, 2017)

Ciente do fluxo de informação entre os centros urbanos e as novas vilas, o padre Sepp, considerado pioneiro tanto na formação musical de colonos e indígenas quanto no desenvolvimento da prática da luteria nas missões jesuíticas, tem suas crônicas comentadas por Lara (2015, p.117), nas quais se veem relatos sobre a luteria guarani:

De forma paralela às suas classes de música, o missionário criou oficinas para a fabricação de instrumentos. E de maneira semelhante aos especialistas em cada instrumento, mestres no fabrico destas peças também começaram a aparecer: "Temos dois órgãos, um dos quais trazidos da Europa, ao passo que o outro foi feito pelos índios, e tão semelhantes, que a princípio eu mesmo me enganei e levei o órgão indígena por conta do europeu." Mais uma vez a habilidade imitativa dos nativos recebe destaque. A partir de modelos oferecidos pelos jesuítas (o próprio padre Sepp trouxe alguns instrumentos da Europa), os indígenas produziam cópias, desenvolvendo assim a fabricação destes objetos na missão de Yapeyú. Além disso, a produção abastecia não só a própria redução, como também era exportada para outras missões e até mesmo para as cidades coloniais espanholas. E a variedade era grande:

(...) o órgão, as violas da gamba em seus diversos tamanhos, os violinos, bombardas, chirimias, dulcianas, flautas, harpas, guitarras e vihuelas (antepassado do violão), alaúdes, trompetes, trompas e tambores. Todos os instrumentos, de fabricação muito cuidada, saíam das oficinas guaranis.

Apontamos assim a relevância do trabalho inaciano na dispersão da música europeia e neobrasileira, trânsito intensificado pela implementação das reduções, reverberando mesmo após sua dissolução no ano de 1767, em contingentes indígenas reduzidos e "preados" pelos bandeirantes paulistas, indígenas e colonos formados nas artes e ofícios do canto e da luteria. Apesar da complexidade imposta à coleta de dados históricos que versem especificamente sobre 
esses acontecimentos, com foco na difusão da arte musical no Brasil meridional por remanescentes das reduções, a apropriação e transconsubstancialização de instrumentos como a viola e o rabel entre populações Mbyá, assim como o contínuo fluxo de mobilidade, parecem dar sentido ao argumento. Cabe sinalizar o fato de que a atual associação imediata do mbaraka e do ravé com a cultura material e imaterial Mbyá tem origens remotas e se dava na intensa circulação desses itens já nas primeiras décadas de contato com populações europeias. Mesmo que em outro recorte temporal, Kilza Setti questiona a perpetuação do uso percussivo do violão [mbaraka] entre os Mbyá:

Teriam mantido, como resíduo da herança jesuítica, preferência por instrumentos que levam à conformação de melodias construídas dentro de determinado clima ou ambiente tonal? A firmeza com que mulheres e crianças acompanham as sequências intervalares entoadas pelo rezador solista leva a crer que se trate de padrões melódicos sempre repetidos, mas quando ocorrem cantos supostamente novos ou inovadores, estes são também facilmente acompanhados pelo grupo coral. É viável pensar-se que isso se dê em virtude do sistema único de afinação dos violões e que possa esse ser visto como nivelador na condução das linhas melódicas dos porãhey. O canto assim submetido ao uso sistemático do bordão das cordas tende a limitar o elenco de sons da melodia e, consequentemente, propiciar maior adestramento do grupo coral em acompanhar responsorialmente os cantos na pajelança (SETTI, 1993, p. 9/10).

Se tais fatos podem ser observados junto às populações Guarani, como articular estes componentes culturais no convívio entre colonos, entre colonos e guaranis, e entre os últimos dois com os jesuítas? É nesse momento histórico - e no trânsito entre Cananéia e Paranaguá, tendo o lagamar principal via de acesso - que se dá o intercâmbio social e político necessário para disseminar o ideal colonialista cujas variantes espanholas e portuguesas se faziam presentes.

Em Paranaguá, no que diz respeito ao antigo Colégio de Jesuítas (inscrito no livro tombo 37-II , processo $n^{\circ} 38 / 72$ ), consta que:

Em 1605, de acordo com Ermelino de Leão, "o Padre Fernão Cardim, superior da casa das Missões em Cananéia - a que mais próxima ficava dos índios carijós de Paranaguá -, enviou os padres João Lobato e Jerônimo Rodrigues para substituir outros missionários no trabalho de catequese no Sul do Brasil ". Entre 1606 e 1640 os jesuítas instalaram no Superagüi, junto ao Varadouro Velho, a primeira casa de missões no território do Paraná atual. Segundo todas as indicações, com o transcorrer do tempo, não satisfeitos com a "casa pobre de Superagüi”, desejaram fosse construído um colégio em Paranaguá.

Da influência desses catequistas iria resultar o estabelecimento dos primeiros templos e colégios católicos ao Sul de Cananéia. Cabe, entretanto, aos jesuítas a quase totalidade do esforço missionário desenvolvido, pelo que 
se infere da petição da Câmara Municipal de Paranaguá ao provincial da Companhia de Jesus, na qual é solicitada a indicação para aquela vila de seis padres da Ordem, "para que dessem aulas de ensino e latinidade, bem como dogmas de Religião", em troca de numerário para a compra de escravos e doações de terras para seus estabelecimentos de agricultura e, também, "residência à custa do povo". Esse "documento" data de 10 de setembro de 1682.

Ainda segundo Ermelino de Leão, "a Câmara de Paranaguá, em nome do povo, fez promessa aos missionários de erigir para a Companhia de Jesus um convento sob a égide de Nossa Senhora das Mercês (a santa da Ilha da Cotinga). A ilha, desde 1548 era motivo de agitada demanda entre a Câmara e o provedor Manoel Lemos Conde e seu filho e sucessor, Antônio Morato.

Ainda sobre a construção do colégio em Paranaguá, é notório que, embora os historiadores comentem o início das obras do colégio somente no século XVIII (em 1708 e 1720), em artigo publicado em 1940 pelo IPHAN há uma referência de Vieira dos Santos Memória Histórica de Paranaguá - que faz supor que a construção já tivesse sido iniciada no século anterior: Diz ele, pág. 43 - (1697). "Neste ano foi levantada em Paranaguá a casa real de fundição dos quintos de ouro na rua do colégio, para nela se fundir...[...]"

O padre provincial João Antonio Andreoni (Sendo preposto geral o padre Tamborini) concedeu licença para construção do colégio, e a 14 de maio de 1708 os jesuítas padres Antonio da Cruz e Tomaz de Aquino faziam sua entrada solene na vila de Paranaguá, sendo recebidos debaixo de pálios e conduzidos com grande acompanhamento à igreja matriz, cantando-se aí um “Te Deum” em ação de graças. (IPHAN, 1940, p. 365)

Roderjan também menciona o fato de que o fluxo do povoamento de Paranaguá, em épocas mais remotas, no século XVII, deu-se por sucessivas levas de paulistas, alegando ser comum encontrarmos na genealogia das famílias mais antigas, casamentos com pessoas vindas de Iguape, Cananéia, São Vicente, Santos e São Paulo. "O elemento português também é constante, vindo de São Paulo ou diretamente de Portugal, pelo porto de Paranaguá. Daí dizermos que o Fandango, no Paraná, foi trazido pelos portugueses e pelo luso-brasileiro, mais propriamente pelo paulista." (RODERJAN, 1981, p. 31)

Também em Roderjan localizamos indicações de que as primeiras penetrações de europeus em solo paranaense se deram como rotas de passagem, posteriormente tendo a finalidade em "prear" indígenas. "Fase que culmina com as investidas dos bandeirantes paulistas às 13 reduções fundadas por jesuítas no Oeste Paranaense, onde estavam aldeados cerca de 100.000 índios (1588 e 1629).” A folclorista se vale ainda de Alfredo Romário Martins (s.d.) para atestar que "60.000 índios foram levados como escravos para São Paulo, e teriam padecido 15.000 nas lutas. Os padres reuniram os remanescentes do êxodo no Sul, na margem esquerda do rio Uruguai, fundando as missões.” (RODERJAN, 1981, p. 6) 
Outro ponto de convergência entre as dinâmicas de mobilidade e a construção e o uso de instrumentos musicais pelo esforço jesuítico é descrito por Protásio Paulo Langer, que organizou um conjunto de fontes sobre o estudo da música no período pós-Jesuítico, com base nos inventários dos bens dos povoados missioneiros redigidos por ocasião da expulsão da companhia de Jesus. Francisco Curt Lange se vale desta documentação (1986, p.58) para compilar o acervo instrumental de 19 missões, elaborando um quadro comparativo de tais inventários nos quais encontramos 69 Harpas, 41 Bajones (Vajones), "Muchas” Bandurrias (da família dos alaúdes espanhóis), 35 Clarines, 5 Claves, 7 Cornetas, 92 Chirimias, 12 Espinetas, 2 Fagotes, 3 Fagotillos, 10 Flautas, 1 Guitarra, 2 Liras, 3 Oboés, 22 Organos, 1 Trompa de Caza, 3 Timpanos, 84 Violines (Rabeles), 16 Violones (Rabelones), 2 Violas e 2 Vihuelas. (LANGER, 2012, p.336, grifo nosso).

Nosso grifo aos instrumentos de cordas, seja pela indicação das "muchas" bandurrias ou pela expressiva quantidade de violines (rabeles), violones (rabelones) e ainda das violas e vihuelas. Nos casos das bandurrias, apesar da configuração consolidada do instrumento na atualidade, não devemos nos evadir das inúmeras contradições históricas que cercam os estudos epistemológicos sobre o instrumento, indicando que sua raiz linguística guarda traços sumérios (pan-tur), gregos e romanos (pandoura ou pandura), ou ainda do latím medieval, onde são encontradas variantes como (mandurium e pandurium). Pedro Chamorro (2006) reúne diferentes estudiosos do tema no artigo intitulado "Historia de la bandurria - La Bandurria en la Edad Media", aventando que os musicólogos de um modo geral, ou não sabiam, ou não queriam denominar este instrumento por seu nome mais usual, criando confusões terminológicas entre alaúdes (curtos e longos) e instrumentos tipo alaúde (qualquer cordófono com braço, caixa de ressonância, mão e cravelhas), a partir do uso demasiado rígido da teoria de Curt Sachs.

Este erro causou o uso indevido do termo Mandora que é posterior à era medieval, embora possa ser a evolução da palavra mandurria - mandorre mandore-mandora - mandola desde os séculos medievais até o século XVII, cruzando a Península Ibérica, sendo alí denominado pandura, em latim medieval mandurium - pandurium por Navarra e no País Basco, onde o termo urria é incluído (porque é um instrumento pequeno e reduzido), isto é, mandurria; chegando na França com a denominação mandorre - mandore e mais tarde mandora até o norte da Itália como mandola. (CHAMORRO, 2006, p. 42 - grifos no original $)^{32}$

\footnotetext{
${ }^{32}$ Este error ha provocado la utilización indebida del termino Mandora que es posterior a la época medieval, aunque sí podría ser la evolución de la palabra mandurria - mandorre-mandore - mandora - mandola desde los siglos medievales hasta el siglo XVII, recorriendo la península ibérica desde que se denominaba pandura, en latín medieval mandurium - pandurium por Navarra y País Vasco donde se le incluye la voz urria (por ser instrumento
} 
Em Portugal, ainda recentemente, o termo bandúrria pode se apresentar como sinônimo da Viola Beiroa, como nos esclarece Susana Vicente da Silva Dias, no caderno de especificações técnicas desse instrumento, produzido e editado pela Câmara Municipal de Castelo Branco e pela Associação Recreativa e Cultural Viola Beiroa no ano de 2016:

Este cordofone [viola beiroa] pertence à família das Violas de Arame tradicionais portuguesas. Também é chamada de Bandurra ou Viola de Castelo Branco sendo originária da região da Beira Baixa. Esta viola é, provavelmente, o parente popular do instrumento de corda chamado Vihuela, muito tocado na Península Ibérica nos séculos XVII e XVIII. Tem cinco ordens de duas cordas de aço que podem ser pisadas ao longo da escala. Uma das diferenças em relação às suas congéneres do Norte, Sul e Ilhas de Portugal são duas cordas muito agudas, as requintas [turinas ou cantadeiras], que não podem ser pisadas sendo tocadas só com a mão direita. (CÂMARA MUNICIPAL DE CASTELO BRANCO, 2016, p. 4 - grifo nosso)

Já no caso dos violines, não há possibilidade de se precisar as características organológicas dos instrumentos, se estes (rabeles) eram de 4 ou de 3 cordas, confeccionados com aros ou escavados em peças únicas. Faz-se menção ainda a instrumentos que não foram contabilizados por estarem em poder dos construtores e dos músicos que os utilizavam.

Mesmo que historicamente seja predominantemente reproduzida a viola de 5 ordens (agregada ou não de turina), podemos elocubrar - a partir da quantidade indicada de bandurrias $^{33}$ - sobre um papel mais relevante do machete em períodos coloniais, sabendo ser essa a denominação corrente de grande parte dos instrumentos em forma de meia-pêra de dimensões reduzidas, abrindo outro viés interpretativo ao termo bandurria, que, assim como a viola de cinco ordens e a guitarra mourisca, apresenta descendência organológica vinculada ao Luth (Ud) Al-andaluzo. Como mencionado por Manzano (1993, p. 1377[21]):

Mas por sua vez, em al-Andalus o 'ud' se singulariza, como correspondente aos processos culturais que desembocarão no Califado de

\footnotetext{
pequeño y escaso), es decir, mandurria; llegando a Francia con la denominación mandorre - mandore y más tarde mandora hasta el norte de Italia como mandola.

${ }^{33}$ Outra derivação do termo pode ser encontrada em solo espanhol: "Cordofone para instrumentos da família do alaúde, muito comum na música popular hispânica. De dimensões reduzidas (cerca de $50 \mathrm{~cm}$ ), caixa traseira plana e em forma de pêra, uma pega muito curta em proporção à caixa, dividida em menos trastes (catorze) do que a guitarra, e sem cordal [ponte], figurou, em conjuntos de bandurrias e guitarras, no espectro, aguda, soando por meio de um plectro, em tempo quase constante (dada a curta duração de seu som). Desde o século XIV, ele evoluiu notavelmente: no século XVI, havia três cordas afinadas em quintas (sol 3 - re 4 - la 4); no início do século XVIII, cinco cordas duplas afinadas em quartas (do 3 - fa 3 - mi 4 - la 4), às quais foi acrescentada outra corda dupla (na segunda metade do mesmo século) (sol 2), e assim atingiu as seis cordas duplas atuais." (ENCICLOPÈDIA CATALANA, acesso em 12/12/2018)
} 
Córdoba, e será o de Ziryãb, ao qual ele acrescentou uma quinta corda dupla, além de outras melhorias, que simboliza a peculiaridade de al-Andalus frente o califado abássidí e fãtimí. A evolução da "guitarra morisca" poderia significar mais um passo neste processo de autoctonia, configurando-se como o instrumento singular da etapa mudéjar e mourisca, tanto na Península Ibérica como na Sicília. ${ }^{34}$

O panorama apresentado pelos autores nos mostra uma imagem datada, na qual efervesciam artífices nas artes musicais em uma intrincada rede de trocas, de relações e labores, tendo em vista a atender demandas contínuas vinculadas à igreja e seus rituais, notadamente a presença da música no rito litúrgico. Panorama que se dilui de forma drástica no período posterior à retirada forçada dos inacianos do território sul-americano, sendo tarefa hercúlea tentar traçar com precisão os movimentos desses agentes, centenas de milhares de indígenas que, coletivamente, ou de modo restrito a grupos familiares, iniciam novos processos de busca por territórios ou ainda dos colonos, padres e noviços que, buscando novos horizontes, somamse às massas proto-urbanas nos aglomeramentos humanos do Brasil daquela época.

Instrumento emblemático para o fandango paranaense, cujo uso nas últimas décadas o colocou próximo da invisibilidade, o machete (e recentemente o cavaquinho) tem uso histórico e continuado no litoral centro-norte paulista e sul fluminense. A expressiva quantidade de bandurrias e rabeles nos inventários catalogados por Curte Lange, assim como depoimentos mais recentes, como aqueles esboçados nas primeiras décadas do século XIX por Saint-Hilaire, fazem-nos crer que esses instrumentos tinham grande número de adeptos também no interior do estado, demonstrando as muitas vias de circulação desses artefatos:

O sargento-mor reunira os músicos das redondezas em sua sala, que não era ladrilhada nem assoalhada, tal como as modestas tabernas das nossas vilas. Entre os músicos que ali ouvi, achava-se um homem que tocava viola com muito gosto, sem conhecer uma nota sequer. Outro, senhor de pequeno instrumento chamado machete, que não é outra coisa senão uma viola de bolso, tocava-o em todas as posições imagináveis, tendo o talento de tirar partido disso. Fazia ainda esse homem tantos trejeitos, que um famoso saltimbanco, então conhecido em Paris por le grimacier, lhe teria inveja. Além de música, houve danças. Sendo quaresma, não foi permitido o batuque

\footnotetext{
${ }^{34}$ Pero a su vez, en al-Andalus el 'ud se singulariza, como corresponde a los procesos culturales que desembocarán en el Califato de Córdoba, y será el 'ud de Ziryãb, al que le añadió una quinta cuerda doble, aparte de otras mejoras, quien simbolice la peculiaridad de al-Andalus frente al califato 'abbasí y fãtimí. La evolución de la "guitarra morisca" podría significar un paso más en este proceso de autoctonía, configurándose como el instrumento singular de la etapa mudéjar y morisca tanto en la Península Ibérica como en Sicilia.
} 
(danças obscenas, sobre as quais já me referi em outras obras). Dançaram a dois, como nas antigas danças alemãs, e a quatro, marca coreográfica chamada na região de anu e chula. Em que sapateiam furiosamente, dobrando os tornozelos, aliás, com certa graça. Os tocadores de viola também cantaram, não sendo aí, todavia, que brilham os brasileiros que vivem longe das grandes cidades e não aprenderam música. Algumas modinhas (cantigas populares, geralmente muitos livres) são sem dúvida bem bonitas; entretanto, nada mais triste e monótono que os cantos populares das Províncias por mim percorridas. (SAINT-HILAIRE, 1964 [1851] p. 81/82)

O comentário de Saint-Hilaire, demonstrando a perícia do instrumentista que "tocava-o em todas as posições imagináveis", indica outros toques além dos rasqueados, elemento que diferenciava os toques entre vihuelas e guitarras portuguesas e espanholas no século XVI.

Em 1555, as Vihuelas de 7 ou 6 ordens de cordas eram tocadas de forma ponteada, e não rasgueada, ao invés das Guitarras de 4 ou 5 ordens de cordas que eram tocadas de ambas as formas. Nesta altura existiam, já, registos de instrumentos, semelhantes à Vihuela, que tinham uma forma de tocar rasgueada, sendo usados em festas do povo. (CÂMARA MUNICIPAL DE CASTELO BRANCO, 2016, p. 4).

Vilela, ao tratar das origens da música caipira, menciona o fato de que "nos dois primeiros séculos de Brasil, as instâncias administrativas portuguesas estiveram mais voltadas para ao Nordeste graças às rentáveis atividades económicas com a cana de açúcar." Argumentando que, por conta desse fato, fixaram-se formas cultas do tocar (ponteado), o que não ocorre no Sudeste, onde a viola nas mãos de bandeirantes e mamelucos teria perdido seu "requinte técnico", ganhando uma abordagem rítmica mais aberta, elementos que podem ser evidenciados na prática contemporânea do fandango nos estados do Paraná e de São Paulo, salvo raras exceções, como mencionado por Roderjan (1981), Araujo, (1964) e Pimentel et al (2006). "Seu” Martinho, por exemplo, mestre já falecido que viveu no município de Morretes no litoral do Paraná, tinha a prática de pontear sua viola, fato que, segundo os autores, dificultava a interação do mestre com outros fandangueiros da região.

Essa discussão é antiga, figurando em conjecturas sobre o modo de se tocar estes instrumentos desde o século XV:

A partir de meados do século XV, a guitarra [morisca] parece ocupar uma posição secundária em relação ao alaúde, um instrumento que, como já disse, continua presente e se desenvolve ao longo da Idade Média. No entanto, um documento mostra que a guitarra é a protagonista de uma mudança de técnica que causará importantes consequências musicais: o abandono do plectro e o jogo direto com os dedos. É Alfonso de Palencia (1490), que nos oferece este texto revelador:

Mas naquele ajuntamento dos deuses ele foi julgado mais diligente 
Apollo, como aprovisionando campos verdes e montanhas cheias de folha e formosura de perfumados vergéis, e tocasse muitos instrumentos musicais suaves e particularmente a guitarra, com seu próprio polegar, tendo deixado o plectro [pena] ${ }^{35}$

Atualmente, a maioria dos violeiros paranaenses e paulistas (centro-sul) dispensa o uso da palheta na viola, tocando rasqueado sem pontear melodias, salvo frases curtas no início de marcas batidas, no Paraná. No litoral norte de São Paulo e sul fluminense, nota-se com mais frequência o uso de palhetas e a execução de frases melódicas, tanto nas violas como nos violões. No caso do machete, no estado do Paraná, pouco uso se faz da palheta, diferente dos instrumentistas paulistas e fluminenses, que, em geral, ponteiam seus instrumentos com auxílio do acessório.

Como bem mencionado pelo musicólogo lusitano Rui Camacho e pelo antropólogo Jorge Torres (2006, p. 8):

A origem de qualquer instrumento da tradição popular é sempre incerta, controversa e por vezes historicamente complexa. A falta de informações iconográficas não nos permite avaliar melhor como pretendíamos. O que é certo é que todos estes instrumentos são usados na música tradicional e popular com uma função lúdica. (...) Os instrumentos são excelentes informações históricas importantes para compreensão de nossa cultura musical.

À medida que nos debruçamos sobre as esparsas informações que nos restaram sobre a música praticada nas áreas rurais do Brasil meridional nos séculos XVIII e XIX, mais incertezas e variáveis são inseridas no cômputo, tamanha a discrepância de apropriações e variabilidade nas práticas musicais registradas que ocorriam nesse período.

\footnotetext{
35 “A partir de la moitié du XVe siècle la guitarra semble ocuper un rang secondaire par rapport au laúd, instrument qui, comme je lái dejà dit, ne cesse d'être présent et de se développer durant tout le Moyen Age. Cependant, un document montre que la guitarra est la protagonista dún changement de technique qui entraînera dímportantes conséquence musicales: l'abandon du plectre et le jeu direct avec les doigts. C'est Alfonso de Palencia (1490) qui nous offre ce texte révélateur: Pero en aquel ayuntamiento de los dioses fue juzgado más diligente / Apolo, como aparejase verdes campos e montes llenos de foja e fermosura de bien olientes vergeles, e tañese muchos suaves instrumentos de música e señaladamente la guitarra, con su próprio pulgar, dexada la péñola.” (REY, 1999, p.108)
} 


\section{Poéticas}

Apesar de traçar, brevemente, laços historiográficos e musicológicos de momentos diacronicamente tão distantes, não há aqui o interesse em remeter a possíveis origens ou buscar um cerne fundante do fandango caiçara, da folia do divino ou das demais manifestações atreladas a estas. Nosso interesse se concentra em como estas manifestações seguem ocupando papéis preponderantes na manutenção de sociabilidades, de socialidades e de identidades das populações onde estas manifestações incidem, sublinhando seu viés político, territorial, cultural e performático na atualidade, elencando protagonismo à narrativa discursiva de fandangueiros e fandangueiras, e aos seus fazeres e pensares, contraponto aos embates musicológicos, tecnológicos, socioculturais e sociopolíticos que os cercam. Vale lembrar, que assim como propõe Blacking, a fim de compreender tanto uma tradição musical quanto as contribuições que compositores individuais dão a ela, "um sistema musical deve ser compreendido como um dos diferentes quadros de símbolos pelos quais as pessoas aprendem a produzir um sentido público de seus sentimentos e da vida social." (BLACKING, 2007, p. 205)

Imbricado a este sistema de relações, toma corpo o dinamismo criativo insuflado pela arte ibérica, cuja confluência histórica é sincrônica ao período das grandes navegações, que trouxeram entranhados em seus carregamentos, um mosaico multiétnico inacabado e fluido de musicalidades onde confluem aspectos de materialidade e imaterialidade. Bollo-Panadero (2012, p. 9) comenta como as manifestações artísticas, em sua maior parte financiadas por quem detinha o poder, incidem no território Al-andaluz com um sentido "representativo e legitimador dos valores imperantes; entre eles, os políticos".

Expoente dos gêneros poéticos disseminados pela cultura Al-Andaluz, a moaxaja vai além da simples acumulação das línguas árabes, hebraica e do romance, e não deve de modo algum ser reduzida a esses termos, o que, segundo Bollo- Panadero, a aproximaria de um corpo sem alma. Assim, a alma da moaxaja, sua razão de ser, reside na expressão de um novo produto resultante das mais diversas mestiçagens culturais. Vilela corrobora com estas ideias ao mencionar que "A península ibérica foi, desde tempos remotos, palco de invasões e entrelaçamentos das etnias mais diversas. Por lá estiveram calaicos, iberos, celtiberos, tartessos, fenícios, romanos, godos, visigodos, suevos (no noroeste) e por fim, árabes.” (VILELA, 2013, p. 32) 
Em La Musique, título enciclopédico organizado por Dufourcq (1946, p. 74), encontramos a seguinte afirmação no texto de Alexis Chottin, denominado La Musique Musulmane: "A estética musical e a rítmica se confundem com o estudo dos gêneros poéticos, os quais não são meras criações da mente, mas correspondem a necessidades vitais, a funções sociais". ${ }^{36}$ (Tradução e grifos nossos) Já nas primeiras décadas do século XX, a musicologia sistemática e seus então recentes estudos já indicavam valores sociológicos, antropológicos e políticos inerentes à inserção da música, da métrica rítmica e poética e da ação artística e performativa, denotando anseios de cunho musical tanto na conquista de territórios como na afirmação identitária. Essa alegação pode ser atribuída tanto às populações árabes, na península ibérica, quanto aos portugueses e espanhóis em suas empreitadas colonialistas em terras sulamericanas.

Ao estudar a tradição musical e a poética no folclore do sertão nordestino, Soler transita entre termos como glosadors, que, nas ilhas Baleares, correspondem aos nossos violeiros, cantadores ou repentistas (termo ainda utilizado em algumas regiões da Espanha e Portugal, até no sul da península italiana e Sicília), ou dos payadores, denominação corrente nas nações do Rio da Prata, na América do Sul. Segundo Soler, essas tradições são importadas "precisamente na hora em que os últimos resplendores do ocaso muçulmano apagavam-se nos Céus europeus, mas ficavam definitivamente diluídos no sangue dos povos cujos destinos tinham norteado por longos séculos". (SOLER, 1995, p. 19)

Ao aproximar as vicissitudes dessa criação andaluza ao conceito de rizoma, utilizado por Deleuze e Guattari, Bollo-Panadero indica que "toda cultura é resultado de uma relação rizomática de todos os aspectos culturais dos substratos que a formam" (BOLLO-PANADERO (2012, p.12), o que não difere do nosso fandango caiçara, inundado de referências culturais e intrinsecamente ligado ao meio sociopolítico e cultural que o produziu e ao qual se inseriu.

No caso ibero-andaluz, a partir da moaxaja surge também o zéjel (ou zegél), de índole mais popular e sem estrutura fixa. Constituído por estribilho ou tema, o zegél habitualmente é composto por dois versos, seguido de uma quadra, cujo último verso arremata a rima e chama o estribilho. Desse modo, evidencia-se que o zegél seja o modelo germinal do qual os provençais alavancam as poéticas trovadorescas nascidas em solo ibérico que, após imbuir os poetas cristãos na península, representaram um passo importante para o trânsito da tradição poética árabe à cultura literária do ocidente. Tanto Soler quanto Chottin são incisivos nesta

\footnotetext{
36 "L'esthétique musicale et la rythmique se confondent avec l'études des genres poétiques, lesquels ne sont point de pures créations de l'espirit, mais correspondent à des besoins vitaux, à des fonctions sociales."
} 
afirmativa: "Pois como a cada dia fica mais provado, foi do solo ibérico que partiram as influências árabes que fecundariam o movimento dos trovadores, movimento que por sua vez conquistou, desde a Provença, tanto os países românticos, como os germânicos." (SOLER, 1995, p. 51) Considerando os sistemas métricos da versificação árabe, Chottin afirma que "um novo sistema de poesia lírica essencialmente espanhol, é constituído [...] Estes dois gêneros [muachchah/zajal] infundem sangue novo na antiga versificação, consequentemente, transformam totalmente a métrica musical." ${ }^{, 37}$ (DUFOURCQ, 1946, p. 77 - tradução e grifos nossos)

Na moda “No Jardim”, assim como em muitas outras canções do cancioneiro caiçara, encontraremos versos com a função de refrão.

$\begin{array}{ll}\begin{array}{l}\text { No Jardim } \\ \text { (marca tradicional bailada - Dom-dom) }\end{array} & \\ \text { Passarinho preso canta } & \text { Vâmo na pracinha nova } \\ \text { Em vez de preso chorar } & \text { Na bancada os dois sentar } \\ \text { Vâmo moreninha vâmo } & \text { Lembrança dos namorados } \\ \text { Onde os dois vem se abraçar } & \\ \text { No jardim vem passear } & \text { Menina dá aqui um abraço } \\ \text { Como é preso sem culpa } & \text { Que eu terei como pagar } \\ \text { Canta para aliviar } & \text { Vâmo moreninha vâmo } \\ \text { Vâmo moreninha vâmo } & \text { No jardim vem passear } \\ \text { No jardim vem passear } & \\ & \text { Quem me dera se eu te visse } \\ \text { Vâmo na pracinha nova } & \text { Trinta dias em um mês, ai } \\ \text { Na bancada os dois sentar } & \text { Vâmo moreninha vâmo } \\ \text { Lembrança dos namorados } & \text { No jardim vem passear } \\ \text { Onde os dois vem se abraçar } & \\ & \text { Sete dias da semana } \\ \text { Menina dá aqui um abraço } & \text { Cada minuto uma vez } \\ \text { Que eu terei como pagar } & \text { Vâmo moreninha vâmo } \\ \text { Vâmo moreninha vâmo } & \text { No jardim vem passear } \\ \text { No jardim vem passear } & \\ & \text { Vâmo na pracinha nova } \\ \text { Meu amor é uma rosa } & \text { Na bancada os dois sentar } \\ \text { Que eu mesmo fui escolher } & \text { Lembrança dos namorados } \\ \text { Vâmo moreninha vâmo } & \text { Onde os dois vem se abraçar } \\ \text { No jardim vem passear } & \\ & \text { Menina dá aqui um abraço } \\ \text { Na roseira não dá outra } & \text { Que eu terei como pagar } \\ \text { Mesmo que torne a florescer } & \text { Vâmo moreninha vâmo } \\ \text { Vâmo moreninha vâmo } & \text { No jardim vem passear } \\ \text { No jardim vem passear } & \end{array}$

\footnotetext{
37 "Un nouveau système de poésie lyrique, essentiellement espagnol, se consitue. [...] Ces deux genres infusent dans la vieille versificacion un sang nouveau qui va, par voie de conséquence, transformer totalement la métrique musicale."
} 
Vamos dar por despedida

Despedida já tô dando

Vâmo moreninha vâmo

No jardim vem passear

Minha boca se vai rindo

Meu olho se vai chorando

Vâmo moreninha vâmo

No jardim vem passear
Vâmo na pracinha nova

Na bancada os dois sentar

Lembrança dos namorados

Onde os dois vem se abraçar

Menina dá aqui um abraço

Que eu terei como pagar

Vâmo moreninha vâmo

No jardim vem passear

Diferente das modas que se valem de uma estrutura fixa durante sua execução, a arte do improviso surge como elemento fundamental das demais formas de criar versos e cantar, estando a poesia ligada intimamente ao poeta que a concebe, seu meio de vida, suas pulsões, paixões, rixas, festas, necessidades e vicissitudes. As conexões sugeridas permanecem vivas e podem ser observadas em distintos rincões do planeta, pois, como mencionado por Chottin, "transformam totalmente a métrica musical”, marco diacrônico dos parâmetros aplicados à versificação musical em escala global, inclusive nos complexos estuarinos e lagamares da faixa atlântica do litoral sul brasileiro.

Dentre os valsados, a chamarrita e o dandão são os mais comuns, dançados entre as marcas batidas, para que os batedores descansem. A chamarrita quase sempre dá início ao fandango, saudando o dono da festa. A grande maioria não possui refrão, o violeiro canta os versos que ele já conhece de cor adaptados às diferentes melodias por ele conhecidas. Os dois violeiros usam a mesma batida e a rabeca acompanha em uníssono o cantor, possuindo alguns solos tradicionais para os entremeios das estrofes. Em São Paulo, a maior parte das chamarritas registradas possui refrão. Os toques tradicionais de rabeca são diferentes dos toques paranaenses e o violeiro não precisa cantar todos os versos do refrão depois dos versos da despedida, podendo cantar apenas o primeiro e o último. $\mathrm{O}$ dandão, ao contrário da chamarrita, apresenta refrão na grande maioria dos casos. Podem começar tanto pelo refrão como por qualquer uma das quadras escolhidas pelo fandangueiro. Depois da despedida, o violeiro canta todo o refrão. (PIMENTEL et al, 2011, p. 7)

Patrícia Martins também comenta sobre as estruturas poético-musicais do fandango:

Inicialmente podemos dividir as danças em dois grandes grupos: o fandango batido e o fandango bailado ou valsado. No fandango batido, temos formas musicais diversas, "fraseados", versos, e uma infinidade de elementos que diferenciam estas marcas (música). Cada marca batida tem sua própria estrutura de "refrões", de toques de violas, de rabecas e no próprio batido, além de possuírem algumas variações, dependendo da região em que são executadas (MARTINS, 2006, p. 17).

No Fandango, sobretudo, as letras estão imbuídas de fortes percepções do ambiente, juntamente com aspectos de seus cotidianos e temas envolvendo sentimentos, emoções e afetos de ordem subjetiva. Além disso, o próprio processo de "bricolage" que ocorre na composição das letras, onde recortes e 
trechos de autorias variadas vão se misturando no trânsito destes versos entre tempo e espaços diferenciados, demonstra o aspecto relacional e multiagentivo da "criatividade" no fandango. (MARTINS, 2018, p.172)

Tais processos criativos se servem tanto de acervos tradicionais de memória oral, como também podem ser inventados pelos próprios cantadores. "No fandango a letra não é necessariamente fixa, o que há de fixo são as modinhas ${ }^{38}$, mas como há mais de uma modinha por marca, os violeiros podem escolher uma delas ou mesmo inventar outras" (MARTINS, 2006, p. 17). Alegações semelhantes podem ser encontradas também nos "pés de moda",39 recolhidos com Dina Alves Costa, por Muniz (2017, p. 118): "cantar e trovar versos / não aprendi com ninguém / tiro da minha cabeça / do meu juízo vem”, assim como em (GRAMANI e CORRÊA, 2006, p. 23), que trazem o depoimento de Arnaldo Mandira:

$\mathrm{O}$ verso não é que a gente faça, entende? $\mathrm{O}$ verso que eu canto, a gente inventa, conforme a natureza que faz talvez aquilo. (...) então é a mesma coisa de eu, qualquer outro de nós, ele pega na viola e vai tocar, conforme ele vai cantando, aquele verso vem vindo na memória dele. Não é que a pessoa seja poeta, aquilo a pessoa já tem de natureza. São coisas que a gente sabe, já tem na cabeça, assim, por exemplo, quando a gente está com a viola tocando, o verso vem.

Outro dia, em uma janta aqui em casa, Herbert dos Santos fez os seguintes comentários:

A cabeça da moda, é esse refrão. Faz uma rima, é a cabeça da moda, a cabeça da moda! Cabeça da moda é o que a galera tenta decorar, por que o resto ninguém consegue (Risos). É difícil quem entenda a rima. Mas a cabeça é aquela que você repete, repete, repete. (Cadernos de campo, 12/2018 transcrição nossa)

Outro camarada e parceiro nas peregrinações do Divino Espirito Santo, Pedrosa (2018, p. 37) argumenta que "os fandangos não são canções, porém estruturas rítmicas, melódicas e harmônicas onde se podem colocar versos".

Pedrosa ainda lembra que, de forma diferente dessa construção, na atualidade, tem sido

\footnotetext{
${ }^{38}$ Usualmente, por todo território caiçara, o termo toada é utilizado para denominação de linhas melódicas fixas, trate-se de moda bailada ou marca batida.

39 “O Fandango Caiçara, suas modas e/ou marcas são compostas de 'pé' e 'cabeça', ou seja, versos e refrão, ou estribilho como [Cústódio] Pinto (1992) chama, afirmando serem estes geralmente trazidos pelos nossos colonizadores. Em alusão a isso, Azevedo (1978, p. 4) afirma nas letras do Fandango se encontrarem décimas tradicionais conhecidas em outros estados e em Portugal. É quase regra que existe a 'cabeça da moda' ou refrão e este sempre acrescido de diversos 'pés de moda' ou versos. São usuais 'cabeças de moda' com 4, 6 ou 8 partes (linhas, frases ou sílabas poéticas) e os 'pés de moda' geralmente com 4, porém, existem uma possibilidade de execução, variando de acordo com a toada e em todos os casos sempre existe a rima, porém, em modalidades diferentes." (MUNIZ, 2017, p. 119)
} 
corrente entre os mestres mais novos, práticas composicionais que se valem de letras fixas, em cujos versos corridos não há incidência de versos tradicionais. (PEDROSA, 2018, p. 37) Parecenos que a possibilidade da reprodução fonográfica, assim como os ímpetos de inovação, somados ao ativismo territorial e à salvaguarda do fandango, amparam essas novas práticas.

Para além das estruturas melódicas e poéticas que conformam o material musical das cabeças e dos pés das modas, o improviso é elemento presente de forma viva nos bailes e funções fandangueiras, no qual é corriqueiro que mestres "coloquem" versos sobre temas diversos: um visitante ilustre que chega de um vilarejo distante, uma situação cotidiana, um casal dançando de forma curiosa. Qualquer elemento circundante pode vir a ser um novo verso inserido nas estruturas pré-estabelecidas das diferentes modas tocadas durante um baile. Aspectos emoldurados pelas memórias, expressos ainda com maior visibilidade nos versos ao Divino Espírito Santo, inspiram foliões e mestres de folia que se valem inevitavelmente de versos improvisados durante as peregrinações que antecedem o domingo de pentecostes, tendo uma bíblia sobre a mesa, um retrato de família ou mesmo solicitando café para alento dos foliões.

Atento ao dinamismo das criações melódicas e poéticas que se movem impulsionadas pela inventividade e pela interação contínua entre atores, vale concatenar que a construção conceitual do fandango caiçara guarda consigo elementos híbridos, que transcendem as fronteiras geopolíticas e a conjuntura colonial brasileira. Traz em sua bagagem hibridismos outros que podem aludir, por exemplo, à dominação muçulmana nos territórios ibéricos, padrões e metapadrões que se configuraram cultural e socialmente por uma grande diversidade de grupos étnicos (árabes citadinos, berberes campesinos, uma maioria de cristãos autóctones e ainda uma pequena porcentagem de judeus já integrados culturalmente em território peninsular). Concordamos também com Zumthor (1989, p. 141) que, ao tratar de temas cultos e populares do período medieval, afirma que "nenhuma cultura é homogênea". Pelo viés poético de afirmação identitária e territorial, a moaxaja e o zegél, por exemplo, idênticos em suas intenções, firmam-se no vocabulário musical al-andaluz com diferentes modos de expressão: "a primeira escolhe incluir a linguagem clássica; a segunda adota inteiramente o coloquial. Esta é a diferença básica entre uma forma e outra, mas não a única, a rima é diferente e, portanto, o seu ritmo." (BOLLO-PANADERO, 2012, p. 10). Um dos elementos desta consolidação de gêneros poéticos que nos é de relevante conteúdo musicológico e etnomusicológico trata de outra disparidade presente entre os dois modelos: em "sua extensão, o zegél é geralmente mais longo que a moaxaja, pois por não ter uma estrutura fixa, o poeta pode alongar o quanto quiser. 
Como esperado, o zegél teve uma recepção ainda maior do povo do que a moaxaja." ${ }^{40}$ (BOLLO-PANADERO, 2012, p. 10)

A peculiaridade do improviso e da linguagem coloquial, distendidos pela efemeridade da duração, podem ser correlacionados às práticas hodiernas no litoral caiçara, seja nos longos encerros que presenciei durante as romarias, em que uma única toada pode se estender por mais de 40 minutos, seja nos bailes de fandango, onde os dançarinos, já exaustos, seguem dançando em dinâmica interação com os instrumentistas.

Existe um fluxo de troca constante no andamento do baile, aqueles que estão dançando acabam por ditar o andamento das músicas e também sua duração. Já que os versos são improvisados, a música não acaba enquanto o mestre não puxa os versos de despedida e pede o fim da música entoando a frase "Ô de casa!". Dependendo da animação das pessoas dançando a música pode se alongar indefinidamente. (MIGUEZ, 2017, p. 53)

Ainda sobre tema ibérico, outro autor que nos esclarece sobre esse momento crucial da história de nossas musicalidades é Manuel Pedro Ferreira que, ao discorrer sobre emulação e hibridismo na Península Ibérica, versa sobre os antecedentes medievais dessa empreitada, e argumenta que:

O hibridismo ocorre quando a mesma região sofre influências culturais concorrentes, o que de facto sucedeu no sul da Península. Nos séculos IX e X, a música e poesia árabes e a herança europeia ocidental adaptaram-se mutuamente, conduzindo à criação da canção zajalesca, na sua dupla forma de zajal (que usa árabe coloquial) e muwaxxah (que usa língua literária clássica). Neste caso a hibridação e a emulação ocorreram em simultâneo, já que a muwaxxah se baseia normalmente na citação textual da canção popular revelada no final da composição. Esta citação textual é frequentemente em árabe coloquial e, por vezes, em língua romance; pode também ter envolvido a melodia da canção, estando nesse caso implícita alguma forma de contrafacção.

A mistura de componentes árabes e europeus neste tipo de canção não é fácil de discriminar com exactidão. Um debate antigo opõe aqueles que julgam derivar directamente da tradição popular romance uma forma estrófica que inclua versos curtos e rimas múltiplas, e aqueles que a consideram o resultado de uma adaptação local, feita com base em antecedentes árabes. Estes últimos tendem a considerar os versos iniciais como um mero prelúdio, mas James T. Monroe demonstrou convincentemente que, em contexto de actuação musical, esses versos funcionavam como refrão. (FERREIRA, 2015, p. 139 - grifo nosso)

\footnotetext{
40 "Moaxaja y zégel, idênticos em su intención, eligen vías de expresión distintas: La primera elige incluir La lengua clássica; El segundo adopta integralmente La coloquial. Ésta es la diferencia Basica entre una forma y otra, pero no la única, la rima es diferente, y por tanto, su ritmo. Otra disparidad se presenta em su extensión, el zégel suele ser más largo que la moaxaja, pues al no tener una estructura fija, el poeta puede alargarse cuanto quiera. Como era de esperar, el zégel tuvo una acogida aún mayor por parte del pueblo que La moaxaja.”
} 
Fatos também evidenciados por Villela, que, assim como Soler e Chottin, recorda-nos que, como cultores da poesia e da fala, "os árabes introduziram a rima no mundo ocidental pois a poesia latina contava apenas com a métrica". (VILLELA, 2013, p. 32).

As contrafacções "pela lingoa", em meio à descurada organização social portuguesa, indicam como plausível a circulação de formas poéticas medievais al-andaluzas no Brasil Colônia; formas estas utilizadas pelas populações menos abastadas, em seus momentos de entretenimento, por um lado - ainda que cerceadas e emolduradas pela empreitada jesuítica e, por outro, firmadas pela plasticidade e adaptabilidade do autóctone "gentio" e do mameluco campesino.

Sobre o legado ibero al andaluz, encontramos em Ferreira (2012, p. 144), indícios de que as principais formas musicais das Cantigas de Santa Maria ${ }^{41}$ são de dois tipos: "o virelai propriamente dito ou padrão, em que a música do refrão inicial é seguida por uma melodia contrastante na estrofe e depois retorna no final da estrofe; e o rondel andaluz, onde todo o material musical é apresentado no refrão, cuja segunda parte fornece as frases iniciais da estrofe, após o que a música é integralmente recapitulada.”

O grau de hibridismo nas Cantigas de Santa Maria é de facto extraordinário: nelas surgem agregadas a devoção cristã, modelos franceses de contrafacta devocionais e formas e ritmos andaluzes, o que permitiu à música ser potencialmente um veículo de integração cultural nos territórios recentemente conquistados no sul da Península.

Deste modo, nota-se que após a sua expansão inicial no mundo islâmico, as suas imitações corteses em língua romance da segunda metade do século XIII e a sua reformulação, por volta de 1500, em ambiente ibérico, um género periférico andaluz, híbrido de cultura europeia e árabe, acabou por alcançar o México, o Brasil e a Índia. Apenas se definirmos a centralidade unicamente em termos europeus, pode ela ser negada ao vilancico ibérico do século XVI. (FERREIRA, 2012, p. 145)

Ferreira (2012) nos indica, assim, que tanto virelai quanto o rondel andaluz surgem na tradição andaluza, transmitidas de forma oral e ainda vivas no norte da África, alegando ainda que o tipo de rondel andaluz está completamente ausente da tradição medieval de alémPireneus; indicando, deste modo, que o seu caráter andaluz seria indiscutível.

\footnotetext{
${ }^{41}$ A primeira grande coleção de canções em que figura, de forma proeminente, o tipo formal de dansa/virelai, compostas e compiladas sob a supervisão de Alfonso X, o Sábio (1221-1284), rei de Leão e Castela. O núcleo desse projeto, que foi em larga medida realizado em Sevilha durante os seus últimos vinte anos de vida, consiste em centenas de relatos em versos dos milagres da Virgem Santa Maria, postos em música. A primeira série de cem cantigas desta coleção data, provavelmente, de antes de 1270, uma geração antes de o virelai ter ficado em voga no norte de França.
} 


\section{Polissemia}

Claro exemplo da distinção social, o vilancico, cuja etimologia está associada à palavra villano (vilão), que designa rude, rústico, plebeu ou inculto, em castelhano, possivelmente surge com o objetivo de designar algum texto literário que deveria ser cantado.

A tradução de villano é vilão e este era caracterizado por ser, inicialmente, habitante das villas, localizadas no campo, ou seja, era o camponês. Porém, com o desenvolvimento das cidades, o termo foi ampliado e atingiu as categorias mais baixas do artesanato e do comércio de forma depreciativa (MACEDO, 2004) $)^{42}$.Observa-se, então, que a origem do vilancico está marcada pela linguagem vernacular, não estando presente no meio aristocrático. (MARCOJE, 2014, p. 2)

Inicialmente disseminados pela Espanha através de cancioneiros no início do século $\mathrm{XV}$, os vilancicos apresentavam conteúdos profanos em suas letras, segundo Lopez, chegando em Portugal apenas no final do século XVI, época na qual começa a ser introduzido nos ambientes religiosos: "o vilancico se desvinculou do caráter essencialmente profano que detinha os cancioneiros quinhentistas, para se posicionar, a pouco e pouco, no coração das práticas cerimoniais promovidas regularmente pelas igrejas e catedrais ibéricas" (LOPES, 2006, p. 7).

Idiossincrasia posta, o vilão figura de modo abundante nas pesquisas folclóricas paranaenses, como em Azevedo (1978), Zagonel (1980), Roderjan (1981) e Custódio Pinto (2010), indicado como marca tradicional do fandango caiçara, cuja peculiaridade coreográfica o faz tomar lugar de destaque. Em coreografias minuciosamente registradas como catalogação museológica, os folcloristas acima citados observam e registram o que lhes é posto, e em nenhum dos autores e autoras acima mencionados são encontrados quaisquer dados sobre a marca, que não o registro restrito da música e da coreografia. O valor historiográfico nos é caro, mas cabe ressaltar que o método empregado nos distancia do âmago de nossas questões.

O vilancico religioso conheceu em Portugal, tal como em Espanha, uma vasta disseminação nos séculos XVII e XVIII, impulsionada não apenas pelo seu cultivo intensivo em centros musicais de primeiro plano, como o Mosteiro de Santa Cruz de Coimbra, como também por um interessante fenómeno de divulgação que resultou da edição regular de folhetos por parte das oficinas

\footnotetext{
${ }^{42}$ MACEDO, José Rivair. O real e o imaginário nos fabliaux medievais. Revista Tempo, v. 9 n. 17, p. 9-32, 2004. Disponível em <http://www.historia.ufrj.br/ pem/arquivo/joserivair004.pdf>. Acessado em 01/04/2014
} 
tipográficas de Lisboa, Coimbra e Évora, até ao início da terceira década de setecentos, altura em que o vilancico foi definitivamente afastado da vida musical portuguesa. A forte presença do vilancico na prática musical seiscentista é também sublinhada pelos mais de dois mil títulos descritos no catálogo da Biblioteca de Música de D. João IV (1604-1656), fonte inestimável para o conhecimento da música deste período. (LOPES, 2006, p. vi).

Para além da prática litúrgica, podemos encontrar evidências de que o gênero também seguiu com trânsito por ambientes secularizados, constando, por exemplo, no códice manuscrito Cifras de música para saltério, escrutinado por Rogério Budasz (1996).

Indiferente do entendimento do termo como gênero, moda ou auto, e, ainda, mesmo que as melodias não nos pareçam semelhantes, distanciamo-nos da catalogação estática e nos aproximamos de Hobsbawm, entendendo que não nos cabe nenhum melindre pelo fato de que se tenham modificado com o tempo:

O objetivo e a característica das "tradições", inclusive das inventadas, é a invariabilidade. O passado real ou forjado a que elas se referem impõe práticas fixas (...). O "costume", nas sociedades tradicionais, tem a dupla função de motor e volante. Não impede as inovações e pode mudar até certo ponto, embora evidentemente seja tolhido pela exigência de que deve parecer compatível ou idêntico ao precedente. Sua função é dar a qualquer mudança desejada a sanção do precedente (...). O "costume" não pode se dar ao luxo de ser invariável, porque a vida não é assim nem mesmo nas sociedades tradicionais. (HOBSBAWM, 1997, p. 10).

As nomenclaturas villano e vilancico guardam em si uma miríade de significações outras, etimológicas e epistemológicas, que as correlacionam ao modo como foram utilizadas em distintos contextos, seja no termo pejorativo que fazia referência ao habitante das villas, aos camponeses, seja sob a égide de Dom João IV, disseminado nas capelas reais e ducados de Bragança, perpetuado mesmo após a centralização da corte em Lisboa.

Conheci o "Vilão de Lenço" quando fui convidado pelo professor Lydio Roberto para montagem do espetáculo e para a gravação do disco Nhengarí Inami, concebido e desenvolvido em parceria com a cantora Cris Lemos e com o músico Ricardo Janotto (vulgo Ô, Rosinha) em homenagem à Inami Custódio Pinto. Além de composições de caráter popular do próprio Inami, integravam o repertório do disco marcas coletadas pelo folclorista entre as décadas de 50 e 70. Entre elas, "Vilão de Lenço", "Cana Verde", "Pau de Fitas", "Cuá Fubá", "Marinheiro" e "Balainha".

Em minhas imersões de campo, apesar de mencionado por interlocutores, não presenciei a execução dessa marca e nem de sua coreografia por fandangueiros, tanto no Paraná quanto em São Paulo. 
Vilão. Baile popular em Goiás (...) Constitui uma espécie de moulinet da quadrilha francesa, no qual os dançantes formam uma grande roda ligados pelas extremidades de lenços. É também conhecida pelo mesmo nome uma variante, em que, em vez de lenços empregam-se paus apropriados ou mengueras, e no fim das diversas figuras formam uma grade com os cacetes, em cima da qual o violeiro sobe e é carregado pelo grupo. Ainda se dança no Brasil central o Vilão da Faca, em que se empregam em vez de lenços ou paus, facas. Em São Paulo, dançam o Vilão de Lenço e o Vilão de Mala. No vilão de Lenço os dançadores ficam em duas alas e na frente do violeiro. Quem rege o baile diz-se "mestre de Fandango". (...) A dança ou baile do Vilão (morador na vila, camponês), é citada em Portugal como popular, desde o séc. XV. Na Madeira [Ilha], há o bailinho dos vilões. Vilão é o tipo que representa o elemento mau nas peças teatrais populares, o intrigante, o malvado o caluniador, castigado no último ato. (...) Alceu Maynard Araújo cita no fandango paulista o "Vilão de Agulha" (Ubatuba). (CÂMARA CASCUDO, s/d, p. 908)

Percebermos a polissemia do termo, ao verificarmos sua dispersão, em Minas Gerais, por exemplo. Uma dessas formas de vilão se adaptou ao ciclo festivo do rosário, convertida em folguedo de fundo religioso, no qual se conformou como um dos tipos básicos do congado, que, dentre tantas modalidades, se destaca por seu ritmo acelerado e uma dança agitada, enérgica, que em geral usa acessórios, tais como manguaras, que são varas longas e enfeitadas de fitas multicores e, em alguns grupos, facões de madeira.

Nosso ímpeto em pontuar elementos de relevância na construção das tradições ainda vivas no universo caiçara vem nos mostrando quão complexo e imbricados de fatores diversos foi esse processo, contando ainda com a possibilidade da inversão do fluxo de difusão até aqui concebido.

O historiador Peter Burke considera a possibilidade de que o fandango tenha suas origens na América Latina, havendo sido exportado para Espanha em 1700, ao traçar um painel do período que vai, aproximadamente, de 1500 a 1800, período que "Em outras palavras, corresponde ao que os historiadores muitas vezes chamam de "inícios do período moderno"”. A área geográfica investigada pelo autor diz respeito ao conjunto da Europa, da Noruega à Sicília, da Irlanda aos Urais. No capítulo em que se refere às Formas Tradicionais, comenta sobre distintos gêneros musicais dessas regiões naquele período. Após explicitar que a sarabande fora descrita por um escritor moderno como "uma pantomima sexual de expressividade sem igual", comenta haver sido introduzida na Espanha no final do século XVI, "possivelmente a partir do mundo árabe, e foi rapidamente condenada pelos moralistas."

Seu próximo comentário diz respeito exatamente ao fandango: 
A ela [sarabande] se seguiu o fandango, que veio da América para a Espanha por volta de 1700, e fez com que uma testemunha comentasse que "me pareceu impossível que, depois de uma dança dessas, a moça pudesse recusar qualquer coisa ao seu parceiro". A testemunha devia saber do que estava falando, pois seu nome era Casanova. (...) No fandango, os casais nunca se tocavam; no volto provençal, igualmente condenado pelos moralistas, os casais se abraçavam, rodopiavam e, ainda entrelaçados, pulavam no ar. Outras danças de girar, também condenadas, incluíam o Dreher alemão e sobretudo o Walzer, a valsa, dança camponesa adotada pela nobreza e burguesia no final do século XVIII. (BURKE, 1999, p. 210)

Daniella Gramani já atentou sobre esse argumento, comentando que pesquisadores brasileiros, como Araújo (1967), Roderjan (1981), Rando (2003), Custódio Pinto (1983) discordam de Burke, apontando para a influência ibérica do fandango no Brasil. A autora cita ainda Gottfried (2005), Sardinha (2004) e Almeida (1942), atestando que "tendo origem no fado português com terminação africana ou tendo nascido na América e levado à Europa, o termo fandango parece ser fruto das mestiçagens culturais características da época". Neste sentido, já no século XVII o fandango era apreciado em Portugal por todas as camadas sociais, havendo sido diluída sua origem espanhola a ponto de ser considerado português.

Como contraponto ao embróglio, trago o comentário jocoso do mestre de fandango, Leonildo Pereira: "De repente chegava por lá um ou outro [pesquisador], 'viu o fandango é dos estrangeiros' e eu dizia: 'já mudou de novo?", 43

Dos tempos dos sítios, vem a ideia de como essa tradição se consolida no território caiçara de forma diversificada e variável, de acordo com as localidades onde incide e que o perfazem, entendendo o território como um lugar existencial. ${ }^{44}$ Como nos sugere Cleiton do Prado:

Eu acho que o meu território, o território do caiçara, é aquele lugar onde a gente estava ontem [referindo-se Grajaúna-Jureia], onde você se sente bem, onde você muda um passo e você sabe porque está mudando aquele passo. Aqui [Barra do Ribeira, Iguape/SP], hoje em dia, se você muda um passo, dependendo do lugar que você muda o passo, você está no quintal de outra pessoa, é muito muro, muita cerca, muita coisa.

Eu acho que território, para mim, não é uma coisa demarcada, não é um quadrado que você está morando ali dentro. Não é o espaço físico, é meio que o espaço espiritual onde você vive, onde você tem toda essência de uma

\footnotetext{
${ }^{43}$ Leonildo Pereira apud Muniz (2017, p. 54).

${ }^{44}$ Ao dialogar com a perspectiva de Deleuze e Guattari (2000) abordando a territorialidade caiçara a partir das expressões que fazem desse território um lugar existencial, Karina Coelho nos indica que o território não se conforma apenas de um lugar [ou lugares], uma localização geográfica. Um território é marcado por movimentos (das marés, dos ventos, de pessoas, de Bandeiras [do Divino Espírito Santo] e de palavras), pelas histórias e experiências individuais e coletivas. (COELHO, 2018, p. 3).
} 
cultura dentro daquele lugar. É um lugar que você não pode perder vínculo, um lugar extremamente familiar, extremamente apropriado para você. (DE BONA, 2016, p. 35 e 38).

Retomando o sentido de localidade dado por Appadurai (1996), vejamos o sentido dado por fandangueiros ao que podemos chamar de lugar de origem do fandango e à sua etiologia. Em um de seus "mitos de origem" (ou etiologias), narrado por "Seu" Nemésio Costa 45 , indicase o Rio dos Patos (litoral norte do Paraná) como a localidade de origem do fandango caiçara:

- Quando me perguntam nas entrevistas de onde veio o fandango, eu digo: Veio do Rio dos Patos, eu morei lá! (Risos). (Cadernos de campo, 03/2017) Já para "Seu” Anísio Pereira, que atualmente reside na Ilha dos Valadares, município de Paranaguá, - A coisa toda começa em Araçauba, um tanto mais ao norte.

Já no litoral paulista, nas conversas com integrantes de grupos de fandango em Iguape e Peruíbe, parece ser ponto pacífico o fato de que a tradição fandangueira tem início nas redondezas da Jureia, mais especificamente na Cachoeira do Guilherme, cuja conformação religiosa ímpar ${ }^{46}$ torna a localidade uma referência à parte no universo fandangueiro.

Nesse sentido, deve-se ter em vista que questões de localidade e ascendência se ampliam a partir de pontos fixos e suas adjacências, desdobrados em uma miríade de localidades ditas originárias. Das possíveis “origens” à atualidade, o uso e a função da métrica, da rima e das características organológicas do instrumental, foram e continuam sendo ferramentas de mediação inter-relacional e afirmação identitária.

Se a cunhagem do termo vem de lá para cá ou de cá para lá, seguimos epistemologicamente incógnitos nesses percursos. Ainda parafraseando mestre Leonildo, “O Fandango é nosso, gente, toda a verdade dizer, que é a nossa cultura gente” (MUNIZ, 2017, p. 54), e disso ninguém duvida. As características que se constroem e perpetuam no tempo e no imaginário das populações caiçara guardam em si a experiência única de interação e sinergia com o meio onde se reproduz e se transforma de modo peculiar.

Devemos descobrir precisamente como as pessoas são capazes de relacionar as experiências com os símbolos musicais e como outras formas de atividade social e intelectual, e explicar isto como mais do que reações aprendidas. Este nível de explicação deve ir além dos tipos de argumento ou

\footnotetext{
${ }^{45}$ Violeiro e rabequista, falecido em abril de 2019, por muitos anos atuou na liderança do grupo Pés de Ouro, uma das referências do fandango de maior idade em Paranaguá.

${ }^{46}$ Em vista de relatos de moradores de Iguape e Peruíbe, a comunidade que ali residia até o momento em que foram pressionados pela implementação de reservas ambientais, diferente de outras localidades do litoral, apresentava uma homogeneidade religiosa de índole espiritualista kardecista, havendo restrições quanto ao modo de se dançar (evitando-se o contato físico), entre outras peculiaridades quanto ao fandango que era ali executado, lembrando que, atualmente, não existem mais moradores na localidade.
} 
de suposição que afirmam ser tal ou qual padrão de som destinado para - ou associado com - uma atividade ou convenção social particular, devendo, portanto, procurar seus significados essenciais nos significados desta atividade social. (BLACKING, 2007, p. 209)

No sentido proposto por Blacking, observemos como se comportam as estruturas musicais que derivam do termo fora do território brasileiro. A pesquisa de Berlanga (2015, p. 173), por exemplo, engloba e enumera três distintos tipos de fandango e concebe questionamentos sobre significados, funções e possíveis genealogias formais que os aproxime, entendendo o termo como significado genérico para formas musicais diversas: 1 . Música De Fandango - 1.a) Fandangos Do Sul: de ocorrência no sul da Espanha; 1.b) Os "Outros Fandangos": de ocorrência em partes da Espanha, assim como em outros países hispano falantes, como México, Porto Rico, Cuba, Panamá, Venezuela, Colômbia, Brasil, incluindo também as Filipinas; 1.c) Jotas, Seguidillas e Fandangos como Músicas de Fandango: onde insere fandangos, jotas e seguidillas; 2) Fandangos como Rituais Festivos: realizado "até meados do século XX, em algumas áreas rurais, o ritual coincidia em suas linhas essenciais com o ritual descrito sobre os bailes de candil do século XIX”. Nesse aspecto, Berlanga indica que o flamenco, sobretudo em suas primeiras fases, herdou dos fandangos não apenas a música, "mas também uma espécie de ritual de reunião, que apareceu nas antigas festas de flamenco"; e 3) Fandangos Americanos: nesse tópico, o autor realiza questionamentos sobre quais características musicais e rituais poderiam ser encontradas nas variantes latino-americanas do fandango. Quais seriam as características compartilhadas no nível formal - música, coreografia, letras - que podem ser discernidas nos diversos tipos de fandangos da Espanha e das Américas? "Pode-se criar uma genealogia dos ritmos, versos, estruturas melódicas e sintaxe de improvisação dos fandangos?",47

As características formais e simbólicas tabuladas no estudo de Berlanga, à guisa de conclusão, podem nos auxiliar no melhor entendimento desses processos:

\footnotetext{
47 "Until the middle of the 20th century, in some rural areas the ritual coincided in its essential lines with the ritual described the texts that have arrived to us about the bailes de candil of the 19th century. (...) In this sense, flamenco, especially in its first phases, has inherited from fandangos not only the music, but also a kind of ritual gathering, which appeared in the old flamenco fiestas.

What of these musical and ritual characteristics (that we have only described here in an approximate manner) are found in the fandangos of the Americas? As we saw in the original questions, what are some of the shared traits at the formal level (music, choreography, lyrics) that can be discerned in the diverse types of fandangos from Spain and the Americas? Can one create a genealogy of the rhythms, verses, melodic structures, and improvisatory syntax of fandangos?"
} 
Outras continuidades entre o fandango espanhol e americano também são claras, não entre o fandango espanhol do sul e o fandango latino-americano (só conhecemos o caso da Malagueña da ilha Margaret), mas entre a música tradicional de casais que dançam de ambos os lados do Atlântico. A estrutura de introdução / canto / interlúdio / canto / interlúdio, as formas estróficas das canções, bem como a importância da pequena orquestra repleta de cordas dedilhadas (e harpa em algumas regiões americanas) destacam-se como semelhanças.

Também as performances incluem a mesma importância da improvisação poética. Essa característica permaneceu predominante nos países americanos, prevalecendo a décima. Outras diferenças notáveis são o aumento da presença das tábuas do assoalho, do trabalho dos pés, das roupas e lenços ... nas danças americanas, mas isso merece um estudo distinto e detalhado. ${ }^{48}$ (BERLANGA, 2015, p. 182)

Em vista da ausência dos fandangos brasileiros (gaúcho, alagoano, paulista e caiçara) no quadro comparativo elaborado pelo autor, cabe mencionar também a prevalência da viola de cinco ordens e do acompanhamento percussivo, dos ciclos de doze compassos e da sonoridade do modo mixolídio que, por vezes, pode ser percebida no contexto melódico das modas do fandango caiçara, cujas harmonias, via de regra, valem-se de ciclos de tônicas e dominantes com sétimo grau menor. Ocasionalmente há ocorrência de acordes de subdominante nos estados de São Paulo e Rio de Janeiro. No estado do Paraná, acordes de subdominante aparecem apenas na finalização das modas, aspectos que podem ser visualizados nas cifras adiante.

\footnotetext{
48 "Other continuities between Spanish and American fandango are also made clear, not between the Southern Spanish and (Latin) American fandango (we only know the case of the Malagueña from Margaret Island), but between the traditional music of dancing couples from both sides of the Atlantic. The introduction/lyric/interlude/lyric/interlude structure, the strophic forms of the songs, as well as the importance of the little orchestra filled with plucked strings (and harp in some American regions) all stand out as similarities. Also the performances include the same importance of lyrical improvisation. This characteristic has remained prevalent in American countries, most prevalent within the décima. Other notable differences are the increased presence of the floorboards, the footwork, the outfits and scarves... in American dances, but this deserves its own distinct detailed study."
} 
Menina você tá lembrada

Grupo Manema

Raul Prado

.$=128$
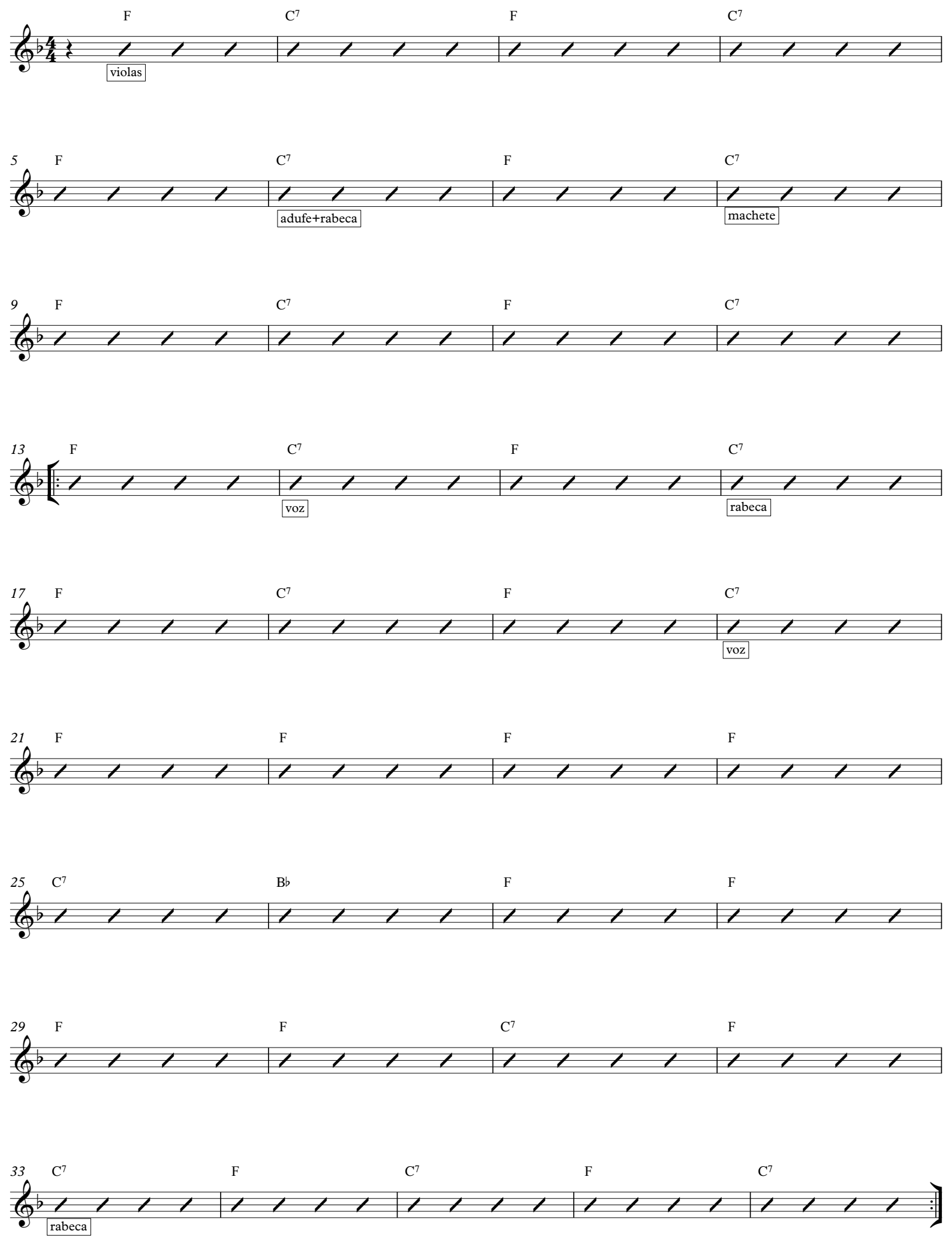

Figura 1.22 - Cifra da moda Menina você tá lembrada, grupo Manema (SP)

104 


\section{Chora morena}

Grupo Pés de Ouro

$\cdot=114$

$C^{2}$

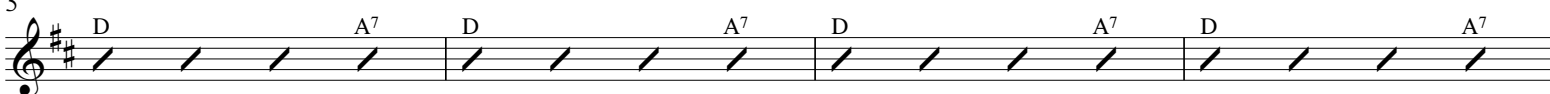
$C^{9}$

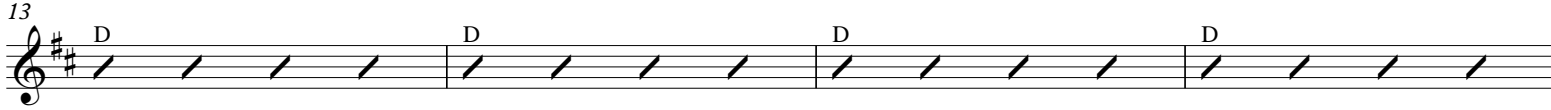
$l^{17} /$ / (l/ /

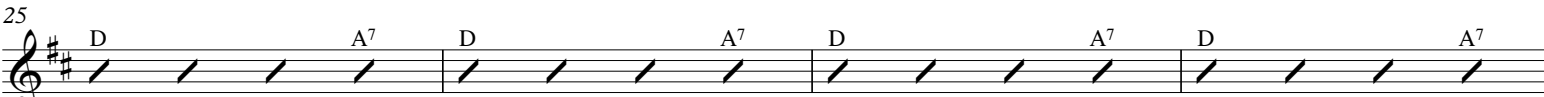
(2/ / (l/ $\overbrace{}^{37}$

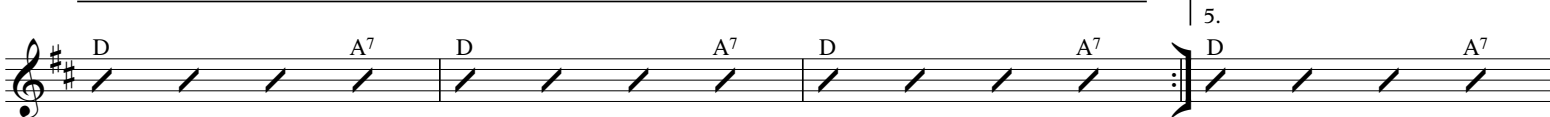

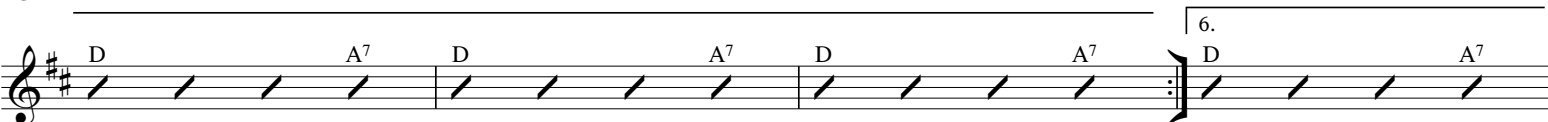

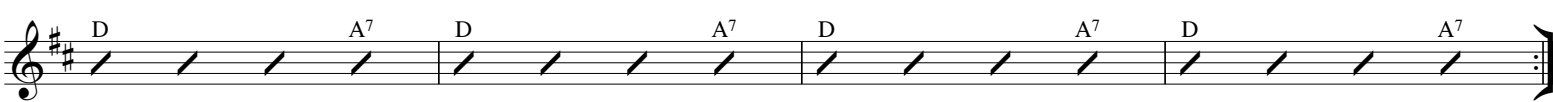

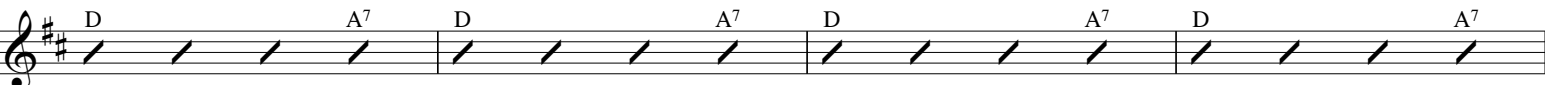
(L/

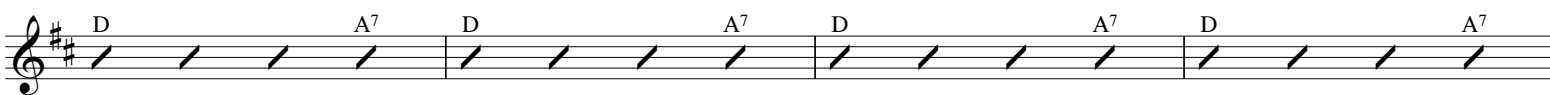
$\overbrace{0}$

Figura 1.23 - Cifra da moda Chora morena, grupo Pés de Ouro (PR) 


\section{Despedida}

Mais que elucubrar sobre a síntese epistemológica de um termo tão amplo e que corresponde a inumeráveis possibilidades trazidas à tona por estudos musicológicos e historiográficos, toma-me o fascínio pela ambiguidade e pela maneira como as verdades tidas como absolutas são superadas frente a modelos sociais correntes e pelo avanço das pesquisas nos campos da musicologia, da etnomusicologia e da antropologia. "Em ciência, a gente não pode afirmar nada com certeza absoluta. A ciência não funciona com verdades finais. O que a gente conhece hoje, é o que a gente pode medir do mundo hoje!"49

Ora mais abertos, ora mais conservadores. Tal gangorra de julgamentos morais, acepções e aceitação de termos e condutas também se faz elemento probabilístico, no qual a antítese entre ser e vir-a-ser se torna operante. Nesse sentido, poderíamos ir ainda mais longe em nossa crono-reflexividade sincrônica: Tales de Mileto, Teofrasto e Anaximandro davamnos a deixa: "Àquilo, de onde surgiram, as coisas retornam, conforme foi ordenado, para oferecer a outra reparação e simpatia, pela injustiça cometida na ordenação do tempo". A mesma lógica é levada a extremos em Heráclito de Éfeso, que amplia o conceito de vir-a-ser quando diz que a "dificuldade - a de conciliar a ideia de um único princípio fundamental com a variedade infinita dos fenômenos - é resolvida por ele pelo reconhecimento de que o conflito dos opostos é realmente um tipo de harmonia." (Heisenberg, 1981, p. 30/31). Assim, a causalidade ainda é componente intrínseco às considerações teóricas que alcançam Kant e Descartes. Na física moderna, a "coisa-em-si" se desdobra em estruturas matemáticas que, contrariamente ao que pensava Kant, podem ser deduzidas indiretamente da experiência.

Quaisquer palavras ou conceitos que foram criados no passado, frutos da interação do homem com o Mundo, não são de fato precisamente definidos no que se refere a seu sentido; isso quer dizer que não sabemos exatamente quão longe palavras e conceitos nos ajudarão a achar nosso caminho no entendimento do Mundo. Frequentemente, sabemos que eles podem ser aplicados a um domínio amplo de experiências interiores e exteriores, mas na prática, jamais saberemos precisamente os limites de sua aplicabilidade. Isso é verdade mesmo para os conceitos mais simples e para os mais gerais como

\footnotetext{
49 Marcelo Gleiser em entrevista ao Canal Livre da Band, Programa exibido em 23/07/2012. https://www.youtube.com/watch?v=iX5acT9d1HE
} 
"existência”, e "espaço-tempo". Portanto, jamais será possível chegar-se, pela razão pura, a alguma verdade absoluta. (HEISENBERG, 1981, p. 50)

Componentes historiográficos e filosóficos postos, a prática atual segue em dinâmica reorganização, reconstrução, rememoração, revivalismo e apropriações diversas. Eis nosso vira-ser, não apenas do termo fandango e seus desdobramentos, mas dos futuros possíveis que engendram a ontologia étnico-territorial de seus artífices. 


\section{FANDANGO, PROTESTO E ATIVISMO}

Dios, que es tan poderoso debía de hacer un mundo nuevo pa no ver tanta mentira porque tan mala es la vida que solo impera el dinero se diga lo que se diga ${ }^{50}$

Diego del Gastor,1930

Na ilha de Superagui (PR), assim como em outras áreas do território caiçara, a função do Fandango vem extrapolando seu papel poético e festivo, assumindo-se também como ferramenta para que as comunidades afirmem sua identidade frente a pressões externas, sobretudo no que se refere aos conflitos territoriais e de direitos humanos dessas populações. Referendados pelo processo IPHAN $\mathrm{n}^{\circ}$ 01450.014268/2008-59 e registrado no Livro de Registro das Formas de Expressão em 29 de novembro de 2012, o fandango é assumido por seus artífices como "forma de expressão central no compartilhamento de práticas, modos de vida, saberes e cosmovisões das populações caiçaras", o que tangencia a ideia de "identidade pública conservacionista" sugerida por Manuela Carneiro da Cunha e Mauro Almeida (CARNEIRO DA CUNHA, 2009).

Citadas pela primeira vez no texto constitucional em 1988, ratificadas por dispositivos infraconstitucionais, tais como as constituições estaduais, legislações municipais e convênios internacionais, como no caso da Convenção 169 da OIT, tomam forma as ferramentas jurídicas que possibilitam a luta de populações tradicionais e povos indígenas ao seu reconhecimento como alteridade, assim como a ocupação de faixas territoriais que lhes são de direito. Por fugir de lógicas mercantilistas da atual estrutura agrária, que visa lucro e exportação, e por se iniciar um processo de afastamento da invisibilidade social que historicamente atinge esses povos, visando à qualificação de suas terras e o direito à diferença assegurados pela constituição

\footnotetext{
${ }^{50} \mathrm{Na}$ década de 1950 [na Espanha], Diego del Gastor, um guitarrista que, para muitos, simboliza o flamenco não comercial, foi admirado por possuir o que um de seus amigos próximos denomina "um completo desrespeito, até mesmo desprezo, por dinheiro e bens materiais" (POHREN, 1979, p.22)*. Essa ambivalência em relação ao capitalismo pode ser encontrada em muitos versos semelhantes a este fandango dos anos 30 intitulado Por No Haber Tanta Mentira [Para não haver tanta mentira] (DUMAS, 2015, p. 529) * Pohren, Donn. A Way of Life. Madrid: Society of Spanish Studies, 1979.
} 
brasileira, podemos perceber que tais implementações legais fomentadas nas últimas décadas pelo esforço de órgãos públicos, pesquisadores, mediadores culturais e das próprias comunidades, ainda está aquém dos patamares almejados. Dessa conjuntura emergem movimentos provenientes da organização dessas populações a fim de pressionar o Estado em busca de seus direitos.

Mesmo levando em conta que o poder é efetivamente expresso sob uma forma jurídica ou que a linguagem do poder é o direito, há enormes dificuldades de implementação de dispositivos legais desta ordem, especialmente em sociedades autoritárias e de fundamentos coloniais e escravistas, como no caso brasileiro. [...] A própria categoria "populações tradicionais" tem conhecido deslocamentos no seu significado desde 1988, sendo afastada mais e mais do quadro natural e do domínio dos "sujeitos biologizados" e acionada para designar agentes sociais, que assim se autodefinem, isto é, que manifestam consciência de sua própria condição. (ALMEIDA, 2004, p. 11/12)

A autoapresentação que se encontra na seção 3 do relatório Grupos de Trabalho: autoidentificação, do I Encontro Nacional de Comunidades Tradicionais, realizado no ano de 2005, teve representação caiçara pela Rede Caiçara de Cultura e pela União dos Moradores da Jureia (UMJ), aproximando-nos de questões já mencionadas:

A situação fundiária é problemática, pois existem proibições para a pesca. Atualmente lutam pela criação de reservas extrativistas. A pesca predatória prejudica e causa grande impacto ambiental. Grandes projetos de turismo expulsam pescadores da praia. Interesses econômicos conseguem autorizações para a destruição de grandes manguezais. Existe também o turismo predatório, que gera poluição das águas e praias. Os turistas compram terrenos pequenos e cercam áreas grandes, muitas vezes incluindo a praia, não deixando os pescadores atuarem ali. Há descaso por parte do Instituto Nacional de Colonização e Reforma Agrária (INCRA) quanto à grilagem das terras, e os pescadores estão perdendo espaço não apenas de pesca como também de moradia. Outro problema são as unidades de conservação de proteção integral, proibindo a atuação das comunidades em áreas de uso tradicional. Sugeriram o turismo comunitário, onde quem ganha dinheiro é a comunidade e não os grandes empresários. (RELATÓRIO DO I ENCONTRO NACIONAL DE COMUNIDADES TRADICIONAIS, 2005, p. 9)

O panorama citado, infelizmente se amplia ao levarmos em conta as propostas largamente publicizadas pelo recentemente eleito presidente de nossa república no ano de 2018 , sendo limitadas, se não trágicas, as expectativas para maiores avanços nas áreas do meio ambiente, da cultura e dos direitos humanos no Brasil nos próximos anos.

Assim como exposto na autoapresentação acima mencionada, a "Moda da Força Verde" retrata conflitos ainda em curso, o que leva a comunidade caiçara de Superagui/PR a se organizar a fim de minimizar a problemática instaurada pela violação de direitos humanos, 
provocada pela implantação de parques nacionais sobrepostos a territórios de comunidades caiçaras, inseridos ali pescadores artesanais que vivem no litoral norte do Paraná. A consolidação de parcerias em prol do Movimento dos Pescadores e Pescadoras do Litoral do Paraná (MOPEAR) e dos Pescadores e Pescadoras Artesanais do Brasil (MPP) ocasionou a produção de peças audiovisuais de divulgação, no intuito de informar a sociedade de modo geral acerca dos conflitos vivenciados localmente. Depois de levantar graves equívocos contidos na documentação apresentada pelo Instituto Chico Mendes de Conservação da Biodiversidade (ICMBio), o documentário Na terra e no Mar: Nós Vamos Lutar! foi realizado a partir do encontro sobre a violação de direitos humanos provocados pela sobreposição de parques nacionais em territórios de comunidades caiçaras e de pescadores e pescadoras artesanais no Paraná.

Anexo ao vídeo documentário postado no YouTube, segue uma "Carta Aberta à Sociedade Brasileira" descrevendo os principais tópicos do conflito e apontando soluções viáveis para a implementação participativa do Parque Nacional de Superagui, carta aqui reproduzida integralmente devido à sua relevância para este capítulo:

Encontro Sobre A Violação De Direitos Humanos Provocados Pelos Parques Nacionais Em Territórios De Comunidades Caiçaras E Pescadores E Pescadoras Artesanais No Paraná

Carta Aberta À Sociedade Brasileira

Somos comunidades tradicionais caiçaras, Ilhéus do Rio Paraná, Pescadores e Pescadoras Artesanais atingidos por Parques Nacionais no Estado do Paraná. Estivemos reunidos na Vila de Superagui no dia 06 de dezembro de 2013 para denunciar injustiças praticadas pelo ICMBio contra os DIREITOS de nossos povos, em especial nesse encontro, as comunidades caiçaras, pescadores e pescadoras artesanais atingidos pelo Parque Nacional de Superagui, em Guaraqueçaba, PR.

Com apoio e presença de diversas instituições e movimentos, dentre eles: comunidades Faxinalenses, Indígenas, Benzedeiras, Cipozeiros, Ilhéus do Rio Paraná, Caiçaras, grupos de fandango, além de representantes de Universidades/Instituto Federal, Conselho Estadual de Direitos Humanos, Comissão de Direitos Humanos da Assembleia Legislativa do Paraná, Comissão de Direitos Humanos da Ordem dos Advogados do Brasil, Defensoria Pública da União, Defensoria Pública do Estado do Paraná, Ministério Público Estadual - CAOPDH, Secretaria Comissão Nacional de Povos e Comunidades Tradicionais, Rede Puxirão de Povos e Comunidades Tradicionais, além de diversos movimentos sociais do Paraná.

Estamos aqui reunidos para denunciar o preconceito, a violência e o descaso que vem sofrendo nossas comunidades tradicionais da parte dos órgãos ambientais, em especial do ICMBio, ao criminalizar nossas comunidades e impedir o avanço de iniciativas e entendimentos baseados no diálogo democrático, uma vez que nosso interesse é verdadeiramente participar da elaboração do Plano de Manejo do PNS, para tanto o ICMBio necessita reconhecer nossos direitos territoriais. 
Denunciamos medidas e tomadas de decisão autoritárias e arbitrárias de gestores em posição de poder, que tem promovido a ampliação da desigualdade e da exclusão social em nossas comunidades, ao desconstituir direitos territoriais, ignorar o reconhecimento e a efetivação de nossos direitos, e impedir a reprodução do modo de vida de nossas comunidades, compatíveis com a conservação dos recursos naturais.

Denunciamos o ocultamento dos efeitos do Parque Nacional de Superagui sobre nossa identidade étnica e territorial nos "estudos" encomendados pelo ICMBio e, contestadas por Parecer Técnico de pesquisadores independentes.

Denunciamos a forma como os órgãos ambientais ignoram e descumprem políticas públicas e legislações de interesse de povos e comunidades tradicionais, conforme menciona a $\mathrm{CF} 216^{\circ}$, o art $28^{\circ}$ da Lei $9.985 / 2000$ (SNUC) e a própria Lei da Mata Atlântica em seus art. $9^{\circ}$ e $26^{\circ}$. Cobramos imediata aplicação do disposto na Convenção 169 da OIT, em especial em seu artigo $6^{\circ}$, que determina a consulta aos povos e comunidades tradicionais interessados, "por meio de procedimentos adequados sempre que sejam previstas medidas legislativas ou administrativas suscetíveis de afetá-las diretamente". Princípios estes presentes nos instrumentos de gestão participativa previstas na Lei do SNUC.

Considerando as denúncias apresentadas no decorrer do Encontro, requeremos ao ICMBio: 1) a realização de novos "estudos" através da verdadeira participação das comunidades afetadas pelo PNS, antes da aprovação do Plano de Manejo; 2) A elaboração de Laudo Antropológico das comunidades afetadas pelo Parque Nacional de Superagui, conforme recomendação da $6^{\mathrm{a}}$ Câmara do Ministério Público Federal, como condição para aprovação pelo ICMBio dos Estudos de Usos Público e Turismo e Relatório Socioeconômico, Histórico e Cultural do PNS, e 3) Definir um espaço de discussão com as comunidades para que elas explicitem quais usos são necessários para sua reprodução social e, que o ICMBio forneça o acesso imediato a seus territórios tradicionais para que realizem seu modo de vida conforme manda a legislação do SNUC e da Lei da Mata Atlântica, além da Constituição Federal em seu art. 216º e o Decreto Federal n. 6040/2007.

Confiantes na justiça como guia do Estado Democrático de Direito, e na Constituição Federal, que nos assegura a dignidade e a igualdade pelo reconhecimento da nossa diferença, exigimos o cumprimento da legislação federal no que concerne aos direitos dos povos e comunidades tradicionais no Sul do Brasil.Na terra e no mar: nós vamos lutar!!! Coordenação MOPEAR/MPP Movimento Dos Pescadores E Pescadoras Do Litoral Do Paraná - MOPEAR Movimento Dos Pescadores E Pescadoras Artesanais Do Brasil - MPP (NA TERRA E NO MAR: NÓS VAMOS LUTAR, 2014)

Durante as reuniões, as comunidades se valem de pequenos esquetes cênicas, denominados "místicas", onde encenam desmandos praticados por órgãos ambientais contra pescadores das localidades a fim de comunicar à audiência as problemáticas enfrentadas em seu cotidiano, demonstrando a autoconsciência cultural e a eminente verticalidade na implementação do Parque Nacional do Superagui. Entre as místicas, seguem depoimentos de moradores, lideranças comunitárias e mediadores, dos quais extraímos alguns fragmentos: 
Esse tal de plano de manejo, aqui, que ninguém sabe nem o que que é! Pode ser que seja a mesma lei que colocaram no parque ou pode ser pior ainda! $\mathrm{O}$ que que eles querem fazer com esse tal plano de manejo, que ninguém sabe o que que é? Pode ser que venha a prejudicar nós mais ainda.

Porque, primeiro, antes do parque chegar aqui, você desfrutava de tudo quanto era coisa, você podia largar uma redinha ali, você podia ir no mato pegar um palmito, ir no mangue pegar uma ostra, um caranguejo, ninguém te prejudicava. Aí, depois que chegou o Parque Nacional aqui, não podêmo fazer mais nada disso, e isso dificultou muito o nosso modo de vida. (Milton, morador de Superagui)

Eu não significo muito isso daí, eu não sei bem o que que deve ser isso daí, eu não entendi ainda bem isso daí! Depois do parque, mudou, foi uma transformação bem grande. Eu não sei como que foi isso daí, quando a gente soube, já tinha tombado o parque. (Abigail, Moradora de Superagui)

Plano de manejo, eu tô afastado disso daí, que eu não estou experiente com eles. Fazer os encontros deles, não convidam as pessoas. Agora que começaram a me convidar, aí eu vou sair com eles pra tomar mais uma atenção de como que é o regulamento.

Antes do parque, nós vivia tranquilo, todo dia de manhã - sete, oito horas - levantava e ia pra roça, limpar sua roça, fazer a colheita, dava os fruto para os filho. Agora não tem mais nada! Hoje em dia, depois do parque, vinte e quatro anos atrás, nada disso pude fazer mais. Nós, nosso parque aqui, a divisa lá da barra da lagoa ao Rio das Paca, eles entraram devagarinho aqui e nos fecharam. Tâmo da placa do IBAMA (a casa que eles têm ali) à ponta da praia. Eles tomaram conta de tudo, ainda ameaçaram de expulsar nós. (Antonio Francisco, Morador de Superagui)

Muitos de nós não temos noção, dimensão de quanta coisa tá vindo de cima para baixo e nos afetando. Cada dia é uma portaria, cada dia tiram um pedaço de nós. O que vai ser se nós não lutarmos? Acredito que uma hora vão ouvir, então vamos gritar, gente, vamos se fazer presente! Vamos dizer: nascemos aqui, aqui queremos viver, aqui queremos morrer. [...] Não é só questão de terra, é questão de terra e água, é o que nós precisamos para sobreviver. (Cleonice Silva do Nascimento, MOPEAR)

Eu plantava, eu era pescador, plantava. Quando a maré dava pra nós pescar, ia pescar; quando a maré ficava ruim pra pescar, ia pra roça. Então, eu tinha dois modo de sobreviver, e isso pra mim era muito importante pra mim, eu tirava da própria terra o alimento pra mim comer e dar pros meus filhos.

Só pude pescar. Agora nem pescar estou podendo mais, porque se eu largo uma rede ali, vem a Força Verde e me leva a minha rede, carrega. Ele chega, ele não me explica assim: se essa rede é seu, eu vou levar essa rede. Ele chega e rouba, ele chega, pega e leva. (Antonio Custódio, morador de Barbados)

Lá onde eu plantava minha roça lá, tá tudo mato alto, coivara, e eu não pude plantar mais, tô com essa idade. De quinze anos, trabalhava com meu pai, nunca fui multado, depois que entrou esse parque, foi, acabado tudo, terminou tudo na minha vida. Queriam me algemar lá no meio da minha roça, mas eu não tava matando, eu não tava robando: tava plantando para o alimento do meu corpo e da minha família, e agora não posso fazer mais nada. Me multaram, fiquei doente do coração e fiz um empréstimo no banco pra poder procurar recurso pra mim. E agora quem é que vai me dar isso? Ninguém. Ninguém me dá. Eu vendi tudo, acabei com tudo, fiquei na miséria. (Antônio Castanho, morador de Superagui)

Nós, do movimento de pescadores e pescadoras, não temos muito traquejo e muito estudo para avaliar analisar um documento técnico; e, pelo ICMBio, foi criado, foi feito um documento, aonde esse documento é ligado ao plano de manejo. Então, nós do movimento pedimos o apoio de algumas 
universidades, de algumas pessoas da parte jurídica, para ajudar a gente neste parecer técnico. Então, hoje, a Letícia vai ajudar a gente neste parecer técnico. (Cleonice Silva do Nascimento, MOPEAR)

Esses estudos e esse plano de manejo em si representam uma síntese de vinte e quatro anos de conflito que vem acontecendo nessa região. Surge, nesse momento, uma possibilidade inédita de resolução de conflitos, de uma participação efetiva da comunidade nas discussões acerca da unidade de conservação. Só que esse documento, que poderia servir pra tudo isso, do contrário, ele silencia, ele oculta e ele simplifica a voz desses sujeitos que aqui se encontram, e a gente veio aqui tentar fazer uma crítica construtiva a estes estudos preliminares no sentido de tentar contribuir para que o planejamento seja efetivamente participativo e que contemple não só os objetivos da unidade de conservação, mas também das comunidades.

A primeira abordagem que diz respeito a tudo isso que eu falei anteriormente, ela diz respeito ao silenciamento, ou ao ocultamento de particularidades polêmicas do contexto socioespacial estudado; ou seja, existem informações que estão sendo propositadamente ou não (a gente não veio dizer isso), estão sendo silenciadas, estão sendo ocultadas. De certa forma corresponde à manipulação da informação. Uma vez que a gente identifica que diversas das práticas que ainda existem aqui, elas são tratadas sempre no passado, de uma maneira depreciativa, como se fossem remanescências, como se fossem atividades que estão em declínio, em vias de desaparecimento ou efetivamente tenham desaparecido. Eu vou trazer um exemplo disso pra vocês, que é quando o estudo socioeconômico fala sobre o fandango, e que isso pode gerar uma interpretação equivocada sobre a atividade: "O fandango deixou de ser uma expressão de sociabilidade caiçara, ele não tem mais relação alguma com o estilo de vida que marcou e definiu a cultura caiçara". (Letícia Ayumi Duarte, UFPR) (NA TERRA E NO MAR: NÓS VAMOS LUTAR, 2014 - transcrições nossas)

Nesse momento do vídeo, são apresentadas cenas do bar do Aikidov, em Superagui, registradas pelo documentário Trânsitos caiçaras em redes fandangueiras ${ }^{51}$ realizado sob os auspícios da FUNARTE no ano de 2011.

Nós queremos o quê com isso, com esse encontro?

Esse tal plano de manejo que nós falamos tem que sair, né? Não saiu já faz vinte e cinco anos e estão querendo fazer em três meses. Nós pedimos que, se tiver que sair, que saia, mas, queremos, nós, pescadores, participação nele profunda! É só o que nós queremos. Que nós possamos fazer nosso cerco, que nós possamos pescar com a nossa rede de arrasto e por mais gente: que nós possamos plantar! É o que nós queremos.

\footnotetext{
51 “A Pesquisa localiza os trânsitos fandangueiros entre o litoral norte do Paraná e o litoral de São Paulo, em suas diferentes dimensões de sociabilidade, daquelas orientadas pelas relações familiares às acionadas pela inserção dessa expressão em cenários da produção e circulação artística, em programações culturais e turísticas. Viabilizada pela Bolsa Funarte de Produção Crítica em Culturas Populares 2010, este projeto teve sua pesquisa de campo guiada por passadinhos e bailados, sendo embalada pela sonoridade de rabecas, adufos e violas. Em uma busca permanente de traduzir em textos e na linguagem audiovisual os movimentos peculiares do fandango."
} (TRÂNSITOS CAIÇARAS, 2017. Acesso em: 20 nov. 2018) 
Nós viemos nesse encontro fazer o quê, gente? Lutar pelos nossos direitos, lutar para que nós possamos viver em paz em todas as nossas comunidades. Na terra ou no mar, nós vamos lutar! (Didi, MOPEAR) (NA TERRA E NO MAR: NÓS VAMOS LUTAR, 2014 - transcrição nossa)

A partir dos fragmentos das entrevistas com moradores das ilhas, podemos perceber a gravidade da situação em que se encontram essas comunidades e como as mesmas têm tomado papel de protagonismo nas lutas por seus direitos. Infelizmente são situações recorrentes em diversas localidades caiçaras - em alguns casos, no que se refere à exploração imobiliária e, em outros, pela sobreposição de reservas ambientais, seja de uso restrito ou de proteção permanente. Fatores que, desde meados do século XX, ocasionam uma intensa mobilidade de indivíduos e comunidades que, em muitos casos, acabaram por se dispersar em direção aos centros urbanos em busca de trabalho e outras formas de subsistência. A ocultação e o silenciamento dos maiores interessados em suplantar o componente caiçara de seus domínios é recorrente. No Estado de São Paulo, o "processo velado de expulsão" diz respeito à proibição dos modos de vida tradicionais. No caso da criação da Estação Ecológica Jureia-Itatins, o fechamento das escolas impossibilitou o acesso a um direito social - a obstrução de caminhos compõe políticas deliberadas de expulsão das famílias caiçaras por meio da criação de entraves ao seu desenvolvimento social. Chegando-se, assim, à conclusão de que a postura do Estado de São Paulo é nociva às comunidades caiçaras, forçando-as a saírem de seus territórios sem sequer reconhecer sua diversidade cultural ou pagar indenizações. "Esse processo velado de expulsão dá a ideia de que a saída das famílias acontece por livre e espontânea vontade." (DE BONA, 2016, p. 61)

O Movimento dos Pescadores e Pescadoras do Litoral do Paraná, a Rede Caiçara de Cultura, a União dos Moradores da Jureia e a Associação Jovens da Juréia, são exemplos de reação a esse processo paulatino de expulsão, da emergência de movimentos sociais de caiçaras que lutam para defender seus direitos territoriais enquanto comunidades tradicionais, reconhecidos pela Convenção Internacional 169 da Organização Internacional do Trabalho e pela legislação federal.

Sobre a peça audiovisual acima mencionada, cabe relatar que a mesma se inicia com o som peculiar de uma rabeca executando o hino nacional e é finalizada com a seguinte moda de fandango: 
Moda da Força Verde

(marca bailada - Chamarrita)

Aorélio Domingues e Ivo Costa

Coitado do pescador

Que precisa de pescar

Companheiro Chico Mendes

Atrás da nota de cem

Pro pão não deixar faltar

A turma da força verde

Estão saindo pro mar

Revira no seu caixão

Vendo o que o ICMBio

Tá fazendo com o povão

Usando seu nome ilustre

Pra acabar com a tradição

A turma da força verde

Se dizem de autoridade

Coitado do Chico Mendes

Chegando na embarcação

Que está lá no cemitério

Eles multam de verdade

Tá vendo a razão do povo

De gente que fala sério

Se a malha não der certo

Vê o caiçara sofrendo

Eles mandam pra cidade

Com a turma do ministério

Eles vêm de voadeira

E prendem nosso pescado

Nem mesmo o meu fandango

Depois vão com a família

Eu posso mais tocar

Almoçar lá no mercado

Depois comem com cerveja

Pra viola de fandango

Caxeta não retirar

$O$ peixe que foi pescado

Os fabriqueiros desistiram

De tanta multa levar

Eles prendem malha cinco

Vamos dar por despedida

E prendem meu gerival

Bem na beirinha da praia

Não deixam mais dar um cerco

Antes que o IBAMA venha

Não deixam cortar um pau

Proíba tomar Cataia

Liberam a pesca lá fora

Dizendo que não faz mal

Só falta eles proibirem

De ter um rabo de sai

A moda foi composta e gravada no intuito de compor a peça audiovisual. Durante a edição do material tive a oportunidade de contribuir, realizando a gravação, a mixagem e a masterização da primeira versão da Moda da Força Verde. Naquela ocasião, consciente das limitações técnicas inerentes aos estúdios caseiros, do prazo apertado e das participações voluntárias, Aorélio Domingues executou todos os instrumentos, assim como cantou a primeira e a segunda voz. Em 2017, o tema foi regravado no disco intitulado Amanhece - Fandango Pancada ${ }^{52}$, produção que sublinha o trânsito e a dinâmica dos processos criativos das populações caiçaras.

\footnotetext{
${ }^{52} \mathrm{O}$ termo nasce concomitantemente à gravação do disco Amanhece, aludindo a novas formas de se tocar fandango, marcadamente "no ataque", onde as modas têm andamento mais acelerado. A evidência de frequências graves como as do baixo elétrico e aquelas subgraves (resultantes do trabalho de masterização) são notadas quase que na totalidade das faixas do disco.
} 
$\mathrm{Na}$ atualidade, o intercâmbio entre diferentes localidades e os recorrentes conflitos de naturezas diversas incitam vertentes criativas e performáticas, atravessando o cotidiano das comunidades que vivenciam tais conflitos:

Moda do Peixe Morto (marca bailada - Chamarrita) Aorélio Domingues, Jairo de Souza e Poro de Jesus

Dinheiro do peixe morto Eu não paro de pensar Se eu pegar esse dinheiro Eu penso em me casar

$\mathrm{O}$ advogado disse Sobre o dinheiro do porto Uma verbinha que venha Com nome de peixe morto Eu não pego toda verba Pois tenho sociedade Vou pegar trinta por cento O resto é para a autoridade

$\mathrm{O}$ advogado disse Que essa verba é muito boa Dá pra comprar dez motor E mais de quarenta canoas

Eu preciso dessa verba Pois eu não tenho nem calça Tem gente que recebeu A verba com carteira falsa

Se eu pegar esse dinheiro Vou comprar meu batelão Se eu deixar com mulher Ela vai gastar no Avon

Se eu pegar esse dinheiro Vou dar um pouco pro padre E vou gastar o restante Na loja do Ariade

E chega de caranguejo De pupunha e de manjuba Ir no baile de fandango Atrás de velha viúva

Quem pegou esse dinheiro O homem que não tem renda Já dá para perceber Faz varanda em vossa casa Com forro de PVC

É um cidadão que sofre Enche a cara de cachaça No baile do Akidov

Se eu pegar esse dinheiro

Quero dar a despedida Pago a multa da marinha No pé do Guapiruvu Vou reformar minha casa Se eu não pegar essa verba Aumentar minha cozinha Eu vou tomar uma Cataia.

Nesse exemplo, na prática composicional de modas de fandango - alinhadas a contextos de pressão política, financeira e ideológica, pontuam-se conflitos referentes à especulação de advogados no repasse de recursos indenizatórios devidos a pescadores locais por ocasião da explosão do navio Vicuña, próxima ao porto de Paranaguá, em novembro de 2004 - evento trágico e de impactos ambientais negativos jamais evidenciados na localidade. 
O ativismo político e territorial vêm sendo mote de militância em várias frentes de atuação. A novidade que se estabelece como regra é que a juventude fandangueira e boa parte de seus interlocutores e produções transitam por diversos meios e circulam por localidades com velocidade e frequência antes intangíveis. Esse ativismo, impulsionado pelas políticas públicas para as culturas populares e pelo surgimento de novos canais de diálogo, tanto virtuais como presenciais, possibilitaram desdobramentos como a execução de projetos para o mapeamento e visibilidade de detentores, a participação em reuniões de salvaguarda e a promoção de prêmios e editais destinados aos saberes e fazeres tradicionais. Um panorama da conjuntura deve levar em conta também o componente territorial, onde nos deparamos a ações governamentais guiadas por perspectivas de um ambientalismo radical que, via de regra, ignora o componente humano, atuando no cerceamento do uso e do acesso das comunidades tradicionais caiçaras ao território, proibindo práticas tradicionais de subsistência e o acesso a serviços de educação, saúde, transporte e energia elétrica, ou seja, "privando e cerceando os meios de vida das comunidades caiçaras". (DE BONA, 2016, p. 60)

Apesar do cenário autoritário de restrições impostas pelas políticas ambientais brasileiras, nos últimos anos os caiçaras têm tentado orientar sua luta também pelas vias legais e institucionais reivindicando seus direitos e a recategorização do território em que vivem. (ibid., p. 61)

Financiado pelo programa Cultura Viva, o então Ponto de Cultura Casa Mandicuera produziu, entre 2009 e 2011, uma série audiovisual com seis capítulos tratando de temáticas da cultura caiçara, incluindo lendas, crenças, elementos idiomáticos, temas do cotidiano e conflitos locais. Além de homônimos jocosos, sátiras dos usos e costumes e enfrentamentos de militância política, os episódios também exprimem parte das demandas prioritárias vivenciadas por essas populações, entre elas aquelas de cunho socioambiental, escancarando conflitos junto a órgãos como IBAMA, ICMBio, IAP e Polícia Ambiental, como exemplificado no episódio 06 denominado RIBANA. (RIBANA, 2011, acesso em 21 abr. 2017)

Em RIBANA, o roteiro trata de dois jovens interessados nos saberes da tradição fandangueira que, depois de recepcionados por um mestre fabriqueiro ${ }^{53}$, seguem para a mata a fim de cortar caxeta para construção de instrumentos. Enquanto o mestre discorre sobre a necessidade de cuidado de manejo no corte da caxeta, indicando a sustentabilidade inerente às práticas extrativistas tradicionais, são surpreendidos, conduzidos coercitivamente e constrangidos perante a comunidade local por agentes do RIBANA. A evidente sátira aos

\footnotetext{
${ }^{53}$ Termo utilizado pelos fandangueiros para se referirem aos mestres da luteria caiçara.
} 
órgãos de fiscalização se dissolve quando os envolvidos são libertados de seus algozes por personagens fantásticos que compõem o enredo do Boi de Mamão. Em última análise, uma metáfora da força libertadora imanente à cultura caiçara.

A iniciativa do Ponto de Cultura Casa Mandicuera em arregimentar membros da comunidade passarem pela experiência da labuta de uma produção audiovisual teve por objetivo aproximar jovens e adolescentes do trabalho da associação.

Aventamos, assim, um diálogo com Sahlins, quando este nos sugere que estaríamos vivendo sob o paradigma de um "novo culturalismo", no qual ocorre uma "autoconsciência cultural dos povos", que manipulam suas identidades fazendo um uso "autorreflexivo de suas culturas". A objetivação da cultura, portanto, é a apropriação por parte dos "nativos" de sinais diacríticos, que os identificam enquanto grupo. Para Sahlins, esse processo acontece em nossos dias como forma de "adaptação dos povos locais ao Sistema Mundial". (SAHLINS, 1997, p. 133)

Roland Robertson defende que as teorias da globalização aspiram a sobrevalorizar a dimensão temporal relativamente à dimensão espacial. A utilização do paradigma da compressão do espaço tempo - elemento nuclear da definição de globalização - tem conduzido à generalização da ideia de um processo contínuo de homogeneização cultural à escala global. Contrário a este ponto de vista, Robertson (1992) sugere o uso do termo glocalização, enquanto processo em que o local e o global se entrosam para constituir o que designa por glocal.

Dois aspectos são centrais na sua proposta: a noção de globalização integra a ideia de interpenetração do global e do local, ou, de um modo mais abstracto, do universal e do particularismo; que as noções contemporâneas de localidade são correntemente o produto de ideias globais, embora, como enfatiza, seja errado pensar que todas as formas de localidade sejam substantivamente homogéneas. (LOURENÇO, 2014. Acesso em: 10 Jan. 2017)

Percebemos assim que as premissas ${ }^{54}$ de determinado traço cultural abarca em si uma rede complexa de variantes, atravessadas pelos processos de globalização, mas sem perder de vista a alteridade dos indivíduos e a importância dos territórios que ocupam - dinâmicas contínuas em perpétuo movimento.

“O padrão que liga é um metapadrão. Ele é um padrão de padrões. Ele é aquele metapadrão que define a vasta generalização que, aliás, são padrões que ligam." (BATESON, 1986, p. 19, grifos no original). Padrões poéticos, organológicos e coreográficos árabes, que se ligam aos padrões al-andaluzos e, posteriormente, agregados a elementos indígenas e africanos,

\footnotetext{
54 "Uma premissa é uma afirmação generalizada de uma determinada pressuposição, ou implicação, passível de ser reconhecida em vários componentes de comportamento cultural.” (BATESON, 2008, p. 88)
} 
dão corpo à configuração da musicalidade neobrasileira, metapadrões, conexões, ligações, afectos e subjetividades.

Bateson já nos alertava na década de 1950 sobre a imediata e evidente necessidade em considerar a relação entre dois indivíduos como passível de se alterar no tempo, mesmo na ausência de perturbações externas. "Temos não apenas de considerar as reações de A ao comportamento de $\mathrm{B}$, mas ir adiante e considerar como estas afetam o comportamento posterior de B e o efeito disso sobre A". (BATESON, 2008, p. 223)

Acerca da circularidade relacional, cujo motor é a retroalimentação, conceito-chave da cismogênese batesoniana ${ }^{55}$, os muitos sistemas de relacionamento, individuais ou em grupo, carregam aspectos geradores de mudanças progressivas. ${ }^{56}$ Tais mudanças, apresentam-se na maneira como os padrões culturais podem ser julgados como adequados ou não, em certa ocasião. Bateson questiona o modo como se inculca em cada indivíduo o sistema apropriado de atitudes emocionais, notadamente de modo mais complexo que a organização estímulo-resposta behaviorista. Como já mencionado, "não chegamos a retratos do indivíduo, mas a retratos dos eventos em que o indivíduo está envolvido", ampliando o sentido do termo personalidade para aspectos de interação do "indivíduo no mundo". (BATESON, 2008, p. 305)

Ininterruptamente, fandangueiros fazem uso das formas poéticas (décimas, sextilhas, quadras, zegéles, rondéis e virelais) e das instrumentações modificadas a partir de elementos ibero-al-andaluzos, indígenas e neobrasileiros. Legados reinventados, repaginados, deslocados e alocados em embates políticos, onde a luta por território e identidade é atualizada constantemente, onde manifestações culturais incidem na alteridade de seus detentores em meio ao frenético mundo que se globaliza. Como se um novo campo (no sentido quântico do termo) se descortinasse, campo no qual a excitação que o mantem se faz resultante direta da interação cumulativa dos indivíduos.

\footnotetext{
55 Uma possível transposição teórica, do campo etnográfico à performance poético-musical-coreográfica, evidencia o momento presente, a empatia momentânea e a retroalimentação circular da audiência em relação à alteridade do músico/instrumentista. Bateson sugere que este campo de estudos pode ser definido em termos das reações de um indivíduo às reações de outro indivíduo. "Bateson define cismogênese como um processo de diferenciação nas normas de comportamento individual, resultante da interação cumulativa dos indivíduos." (BATESON, 2008, p. 223)

56 No intuito de retificar possíveis equívocos conceituais, Bateson (no epílogo de 1936) adverte que as representações da cismogênese não deveriam ter fornecido indicações de que se tratam de processos diacrônicos, ou de mudança. Nominalmente, cada um dos métodos utilizados pelo autor em Naven, são estritamente sincrônicos, devendo oferecer um corte sincrônico da cismogênese, no qual o processo de mudança seria observado como estacionário em qualquer momento isolado. (BATESON, 2008, p. 307)
} 


\title{
Proibição e cerceamento: o futuro não é mais como era antigamente
}

\begin{abstract}
"Lute pelo direito de festejar" não é, na verdade, uma paródia da luta radical, mas uma nova manifestação dessa luta, apropriada para uma época que oferece a TV e o telefone como maneiras de "alcançar e tocar" outros seres humanos, maneiras de "estar junto!"
\end{abstract}

Hakim Bey

É de longa data que o fandango - ainda que como termo genérico vinculado a bailes ruidosos, festas de batuques e bate-pés - sofre cerceamentos, agenciamentos políticos de cunhos autoritário e dominador, onde as manifestações populares soam como discrepâncias de manutenção da "ordem", "civilidade" e "bons costumes" da patriarcal e oligárquica descendência brasileira.

Ainda na atualidade, associam-se os fandangos ao universo de festas religiosas que ocorrem no litoral caiçara, como Folias de Reis e Bandeiras do Divino Espírito Santo, ao Carnaval, e outros ajuntórios - dos quais derivam casamentos, aniversários e batizados -, ou ao simples divertimento dos encontros em dias de descanso.

Não se repassava isso, tanto o fandango como a bandeira do divino, não se passava para os mais jovens, então, o nosso foco é aprender com os mais velhos, e tentar passar para os mais novos de uma forma que eles entendam isso. Não só como folclore, mas como uma coisa viva e que faz parte da gente aqui. Que a gente não pode deixar acabar entende? Se caminha junto, não tem como separar. A bandeira é religiosa, o fandango é profano. Mas não tem como separar isso, de todo jeito é uma festividade também. Já diz o nome, folia. Então a gente chega nas comunidades, e a nossa bandeira também é o fandango, bandeira cultural de identidade, vai junto, bandeira e fandango sempre. (Poro de Jesus) (O DIVINO, O POPULAR E O ERUDITO, 2017)

Antigamente, "de primero", costumava-se fazer o entrudo - brincadeira que originou o carnaval de hoje em dia - durante quatro dias, nos quais, segundo Inami, o litorâneo não fazia outra coisa senão bater o fandango e comer barreado. Derivado do latim, introitus, o termo significa começo, introdução do período da quaresma.

Devido aos condimentos à base de carne verde, toucinho e temperos, o barreado é um prato saboroso, fácil de fazer e relativamente barato. Pode ser requentado muitas vezes sem perder o sabor original e leva muitos dias sem se deteriorar. "Por isso, as folgadeiras e os 
folgadores preparavam o prato no sábado e o requentavam durante os dias de entrudo, dispensando o trabalhão que seria, depois de uma noite de bateção, cozinhar no dia seguinte." (CUSTÓDIO PINTO, 2010 p. 106)

Como zona autônoma, o entrudo, que no território caiçara paranaense agrega o elemento culinário do barreado, almeja a liberdade de tempo para satisfazer os "prazeres da carne", exprime pulsões de vida vivenciadas coletivamente à parte das vigilâncias diárias no tempo dos senhores, dos coronéis que operavam sob ótica patriarcal, oligarca e cristã.

Na Idade Média, quase um terço do ano era reservado para feriados e dias santos. Talvez os protestos contra a reforma no calendário tenham tido menos a ver com os "onze dias perdidos" do que com a sensação de que a ciência imperial estava conspirando para preencher esses espaços vazios dentro do calendário, onde a liberdade das pessoas havia se concentrado. Um golpe de Estado, um mapeamento do ano, a dominação do próprio tempo, transformando o cosmo orgânico num universo que funciona como um relógio. A morte do festival. (BEY, s.d., p. 9)

Historicamente, tais intentos podem ser percebidos no livro do professor Francisco Ribeiro Azevedo Macedo, bisneto do Coronel Diogo Pinto Azevedo Portugal, que, ao interpelar em favor de seu bisavô, nos aproxima de uma realidade histórica ímpar, em referência à fundação da freguesia de Nossa Senhora de Belém dos Campos de Guarapuava, feita que se deu no ano de 1819. Entre picuinhas, ciúmes e articulações políticas dissolutas, Macedo traz elementos cabais necessários à manutenção da honra de seu bisavô, borrada pelos acontecimentos que se desdobraram na época, sobretudo pela maneira equivocada como o Padre Chagas conduziu o processo de povoamento de Guarapuava. No prefácio do livro, David Carneiro sintetiza parte do enredo dessa narrativa:

Padre Chagas que via em Diogo Pinto um católico liberalíssimo, desejouo longe de si como herege ou ateu, e, por portas travessas, obteve a retirada da força miliciana, essa mesma de que dependia a ordem naquela região, e que era acusada de atrapalhar a perfeita catequese.

O padre, porém, não tarda muito a voltar a si de seus enganos. Ele mesmo dirá nas suas memórias, que já em 1818, "habitantes dos campos iriam inquietar as hordas de índios, nos sertões, movendo-lhes guerra e aprisionando a muitos". [...]

Não se discute para o caso vertente a santidade de um padre Chagas, nem a sabedoria de um Saint'Hilaire. Ambos, entretanto, para não citar sinão êles, erraram nos seus conceitos; o primeiro por paixão religiosa ou por ciúme, e o segundo por dar ouvidos aos aleives daqueles que se viam prejudicados pela maneira justa como agia na questão do levantamento de tropas, o comandante [Diogo Pinto Azevedo Portugal] da expedição em 1809. (MACEDO, 1951, p. 14/15) 
Segundo os comentários do prefácio, encontramos algumas considerações sobre SaintHilaire, que, na narrativa, toma parte pelos fazendeiros de Castro, suscitando dúvidas quanto às características tidas por isentas em seus relatos. David Carneiro tenta amenizar tais críticas incisivas contidas no opúsculo: "quem conhece a boa fé deste naturalista que passou aqui em 1820 [...] encontrará nessa boa fé e no desejo de reproduzir fielmente todas as informações que ouvia", dando assim motivos para desculpá-lo levando em conta, "na balança dos méritos, o muito que fez pela nossa história, em face do pouco peso dos seus desacertados juízos, que nem eram seus, mas de quem se fez porta voz". (MACEDO, 1951, p. 15)

Ao discorrer sobre "outras feições psicológicas dos antigos curitibanos" (ibid., p. 57/ 58), Macedo nos brinda com relatos de grande interesse sobre a cena cultural da região na época e de como as autoridades interagiam com situações ditas problemáticas. Apesar de longos, registro aqui tanto os três parágrafos iniciais do citado capítulo quanto as notas de rodapé redigidas pelo autor:

§1. Os curitibanos eram católicos, não poucos com exagerado fervor. Havia religiosos moderados e havia indiferentes... Mas, ninguém se recusava a contribuir para as despesas do culto, impostas por lei.

Obrigatória a presença dos vereadores, juízes e demais autoridades nas profissões em outras solenidades.

Nascimentos de príncipes, seus aniversários e casamentos, eram festejados com tedéuns, procissões e luminárias.

Cada família tinha em sua casa um oratório com imagens de santos, enfeitado de flores, junto ao qual estava continuamente acesa uma candeia. Nas chácaras, nos sítios e nas fazendas, havia oratórios grandes ou capelas. Extraordinariamente, mediante licenças especiais, celebravam-se ali missas, casamentos, batizados. E faziam-se rezas cantadas ou novenas, ordinariamente, precedentes aos dias de Santo Antonio, de São Pedro, de São João, etc. terminado por festas ruidosas, banquetes, sem faltarem foguetes e roqueiras, nem fandangos. ${ }^{57}$ [nota (1) do original] E mastros, na frente dessas casas, eram então solenemente erigidos, com a efígie do santo festejado.

Dias antes, ecoavam pelos matos o rufar do tambor e as cantigas dolentes dos foliões que iam de sitio em sitio, angariando esmolas para as festas.

\footnotetext{
57 "Fandango foi a dansa dos caboclos, dansa de sapateados e requebros, com cantigas ao som de viola. Ainda hoje usada nos sítios, à noite, como complemento de uma festa religiosa ou de um pixerão (auxílio prestado, durante um dia, por pequenos agricultores a seu colega, no tempo de plantações ou de colheita). Nalguns lugares chamam mutirão, noutros ajutório.

Nos fandangos, os comparsas quasi sempre se embebedavam e faziam desordens. Por isso, em 1792, foi, por edital, ordenado que 'ninguém faça fandangos ou rodas a pretexto de devoção de Santos, com pena imposta nas Ords. do livro 5..$^{\circ}$ tit. 90 e desta proibição se excetuam as rodas que se fazem nas festas do Espírito Santo e as que se fizeram em particular, em suas casas, entre os parentes até o $4 .^{\circ}$ grau'. (Boletim do Arquivo Municipal, vol. 34, p. 64).

Em 1807, outro edital proibiu fandango, principalmente aqueles em que costumam entrar os escravos cativos, no qual se declarou a pena aos mesmos de cincoenta açoutes no pelourinho e 30 dias de cadeia e seis mil réis de condenação aos que dessem casa para êsse fim'. [sic] (Boletim cit. vol. 37 pag. 77). A pena de açoute era expressa no livro $5^{\circ}$ das ordenações, para 'bodas e batismo de fogaça'. Ao que parece, a cominação da pena, então, em Curitiba, visava prevenir, intimidando".
} 
Conhecidos costumes ainda hoje em voga no interior, atualmente [194050] regulamentados nas posturas municipais.

$\S 2$. Festas de Natal, de Ano Bom e de Reis, consagradas ao culto do Menino Jesus. Missa do Galo, como ainda hoje. Presépios na igreja e em algumas casas, muito visitadas pelo povo que admira a arte com que são organizados. Em louvor do Menino Jesus, distribuem-se presentes às crianças, sem distinção de pobres e ricos. Visitas de amizade, dansas, cânticos votivos.

- Não havia o absurdo pinheirinho enfeitado, nem o mentiroso velhinho do natal que os alemães nos impingiram. Falso velinho, símbolo da opulência, que visita sòmente os filhos dos ricos, obscurecendo no espírito das crianças a idéia de Jesús o seu verdadeiro amigo.

$\S 3$. Nos documentos históricos dos primeiros tempos até muito depois de 1820, não se encontrava referência alguma às belas artes em Curitiba! Mas não é possível que disso ninguém então cogitasse. Não há vida social humana, mesmo entre selvagens, sem estesia e sem as manifestações desta. ${ }^{58}$ [nota (2) do original]

Quanto à música, pode-se afirmar que não faltavam a viola, o violão, a guitarra, a flauta, tão comuns no velho Portugal. Na igreja, certamente havia já, antes de 1820, um órgão e, de certo, um organista. ${ }^{59}$ [nota (3) do original] $\mathrm{E}$ as rezas cantadas. As serenatas nas ruas. E, nas casas, cantigas populares, velhas ou novas, tristes ou jocosas. E as porfias. Os jogos. (MACEDO, 1951, p. $57 / 58$ - grifos nossos)

Os exemplos acima citados corroboram a ideia de cerceamento "legal" pelo qual passou o fandango, em seu sentido genérico, durante o período que se inicia em fins do século XVIII e avança até fins do século XIX.

Pereira ainda nos informa que os bailes promovidos pelas elites locais estavam longe de ser festas familiares entre "parentes de até $4^{\circ}$ grau", como previa a legislação colonial portuguesa. A partir desta constatação, o autor indica o fato de que tais bailes passam a ser percebidos com maior tolerância em relação aos bailes promovidos pelas classes baixas. "Porém, assim como no começo do século, esta elite não aceitava que seus bailes fossem equiparados aos fandangos. Consideravam humilhante requerer licenças policiais." (PEREIRA, 2004, p. 68)

\footnotetext{
58 "Paranaguá em tudo, muito mais adiantado do que Curitiba. Primeira povoação fundada em território paranaense ficou sendo logo cidade capital, domicílio das mais altas autoridades judiciárias, administrativas, fiscais e militares. Não lhe faltaram famílias com foros de nobreza. Solares faustosos. Ricas igrejas, frequentadas pelos magnatas e pela Câmara Municipal, incorporada com seu Real Estandarte, sendo recebidos com aspersórios, à porta da entrada e à saída. Requintes de luxo. Apuros de elegância com uns laivos de cultura literária. Música religiosa. Música profana. Dansas.

A Curitiba chegaram os rumores dêsse esplendor que depois da independência, foi arrefecendo, arrefecendo e... não chegou a subir a serra.

Só mais tarde, depois de 1853, é que se desenvolveram as belas artes na já então cidade de Curitiba, capital da província do Paraná."

59 "Em 1826 o Capitão João Antonio da Costa, um dos fundadores da povoação de Nossa Senhora da Piedade de Campo Largo, a fim de abrilhantar as festas da inauguração da respectiva igreja, obteve, em Paranaguá, por empréstimo, um órgão que, de vinda e de volta, foi transportado a pulso de homens, através da serra do Itupava."
} 
Outro documento que auxilia Pereira em sua argumentação diz respeito à tratativa proposta em 1864 à Câmara de Curitiba, no intuito de diferenciar legalmente as duas manifestações culturais:

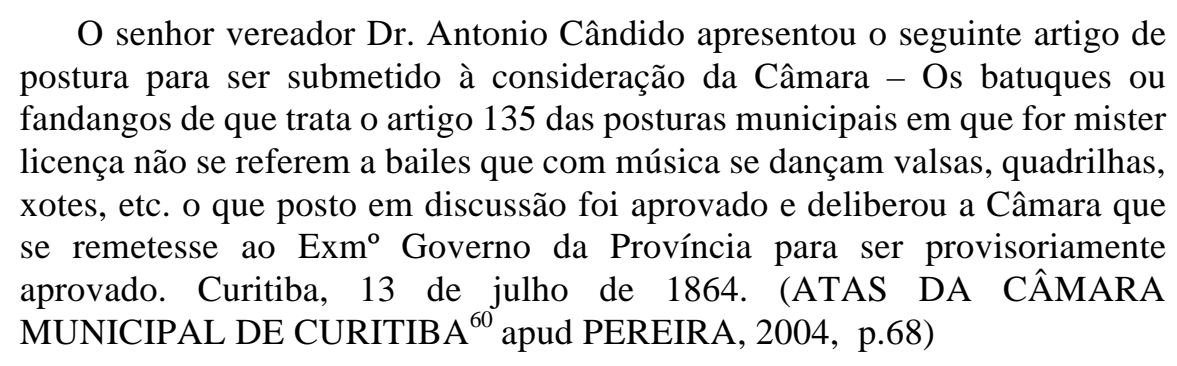

$\mathrm{Na}$ tentativa de caracterizar os bailes justamente através daquilo que era dançado pela burguesia - a valsa, a quadrilha e o xote - a proposta de postura não foi aprovada pelo governo provincial, "e de qualquer modo seria uma providência inútil”.

Pelos apontamentos de Magnus Pereira, percebe-se que lentamente as classes baixas urbanas começaram a adotar maneiras de dançar próximas às da elite. "Os batuques ou fandangos se tornaram festas eminentemente rurais." No ambiente urbano, a criadagem, os escravos e os operários encontrariam divertimento barato em bailes, onde se pagava entrada. "Nessa nova modalidade de baile popular, conhecida por sumpf, também se dançavam polcas, xotes e valsas." (PEREIRA, 2004, p. 68)

O autor ainda comenta que o acompanhamento musical não era feito nem pela orquestra dos bailes burgueses nem pelos instrumentos de corda utilizados nos fandangos. "Os imigrantes alemães e da Europa ocidental se encarregam de introduzir junto com seus ritmos o gosto pela sanfona e pelos instrumentos de sopro." Sendo tais atividades merecedoras de atenção das autoridades policiais, qualificadas como ambiente desregrado e corruptor. Conforme mencionado pelo relatório do chefe de polícia no ano de 1880: "Esses divertimentos com raras exceções, são freqüentados por criadas estrangeiras, libertos, escravos, menores e filhos de famílias que muitas vezes se deixam corromper pelos funestos exemplos que ali observam." (DANTAS FILHO ${ }^{61}$ apud PEREIRA, 2004, p. 68)

Modificações paradigmáticas parecem ter início quando vertentes nacionalistas emergem em defesa do ideal iluminista que fundamenta a ideia de Estado-nação, marcadamente no período posterior à Revolução Industrial francesa. Na Polônia, com Chopin; na Hungria,

\footnotetext{
${ }^{60}$ Atas da Câmara Municipal de Curitiba. Boletim do Archivo Municipal de Curitiba, 63, p. 74.

${ }^{61}$ Relatório do Presidente Manoel Pinto de Souza Dantas Filho: Relatório do Chefe de Polícia (CURITIBA, 1880, p. 7)
} 
com Liszt; Alemanha, com Wagner ou, na Itália, com Verdi, elementos em defesa de territórios, enaltecendo e buscando subsídios composicionais nas musicalidades das populações originárias geraram novos aspectos e motivações para criação musical no século XIX. Atinamos que tais elementos chegam inicialmente ao Brasil de modo enviesado, como mencionado por Magnus Pereira (2004, p. 67):

Acompanhando uma tendência mundial, as classes dominantes paranaenses acabaram adotando a valsa e o xote, danças de rodopiar que, durante o século XIX, tomaram conta dos salões da aristocracia européia, para depois espalharem-se pelo restante do mundo "civilizado".

Ímpetos nacionalistas intrínsecos a compositores consagrados, como o austríaco Johann Strauss (1825-1899), foram motivados pela música e a dança popular, valsas e polcas, que acabaram por se tornar o próprio espírito do povo vienense. Tais ímpetos aportam em nossas terras com algum lapso temporal em relação aos países europeus. Podemos citar o paulista Alexandre Levy (1864 -1892), que se utilizou do folclore como base de algumas de suas composições, assim como o paranaense Brasílio Itiberê (1846 -1913), possivelmente o primeiro a expressar a tendência nacionalista da música brasileira, em sua obra para piano A Sertaneja, composta em 1869, onde figuram elementos da canção tradicional "Balaio, Meu Bem, Balaio", tema recolhido por ele na cidade de Paranaguá.

De todo modo, os anseios individuais desses compositores pouco modificaram o panorama político de proibição e criminalização dos bailes populares, cuja liberalização atrelada à adoção de posturas de redação simplificada pelos municípios, dizia mais respeito à preocupação das câmaras em não perder a fonte de renda representada pelas licenças.

No que diz respeito aos fandangos, reduzindo progressivamente a ação destas câmaras a questões meramente fiscais, como podemos observar no Artigo $6^{\circ}$ datado de 08 de abril de 1874, no município de Castro, que consta na Coleção de Leis, Decretos e Regulamentos da Província do Paraná, redigidos em Curitiba no ano de 1874, à página 35: “Aquele que promover ou consentir batuques, fandangos ou ajuntamento de escravos nas povoações e seus subúrbios, incorre na multa de $20 \$ 000$, salvo tendo licença da autoridade policial, pela qual pagará o imposto de 5\$000.”. (PEREIRA, 2004, p. 66)

A partir dos últimos anos do século XIX e início do século XX, "a questão do fandango e de outros costumes populares entraria em uma nova fase", como mencionado por Pereira: "Os mesmos intelectuais que naquele período costumavam exaltar a modernidade e o progresso do Paraná lançariam olhares lacrimosos para a singeleza e a pureza dos costumes de 'antigamente'." Valendo-se de relatos de José Francisco da Rocha Pombo, o autor demonstra 
que, mesmo no campo, as "tradições" estavam desaparecendo: “A vida dos centros, o bucólico das cidades, foi contrafazendo a primitiva simplicidade dos costumes e usos populares. Baniuse o que havia de mais poético entre a população dos campos". Pereira indica, assim, que "a transfiguração do fandango, que setenta anos antes, era considerado um ajuntamento para 'dar pasto à devassidão e à desordem da crápula', seria encarada como perda.” Ainda se valendo das palavras de Rocha Pombo, faz alusão ao fato de que "O fandango está tão desfigurado que nem recorda mais as antigas expansões ruidosas do baile rústico. As danças são as modernas, importadas das cidades, e tudo está contrafeito, tudo perdeu a graça e a singeleza que tinha.” (PEREIRA, 2004, p. 69)

A "ambigüidade" cultural brasileira a partir do embate entre a tradição patriarcal e o processo de "ocidentalização" a partir da influência da Europa "burguesa", e não mais portuguesa, que toma de assalto o país no séc. XIX. Esse processo tem sido percebido, geralmente, como "mudança de hábitos" de vestir, de leitura, de consumo em geral. O brasileiro se transveste de "civilizado", conferindo sentido àquela frase ainda hoje utilizada por todo brasileiro, civilizando-se "para inglês ver". (SOUZA, 2000, p. 72)

Inconteste, as classes populares paranaenses produziram certos sincretismos culturais como o sumpf, seja pela repressão, seja por adotarem progressivamente os hábitos burgueses. "Ou seja, morigeraram um pouco seus hábitos e adotaram maneiras de dançar próximas às usadas pelos burgueses em seus bailes, tentando assim preservar seu espaço de diversão." (PEREIRA, 2004, p. 69)

Esse panorama nos proporciona melhor entendimento sobre como a manifestação acaba por manter características singulares nas localidades mais afastadas no litoral do Estado, sendo menores a repressão e controle de tais feitas em áreas que deixaram de ter o vulto e importância econômica, cultural e política que tinham nos séculos anteriores pela prática de uma economia agrícola que tinha como base grandes propriedades de terra e o trabalho escravo, pela descoberta de ouro em Serra Negra, pela produção de café, arroz e açúcar e, posteriormente, pela exportação da erva-mate.

As então novas abordagens de estudos culturais - personificadas no folclore e de cunho nacionalista, de políticas públicas de registro de manifestações culturais diversas, levadas a cabo nas primeiras décadas do século XX - acabaram por firmar as bases necessárias para manutenção e reconhecimento das práticas culturais tradicionais no litoral do Estado, que vivenciariam novas perspectivas a partir da década de 1960, com o revivalismo das manifestações tradicionais capitaneadas por pesquisadores e folcloristas, temas que trataremos mais adiante. 


\title{
Masculan feminan: a novidade é o máximo do paradoxo
}

\author{
Mas a mulher é muito importante no fandango, porque \\ ela que faz a dama do fandango né, ela que dança o \\ batido, o bailado. Só que a mulher, naquela época, ela \\ não batia, lá nunca aconteceu das mulheres quererem \\ bater o tamanco. Hoje não, hoje as meninas já estão \\ batendo, inclusive a Luma e a Malu [suas netas] já estão \\ batendo bem o fandango.
}

Aliete Domingues

Cabe salientar que o objetivo da colonização açoriana "era implantar um núcleo de ocupação lusitana permanente para justificar a apropriação da área em face do governo espanhol e também para operar como uma retaguarda fiel das lutas que se travavam nas fronteiras" (RIBEIRO, 2006, p. 386), sendo ínfima a integração de mulheres europeias nesse meio-tempo.

No caso brasileiro, a influência árabe e maometana atinada por Freyre é representada pela possibilidade de identificação do patriarca com seus filhos ilegítimos ou naturais com mulheres escravizadas ou nativas ${ }^{62}$. "A ênfase norte-americana na pureza da origem", por exemplo, retirava de cena essa possibilidade. (SOUZA, 2000, p. 85)

Foi sádica a relação do homem português com as mulheres índias e negras. Era sádica a relação do senhor com suas próprias mulheres brancas, as bonecas para reprodução e sexo unilateral de que nos fala Gilberto Freyre (1957, p. 60, 326 e 332). Era sádica, finalmente, a relação do senhor com os próprios filhos, os seres que mais sofriam e apanhavam depois dos escravos (cf. Freyre, 1990, p. 68 e 71$)$.

O senhor de terras e escravos era um hiperindivíduo, não o super-homem futurista nietzscheano que obedece aos próprios valores que cria, mas o superhomem do passado, o bárbaro sem qualquer noção internalizada de limites em relação aos seus impulsos primários.

Jessé de Souza ainda nos indica a existência de toda uma gama de funções de "confiança", exercidas no controle do trabalho e caça de escravos fugidos, citando, ainda, serviços "militares" em embates territoriais, entre outros, que seriam melhor exercidas por membros da "família ampliada" do patriarca. "E aqui já temos uma primeira versão da ambígua

\footnotetext{
${ }^{62}$ Nos evadimos aqui de quaisquer julgamentos morais que pudessem incidir sobre tais parcialidades étnicas. Nosso intutito se direcionou em localizar informações de interesse dentro de recortes diacrônicos consolidados historicamente.
} 
'confraternização' entre raças e culturas distintas, que a família ampliada patriarcal ensejava." Serviços de controle e guarda eram exercidos exclusivamente por brancos nos EUA; no caso

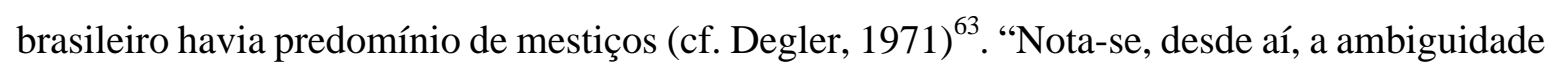
entre possibilidade de ascensão social para os mestiços no familismo patriarcal em troca de identificação com os valores e interesses do opressor." (SOUZA, 2000, p.85). Paulo B. Preciado, nos acrescenta o seguinte:

Daí que família, sexualidade e corpo não sejam simplesmente instituições ou realidades anatômicas, mas autênticas tramas libidinais feitas de afetos e perceptos que escapam ao âmbito da consciência individual.

Do mesmo modo que a crítica descolonial macropolítica fala do extrativismo dos recursos naturais, Rolnik alerta-nos para o extrativismo colonial dos recursos do inconsciente e da subjetividade - a pulsão vital, a linguagem, o desejo, a imaginação o afeto... (PRECIADO, 2018, p. 19)

Neste sentido, a discussão sobre o papel do núcleo familiar na formação da identidade nacional brasileira toma assento. $\mathrm{O}$ mito da cordialidade senhorial brasileira se introjetou de tal maneira em nossas subjetividades, em nosso inconsciente colonial-capitalístico ${ }^{64}$, que se faz presente em todos nós, prefigurando a forma como percebemos a realidade e interpretamos o mundo.

Tanto Gilberto Freyre (1933) quanto Sérgio Buarque de Holanda (1995), que apesar de seus distintos pontos de vista sobre a conformação familiar e seus reflexos na atividade política e citadina no período colonial, concordam na confluência de traços patriarcais, oligarcas, ${ }^{63}$ DEGLER, Carl. Neither black nor white: slavery and race relations in Brazil and United States. Madison,
University of Wisconsin Press. 1971.

64 "Nas subjetividades sob domínio do inconsciente colonial-capitalístico, reduzidas que são a sua experiência como sujeito, prevalece uma micropolítica reativa: Tende a impor-se em maior ou menor escala o movimento de conservação das formas de existência em que a vida se encontra corporificada no presente. (...) O abuso profanador da pulsão é difícil de captar, já que ele se dá numa esfera que escapa à consciência e cuja experiência é anestesiada no modo de subjetivação hegemônico, sob o feitiço da sedução perversa que captura as subjetividades. (...) Os exemplos de manifestações do abuso profanador da vida acima mencionados [relações com o meio ambiente geradoras de desastres ecológicos, relações de poder classistas, machistas, homofóbicas, transfóbicas, racistas, xenofóbicas, chauvinistas, nacionalistas, colonialistas etc.] não são por tanto epifenómenos do regime, mas sintomas de sua própria medula na esfera da política dominante de desejo e de subjetivação. Diante disto, fica evidente que não basta subverter a ordem dos lugares destinados a cada um dos personagens em jogo na cena das relações de poder (insurreição macropolítica), é preciso abandonar os próprios personagens e suas políticas de desejo (insurgência micropolítica), inviabilizando assim a continuidade da própria cena - como ocorre quando se dá a quebra do feitiço do poder do cafetão na subjetividade de sua presa. Com lógicas e temporalidades díspares e paradoxais, da insurgência contra a violência em ambas as esferas depende, incontornavelmente, a dissolução do regime por toda parte e em cada uma das atividades humanas. Esta é a condição sine qua non para que se viabilize uma transmutação efetiva do presente, já que, em sua nova versão, o regime logrou colonizar o conjunto do planeta, incidindo macro e micropoliticamente em todas as suas entranhas, ao ponto de que hoje nenhuma atividade humana lhe escapa. Daí Guattari chamar o novo regime de "capitalismo mundial integrado", já no início dos anos 1980, quando este apenas começava a mostrar seus sinais, ou Milton Santos chamá-lo de "capitalismo globalitário". (ROLNIK, 2018, p. 116/117) 
despóticos e cristãos, como marcos fundantes da sociabilidade brasileira. Para elucidar a questão, retomamos abaixo um fragmento do depoimento de Aorelio Domingues já citado no capítulo anterior.

Você acha que as índias iriam dançar igual nos Açores? Claro que não! Elas estavam ali submissas, assustadas. E eles ali: festa, vinho, terra de ninguém...

Mas tem uma coisa interessante nessa tristeza toda: é a gente observar que não tinha mulher portuguesa.

Tanto nesta fala de Aorélio quanto em depoimentos colhidos em outras oportunidades com o próprio Aorélio e outros interlocutores, temos por evidência histórica o papel diminuído do universo feminino no fandango, fato que vem sendo modificado nos últimos anos, quando a presença feminina toma novos contornos, tornando-se cada vez mais evidenciada. Segundo Aorélio:

O universo da mulher é diferente do do homem. Ela capta muito mais detalhes do que o homem, que está ali tocando simplesmente e dançando e se divertindo. As mulheres, geralmente elas lembram muitos mais versos que os homens, detalhes, coisas que aconteciam por exemplo nas salas ao lado, haja visto que os homens só ficavam nas salas do meio para dançar. É importante que ela bata, é importante que ela ocupe o espaço de importância dela na manifestação, por que a gente precisa, para a salvaguarda, que a mulher tome, ocupe o espaço dela, que é de direito e de importância também. (BARREADO, FAMÍLIA, RABECÔNICA, 2018 - transcrição nossa)

Em 2015, buscando atender a uma demanda já antiga quanto ao registro fonográfico dos grupos de fandango em Paranaguá, a então Fundação de Cultura de Paranaguá financiou a gravação do disco Fandango a Arte e Expressão Popular. Os quatro grupos de fandango, que na época atuavam em Paranaguá, participaram do disco (atualmente somam seis os grupos em atividade). Uma das cinco faixas executadas pelo grupo Mandicuera contou com a participação da cantora curitibana Ana Decker ${ }^{65}$ na primeira voz - aspecto sem precedentes na discografia disponível ou nos relatos da rede de interlocutores de maior idade na porção paranaense do território caiçara. A participação da mulher nessa função, segundo Aorélio, é uma das "inovações" do fandango caiçara a ser difundida e multiplicada.

No litoral norte de São Paulo a participação feminina tanto no instrumental como na condução das vozes tem sido mais evidente, como mencionado por Catharina Apolinário:

\footnotetext{
65 Ana Decker há alguns anos vem acompanhando a romaria do divino como tipe e, ocasionalmente, faz participações em bailes e apresentações do grupo.
} 
Uma inovação na cultura tradicional do Fandango e uma quebra de paradigmas, a presença da mulher tem crescido, não apenas nas rodas de dança, mas, de forma especial, tocando instrumentos. Em Paranaguá Luciene Fernandes de Oliveira, tocadora de caixa de folia do grupo Fandango Bacurau, de Ubatuba, foi convidada a tocar com os mestres de Paranaguá, com honras. Ela conta como foi. "Fiquei muito feliz por que a mulher está sendo reconhecida. Eu sinto que tem um certo preconceito ainda. Eu comecei dançando e comecei a tocar caixa e vi que eu tinha habilidade, mas aos poucos o reconhecimento tem sido mais forte". Luciene contou que sua inspiração foi outra mulher de Ubatuba que toca caixa, Laureane. "Eu me inspirei nela. Através dela eu vi que eu poderia sim. Eu imagino tudo o que ela já passou, eu tenho certeza de que o espaço para ela era ainda menor". (JORNAL MARTIM-PESCADOR n $\left.{ }^{\circ} 156,2018, p .11\right)$

"Dona" Lauriana, além de fandangueira, coordena a Folia do Divino Espírito Santo, onde é tipe e toca caixa de folia. Conhecedora das danças e das tradições do litoral ubatubano, desde tenra idade vivencia a cultura caiçara pelo fato de haver nascido em família de tocadores, cujo reconhecimento lhe rende versos e elogios por onde passa.

Canta muito, muito, muito, muito! Ela lembrou uma senhora que chamava "Dona" Cecília, aqui na região da Barra do Una, ela com o marido cantando. Canta muito, assim bonito de ver, que nem ela, assim, uma grande pessoa. "Dona" Laureane mandou bem, encantou todo mundo na Cooperfesta. (Cadernos de campo, dez. de 2018 - transcrição nossa) ${ }^{66}$

Em Cananéia, "Dona" Cleusa, animada com o movimento fandangueiro, voltando da Festa de Paranaguá em 2017, fez por bem reunir as crianças e ensaiou oito pares delas junto a tocadores locais a fim de integrar a abertura da Festa do Fandango de Cananéia daquele ano. Vale lembrar que "Dona" Cleusa foi indicada como uma das representantes de Cananéia na atual composição do Comitê de Salvaguarda do Fandango Caiçara (desde 2018), e vem contribuindo com as discussões levadas a cabo por este coletivo.

\footnotetext{
${ }^{66}$ Mauricio Alves do grupo Manema tecendo comentários sobre a participação de "Dona" Laureane na II Cooperfesta ( $2^{\circ}$ Festa do Pescador artesanal, e $2^{\circ}$ Encontro de Fandangueiros), realizada na sede da Cooperpesca na Prainha, em Iguape, no ano de 2018.
} 
Figura 2.1 - Abertura da II Festa do Fandango de Cananéia, crianças saudando São Gonçalo

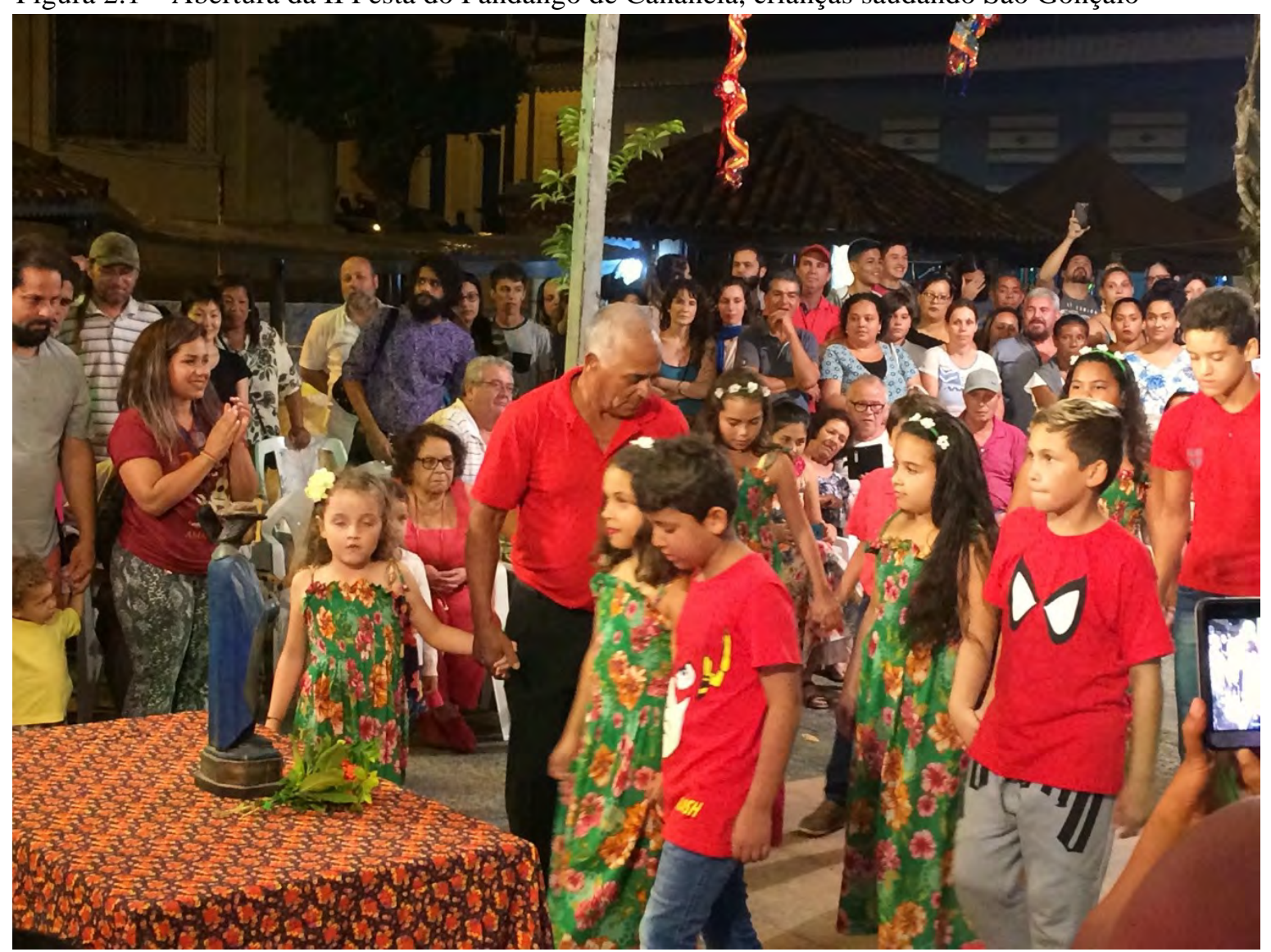

Fonte: Acervo pessoal

Transbordando para além do território caiçara, recentemente, em janeiro do ano corrente (2019), tive a oportunidade de acompanhar Aorélio Domingues e Leo Cardoso na gravação de duas faixas do disco Nós, iniciativa da cantora potiguar Cida Airam que, atualmente, reside em Curitiba e transita por distintas esferas como intérprete da música popular brasileira. Ela nos conta:

O fandango, eu conheci quando eu cheguei aqui no Paraná. Eu cheguei em 2005, e no ano seguinte, eu já fui para um baile, em Superagui se não me engano. E me causou uma estranheza aquela sonoridade, eu sempre fui ligada muita à canção, eu não conseguia entender a letra, e aquela rítmica era muito diferente, mas me deixei levar no embalo da dança, e quando depois, vi um pouco do tamanqueado, fiquei bem encantada. Porque o tamanqueado, me fez a relação com o coco de roda lá do Nordeste, que em alguns lugares, o coco também é dançado com o tamanco. Aí passou o tempo, eu vi algumas apresentações na cidade de Curitiba, vi o movimento de alguns músicos tentando trazer o fandango aqui pra Curitiba, e aí, no ano retrasado, eu comecei a trabalhar a feitura desse novo CD com canções de domínio público brasileiras e eu não podia deixar o fandango de fora, e também de algumas canções da Ilha dos Açores em Portugal. Aí eu soube dessa relação entre Portugal e o fandango daqui, aí busquei o mestre Aorélio [Domingues] ele me explicou essa relação, essa referência, e fui entendendo também porque não 
tinha a presença feminina no fandango. Não que fosse uma imposição do fandango, mas quando o fandango começou a ser realizado no Brasil, em sua maioria eram homens. E me interessei nesse novo trabalho em fazer uma gravação, chamando mestre Aorélio e outros músicos que já dominam o fandango. Mas eu me coloquei querendo cantar. Não foi fácil sair da minha zona de conforto para entender aquela melodia, a métrica, as divisões rítmicas, e deixar a palavra, o texto em um lugar mais compreensível. Então eu propus subir a tonalidade, que sempre os fandangos estão sempre na mesma tonalidade de ré, então subindo a tonalidade também iria mexer um pouco na afinação de alguns instrumentos. Mas o mestre Aorélio aceitou super bem essa proposta; ele entendeu que nessa tonalidade fica mais fácil para as mulheres cantarem o fandango. Ainda não é uma região de brilho para mim, mas eu entendo agora que o fandango não é só a letra e a canção; a rabeca, toda instrumentação está num mesmo nível de entendimento, de musicalidade que a letra. Como eu tenho essa relação muito forte com a letra, então a melodia e a letra numa canção ficam muito presentes; a instrumentação, a harmonia, os instrumentos que fazem o ritmo ficam sempre em outro plano. No fandango não. Tem uma linearidade - eu acho que essa é a palavra - e que deixa tudo ali bem audível. Tem a hora de cantar, tem a hora de vim a rabeca, tem a hora do tamanqueado. Então isso me chamou muito a atenção, foi e está sendo uma experiência muito boa. (Cadernos de campo 20/02/2019 - transcrição nossa)

A aproximação de Cida Airam ao fandango acabou por ativar memórias e afetos, sonoridades que, em breve, estarão disponíveis a outros públicos, em um formato pouco convencional no universo fandangueiro.

A recente inserção feminina nas linhas de frente da vertente artística do fandango vai de encontro com as lutas e reivindicações das mulheres por direitos civis, políticos e sociais que ocorrem já há muito tempo no Brasil e no mundo.

Ainda que vários avanços tenham sido conquistados, as ações continuadas do movimento feminista são decisivas para que se alcancem efetivamente panoramas de equidade e igualdade de gênero.

A história do movimento feminista possui três grandes momentos. $\mathrm{O}$ primeiro foi motivado pelas reivindicações por direitos democráticos como o direito ao voto, divórcio, educação e trabalho, no fim do século XIX. O segundo, no fim da década de 1960 , foi marcado pela liberação sexual (impulsionada pelo aumento dos contraceptivos). Já o terceiro começou a ser construído no fim dos anos 70, com a luta de caráter sindical. (PORTAL BRASIL, 2017)

Em 1910, deu-se a fundação do Partido Republicano Feminino. Mais tarde, em 1918, a fundação da Federação Brasileira para o Progresso Feminino (FBPF), o jornalismo feminista e o feminismo anarquista são tópicos indicados por Céli Regina Jardim Pinto (2003), como prelúdio da atuação feminista que, a partir do golpe, em 1937, sofre refluxos. Vista a efervescência dos movimentos que fomentaram a revolução dos costumes e a radical renovação cultural em passo nos Estados Unidos e Europa, o Brasil seguia norteado pela ditadura militar 
onde, via de regra, ideais dessa natureza foram relegados à repressão e à morte. A reorganização do movimento no início da década de 1970 é intimamente relacionada ao cenário norteamericano.

Entre os eventos que marcaram a entrada definitiva das mulheres e das questões por elas levantadas, a autora destaca a organização do evento para a comemoração do Ano Internacional da Mulher, em 1975, decretado pela Organização das Nações Unidas (ONU). Realizado no Rio de Janeiro sob o título "O papel e o comportamento da mulher na realidade brasileira", um dos desdobramentos desse evento culminou com a criação do Centro de Desenvolvimento da Mulher Brasileira. O mesmo ano de 1975 também passa a ser considerado como momento inaugural de expressividade do movimento feminista, saindo da condição de grupos específicos fechados e intelectualizados para incorporar segmentos sociais que se fizeram presentes em eventos mais amplos que marcaram a participação da mulher na esfera pública. A militância toma novos direcionamentos depois do período da redemocratização na década de 1980, quando o movimento feminista aborda questões não restritas à temática política, havendo emergência de temas relacionados à violência e à saúde, o que faz surgir neste período inúmeras organizações de apoio à mulher vítima da violência. Nesse momento, a temática da violência contra a mulher vai tornar clara a diferença entre categorias sociais. Segundo a autora, uma das novas formas adotadas pelo movimento se dá pela organização, com assessoramento na área jurídica. (PINTO, 2003)

Da redemocratização à atualidade, as demandas pela equidade de gênero se desdobram na formulação de legislações que considerem tais questões, como a Lei Maria da Penha, sancionada em 2006 e celebrada como importante avanço contra a violência doméstica, assim como a Lei do Feminicídio (Lei 13.104), sancionada por Dilma Rousseff em 09 de março de 2015. A lei altera o Código Penal (art.121 do Decreto-Lei no 2.848/40), incluindo o feminicídio como uma modalidade de homicídio qualificado, entrando no rol dos crimes hediondos.

O inconsciente colonizado-capitalístico brasileiro ainda pende a um imaginário povoado pelo patriarcado machista, sexista e, em não poucos casos, misógino, demonstrando que muito ainda devemos avançar neste sentido.

De todo modo, etologicamente, a autoconsciência do potencial social e político que emerge a partir do avanço dos direitos humanos em âmbito global, e especificamente nas últimas décadas, também tem sido debatida e trazida à baila no universo fandangueiro.

Algumas modas cujas letras denotam quaisquer transgressões de tais liberdades têm sido, por vezes, excluídas dos repertórios, e quando tocadas geram desconforto por parte da audiência, como no caso das modas "Vida de Casado" e "Menina do Cabelo Comprido", cujas 
cabeça de moda seguem abaixo:

A vida do casado é bom,

A do solteiro melhor é

Porque o solteiro vai a onde quer

E o casado tem que levar a mulher
Menina do cabelo comprido

Que dá para fazer uma trança

Ainda é muito nova

Para usar uma aliança

Nem todos os grupos atentam para questões dessa natureza, sobretudo os de mais idade. Ao refletir sobre alteridades, nesses casos, podemos nos colocar momentaneamente em contextos históricos onde o matrimônio precoce ou prerrogativas do patriarcado despótico fossem exaltados. Atualmente, tais insinuações já não passam despercebidas. Em nosso entendimento, justamente a tomada de consciência de tais questões por parte dos detentores do fandango caiçara indica novos direcionamentos com vistas à desconstrução do comportamento machista e sexista ainda presentes nos modelos de sociabilidade brasileira, inclusas aí as populações caiçaras.

Seguimos no intento de formular outras considerações sobre as alterações paradigmáticas do papel feminino no fandango. A primeira diz respeito aos desdobramentos de ações de salvaguarda deste bem imaterial no litoral norte do Paraná, em um episódio comemorativo posterior à VII Festa do Fandango Caiçara de Paranaguá, em 2016. Depois da participação do jovem grupo de fandango de Superagui, Raízes Fandangueiras, na mencionada festa, os dirigentes do grupo convidaram tanto a equipe de organização do evento, onde me incluo, quanto o Mestre Nemésio Costa e seu irmão Anoldo ${ }^{67}$ para participar da festa do primeiro aniversário do grupo, na Ilha de Superagui. A atividade se configurou em uma grande oficina-baile, onde se pode constatar um maior interesse das jovens e adolescentes da ilha na prática do canto e nos toques de viola fandangueira. Nesta localidade o interesse das jovens aprendizes em tanger instrumentos e aprender versos e marcas demonstra novos rumos na construção de coletivos fandangueiros na ilha. Surpreendente que, em muitos dos momentos de repasse, quando os mestres ensinavam pacientemente as posições, os toques e as modas, a participação feminina foi irrestrita.

\footnotetext{
${ }^{67}$ Durante a festa daquele ano, mestres Nemésio e Anoldo haviam dado uma oficina de toque e versos na casa de "Seu" Nemésio, durante festa em Paranaguá. Em 2016, os recursos foram limitados. Além das tendas e do tablado oferecidos pela prefeitura, a organização da festa contou ainda com o apoio do IPHAN, no tocante à realização da reunião do Comitê de Salvaguarda, do projeto Mutirão Mais Cultura na UFPR, na logística, e de bolsistas e voluntários tanto da UFPR quanto do IFE/Paranaguá, apoios fundamentais na execução da proposta. Ao comentarmos com "Seu” Nemésio que havíamos previsto um café durante a oficina, disse para que não nos preocupássemos. Boa parte dos inscritos na oficina de toques e versos era de Superagui. Auxiliando na produção executiva, em trânsito entre as atividades da tarde, ao visitarmos a oficina em curso com café e bolo de banana em mãos, fomos surpreendidos pela fartura posta à mesa. Na mão da meninada, violas, versos e risadas!
} 
Figura 2.2 - Atividade de repasse de toques e versos em Superagui, 2016

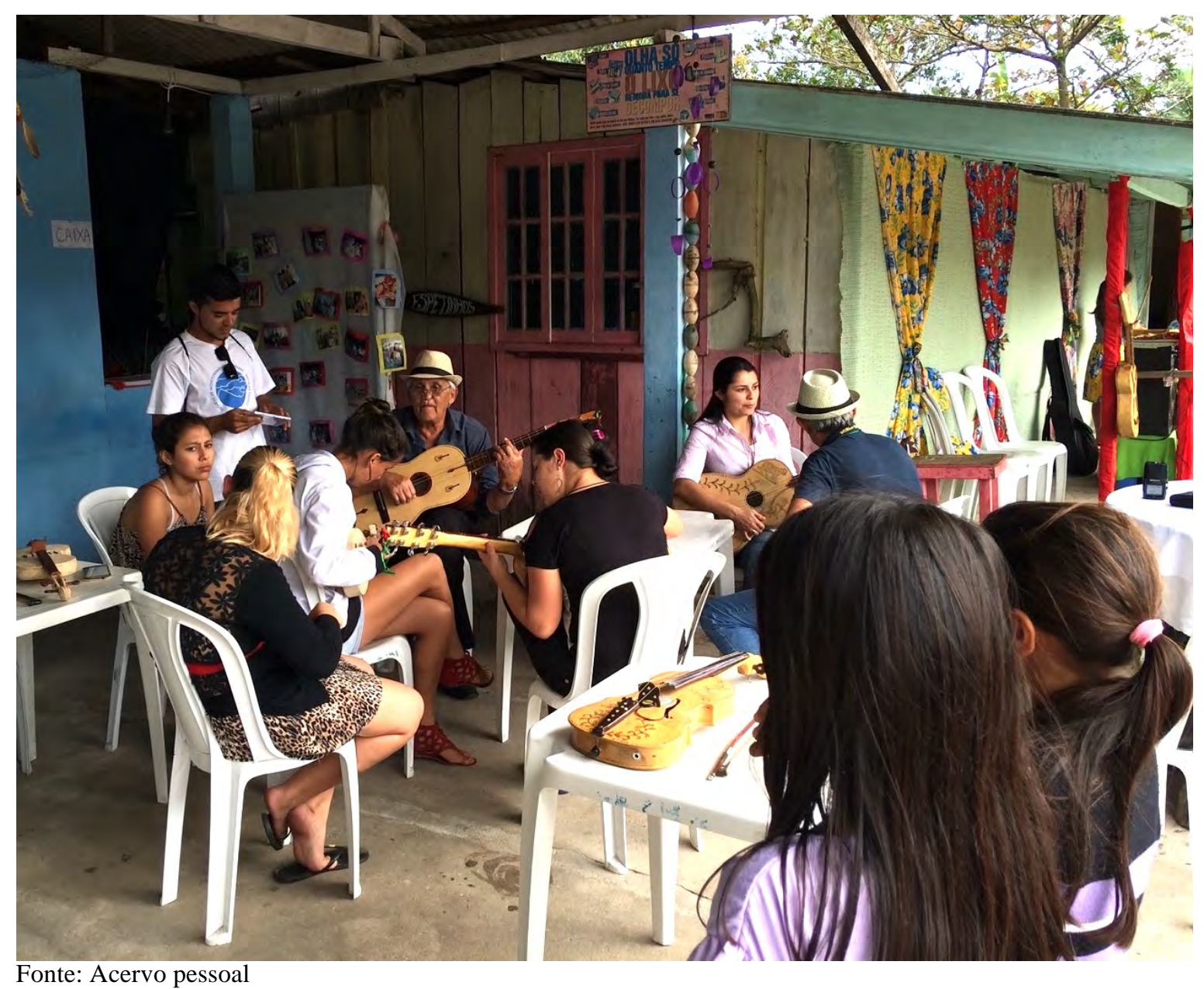

No conturbado momento histórico, onde guerras híbridas somadas a golpes jurídicos midiáticos e a um conservadorismo neoliberal indiferente às questões de gênero e de direitos humanos vêm abalando o mundo, a presença feminina entre músicos e instrumentistas do universo fandangueiro avança de maneira paulatina. Assim, as mulheres se colocam na posição de agentes em potencial da insurgência micropolítica necessária para que a subjetividade possa habitar simultaneamente o sujeito e o fora-do-sujeito, "em busca de retomar em suas mãos o poder de decidir o destino da pulsão, reassumindo assim sua responsabilidade ética perante a vida". (ROLNIK, 2018, p. 126)

Observando tais contextos, a conjuntura sociocultural que domina o senso comum desde o Período Colonial e que consolidou as práticas e fazeres culturais - incluindo-se aí a prática instrumental e a do canto no fandango caiçara, onde o gênero masculino assume papel dominante - parecem fruir novos desdobramentos. O crescente interesse das jovens $\mathrm{e}$ adolescentes em participar mais ativamente das funções musicais fandangueiras, seja na Ilha de Superagui, Ilha dos Valadares, São Miguel, Cananéia ou em Ubatuba, deve ser considerado 
tanto quanto o ânimo e perseverança de detentoras de mais idade, cujo pertencimento e participação nas ações de salvaguarda desse bem imaterial se fazem notáveis.

Durante a VIII Festa do Fandango de Paranaguá, no ano seguinte ao relato acima mencionado, a programação contemplou rodas de conversa que antecediam aos bailes, na noite de nove de agosto de 2017, uma delas intitulada A presença da mulher no fandango caiçara, contou com a presença de Graziane Cruz e de nossas divas da melhor-idade: Benedita Vidal Cordeiro, Aliete Domingues, Nadir Vidal, Lauriana Lucia de Oliveira Santos e Cleuza da Silva dos Reis, onde discorreram descontraidamente sobre suas experiências no universo fandangueiro.

Esse é um momento de muita alegria para nós fandangueiros[as], que acontecesse aqui no Valadares, porque o fandango teve uma ameaça de acabar. Mas, graças a Deus, essas grandes pessoas que correm atrás, vão atrás de recursos, vão atrás de grupos de fandango, atrás de uma coisa aqui, uma coisa ali, e acontece essa grande maravilha que hoje nós estamos vendo na oitava Festa do Fandango de Paranaguá. Eu sou coordenadora do grupo de fandango Vida Feliz de Cananéia. Nós temos o grupo, temos o grupo de folia de Reis também, que está meio parado, mas, se Deus quiser, ano que vem nós vamos reerguer também esse grupo. E o Fandango, para nós mulheres, na minha opinião é uma coisa muito especial. Eu aprendi o fandango com meus tios, com meus avós. Desde criança meu pai não deixava eu ir dançar. Então, quando eu era jovem, meus tios, a gente ia pra roça. Eu sou da roça, trabalhei muito na roça. Agora que eu vivo em Cananéia. Nós íamos pra roça, meu tio levava a viola escondida dentro de um saco, pra que, na beira da roça, ele me ensinasse a dançar e tocar viola. Eu aprendi um pouquinho, toco cavaquinho, mas o que eu toco mais é bumbo e triângulo. O fandango é uma coisa muito especial na nossa vida, na vida dos jovens, na vida das mulheres, dos homens. A dança do fandango é uma terapia, uma terapia muito grande. Se eu for falar dos efeitos do Fandango, a gente "Amanhece"! Quando eu vejo uma viola tocar, meu pé já tá coçando! ("Dona" Cleusa - transcrição nossa)

A gente tem que levar a vida assim, né? Brincar, comer, beber, brincar e se divertir, né? A gente já tá com idade, já, né? Eu estou com 68 anos, mas gosto de dançar o fandango ainda. Meu marido [Waldemar Cordeiro] quando nós se namorava, um dia eu fui num fandango com ele, aí tocaram uma meia canja [graciosa] ${ }^{6}$, uma meia canja e eu fui tirar ele pra dançar, aí tocaram o bailado. Na virada que deu lá, foi a minha vez de cantar e eu cantei lá, cantei um versinho pra ele: Pus meu lencinho branco/Na janela do Vapor/ Eu dançando meia canja/ Nos braços do meu amor. (Benedita Cordeiro transcrição nossa)

Quando eu me criei, lá onde nasci e me criei, o fandango, além de diversão, era de utilidade. A gente fazia o mutirão, o pai da gente, o tio, o avô, e pagava com o baile à noite o trabalho que foi feito durante o dia. Só que eu nunca dancei o fandango lá, porque meu pai não deixava porque eu não tinha idade pra dançar fandango. Lá, pra ir na roda do salão, tinha que ter dezoito anos. E eu saí de lá, não cheguei a dançar o fandango, mas via meu pai tocar,

\footnotetext{
${ }^{68}$ Tipo de moda bailada que conta com a participação da audiência para colocar versos. A cada pé de moda (novo verso), há uma pausa no instrumental para que o casal que pare em frente aos músicos recite um verso que de imediato é musicado pelos violeiros.
} 
fazer viola, fazer rabeca, vender, tocar, fazer mutirão. E um dia meu pai me ensinou e disse assim pra mim à noite. - Ó, minha filha, quando não tem o adufo, a gente toca colher. E eu disse: - Mas como colher, Papai? Aí ele disse, vai lá na cozinha e traga duas colheres. Eu fui lá, trouxe duas colheres, aí ele me ensinou como batia as duas colheres. Só que depois eu não toquei mais, ele não me ensaiou mais, não me ensinou. Aí um dia, meu filho Aorélio [Domingues] tinha grupo, e eu conversando com ele, ele gosta muito de história, eu contei pra ele, ele perguntou: - O que vocês faziam a noite? Minha mãe trabalhava, a gente ajudava, papai tocava viola. Contei da colher, aí ele disse: - A senhora vai tocar pra mim! - Mas eu não sei, nunca toquei, só peguei uma vez. Ele disse, vou te dar um $C D$ e a senhora vai ensaiar. Ele mandou o $\mathrm{CD}$, eu comecei a ensaiar, dois dias depois do ensaio ele já me chamou pra tocar na Oca [Bar], em Curitiba. Aí, eu disse: - Meus Deus! Mas eu não sei nada, e ele disse: - A senhora vai! Nós vamos lá e a senhora vai tocar. Eu ia saindo na porta e pensando assim: - Senhor, onde estiver, vai comigo pra me ajudar, porque foi o Senhor que me pois nesse caminho, mas eu não sei tocar... Aí fui com Aorélio, tocamos baile lá até quase de manhã, a turma não queria que o baile terminasse, e eu me saí tão bem que até eu admiro até hoje como que eu toquei! [risos e aplausos] (Aliete Domingues transcrição nossa)

Figura 2.3 - Roda de conversa “a presença da mulher no fandango caiçara”, Paranaguá, 2017

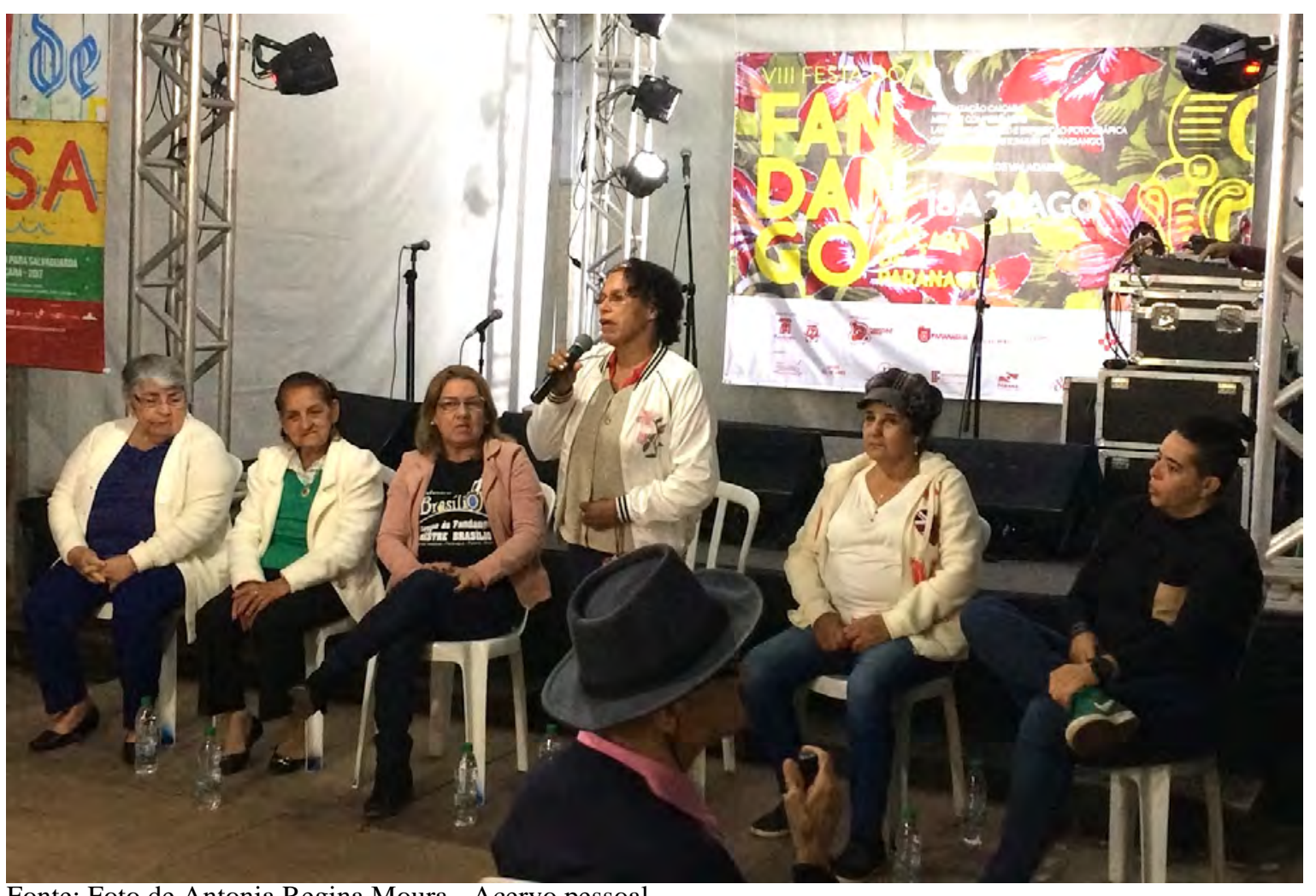

Fonte: Foto de Antonia Regina Moura - Acervo pessoal 
Em outra oportunidade, durante a $9^{a}$ edição da festa, em dois mil e dezoito, Malu Domingues - uma das filhas de Aorélio Domingues - depois de uma pequena apresentação integrando a equipe instrumental do grupo mirim do Mestre Eugênio, fez o seguinte discurso:

Figura 2.4 - Malu Domingues na IX Festa do Fandango Caiçara de Paranaguá, 2018

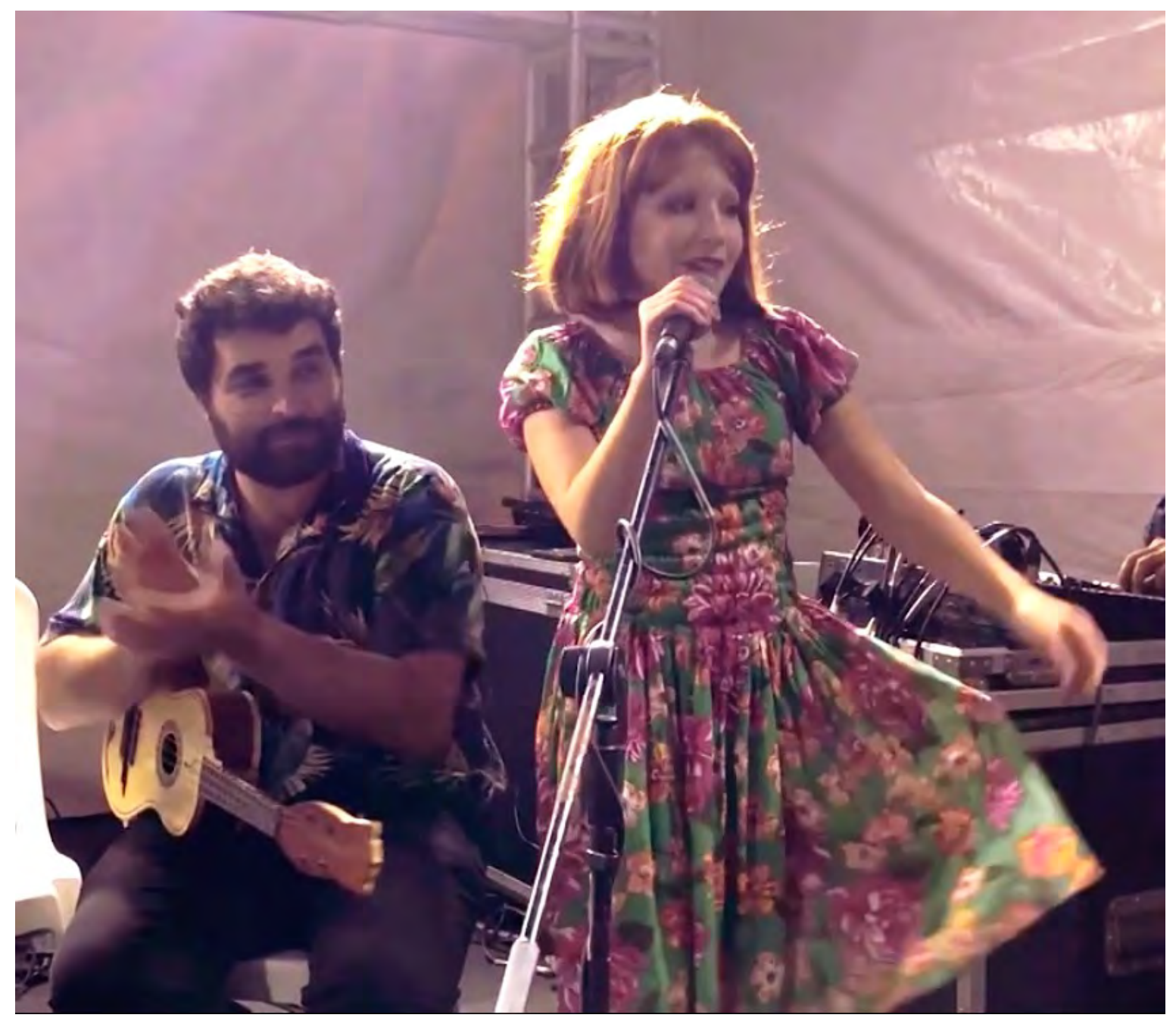

Fonte: (BARREADO, FAMÍLIA, RABECÔNICA, 2018) 
Ainda com a palavra, as gêmeas Malu e Luma, em entrevista captada pelas câmeras do Canal Futura, na pequena série de quatro episódios denominada Sou Fandango, teceram os seguintes comentários:

[Malu] Meu pai fazia uma rodinha com os meninos, eu e a Luma, a gente entrava também para aprender a bater o tamanco. Foi bem emocionante, eu fiquei bem nervosa, assim! Porque era a primeira vez e eu queria saber o que o povo ia achar, e tudo mais, né? Porque era a primeira vez para algumas pessoas que estavam lá assistindo e que tiveram a oportunidade de ver uma das primeiras meninas a bater tamanco no fandango! [Luma] Eu ficava vendo o mestre Zeca tocando, o meu pai tocando! Nossa, é um instrumento pequeno [machete], deve ser fácil o instrumento! Aí eu comecei com umas coisinhas. Aí foi indo, aprendendo cada vez mais, mais profundamente. Eu quero ser uma "mestre", porque, como eu falei, é uma paixão. Não é só por causa de trabalho nem de dinheiro, é por causa que é uma paixão! (BARREADO, FAMÍlIA, RABECÔNICA, 2018. Acesso em 10/01/2019 - transcrição nossa)

Além da prática artística em se tanger um instrumento, cantar ou bater tamancos numa roda de fandango, vale mencionar o importante papel que vem sendo desempenhado por articuladoras, mediadoras e pesquisadoras, estejam elas envolvidas com a manifestação por laços de consanguinidade, afinidade ou entusiasmo.

No cenário paranaense, mais especificamente em Paranaguá, devemos mencionar Mariana Zanette, que, a partir de seu envolvimento com Aorélio Domingues, com quem é casada há mais de quinze anos, tem realizado intervenções marcantes na prática fandangueira desta localidade.

\section{Eu sou colombina; você, pierrô}

Mestre Eugênio, uma das mais notáveis personalidades do fandango parnanguara, falecido em 2011, foi um dos fundadores da União da Ilha (Grêmio Recreativo Escola de Samba União da Ilha dos Valadares). Toda família de mestre Eugênio tem envolvimento constante com a agremiação, que foi campeã nos anos de 2002, 2004, 2012, 2014 e 2015, tanto nos bastidores - na confecção das fantasias e na organização dos desfiles - ou na avenida, como mestre sala ou componentes das alas, tendo filhas, netos e sobrinhos participando ativamente do carnaval de Paranaguá. Não apenas a família de mestre Eugênio, mas também Aorélio Domingues, que foi, por mais de uma vez, o carnavalesco da escola. 
O ocorrido que aqui será descrito se deu no ano de 2004, quando fui convidado para participar do corpo de jurados do Carnaval de Rua de Paranaguá, evento cujo caráter competitivo gerava e ainda gera grande alvoroço entre as escolas de samba da cidade.

Fui convocado para avaliar Harmonia; a Daniella Gramani, Samba Enredo; Greice Barros, Evolução; Roseane Santos, Alegorias; Rodrigo Goes, Bateria e Flavia Diniz, Comissão de Frente. Já estávamos na van com destino à Paranaguá quando tivemos a notícia de que Cláudia Andrade (Cau), jurada que seria responsável pela avaliação do quesito fantasia sofreu um contratempo e não poderia nos acompanhar. De antemão, Cau havia contatado Mariana Zanette, já velha conhecida de minha esposa Greice Barros e de Daniella Gramani. Mariana tem experiência em figurino, direção teatral e fotografia, e nos auxiliaria no impasse. Após contato telefônico, estávamos em frente ao seu apartamento. Dirigimo-nos a Paranaguá e tudo correu a contento - carnaval, desfiles e entrudos com fandango no Mercado do Café.

Em nosso retorno, Mariana não nos acompanhou, ficou em Paranaguá por mais alguns dias.

A parceria de Mariana Zanette com Aorélio Domingues tem sido contínua desde então - a experiência como atriz, diretora de teatro, roteirista de cinema e produtora cultural em muito vem auxiliando a entrada do coletivo Mandicuera em editais, eventos artísticos e culturais e ações de salvaguarda, fomentando projetos como Fandango na Escola, Ponto de Cultura Mandicuera, festas do fandango, circulações com espetáculos e demais ações levadas a cabo pelo coletivo. Como mencionado por Aorélio Domingues, em uma conversa enquanto íamos de Curitiba a Paranaguá para participarmos de uma das reuniões relativas à execução do Programa TCP de Gestão do Bem Cultural Fandango Caiçara:

Por exemplo, o pessoal falando da gente lá no encontro em registro [Ciclo de Estudos sobre Cultura Tradicional e Contemporaneidade ${ }^{69}$ : Uma das coisas que eu mais tenho batido hoje em dia, e falei lá também, é que a gente não pode se isolar. Eu falei: Eu não faço as coisas sozinho, Deus me livre! Se eu tivesse sozinho, eu seria tido na cidade como um louco, um cara que estaria com uma viola tocando lá na praça, assim, mendigo, sei lá o que, porque ninguém ia me dar bola. Quando a gente tá sozinho, ninguém te dá bola.

Eu falei da galera da universidade, Ary, Pati [Patricia Martins], Jana [Janaina Moscal]. Esse pessoal ligado à universidade, sempre nos apoiando. A minha mulher também, é produtora, e há muito tempo está atuando com a gente lá. Então, não sou eu que formato projeto. A gente começa a estabelecer atividades com todo mundo. Tem que entender o perfil das pessoas e dar

\footnotetext{
${ }^{69} \mathrm{O}$ evento realizado no município de Registro, Estado de São Paulo, integrou as atividades das Oficinas Culturais, Programa da Secretaria da Cultura do Estado de São Paulo, gerenciado pela Poiesis, em parceria com a Prefeitura de Registro, por meio da Secretaria Municipal de Cultura e Turismo, o evento aconteceu entre os dias 28 e 29 de setembro de 2018, no Centro de Formação Artística Fermino Gonçalves de Freitas. (PREFEITURA DE REGISTRO, 2018)
} 
espaço para o cara que chega da cidade, que quer ajudar, ajuda. É um mutirão muito grande. Por isso que as coisas estão dando certo lá! Eu falei isso! Como essa coisa da TCP: foi uma briga grande, houve muito estudo do entorno pra saber o que tava acontecendo, e pra gente conseguir alguma coisa. Mas isso não fiz sozinho, muito pelo contrário, e é isso que tem que acontecer. Eu vejo muito mestre com condições de ter um trabalho legal, mas sozinho não adianta, o cara tá lá dando uma aula aí tem que correr no correio, se oferecer pra prefeitura pra alguém fazer um projeto, não adianta, não vai fazer. Tem que ter produção, tem um monte de produtor aí, querendo fazer alguma coisa dentro da comunidade. Tem que pegar esses caras e dar um voto de confiança. Tenho falado muito isso, tenho falado isso com Cleiton [do Prado]. Eu falei: - Cleiton, você é o cara! Se eu sou referência para os outros, imagine você! Você é uma referência pra mim. Pode ter certeza. Sabe qual é a nossa diferença? Nossa diferença é que eu tenho produção. Minha mulher é produtora, tá todo dia em casa, todo dia tô conversando com ela, e, fora isso, a galera toda, Ary, Patrícia, Jana. (Cadernos de campo: 04/10/ 2018 transcrição nossa)

Como mencionado por Domingues, outra importante parceira nessas empreitadas tem sido a antropóloga, e mais recentemente tipe na bandeira do divino, Patrícia Martins. Entusiasta das manifestações tradicionais e populares, Patrícia realiza agenciamentos contínuos para manutenção e salvaguarda da cultura caiçara, tendo participado ativamente da elaboração do dossiê que substanciou a patrimonialização do fandango caiçara, realizando documentários, estudos e aprofundadas pesquisa sobre os trânsitos destas populações. (MARTINS, 2006 e 2018)

Por conta das ações do comitê de salvaguarda, o qual fui integrante nos últimos quatro anos de sua constituição provisória, pude também conhecer Ana Carolina Barbosa, que vem desenvolvendo ações relevantes para salvaguarda da manifestação no litoral norte de São Paulo, em Ubatuba.

Nos três casos encontramos formações diversas: a primeira, atriz, figurinista, aderecista e diretora de teatro; a segunda, historiadora e antropóloga; e a terceira, licenciada em educação física, com formação em matemática financeira e, ocasionalmente, exerce atividades de guardavidas. O comprometimento dessas mulheres com a causa caiçara salta aos olhos - o ativismo, a militância e os resultados de suas ações consolidam concretamente as prerrogativas de salvaguarda de nossos patrimônios culturais, assim como a busca de condições dignas de vida e bem-estar de seus detentores. A interdisciplinaridade e a interação de agentes com finalidades múltiplas são objetivamente visualizadas nos desdobramentos que emergem do fortalecimento das redes de interação caiçara na atualidade, atuação via ressonância entre frequências de afetos (emoções vitais) para a construção do "comum". Rolnik nos indica ser este um dos possíveis modos de cooperação para insurgência micropolítica. Tecer múltiplas redes, onde são criados territórios relacionais temporários, "sinergias coletivas, provedoras de um acolhimento 
recíproco que favorece os processos de experimentação de modos de existência distintos dos hegemônicos, valorizando e legitimando sua ousadia.” (ROLNIK, 2018, p. 141)

Eu queria só compartilhar das conversas que tenho conseguido acompanhar nestes últimos três dias, uma fala que vem mais permeada pela política. Eu não ouvi nestes três dias a palavra golpe. Nós estamos vivendo um golpe. Nós temos pessoas governando nosso país, todas com problemas muito graves de corrupção. A gente está vivendo um golpe, o Ministério da Cultura foi quase extinto, quase acabou o IPHAN. Eu acho que esse momento que a gente está vivendo aqui [Ubatuba] esses dias, parece uma brecha, parece que ele está fora do tempo que a gente está vivendo agora, e estamos compartilhando isso. Isso [II Festa do Fandango de Ubatuba] é muito forte, é muito potente. A política, os governantes que nós elegemos, me incluo, todos nós erramos muito quando votamos. A gente ainda erra muito. A gente está aprendendo, porque a nossa democracia é muito jovem. A gente nem chegou a exercer ela e ela já foi tirada da gente. A gente está aprendendo a viver isso, e isso aqui é muito importante, é um processo democrático incrível que é só a arte que permite. Isso é muito potente. Porque essas pessoas que estão lá dentro do gabinete dizendo o que vai ser bom para gente, o que eles querem é a desarticulação, o que eles querem é que a gente se separe, eles querem que a cultura popular fique contra o teatro, que o teatro fique contra a música, que as artes todas sejam desarticuladas, e que a gente fique só cultuando as celebridades e esse mundo que não nos pertence, essa [mídia de massa] não é a arte que faz o nosso país viver. Estamos aqui, pessoas do Paraná, de São Paulo, do Rio de Janeiro, juntos durante três dias discutindo, tendo o comitê [de salvaguarda], o IPHAN. Essas pessoas, elas virem aqui, se aproximar, isso é histórico, a gente está fazendo história. As nossas crianças que estão aqui, isso é a salvaguarda! Eu estou saindo daqui com a alma lavada, é um momento muito potente. Realmente, quando a gente vive isso de estar vivendo um momento de exceção, quando artistas estão sendo cerceados, é tirado o direito da pesca, tirado o direito de tocar sua música, tirado o direito de falar sua poesia, de protestar, quando nos tiram esses direitos, estamos vivendo um momento de exceção. Esse momento é muito potente, tem muita força, e acho que a gente tem que se unir, com as nossas diferenças, temos que manter as nossas diferenças, não somos todos iguais. Gente, isso aqui é muito, muito, muito emocionante, acho que eu vou fechar 2017 e abrir 2018 acreditando, acreditando na gente junto! (Greice Barros, na reunião final na II Festa do Fandango de Ubatuba - Transcrição nossa).

Seria furtivo não mencionar aqui as demais agentes, cuja disponibilidade e envolvimento com a causa caiçara se fazem presentes: Antonia Regina Moura e Aline Braida, em Paraty (RJ); Julia Basso, Greice Barros, Karina Coelho, Janaina e Jandaíra Moscal, em Curitiba (PR); Adriana Alves Carneiro, em Iguape (SP); e Camila Fernanda de Paula e Vânia Cristina, em Peruíbe (SP). Em todos os casos, apenas nominando personalidades próximas ao meu círculo de interações. Mesmo não mencionadas, detentoras, ativistas e militantes da causa caiçara seguem realizando seus trabalhos junto às comunidades, nos bastidores e nos palcos. Certamente teríamos uma extensa lista, à qual, mesmo que inominada, rendemos nossos mais sinceros e elogiosos acenos. 
Figura 2.5 - Carolina Barbosa Festa do Fandango de Ubatuba em 2017

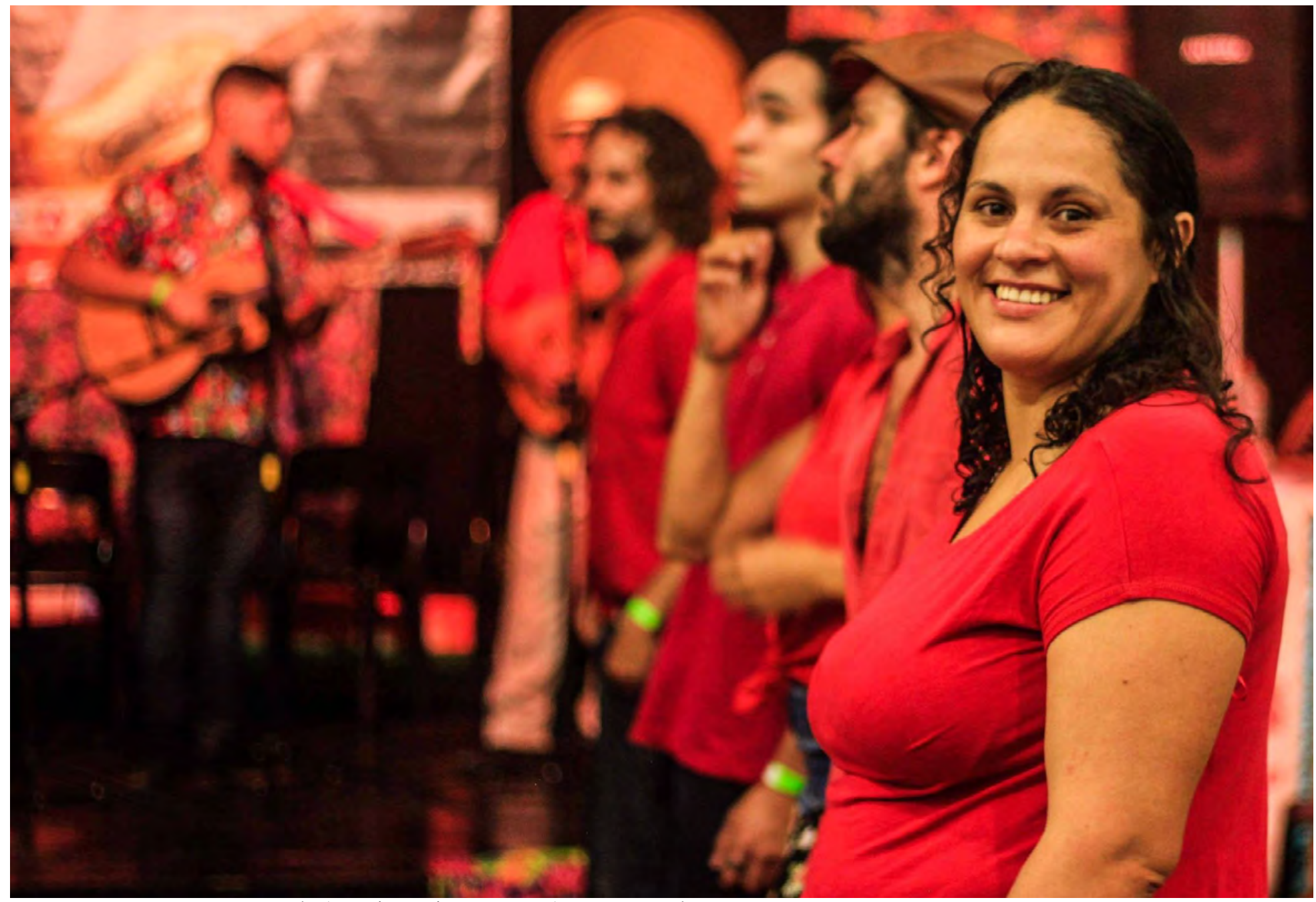

Fonte: Foto de Antonia Regina Moura - Acervo pessoal. 


\section{Revivalismo, Mecenato e Mitigação}

A emergência de grupos de fandango, em Paranaguá, além do estímulo inicial revivalista ${ }^{70}$ de Inami Custódio Pinto e Manoel Viana, acaba também por absorver a identidade jurídica no trato com setores públicos e, posteriormente, também, com a iniciativa privada. No caso de Paranaguá, os recursos financeiros geridos pelos grupos foram e - em menor intensidade, na atualidade - continuam sendo temas tabus, tanto internamente como entre os grupos. Nas atividades que envolvem mais de um dos coletivos fandangueiros em Paranaguá, como no caso dos bailes quinzenais no Mercado do Café, nas festas do fandango ou nos processos de mitigação junto a empreendimentos de grande porte, o entendimento dos diversos envolvidos sobre as demandas burocráticas dessas tramitações é ainda heterogêneo. Faixas geracionais de escolarização e a intervenção parasitária de agentes e/ou instituições se apresentam como os principais entraves ao melhor entendimento desses trâmites entre os detentores.

A melhor compreensão dessas demandas e das atividades de capacitação, levadas a cabo por instituições de ensino tanto na formação regular quanto por meio de ações de extensão por órgãos públicos e suas autarquias, fundações e institutos, organizações não governamentais e, ainda, produtores e empresas voltadas à área da cultura, vem impactando o cenário nas três últimas décadas. Vale lembrar que nos efervescentes finais do século passado e nos primeiros anos do século XXI, questões tão simples como o desconto do imposto de uma nota fiscal para prestação de serviços artísticos, poderia gerar confusões de tamanha magnitude a ponto de quebrar laços de sucessão discipular, onde um dos mestres de mais idade corta relações com um de seus mais notáveis aprendizes em razão de um contratempo dessa natureza. Fissura que não pôde ser conciliada em vida, mas que parece se dissolver na construção de novas alteridades junto aos descendentes consanguíneos daquele memorável fandangueiro.

\footnotetext{
70 "A análise de processos de tradicionalização, em geral, muito deve aos conceitos de "invenção da tradição" de E. Hobsbawm e T. Ranger (1983) e de "objetificação da cultura" (Handler, 1988, Handler e Lennekin, 1984). Na literatura etnomusicológica tem se operado, em regra, com a noção de revificação musical (music revival), que se define como um movimento social orientado para recuperação de um sistema musical tido por desaparecido para ser desfrutado no presente. Ainda de acordo com T. Livingston, a revificação caracteriza-se por: a) presença de indivíduos militantes da causa, b) existência de informantes ou fontes originais, c) ideologia e discurso revivalista, d) constituição de uma comunidade revivalista, e) atividades organizadas, f) organização comercial associada ao mercado revivalista." (CASTELO-BRANCO e BRANCO, 2003, p. 2)
} 
A modificação do panorama de existência e interação dos coletivos fandangueiros já tem sido foco de reflexões, que transitam de velada crítica à construção conceitual do tema, no bojo dos movimentos capitaneados por pesquisadores e mediadores culturais, típicos dos trabalhos de gabinete, nos quais não se busca melhor compreender o impacto de tais intervenções nas práticas cotidianas. Argumentações que por vezes se perdem no vazio onde a busca de novidades referenciais, ou o uso equivocado de conceitos como o da "invenção da tradição", perdem de vista arcabouços histórico e sociológico que impulsionaram a continuidade dessas manifestações na atualidade.

\section{Engajamento, educação patrimonial, violas e mbarakas}

Pela afinidade com a temática e pela força de atração inerente ao ambiente e aos atores envolvidos, já há alguns anos tenho como agenciamento a manutenção do trânsito e das relações que venho construindo no universo caiçara. Nascido no interior paranaense, convivi mais com o gauchismo guarapuavano que com qualquer outro ambiente cultural na primeira infância.

Meu ingresso na Faculdade de Artes do Paraná, em 1998, assim como a interação com personalidades como Nélio Spréa, Itaércio Rocha ${ }^{71}$ e Daniella Gramani, pesquisadores imersos no universo da cultura popular, foram para mim de fundamental importância aos encaminhamentos ulteriores. A militância estudantil e o envolvimento na constituição do Diretório Acadêmico e na promoção de atividades e projetos culturais no ambiente universitário incluíam a elaboração de programações artísticas para os intervalos de aula na cantina e a execução de mostras multiárea envolvendo os cursos de música, teatro, dança, artes plásticas e

\footnotetext{
71 Além da atuação do maranhense Itaércio Rocha no cenário cultural curitibano, como no caso das rodas de Cacuriá e da fundação do bloco pré-carnavalesco Garibaldis e Sacis, é notável sua participação na revitalização e revivalismo de práticas culturais, como a congada da Lapa e na formação do grupo Fâmulos e Bonifrates, em Guaraqueçaba: "Em 14 de Dezembro de 1999, após oficina de Teatro de Bonecos de 120 horas com Itaércio Rocha surge os Fâmulos de Bonifrates. Projeto de Ivan da Silva Araújo e José Carlos Muniz que tinha como objetivos resgatar todas as formas de cultura e folclore da região e trabalhar com elas em forma de teatro de animação. Desde então o trabalho vem sendo desenvolvido com várias formas de animação como a luva, vara, sombra, bonecos gigantes entre outros. A cultura popular guaraqueçaba encontrava-se dizimada e não existia nenhum desenvolvimento há anos. Hoje o Mamulengo Fâmulos de Bonifrates é um modelo de como se pode aprender com nossas próprias raízes e é popularmente conhecido por todos como Mamulengo. Do resgate ao texto, da confecção à apresentação, Divino Espírito Santo, Lendas, Cacuriá, Fandango que há mais de 40 anos não se ouviam falar, escutamos hoje nas brincadeiras das crianças, é o objetivo alcançado. O principal objetivo sempre foi o resgate da cultura local, o Fandango e seus mitos, mas estendemos pesquisas à área cultural brasileira como o Boi de Mamão, Cacuriá e Carimbó, folclore típico do norte e nordeste brasileiro." (Histórico do grupo Fâmulos e Bonifrates, datado de 15/03/2005 - Acervo pessoal)
} 
musicoterapia - áreas que, naquela época, integravam a oferta de cursos da instituição. Entre assembleias com coletivos estudantis, reuniões do conselho universitário e com colegiados de cursos, encontros municipais, estaduais e nacionais de estudantes, aulas para ensino fundamental, ensaios e shows com a Caxaprego, batucadas no então imberbe bloco précarnavalesco Garibaldis \& Sacis, deram-se as primeiras idas e vindas ao litoral paranaense. Por essas empreitadas me familiarizei com elementos da cultura popular, com a elaboração de projetos culturais e com os procedimentos que envolvem a manutenção de identidades jurídicas.

Em 2002, minha aproximação dos parnanguaras se deu por ocasião da I Festa do Fandango Caiçara de Paranaguá, onde contribuímos com a organização do evento tocando com o grupo CaxaPrego no encerramento da festa. De lá para cá, a convivência - hora mais intensa, hora mais espaçada - com interlocutores no litoral do Estado vem se fazendo de forma continuada, moldando minhas ações a partir das demandas levantadas por parceiros e camaradas, sugerindo, criando, elaborando e executando propostas e planos de ação no universo da musicalidade caiçara.

Em 2005, a partir de ações financiadas pelo Ministério do Desenvolvimento Agrário, proposta-piloto denominada "Projeto Cotinga - Implantação de Tecnologia em Sistemas Agroflorestais e Revitalização Cultural em Terra Indígena do Paraná” se desenvolveram metas como a elaboração de diagnósticos participativos, cursos sobre coletas de sementes, intercâmbios entre comunidades, cursos para aprimoramento de técnicas artesanais e desenvolvimento de quintais agroflorestais. Pude vivenciar com mais proximidade o cotidiano parnanguara, naquele momento com foco na comunidade Mbyá Guarani Pindoty - terra indígena localizada na Ilha da Cotinga ${ }^{72}$. As ações do projeto possibilitaram um contato estreito com os moradores da ilha, além de proporcionar o diálogo com instituições como a FUNASA (Fundação Nacional da Saúde), a Fundação de Cultura de Paranaguá e a Associação de Cultura Popular Mandicuera. Entre outros desdobramentos, surgiu o convite para integrar a equipe do Projeto Fandango na Escola, proposta que, financiada pela SEED (Secretaria do Estado da Educação do Paraná), atendeu à totalidade das escolas estaduais nos municípios do litoral do Estado com atividades de formação de professores da rede pública e de monitores (selecionados pelos grupos de fandango da Ilha dos Valadares), que auxiliavam os professores em sala de aula, em atividades relacionadas ao fandango caiçara, criando ferramentas didáticas para o repasse de coreografias, marcas batidas, modas bailadas, elaboração de versos e contato com repertórios do universo musical caiçara.

\footnotetext{
${ }^{72}$ Ver (GIORDANI, 2009).
} 
Figura 3.1 - Atividade de capacitação de monitores - Projeto Fandango na Escola, 2007

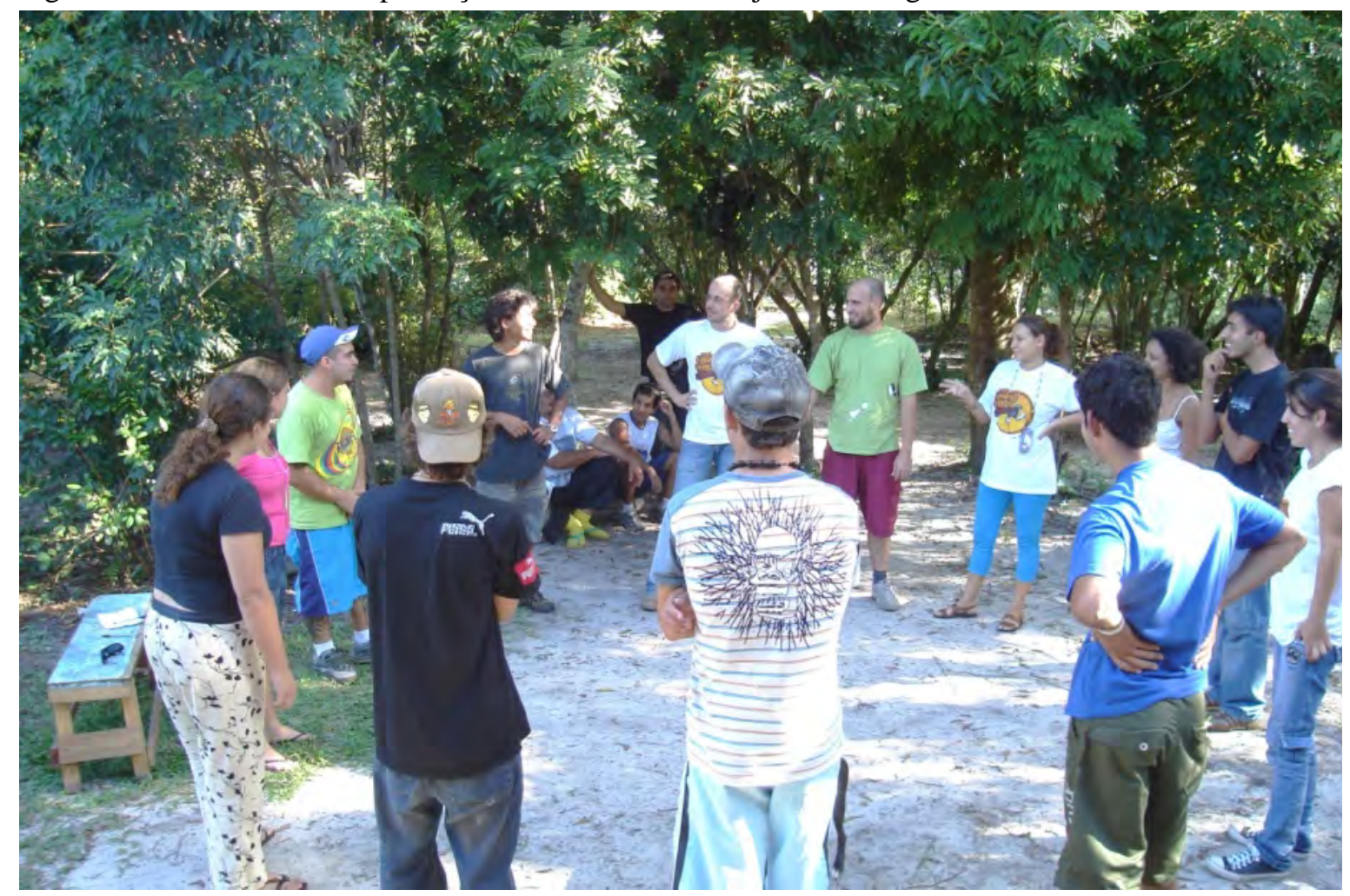

Fonte: Acervo pessoal

Do primeiro encontro com os monitores que acompanhariam os professores em sala, resgato, aqui, as observações de Nélio Spréa sobre o projeto, no intuito de demonstrar nossos anseios enquanto equipe de coordenação pedagógica da proposta:

Nosso primeiro encontro pedagógico com os monitores do projeto foi bastante produtivo. Para cada um daqueles jovens presentes no evento, corresponde um desejo de superação e formação pessoal, que coincide com a proposta do projeto Fandango na Escola. Essa coincidência não é à toa, pois o fandango faz parte da história deles e suas trajetórias individuais incluem, há tempos, a vivência dessa tradição.

Todos ali detêm esse saber, pois, ao longo de anos, vivenciaram em seus corpos os movimentos, o ritmo, os versos e todo conjunto de significados que circundam a prática do fandango. Todos ali têm, portanto, coisas para contar, coisas para ensinar.

Para nós, da coordenação pedagógica, cabe apenas avivar o que, de um modo ou de outro, cada um dos monitores já expressa: a vontade de passar adiante esse conhecimento. Não se trata de servi-los de uma metodologia acabada, e, sim, de entusiasmá-los com as possibilidades didáticas que a suas histórias pessoais já oferecem. Estamos ali para acompanhá-los, oferecendo recursos teóricos e práticos, como foi no caso dos guias para o planejamento e para o relatório.

Estamos ali para esclarecer algumas questões que possam dizer respeito ao funcionamento do projeto, ao convívio dentro da escola, ao universo da criança e do adolescente. Estamos ali para avaliá-los também em seu desenvolvimento, percebendo os obstáculos e valorizando as melhorias. 
Dessa relação de "parceiros observadores" poderá surgir uma metodologia coerente com o que é a prática do fandango e coerente com o que é a realidade da escola. Nesse primeiro encontro pudemos oferecer, de um modo esclarecedor, diferentes abordagens sobre a prática pedagógica.

$\mathrm{O}$ fato de estarmos trabalhando em conjunto exige que tenhamos muito rigor no que se refere ao nosso planejamento, mas isso aponta para algo muito positivo: a estruturação de um modo de operar, uma estrutura metodológica específica para a revitalização de práticas culturais valiosas. (SPRÉA, 2007)

Em linhas gerais, o projeto apresentou a noção de que a identidade cultural tem sido cada vez mais utilizada como importante ferramenta na construção da educação e da cidadania, dentro ou fora das escolas, inserindo estrategicamente elementos da cultura popular nesse caminho, como forma de propor a reflexão histórica em suas particularidades locais e regionais.

Nessa linha de atuação se insere o trabalho desenvolvido pela Associação de Cultura Popular Mandicuera, propondo às escolas a transposição didática e a reflexão sobre o fandango e a cultura caiçara. A ideia central consistia em levar o fandango para o ambiente escolar, de forma lúdica e interdisciplinar, propondo oficinas integradas entre professores, monitores e alunos. Para isso, o projeto produziu uma cartilha ilustrada ${ }^{73}$, acompanhada de um CD - com marcas batidas e modas bailadas - e um DVD que, resultante de amplas discussões sobre a metodologia de transposição didática adequada, apresentava didaticamente as coreografias e a musicalidade dessa manifestação. Também foram levadas a cabo oficinas para capacitação de professores da rede estadual de ensino e atividades de acompanhamento, reunindo equipe pedagógica, professores, monitores e mestres fandangueiros.

A dissolução das atividades se deu pelo descompasso entre as entidades financiadoras, SEED, núcleo regional de educação de Paranaguá e proponentes do projeto. A falta de trato administrativo e de sensibilidade dos representantes dos órgãos envolvidos criou animosidades, inclusive entre grupos de fandango que, na época, não apresentavam recursos humanos para integrar a proposta e de alguma forma não se sentiram contemplados pelo projeto. Não havendo incentivo para mediação dos pequenos conflitos, o projeto se diluiu, mormente pelos conflitos de interesses, onde individualidades e jogos de pequenos poderes na esfera da administração pública findaram a iniciativa.

De todo modo, o projeto rendeu frutos. Recentemente, ao visitarmos Guaraqueçaba para entregar instrumentos produzidos por outro projeto denominado “Artesanias Caiçaras”, tivemos a grata surpresa em saber que os tablados utilizados rotineiramente para a prática do fandango batido são ainda aqueles distribuídos para as escolas em 2007. Além das atividades didáticas

\footnotetext{
${ }^{73}$ Devido a dificuldade em acessar o material e de seu potencial didático, após solicitar os devidos consentimentos dos realizadores, insiro na integra a cartilha como anexo da tese.
} 
propriamente ditas, foi prerrogativa do projeto a distribuição de um kit, onde, além das cartilhas, CDs e DVDs, as escolas também recebiam um tablado e pares de tamanco, visando a prática nas distintas localidades beneficiárias.

Serra acima, outro desdobramento do projeto Cotinga se deu no auxílio para melhor assentar as famílias Mbya, Kaingang e Xetá, que viviam em condições de insalubridade na Reserva Biológica do Cambuí - localizada entre as cavas de escoamento do Rio Iguaçu -, altamente sujeita a alagamentos.

Fato marcante na implementação colaborativa de Kakané Porã se deu nos primeiros contatos com Werá Popygua (Rivelino Gabriel de Castro), na busca por um intérprete para auxiliar nas atividades de coleta de sementes na Ilha da Cotinga. A necessidade em realocar os indígenas que residiam no Cambuí, à época, também era planejada pela Assessoria Especial de Assuntos Indígenas do Paraná, representada por Evídio Batistelli, sob constante diálogo com a associação ORCCIP CURIM (Organização de Resgate Crítico da Cultura Indígena de Curitiba e Região Metropolitana), mas sem nenhuma alternativa plausível à demanda. Sensibilizado pela conjuntura, o arqueólogo Miguel Gaissler, à época, presidente do Instituto Indigenista e de Estudos Socioambientais Terra Mater (instituição responsável pela gestão do projeto-piloto), também se juntou ao pleito buscando parcerias outras. Nos casos da Prefeitura Municipal de Curitiba e da COHAB, fomos acolhidos pelo vereador Tito Zeglin e pela arquiteta Teresa Elvira Gomes de Oliveira, então diretora da Companhia de Habitação Popular de Curitiba, os quais prontamente nos auxiliaram, indicando as possíveis áreas disponíveis e elaborando os projetos das edificações e do loteamento, visando melhores condições de vida àqueles indígenas.

O processo, desde seu início - com a cessão do lote na estrada da Caximba à elaboração e entrega à $\mathrm{COHAB}$ do relatório diagnóstico onde foram levantados os dados dos indígenas que firmariam residência em Kakané Porã -, foi acompanhado por integrantes do Projeto Cotinga, em diálogo com representantes da Assessoria Especial de Assuntos Indígenas do Paraná, da prefeitura municipal de Curitiba e de representantes das etnias indígenas envolvidas.

Ao elaborar o laudo, valendo-me de um questionário criado para execução do Diagnóstico Rápido Participativo (aplicado na Ilha da Cotinga), confesso ter sido invadido por um misto de nostalgia e curiosidade. Nostalgia por se tratar de uma aldeia multiétnica reunindo Guaranis, Kaingangs e Xetás, visto que Tiquen, um dos poucos remanescentes da etnia Xetá ainda vivos, estabeleceu moradia junto ao coletivo ORCCIP CURIM, associação que institucionalizou a reunião de indígenas que moravam em Curitiba e adjacências. Como pautas da associação, figuravam os direitos indígenas, a manutenção de sua cultura e a luta por território; curiosidade, pela riqueza das dinâmicas culturais inerentes aos assentamentos 
indígenas urbanos - onde a miscigenação toma acento nos laços de afinidade, seja na administração de uma pizzaria ou na coleta de sementes e materiais para artesanato nas avenidas da metrópole; em ambos os casos, atividades realizadas por indígenas que residiam no Cambuí. São reflexões que me acompanham ao longo dos anos, visando articular propositivamente ações voltadas ao bem-estar dos indivíduos que compõem essas populações singulares.

Ainda no Cambuí, recordo-me de dois momentos marcantes: primeiro Carlos (liderança Kaingang) e Werá (liderança Mbyá) tomando seu mate na varanda do antigo Museu de Ciências Naturais da Reserva Ecológica do Cambuí, enquanto discutiam a fusão Jê/Tupi para a denominação da aldeia multiétnica; depois a oportunidade festiva em presentear Werá com um violão no intuito de que fosse transformado em mbaraka para auxiliar na realização dos mborays e jerokys (cânticos sagrados da cultura Mbya).

Ações de interesse para esta narrativa foram os cursos de aprimoramento de técnicas artesanais e as viagens de intercâmbio realizadas pelo projeto-piloto financiado pelo MDA. A primeira foi responsável por me familiarizar com o mbaraka, instrumento utilizado cotidianamente nas opy (casa de reza guarani); a segunda, por proporcionar a visitação de aldeias Mbyá e Avá Guarani em localidades no interior paraguaio e nos Estados da região Sul do Brasil, possibilitando o acesso a iniciativas associativistas e cooperativistas de alto potencial agregador intercomunitário.

Em dezembro de 2006, com objetivo de realizar a primeira etapa das atividades de capacitação em aprimoramento de técnicas artesanais - meta 09 do projeto "Implantação de Tecnologia em Sistemas Agroflorestais e Revitalização Cultural em Terra Indígena no Paraná” -, convidei Aorélio Domingues para ministrar atividade de confecção coletiva de um mbaraka a partir de dados coletados na ação de intercâmbio onde visitamos aldeias Mbyá, no Paraguai. Um estudo preliminar foi realizado utilizando como base imagens e relatos sobre os instrumentos artesanais utilizados pelas comunidades de Nueva Esperanza e Punta Porá. Reflexões que delinearam a primeira parte desta tese, revisitando o trânsito e mobilidade guaranis como componentes da disseminação da instrumentação ibérica al-andaluza no território caiçara e, consequentemente, seus impactos na musicalidade dessas populações. 
Figura 3.2 - Mbaraká e Ravé de manufatura artesanal, Punta Porã, Campo Nueve (PY)
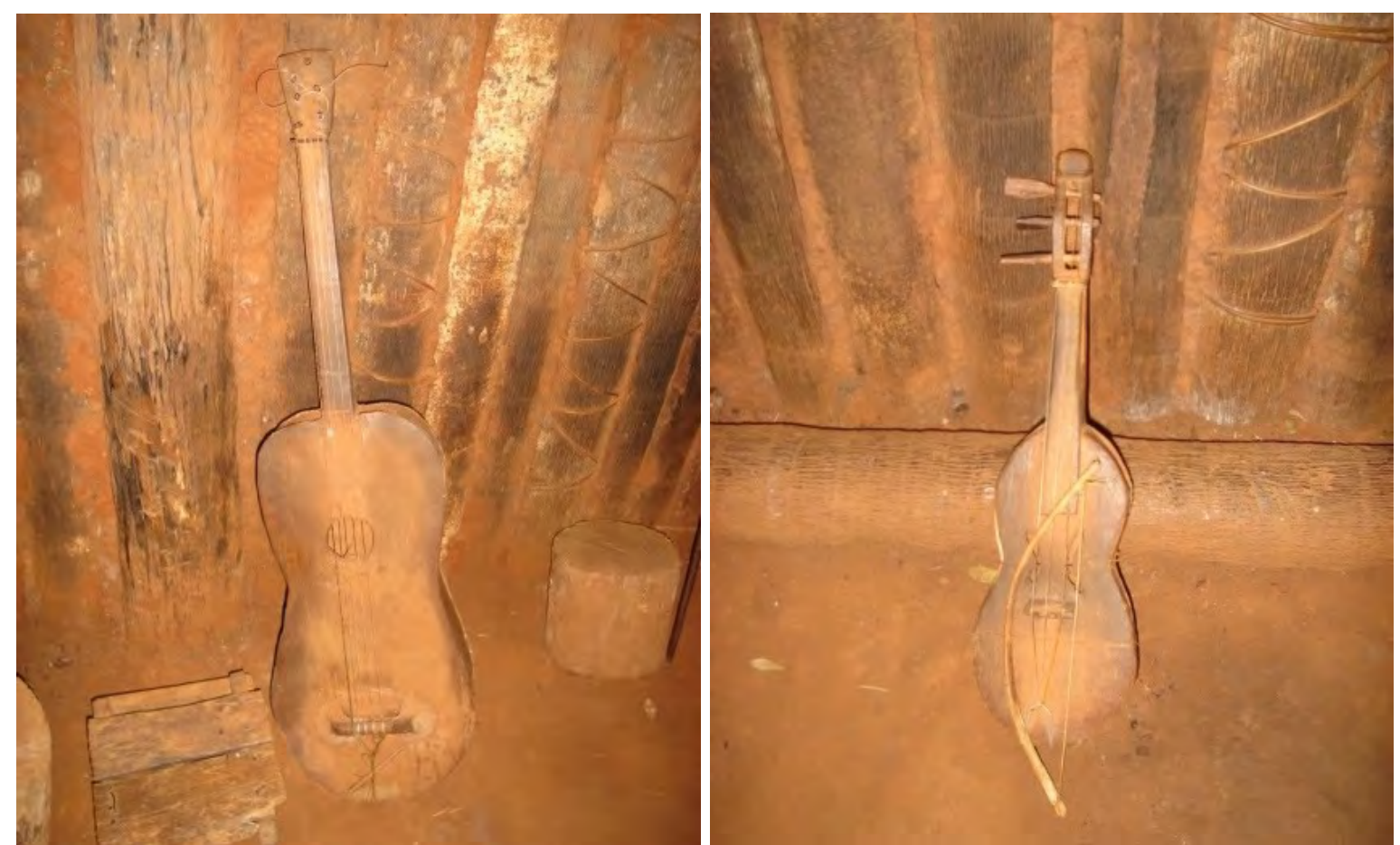

Fonte: Acervo pessoal

Figura 3.3 - Visita à comunidade Mbya Guarani de Nueva esperança, no Paraguai, 2006

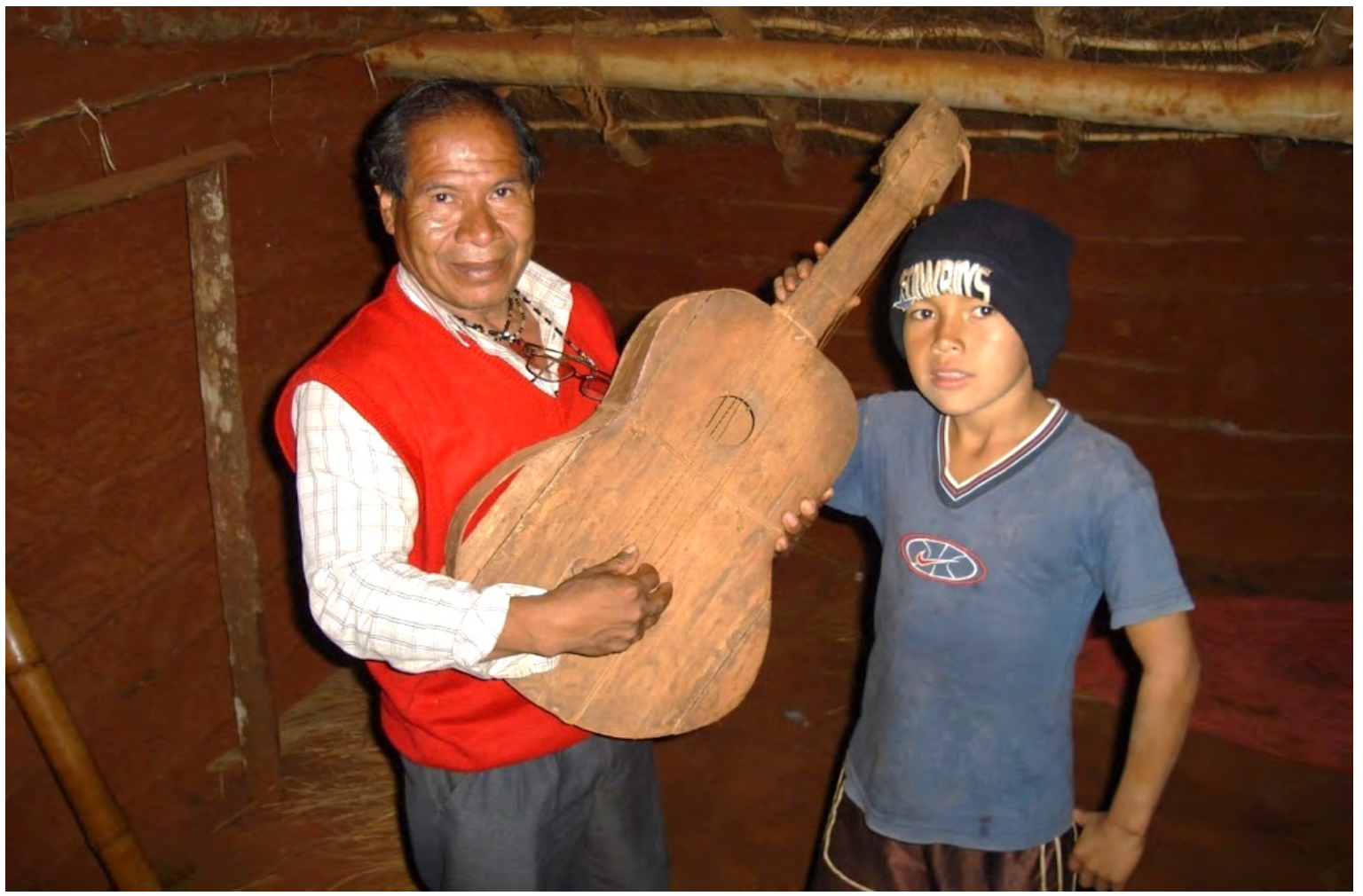

Fonte: Acervo pessoal 
Figura 3.4 - Visão geral da opy de Punta Porã, Campo Nueve (PY)

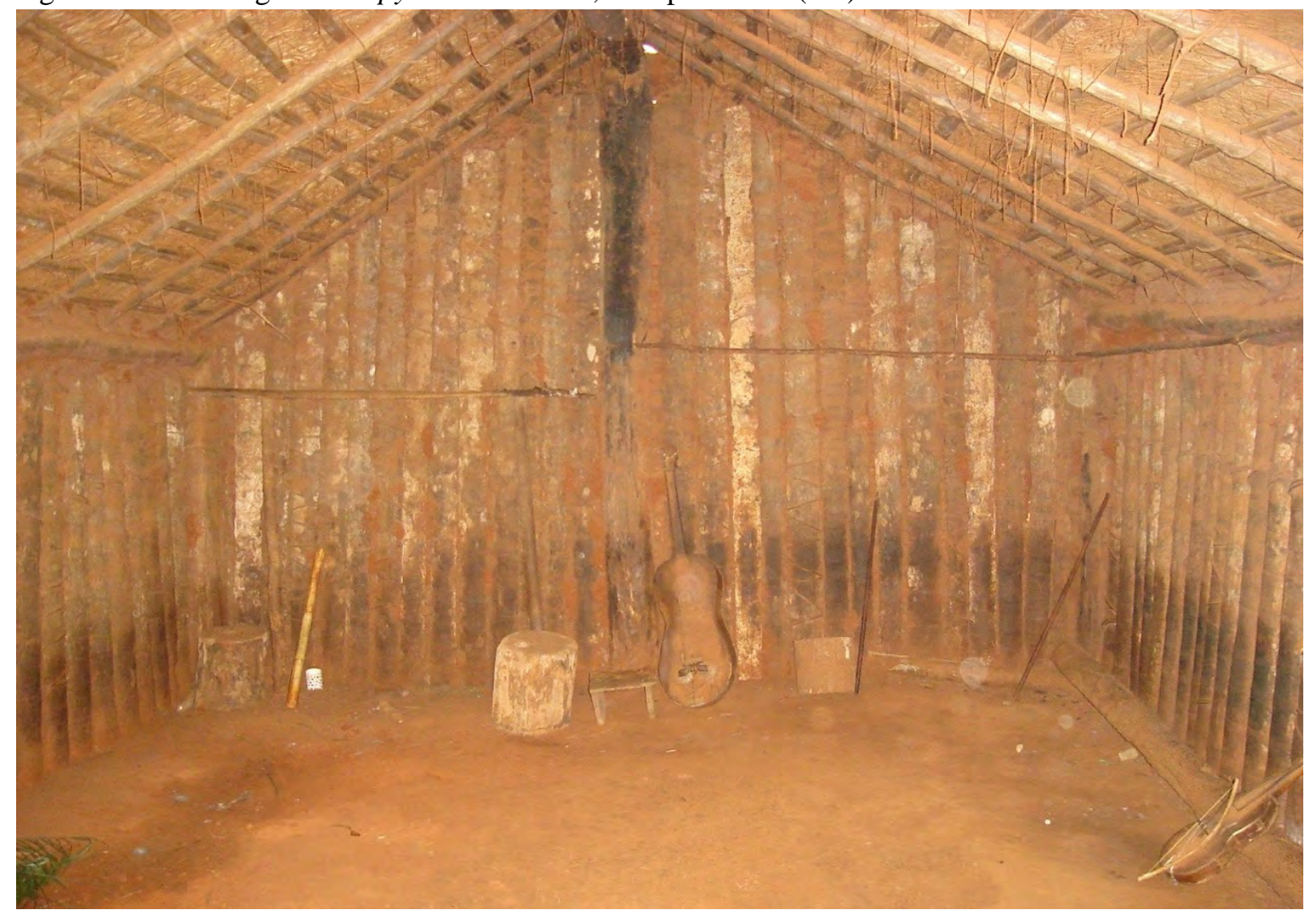

Fonte: Acervo Pessoal

Sugeri a Aorélio que trabalhássemos técnicas de confecção do mbaraka. As atividades foram realizadas à sombra de um Guapé, inicialmente apresentando aos participantes as fotos coletadas e as ferramentas que utilizaríamos durante a oficina - cepilhos, serrote, facão, facas e formões. Cabe salientar que parte dos formões era de produção artesanal e foram confeccionados especificamente para aquele fim, sendo muito apreciados pelos indígenas, tendo em vista a facilidade de manuseio, o fio e a precisão no corte.

Em seguida, Aorélio conduziu as atividades dividindo as funções a serem executadas no intuito de que, ao final da oficina, tivéssemos confeccionado um mbaraka de maneira participativa. Valdemir se ocupou da confecção do braço do instrumento; Ambrósio, em serrilhar as pequenas peças que serviriam de base à colagem do tampo e fundo no interior do instrumento; enquanto Darci e Dionísio cepilhavam as primeiras peças de caxeta que se converteriam em tampo e fundo do instrumento. 
Figura 3.5 - Interior da opy na TI Pindoty (Ilha da Cotinga)

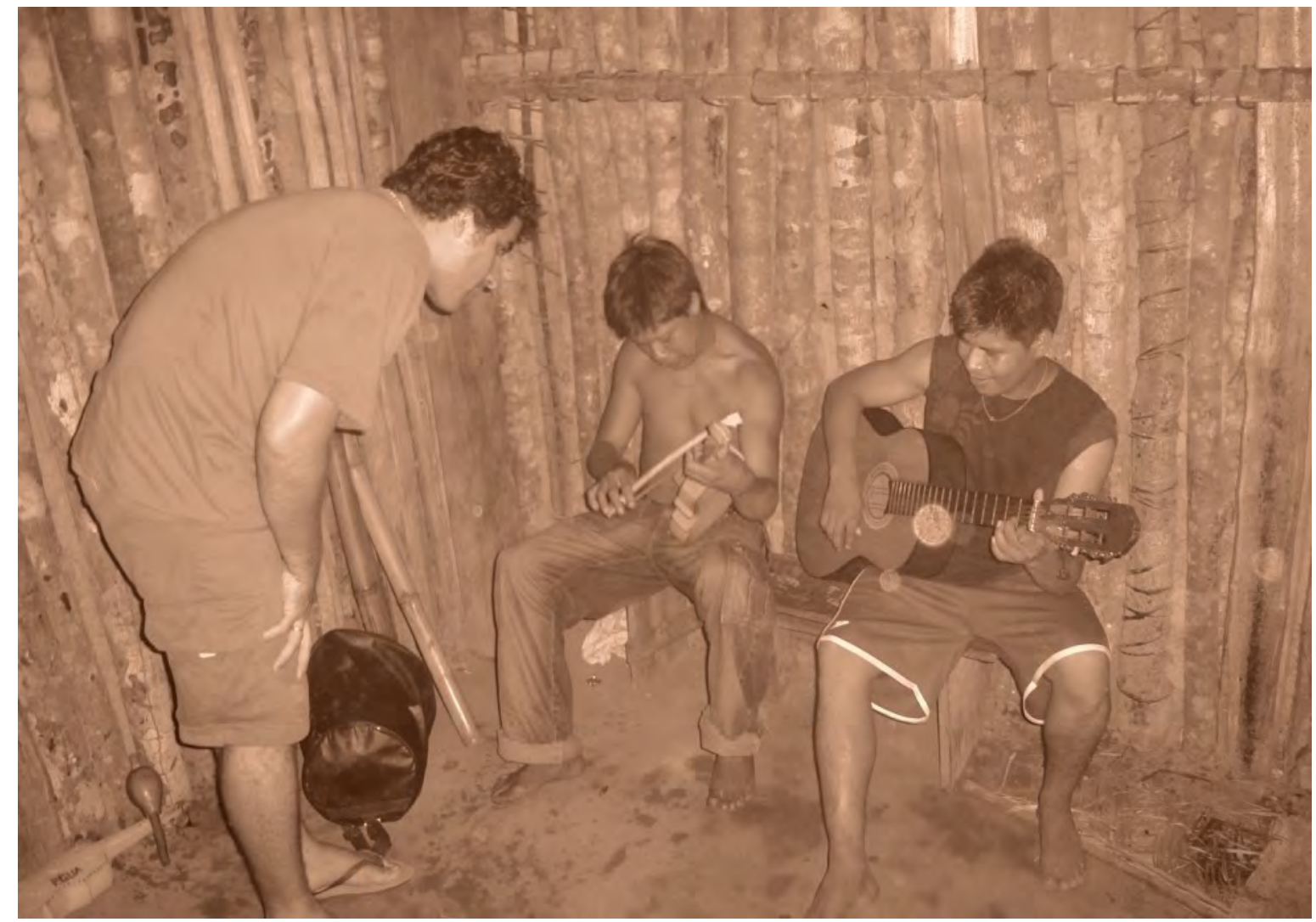

Fonte: Acervo pessoal

Sabendo do tempo restrito a três dias de oficina, Aorélio trouxe consigo algumas peças já adiantadas, assim como os moldes de madeira, a fim de otimizar trabalho, além de exemplificar o resultado esperado. As atividades seguiram durante a tarde e, à noite, fomos convidados a participar do Oporai, cotidianamente realizado na opy. Na figura 3.5, Aorélio observa os instrumentistas, e, percebe-se além da rabeca utilizada, outra rabeca (no canto inferior esquerdo) - ambas confeccionadas pela técnica de cavoucar, que, diferente dos instrumentos feitos com aros, é esculpida em uma única peça de madeira.

$\mathrm{Na}$ manhã seguinte, iniciamos as atividades, realizando uma pequena caminhada pelos arredores da comunidade a fim de coletarmos sumbare - vegetal cujo caule, quando aquecido, fornece uma espécie de cola natural, utilizada pelos antigos construtores de violas e rabecas para a confecção destes instrumentos. Durante as atividades, contamos com a presença de Odair Siqueira (in memoriam), mais conhecido como "Seu" Beso, fandangueiro e pescador que nasceu na ilha da Cotinga, no ano de 1934, tendo residido em Tibicanga, município de Guaraqueçaba/PR, onde aprendeu a tocar viola com os vizinhos. Na época, "Seu" Beso não tocava com muita frequência, mas acompanhava funções com "Seu” Pedro Miranda, na Barra do Superagui. 
Figura 3.6 - Coleta de sumbare, na aldeia Pindoty, dezembro de 2006
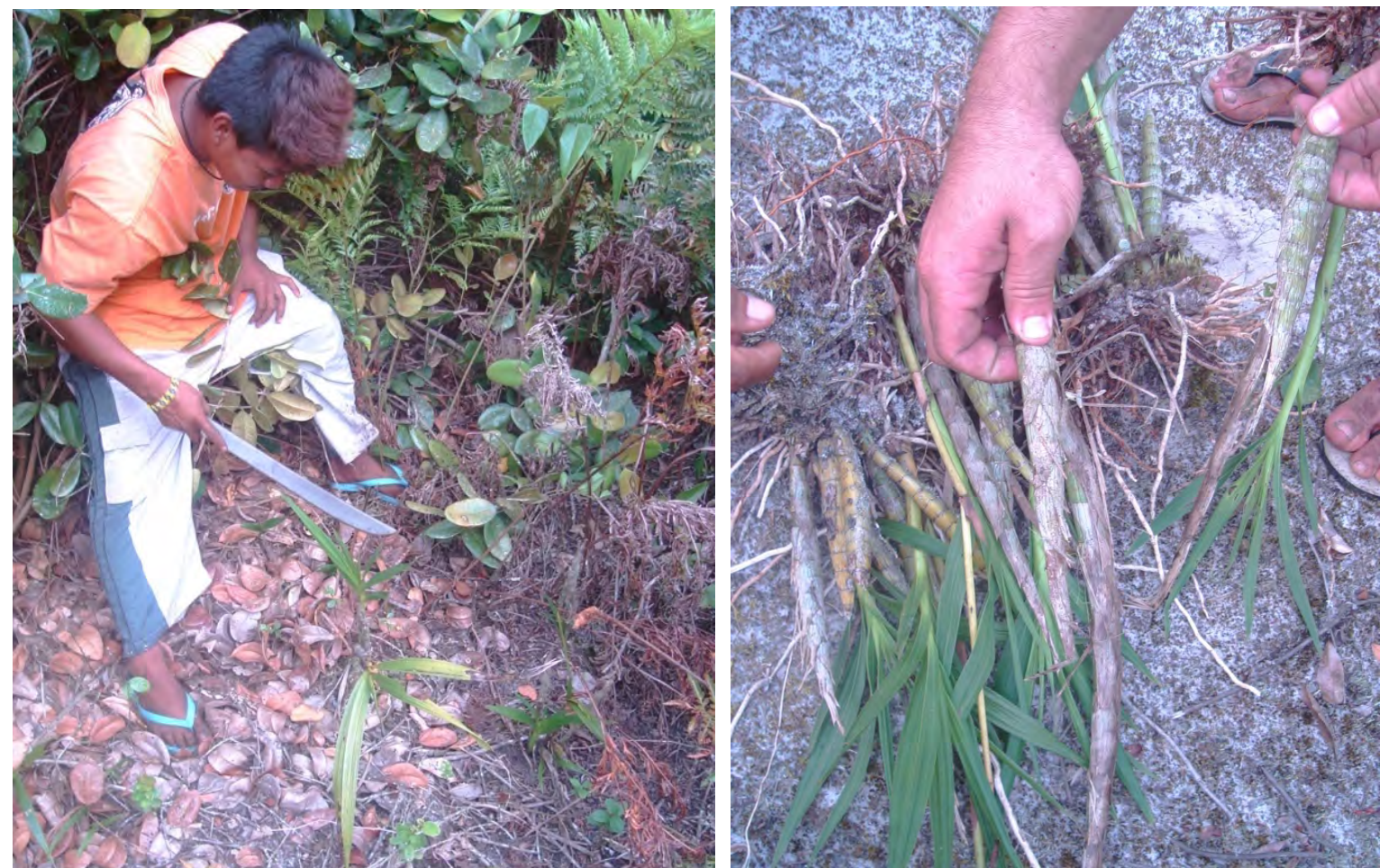

Fonte: Acervo pessoal

Iniciamos a montagem do corpo do mbaraka utilizando um molde de madeira, pequenas morsas e as lâminas de caxeta já cepilhadas e deixadas imersas em água durante a noite, a fim de que fossem modeladas na forma desejada. A participação das crianças durante a oficina foi sempre intensa: interessados e prestativos, auxiliavam na finalização de pequenos objetos, como lixar as cravelhas, ou buscar a bacia de pipocas e as xícaras para servir o lanche da tarde, além de retratarem em desenho livre as atividades vivenciadas naqueles dias. Na manhã do último dia, seguimos com a montagem do instrumento, dando atenção ao acabamento e a finalização de peças a serem anexadas ao corpo e mão do instrumento, como o cavalete e as cravelhas; após o almoço, finalizamos as peças. Antes da colocação, ajuste e colagem do tampo, todos assinaram o instrumento, fechando a parte superior e o deixando para secar. $\mathrm{O}$ encordoamento poderia ser feito apenas depois de pelo menos três dias no intuito de não prejudicar o processo de colagem. Apenas depois de finalizadas as atividades da oficina, o Sr. Cristino da Silva (in memoriam), então, líder religioso da comunidade, levantou um apontamento sobre a madeira que utilizamos, indicando que a utilização do ygari (cedro) como matéria prima seria mais apropriada, tradicionalmente inserida nos artefatos de uso ritual na casa de reza. 
Figura 3.7 - Atividade de capacitação e aprimoramento em técnicas artesanais (Mbaraka)

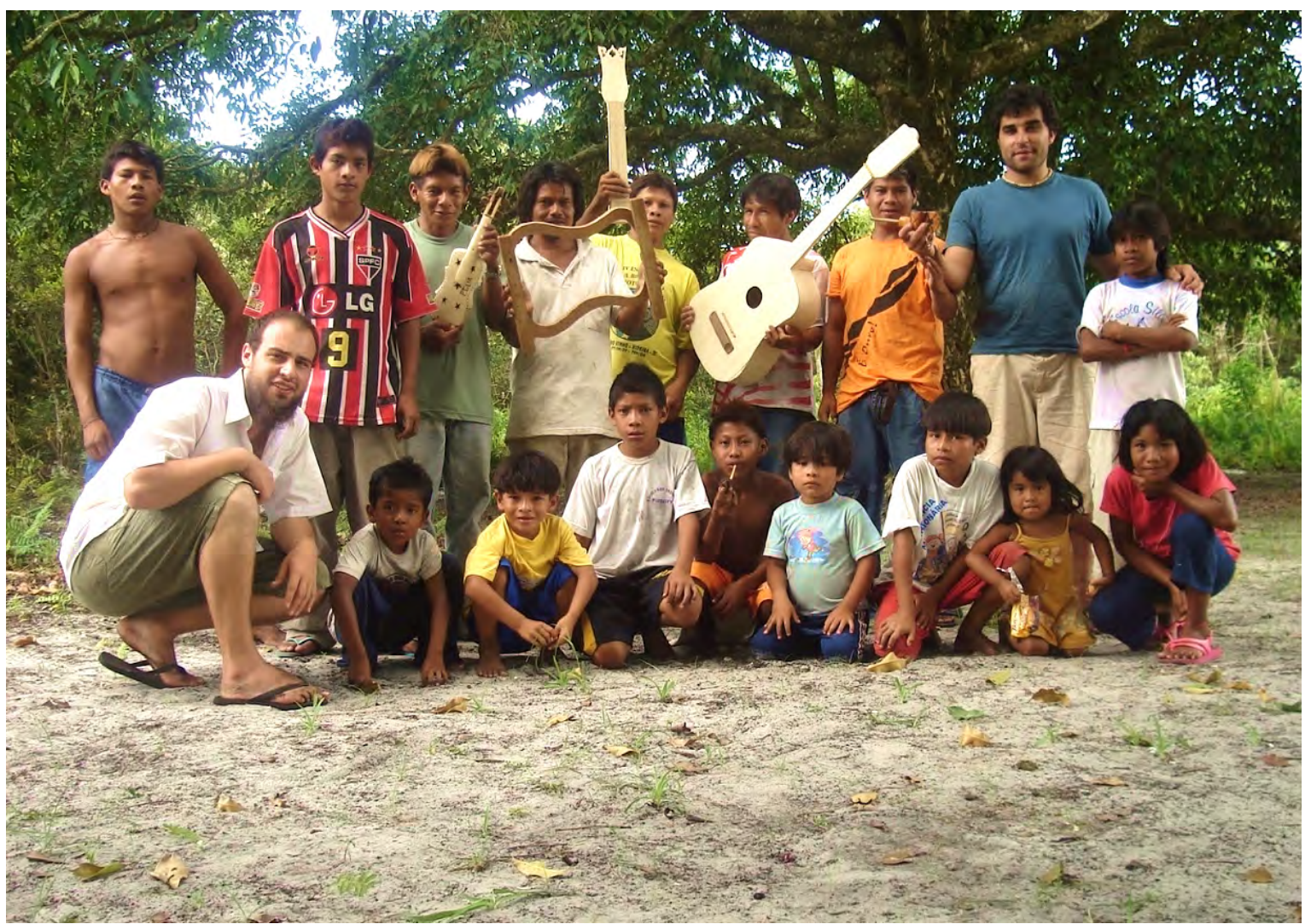

Fonte: Acervo pessoal

Em uma conversa com Mário Gato ${ }^{74}$, houve menção sobre o fato de ser comum os artesãos do litoral norte de São Paulo utilizarem o cedro como matéria prima para confeccionarem suas rabecas. Em Iguape/SP, há também a presença marcante do cedro na confecção dos instrumentos, como sugere Cleiton do Prado no pequeno manual ${ }^{75}$ que fez no intuito de repassar minúcias técnicas da confecção da viola branca e da rabeca, indicando que o uso do cedro pelos Guarani foi apropriada e ressignificada pelas populações caiçaras, tornando-se expressão singular de sua manufatura. Quanto ao ofício indígena, Langer nos apresenta informações interessantes sobre como as ferramentas utilizadas no processo de fabricação de instrumentos são classificadas:

\footnotetext{
"Tradicionais" - conhecidas e transmitidas pelos ancestrais; e "não indígenas". As tradicionais são mais aplicadas no acabamento, tais como lixas, polidor e verniz. Dentre as lixas, existe a cerâmica, especialmente confeccionada para este fim, e outra de folha de $a m b a^{\prime} y$ do mato (embaúba Cecrópia pachystachya), que, ao ficar um dia exposta ao sol, torna-se abrasiva.
}

\footnotetext{
${ }^{74}$ Liderança comunitária, fandangueiro e fabriqueiro que reside em Ubatuba (SP).

${ }^{75}$ Gentilmente cedida pelo autor, a cartilha compõe o segundo anexo da tese.
} 
Outro produto usado no acabamento é a cinza do bambu, que funciona como polidor. Finalmente, o verniz, feito à base de óleo de coqueiro jataí. "Quando o violino [ravé] estiver polido, aplica-se o óleo com um pedaço de pano de algodão, molhado e passado em todo o instrumento ao longo de cinco dias" (VERÓN CAVALHEIRO, 2011, p. 10). ${ }^{76}$

No cozimento das amêndoas do coquinho, era adicionado uma planta muito odorífera denominada tupã kaa. Essa planta deixava o óleo esverdeado e o violino perfumado.

Entre as ferramentas "não indígenas" figuravam em destaque o machado, o facão, a lima, o serrote traçador, a grosa, o enxó, a morsa de madeira, entre outras, ocasionalmente produzidas a partir de objetos de metal, tais como colheres amoladas usadas para escavar madeira. (LANGER, 2012, p. 324)

A questão do envernizamento tem voltado à baila entre fabriqueiros e fandangueiros. Em janeiro de 2019, Aorélio Gasparini Jr. postou algumas fotos (lâmina 3) onde indicava estar preparando os instrumentos para festa do Marujáa ${ }^{77}$, às quais se seguiu a seguinte discussão por WhatsApp, que transcrevemos mantendo a redação original:

Aorélio Domingues: Só passe verniz nitrocelulose ou p.u.

Se não perde o som!

Aurélio Gasparini: Goma-laca indiana, receita Stradivarius!

Fernando Alcantara: Essa aí cola violão no dono? Kkk

Aurélio Gasparini: A ideia é essa! Kkkkk

Caio França: Fóda!

Aorélio Domingues: Sim goma laca!

Especialmente Rsrs,

Nem sei porque tô me metendo no serviço dos outros.

Aurélio Gasparini: Kkkkk quem é da família não se mete meu amigo se ajuda! Aliás venho fazendo diversos experimentos com ceras, vernizes e tintas para ver os diversos tipos de resultados.

Aos poucos vou compartilhando aí!

Aorélio Domingues: Kkkkk.

É que mestre Nemésio uma vez colocou o verniz marítimo e estragou a viola, putz nem sabia o q dizer pra ele, fiquei com trauma.

Aurélio Gasparini: Este eu fiz com cera líquida automotiva, não serviu de acabamento mais a caxeta fica mais branquinha que pele de polako kkkk .

Acho que conheço uma dessas violas [de mestre Nemésio] kkk

Essa já foi com verniz spray, 5 camadas extremamente finas, ficou top!

Esse foi verniz no braço e cavalete, no corpo cera de abelha que ficou ótimo, bem lisinho, mais para polir.

Essa fiz inteira com cera de carnaúba foi a que ficou melhor!

Aurélio Domingues: Orra!

Quem fez esta [tratada com cera de carnaúba]?

Tira uma foto do cavalete.

Aurélio Gasparini: Heraldo Pereira, cavalete cabeça de tamanduá.

(Conversa via WhatsApp em 8/01/ 2019)

\footnotetext{
${ }^{76}$ VERÓN CAVALHEIRO, Ládio. Os Ensinamentos Tradicionais de João Aquino - O Caso dos INstrumentos Musicais Executados com Arco. (TCC em Literatura indígena) . Dourados: UFGD, 2011.

${ }^{77}$ Que ocorreu na Ilha do Cardoso, município de Cananéia, entre os dias 25 e 27 de janeiro de 2019.
} 
Como que por um lapso, a grande maioria dos fabriqueiros não vinha fazendo uso de vernizes nas últimas décadas, sendo recente a retomada desta prática no universo caiçara, tanto pela durabilidade e sonoridade que proporciona, como pelo resultado estético do envernizamento. Juarez Bergmann nos elucida algo de curioso quanto a isso:

A respeito do acabamento nas Rabecas, a maioria delas não possui verniz, inclusive as Rabecas tarahumara $^{78}$, que não utilizam o artifício da aplicação de uma camada de verniz ou de nenhuma outra proteção.

No caso das Rabecas brasileiras, esta característica acabou marcando o instrumento como uma função propositadamente pensada, o que contribui para a percepção do instrumento com esta aspereza ao toque. Sonoro e ao tato.

Porém, um relato do Aorélio parece diferenciar esta percepção. Aorélio comentou que uma vez chegou em seu ateliê e o saudoso Mestre Eugênio estava envernizando uns instrumentos.

Aorélio estranhou aquela situação e perguntou pro Mestre:

- Mestre, pode colocar verniz nos instrumentos do Fandango?

E o mestre disse: - Claro, eu só não faço porque não tenho verniz e é caro comprar, mas você tem. Então estou usando.

Esta narrativa de Aorélio demonstra o quanto a escassez de um material acaba provocando uma situação que se perpetua e acaba sendo percebida, conforme o tempo como algo proposital, criando uma "tradição". (BERGMANN, 2016, p. 169)

Tais como fragmentos de exercícios etnográficos, das ditas “descrições leves”, a la José Jorge Carvalho, seguimos reunindo impressões pessoais, minhas e dos demais interlocutores, as quais revelam atravessamentos estéticos, tecnológicos e políticos, ensejos múltiplos aos agenciamentos multidimensionais norteados pelo inter-relacionamento desses atores. Como mencionado por Jackson (2013, p. 149) ao remomorar uma fala de Minh-ha: “A pesquisa é uma relação com a comunidade", ela nos disse. "Não há fim para isso."

\section{LÂMINA 3}

Testes de verniz, por Aurélio Gasparini: Goma-laca (superior esquerda), Cera líquida automotiva (superior direita), Verniz spray (centro esquerda),

Cera de abelha (centro direita), Cera de carnaúba (abaixo).

Fonte: Fotos de Aurélio Gasparini - Acervo pessoal

\footnotetext{
${ }^{78}$ Instrumentos feitos na região de Serra Madre no México pelo coletivo tarahumara, chamados entre o povo tarahumara de Rabel ou Ravel. Segundo Bergman, "naquela comunidade, os violinos foram introduzidos pelos espanhóis no final do século XVI a partir de missões jesuítas. Após serem adotados pelos habitantes locais, tornaram-se parte integrante de danças cerimoniais conhecidas por matachines e outras reuniões da comunidade, chamadas de tesgüinadas. Assim como em Valadares, as festas são momentos importantes da comunidade tarahumara e revelam, principalmente, a religiosidade de seu povo. As danças executadas por eles não são exatamente sociais, mas cerimônias cheias de significado; são orações cuidadosamente executadas." (BERGMANN, 2016, p. 164 e 169)
} 


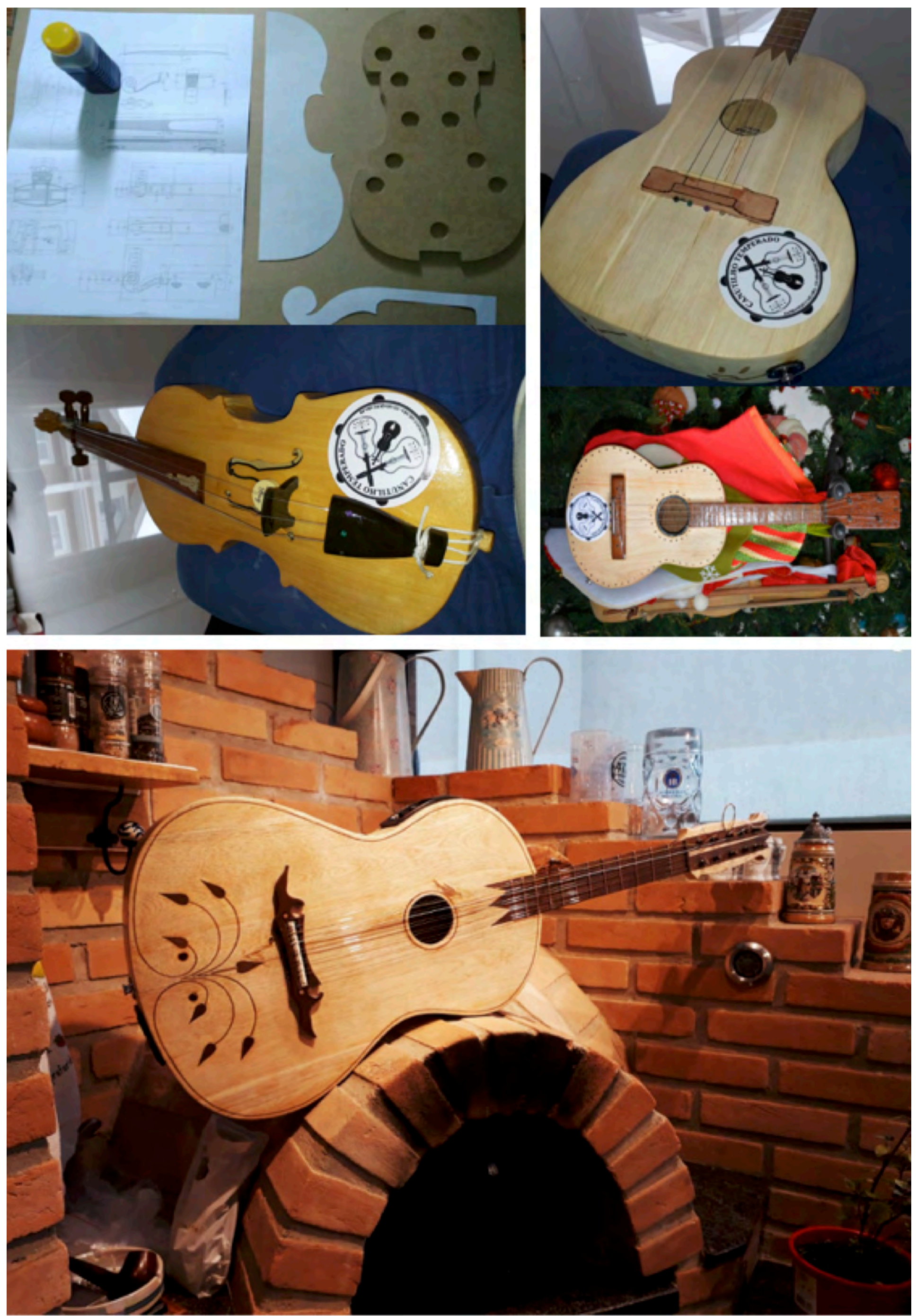




\title{
Fomento, financiamento e mercado
}

\begin{abstract}
Atualmente o fandango vem passando por um momento extremamente novo e peculiar onde percebemos a enorme vitalidade desta manifestação, bem como, sua extrema plasticidade. Apesar das preocupações de muitos estudiosos folcloristas com a possivel dissolução, fragmentação e a perda de uma "autenticidade" do fandango, este se mantém atualizado independentemente do contexto onde é realizado. Atualmente, na ilha dos Valadares grupos de fandango se fazem e se refazem a todo momento, e ainda, fora desta ilha encontramos uma variedade de fandango sendo praticado.
\end{abstract}

Patrícia Martins

Ponto pacífico da importância singular do projeto Museu Vivo do Fandango foi a sua inclusão no ano de 2011 na Lista de Melhores Práticas de Salvaguarda do Patrimônio Imaterial da Humanidade, da Unesco. O projeto foi desenvolvido sob a forma de uma pesquisa-ação participante que envolveu comunidades caiçaras do litoral das regiões Sul e Sudeste do Brasil.

O projeto constatou que a prática dessa manifestação cultural, por diversos fatores, apresentava-se de maneira desarticulada e cada vez mais rara. Implementada a partir de 2005 , a pesquisa envolveu a participação de cerca de 300 fandangueiros da região e teve como principal desdobramento a constituição do museu comunitário a céu aberto, sob a forma de um circuito de visitação e troca de experiências em cinco municípios da região. $\mathrm{O}$ circuito inclui casas de fandangueiros e artesãos de instrumentos musicais, centros culturais e de pesquisa, espaços de comercialização de artesanato caiçara, além de locais de disponibilização de acervos bibliográficos e audiovisuais. (IPHAN, 2014)

O Museu Vivo foi criado para promover atividades em prol da salvaguarda do fandango (cujo modelo de prática de salvaguarda se baseia na cooperação), como elemento importante do patrimônio cultural das comunidades envolvidas, e promoveu a sensibilização do público por meio da apresentação de espetáculos locais, de seminários com professores, publicação de livros e CDs, e da disponibilização de coleções bibliográficas e audiovisuais para consulta. Infelizmente a página construída pela ação se encontra desativada, havendo esforços por meio do Comitê de Salvaguarda do Fandango Caiçara para que seja novamente disponibilizada na rede. 
Os Encontros de Fandango e Cultura Caiçara foram realizados nos anos de 2006 e 2008, na cidade de Guaraqueçaba/PR. A primeira edição contou com financiamento do Programa Petrobras Cultural e apoio da Prefeitura Municipal de Guaraqueçaba. A gestão foi feita pela equipe envolvida com o projeto Museu Vivo do Fandango (Associação Cultural Caburé/RJ) e por um coletivo de associações culturais da região - Associação de Cultura Popular Mandicuera/PR, Ponto de Cultura Caiçaras/SP, Associação de Fandangueiros de Guaraqueçaba/PR, Associação Jovens da Jureia/SP e Rede Cananéia/SP. Nesta ocasião foram lançados o livro e o CD resultados do projeto. Já a segunda edição foi viabilizada pelo Prêmio Avon Cultura de Vida, também com apoio da Prefeitura de Guaraqueçaba, e gerida pela Associação de Fandangueiros de Guaraqueçaba, juntamente com o coletivo de associações. (IPHAN, 2011, p. 13).

Em Paranaguá, além das inúmeras ações levadas a cabo pelos grupos fandangueiros que lá se configuraram, como bailes, oficinas e ações de formação, uma iniciativa iniciada em 2002 vem reverberando, ampliando as discussões sobre a prática fandangueira e subsidiando, inclusive, novas legislações nos âmbitos local e regional. A iniciativa denominada Festa do Fandango Caiçara de Paranaguá vem desde sua criação possibilitando este espaço de vivências, trocas e intercâmbios.

A $1^{\text {a }}$ edição, que aconteceu entre os dias 26 e 29 de setembro de 2002, contou com a apresentação do grupo do Mestre Romão, Mestre Eugênio, da Família Pereira e dos grupos Fandango do Paraná, Viola Quebrada, Mundaréu e CaxaPrego, apresentações da Banda Fato e dos artistas Leonardo Damião e Guilherme Costa. Além das apresentações e dos bailes de fandango, houve o relançamento do livro "Tocadores, homem, terra, música e cordas", lançamento da edição especial do gibi Jekupé e lançamento oficial do CD Cantos de Festa e de Fé. Também foram realizadas oficinas de fandango, contações de estórias e causos. Durante todo o evento houve feira de artesanatos, exposição de artes plásticas e atividades recreativas e culturais.

\section{LÂMINA 4}

Cartaz da $1^{\circ}$ Festa do Fandango de Paranaguá, 2002

Fonte: Acervo pessoal 


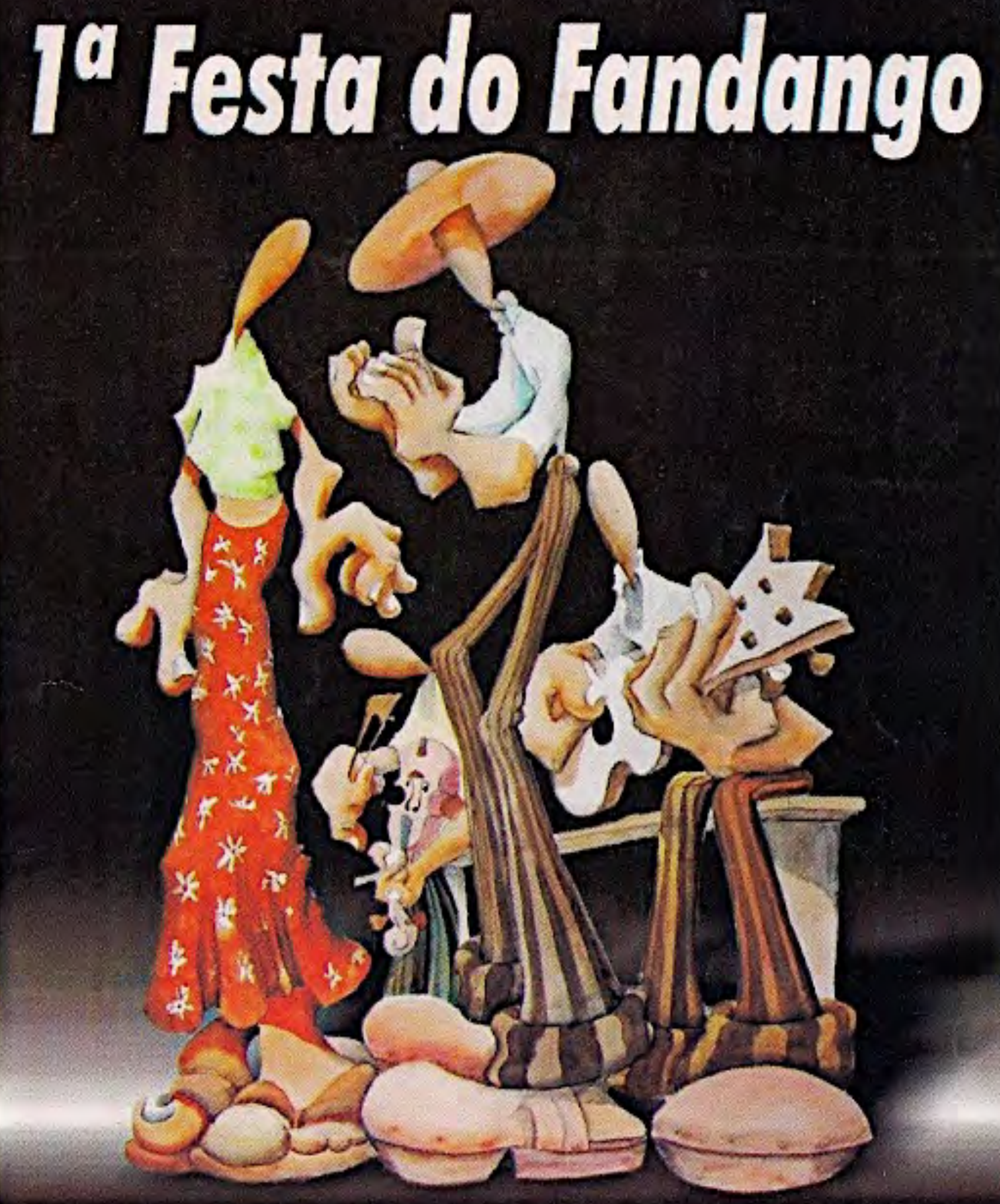

Local : Pça. Ciro Abalem - Ilha dos Valadares Data : 26 a 29 de Setembro de 2002

Realizaçoio:

Comun. N. 5". das Maregantes

Grupo de Fandange:

- mestre Euginio

- Caigrans de Parand
Pofrocínio:

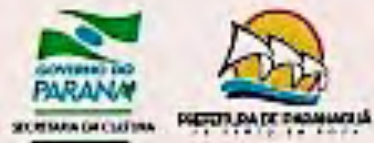

SESC
Co-Patrocínio:

Eli

TRANSPETRO 
Entre a quarta e a quinta edições da festa, houve um longo período, de nove anos, em que a mesma não foi realizada. Nesse intervalo, tive a oportunidade de participar de outras ações em conjunto com a Associação de Cultura Popular Mandicuera, como a elaboração e execução de ações junto à SEED (Projeto Fandango na Escola), acima citado, e ao MINC (Projeto Pontos de Cultura), que, entre outras atividades, implementou o Atelier de Luteria Rodrigo Domingues, na sede da associação.

Foi nesse período também que se iniciou a execução do projeto Cotinga, já como atividade de extensão universitária vinculada ao Curso Superior de Produção Cênica da Universidade Federal do Paraná, que, entre outras ações junto a parceiros do IFPR, da prefeitura de Paranaguá, do IPHAN e dos grupos de fandango de Paranaguá, vem auxiliando a realização das festas desde então. Cabe salientar que nosso entendimento quanto às ações de extensão têm a ação comunicativa ${ }^{79}$ como norte, inspirando-se nos modelos difundidos pelo educador Paulo Freire, onde a comunicação dialógica - seja em torno de um conhecimento científico e técnico seja de um conhecimento experiencial - "é a problematização do próprio conhecimento em sua indiscutível reação com a realidade concreta na qual se gera e sobre a qual incide, para melhor compreendê-la, explicá-la, transformá-la." (FREIRE, 2015, p. 06)

Agregando e confluindo linhas de reflexão que convergem a tais propósitos, a programação da quinta edição da festa contou com a presença do professor Carlos Diegues, da Universidade de São Paulo, que prestou auxílio aos grupos de trabalho, que tinham por objetivo discutir demandas e metas para o Plano de Salvaguarda do Fandango Caiçara em Paranaguá. Os documentos elaborados durante a festa vieram a integrar o plano de cultura do município, que, em 2014 e 2015, contou com editais específicos para o fandango caiçara, além de contemplar também outras áreas culturais e artísticas de incidência no município.

\footnotetext{
${ }^{79}$ Jürgen Habermas será o autor que buscará enfrentar os fantasmas detectados por Weber, Adorno e Horkheimer nos processos de racionalização societária. [...] A dominação do homem sobre a natureza, converte-se em dominação do homem sobre o homem, em mundo administrado em nome da técnica, abrindo espaço para a eclosão da des-razão no seio da sociedade de consumo moldada pela indústria cultural. Para Habermas, a análise destes autores chega a um impasse porque eles trabalham com um conceito restrito de razão. Em virtude disto, eles confundem o processo de modernização capitalista, que é calcado na razão instrumental, como sendo a própria racionalização societária (Habermas, 1987). Agindo desta forma, confundindo racionalidade do sistema com racionalidade da ação, estes autores só conseguiram situar a espontaneidade livre de reificação em poderes irracionais como o carisma, no caso de Weber, a arte, para Adorno e o amor, para Horkheimer. Para sair deste impasse, Habermas propõe um salto paradigmático, no qual abandona-se o paradigma da consciência a que estes autores encontram-se presos, em prol de um paradigma da comunicação.[...] Depois que Hegel mostrou o caráter intrinsecamente social e histórico das estruturas da consciência, que Marx revelou que a mente não é o campo da natureza, mas o inverso e que as formas de consciência são representações ocultas das formas de reprodução social; depois que Darwin estabeleceu o vínculo entre inteligência e sobrevivência e, finalmente, que Nietzsche e Freud revelaram o inconsciente no âmago da consciência, dá-se uma dessublimação do espírito e um enfraquecimento da filosofia (McCarthy, 1984). O pensamento filosófico perde sua auto-suficiência, caem as esperanças de se encontrar os fundamentos últimos de uma primeira filosofia. (PINTO, 1995, p.78)
} 
O fandango caiçara recebeu o título de Patrimônio Cultural Brasileiro do Ministério da Cultura em 2012, mas foi durante a $5^{\text {a }}$ Festa do Fandango Caiçara de Paranaguá - realizada entre os dias 15 e 17 de agosto de 2014 - que ocorreu a entrega das certidões de registro aos mestres fandangueiros de lá. A cerimônia teve espaço na agenda de vereadores e do prefeito, os quais receberam autoridades estaduais e nacionais do IPHAN para a entrega dos títulos de reconhecimento aos representantes dos grupos locais. A solenidade de abertura ocorreu na Câmara de Vereadores de Paranaguá, sendo homenageados como representantes dos grupos fandangueiros os mestres Brasílio Ferrer, Nemésio Costa, Aorélio Domingues e Romão Costa (representado por seu neto Luiz Aguiar Junior).

A $6^{a}$ Festa de Fandango Caiçara aconteceu entre os dias 14 e 16 de agosto de 2015. Contando com a Exposição Fotográfica As Marcas de Valadares, o lançamento de livros e do CD Fandango - A Arte e a Expressão Popular, disco gravado com módico financiamento público, mas que contemplou a totalidade dos grupos da Ilha dos Valadares. A festa nesse ano foi sediada na Casa Dacheux, prédio histórico que durante a gestão da então Fundação de Cultura de Paranaguá esteve disponível para os grupos locais realizarem ensaios e reuniões. A programação ainda contou com rodas de conversa, apresentações infantis, mesas de debate sobre planos de manejo da madeira caxeta - visando à sustentabilidade das ações culturais e ambientais em território caiçara - e uma conferência sobre a experiência pernambucana de valorização dos mestres da tradição oral, com a presença da antropóloga Maria Acserald.

Quando o assunto trata de legislação, as questões parecem demandar esforços sobrehumanos, seja na elaboração dos textos necessários, seja pelas dificuldades de encaminhamento que, via de regra, circundam esses trâmites. A antropóloga Maria Acserald esteve à frente da Coordenadoria de Cultura Popular e Pesquisa/Fundarpe, na coordenação do Edital do III Concurso Público do Registro do Patrimônio Vivo de Pernambuco, realizado em 2007, e compartilhou conosco suas experiências nesse pleito, expondo alguns dilemas identificados ao assumir um cargo na gestão pública para a cultura. Permitindo melhor diálogo com as comunidades a fim de minimizar problematizações desenvolvidas nos debates acadêmicos e institucionais sobre o tema.

Neste mesmo ano aconteceu o lançamento do Projeto Artesanias Caiçaras: a Sustentabilidade do Fandango Através da Construção de Instrumentos Musicais, financiado pelo edital do Programa Nacional do Patrimônio Imaterial (PNPI) do Iphan.

Desde então a festa tem acontecido todos os anos, de forma ininterrupta, consolidando a rede fandangueira e oportunizando o diálogo, a troca de experiências e o aprendizado mútuo dos envolvidos. 
O projeto Orquestra Rabecônica do Brasil teve inicialmente por objetivo possibilitar à comunidade curitibana o acesso a elementos da história e da cultura caiçara, pensados, principalmente, através de suas tradições orais, reunindo, sob os auspícios da Lei Municipal de Incentivo à Cultura de Curitiba, músicos e instrumentistas de formações variadas, alavancando ainda um processo ímpar de experimentalismo organológico. Além de violas, rabecas e machetes, foram também produzidos rabeolas (violas de arco), rabecões (contrabaixos acústicos) e rabellos (cellos), todos com madeiras locais (ou similares) e nos moldes estéticos dos instrumentos caiçaras, possibilitando, ainda, o diálogo da música tradicional do litoral com circuitos de difusão que, em geral, são ocupados pela música erudita em Curitiba.

Figura 3.8 - Ensaio da Orquestra Rabecônica do Brasil, 2011

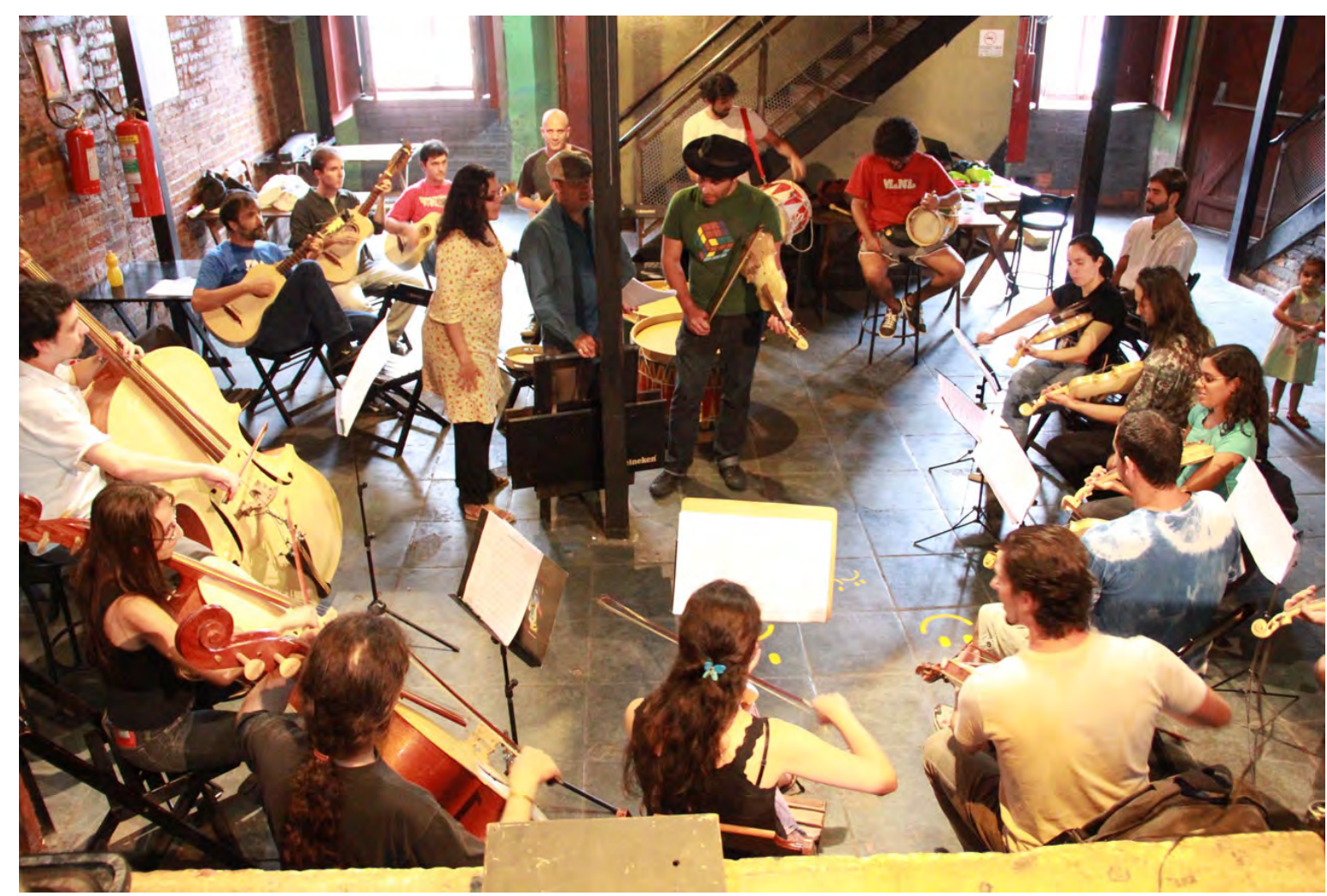

Fonte: http://orquestrarabeconicadobrasil.blogspot.com/

O projeto Sementes Caiçaras, do grupo Fandango Caiçara de Ubatuba foi realizado no ano de 2018 sob os auspícios do Programa de Acesso à Cultura, promovido pela Secretaria de Cultura do Governo do Estado de São Paulo. Ações voltadas à transmissão de saberes da cultura caiçara, tanto em Ubatuba quanto em outras regiões do litoral paulista, e iniciativas com vistas à mobilização e articulação de fandangueiros, grupos de fandango caiçara, instituições parceiras da sociedade civil e poderes públicos dos municípios, têm sido levadas a cabo nos últimos anos, como no caso da $1^{\text {a }}$ Festa do Fandango, realizada em Cananéia, no ano de 2016, 
que contou com apoio da Secretaria da Cultura do Estado de São Paulo, por meio do Programa de Ação Cultural (ProAC). Iniciativas que vêm contando também com o apoio dos municípios do território caiçara paulista, suprindo necessidades básicas de infraestrutura (tendas e sonorização) para a realização das festas do fandango.

O projeto Ô de Casa: Mobilização, Articulação e Salvaguarda do Fandango Caiçara ${ }^{80}$ foi outro exemplo de ação com vistas a mobilizar e articular os atores culturais do território caiçara para construção do Plano de Salvaguarda do bem registrado Fandango Caiçara, integrando paranaenses, paulistas e fluminenses para constituir um coletivo deliberativo, responsável pelo monitoramento, a avaliação e proposição de ações relativas ao bem cultural. Para tanto, foram realizadas reuniões de mobilização e articulação, oficinas, fóruns institucionais (poder público e privado), mesas de debate, entre outras atividades correlatas, envolvendo os municípios de Paranaguá e Guaraqueçaba, no Paraná; Cananéia, Iguape, Peruíbe e Ubatuba, em São Paulo; e Parati, no Estado do Rio de Janeiro. Também foram realizadas ações de promoção do bem cultural visando ao fortalecimento da articulação entre os fandangueiros e o intercâmbio entre os diferentes atores envolvidos. Desse modo, a prática e a salvaguarda do fandango caiçara, como ação e mobililzação, propiciaram espaços de diálogo e integração entre os detentores, entidades civis e governamentais, pesquisadores, produtores culturais, artistas e demais interessados em temas da cultura caiçara - culminando com a consolidação do Comitê Gestor de Salvaguarda do Fandango Caiçara, na última ação do projeto, realizada no município de Ubatuba, em dezembro de 2017.

No Paraná, programas como o Prêmio Arte Paraná, da então Secretaria de Cultura do Estado, possibilitaram a circulação de grupos de fandango e folia do Divino, de Paranaguá, Guaratuba e Guaraqueçaba pelo interior do Estado, no ano de 2017, ano em que também foi realizado o espetáculo Lendas do Mar de Lá, com autoria e direção de Mariana Zanette. O espetáculo nasceu como fruto de pesquisa conjunta com os membros do coletivo da Associação Mandicuera, tendo como estrutura narrativa contações de histórias e lendas da cultura do litoral paranaense e, como público, mais de mil crianças, na região metropolitana de Curitiba.

Tais exemplos não dão conta de abranger a totalidade das ações levadas a cabo pelos diversos coletivos fandangueiros nos últimos anos, mas são suficientes para ilustrar o impacto e o rendimento dos debates no âmbito da implementação de políticas públicas para a cultura no território caiçara.

\footnotetext{
${ }^{80}$ Contemplado pelo Chamamento Público n ${ }^{\mathbf{o}}$ 01/2015 - Salvaguarda do Fandango Caiçara (Processo 01450.009749/2015-71)
} 
Figura 3.9 - Cena do espetáculo Lendas do Mar de Lá, Centro Cultural Boqueirão, Curitiba, 10/2017

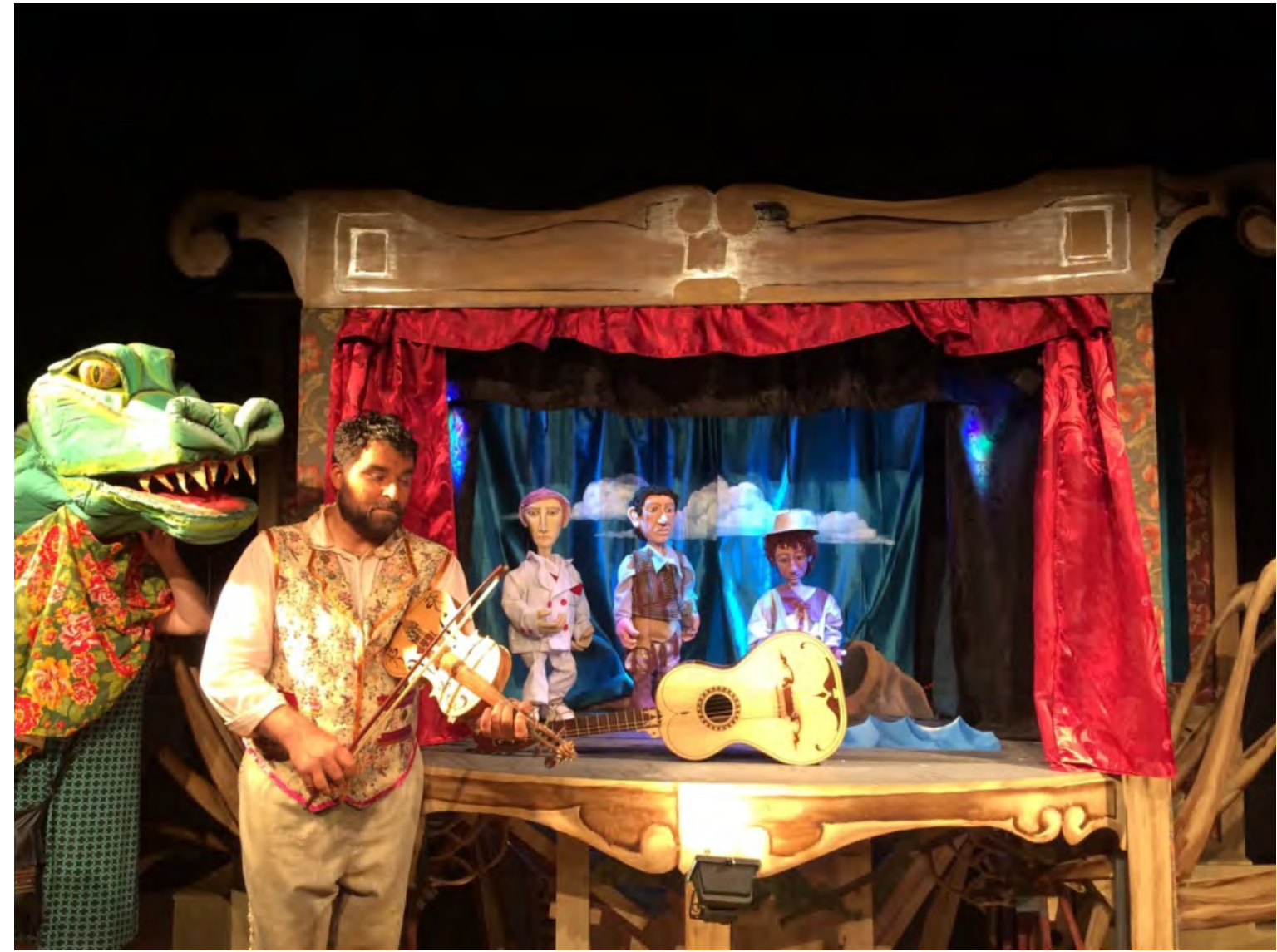

Fonte: Acervo pessoal

De fato, os agenciamentos junto a iniciativas públicas e privadas, prêmios, leis de incentivo fiscal e fundos municipais e estaduais voltados para ações culturais foram alavancados nas últimas duas décadas, quando houve uma interação significativa entre o poder público e os detentores de bens culturais. Passamos, atualmente, por um conturbado momento, no qual o desmanche das políticas públicas e das instituições culturais e artísticas se faz evidente. Apesar disso, percebe-se que os coletivos fandangueiros vêm, cada vez mais, buscando fontes alternativas de financiamento, inclusive realizando, por exemplo, as festas do fandango de modo independente. Como já mencionado, o conceito de mutirão vem sendo reinventado e aplicado aos ajutórios interestaduais realizados no ano de 2018 em Paranaguá, Cananéia, Ubatuba, Iguape e Peruíbe; e, em janeiro de 2019, no Marujá (Ilha do Cardoso, município de Cananéia) e com sinalização de que seja realizado, ainda, um encontro em Paraty no segundo semestre de 2019, agregando cada vez mais participantes às ações, consolidando e ampliando as redes de interação fandangueira. 


\title{
Espetacularização e Associativismo: o fandango como pessoa jurídica
}

\author{
A natureza humana, seu meio específico e seus objetos \\ estão em processo ininterrupto de modificação e \\ produção de si nos devires, tempos e movimentos reais \\ que atravessam a existência desse animal que se \\ autodenomina homem.
}

Luiz Fuganti

Cabe ressaltar que a influência de folcloristas e entusiastas das manifestações populares desde as primeiras décadas do século XX, sobretudo entre as décadas de 1940 e 1960, foi de fundamental importância para a manutenção da prática do fandango no Estado do Paraná e, de modo mais amplo, no universo caiçara. É notória a contribuição de José Loureiro Fernandes, Fernando Corrêa de Azevedo e Manoel Viana, sendo, o último, responsável pela coordenação da Subcomissão Paranaense de Folclore, fundada em Paranaguá no ano de 1959. (RODERJAN, 1998, p. 6/7) Nesse período de efervescência cultural, onde estava em curso a implementação das comissões estaduais e subcomissões de folclore, é que Inami Custódio Pinto retoma sua proximidade com atividades no litoral.

Inami Custódio Pinto (1930-2014), folclorista que ganhou grande projeção no Paraná. Natural de Curitiba, passou a infância em Paranaguá, onde conheceu o fandango. [...]

Durante a Segunda Guerra, o pai de Custódio Pinto foi transferido para Santa Catarina. Em 1952 ele retornou ao Paraná e, de volta a Paranaguá, surpreendeu-se com a desarticulação do fandango, que, segundo ele, teria sido alvo de proibições durante o período de guerra. A partir de então, resolveu empreender pesquisas sistemáticas sobre o tema. A forma como se envolveu com o fandango é bastante emblemática da afetividade e identificação com que muitos folcloristas desse período se relacionavam com o campo de pesquisa, procurando afirmar a legitimidade de sua atuação. (CORRÊA, 2016, p. 420)

Período, também, em que os primeiros grupos de fandango são constituídos institucionalmente. O trabalho iniciado por Inami, na década de 1960, toma novos contornos, incitando o diálogo com instâncias das administrações pública local e estadual, de forma direta, obtendo subsídios públicos para manutenção do grupo, então capitaneado pelo Mestre Romão, como mencionado em entrevista para o Museu Vivo do Fandango (2006, p. 54), que reproduzimos mantendo a redação original: 
O Inami disse: "olha eu to querendo fazer um grupo de fandango, resgatar o fandango, como é que nós vamos fazer?". Eu disse: "olha eu não posso". (...) Aí ele disse: "Amanhã eu vou lá em tua casa. Eu falei com o secretário que ia um grupo de fandango pra lá [Curitiba] e agora fica ruim. Andamos por tudo quanto é parte e não encontramos fandangueiros. Nas ilhas, Serra Negra, Guaraqueçaba, Rio dos Patos, Antonina, Rocha Pombo: não encontramos em parte nenhuma". Aí eu disse: “tá, eu dou uma ajuda pra vocês". "Ah, então você procura aí”. Aí eu procurei, até falei com Eugênio, o Moacir. O pessoal era um pouco de Guaraqueçaba, um pouco do Maciel, que era Brasílio. E fizemos, fizemos doze par[es]. Aí fomos ensaiar. Tinha uma casa aqui, que fazia fandango, fazia baile. "Ah, dá pra nós dançar aqui?" "dá”. Aí fizemos doze ensaios, mais ou menos. Aí um dia: “Ó, Romão, nós vamos pra Curitiba, no Colégio Estadual. O Secretário está esperando nós’. Aí fomos recebidos muito bem. (...) Aí começamos a sair por aí, pra se apresentar.

A partir da década de 1960, é inaugurado um novo modelo de manutenção desse bem imaterial, onde a formatação de grupos para apresentações artísticas, a inserção de indumentárias e a compactação da duração das modas - visando apresentações para audiências variadas - se consolidam como elementos éticos, estéticos e artísticos, ainda presentes na atualidade, não apenas no contexto paranaense, mas, também, em outras localidades do território caiçara.

A citada "compactação do tempo" em apresentações, com vistas a atender demandas artísticas em eventos culturais fora do contexto caiçara, é ainda recorrente, como ilustra o depoimento de integrantes do grupo de Ciranda Caiçara de Tarituba, versando sobre a formatação de suas performances para atender demandas de atividades culturais junto ao SESC de Paraty:

A Gente apresentou no circuito SESC Rio, na época que a gente lançou o livro ${ }^{81}$ Projeto seis e meia. Então é assim, a pessoa tá lá no Rio, saindo do trabalho, vai lá, meia horinha, que você vai fazer uma atividade cultural. A gente não conseguia encaixar, em meia hora, um baile. Não conseguia, um baile segue noite adentro. Como você vai encaixar em meia hora? Deu um desespero: vai, cronometra, isso é muito estranho. Parece que você está sendo partido, assim. Aí mandaram um coreógrafo pra gente, não pra coreografar, mas pra orientar, pois a gente não conseguia enxugar. Porque é difícil você falar pro mestre, se ele está num improviso: Parô! [...] A gente acaba colocando umas regras que acabam prendendo muito a gente, a gente tá pra brincar, nós somos brincantes. As pessoas não entendem, nós não somos Show. A gente tá fazendo, mas somos brincantes, temos que brincar, tem que ser prazeroso pra gente. (Simone Bulhões, durante a reunião em Ubatuba dez 2017 - transcrição e grifos nossos)

${ }^{81}$ Vamos Indo Na Ciranda: Mestre Chiquinho De Tarituba - De Bailes E Historias (Bulhoes Netto et al, 2004). 
Rogério Gulin ${ }^{82}$ também comenta aspectos de espetacularização do fandango a partir de sua experiência junto a coletivos fandangueiros:

O fandango está neste espaço, a gente tem levado eles para se apresentar em SESCs em São Paulo, aqui em Curitiba, ele [fandango] assumiu uma característica de show, e mesmo na época [60/70] ele já era usado né. Eu me lembro do Inami contar que eles traziam gente de fora, por exemplo o cônsul da Noruega, faziam baile de fandango para os caras, apresentação. Vinda de secretários, eles desciam para Morretes, então sempre esteve muito associado a isso. (TRÂNSITOS CAIÇARAS, 2017, 29'03”' - 29'30" - transcrição nossa)

A moda citada por Gulin foi recolhida por Custódio Pinto e transcrita por Carlos Todeschini, tratando-se de uma chamarrita de louvação, de autoria de Manequinho da Viola. Segundo Custódio Pinto (2010, p. 122), nessas modas de louvação, “os violeiros, que também são cantores, improvisam os versos que brotam espontâneos de sua alma, agradecendo aos convidados especiais presentes e ao provedor da festa", mencionando incentivadores, organizadores ou patrocinadores, narrando fatos históricos nacionais e regionais.

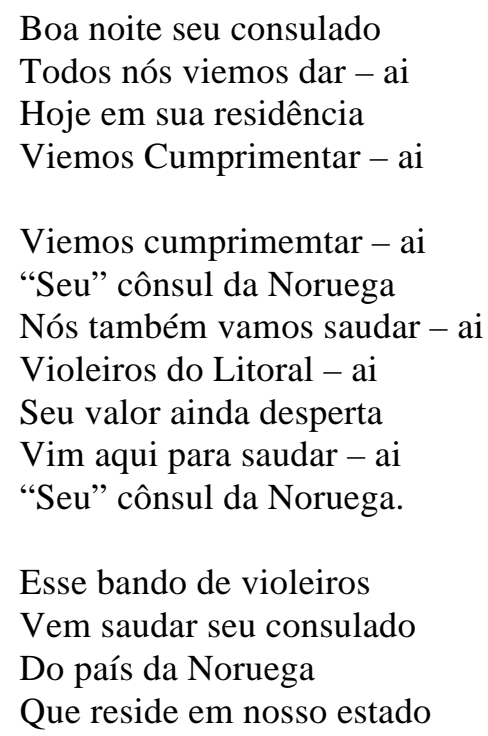

Menções ao fandango como prática festiva, musical e coreográfica, surgem a partir dos compêndios do folclore nacional, consolidados pelo estabelecimento da Comissão Nacional de Folclore, em 1947, posteriormente escrutinados e sistematizado por autores como Alceu Maynard de Araújo (2014), Rossini Tavares de Lima (1981), Fernando Corrêa de

\footnotetext{
${ }^{82}$ Compositor, instrumentista, arranjador e pesquisador musical (folclore e música caipira). Entre outros trabalhos junto aos grupos Viola Quebrada e Terra Sonora, cuja propostas artísticas se voltam ao gênero caipira e a musicalidade do mundo, em 2005, fez juntamente com Oswaldo Rios a direção musical do projeto Museu Vivo do Fandango, cujo resultado fonográfico contou com a participação de cerca de 300 fandangueiros das regiões de Paranaguá, Morretes e Guaraqueçaba, no Paraná, Cananéia e Iguape em São Paulo.
} 
Azevedo(1973 e 1978) e Inami Custódio Pinto (1983, 1992, 2003, 2004, 2010), sendo, este último, um dos principais entusiastas paranaenses da manifestação, cuja interação com fandangueiros se consolida nas décadas de 1950 e 1960. Seu reconhecimento e relevância parecem ser ponto pacífico tanto entre fandangueiros quanto nos círculos intelectuais e acadêmicos. À parte as críticas sobre seu papel na "folclorização" do fandango, e a pejoratividade que, por vezes, inunda seu discurso, é notável seu esforço na divulgação e difusão deste folguedo. Alavancado pela institucionalização do primeiro grupo de Fandango, articulado por Inami e com apoio de Manoel Viana, seu mentor intelectual e principal colaborador, este novo modelo de produção e difusão do fandango vem deixar traços marcantes no desenvolvimento posterior dessa manifestação cultural no Paraná, em que se pese sua interface com as políticas patrimoniais, haja vista que o fandango foi registrado como patrimônio imaterial no ano de 2012 e que sua circulação por mercados em dimensões locais e globais representa interessante ponto de inflexão e reflexão.

Após o desenvolvimento da recente legislação que rege os procedimentos sobre o patrimônio imaterial, como no caso da política de patrimonialização dos bens culturais imateriais - objeto do Decreto 3551/2000 (Presidência da República, 2000) que instituiu o Inventário Nacional de Referências Culturais (INRC), no intuito de "identificar e documentar os bens culturais atendendo à demanda pelo reconhecimento de bens representativos da diversidade e pluralidade culturais dos grupos formadores da sociedade" (IPHAN, 2000, p.8) compreendemos que, anteriormente à formulação de tais políticas de patrimônio, os antropólogos e mesmo os folcloristas já vinham desenvolvendo pesquisas e/ou inventariando diferentes bens culturais, porém sem vínculos com ações de políticas públicas que acarretassem no reconhecimento, divulgação e fomento dessas expressões.

Nesse contexto, nosso foco permeia a participação dos coletivos artísticos fandangueiros na vida sociocultural das localidades onde incidem e se atualiza a partir das transformações paradigmáticas vivenciadas e provocadas por atores diversos, mediadores, produtores culturais, pesquisadores, detentores e fazedores de fandango, direcionando-se mais aos desenvolvimentos ulteriores que aos elementos ditos "tradicionais" pela bibliografia e pelos interlocutores consultados.

Constantemente o fandango em Valadares [e generalizadamente no território caiçara] passa por re-significações a partir destas relações que estão acontecendo entre o sítio, a ilha e a cidade. Observando esta dinâmica podemos destacar três modalidades que envolvem o fazer fandango atualmente na ilha. O primeiro deles seria o "fandango doméstico", aquele fandango realizado nos bares e nas casas de fandangueiros em Valadares. 
Estes momentos estariam restritos a um círculo mais íntimo que envolve parentes e camaradas, remetendo diretamente ao tempo dos sítios. Em seguida, teríamos o "fandango de baile", momento onde os diversos grupos de fandango e fandangueiros reúnem-se para fazer fandango na ilha. Realizados nos finais de semanas, o "fandango de baile" é a ocasião onde ocorre a "mistura" de diferentes estilos e "linhagens fandangueiras". E, finalmente, encontramos o "fandango de espetáculo", momento onde o fandango extrapola os limites dos sítios e da ilha e vai ao encontro dos circuitos urbanos, através de apresentações, oficinas, gravações de imagens e de cd's, entre outros" (MARTINS, 2006a, p. 11)

As constatações de Patrícia Martins nos conduzem ao melhor entendimento das facetas multidimensionais nas quais transitam o fandango na atualidade. Ao enunciarmos as características do fandango doméstico, os agenciamentos decorrem ainda do compadrio e das relações vicinais e de camaradagem sendo restrito às localidades e contextos onde ocorrem. Já o fandango de baile, introduz novas dimensões a serem escrutinadas, mesmo que ocorrendo nas comunidades, pressupõe demandas de produção executiva no que se refere à agenda dos espaços, a divulgação do evento junto à comunidade, contatos, equipamento de som e cachês, elementos imprescindíveis no caso do fandango de espetáculo (salvo situações de parcerias institucionais ou ainda atividades de cunho filantrópico, quando os participantes abrem mão de seus cachês).

Neste panorama, o traquejo junto a diversos órgãos públicos e a busca por fontes de financiamento se faz mister, em menor medida nos bailes e corriqueiramente no fandango de espetáculo.

Como mencionado anteriormente, a intervenção propositiva de mediadores, produtores e pesquisadores reverbera no cotidiano de nossos interlocutores, parceiros e camaradas:

Com a antropologia fui aprendendo a olhar de forma mais dialética a relação entre transformações e permanências, sabendo que as mudanças devem ser pensadas dentro de alguns princípios que estruturam o sistema social. Em meu caso, as transformações vistas no fandango de alguma forma estavam conectadas com as experiências de um "fandango da memória" destes fandangueiros, bem como, com suas aproximações com um contexto urbano. Não quero dizer com isso que os fandangueiros e seus fandangos se adequam mecanicamente a uma modernidade que lhe é externa. Acredito que este processo ocorre a partir de apropriações sempre negociadas, havendo respostas nativas bem sólidas frente às suas condições de modernidade e tradição. Até este momento da pesquisa podemos compreender que fandangos e fandangueiros da ilha dos Valadares combinam diferentes formas de se relacionar com o passado, ao re-significarem o fandango tornando-o um 'bem cultural' valorizam-na não só dentro de um mercado cultural ou em circuitos de difusão, mas também na constituição de suas identidades e sociabilidades. (MARTINS, 2006a, p. 17) 
A institucionalização dos grupos de fandango, para além das motivações folcloristas das décadas de 1960 e 1970, apresenta novas demandas desde os anos 1990, quando a configuração de pessoas jurídicas passa a ser de relevante importância para contratação de serviços artísticos e culturais, tanto no trato administrativo junto a órgãos municipais, estaduais e federais de fomento, quanto na ampliação da possibilidade de concorrência em editais, prêmios e demais ferramentas dessa natureza, voltadas a práticas culturais, sociais, ambientais ou educacionais.

A consolidação do grupo parnanguara Mestre Romão, na década de 1960, tem como contraponto epistemológico e metonímico a Associação Jovens da Juréeia, em território paulista - organização não governamental, sem fins lucrativos, criada no ano de 1993 e institucionalizada em 1998, cujos principais objetivos se concentram na geração de renda, na revitalização e na manutenção da cultura caiçara, e, sobretudo, na permanência das comunidades da Jureia em seu território. Com o intuito de consolidar sua atuação na região e publicizar o fato de que, além da perda de seu território, seus atores estavam perdendo, também, a sua cultura, uma das estratégias levadas a cabo por esse coletivo foi a criação de um grupo de fandango pioneiro dentre os inúmeros grupos que hoje atuam no Estado de São Paulo. Coagidos a abandonar suas casas em decorrência da criação da Estação Ecológica da Juréia-Itatins, no ano de 1986, pelo Governo do Estado de São Paulo, a associação se estabelece como foco de resistência, com o intuito de se organizar para lutar pelos seus direitos.

Então, tem várias ideias de porque que a Juréia é tão visada. Na área ambiental é porque ela possibilita a ascensão política e da vida universitária de muitas pessoas. Muitas pessoas construíram a carreira em cima da Juréia. E essas pessoas que construíram a carreira em cima da Juréia, elas não querem desmanchar os seus conceitos, pelo simples fato de que uma comunidade tradicional tá falando que não é aquilo que ela falou. Então eles ficam batendo o pé. Toda uma visão que ela fez que muitas vezes é errada, ela bate o pé. E o que nós estamos fazendo com os trabalhos que estamos realizando dentro da Juréia são essas desconstruções. Essa é uma questão, parte tem outras percepções, que é da questão do valor não só ambiental. Ali tem urânio, ali queriam construir usina nuclear. Tem um projeto para usina nuclear feito, engavetado, que está engavetado, está ativo. Enquanto você não joga fora, não amassa, não destrói isso, existe um projeto. É um projeto, está ali e pode vir à tona a qualquer momento. Investimentos pelo simples fato de ser conhecido por países do mundo inteiro, da parceria Brasil-Alemanha, por exemplo, até hoje, é muito fácil você conseguir verbas para preservação ambiental da Alemanha por exemplo, a GTZ é uma das parceiras da preservação. KFW ajuda na preservação. Será que é só preservação mesmo ou tem essa visão de que está protegendo algo que não é só ambiental? Enquanto tiver uma estação ecológica lá, tudo que está lá dentro levado pelo lado ambiental ou não, vai estar protegido de quem está fora. Quando quiser ter acesso, vai estar intacto. E também tem a questão de ego das pessoas que ajudaram a formar a estação ecológica e que acham que a estação ecológica foi a melhor coisa que foi feita lá. Enquanto as comunidades acham que não, tem tantas outras formas de 
unidade de conservação que poderiam ser criadas, que mantivessem a conservação do lugar e também mantivesse a comunidade lá dentro. Por exemplo, uma reserva de manejo sustentável, uma reserva extrativista, ou até o território caiçara, porque o caiçara não vai querer fazer uma usina nuclear no seu território, ele vai querer utilizar aquilo ali simplesmente pra sobreviver lá dentro, da pesca, da caça. Então é isso que nós queremos provar hoje com o nosso trabalho lá dentro, que pode ser feito essas coisas sem que isso influencie na preservação. (Anderson Prado) (DE BONA, 2016, p.63)

À mercê das novas legislações ambientais, da mobilidade espacial inerente a esses embates e interagindo, mesmo que de modo incipiente, com o avanço das políticas públicas, as décadas subsequentes se mostraram solo fértil para emergência de componentes culturais e identitários nas comunidades envolvidas com essa expressão cultural. Neste sentido, a culturalização e ecologização da noção de caiçara implicou em um redimensionamento e em uma revalorização da noção de fandango, que passa a ser entendido como um dos principais dispositivos de insurgência das populações caiçaras.

\section{Fandango e mitigação}

No âmbito do licenciamento ambiental a proteção e salvaguarda do patrimônio cultural material e imaterial está regulamentada pela Portaria Interministerial 60/2015 e Instrução Normativa 01/2015 IPHAN/MinC. Apesar de recente, esta regulamentação está embasada nas diretrizes da Constituição Federal (1988) e na interface da legislação ambiental com os mecanismos jurídicos e administrativos de salvaguarda do patrimônio cultural. Com efeito, desde 1981, com a Política Nacional de Meio Ambiente e, especialmente, a partir de 1986, através das Resoluções do CONAMA, o processo de licenciamento ambiental envolve o diagnóstico e avaliação de aspectos culturais adscritos à caracterização do meio socioeconômico. (CONAMA 001/86, Art. $\left.6^{\circ} \mathrm{c}\right)^{83}$

A normativa 01/2015 IPHAN/MINC, que trata da mitigação por impactos ao patrimônio imaterial, inaugura uma nova conjuntura de interação nas dinâmicas entre detentores de bens culturais patrimonializados, poderes públicos e empreendedores de pequeno, médio e grande portes. A real dimensão dos impactos causados por empreendimentos de grande envergadura, como no caso dos terminais líquidos e secos abrigados pela APPA - Administração dos Portos de Paranaguá e Antonina - em seus aspectos culturais, sociais e ambientais, ainda depende de melhor sistematização para efetiva mensurabilidade, como mencionado no Relatório de

\footnotetext{
${ }^{83}$ (RAIPI/TCP, 2016, p. 13)
} 
Avaliação de Impactos aos Bens Registrados (RAIPI), elaborado no contexto do licenciamento ambiental do empreendimento Ampliação do Terminal de Contêineres de Paranaguá/PR (processo IPHAN n ${ }^{\circ}$ 02001.011059/2015-33 e processo IBAMA n ${ }^{\circ} 02001.003635 / 2015-79^{84}$ ):

É importante considerar que a elaboração deste tipo de relatório é exigência relativamente recente no escopo do licenciamento ambiental. Portanto, para responder a estas orientações e objetivos institucionais é preciso enfatizar que o RAIPI é um tipo de estudo ainda pouco conhecido. Além de não haver referências consagradas de relatórios RAIPI, a avaliação de impactos de empreendimentos sobre bens culturais imateriais é tema complexo, que envolve definições específicas de cultura, desenvolvimento e sustentabilidade. (RAIPI, TCP 2016, p. vi)

Figura 3.10 - Situação da estrutura do terminal TCP, pós-projetos de ampliação

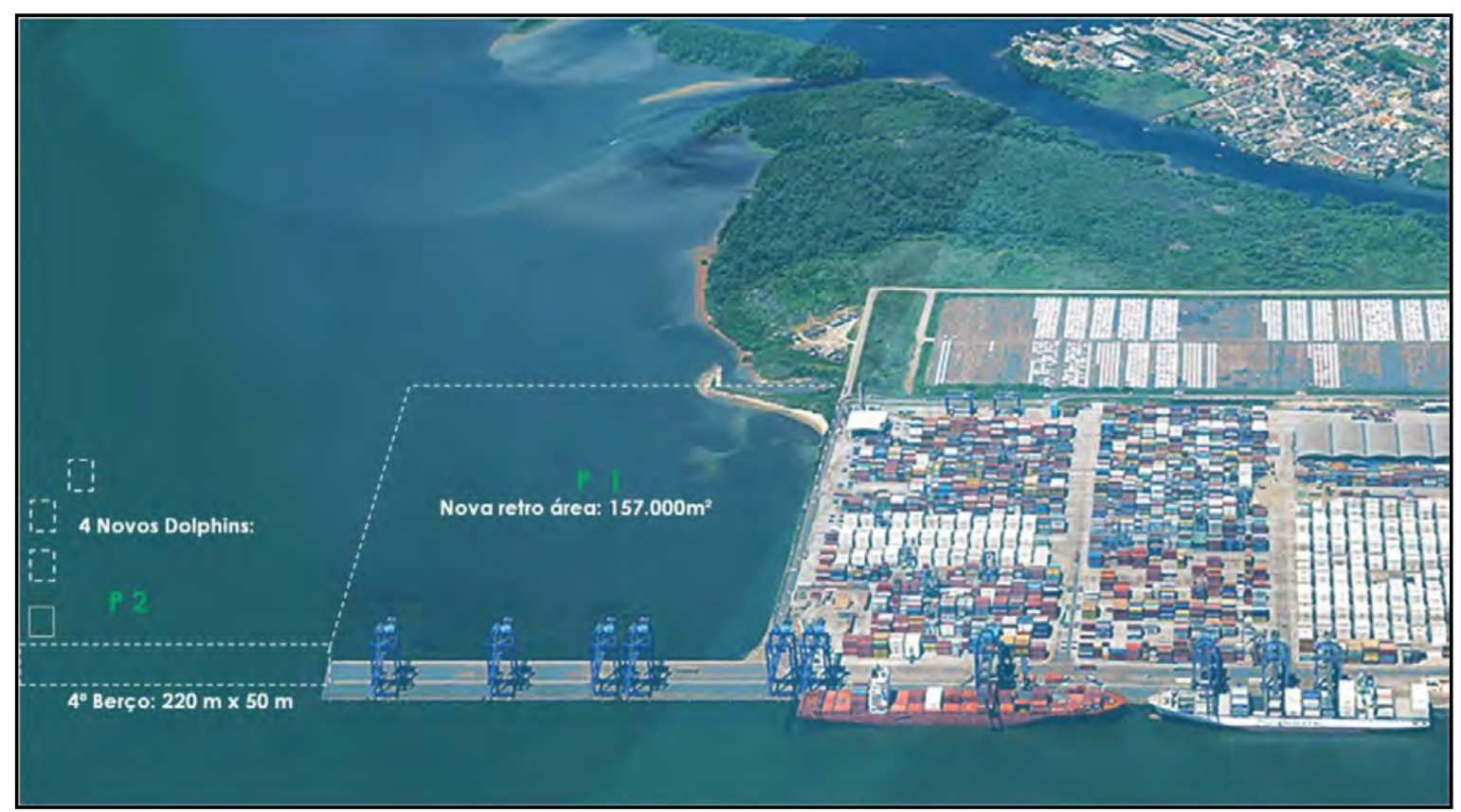

Fonte: (RAIPI TCP/ Contexto Br p.21)

\section{LÂMINA 5}

Mapa geral de localização das terras indígenas, aldeias e das referências da prática fandangueira na área de interesse.

Fonte (RAIPI TCP/ Contexto Br p.vii)

\footnotetext{
${ }^{84} \mathrm{O}$ TCP caracteriza-se como um importante papel no escoamento da produção paranaense, sendo justificáveis as obras de sua ampliação e modernização, considerando a sua relevância para o desenvolvimento regional. Durante as obras de ampliação serão contempladas as seguintes intervenções (ACQUAPLAN, 2016): “a. A construção de um novo cais de atracação (50 m de largura e $220 \mathrm{~m}$ de comprimento) para navios Post panamax, no local onde hoje estão localizados os dolfins; b. A construção de quatro novos dolfins de amarração no extremo leste do novo atracadouro, permitindo a entrada de embarcações Car Carriers (Ro-Ro) com 200 metros de comprimento, substituindo os dolfins atuais, que irão ficar integrados ao novo cais; c. Ampliação do pátio de contêineres para a atual área de retrocais." (ELOY DE FARIA, 2016, p. 8)
} 

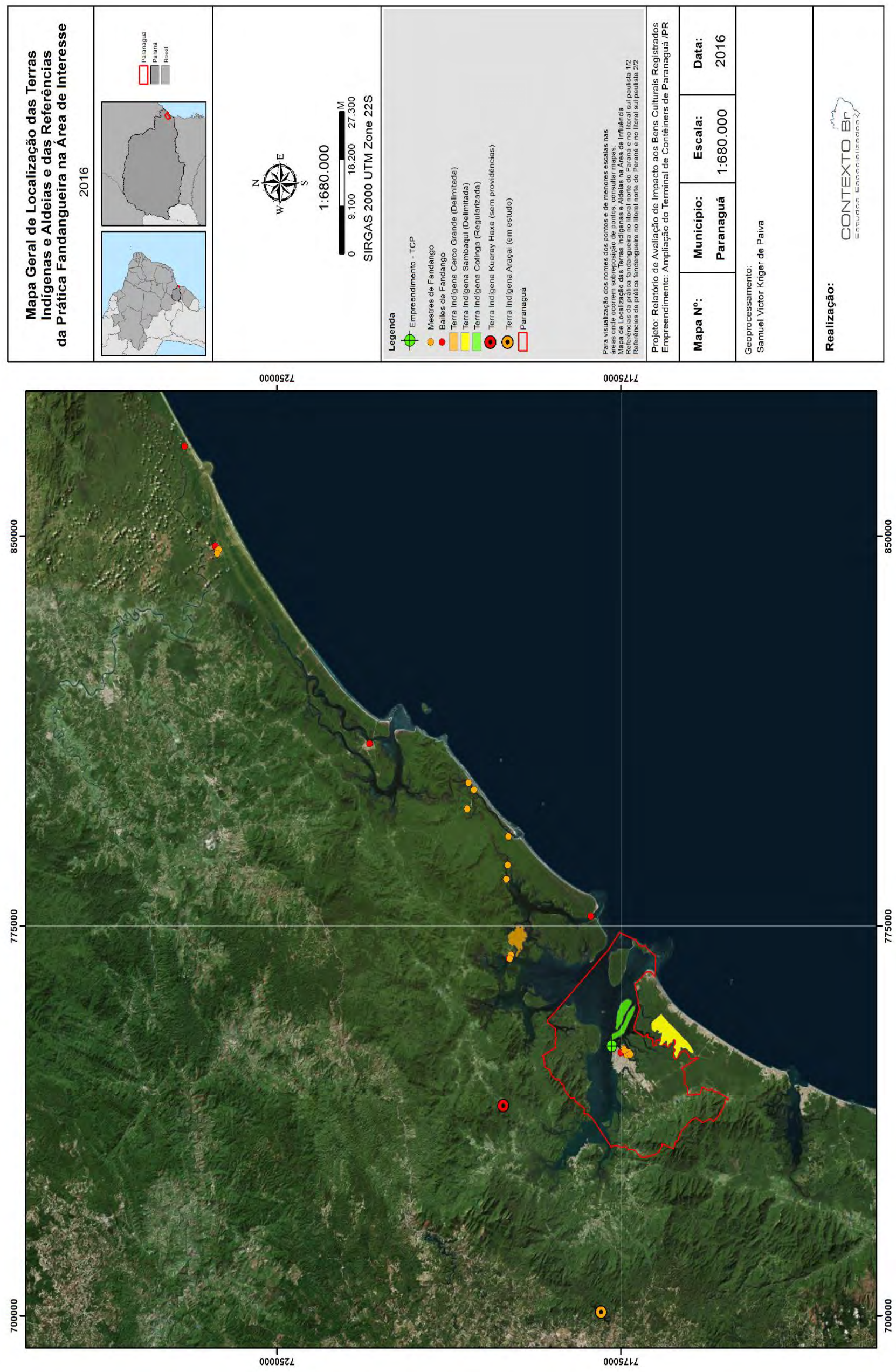
O texto do Relatório de Avaliação de Impactos aos Bens Registrados considera as distinções conceituais entre patrimônio material e imaterial, e atenta ao fato de que o ordenamento jurídico brasileiro prevê instrumentos administrativos diferenciados para a proteção e salvaguarda de cada modalidade de patrimônio.

No caso do patrimônio material, desde 1937, o tombamento é o instrumento de proteção mais utilizado. O patrimônio imaterial, por sua vez, é reconhecido e protegido através do processo de registro, regulamentado pelo Decreto 3.551/2000. Com a institucionalização do processo de registro, a política patrimonial brasileira passou a incluir os componentes humanos, os agentes, os representantes e criadores das manifestações culturais. Para além da "pedra e cal", a política cultural brasileira passou a buscar patrimonializar o intangível: os saberes, os modos de fazer, as formas de expressão. [...] Um dos corolários básicos desta política é a maior visibilidade dada às manifestações da cultura popular, compreendidas como as portadoras legítimas da tradição e da identidade brasileira. Diferentemente do processo de tombamento, o objetivo do Registro não é garantir a integridade física do bem por meio de conservação e restauração, mas assegurar a sua continuidade, por meio da produção de conhecimentos que auxiliem na sua valorização, apoio e fomento. (RAIPI, TCP, 2016, p. 11)

Letícia Vianna nos esclarece que o objetivo do registro e da política patrimonial, de modo geral, busca fornecer uma "ampla base de dados que possa orientar as políticas públicas de preservação cultural e regulamentação de direitos para as comunidades criadoras dos bens culturais em questão". Compreende-se, assim, que "dada a natureza imaterial do bem cultural, ele só se conservará efetivamente se vivido por pessoas em condições, com garantias e interesses de vivenciá-lo de modo dinâmico e criativo". (VIANNA, 2005, p. 97) Os instrumentos administrativos dessas políticas pressupõem, em seus métodos, a configuração de um amplo sistema de documentação, por meio de imagens, gravações e fotografias, além do preenchimento de inúmeros formulários inerentes ao processo de registro, que possui três características distintas do tombamento: a) o caráter coletivo do pedido; b) o caráter descentralizado da instrução do processo; e c) o caráter transitório da inscrição:

As propostas de Registro devem ser necessariamente coletivas, ou seja, todos aqueles que representam os detentores do bem cultural em questão devem consentir e aprovar a abertura do processo de Registro. Portanto, esta não é uma prerrogativa do Estado (IPHAN), mas daqueles que efetivamente dão vida a um determinado bem cultural.

A segunda característica que diferencia o Registro do Tombamento é que a inscrição de um bem cultural em um dos quatro Livros de Registro (dos Saberes, das Celebrações, das Formas de Expressão e dos Lugares) não é definitiva: "o Registro é sempre o retrato de um momento, que deve ser refeito periodicamente, a fim de que se possa acompanhar as adaptações e as transformações que o processo cultural opera nessas manifestações. Este reexame também é importante para o monitoramento e a avaliação dos 
impactos gerados pela declaração desses bens como patrimônio cultural do país."

Neste sentido, a terceira característica que diferencia o Registro do Tombamento, como determina o Decreto 3.551/2000, é que o processo de Registro deve ser renovado no máximo a cada dez anos. Se a revalidação de um bem cultural for negada, se interrompem os "planos de salvaguarda" e mantem-se apenas a sua inscrição em um dos Livros de Registro, indicando que em um tempo determinado aquele bem cultural foi referência cultural brasileira. (RAIPI/TCP, 2016 p. 12/13)

Alexandre Pimentel, Edmundo Pereira e Joana Ortigão nos lembram que o "Brasil foi um dos países pioneiros no atendimento à recomendação sobre a Salvaguarda da Cultura Tradicional e Popular." Os autores mencionam o fato de que no ano de 1997, durante congresso realizado pelo IPHAN, em Fortaleza, foi criado um grupo de trabalho cujos resultados fundamentaram a criação do Programa de Patrimônio Imaterial, instituído pelo Decreto $n^{\circ}$ 3.551 , de 04 de agosto de 2000. Os processos de inventário e registro de bens de natureza imaterial foram instituídos, primeiramente, em âmbito federal, e classificados em cinco eixos que podem ser complementares: "Edificações, Lugares, Formas de Expressão, Celebrações e Ofícios e Modos de Fazer. Qualquer processo de inventário parte do reconhecimento de um sítio ao qual o bem está vinculado, podendo ser desdobrado em distintas localidades." (PIMENTEL, PEREIRA e CORRÊA, 2011, p. 4)

Com vistas a assegurar a continuidade dos bens registrados por meio da produção de conhecimentos que auxiliem na sua valorização, apoio e fomento, um dos nós que foi duramente destrinchado com a equipe de elaboração do Programa TCP de Gestão do Bem Cultural: Fandango Caiçara, do qual participei ativamente, resultava da complexidade da inserção de elementos relacionados à saúde dos detentores e ao dimensionamento de obras destinadas a melhorias nos espaços utilizados pelos grupos de fandango, no tocante à mitigação relacionada ao processo supracitado. Ruídos na comunicação agregados à pressão do empreendedor sobre os coordenadores, os prazos e a conjuntura hierárquica dos órgãos públicos correlacionados (saúde, saneamento, segurança e urbanismo) consolidaram argumentos contrários à inserção integral de tais demandas naquele documento. Elementos que, somados a desvios etimológicos, epistemológicos (relativos à circunstanciação dos espaços de ensaio) e o evidente interesse mercantil capitalístico que envolve tais processos, causaram contratempos desnecessários, angústias que compartilhei com a equipe por mensagem eletrônica, em janeiro de 2017: 
Prezadxs todxs,

Gostaria de compartilhar com vocês algumas impressões que concatenei em minha última atividade de campo, que seguida da reunião ampliada, deuse durante toda semana na Ilha dos Valadares.[...]

Sabendo que questões de saúde pública vão para além do trabalho que estamos realizando, mas que podem subsidiar a discussão, caso lhes pareça útil, ou ainda questões a serem refutadas, de todo modo que as tenhamos em plano de fundo.

Aos amigos, colegas e colaboradores na construção do Programa de Gestão dos bens Imateriais Registrados, em referência à normativa 001/2015, no que toca a ampliação do Terminal de Contêineres de Paranaguá em 2017, em vista do coletado em trabalho de campo, somado a vivência contínua de mais de 15 anos junto aos interlocutores caiçaras e Mbyá transitando entre esferas públicas e privadas, assumindo diferentes papéis, em diferentes contextos, proponho atentarmos aos seguintes fatos:

- Para concreta salvaguarda dos patrimônios imateriais inerentes ao processo, a saber: o Fandango Caiçara e a língua Mbyá Guarani, faz-se mister assegurar condições de saúde e bem-estar a estas populações. A contaminação da água, do solo e do ar, por si só, impacta diretamente sobre estruturas complexas de inter-relacionamento.

- Parte expressiva dos detentores consome diariamente o produto da pesca de subsistência, não apenas nas localidades mais isoladas, mas também em Paranaguá, nas ilhas dos Valadares e Cotinga, São Miguel e Amparo, ampliando-se à baía de Paranaguá de um modo geral.

- Crianças Mbyá, nadam despreocupadas num mar de dejetos, que somados aos resíduos de navegação, incluso aí águas de lastro, sintetizam um panorama já assombroso, que tende a ser intensificado com a ampliação do terminal.

- Uma breve incursão aos dados de saúde pública pode consolidar esta reflexão. A ação iniciada em janeiro de 2016 junto a APPA, previa a urgente necessidade da retirada de 17 mil toneladas de resíduos, inclusos grande quantidade de resíduos contaminados na região de Paranaguá. Apesar do repasse haver sido realizado [R $\$ 3,9$ milhões], a tramitação burocrática cumpre seu papel de costume. O cheiro da soja apodrecida paira por toda a área de circulação de caminhões, as partículas em suspensão no ar causam danos respiratórios crônicos, o contingente de trabalhadores e motoristas inflam o comércio ilegal, a prostituição e o narcotráfico. Um dos casos coletados em campo dizia respeito ao Sr. Anísio Pereira, que ao escutar tiros nas redondezas de sua residência na Ilha dos Valadares (fato corriqueiro, digase de passagem), preocupa-se, pois elucubra que os tiros possam haver vitimado membros de sua família, que também residem nas redondezas.

- O município de Paranaguá esteve em calamidade pública[declarou estado de emergência] por conta da dengue, coincidência ou não, o epicentro dos casos recorrentes encontra-se na região do porto, segundo dados da secretaria municipal de saúde, desde agosto de 2015, até janeiro de 2016 foram um total de 675 casos de dengue em Paranaguá, inclusos aí vários detentores inseridos no processo, dados bastantes concretos no que tange a imaterialidade.

- Em todos os casos, para além da saúde pública, os locais destinados a manutenção das atividades culturais faz-se imprescindível, estas são demandas a serem atendidas, mesmo que sua execução apresente maiores níveis de complexidade, já sinalizadas resoluções positivas tanto por fandangueiros quanto por Mbyas. Como mencionado na fala de Aorélio Domingues na Reunião ampliada: “ $\mathrm{O}$ espaço compromete tudo isso aqui que a gente tá falando aqui. $\mathrm{O}$ que eu vejo aqui, é que de repente a gente não 
conseguir fazer com que a empresa nos dê aquilo que é principal, porque eu tenho certeza que todo mundo vai colocar ali de mais urgente material de som e o espaço, mas aí ele compromete tudo isso aqui. Porque aí a gente não tem espaço e o fandango continua morrendo. Aí a gente tá todo mundo bonito na foto lá e o fandango morrendo, que é o caso do Museu vivo do Fandango. Porque se você pega o livro hoje, você olha ali, mais da metade do livro todo mundo já morreu. Então nós estamos no último suspiro."

- Para além do próprio licenciamento, o programa deve ser célula germinal de processos mais amplos de etnodesenvolvimento, como a já mencionada necessidade da criação de uma cooperativa dos povos e das comunidades tradicionais do litoral do paraná, ou em escala reduzida, ao menos que sejam fomentadas discussões neste sentido, no intuito de que as redes de relação e de economia viva e criativa tome forma, tangenciando ações assistencialistas e fomentando a gestão sustentável e participativa de recursos ambientais e financeiros, independentes das políticas de governo as quais estas minorias estão sujeitas a longa data.

- Apesar das inúmeras possibilidades de diálogo junto a novos empreendedores, percebo o espaço dos fóruns de discussão mais atinados com as trocas de experiência, e como instância real do fortalecimento de redes, tanto junto a detentores como junto a projetos em execução, seja nas áreas da saúde, da educação ou da cultura junto a instituições que desenvolvem ações no litoral.

Como pesquisador, colaborador e mediador das atividades fandangueiras nas últimas décadas, acredito que o programa proposto, tenta dialogar com realidades diversas, cuja mitigação vem em boa hora, mas deve ir além de medidas paliativas voltadas aos interesses dos empreendedores, cujos lucros transcendem cifras palpáveis ao cidadão comum.[...]

Atento ainda que o comitê provisório de salvaguarda constitui-se participativamente, não apenas de detentores, mas de detentores, atores culturais, lideranças comunitárias e militantes em direitos humanos e territoriais, cuja primeira ação, desdobrou-se no registro do fandango caiçara, documento fundamental na tramitação do atual processo, cuja agenda positiva, indica a necessidade de diálogo junto aos empreendedores, sem perder de vista as demandas concretas dos beneficiários, recomendações que de meu ponto de vista vêm sendo consideradas.

Cabe ressaltar ainda da necessidade de uma gestão transversal, onde a produção executiva vislumbre a totalidade das ações, indicando que a fragmentação das atividades, possa acarretar prejuízos nos resultados finais esperados.

Abraço grande (e-mail enviado à equipe de elaboração do programa de Gestão, em 28/01/2017)

Com vistas a ilustrar tópicos acima descritos, apresento algumas das matérias vinculadas pela mídia local associadas ao tema naquele período:

"Com 150 casos, Paranaguá decreta emergência por causa da dengue"85; "IAP e Prefeitura de Paranaguá retiram 1,5 mil pneus do mangue" ${ }^{\text {; }}$; "Volume do lixo coletado dos

\footnotetext{
${ }^{85}$ http://g1.globo.com/pr/parana/noticia/2015/11/com-150-casos-paranagua-decreta-emergencia-por-causa-dadengue.html

${ }^{86} \mathrm{http} / / / \mathrm{www}$. expressao.com.br/noticias/materias/27-01-17-IAP-e-prefeitura-de-Paranagua-retiram-15-milpneus-do-mangue.php
} 
manguezais cresce 560\% em Paranaguá,"87; “Associação recolheu mais de 500 toneladas de resíduos no entorno do porto em 2017",88,"Um a cada três casos de dengue no PR é de Paranaguá; seis novas mortes são confirmadas" ${ }^{29}$.

Podemos ainda mencionar que no ano 2017 o porto de Paranaguá alcançou índices recordes de mais de 50 milhões de toneladas transportadas. Bruno Gurgatz, (2018, p. 31) comenta que as cargas mais movimentadas no Porto de Paranaguá naquele ano foram a soja (11.409.189 toneladas), o adubo (8.847.059 toneladas), e carga geral (3.285.046 toneladas). "Sendo que, dentre estes e outros produtos, movimentou 51.510.701 toneladas em 2017, maior movimentação de toda sua história, e acima da média dos portos brasileiros (APPA, 2017a).”

Contraste evidenciado por Gurgatz na região do litoral paranaense diz respeito à condição de fragilidade das comunidades que habitam essas localidades, caracterizadas por uma política do abandono, propositalmente instalada para permitir a exploração de seus recursos naturais e de sua população, "o que gerou um contexto de injustiça ambiental no município". Outro estudo realizado pelo autor, utilizando cascas de árvore como bioindicadores, encontrou também uma situação de injustiça social no município, identificando uma relação inversa entre a renda da população e os níveis de poluentes analisados (GURGATZ et al., 2016; GURGATZ, 2018).

Análises laboratoriais de 326 amostras de material particulado (do inglês, particulate matter $)^{90}$ recolhidas no município de Paranaguá, entre dezembro de 2016 e dezembro de 2017 , apresentam índices preocupantes, se comparados com os limites propostos pela Organização Mundial da Saúde (OMS):

\footnotetext{
${ }^{87}$ http://www.aen.pr.gov.br/modules/noticias/article.php?storyid=99174\&tit=Volume-do-lixo-coletado-dosmanguezais-cresce-560-em-Paranagua

${ }^{88} \mathrm{https}$ //folhadolitoral.com.br/meio-ambiente/associacao-recolheu-mais-de-500-toneladas-de-residuos-noentorno-do-porto-em-2017/\#.XIDBCINKhE4

89 https://www.gazetadopovo.com.br/vida-e-cidadania/um-a-cada-tres-casos-de-dengue-no-pr-e-de-paranaguaseis-novas-mortes-sao-confirmadas-0mz3fuobh45oowwfwyrzgpyxj/

90 “O Material Particulado é uma mistura de partículas sólidas e/ou líquidas presentes na atmosfera, com tamanho e densidade suficientemente pequenos para que permaneça por determinado tempo em suspensão. Também conhecido como aerossóis, consiste em uma classificação física de partículas encontradas no ar, como poeira, fuligem, fumaça e gotículas líquidas, sendo assim, não são uma substância, mas uma mistura de vários componentes (BRAGA et al., 2001; POLEZER, 2015)”. (GURGATZ, 2018, p.17)

“Os aerossóis são comumente divididos em PTS (Partículas Totais em Suspensão), PM 10 ou “inaláveis" (menor ou igual a $10 \mu \mathrm{m}$ de diâmetro) e $\mathrm{PM}_{2,5}$ ou "finas" (menor ou igual a 2,5 $\mu \mathrm{m}$ de diâmetro). Exalta-se que o tamanho da partícula está relacionado à probabilidade de efeitos na saúde, sendo que quanto menor seu tamanho, maior possibilidade de deposição em áreas mais profundas do sistema respiratório. (US EPA, S/Data; BRAGA et al., 2001; BROOK et al., 2010).” (GURGATZ, 2018, p.18)
} 
Ressalta-se que apesar deste poluente não ser legislado no Brasil, o limite máximo diário recomendado pela OMS $(25 \mu \mathrm{g} / \mathrm{m} 3)$ foi ultrapassado 34 vezes. A média anual ficou em $15 \mathrm{ug} / \mathrm{m} 3$, também ultrapassando o valor proposto pela organização $(10 \mu \mathrm{g} / \mathrm{m} 3)$.

Além dos valores acima dos limites propostos, Paranaguá apresentou níveis médios de $\mathrm{PM}_{2,5}$ comparáveis ao de cidades de grande porte, com maior densidade populacional, ou que também se destacam no setor portuário nacional. [...] É possível notar, por exemplo, que Santos, no litoral Paulista, apresentou em 2016, média similar às encontradas em Paranaguá, sendo que sua densidade populacional é cerca de oito vezes maior que a da cidade portuária paranaense, além de ser considerado o maior porto brasileiro. (GURGATZ, 2018, p. 50/52)

Para maior clareza, segue abaixo o gráfico elaborado pelo autor para exemplificar a distribuição diária do material particulado fino $\left(\mathrm{PM}_{2,5}\right)$ em Paranaguá, no ano de 2017.

Figura 3.11 - Distribuição diária de $\left(\mathrm{PM}_{2,5}\right)$ em Paranaguá no ano de 2017

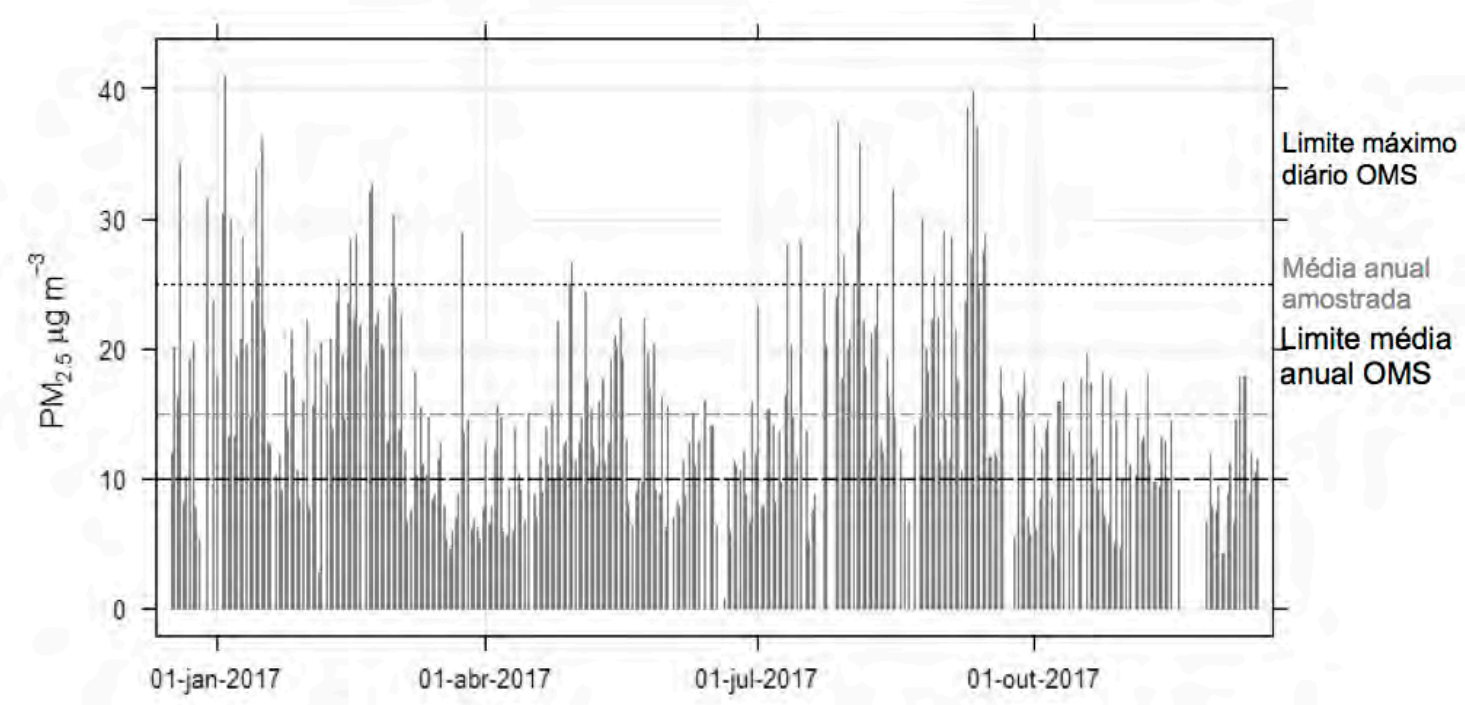

Fonte: (GURGATZ, 2018, p. 51)

Outros dados relevantes dizem respeito à poluição sonora e aos níveis de ruído produzidos pelo porto e pela circulação de veículos nas áreas que o rodeiam, cuja operação se dá de modo ininterrupto, lembrando que essa modalidade de poluição é um sério agente de agressão à qualidade do ambiente urbano. Fernandes (2002) nos elucida que essa “contaminação sonora” é percebida como um som indesejável, fisicamente é de grande complexidade, com superposições desarmônicas de sons provenientes de várias fontes que se convertem em uma problemática e crescente forma de poluição. 
Os valores registrados acusam níveis de desconforto tão altos que a poluição sonora urbana passou a ser considerada uma forma de poluição que atinge o maior número de pessoas. Assim a partir de 1989, a Organização Mundial da Saúde (OMS) já passou a tratar o ruído como problema de saúde pública. Tendo São Paulo e Rio de Janeiro as capitais com maiores níveis de ruído do mundo. (VIANA, 2007). (TEIXEIRA e TONETTI, 2008, p. 5)

Como expresso pela Organização Mundial da Saúde (OMS, 2016), o ruído excessivo prejudica seriamente a saúde dos indivíduos, interferindo em suas atividades cotidianas, seja na escola, no trabalho, em casa ou nos momentos de lazer. "Pode perturbar o sono, causar efeitos cardiovasculares e psicofisiológicos, reduzir o desempenho e provocar respostas de aborrecimento e alterações no comportamento social" $"$.

O artigo 54 da Lei 9.605/98 configura crime "causar poluição de qualquer natureza em níveis tais que resultem ou possam resultar danos à saúde humana[...]”, incluída aí a poluição sonora, regulamentada pela Resolução 008/93, do $\operatorname{CONAMA}^{92}$ que, no tocante aos veículos automotores, estabelece limites máximos, tanto para emissão de partículas como para os níveis de ruído para os diferentes tipos de veículos, conforme suas motorizações e capacidade de carga.

Na coleta de dados realizada por Tonetti, em Paranaguá no ano de 2008, a Avenida Bento Rocha, um dos cinco pontos de coleta de dados, apresentou um fluxo constante de veículos leves com picos de veículos pesados nos horários de liberação de descarga de produtos na área portuária. Devem-se considerar os impactos intermitentes no aparelho auditivo humano quando expostos a níveis de ruído acima dos estabelecidos pela OMS, onde, de 55 a 65 dB são constatados o prejuízo da produtividade no trabalho intelectual e a diminuição do poder de concentração. De 65 a 70 dB, os sons podem acarretar perturbações do sono e alterações bioquímicas e cardiovasculares; acima de $70 \mathrm{~dB}$, perda auditiva e aumento do risco de enfarte. Em relação aos pontos 01 (Av. Bento Rocha x Roque Vernalha) e 02 (Rod. Airton Senna x Av. Cel. José Lobo), intrinsicamente vinculadas ao fluxo de cargas portuárias, apresenta-se uma situação preocupante para pessoas que trabalham e residem nas proximidades.

\footnotetext{
${ }^{91}$ It can disturb sleep, cause cardiovascular and psychophysiological effects, reduce performance and provoke annoyance responses and changes in social behaviour. (OMS, 2016) http://www.euro.who.int/en/healthtopics/environment-and-health/noise/noise

${ }^{92}$ Resolução CONAMA no 8, de 31 de agosto de 1993 Publicada no DOU nº 250, de 31 de dezembro de 1993, Seção 1, páginas 21536-21541.
} 
Figura 3.12 - Distribuição dos usos potencialmente causadores de poluição

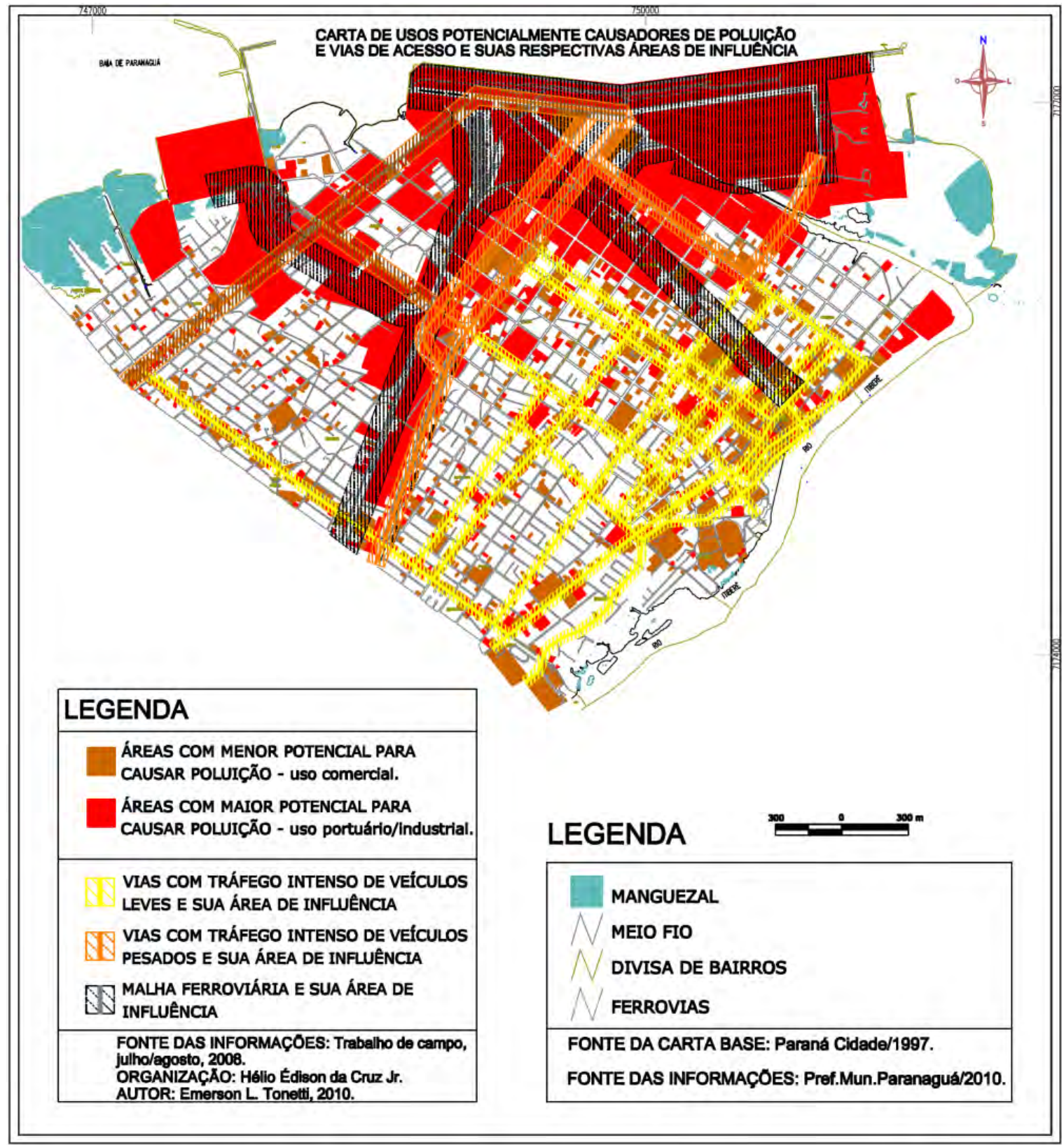

Fonte: (TONETTI et al, 2016, p. 13)

Tais dados agregados a outro estudo realizado por Tonett, Nucci e Valaski (2016), onde a espacialização dos usos potencialmente poluidores indicam as atividades e as vias relacionadas com o Porto D. Pedro II como sendo as principais fontes geradoras de poluição (ruídos, inúmeras partículas e gases nocivos), e nos apresentam, também, um panorama preocupante quanto à qualidade ambiental urbana no segmento estudado. (TONETI, NUCCI e VALASKI, 2016) 
Dados sintetizados no mapa (fig. 3.12) sobrepõem o uso e a ocupação do solo às vias com tráfego intenso de veículos, indicando a distribuição dos usos potencialmente causadores de poluição em parte da área urbana do município de Paranaguá.

Outro aspecto a ser considerado diz respeito ao meio subaquático, onde os diferentes tipos de poluição podem influenciar também o ecossistema e a fauna que habita esses entornos. No caso sonoro, atingindo, sobretudo, cetáceos $^{93}$, que dependem dos sons para comunicação e orientação.

Fontes de ruídos no ambiente aquático incluem o tráfego de embarcações, atividades industriais e de construção (estaqueamento, derrocagem, dragagem), sonares, pesquisa sísmica, dentre outras[...]. Os cetáceos são particularmente vulneráveis ao aumento da poluição sonora, uma vez que o sentido auditivo é extremamente desenvolvido [...]. (PMC-BS, 2015, p. 6)

Figura 3.13 - Mapa de distribuições acústicas de Sotalia guianensis (boto cinza) no Complexo Estuarino de Paranaguá

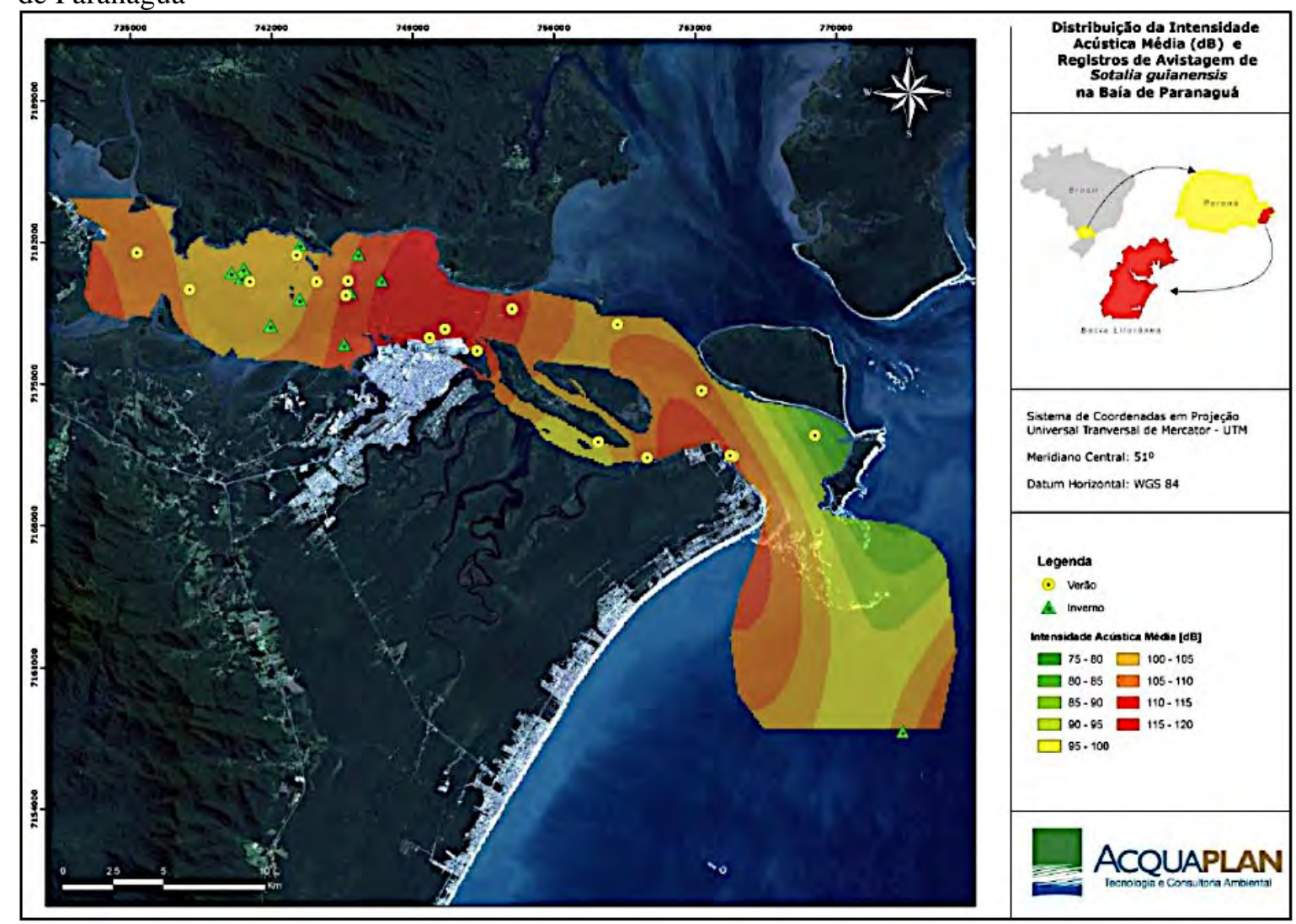

Fonte: APPA (2017, p. 19)

\footnotetext{
93 "Os cetáceos habitam todos os oceanos do mundo, desde mares tropicais até regiões polares (BALLANCE, 2009). São reconhecidas 93 espécies, classificadas em dois grupos (PERRIN, 2015): os golfinhos e baleias com dentes (odontocetos) e as baleias verdadeiras de barbatana (misticetos). Foram registradas 44 espécies de cetáceos no Brasil (LODI \& BOROBIA, 2013), cerca da metade das espécies que ocorrem no mundo."
} 
O Relatório Técnico Semestral (APPA, 2017, p.18), em seus comentários subsidiados pelos estudos de Richardson et al. (1995), indica que algumas alterações comportamentais destes mamíferos podem advir em resposta às novas fontes de ruído, entre outros prejuízos, como o abandono temporário de uma área e a alteração do repertório sonoro de comunicação. “Também podem ser observados impactos ao sistema fisiológico, quando ocorrerem danos à audição. Estes impactos podem ocorrer após longos períodos de exposição ou em situações pontuais, impedindo até mesmo a detecção de importantes sons para estes animais."

No contrafluxo da expansão antrópica, em demonstração de grande adaptabilidade, Domit (2010, p. 32) narra haver verificado botos-cinza perseguindo suas presas em direção ou paralelas ao costado dos navios nos berços de atracação do Porto de Paranaguá, na Baía de Paranaguá. "Durante esta perseguição os animais adotaram a postura lateral e chegaram a tocar o dorso no casco. Capturas das presas na superfície foram observadas. Mesmo com a aproximação de rebocadores, os animais não abandonaram a área dos berços de atracação, nem a estratégia utilizando os navios." No caso narrado, o abandono da área pelos cetáceos deu-se apenas quando o navio entrou em atividade e os rebocadores iniciaram os trabalhos de manobra.

Como se pode ver, a sinergia e adaptabilidade da fauna frente as adversidades antrópicas se faz mister, e se assumimos o mutualismo e a impossibilidade de separação entre animal e ambiente já mencionados no Capítulo 1 (no que diz respeito aos princípios básicos da Abordagem Ecológica à Percepção e Ação), podemos visualizar neste pequeno exemplo como animais de outras espécies mantêm uma intensa relação de interação, tanto com a sociedade englobante quanto, de forma mais intensa, com as populações caiçaras que residem nestas localidades.

Por hora, cabe a reflexão de que tais estudos devam ser sistematicamente atualizados em vista de que a previsão inicial de ampliação do terminal de contêineres tem como projeção o aumento do número de caminhões na ordem de $65 \%$ da capacidade operacional, ou seja, elevando a circulação de caminhões dos atuais 1.400/dia para 2.400/dia. A médio e longo prazos, devem ser acrescidos ainda o fluxo exponencial que será gerado pelos novos processos de ampliação (conforme fig. 3.14), como no caso da solicitação da licença prévia (LP) para Obras de Ampliação do Cais de Acostagem do Porto Paranaguá ${ }^{94}$, somado ao projeto de otimização das estruturas de recebimento, armazenamento e expedição de fertilizantes da unidade da FOSPAR, em Paranaguá.

\footnotetext{
${ }^{94}$ Processo IBAMA n o 02001.004295/2013-31, cujo projeto consiste na implantação de um Píer “T”, a implantação de um Píer "F", a implantação de um Píer "L", além da construção de um complexo náutico.
} 
Figura 3.14 - Projetos de Ampliação - Novas Instalações do Porto de Paranaguá

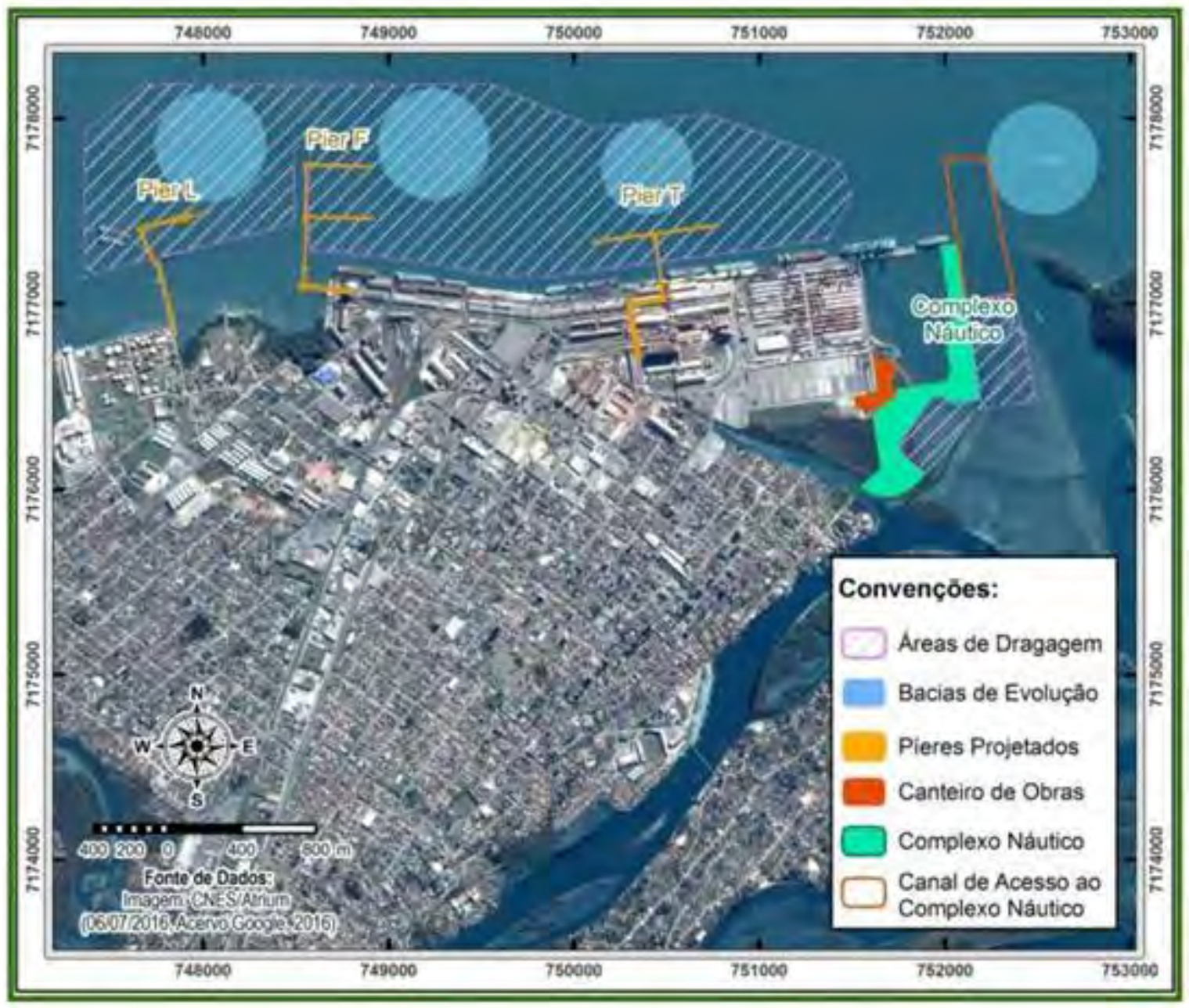

Fonte: (RAIPI/APPA, 2018, p. 14)

Retomando o comentário sobre a construção do Programa de Gestão TCP, outra demanda relevante dizia respeito a pequenas obras de ampliação e estruturação de espaços para ensaios de fandangueiros, tidas como demandas prioritárias por todos os grupos. Tais demandas se converteram no maior imbróglio dentro da ação, somadas à intervenção sabotadora de terceiros que, em vista de conflitos de interesses, acabaram por insuflar desentendimentos entre os grupos e paralisar o processo depois de uma tumultuada reunião, da qual nem os consultores nem parte dos beneficiários foram convidados a participar.

Por intervenção das instâncias superiores do IPHAN - em atenção à carta de repúdio encaminhada pela associação de Cultura Popular Mandicuera e pelo grupo Folclórico Mestre Romão - foram retomadas as atividades de licenciamento, conforme Memorando $\mathrm{n}^{\circ}$ 14/2017/COREG/CGIR/DPI: 
Inicialmente, o empreendedor contou com uma equipe de consultores para produzir o Programa de Gestão. Das informações que foram encaminhadas desde o Relatório de Avaliação de Impacto ao Patrimônio Imaterial, percebemos que a equipe de consultores acatara as recomendações do Iphan para que o processo de elaboração do Plano de Gestão fosse feito com base no diálogo com as comunidades detentoras dos bens imateriais acautelados em Paranaguá (fandangueiros e Mbyá Guarani). Assim, desde o ano passado, têm ocorrido reuniões entre representantes da TCP, da equipe de consultores, das comunidades e do Iphan-PR para levantar as medidas para controle e mitigação de impactos negativos aos bens culturais.[...]

Nesse período [abril de 2017], o Departamento de Patrimônio ImaterialDPI recebeu uma mensagem de repúdio de dois grupos de Fandango Caiçara de Paranaguá sobre a forma de apresentação da TCP sobre o Programa de Gestão, via e-mail do dia 20 de abril de 2017. O Iphan notificou o empreendedor para prestar esclarecimentos sobre as críticas feitas pelos detentores acerca da falta de clareza sobre a finalização do Subprograma de Gestão do Fandango Caiçara. Assim, representantes da TCP, acompanhados de dois representantes de grupos de Fandango de Paranaguá, e representantes do Iphan (do DPI, da CNL e, de modo virtual, da Superintendência no Paraná) se reuniram na sede do Iphan em 20/06/2017. Entre os principais assuntos discutidos nessa audiência, estava a questão da quantidade de demandas, que, segundo a TCP, seriam demasiado extensas. Mas observamos que, nos relatórios entregues pelo empreendedor, os consultores contratados sempre haviam mencionado que as ações decorrentes das demandas dos detentores teriam de passar pela avaliação da equipe, da TCP e do Iphan, e que tais demandas deveriam ser pensadas pelos detentores em termos do que era mais importante para os grupos, sendo necessária uma priorização.

No entanto, o documento final entregue pela TCP não tinha sido chancelado pelos fandangueiros, nem haviam sido priorizadas as ações.

Deram-se os encaminhamentos posteriores com os devidos detalhamentos técnicos e, com a anuência da totalidade dos envolvidos, o processo segue no ano de 2019 em processo de execução.

A partir da interface da legislação ambiental e patrimonial, estas orientações sintetizam a preocupação institucional que instam os atores do processo de licenciamento ambiental a contribuir com a política de salvaguarda do patrimônio cultural imaterial brasileiro. Nos termos do Programa Nacional de Patrimônio Imaterial "a salvaguarda de um bem cultural de natureza imaterial" consiste em "apoiar sua continuidade sustentável. É atuar no sentido da melhoria das condições sociais e materiais de transmissão e reprodução que possibilitam sua existência”. Mais do que contribuir com o licenciamento ambiental, estes parâmetros legais e conceituais colocam os temas cultura e sustentabilidade no centro das decisões sobre o desenvolvimento. (RAIPI/ TCP, 2016, p. 15)

A partir da normativa IPHAN 01/2015, as populações caiçaras - nomeadamente detentoras do fandango, bem cultural acautelado - devem necessariamente ser consultadas, compondo novas instâncias de diálogo frente a esses interlocutores. De imediato, junto às 
empresas cujas solicitações de licenças prévias (LP), de instalação (LI) e de operação (LO) sejam solicitadas em períodos posteriores à publicação da normativa.

Emblema de nosso tempo, sob a ótica do capital, a urbanização é eminente e presentifica as dinâmicas de interação firmadas na pós-modernidade. Perceber tais dinâmicas nos contextos locais e problematizá-las à luz das alternativas que prezam pela sustentabilidade dos aspectos culturais e da biodiversidade são, em tese, prerrogativas das iniciativas de salvaguarda e mitigação - questões, infelizmente, ainda relegadas a segundo plano por parte dos seus principais consignatários. Tal assertiva vai de encontro ao conceito de modos de produção capitalísticos, sugerido por Guattari, que, ao acrescentar o sufixo "ístico" à “capitalista”, espera criar um termo que possa designar não apenas as sociedades qualificadas como capitalistas, incluindo setores do "Terceiro Mundo" ou do capitalismo "periférico", mas também as economias ditas socialistas dos países do leste que, segundo o autor, vivem numa espécie de dependência e contradependência do capitalismo. Tais sociedades, segundo Guattari e Rolnik (1996, p. 15), “em nada se diferenciariam do ponto de vista do modo de produção da subjetividade. Elas funcionariam segundo uma mesma cartografia do desejo no campo social, uma mesma economia libidinal-política.”.

O que caracteriza os modos de produção capitalísticos é que eles não funcionam unicamente no registro dos valores de troca, valores que são da ordem do capital, das semióticas monetárias ou dos modos de financiamento. Eles funcionam também através de um modo de controle da subjetivação, que eu chamaria de "cultura de equivalência" ou de "sistemas de equivalência na esfera da cultura". Desse ponto de vista o capital funciona de modo complementar à cultura enquanto conceito de equivalência: o capital ocupase da sujeição econômica, e a cultura, da sujeição subjetiva. E quando falo de sujeição subjetiva, não me refiro apenas a publicidade para a produção de consumo de bens. É a própria essência do lucro capitalista que não se reduz ao campo da mais-valia econômica: ela está também na tomada de poder da subjetividade. (GUATTARI e ROLNIK, 1996, p. 16)

A concessão de licenças de magnitudes exorbitantes, com seus impactos, via de regra, minimizados pelos empreendedores que executam planos básicos ambientais, e, mais recentemente, os programas de gestão de modo anódino, no intuito de cumprir suas obrigações processuais, alheios aos reais vetores que consolidam tais legislações, implicam em sujeição e custo político: 1) "Seu" Anísio não pode tirar um pau de caxeta do mangue; 2) Na ilha da Cotinga, a solicitação de indígenas pela consolidação de um trapiche se arrasta por anos; 3) Mesmo solicitadas por diferentes esferas do poder público, o IAP não concede as devidas licenças para terreno angariado pela prefeitura de Paranaguá para a construção da casa do fandango, alegando insalubridade no local (onde medidas de infraestrutura como o aterro de 
uma pequena área com menos de cem metros quadrados não é sequer considerada como opção viável à demanda).

"Nossa casa do fandango não vai ser construída em cinco anos, se depender do governo. Aí, vem o governo do Estado e diz que é uma área insalubre, mas o porto está construído onde?", pergunta o representante dos grupos de fandango caiçara da Ilha dos Valadares. ${ }^{95}$

Podemos enumerar algumas ações que essa narrativa política prioriza: ampliação, implementação, gerenciamento, manutenção e expansão de mercados e rotas comerciais euroasiáticas e transatlânticas; manutenção recorrente do status quo; empreendimentos sempre em fluxo, intrinsecamente vinculados às oscilações de mercado nos intervalos diacrônicos desde a renascença até a hipermodernidade.

A oportunidade em auxiliar na elaboração do Programa TCP de Gestão do Bem Cultural: Fandango Caiçara, inicialmente percebido como momento frutífero de diálogo junto aos detentores, converte-se em nova seara de embate, tendo em vista os muitos interesses envolvidos no pleito e, de modo geral, o desinteresse de empreendedores em firmar alicerces concretos para o desenvolvimento sustentável destas práticas.

Uma análise pormenorizada dos autos, disponíveis ao público em geral na página do IPHAN (sei.iphan.gov.br/pesquisapublica) revela a morosidade no atendimento dos ofícios encaminhados pela superintendência do IPHAN do Paraná solicitando a inclusão dos componentes da cultura imaterial, acautelados em âmbito federal e terras indígenas, na caracterização da área de estudo com previsão de impactos. A construção participativa e transversal das ações tem sido diluída pelos processos de licitação, em que a gestão e gerenciamento de tais planos são relegados a terceiros que, apesar de suas competências técnicas, pouco conhecem da realidade dos beneficiários envolvidos e, sobretudo, alinham-se aos interesses capitalísticos dos empreendedores. Tais questões-chave, envolvendo o programa elaborado para o TCP cuja singularidade inaugura procedimentos como esse junto à comunidades e detentores do patrimônio imaterial, na medida do possível vêm sendo revistas e aperfeiçoadas nos processos que se iniciam em relação aos novos empreendimentos.

Tanto agendas neoliberais quanto progressistas apresentam falhas em seus encaminhamentos, o que, pela nossa realidade distópica, nos obriga a dialogar com ambas. Entender o papel de mediador é também assumir um papel crítico diante dos equívocos

\footnotetext{
${ }^{95}$ Luiz Aguiar Jr. Durante a reunião entre APPA e representantes dos grupos de fandango caiçara da Ilha dos Valadares, realizada em 02 de abril de 2018. Processo Ibama: 02001.004295/2013-31 cnl - IPHAN $01450.008639 / 2016-73$
} 
cometidos e às falhas observadas nos processos vivenciados. Fomentar o debate, o diálogo e buscar o aperfeiçoamento das ferramentas legais destinadas à salvaguarda dos patrimônios da cultura imaterial se converte em exercício de cidadania.

Nas novas liberações solicitadas pelo IPHAN/IBAMA se constatam avanços significativos na construção dos documentos que nortearão essa categoria de empreendimento. No novo RAIPI (EIA/RIMA) - referente à Ampliação do Cais de Acostagem (APPA) - se fazem perceptíveis tais avanços já no delineamento dos Programas para a Mitigação dos Impactos sobre o Fandango Caiçara, onde consta um programa de saúde aos mestres fandangueiros, fruto de diálogos internos entre os detentores e do entendimento dos percalços a serem transpostos no decorrer do processo.

Em vista dos embates anteriores, procuramos otimizar as demandas em nossa argumentação, baseando-a em problemas cotidianos, vivenciados pelos detentores no exercício de suas práticas, sendo acolhida e circunstanciada no novo documento. As demandas por espaços físicos como o Conservatório de Música Tradicional Caiçara e a Casa do Fandango, que esperam há longa data por melhores desfechos, foram também contempladas, sobretudo devido à envergadura da ampliação, consequentemente do maior tempo para implementação do novo programa a ser elaborado.

Nesse sentido, ações pontuais inerentes ao manejo sustentável da caxeta, e a atualização dos dados quanto ao número de grupos atuantes em Paranaguá, também puderam ser visualizadas no novo relatório, que faz, ainda, referência à singularidade da Romaria do Divino Espírito Santo na área de abrangência, indicando medidas de fomento a essa prática. Amém.

Aguardemos por novos desenvolvimentos, diga-se, com o coração apertado. Estima-se, inicialmente, que, se implantados, os licenciamentos acima mencionados ocorrerão faseados ao longo dos próximos oito anos.

A reflexão acima mencionada visa ao melhor entendimento dos processos de mitigação e de sua consolidação, considerando que a operação portuária em Paranaguá é histórica e incide diretamente no desenvolvimento econômico do Estado e do país. Como mencionado pelo professor Carlos Marés, durante o II Fórum de Pesquisas em Desenvolvimento Territorial Sustentável, evento voltado à elaboração do Plano de Desenvolvimento Sustentável do Litoral do Paraná, há de se propor um novo modelo porto-cidade para Paranaguá, de modo a mitigar os impactos socioambientais consolidados, com vistas a potencializar a distribuição de renda e a melhoria da qualidade de vida da população - comentário que acabou por integrar a Carta de Matinhos, redigida coletivamente na ocasião. 
Potencializar a capacidade do porto de Paranaguá, a partir de propostas sustentáveis, foi uma das possibilidades levantadas no debate como opção viável às crescentes demandas do desenvolvimento econômico e mercantil, sabendo-se que a liberação de licenças para novos empreendimentos portuários em Pontal do Paraná, por exemplo, inevitavelmente acarretará em impactos irreversíveis tanto sobre o bioma quanto sobre o componente humano que habita a região.

Não se trata de ignorar e se contrapor às demandas de ordem econômicas e mercantis, mas, sim, de adequá-las às premissas de sustentabilidade e equidade, que são prerrogativas para o desenvolvimento social e cultural humano. Entre outras recomendações, a carta indica a necessidade de que o plano deva "contemplar a proposição de cenários de desenvolvimento que respeitem os ecossistemas e os modos de vida das populações locais, em detrimento dos modelos hegemônicos". ${ }^{96}$ É disto que estamos falando: \#salveailhadomel ${ }^{97}$.

\footnotetext{
96 Carta de Matinhos, disponível em http://www.litoral.ufpr.br/portal/wp-content/uploads/2018/08/Carta-deMatinhos-II-F\%C3\%B3rum-de-Pesquisas-Desenvolvimento-Territorial-PDS-em-Debate.pdf

${ }^{97}$ https://www.youtube.com/watch?v=gI9hI3ikTnU
} 


\section{LUTERIA CAIÇARA CONTEMPORÂNEA}

José Jorge Carvalho (2005, p. 34), em conferência no Seminário Nacional de Políticas Públicas Para as Culturas Populares, bem argumenta que "ainda que tendo que passar por hibridismos, as culturas populares conseguiram sobreviver e avançar constantemente". Salvo as limitadas condições de fruição, as sementes frutificaram: conferências municipais, estaduais e nacionais de cultura, encontros e seminários nacionais e sul-americanos voltados às políticas públicas para as culturas populares, elaboração e implementação do Plano Nacional de Cultura, de prêmios para as culturas populares, dos editais para estabelecimento e apoio aos pontos de cultura. "Uma coisa, portanto, é pensar no possível e celebrar isso, e outra é lembrar idealmente quanto poderemos alcançar, vendo as culturas populares como um lugar de demanda de cidadania, de igualdade e de equidade." (CARVALHO, 2005, p. 35 - grifo nosso)

Como objetos dotados de significação, os instrumentos musicais e seus artífices, fabricantes e tocadores gozam de um reconhecimento público peculiar. Como já mencionado por Juarez Bergman ao relatar atividades de campo na ilha dos Valadares:

Notei em meu campo o protagonismo de artefatos musicais; algumas vezes sutil, em outras explicitamente. Devo dizer que no circuito cultural do Fandango que observei, a viola caiçara mais comumente desempenha um papel de protagonista, tanto musical quanto socialmente, e o próprio mestre violeiro tem um status diferenciado. Nos grupos que observei, cabe a ele [mestre violeiro] a condução musical de um baile, por exemplo. Contudo, também ocorreu o protagonismo da Rabeca em algumas oportunidades, principalmente quando observada em relação ao Mestre Zeca.

(...) O Mestre tinha consigo sua Rabeca, em uma capa de nylon, que ele levava a tiracolo. Aorélio sugeriu que o Mestre deixasse a Rabeca na Mandicuera para não carregar o peso desnecessariamente, mas o Mestre negou dizendo:

- Prefiro levar a Rabeca, caso alguém me veja... (frase interrompida)

A fala do mestre imediatamente chamou a minha atenção (...). Neste momento, Zeca se identificava intrinsecamente com o instrumento e era identificado através dele. Ali, sujeito e artefato se transformavam em algo novo, híbrido. Minha interpretação para a frase interrompida é a seguinte, "Prefiro levar a Rabeca comigo, pois as pessoas me reconhecem com a sua presença; com ela sou o mestre rabequeiro".(BERGMANN FILHO, 2016, p. 36)

Experiência grata, outro dia, saindo da casa de Mestre Nemésio, na ilha dos Valadares, pude vivenciar mesmo que na condição de estrangeiro, algo congruente à experiência acima 
mencionada. Já que o machete estava fora da capa, segui a breve caminhada até a cabeceira da ponte com "arma em punho", dedilhando marcas tradicionais do fandango caiçara.

Instrumento leve, de fácil transporte e muito versátil, confeccionado pelo mestre Zé Pereira, que reside em Cananéia, litoral sul de São Paulo. Nesse caso, o machete foi escavado artesanalmente em uma única peça de caixeta, sendo o entalhe em marchetaria substituído por linhas desenhadas com caneta esferográfica. Com afinação semelhante à do cavaquinho, porém, usualmente uma $5^{\mathrm{a}}$ acima deste, soando um acorde de ré maior com baixo em lá, quando todas as cordas são tocadas soltas. É um instrumento que vem retomando o gosto dos fandangueiros paranaenses e que foi por longa data utilizado como instrumento de iniciação ao universo da musicalidade caiçara, como mencionado por "Seu” Waldemar Cordeiro:

Quem me ensinou? Fui eu mesmo que aprendi. Meu Pai tocava bem viola, tocava bem viola, ele dançava, ele que era o puxador de roda. Então eu via ele tocando, então esses dias olhando ali... eu aprendi a tocar viola no machete, depois fizemos uma viola $3 / 4$ que chama "machetona". Aí que peguei na viola grande. (MARCHI, 2016, 5’04” - 5'27” - transcrição nossa)

Figura 4.1 - Machete cavocado de Zé Pereira (Ariri/SP)

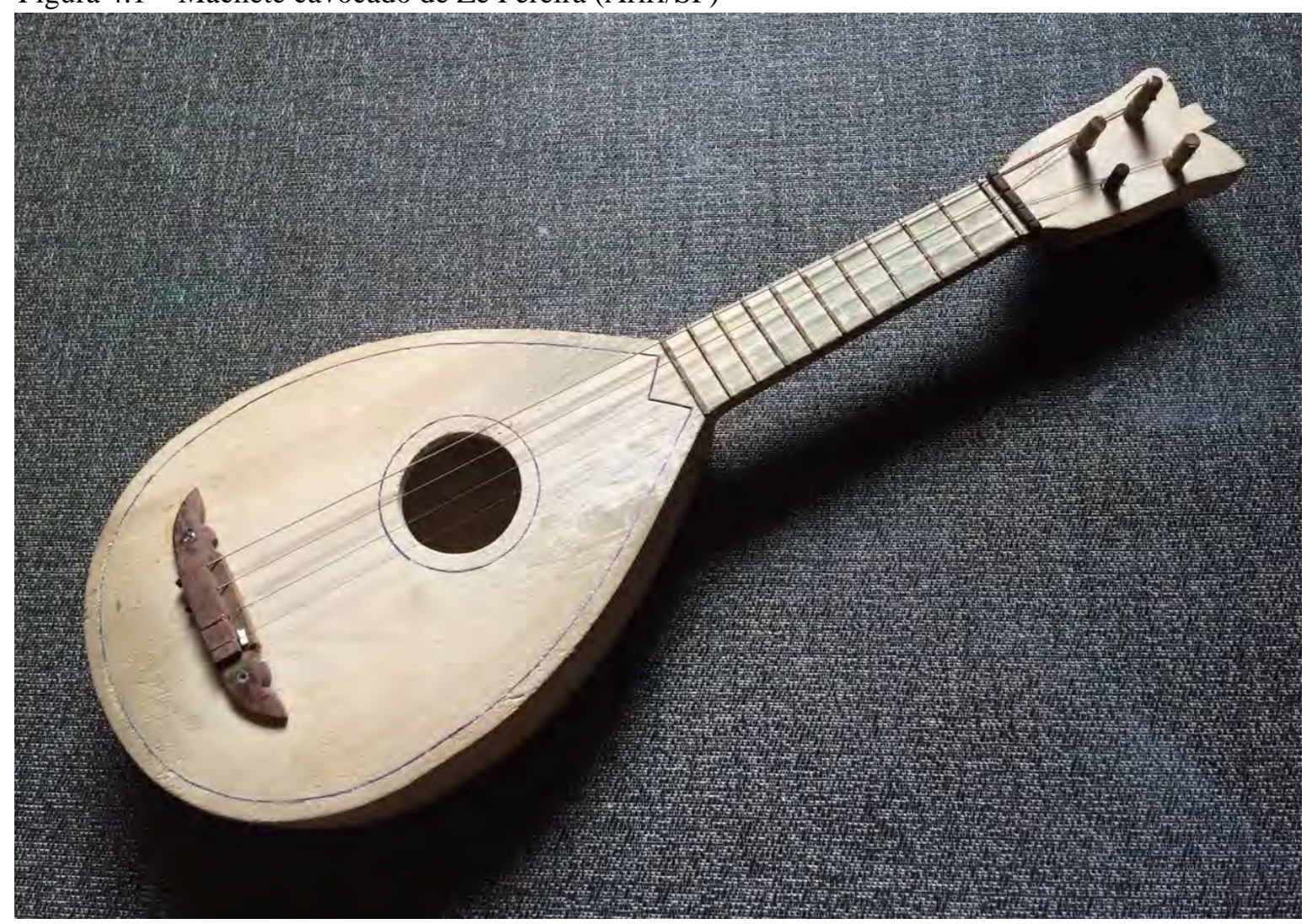

Fonte: Acervo pessoal 
Durante o percurso, fui repetidas vezes abordado: um transeunte que passava de bicicleta comentava a vontade que tinha de aprender a tocar, outro elogiava meus incipientes ponteios sobre uma moda fandangueira inominada, outros ainda saíam de suas casas e ficavam parados em frente ao portão, esboçando sorrisos, cumprimentando ou observando com alguma desconfiança.

Este breve momento me fez refletir sobre como pequenos eventos podem iniciar processos de participação ou atravessamento do cotidiano, assim como a imediata empatia proporcionada pelo simples fato de carregar um instrumento (nomeadamente inserido no universo fandangueiro). Pudera eu ter registrado as imagens, ou melhor, acessado as memóriaslembrança e associações livres principiadas por minha ação despreocupada frente à audiência.

\section{Flanair!}

Na fala de Steill e Moura Carvalho, podemos refletir de que maneira o objetoinstrumento é subjetivado e transformado ao longo deste fluxo de caminhada, assumindo outras dimensões:

\footnotetext{
No jogo epistemológico ocidental, conhecer define-se fundamentalmente como um processo de objetivação em que o sujeito se constitui ou reconhece a si mesmo nos objetos que produz. A esta forma de conhecimento, Viveiros de Castro contrapõe o xamanismo ameríndio, para o qual "conhecer é personificar, tomar o ponto de vista daquilo que deve ser conhecido - daquilo, ou antes, daquele - pois o conhecimento xamânico visa a um "algo" que é um "alguém", um Outro sujeito ou agente" (Viveiros de Castro 2002, p. 358). Assim, se na epistemologia moderna o Outro toma a forma de objeto, no xamanismo o Outro toma a forma de pessoa. (...) Ao mesmo tempo, ambos apontam para um ideal epistemológico que, longe de reduzir o ambiente à condição reificada de objeto, sem vida ou intencionalidade, vai em direção contrária: a da sua subjetivação. Esta crítica ao distanciamento epistemológico com que opera a ciência moderna aparecerá de uma forma ainda mais radical em Tim Ingold, que propõe um novo paradigma que retira o pesquisador da sua posição de observador externo de um mundo de objetos fixos e o situa na convergência de linhas e fluxos de materiais que o atravessam e o constituem como uma unidade generativa que chamamos mundo ou ambiente. (2014, p. 167)
}

No âmbito dessas transformações, a apropriação e o desuso, a incorporação de novos materiais e a desqualificação de outros são movimentos que integram os processos dinâmicos de inter-relação entre grupos humanos e de hibridismos resultantes da miscigenação de componentes étnicos. Esses aspectos são discutidos por Canclini (2013, p. 248), sugerindo que o conceito de "formas híbridas" pressupõe "procedimentos pelos quais as culturas tradicionais dos indígenas e dos camponeses unem-se sincreticamente a diversas modalidades de cultura urbana e massiva". 


\section{Do facão à serra fita}

Reflexo do traquejo no trato com o poder público e a participação ativa de colaboradores e pesquisadores nestes imbróglios, a Associação Mandicuera é um dos exemplos de como as políticas públicas para as culturas populares pode render bons frutos, revelando um terceiro viés de institucionalização, concentrando suas atividades tanto no universo artístico (espetacularização), quanto em ações de salvaguarda e militância política em prol das culturas populares. Uma das atividades realizadas pela Associação diz respeito ao chamamento público $n^{\circ}$ 03/2014 proposto pelo Instituto do Patrimônio Histórico e Artístico Nacional (IPHAN). O Fandango Caiçara, como um bem registrado como patrimônio imaterial da cultura brasileira, torna-se objeto do convênio realizado com a Associação a partir do projeto "Artesanias Caiçaras: a sustentabilidade através da construção de instrumentos musicais", iniciativa que em parceria com os membros do Comitê Provisório de Salvaguarda do Fandango Caiçara, de representantes de grupos de Fandango da Ilha dos Valadares e de instituições como a Universidade Federal do Paraná e o Instituto Federal de Educação do Paraná - desenvolveu atividades para salvaguardar a manifestação, neste caso, especificamente no que diz respeito à construção de instrumentos musicais do universo caiçara.

Figura 4.2 - Instrumentos produzidos pelo projeto Artesanias Caiçaras

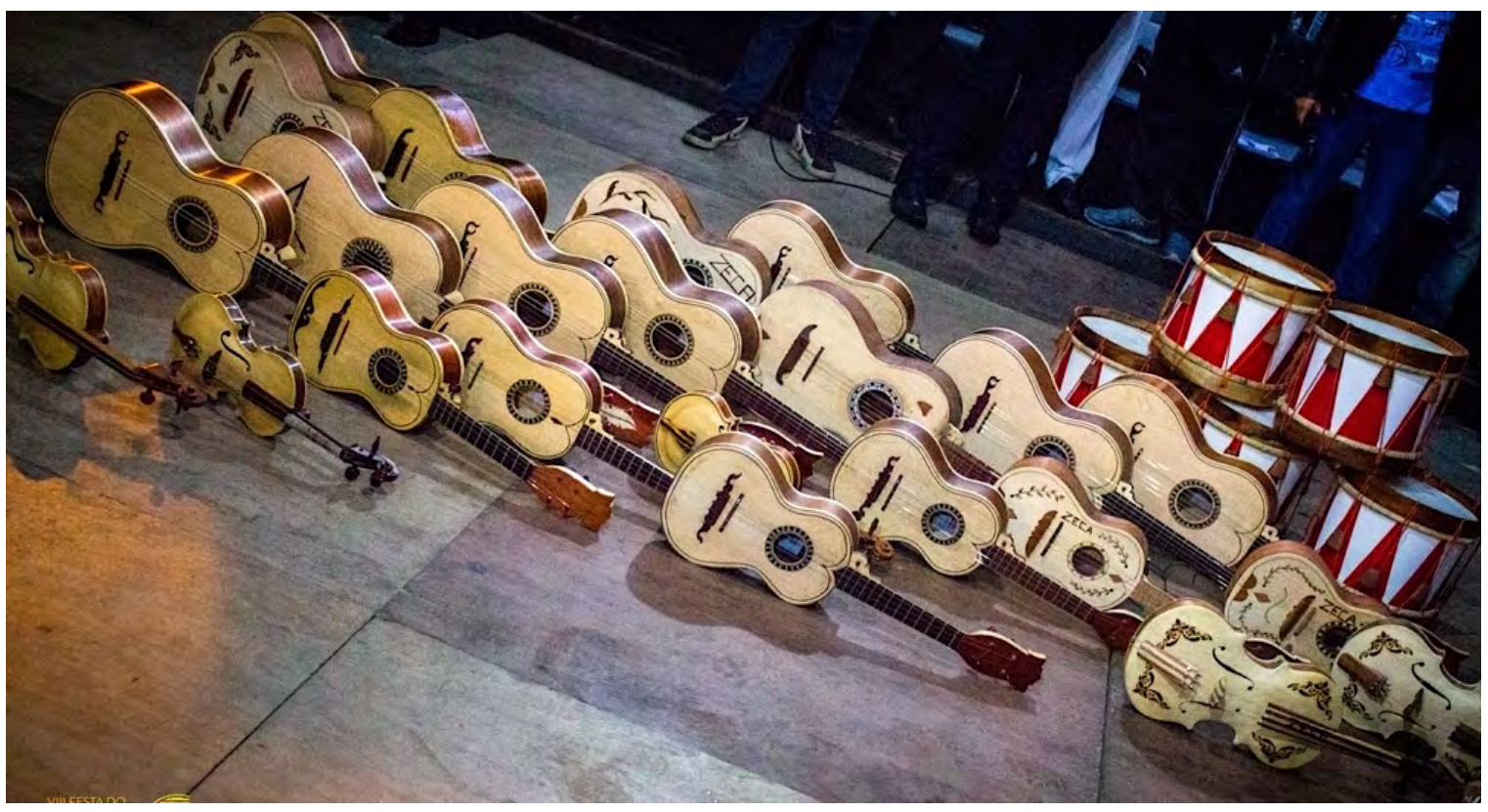

Fonte: Foto de Flávio Rocha 
Os instrumentos produzidos nesse projeto foram distribuídos aos fandangueiros e grupos de fandango durante a VIII Festa do Fandango de Paranaguá no ano de 2017, aproveitando a ocasião que reuniu detentores dos três estados que integram o território caiçara.

Figura 4.3 - Distribuição dos instrumentos durante a VIII Festa do Fandango de Paranaguá (2017)

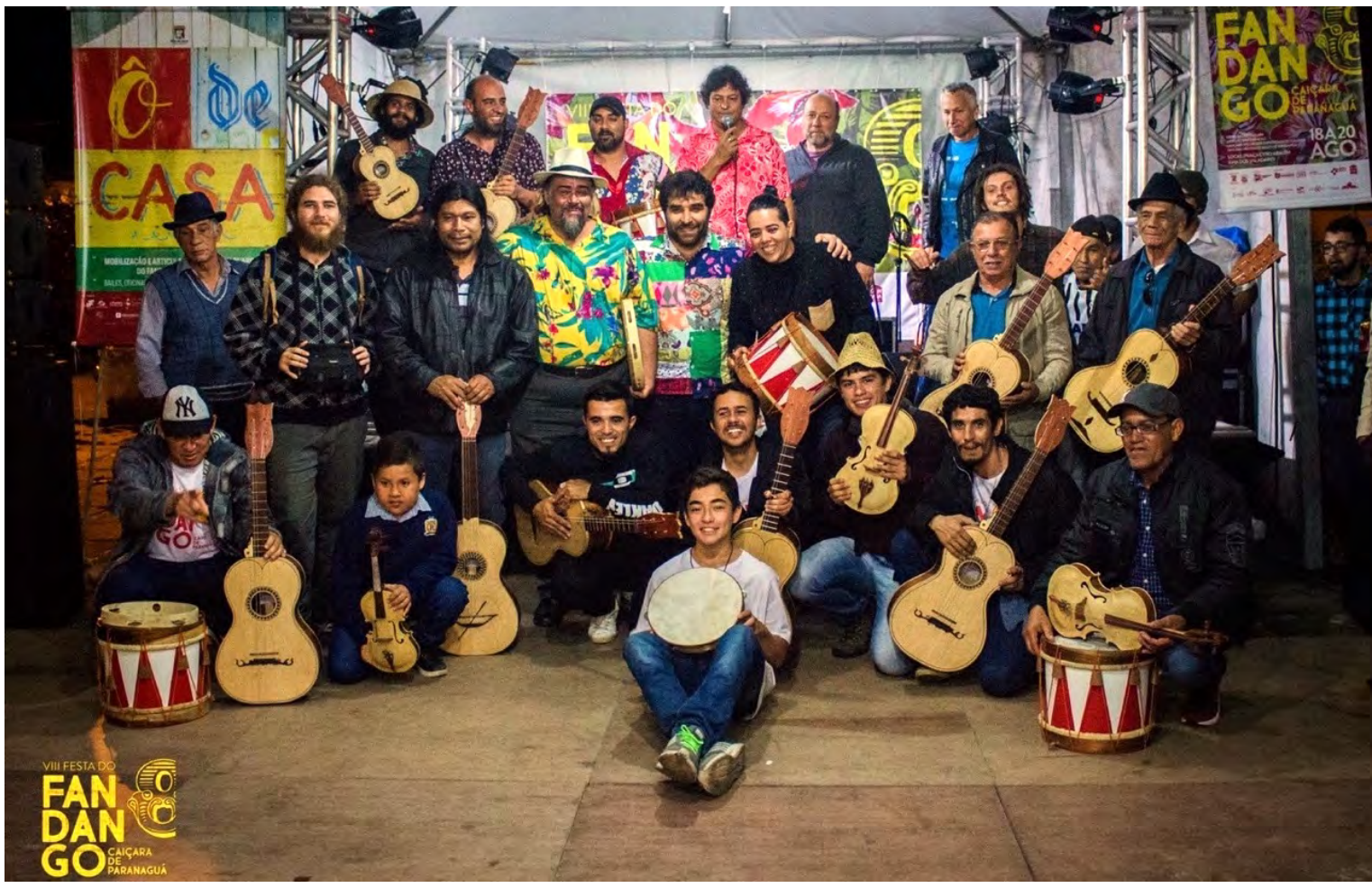

Fonte: Foto de Flávio Rocha

Para compor a equipe de aprendizes/multiplicadores do projeto, foram selecionados por meio de edital público oito bolsistas, cujo contrato previa que vivenciassem todas as etapas de construção de violas, rabecas, machetes, adufos e caixas, construindo junto com os mestres lutiês Aorelio Domingues (Paranaguá - PR), Cleiton do Prado (Iguape - SP) e Filipe Souza (Curitiba - PR) sete conjuntos de instrumentos e um mbaraka, a serem distribuídos para grupos e tocadores do Fandango Caiçara e indígenas Mbyá, tanto na Ilha dos Valadares, município de Paranaguá, quanto em regiões mais remotas do litoral norte paranaense, paulista e sul fluminense, localidades onde se evidencia a carência de tais instrumentos. Os conhecimentos que produzem as musicalidades caiçaras são também aqueles que as podem traduzir, materializando formas de ser e entender o mundo por meio de instrumentos que sonorizam um universo pautado pela circulação e socialização desses saberes. Com atividades circunscritas no município de Paranaguá - Ilha dos Valadares -, o projeto levou este saber fazer a um público majoritariamente jovem (alunos da UFPR, do IFPR, fandangueiros, ilhéus da Ilha dos Valadares 
e indígenas Mbyá Guarani) no intuito de replicá-lo de forma ampla e consciente, compreendendo suas práticas e interações sociais para além das técnicas de construção de instrumentos musicais.

Figura 4.4 - Aula inaugural Projeto Artesanias Caiçaras (2015)

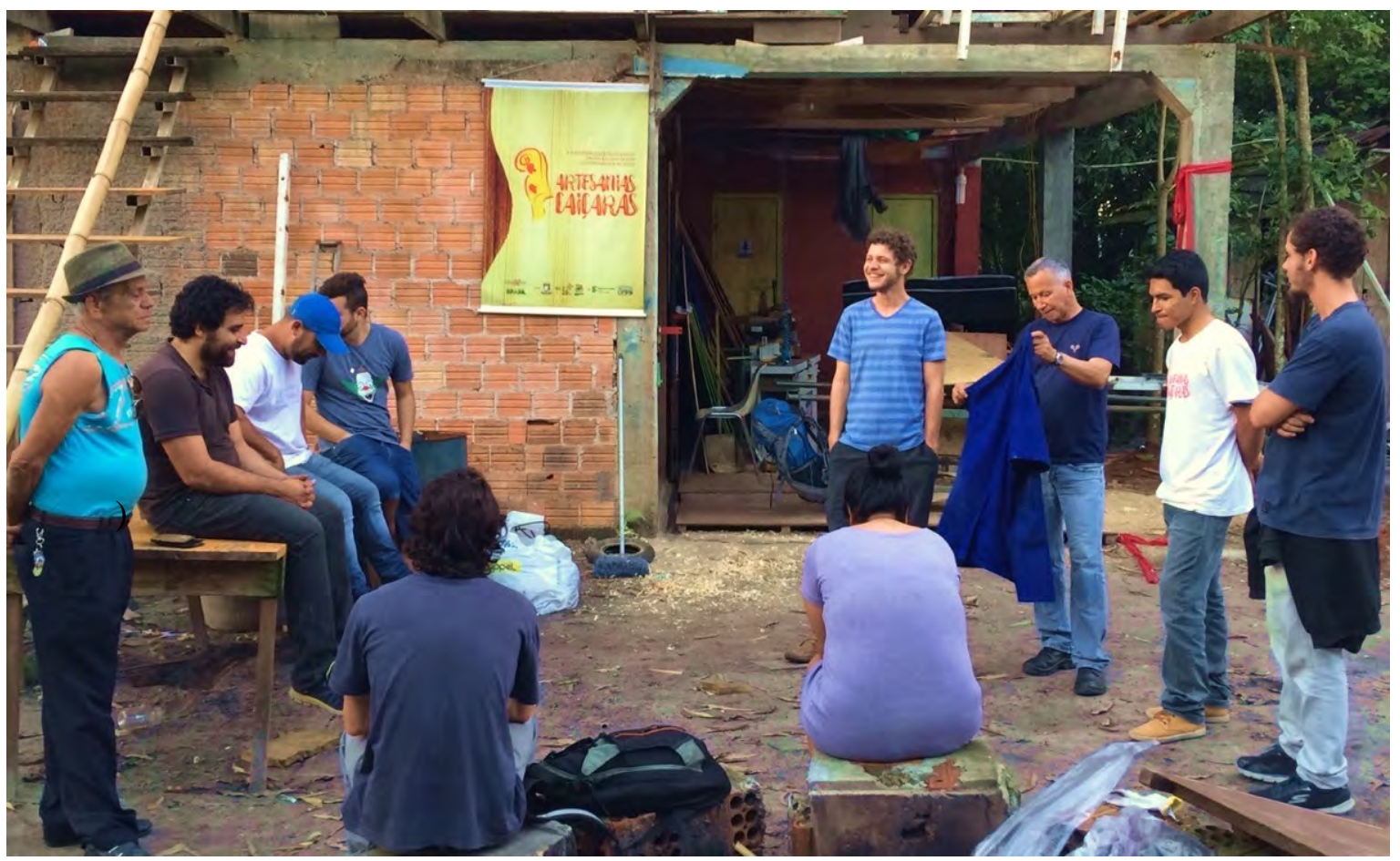

Fonte: Acervo pessoal

[Ruídos de madeira sendo cortada na serra circular]. Esse projeto já nasce para atender uma demanda que era de instrumentos musicais, instrumentos dos mestres, instrumentos para os aprendizes, para dar aulas, para os grupos. Eu acho que o Artesanias, ele traz um respiro, a gente tá num momento muito delicado da cultura popular, porque temos que aproveitar este último elo da cultura popular com a transição dela para o contexto. Aproveitar os mestres ainda que estão vivos, este conhecimento, desde o swing da música até o conhecimento da madeira, da natureza, dessa vivência deles, aproveitar essa experiência deles [mestres mais antigos]. Para a gente, essa construção de instrumentos traz um respiro para toda essa atividade. Porque é difícil a gente pensar que vai ter que ensinar jovens a construir instrumentos, a gente tratar com leis ambientais que proíbem a gente de retirar madeira do mato, tudo isso. Trabalhar tudo isso até chegar ao ponto de ter construtores de instrumento.

O instrumento não é feito da forma tradicional, mas a gente pega a técnica tradicional e organiza ela para esse novo contexto, esse novo jeito de se fazer instrumentos. Não quer dizer que a gente tá mudando a técnica, mas a gente tá agilizando o processo e também organizando o processo para que se repasse. A intenção é deixar isso acessível para o maior número de pessoas possível, para que esses instrumentos cheguem ao maior número de áreas possível, principalmente atendendo à demanda local. Esses primeiros instrumentos vão para mestres, depois a gente pensa em fazer projetos onde estes instrumentos cheguem para aprendizes. 
Então a gente tá atendendo primeiro mestres, grupos, aprendizes, depois músicos regionais que tenham ligação com o fandango e depois a gente começa a atender outras demandas, músicos de outras regiões, outros contextos musicais. A demanda é enorme e a gente sabe que vai crescer isso, muito!

Porque o instrumento, as pessoas vão começar a ver o instrumento como instrumento musical, não apenas de fandango. Ele é um instrumento de fandango, não vai deixar de ser um instrumento de fandango, porém, tem uma afinação específica que pode ser utilizado em outras áreas musicais. (Aorélio Domingues) (ROCHA, 2016, 0' 14” - 2'59” - transcrição nossa)

$\mathrm{Na}$ atual conjuntura também se faz pertinente e necessário pautar a relação sóciohistórica dessas comunidades com o meio ambiente em que vivem, trazendo à tona o debate sobre o acesso e o uso sustentável de seus recursos por parte das populações tradicionais que habitam este território.

O "fazer" dos artefatos destinados à manutenção do Fandango transcende a mera manufatura, arraigado que está a um território específico, assim como às matérias primas disponíveis nessas áreas de abrangência. Como postulado por Ingold, o fabricante junta forças com a matéria ativa e dinâmica que está sendo trabalhada a fim de participar do seu surgimento. Este processo se realiza em detrimento do estado estático da matéria inerte, que toma forma e significado, considerando as coisas em termos de fluidez e de solidez. A construção teórica e metodológica que permeia o projeto acima citado vai ao encontro das ponderações propostas por Ingold, de maneira que a ênfase incida na emergência dos processos e não nos artefatos acabados. (INGOLD, 2013 p. 21).

O desabafo de Aorélio Domingues - ao ser questionado sobre a valoração financeira de seus instrumentos a serem destinados aos demais grupos de Fandango de Paranaguá, por ocasião da execução do Plano de Gestão do Bem Registrado via Terminal de Contêineres de Paranaguá - é esclarecedora:

Antes de mais nada, queria lembrar que este processo faz parte de uma normativa [IPHAN 01/2015] criada justamente para ajudar a promover e proteger o patrimônio imaterial, em especial os já registrados, reconhecido pelo IPHAN como um bem importante para a manutenção da identidade. A TCP está se instalando em cima do nosso território e deve pagar pelo uso e apropriação dele. Dentre outras coisas esta normativa tenta também reparar um mínimo do impacto gerado. Esta viola da qual estamos tratando, não é apenas um instrumento, ela é uma ferramenta de resistência e de legitimidade, tanto nós quanto a TCP quando inserimos este instrumento em uma ação, estamos legitimando algo. Esta viola, não carrega só madeira, ele é feita de oralidade, ela é feita de angústia, de luta, de resistência, de proibições, de séculos de alegria, de crianças, de velhos, de jovens. Quando ela toca, ela soa o ambiente e o meio ambiente, ela resgata lembranças, ela contextualiza, ela une, ela transforma, ela ensina. Então se eu fizer mais barato, ela vai só com 
madeira e só com madeira não é viola, a gente precisa de viola. (Resposta enviada ao responsável técnico em 17/12/2018, às 18:39h, via WhatsApp)

No que toca às dinâmicas estabelecidas durante o processo do projeto Artesanias Caiçaras, foram utilizadas ferramentas industrialmente manufaturadas, como fresas, plainas, serra fita, serra circular, lixadeiras elétricas e demais utensílios disponíveis no atelier de luteria Rodrigues Domingues (implementado pelo programa Pontos de Cultura, entre 2009 e 2011, na sede da Associação Mandicuera). Isso possibilitou também a inter-relação de lutiês formados pela UFPR, fomentando a utilização de novas tecnologias pelos mestres construtores: arqueadores térmicos de laterais e lixadeiras horizontais capazes de adequar e perfilar a madeira nas bitolas necessárias ao feitio dos instrumentos, entre outras traquitanas funcionais. A transferência de tecnologia e a apropriação destas tecnologias pelos fabriqueiros, assim como a própria criação de ferramentas variadas, revela a dinâmica inerente a estas práticas vinculadas à necessidade de produzir uma quantidade considerável de instrumentos em curto espaço de tempo. O estado de fluidez elencado por Ingold, dá-se já na reelaboração do instrumental, na organização do atelier e na seleção das matérias primas, dos agenciamentos múltiplos com uma finalidade comum. Tais agenciamentos se somam às expectativas individuais na manutenção do fandango, como nos propôs Aorélio Domingues:

Eu gosto daquele acorde mais fechado, que a gente fala bufo, né, uma viola com mais bufo! Pelo meio [afinação de viola] não, pelo meio é mais aberta as cordas, tem uma que não fica presa, as cordas são mais finas... A minha necessidade é que as violas tenham sempre um grave mais forte; agora, eu troquei a guarda do tampo da viola, troquei a guarda de dentro, que era uma guarda só para leque! Agora, tem leque no tampo, por dentro, e a viola tem menos madeira, ela tem menos madeira para puxar mais o grave, coisas que tô buscando para mim. Deixar o fandango que eu quero naquela cara assim! Isso sempre me chamou atenção no Canarinho [bar de Pedro Pereira na Ilha dos Valadares], quando eu morava ali na maior parte da minha infância, me chamava atenção no Canarinho era justamente o bufo da viola. "Intaivada" [tipo de afinação usual nos estados do Paraná e de São Paulo].

Quem tocava ali era Vitorino, que era mestre folião também, "Seu" Anibá [outro, não o da vila Fátima], "Seu" Júlio Pereira, Pedrinho Pereira, Zeca, e tinha uma figura que vocês não conheceram: tio Aires, que tinha uma voz fininha, que era tipe de bandeira, mas tocava um fandango que, Meu Bom Jesuis! Fazia uma rabeca! Não que ele era meu tio, mas conhecido por tio Aires por todo mundo ali, ele era Pereira, era irmão... acho que era irmão de Pedro Pereira. Fazia artesanato ali; por aquela parte ali todo mundo mexia com artesanato, trabalhava fazendo violinha, espingardinha de caxeta, colher de pau... A gente trabalhava com isso daí.

Aprendi muito nessa época, meu avô também fazia, foi quando migrei para o "intaivado", mas era muito pequeno, o pessoal não deixava pegar na viola (...), daí morreu tio Aires, morreu Vitorino, morreu Aniba (...).

Eu vivia com esses velhos aí, ia pro mato lenhar, ia pro mato matar passarinho, ia pescar, tirava madeira com eles, foi aí que eu peguei o gosto de 
trabalhar com madeira, cortar lenha, cortar madeira. (Cadernos de campo 25/07/2015 - transcrição nossa)

No caso do projeto Artesanias Caiçaras, o processo de transferência de tecnologia ocorreu de modo informal e prático. Como chegar a resultados satisfatórios fazendo uso de técnicas e ferramentas que estão à mão ou ainda buscando soluções alternativas e inovadoras para efetivação destas demandas, como no caso do "bufo" da viola?

Figura 4.5 - Leque de tampo para viola branca produzido pelos participantes do Projeto Artesanias

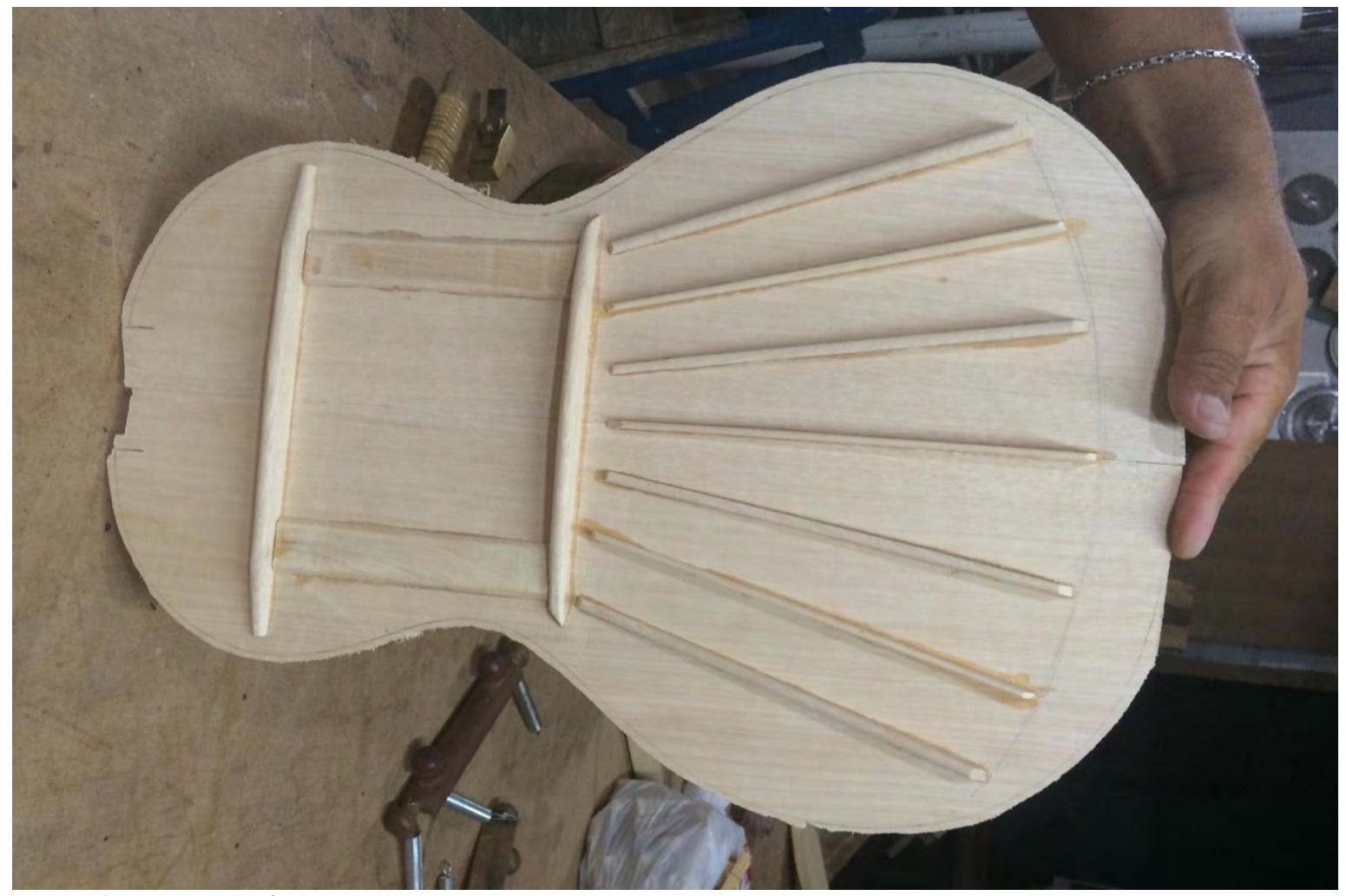

Fonte: Acervo Pessoal

Envergadores de ilharga ${ }^{98}$ confeccionados com resistências de ferros de solda ou uma base para carvão adaptadas a tubos metálicos são práticas ainda comuns no universo caiçara. Nas etapas iniciais do projeto, visitas aos ateliers do Curso de Luteria da UFPR, assim como aos ateliers de alunos egressos, serviram de inspiração para as adaptações necessárias na criação de novas ferramentas, com a finalidade de curvar as laterais dos instrumentos de modo mais ágil e simples. Nesse sentido, também podemos citar a lixadeira cilíndrica para perfilhamento de tampos, fundos e laterais ou o mecanismo para curvar vergalhões de ferro, adaptado para modelagem de aros para caixas e adufes.

\footnotetext{
${ }^{98}$ Parte lateral que segue as encurvações da caixa de ressonância dos instrumentos de cordas.
} 
Não foram feitas inovações, foram feitas adaptações de ferramentas das necessidades, nós não criamos nada, só adaptamos ferramentas que foram desenvolvidas no universo da luteria tradicional. A gente fez o envergador de ilharga, que é um curvador de lateral, tanto da rabeca, da viola e do machete, também adaptamos as formas, o cortador e moldador de platinelas que foi desenvolvido e que foi criado por alunas do curso de Mecânica do IFPR, que nos ajudou muito, uma ferramenta excelente. Também inovamos no acabamento, a gente tem aplicado um acabamento mais fino para nossas violas, a gente usou muito o que Felipe trazia do curso de luteria, do que Cleiton também trouxe das práticas dele lá [Iguape]. (Aorélio Domingues) (MARTINS, 2018, p. 136.)

Aorélio Domingues, Cleiton do Prado e Filipe Souza concordam que o uso deliberado de ferramentas não altera o fator artesanal das peças, que mesmo confeccionadas em um processo serial guardam peculiaridades em sua construção, sobretudo nos detalhes de marchetaria e acabamento, que inserem no artefato as marcas pessoais e autorais de cada artesão lutiê, ilustrados pela lâmina fotográfica $n^{\circ} 8$.

Figura 4.6 - Curvador de aros adaptado (“Seu” Genézio ao fundo)

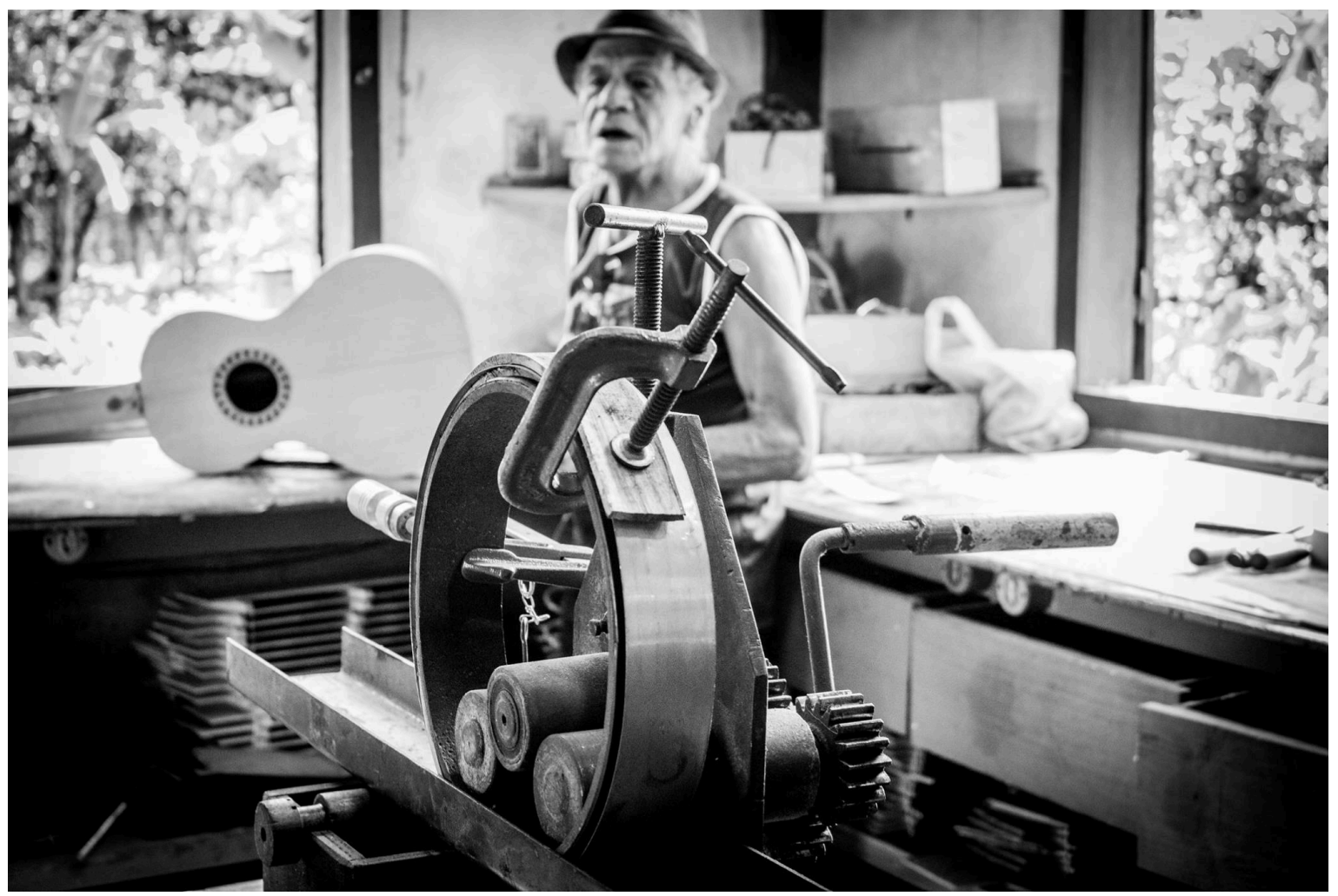

Fonte: Foto de Flávio Rocha

\section{LÂMINA 6}

Envergador de ilharga

Fonte: Foto de Flávio Rocha

\section{LÂMINA 7}

Lixa cilíndrica

Fonte: Foto de Flávio Rocha 


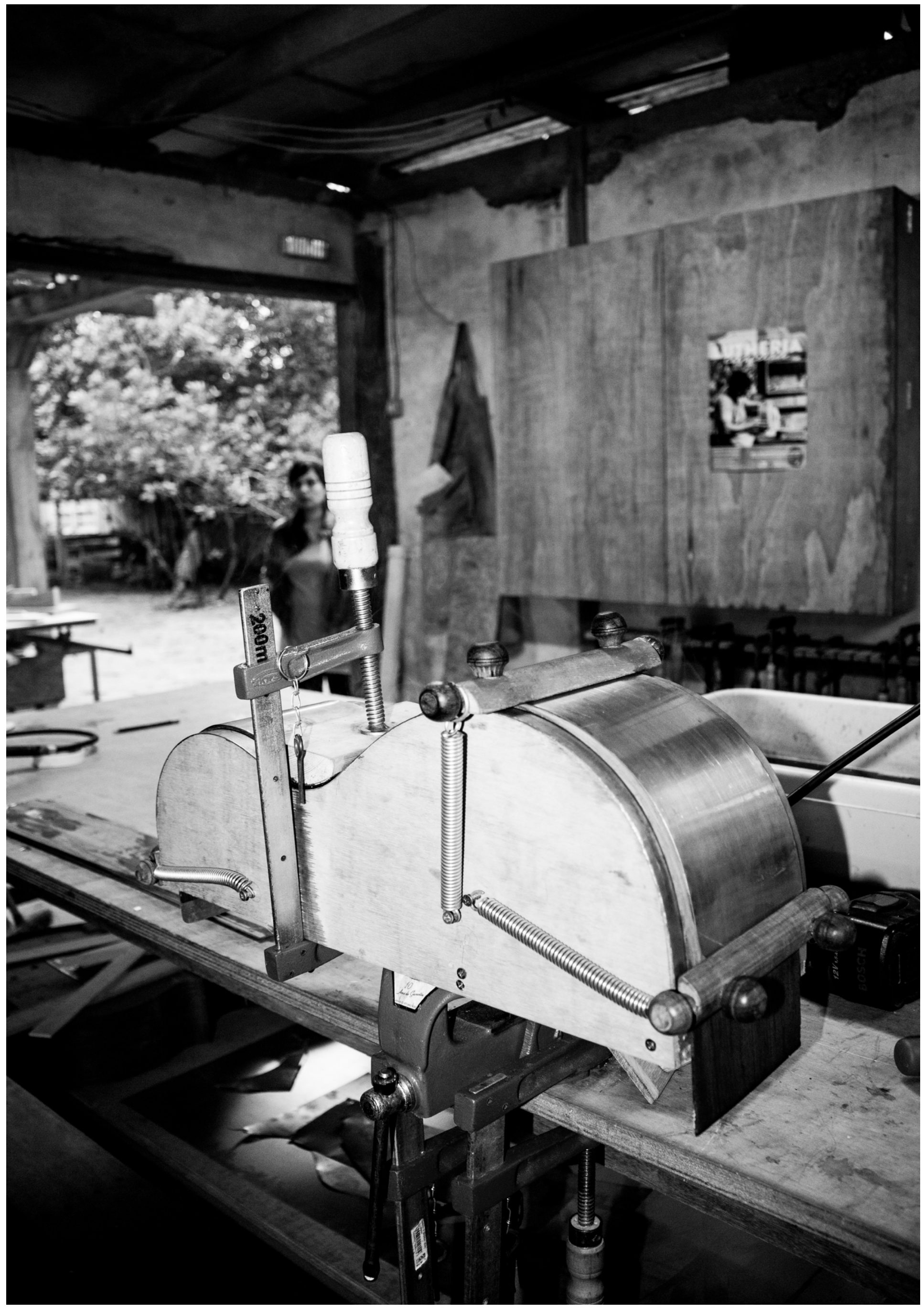




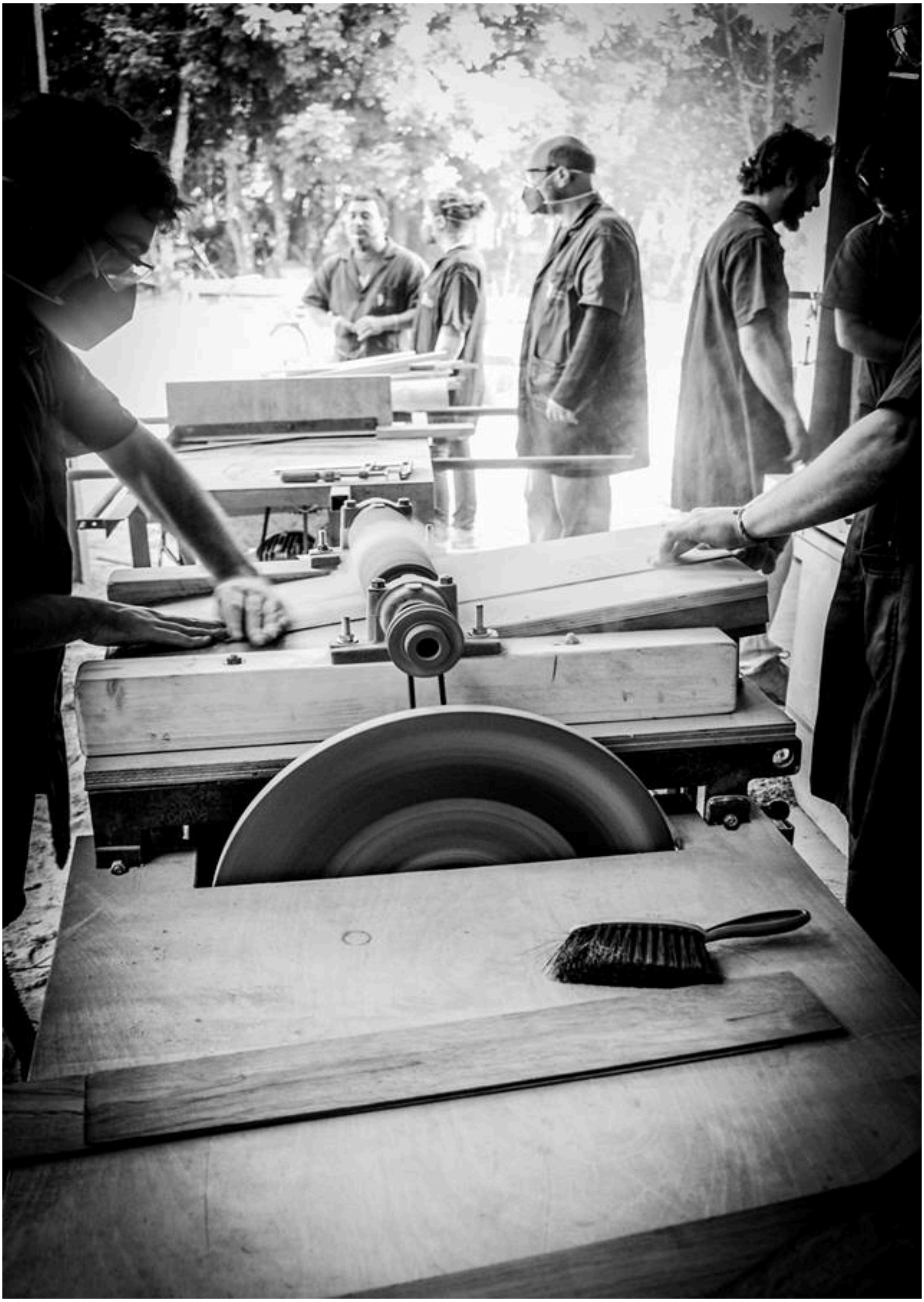




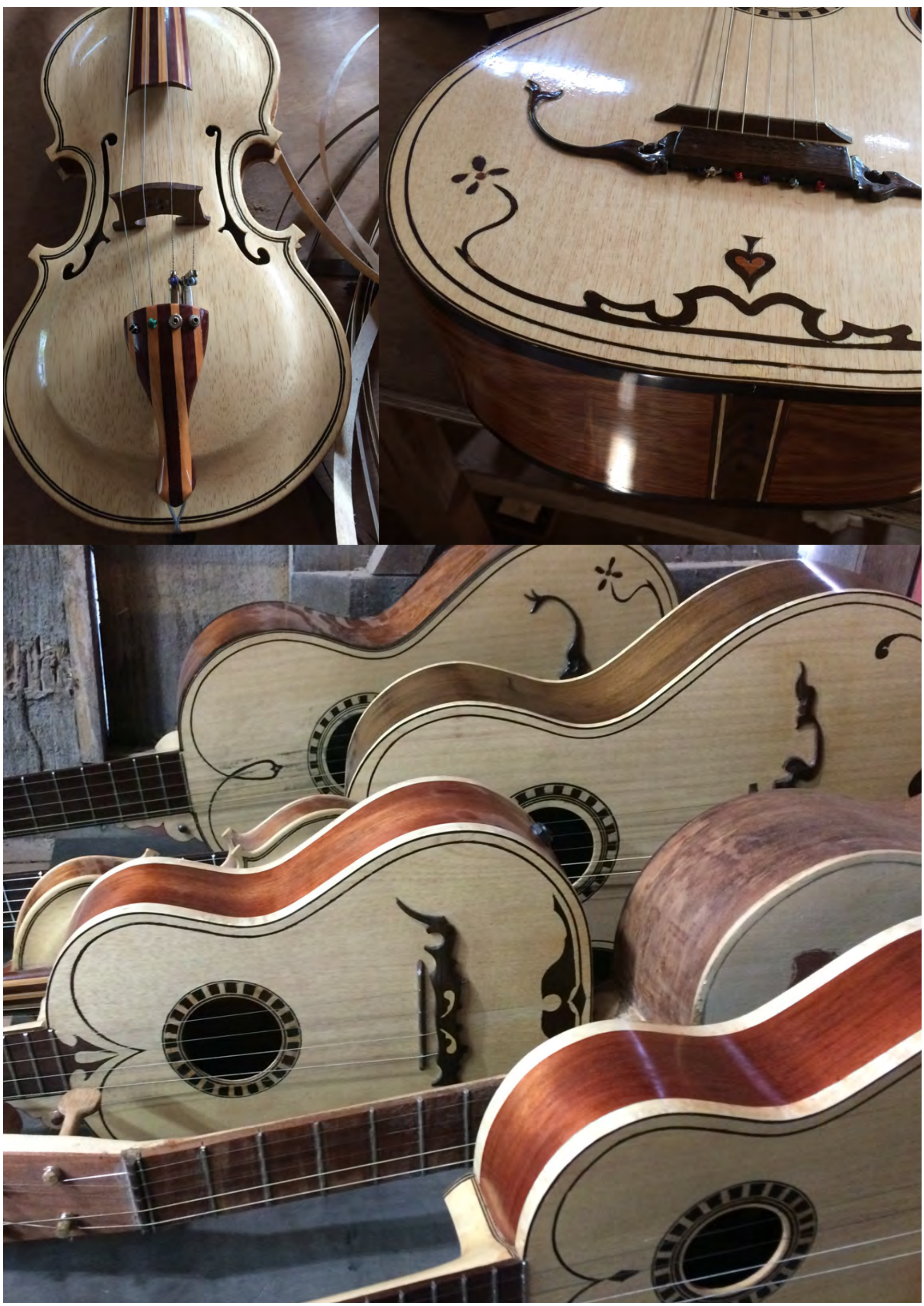




\title{
LÂMINA 8
}

Detalhes de marchetaria (rabeca, violas e machetes)

Fonte: Acervo pessoal

Durante o processo, técnicas tradicionais e contemporâneas foram mescladas, buscando a qualidade na sonoridade, na estética e na durabilidade dos instrumentos.

Um exemplo aqui nos poderia exemplificar as questões acima mencionadas, seja na inventividade quanto as soluções possíveis, ou quanto a singularidade da identidade que o artesão insere em suas peças. O Sr. Genézio Pontes, batedor de tamancos e matador de onças ${ }^{99}$, participou ativamente de todas as ações de construção dos instrumentos. Em meio aos instrumentos tidos como metas da ação, iniciou outros instrumentos por conta própria, marcando diariamente presença na sede na Associação Mandicuera, extrapolando o tempo de permanência proposto e se valendo de inventividade para contornar contratempos no trato de artesão.

Uma de suas soluções, que nos chamou a atenção, foi o recurso encontrado para solucionar um problema que teve com a rosetta de uma de suas violas. Além de auxiliar na construção dos instrumentos do projeto, "Seu" Genézio fez mais 3 violas, 2 machetes e duas rabecas, as últimas utilizando peças de instrumentos desmontados que estavam no atelier aguardando reparos e montagem.

Poderíamos dizer que se tratou de uma meta-solução: Genézio se valeu de um CD "Pixé de Manema", com gravações do grupo Manema de Iguape, onde a imagem impressa no disco é justamente a foto da roseta de uma das violas confeccionadas por Cleiton do Prado. A emergência dos processos (nos termos de Ingold) se dá também pelo atravessamento tecnológico que pode ocorrer nas mais diversas e improváveis situações e que se evidencia na adaptabilidade a situações-problema. Vale lembrar que "Seu” Genézio, na época, já somava 73 anos de idade, sem dúvida esbanjando bom humor e criatividade.

\author{
LÂMINA 9 \\ Viola de "Seu" Genézio \\ Fonte: Acervo pessoal
}

\footnotetext{
${ }^{99}$ Um chiste quanto ao matreirismo. Por ser extremamente calmo o pessoal da oficina repetidamente fazia essa piada com "Seu" Genézio insinuando sua coragem e valentia.
} 


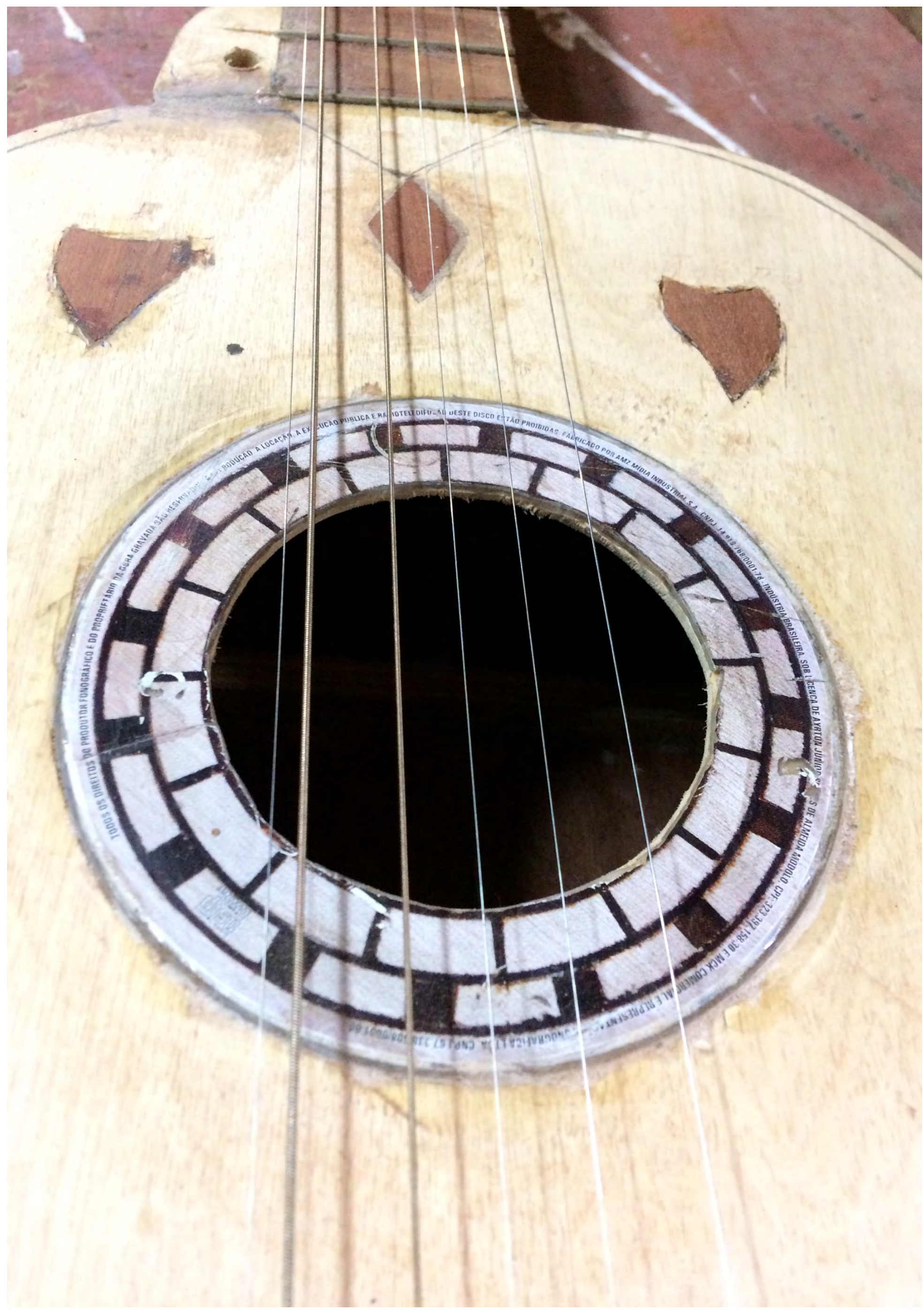




\section{Manufatura, transferência e técnica}

É que primeiro eu fazia esta rebeca escavada, só que quanto mais você vai fazendo, mais vai pegando aquela prática, que hoje em dia eu só faço assim, de aro, né? Ele fica mais fácil de fazer e economiza madeira. É que a madeira hoje tá muito difícil de encontrar, então, e a caxeta é meio proibido cortar! Você pode ver que minha rabeca tá toda feita de emenda, colada. Eu faço esse enfeite, que é feito aqui tudo pra aproveitar a madeira. A escavada, se a pessoa souber fazer e deixar ela meio fina, o som dela soa bastante também, mas se ele não coisa, ela perde de longe pra essas de aro aqui. (Zeca Martins) (MARCHI, 2016b, 13'19”'-14' 08” - transcrição nossa)

"Meu maquinário é só a faca, só!" Este comentário, recorrente entre fabriqueiros de maior idade, leva-nos a perceber o quanto a ideia de rusticidade atrelada ao fazer fandangueiro incita ações e imaginários que corroboram à tal percepção incutida em vertentes mais conservadoras da luteria caiçara.

Na medida do possível, os artesãos fazem uso de ferramentas que têm à disposição, mesmo sendo possível, e em algumas localidades é até corriqueiro, realizar a lavra da madeira apenas utilizando machados, facões e facas, valendo-se ainda de um ferro quente para furar as casas das cravelhas. A disponibilidade de energia elétrica ou de outras ferramentas de trato mais refinado, como formões, serrotes, furadeiras, lixadeiras e plainas, é também recorrente. Em todos os casos, tanto nos mais sofisticados ateliês, como nas mais remotas habitações entre capilares do lagamar, a "faquinha" é tida como estimada ferramenta do fabriqueiro. Ao redigir o parágrafo, de imediato emerge em minha mente a imagem do artesão Mbyá entalhando estatuetas zoomórficas vich'u ranga, usualmente desenhadas a fogo.

Concomitante à finalização dos instrumentos do projeto Artesanias Caiçaras, sob os auspícios do projeto Mutirão Mais Cultura na UFPR, fomentado pelo Eixo Diversidade Atístico-Cultural, foi realizada na sede da aldeia Mbya Kuaray Haxá, em Antonina ${ }^{100}$, uma oficina temática solicitada pelos indígenas, voltada para o aperfeiçoamento das práticas artesanais tradicionais dos Mbyá Guarani. ${ }^{101}$

\footnotetext{
${ }^{100}$ O público alvo foram indígenas Mbyá Guarani das localidades de Antonina (Kuaray Haxá), Guaraqueçaba (Kuaray Guatá Porã), Piraquara (Araçaí) e Pontal do Paraná (Guavirá Ty). A oficina teve por objetivo o aprimoramento do fazer artesanal de peças zoomórficas "vicho ra'anga" cuja principal matéria-prima é a caixeta, trazida pelos indígenas da comunidade de Guavirá Ty (Pontal do Paraná), pela escassez da mesma na aldeia sede do curso. Além das atividades de corte e entalhe na madeira, os participantes passaram por todas as etapas de produção das peças, como os detalhes nos acabamentos e o modo tradicional de dar cor aos artefatos, queimando os mesmos com ferro quente.

${ }^{101}$ Adelino Gonçalves Mbyá que reside na aldeia Yynn Moroti Whera, no município de Biguaçu (SC) comenta da
} 
As atividades foram conduzidas pelos indígenas Paulo Acosta e pelo Sr. João Acosta, ancião Mbya detentor habilidoso das técnicas ancestrais de entalhe em madeira. Saindo de Araçai em Piraquara, passamos ainda em Shangrilá (Pontal do Paraná), antes de nosso destino final em Kuaray Haxá (Antonina). Chegando na aldeia, acompanho a organização do equipamento de trabalho, Paulo separa a pequena faca e os ferros que utilizará para a "queima" de suas peças de artesanato.

Em outras oportunidades no atelier na Mandicuera, durante as atividades de construção dos instrumentos, as "faquinhas" também são concorridas, sobretudo nas etapas finais de acabamento e marchetaria. Cleiton do Prado trazia a sua de Iguape.

Figura 4.7 - Faquinhas de Cleiton do Prado, Paulo Acosta e Aorélio Domingues
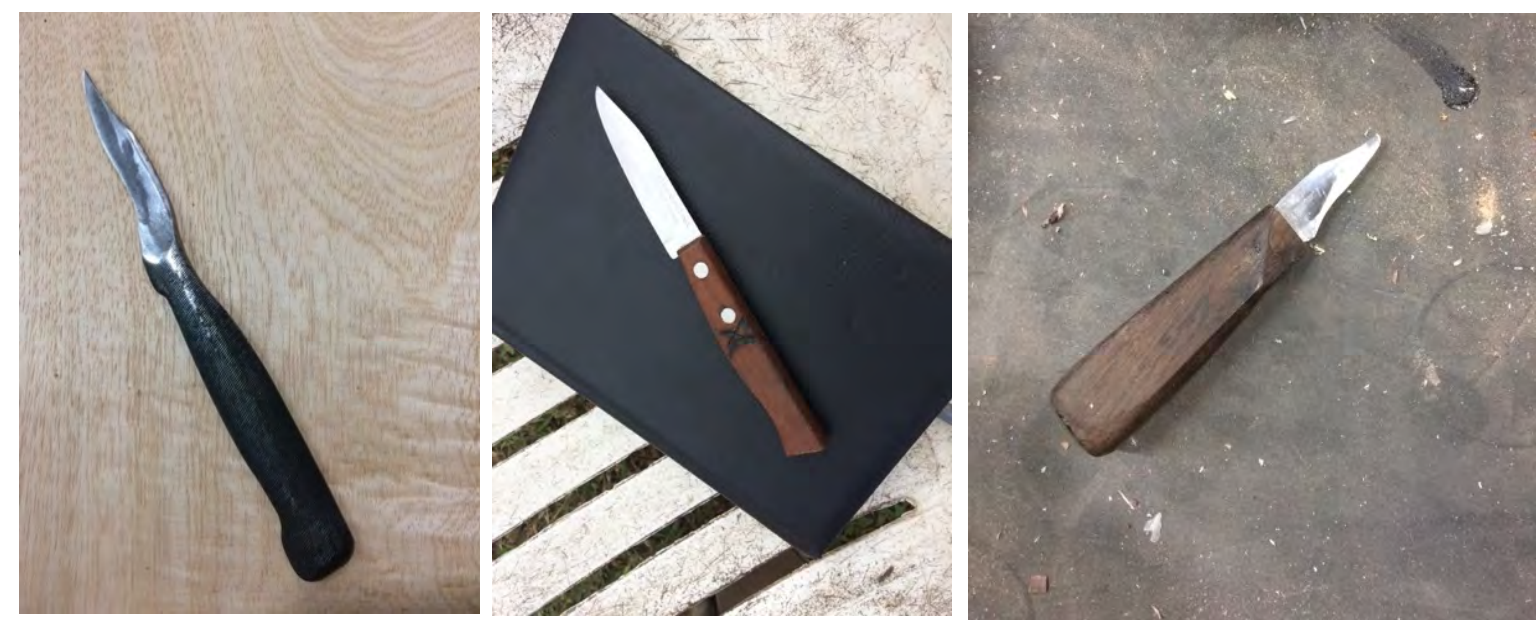

Fonte: Acervo pessoal

importância do artesanato em madeira, tanto na valorização de sua tradição cultural, quanto como alternativa para geração de renda entre as famílias da aldeia. Apesar de muitos grupos tupi utilizarem pequenas esculturas de animais como brinquedos para as crianças ou como peças rituais, as dinâmicas de troca com as sociedades englobantes acabaram por gerar novos sentidos para estas práticas, inserindo também estes artefatos na lógica mercantil de valoração monetária mas sem perder de vista os conhecimentos tradicionais envolvidos, assim como a estreita vinculação com o ambiente ao qual estão inseridos: "O Fabiano Benites fala que ele não sabe realmente como surgiu a escultura na cultura, mais relata que os avós dele contavam que primeiramente faziam os artesanato de madeira para usar no dia a dia. Faziam banquinhos em forma de animais para sentar, utilizados no opy - casa de reza. Depois que tiveram contatos com os brancos que começaram a fazer os bichinhos de madeira pequenos para vender." (...) "Timóteo de Oliveira conta que antigamente os Guarani faziam todos os tipos de artesanatos: alguns bonecos de madeira no formato de homens e mulheres que deixavam no caminho por onde passavam, assim por diante. Antigamente faziam para deixar como marca de caminho. Hoje os artesãos fazem os artesanatos em madeira no formato de pequenos bichinhos, para vender. Antigamente não vendiam, faziam para mostrar para os outros, para as crianças e os mais jovens. Ele fala da importância dos jovens aprenderem a fazer, porque assim vai continuando o conhecimento dos passados, porque os bichinhos que existiam por aqui, muitos já não conhecem mais. (...) Timóteo também fala que quando vai ao mato colher a madeira para fazer os bichinhos, primeiramente tem que pedir permissão ao espírito da natureza e da árvore. Essa, é cortada bem baixa para que possa brotar de novo, pois se não souber cortar ela não brota mais. (...) percebi com a pesquisa que existem muitos conhecimentos e aprendizados a partir de uma simples escultura de madeira. (...) Assim, além de registrar as técnicas de esculpir, falar sobre a importância de preservar essa riqueza cultural guarani, devemos também proteger as matas e demarcar terras para que se possa preservar o ambiente natural dessas espécies tão importantes para o povo guarani." (GONÇALVES, 2015, p. 12, 13 e 18) 
Uma das variantes da faquinha já conhecida dos fabriqueiros há longa data, é o alegre, tipo de ferramenta confeccionada com lâminas curvadas no intuito de escavar tampos e fundos abaulados durante o processo de produção dos instrumentos. No projeto Artesanias Caiçaras, foram projetados e confeccionados protótipos dessa ferramenta para uso no projeto, lembrando que tal ferramenta não se encontra disponível no mercado, mesmo o especializado, fato que mais uma vez - dá relevo à inventividade presente nestes processos.

Figura 4.8 - O Alegre de Heraldo Pereira, e outro produzido durante o Projeto Artesanias Caiçaras

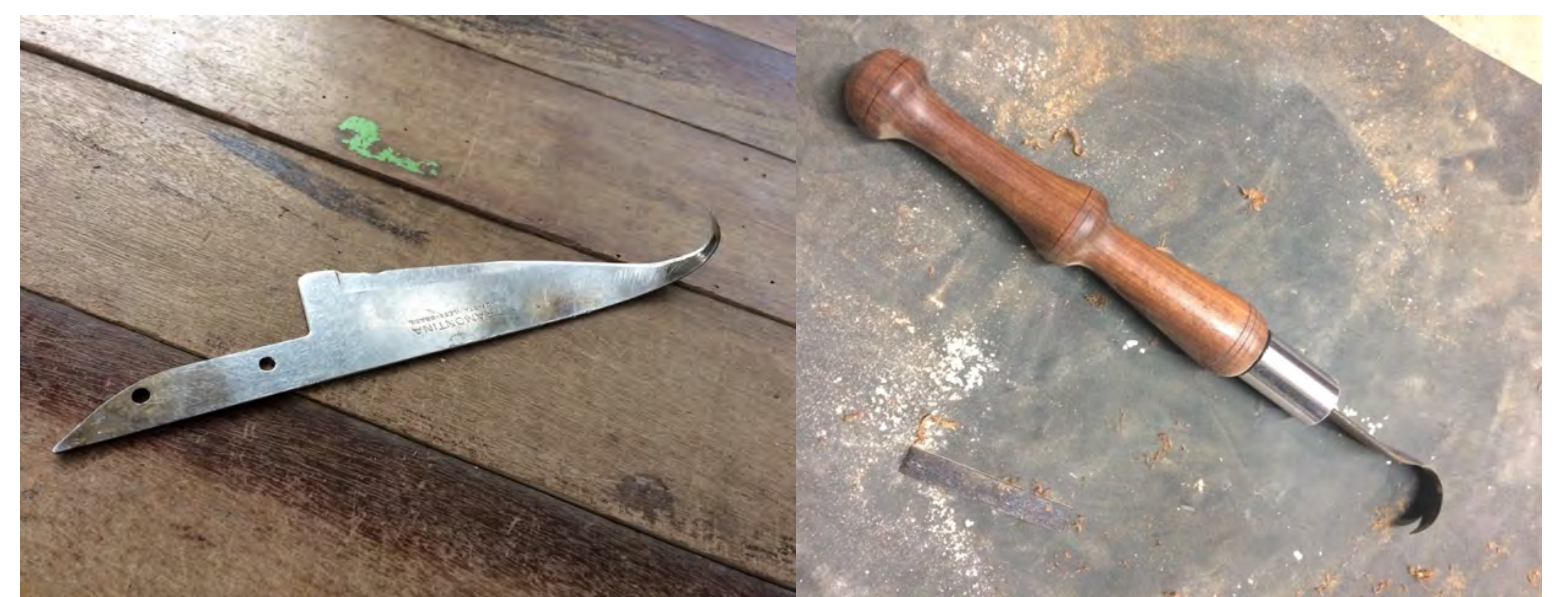

Fonte: Acervo Pessoal

Consenso entre os caiçaras e Mbyá é o fato de que sejam respeitadas as fases da lua para o corte da madeira: "Tem que observar a lua para colher, porque a madeira só pode ser cortado na lua minguante ou crescente para que os artesanatos não se estraguem." (GONÇALVES, 2015, p. 9). A atenção às fases da lua e do tipo de corte (por conta da rebrota dos troncos da caxeta) tanto visa à qualidade e durabilidade dos artefatos, como demonstra a sinergia humanoambiente (e a cosmopolítica entre humanos e seres da mata) imanente a estas práticas. Isso não é impeditivo para o uso de outros recursos, quando a caxeta se torna escassa:

É que agora a gente tá fazendo uma misturagem de madeira, faz um pouco de caxeta, faz um pouco com outras madeiras. Aí já dá um charme na rabeca. O som dela fica até melhor. Não era! Era só caxeta mesmo. Só o contrabraço, esse contrabraço é que a gente fazia com canela, a cravelha tudo! Tem a moda: Minha viola de pinho, caravelha de canela.... Tudo feito de canela [detalhes e peças de maior tensionamento].

No meu tempo quando eu era pequeno assim, não era nada proibido de caxeta, eles iam lá eles traziam aqueles barcos grandes carregado de caxeta e não tinha proibição. Essa proibição ela é meio (....) Porque se você corta uma tora de caxeta, ela vem mais de cinquenta assim as muda dela! Porque a caxeta, ela dá mais no mangue assim, no brejo! Dá muita caxeta, ela é assim uma madeira mole então a gente prefere a caxeta mais pro tampo da rabeca. A caxeta é a madeira melhor pra soar o som do instrumento! Tanto faz da 
viola, da rabeca, tem que ser a caxeta. (Zeca Martins) (MARCHI, 2016b, 10 '07' - 11'29"' - transcrição nossa)

Nas violas da Lâmina 08, por exemplo, encontramos tampos de caxeta, fundos de oiticica e muirapiranga, cavaletes, filetes e marchetaria de imbuia, laterais de jatobá e araribá, espelho de maçaranduva, e braços de goiabão. Não raro se utilizam também madeiras como a caróva, araçapirangua, guaírana (madeira utilizada na confecção de remos), jatobá e peróba. Lembrando também que outras madeiras e até mesmo lâminas de fórmica, usualmente encontradas - e minuciosamente escolhidas - na rua ou em refugos de obras e demolições, também podem compor o inventário de matérias primas utilizadas por fabriqueiros na atualidade.

Sobre o trato com a madeira e para além dele, o depoimento de Anísio Pereira coletado por Patrícia Martins demonstra também as dinâmicas de aprendizado e desenvolvimento de novas técnicas, aprendizados que se dão em paralelo, não necessariamente vinculados a novas tecnologias:

Aí, um dia eu tava lá roçando o terreno de uma pessoa. Lá, cuidando até do terreno. E meu filho disse: papai eu queria fazer uma rabeca! Meu filho mais moço. Aí eu digo: ah, você quer fazer?

Eu vim buscar madeira, aí eu trouxe a madeira pra ele. Aí ele ficou lá trabalhando nessa rabeca. Aí eu fui lá e disse: corta assim primeiro, meça aqui, corte o comprimento, aí ele cortou o comprimento. E aí vai talhando assim ó, depois corte aí, aí ele foi cortando.

Ele já tava cepilhando aqui por cima, talhô bem talhadinha, acabou bem acabadinha, assim, no talho dela, e cepilhou tudo esse tampo aqui por cima. Aonde vai a corda. Cepilhou bem cepilhadinho.

Quando eu cheguei de lá do mato eu disse assim: como você tá cepilhando aí por cima, menino? Pois não é assim, papai? ele falou.

Eu disse: não, isso aí é pra cavocar, a boca pra cavocar, aí depois eu olhei assim e disse: Mas sabe que você tá certo, você tá certo porque a gente cavoca por lá [fundo], aqui pelo menos já fica feito [tampo]. O sobre-braço vai por cima mesmo.

Então, eu ensinei ele a fazer rabeca e ele já me ensinou a cavocar [risos]. Aí... eu disse assim: pois faça assim mesmo, assim é melhor mesmo, aí eu comecei a cavocar a rabeca por trás já.

Você vê como é as coisas, às vezes a gente ensina, e depois o aluno da gente ensina a gente, já. (ROCHA, 2017, 35'51" - 37'16" - transcrição nossa)

Revisando a bibliografia disponível, percebe-se a força da luteria caiçara, intrínseca aos textos que abordam essa manifestação cultural; via de regra, violas, rabecas e tamancos assumem de modo personificado o que poderíamos chamar de "imagem arquetípica do fandango caiçara". 
Figura 4.9 - Colagem do suporte de fundo abaulado

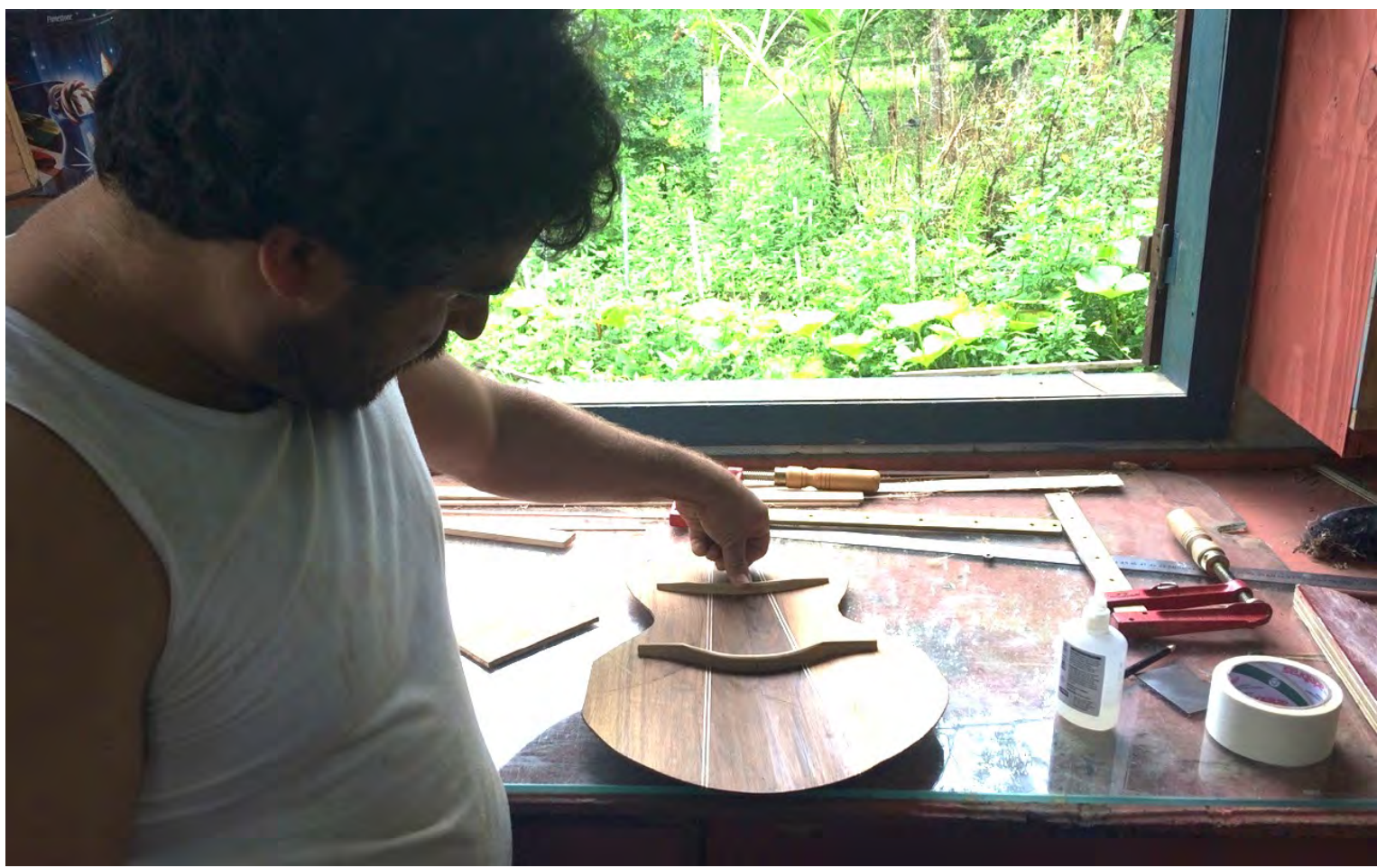

Fonte: Acervo pessoal

Figura 4.10 - Montagem do fundo abaulado na caixa de ressonância

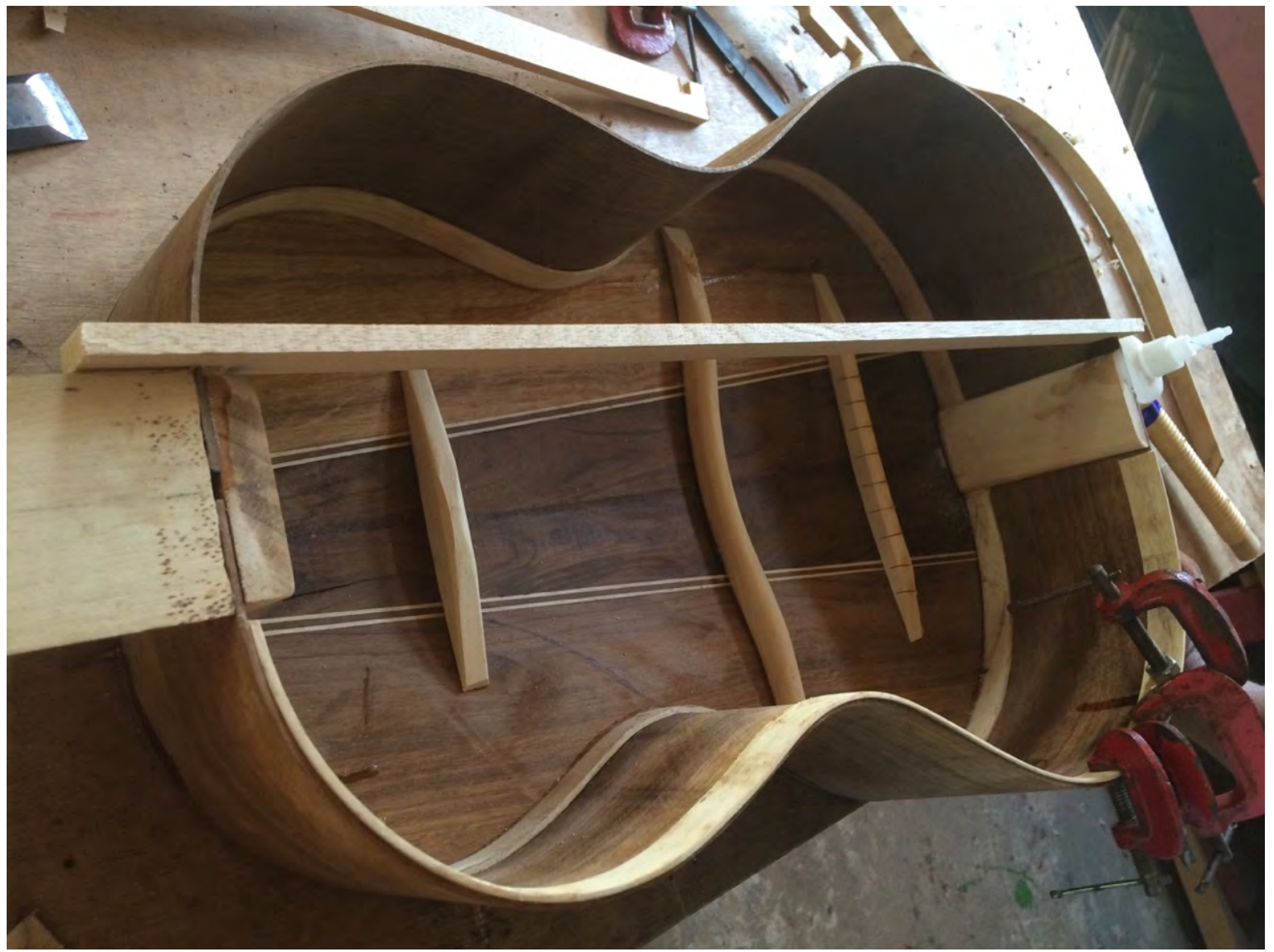

Fonte: Acervo pessoal 
No sentido de concatenar diferentes práticas de luteria com vistas ao melhoramento técnico de confecção e acabamento, será observado adiante o trabalho experimental levado a cabo por Aorélio Domingues, Cleiton do Prado e Felipe Souza. Com isso, também se pretende discutir a potência de usos ampliados desses instrumentos, tanto no território caiçara como fora dele, discutindo sua absorção em outros meios musicais e artísticos.

Dos mais de cinquenta instrumentos produzidos pelo projeto Artesanias Caiçaras, duas violas merecem especial atenção Trata-se de duas violas cujas simetrias e materiais utilizados nos induzem a vê-las como violas "gêmeas". O diferencial destas duas violas diz respeito a seu fundo abaulado, no qual as placas laminadas são modeladas por suportes internos fixados antes da colagem no corpo do instrumento, conferindo, além da forma estética, ampliação das ressonâncias nas frequências graves do instrumento, o chamado "bufo" (figuras 4.9 e 4.10).

O experimento foi proposto por Cleiton do Prado, que já havia feito um fundo dessa maneira. Depois da execução das duas violas, Aorélio Domingues tem utilizado a mesma técnica na construção das violas e machetes nas lavras mais recentes.

Entre outras ações nas quais interagiram academia e tradição fabriqueira, deu-se a execução da Viola Branca para o trabalho de Conclusão de Curso de Filipe Souza, egresso do Curso de Luteria ${ }^{102}$ da Universidade Federal do Paraná. Segue o depoimento coletado com o lutiê a respeito do processo:

O braço, o fundo e a lateral de maple, cravelhas, espelhos de ébano, cavalete de ébano; atrás, uma lâmina de imbuia.

A maioria dos detalhes de marchetaria, a roseta e os mosaicos foram feitos com imbuia marrom e mogno vermelho, filete estilo espinha-de-peixe, que é uma técnica bem tradicional. Aparece nos filetes, nos detalhes da mão. $\mathrm{O}$ cavalete também é de ébano e tem um acabamento em plátano, um plátano mais genérico.

O traste e a pestana são de osso, a estrutura interna eu desenhei, as travessas e as contrafaixas são de cedro-rosa. A estrutura interna do tampo é em abeto e tem uma placa de suporte para o cavalete, que é de maple. Também um reforço, por conta da tensão das cordas, e aqui [atrás] a marchetaria, como chamam nos violinos, é da mesma lâmina de imbuia que foi atrás da mão.

Os filetes também são em maple, na parte de trás, a lâmina de imbuia também aparece atrás do suporte da turina, com o mesmo perfil da mãozinha. Se você reparar, tem o mesmo desenho.

\footnotetext{
${ }^{102}$ Como carreira autônoma, o curso oferece diploma de curso superior em nível tecnológico e se consolida como opção profissional inédita no Brasil. "Implantado em 2009, o curso vem suprir a demanda existente há décadas por construtores de instrumentos musicais, em todos os níveis. O projeto tem em vista, como perspectiva realista, a tendência verificada na América Latina do viçoso crescimento da música entre crianças e jovens, como projeto social, sem perder sua dimensão e profundidade artísticas." (http://www.luteria.ufpr.br/portal/)
} 
A questão dos materiais, eu procurei usar os materiais que são clássicos na luteria europeia, o maple para fundo, laterais e braço, e o abeto, que é bem tradicional nos violinos e violões. Espelho em ébano, justamente porque a intenção do instrumento era que tivesse essa conversa entre os instrumentos caiçaras com luteria tradicional [europeia], e ao mesmo tempo é uma coisa que não aparece e que não tem uma forma definida muito clara; para mim foi o violão flamenco, a guitarra branca, como eles chamam. Tanto pela escolha das madeiras... não que os violões flamencos sejam de maple, eles são de cipreste. Mas tem essa referência do instrumento inteiro branco, foi uma referência para mim no desenho da mãozinha, nos violões flamencos que hoje em dia usam tarracha, alguns violões flamencos por tradição usam cravelhas. É uma concepção bem do violão flamenco mesmo, mas isso foi uma conversa interna minha que tive também.

A roseta também foi um detalhe muito importante por ser um instrumento do TCC; precisava deste tipo de demonstração de habilidade mesmo e então quis usar a técnica tradicional, que é a técnica utilizada nos violões clássicos, que é o mosaico ponto a ponto, apesar de não ser um mosaico contínuo, como aqueles que vão formando um padrão. Os desenhos que são referências da cultura caiçara, para mim, são os caranguejos e a raiz-de-mangue.

Figura 4.11- Detalhes da mão e da roseta da viola de abeto

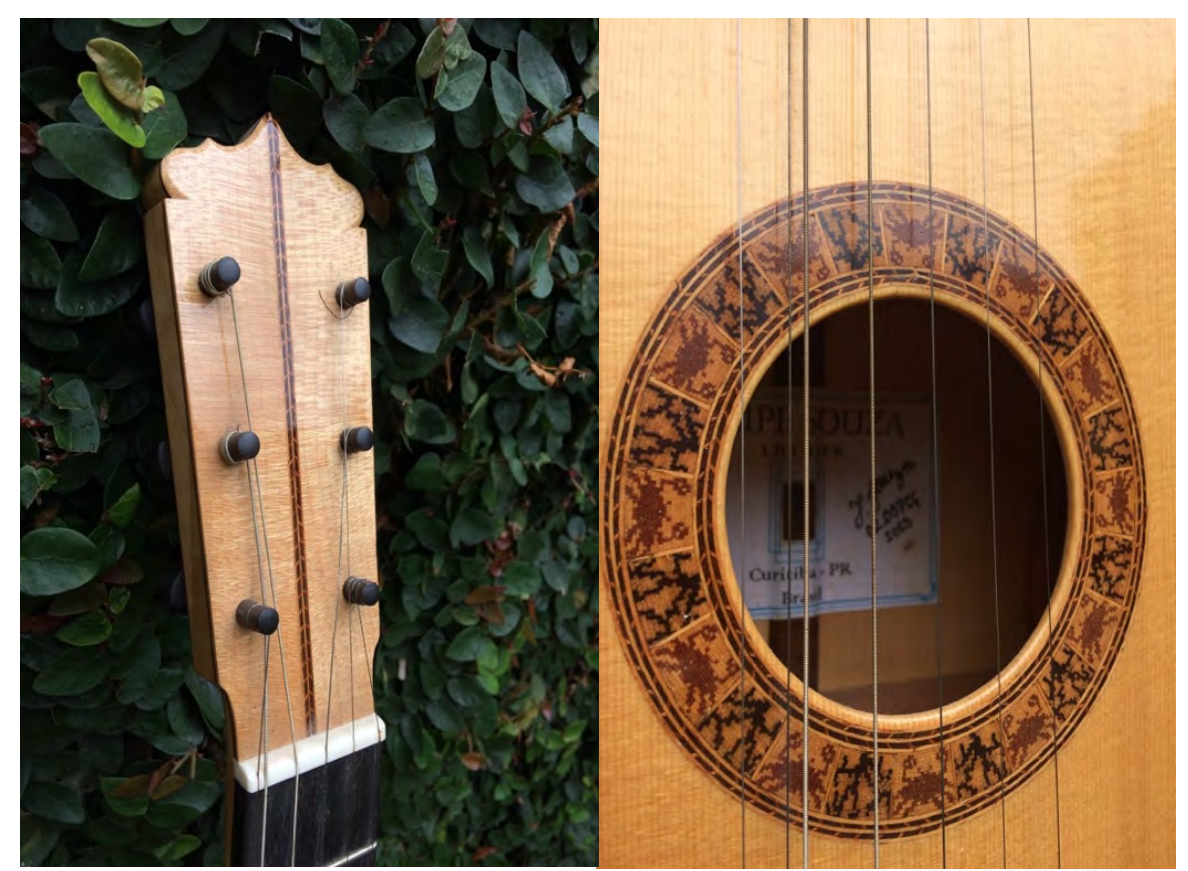

Fonte: Acervo pessoal

Vão se repetindo na roseta, e também a ideia do caranguejo no cavalete, são para mim referências simbólicas bem clássicas. No momento em que eu procurei uma referência artística, eu preferi usar essa referência explícita do que procurar cavaletes de viola caiçara; preferi fazer um negócio original, mas nesse sentido a roseta, particularmente, por não ser um modelo simétrico, não foi tão complicado, mas ao mesmo tempo é uma coisa que não é muito comum, porque nos violões, o espelho chega até em cima da boca, perto da roseta. Então a roseta não precisa ser construída inteira circular, você constrói até onde a escala cobre ela. Então houve um esforço para fazer ela inteira, circular, e pra fazer a marchetaria e encaixar no tampo depois, isso foi desafiador. Eu investi um pouco mais nos materiais. Tinha toda essa questão 
de ser um instrumento para o curso, e depois de tantas idas e vindas, não podia deixar nada marcando, pois, da minha percepção da época, qualquer erro poderia contar contra no processo de avaliação. (Depoimento coletado em dezembro de 2018 - transcrição nossa)

Figura 4.12 - Viola branca de abeto, de Filipe Souza

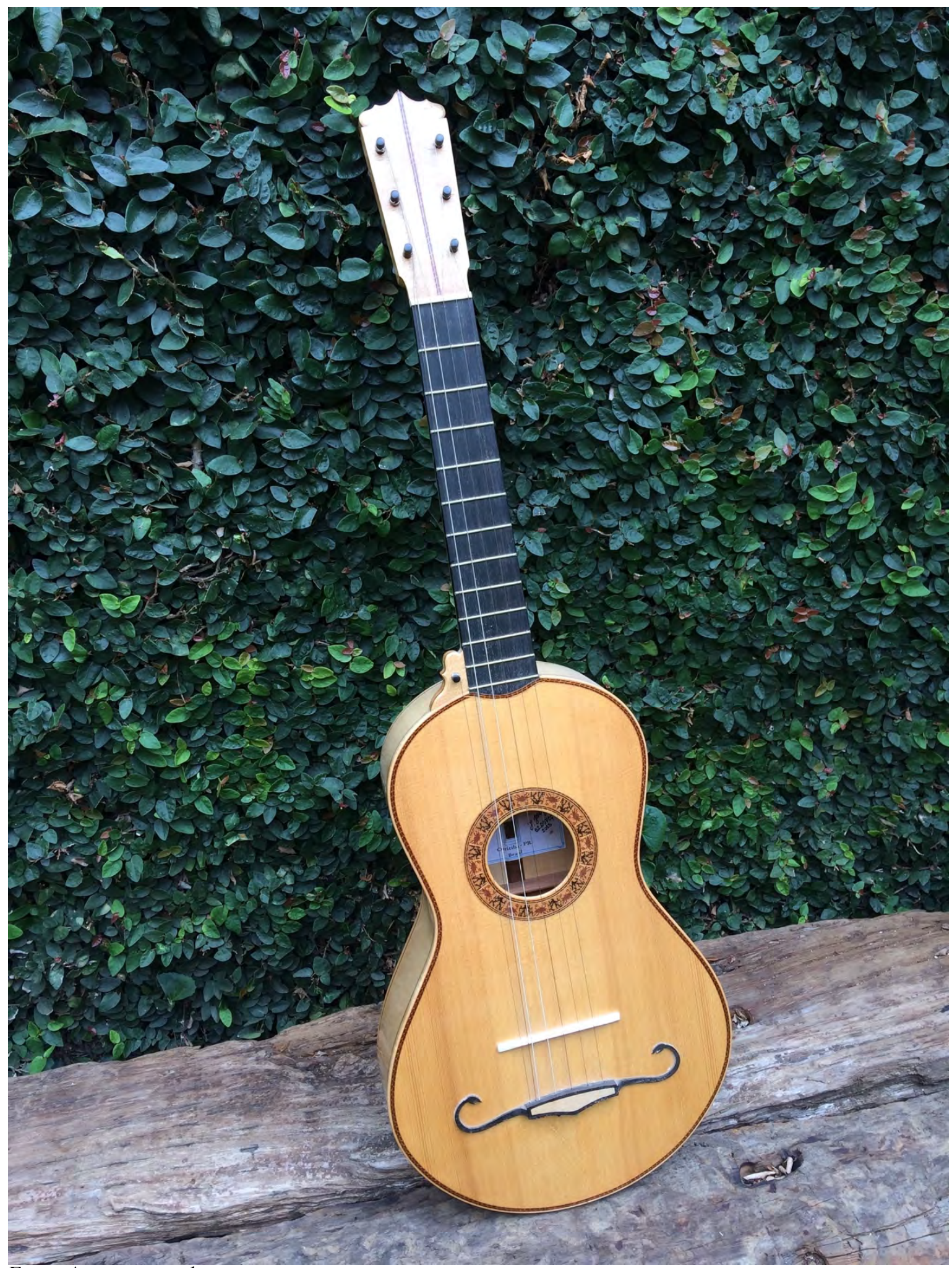

Fonte: Acervo pessoal 
Sobre outro instrumento confeccionado por Filipe, como prerrogativa parcial do curso de Luteria na UFPR que dizia respeito à disciplina de cultura regional ministrada pelos professores Juarez Bergman e Guilherme Romanelli, ele nos esclareceu o seguinte:

Neste caso, tinha essa proposta de construir um instrumento típico, tradicional, brasileiro. A maioria das propostas eram rabecas, não necessariamente caiçaras. Têm rabecas no Brasil inteiro e muita gente partiu para viola caipira ou para instrumentos eletrificados, "guitarra caipira", violas caipira de captação magnética, corpo sólido... e eu na época preferi focar na questão do caiçara.

Essa foi uma outra conversa, diferente da viola do TCC. Não foi uma conversa com as madeiras clássicas, da luteria clássica, foi uma conversa da cultura caiçara com referências aqui do planalto, vamos dizer assim. A questão dos pinhões, das madeiras como a imbuia, a araucária, o suporte da turina é um nó de pinho! Basicamente a viola inteira é imbuia e araucária, então é isso, uma viola caiçara feita com materiais do planalto. Aqui no planalto em Curitiba, a gente não tem caxeta. Foi buscando essa conversa, essas referências visuais, o lance do pinhão paranista ${ }^{103}$, que tem uma história, está representado em Curitiba e em vários lugares. Foi essa referência, essa foi a ideia.

Como era um instrumento para uma matéria secundária do curso, não pude me dedicar tanto pra ele, era uma matéria onde os instrumentos poderiam ser feitos em grupos, mas optei por trabalhar sozinho, por isso não pude me dedicar tanto nele, pois estava simultaneamente construindo outro instrumento, um violão para matéria principal do curso, em termos de acabamento, tanto é que nunca cheguei a fazer o verniz dele, em termos de detalhes, filetes e tudo mais... Apesar de haver investido um certo tempo, por uma empolgação artística, nessa boca e nessa roseta dos pinhões, os demais detalhes foram feitos rapidamente. Os filetes mesmo, o friso que é supersimples, é só uma lâmina de araucária, o que empolgava mais em termos artísticos.

E outra questão foi uma conversa com o Lauri [romeiro do divino]; ele falou sobre o conforto das violas caiçaras. Eu procurei trazer essa modernidade, um espelho com raio, mais próximo do espelho de guitarra, diferente do espelho clássico de violão ou de viola que é reto. Esse daqui tem um raio, ele é arredondado, fica fácil de ver buscando um conforto maior, ele é mais estreito também do que instrumentos mais clássicos, ele é praticamente um bracinho de guitarra. (Depoimento coletado em dezembro de 2018 transcrição nossa)

103 “O Movimento Paranista foi um movimento cultural com fortes vínculos políticos, que ocorreu no Estado do Paraná e que teve seu auge entre 1927 e 1930, quando seus ideais estavam organizados e institucionalizados em forma de práticas culturais. A literatura, a poesia, o teatro, a história, a pintura, a escultura, o desenho, a arquitetura, a música, a moda, todos que produziram nessas áreas destacavam em suas obras temas relacionados a elementos da flora e da fauna considerados representativos da identidade paranaense (ou paranista). O pinheiro-do-paraná, a gralha-azul e os índios da região são os elementos mais marcantes e que persistiram ao longo dos anos." (Salturi, 2014, p. 128) 
Figura 4.13 - Detalhe da boca e do cravelhal (turina) da viola de araucária de Filipe Souza

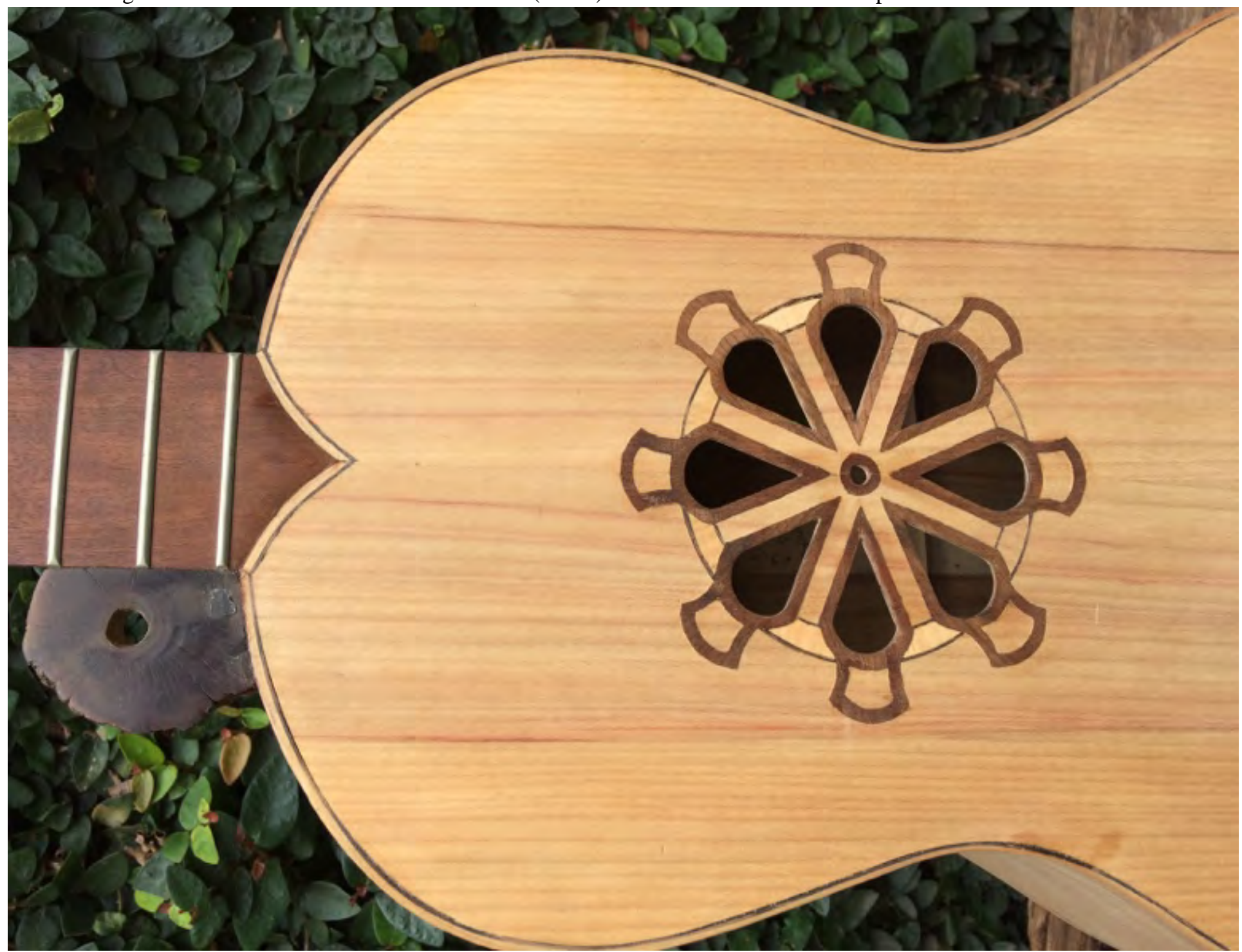

Fonte: Acervo pessoal

Seja no litoral caiçara, seja em Curitiba, a dinâmica nos processos de construção dos instrumentos caiçara segue em atualização constante. Os experimentos de Filipe Souza demonstram a versatilidade e a possibilidade de que estes instrumentos circulem por outras realidades artísticas.

No litoral, no atelier Rodrigo Domingues na sede da Associação Mandicuera, apenas durante os últimos meses (antes da conclusão da tese), outras inovações e ajustes tomaram forma, novas formas com sistemas de fixação das ilhargas, suportes para cavocar fundos e tampos de rabeca e instrumentos com dimensões diferenciadas buscando novas tessituras sonoras têm sido construídos por Aorélio Domingues. Ilustro abaixo os artefatos mencionados: 
Figura 4.14 - Suporte para cavoucar fundos e tampos de rabeca Figura 4.15 - Formas com prendedores

Figura 4.16 - Formas com prendedores (detalhe)

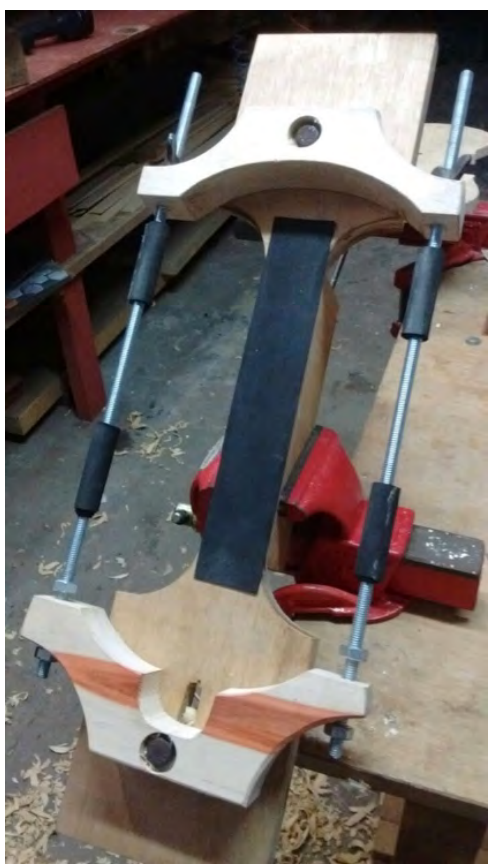

Fonte: Arcevo Pessoal

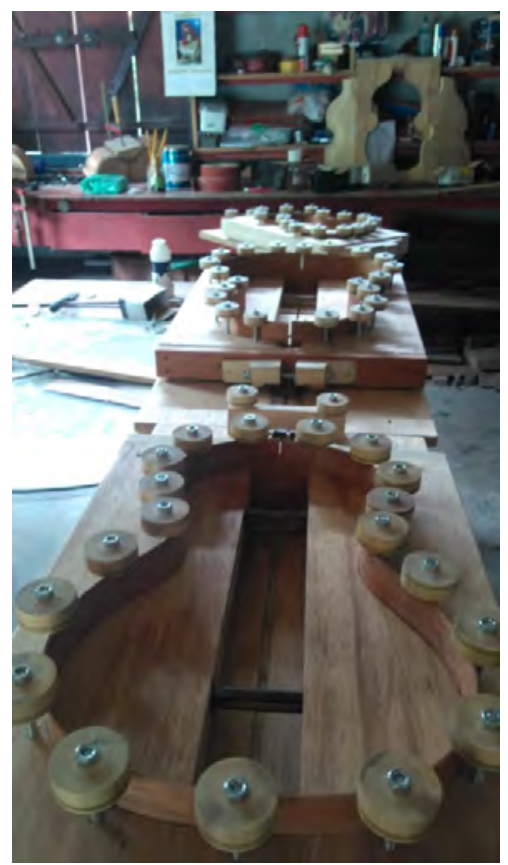

Fonte: Foto de A. Domingues

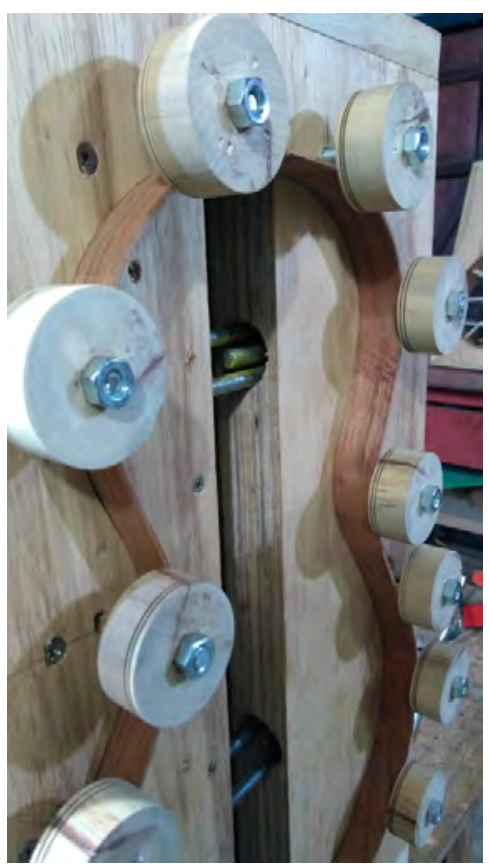

Fonte: Foto de A. Domingues

Figura 4.17- Violona, viola, meia viola (ou machetão) e machete

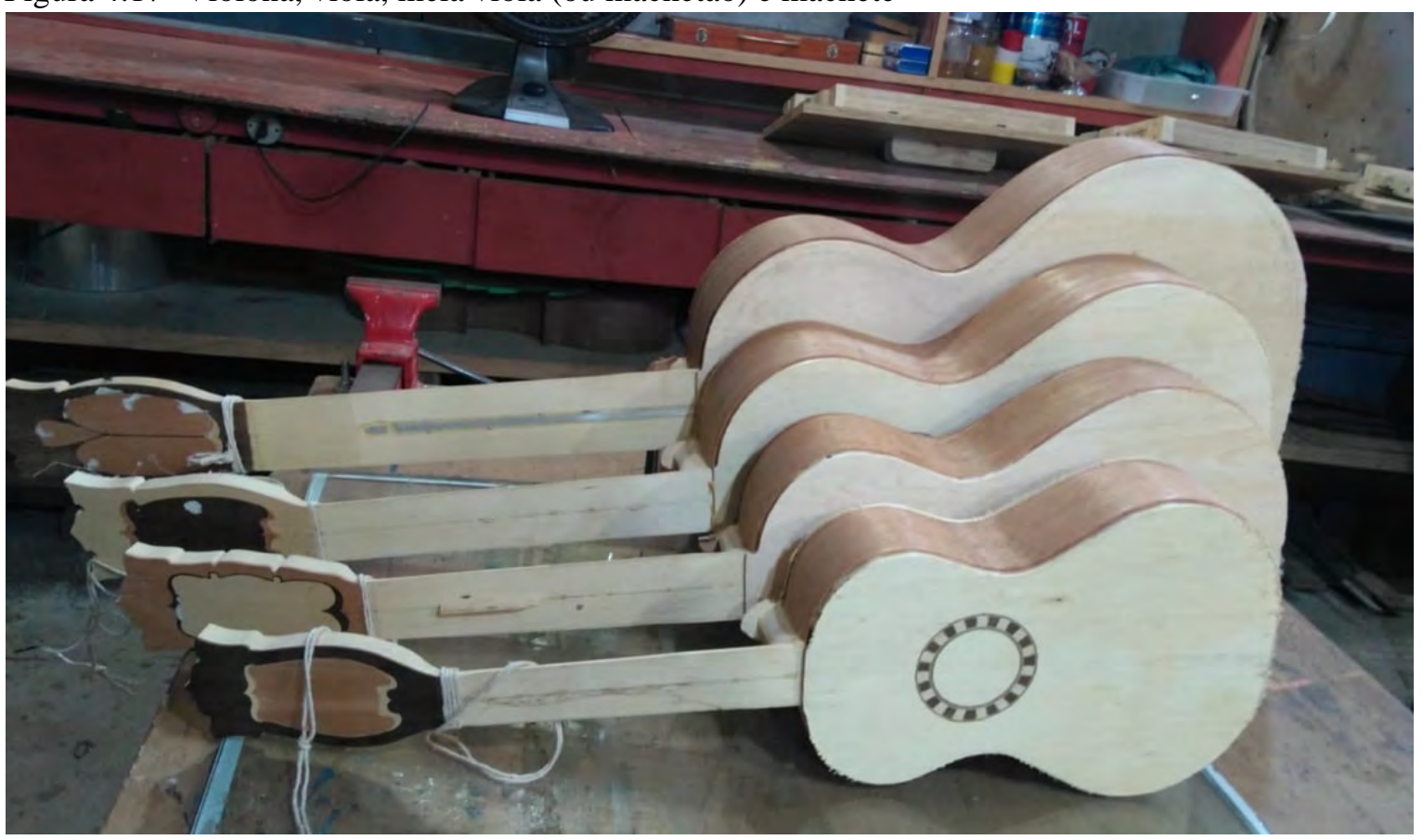

Fonte: Foto de Aorélio Domingues 
A apropriação de ferramentas e técnicas diversificadas por parte dos lutiês caiçaras vem impactando a recepção de tais artefatos tanto universo caiçara quanto para fora dele. Instrumentos com melhores condições técnicas têm atraído tanto a atenção de jovens nos centros urbanos, quanto daqueles que vivem nas localidades mais afastadas do lagamar, alavancando a difusão e a manutenção do fandango caiçara, nesse caso, com vistas aos fenômenos sonoros e acústicos integrados às práticas de construção de instrumentos musicais.

Figura 4.18- Viola de abeto de Filipe Souza e Rabeca de Cleiton do Prado

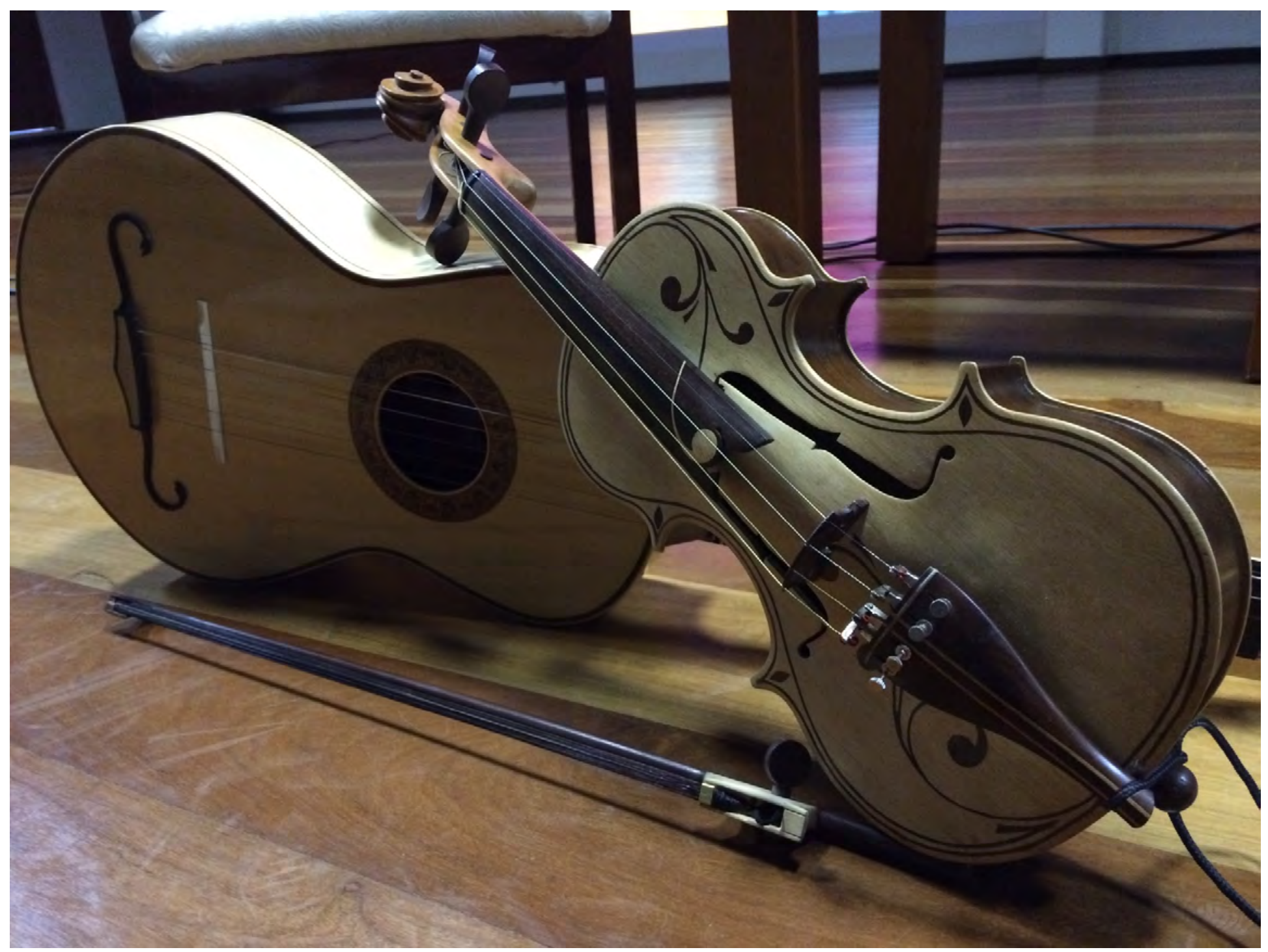

Fonte: Acervo pessoal 


\section{COSMOGONIA, SONOLOGIA E SOCIABILIDADE}

Como já mencionado (cf. GIORDANI, 2018), entendemos o som para além da percepção, vislumbrando-o como agente na construção de um objeto cultural por meio de técnicas de escuta e pela exigência de nomeação. Pode-se traçar aí um paralelo conceitual entre a Acoulogie (acusmática, em português), neologismo proposto por Pierre Schaeffer, redefinido e ampliado por Michel Chion, e a cismogênese batesoniana. Chion (2010) define a disciplina (Acoulogie) como a possibilidade mais ampla de se entenderem o fenômeno sonoro e a escuta, tangenciando, por um lado, a acústica, centrada nos fenômenos vibratórios independentes da escuta, e, por outro, a psicoacústica, ramo que, segundo o autor, transita pelo estudo de correlações entre estímulos físicos e sensações de sons isolados, sem interrogações profundas do som no nível auditivo propriamente dito. Em vista da intenção de Bateson de atualizar suas conjecturas teóricas com os novos modos de pensamento, o epílogo de 1958, além de fundamentar sua aproximação com o pensamento corrente no campo da psiquiatria e da psicanálise, especialmente de abordagens que tratavam dos contextos de aprendizagem, acabou também por inaugurar os estudos da teoria Cibernética como um dos membros da Macy Conference, a partir dos estudos formais dos sistemas de feedback negativo. O conceito de cismogênese, formulado no início da década de 1930, ainda soa atual no escopo aqui proposto.

Na recente teorização da cena, assim como em Cohen (2009, p. 138), percebe-se nas manifestações religiosos do universo caiçara a hibridação de termos como performance e happening; por um lado, pela necessidade de manter a atenção, e, por outro, pela intensa troca que se dá com a audiência.

\footnotetext{
O performer em relação ao praticante do happening necessitará de uma maior habilidade de artista para "segurar a cena". Justamente porque no happening não havia esse sentido de "cena", de "espetáculo", o condutor deste funcionava mais como um xamã, um catalisador, um mestre de cerimônias do ritual. A participação do público diminuía sua responsabilidade enquanto atuante - a ênfase do trabalho se dava na elaboração de sketches e na habilidade de improvisar diante de situações imprevistas.
}

Em vista do caráter sincrônico e efêmero da interação durante a performance, poderíamos submeter elementos a análise mais detalhada, sejam vinculados ao indivíduo em questão (índices dialógicos, políticos e afetivos), ao meio circundante (ruídos de fundo, trânsito, 
pássaros, marcos sonoros) ou ainda às inculcações culturais e sociais contidas no discurso (passividade, agressividade, indignação, acalanto, moral, religião e ética), indicando os aspectos sensoriais e afetivos que poderiam ser mobilizados na audiência a partir da experiência de interação.

O Conceito de "cismogênese" é um reconhecimento implícito de que o sistema contém uma ordem extra de complexidade, devida à combinação da aprendizagem com a interação das pessoas. A unidade cismogênica é um subsistema de duas pessoas. Ele contém a potencialidade de um circuito cibernético passível de passar por mudança progressiva; não pode, por isso, ser conceitualmente ignorado e deve ser descrito em uma linguagem de tipo mais elevado do que qualquer outra usada para descrever um comportamento individual - esta última categoria de fenômeno consistindo apenas em eventos em um ou outro arco do subsistema cismogênico. (BATESON, 2008, p. 325).

Além das violadas e das peregrinações religiosas cuja natureza organológica acústica é imperante, devemos também mencionar aspectos sônicos potencializados pela recente opção pela eletrificação de sistemas de áudio para realização de fandangos, sejam domésticos de baile ou ainda em espetáculos, opção cujas resultantes éticas e estéticas têm-se consolidado nas últimas décadas.

\section{Estetoscópios e fonoautógrafos}

Retomemos brevemente questões históricas que nos permitem entender melhor o desenvolvimento dos sistemas de áudio de que dispomos na atualidade e que fazem parte do cotidiano fandangueiro.

Ao tratar da semiologia médica, Rodolfo Caesar (2011, p. 2) mostra quão relevante foi o desenvolvimento de aparatos acústicos nessa empreitada:

Em sintonia com as demais ciências no séc. XIX, para a formulação de diagnósticos a Medicina firmou uma importante etapa relacionando-se com as novas tecnologias: o uso de mediadores da percepção. Diferentemente das lentes de aumento, que ampliavam o objeto visual, o estetoscópio lançou o observador em situação acusmática, aproximando-o do objeto sonoro, que, sem o apoio verificativo da visualidade, devia ser interpretado conforme indícios meramente acústicos. A semiologia acusmática da medicina veio recolocar o observador na mesma caverna nietzscheana, - aquela que, segundo 
o filósofo, teria sido o berço da escuta musical (NIETZSCHE, 1881) ${ }^{104}$ - a mesma que, no século seguinte, revestiria de penumbra a escuta eletroacústica. Evidentemente, médicos não usavam o estetoscópio para uma escuta musicista, porém este objeto os conduz ao mesmo exercício de sourcebonding (SMALLEY, 1994) ${ }^{105}$. O que seria essa junção-à-fonte medical senão uma transposição da noção aristotélica de causa \& efeito ajustada para a escuta? (grifo nosso)

A seleção de objetos sonoros, imagens sonoras que encontram na memória depósito seletivo de informação, seja no ato propriamente dito da escuta, cuja transdução se dá nos princípios já equalizados por Schaeffer (1966) - écouter, oü̈r, entendre, comprendre -, ou ainda na sua elaboração do conceito de escuta reduzida. ${ }^{106}$ Diferentemente dos aparatos microfônicos e do armazenamento de informação, binário ou magnético, digital ou analógico, se dá no universo contínuo da interação com o outro e com o meio no qual o indivíduo está inserido, cujas idiossincrasias se revelam pelo complexo funcionamento do equipamento eletrobiofísico humano. A audição binaural junto à transdução coclear nos leva a entender o objeto sônico, a imagem do som. "O som é imagem mesmo quando o único suporte disponível é o cérebro, e quando se transmite de boca à orelha, ou das coisas soantes para a orelha" (CAESAR, 2012, p. 7).

As tecnologias de reprodução de som são artefatos de grandes transformações na natureza fundamental do som, do ouvido humano, da faculdade de ouvir e das práticas de escuta que vigoraram ao longo do século XIX. O capitalismo, o racionalismo, a ciência, o colonialismo e uma série de outros fatores - o "turbilhão" da modernidade, para usar a frase de Marshall Berman - afetaram todos os constructos e práticas de som, audição e escuta ${ }^{107}$ (STERNE, 2003, p. 2 - tradução nossa).

\footnotetext{
${ }^{104}$ NIETZSCHE, F. Morgenröthe: gedanken über die moralischen Vorurtheile. Chemnitz, DE: Ernst Schmeitzner, 1881.

${ }^{105}$ SMALLEY, D. Defining timbre, refining timbre. Contemporary Music Review, Harwood, v. 10, part 2, p. 3548, 1994.

106 “A escuta reduzida é uma atitude de escuta. É um direcionamento da escuta para as funções oü̈r e entendre. É uma fuga das escutas condicionadas, as escutas cultural e natural, que tratam o som, respectivamente, como signo e índice. Na contramão da escuta ordinária, que toma o som como veículo, a escuta reduzida é "um processo antinatural, que vai contra todos os condicionamentos" (CHION, 1983, p. 33). No entanto, seu fim não é negar as escutas do som como índice ou signo ou pôr em xeque as noções de escuta que temos como se tivéssemos sido iludidos por nosso sentido. Essa proposta de escuta procura "desembaraçar as diferentes intenções constitutivas e voltar as intenções para o objeto sonoro, enquanto suporte das percepções que o tomam como veículo, para definilo através de uma nova intencionalidade específica, aquela da escuta reduzida" (CHION, 1983, p. 32; REYNER, 2011, p. 103).

107 "Sound-reproduction technologies are artifacts of vast transformations in the fundamental nature of sound, the human ear, the faculty of hearing, and practices of listening that occurred over the long nineteenth century. Capitalism, rationalism, science, colonialism, and a host of other factors - the "maelstrom" of modernity, to use Marshall Berman's phrase_-all affected constructs and practices of sound, hearing, and listening" (STERNE, 2003, p. 2).
} 
Também em Sterne (2003) podemos perceber como o aparato auditivo foi fundamental na estruturação e no desenvolvimento das tecnologias de áudio, vendo o fonoautógrafo ${ }^{108}$ de Leon Scott como um ouvido médio humano excisado como um transdutor, "o funcionamento da membrana timpânica (também conhecida como diafragma ou tímpano) no ouvido humano foi o modelo para os diafragmas em todas as tecnologias de reprodução de som subseqüentes" (STERNE, 2003, p. 22).

Figura 5.1 - Fonoautógrafo de Édouard-Léon Scott de Martinville

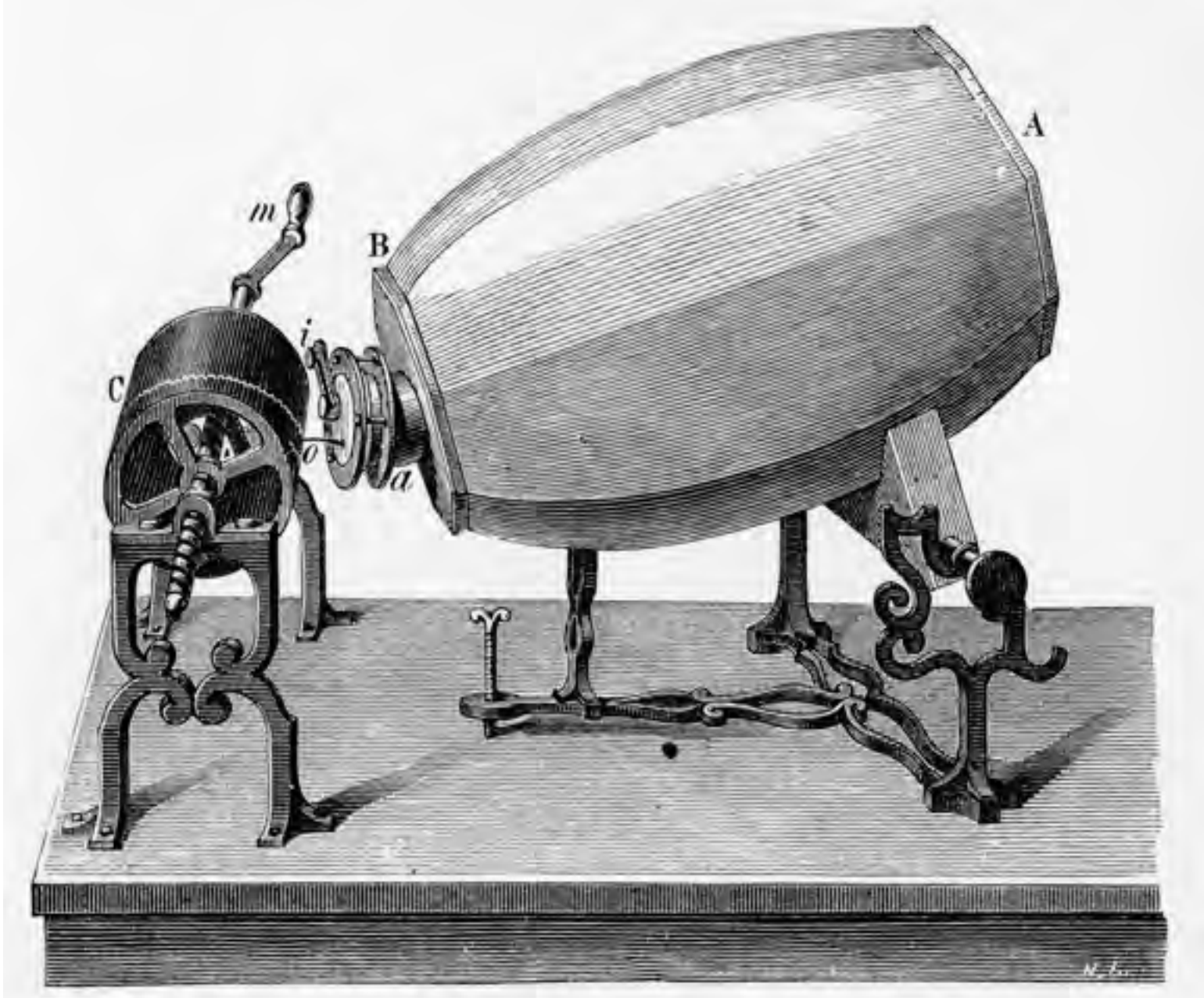

Fonte: Mikanowski (2014, p. 1)

\footnotetext{
${ }^{108}$ Mesmo que o senso comum indique o fonógrafo de Edison como divisor de águas desse pleito, foi ÉdouardLéon Scott de Martinville que, antecipando em 20 anos a função de gravação do fonógrafo com seu fonoautógrafo, fez a façanha de canalizar os sons transportados pelo ar através de um barril para uma membrana que vibrava simpaticamente com os sons, seus movimentos gravados através de uma caneta com ponta de pena numa folha de papel escurecida por pigmentos de fumaça girando sobre um cilindro. [...] O fonoautógrafo fez visível o invisível e fixou o que havia até então sido fugaz (GIOVANNONI, 2010, p. 1 - tradução nossa).
} 
A partir da imagem e de dados iconográficos e documentais, podemos fazer inúmeras reflexões sobre o que historicamente se escutava em tempos idos; reflexões que, apesar de carecer de suportes como fonogramas ou fonoautogramas, permitem conjecturar dados concretos.

No caso do fandango caiçara, tais dados referenciam a instrumentação ibérica alandaluza que, mesmo antes do surgimento do termo epistemológico fandango, demonstra o uso corrente da viola, da rabeca, do adufo e do machete, sendo as demais conclusões, como a conformação das vozes e as formas métricas e poéticas, indicadas por resquícios grafados do que se entende por estado da arte em determinados intervalos de tempo. O advento das tecnologias de armazenamento e reprodução do fenômeno sonoro ajudam efetivamente a lida etnomusicológica, musicológica, sociológica e antropológica, possibilitando assertivas mais efetivas a respeito de tais fenômenos:

A transposição da noção de imagem ao campo do sonoro, esta sim, é que ficou atrelada à fixação em suportes técnicos, e, porque esta chegou tarde para o som, não propiciou ao mundo da sonoridade o mesmo destino cultural reservado à visualidade (CAESAR, 2012, p. 7).

A pesquisa etnomusicológica tem suas bases na musicologia comparada, surgida na Alemanha com profissionais de diversas áreas, mas tendo como carro-chefe a psicologia. $\mathrm{O}$ projeto dos fundadores da musicologia comparada era procurar sentidos transculturais, indagações acerca do significado de determinados intervalos musicais nesta ou naquela cultura, se eram universais os sentimentos relativos a uns ou outros e assim por diante. Cabe ressaltar que, paralelamente à conformação da antropologia e do trabalho de campo, surge o registro fonográfico, possibilitando avanços relevantes nessa área (BASTOS, 1995, p. 21/23). Esses elementos vêm atravessando a prática fandangueira desde sua popularização, nas primeiras décadas do século XX.

\section{Devoção, interação e psicoacústica}

Os pressupostos relativistas, no sentido quântico do termo, apontam uma "ineficiência" dos instrumentais sensórios de que dispomos, sem que lhes seja acrescida a "carga psicológica" que lhes toca e que, em última análise, lhes é intrínseca. A partir dos princípios da psicologia analítica junguiana, Raissa Cavalcanti (2000, p. 89) comenta que, paralelamente à física e sob 
sua influência, já há bastante tempo se discute a necessidade de uma visão mais ampla e totalizante. $\mathrm{O}$ início do século foi particularmente fértil em ideias que propunham uma nova compreensão do real; a física quântica deslocou o arcabouço teórico da física newtoniana e demonstrou a inter-relação dinâmica entre todas as coisas, mesmo que a psicologia indicasse que a vida tem um significado subjacente do qual a consciência humana apreende só uma pequena parte. E tampouco percebe toda a realidade, que é factual e também simbólica.

Como a física em geral, a psicofísica tenta fazer previsões sobre a evolução de um sistema específico sujeito a certas condições iniciais. $\mathrm{O}$ sistema em consideração é o sistema sensorial de um indivíduo (ou de um animal) - órgão receptor e partes afins do sistema nervoso. As condições são determinadas pelos estímulos físicos de entrada, e a resposta é expressa pelas sensações psicológicas despertadas no cérebro e relatadas pelo indivíduo (ou manifestadas pelo comportamento sensorial específico do animal). A psicoacústica, um ramo da psicofísica, é o estudo que relaciona os estímulos acústicos com as sensações auditivas (ROEDERER, 2002, p. 27 - grifos do original).

Aspectos inconscientes em nossa percepção da realidade não devem ser suprimidos no desenvolvimento do raciocínio proposto. A psicologia analítica entende que:

[...] mesmo quando os nossos sentidos reagem a fenômenos reais, as sensações visuais e auditivas, tudo isso, de certo modo, é transposto da esfera da realidade para a da mente. Assim, toda experiência contém um número indefinido de fatores desconhecidos. (JUNG, 1969, p. 23)

Para Jung et al. (1969), uma palavra ou uma imagem podem ser simbólicas quando implicam conotações especiais, além de seu significado evidente e imediato. Nesse caso, entende-se que, por existirem inúmeras coisas fora do alcance da compreensão humana, frequentemente se usam termos simbólicos para representar conceitos que não se podem definir ou compreender integralmente, para ele, "esta é uma das razões por que todas as religiões empregam uma linguagem simbólica e se exprimem através de imagens” (JUNG, 1969, p. 21). $\mathrm{O}$ autor percebe o uso consciente que fazemos dos símbolos como apenas um dos aspectos de um fato psicológico de grande importância: “o homem também produz símbolos, inconsciente e espontaneamente, na forma de sonhos" (JUNG et al., 1969, p. 21). Valendo-se do enunciado junguiano, Murray Schafer (2001, p. 239) reconhece como simbólico um evento sonoro quando ele desperta emoções e pensamentos transpondo sensações mecânicas ou funções sinalizadoras, "quando possui uma numinosidade ou reverberação que ressoa nos mais profundos recessos da psique". Segundo ele, os sons do ambiente têm significados referenciais; não são meros eventos acústicos abstratos e devem ser investigados como signos, sinais e símbolos acústicos. Nesse 
sentido, nossa busca de termos simbólicos para representar conceitos estaria entre aspectos etológicos e etiológicos dos eventos sonoros que incidem nas interações comunicativas.

Para os jungianos, o sonho não é uma espécie de criptograma padronizado que pode ser decifrado através de um glossário para a tradução de símbolos. É, sim, uma expressão integral, importante e pessoal de inconsciente particular de cada um e tão "real" quanto qualquer outro fenômeno vinculado ao indivíduo. (JUNG et al., 1969, p. 12)

No universo caiçara, o imaginário simbólico inerente às manifestações de cunho religioso, em que ainda persistem reminiscências de ritos medievais, é o que mais se afina aos enunciados junguianos: resíduos arcaicos, imagens primordiais concebidas por Jung como arquétipos: "Enquanto os complexos individuais não produzem mais do que singularidades pessoais, os arquétipos criam mitos, religiões e filosofias que influenciam e caracterizam nações e épocas inteiras" (JUNG et al., 1969, p. 79).

Figura 5.2 - Altar preparado para a chegada das bandeiras com as medalhas dos foliões, casa de "Dona" Iolanda, Barra do Ararapira, 2018

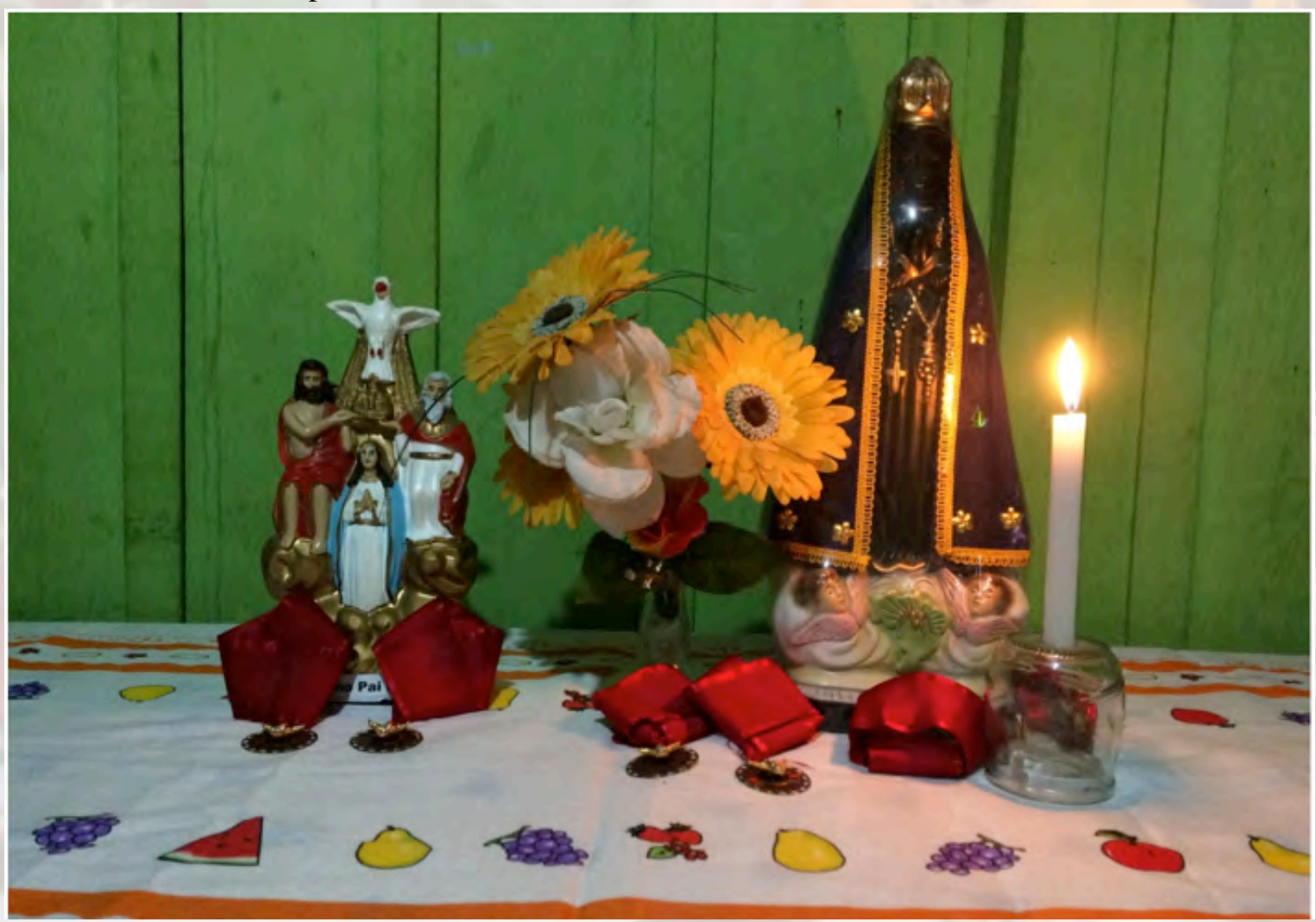

Fonte: Acervo pessoal

Na Figura 5.3, de pé, estão Taquinha, Cleiton, Aorélio, Lauri, Thauy, Aldemir e Aldemirzinho; agachados, Jairo, Malu, Frederico, Ary e Bruno. Patrícia Martins estava em 
Pontal, mas não saiu na foto. Ana Decker e Ronaldo Miguez, apesar de terem acompanhado a romaria, não estiveram na festa em 2018, ano em que foi inserido o machete no conjunto instrumental da bandeira da Ilha dos Valadares - para mim, particularmente, um fato marcante.

Figura 5.3 - Tripulação da romaria parnanguara (Pontal, Ilha do Cardoso, 2018)

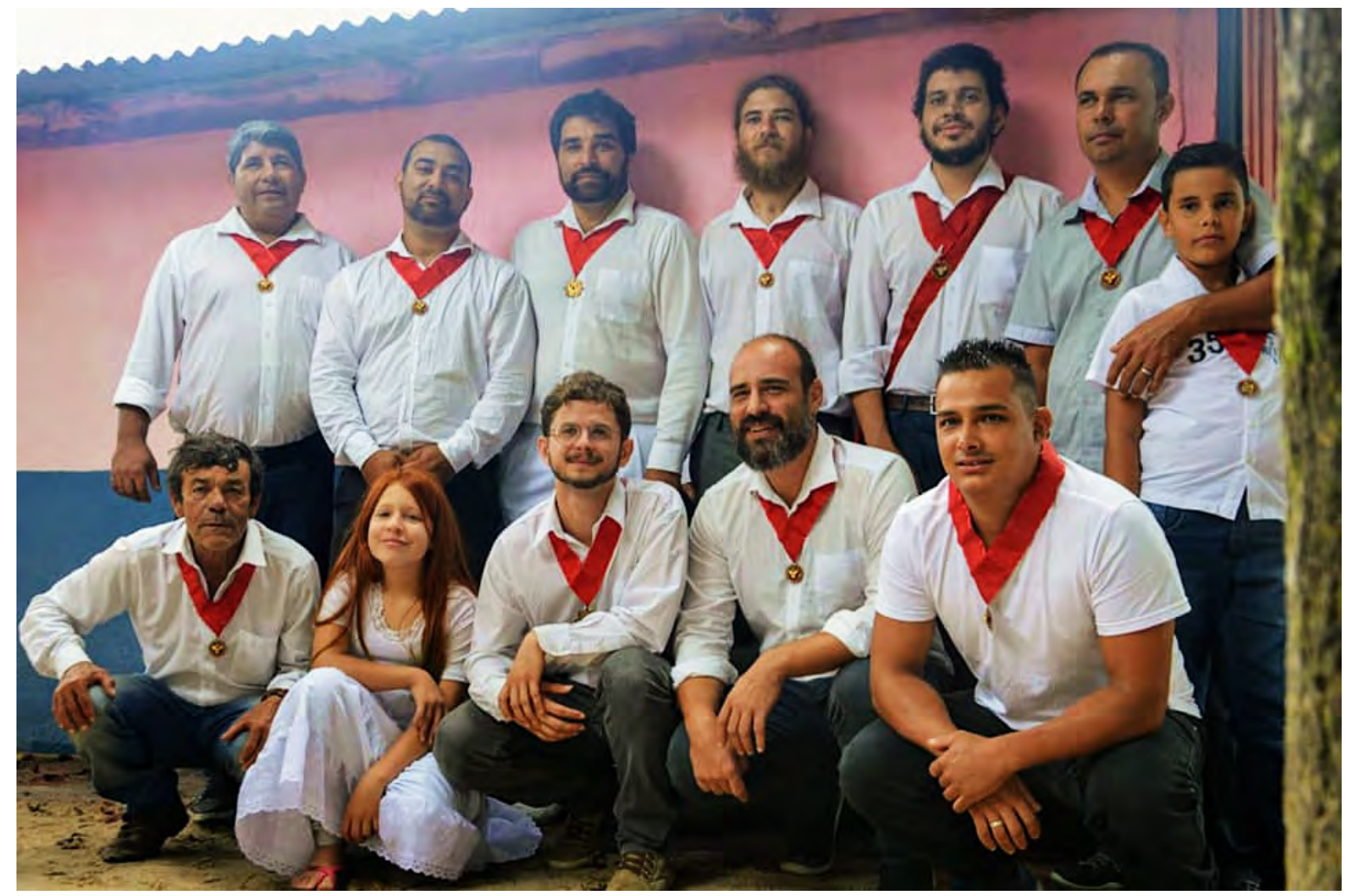

Fonte: Foto de Carolina Iarosz - Acervo pessoal

A tripulação é variável e se configura conforme a disponibilidade dos cantores e instrumentistas. Diferentemente dos romeiros, que acompanham determinados períodos de peregrinação, Jairo, Aorélio e Poro formam uma espécie de núcleo permanente da romaria parnanguara. Em 2018, pude acompanhar o giro de Paranaguá rumo a Guaraqueçaba, de lá para a Barra do Ararapira, depois Pontal, Vila Rápida, Nova Enseada, ${ }^{109}$ Marujá, Pereirinha e, por fim, Cananéia, onde, depois de compartilhar uma efusiva comoção no encontro com mestre André, referência da cultura caiçara no município de Cananéia - violeiro, rabequista e mestre

\footnotetext{
${ }^{109}$ Em 2018, a Enseada da Baleia foi dividida por um processo de erosão, modificando a geografia local e criando uma nova ilha, a ponta sul da Ilha do Cardoso, onde atualmente estão as comunidades da Vila Rápida e de Pontal do Leste. Fortes ressacas em 2016 já havia levado à criação de um plano de emergência pela Defesa Civil e à mudança das casas de 15 pescadores que viviam ali, hoje alocados na Nova Enseada, ao norte da antiga região atualmente convertida em nova barra.
} 
da Romaria do Divino Espírito Santo -, Cleiton e eu nos despedimos da folia, que retornaria dali para o Marujá e depois seguiria para Vila Fátima, Subuí, Tibicanga...

Foram visitadas no total 270 casas de devotos [2018], incluindo a residência de mestre André, em Cananéia. Percorrendo mais de 600 quilômetros por via aquática e terrestre, registrados por GPS, contabilizando nessa medição a volta dos foliões para casa e o retorno a Pontal de Leste, onde ocorreu a festa de encerramento da Bandeira, no dia de Pentecostes (informação pessoal). ${ }^{110}$

Figura 5.4 - Trajeto dos locais visitados pelos foliões da Bandeira do Divino Espírito Santo em 2018

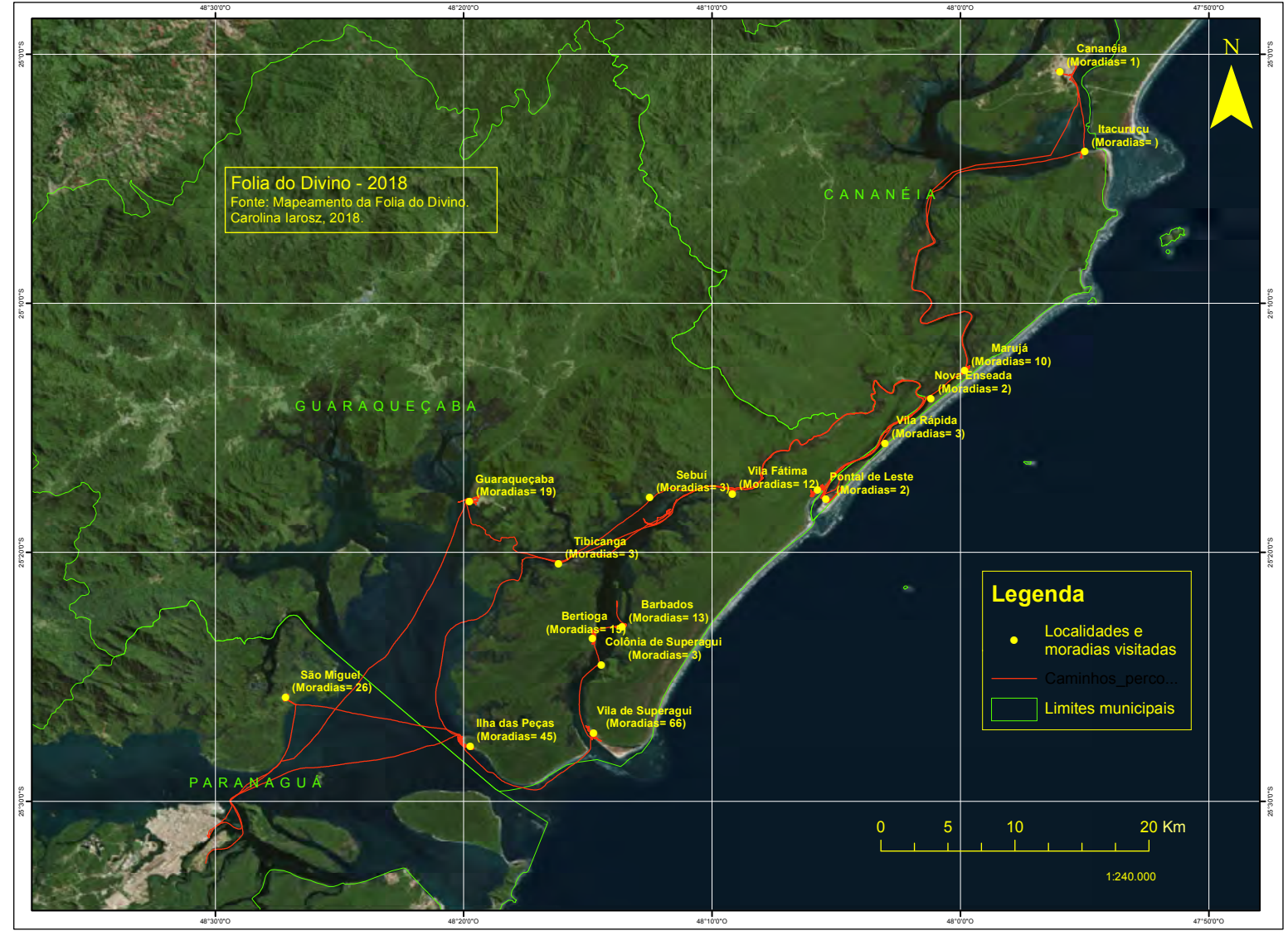

Fonte: Mapeamento e georreferenciamento da Folia do Divino por Carolina Iarosz

Adiante, conto de nossa estada na Barra do Ararapira em 2018. O tempo lá corre diferente nos dias da folia: a romaria é mais lenta, as visitas mais espaçadas. Não que não haja deslocamentos temporais em outros lugares, mas, especialmente na Barra e nas adjacências (Pontal, Vila Rápida e Nova Enseada), a movimentação tem outros sentidos. Toda a comunidade da Barra é católica, e há um acordo geral quanto ao trabalho missionário de congregações neopentecostais. Apesar de todos receberem bem tais visitas, o fato é que não

${ }^{110}$ Carolina Iarosz, informação fornecida em março de 2019 via E-mail. 
existem igrejas ou cultos de outra ordem religiosa nessas comunidades. Some-se a essa conjuntura a presença de antigos mestres e tocadores de fandango, assim como a do lugar na extração da folha da cataia na região. São caiçaras cuja musicalidade transborda não apenas nas violas e rabecas, mas nos violões sertanejos e nos teclados do arrocha e do tecnobrega, nas crianças batendo funks em galões plásticos, em aparelhos sonoros portáteis ${ }^{111}$ e nas caixas multiuso que embalam os luais à beira-mar.

Figura 5.5 - Equipamento de som e teclado na casa de Márcio e Nica (Barra do Ararapira, 2016)

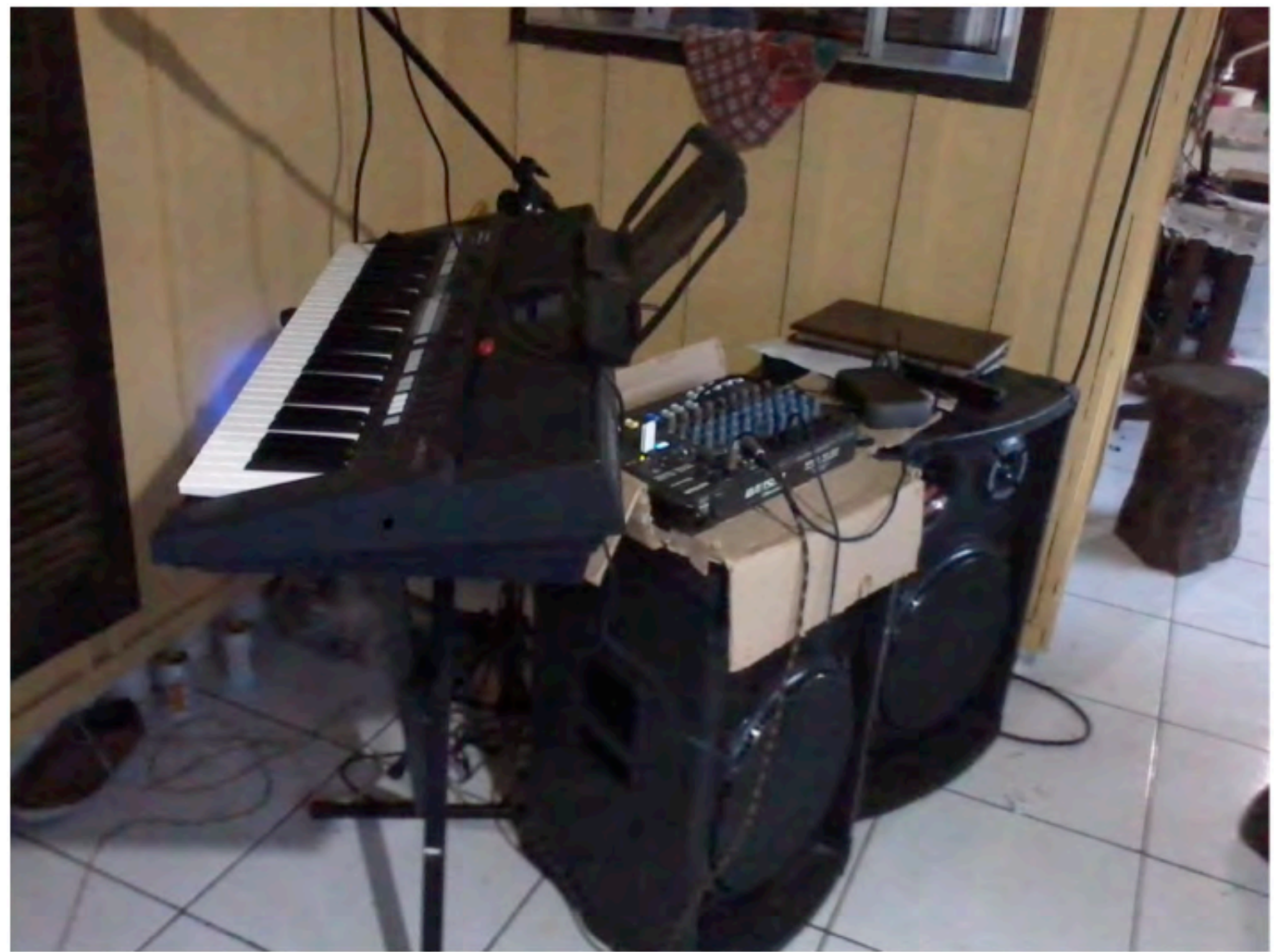

Fonte: Acervo pessoal

\section{LÂMINA 10}

Romaria caminhando na Barra do Ararapira em 2018

Fonte: Foto de Carolina Iarosz - Acervo pessoal

\footnotetext{
${ }^{111}$ Durante nossa estada na Barra do Ararapira em 2018, tive oportunidade de conversar um pouco com um vendedor ambulante que visita regularmente o circuito de comunidades espalhadas pelo lagamar vendendo equipamentos eletrônicos como rádios, alto-falantes portáteis, relógios e calculadoras. Naquele ano, comentou que os moradores preferiam pequenos alto-falantes alimentados a pilha com entrada USB e conexão bluetooth para amplificar músicas reproduzidas por celulares ou armazenadas em cartões de memória ou pendrives.
} 


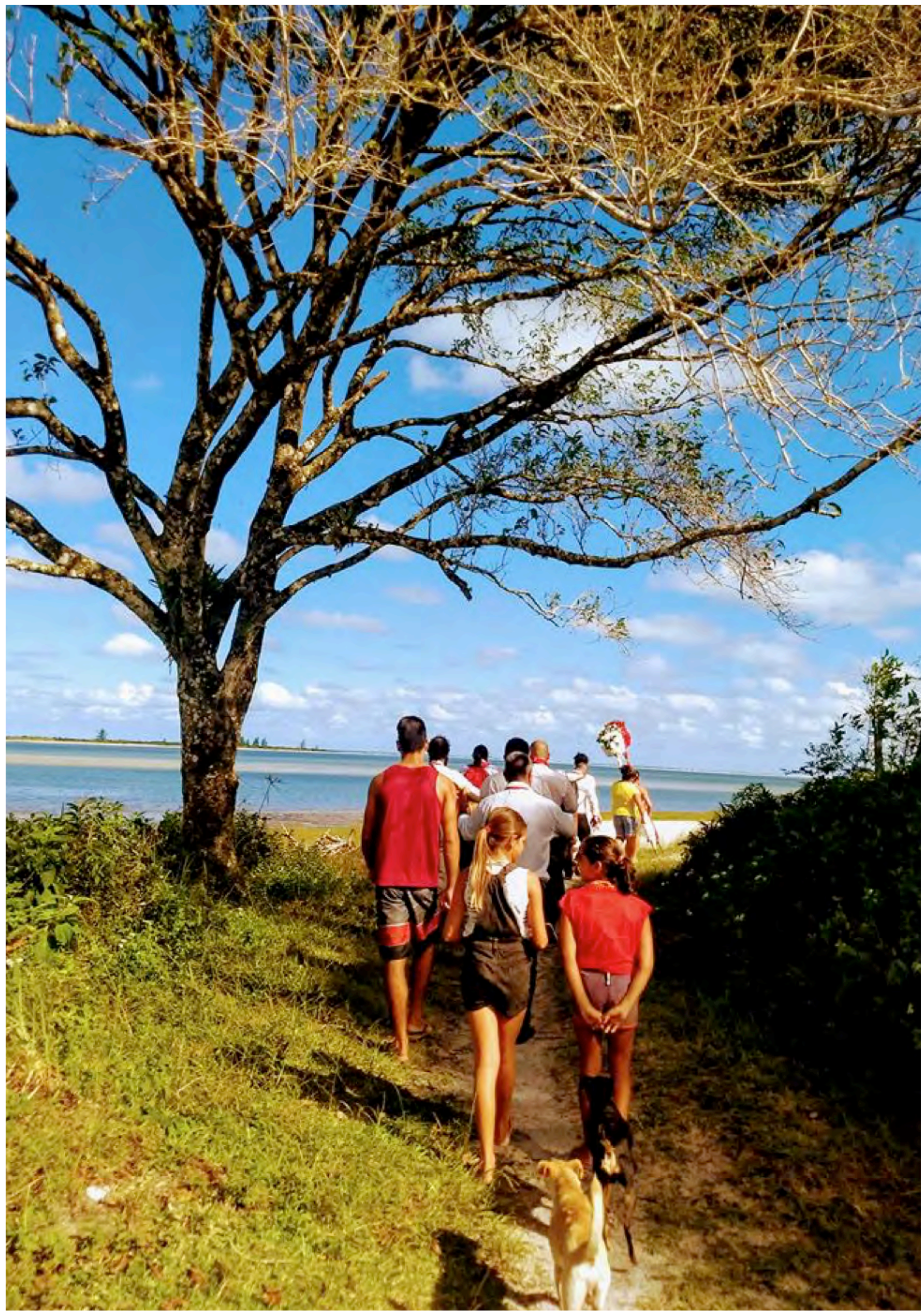


$\mathrm{Na}$ Barra, durante a romaria, o tempo para de modo participativo. A comunidade suspende suas atividades cotidianas durante o tempo da Bandeira. O carinho, o cuidado, os afetos e afecções são demonstrados no aconchego do pouso, na alegria das conversas e na fartura do alimento. Considero um privilégio ter sido recebido nesses lugares, em boa medida valendo-me de uma empatia canalizada pela Bandeira do Divino e também de interações face a face que procuro estabelecer como aprendiz.

Nos outros anos, ou eu acompanhava a festa, ou participava como violeiro; o episódio do machete aconteceu de modo inusitado. Conversando com o pessoal de Paraty, Ubatuba e Iguape nas últimas festas em Paranaguá e Ubatuba (2017), entendemos um tanto mais a instrumentação e as características das folias do Divino por ali. A partir dessas conversas, perguntei a Aorélio se não havia memória do uso do machete na romaria nos tempos de mestre Gabriel ou antes. Ele respondeu: “- Se não tinha, vamos colocar! Vai ficar bonito”.

A partir daí, minha relação com o instrumento tomou novo sentido: procurei entender a lógica organológica e as possibilidades de intervenção do machete no conjunto. Além das conversas com Cleiton e Aorélio, pude também recorrer às transcrições de Ronaldo Tinoco Miguez (2014 e 2017) no período de preparação anterior à circulação da romaria, cuidado e sensibilidade expressos em frutífero diálogo entre comunidade e academia.

Em 2018, saindo de Paranaguá, a tripulação era composta por Jairo na caixa, Aorélio na voz de mestre e na rabeca, Roni Miguez na viola, eu no machete, Cleiton cantando como tenor, Ana Decker fazendo a voz de tipe e Poro, nosso sempre alferes ${ }^{112}$. E ainda se reuniram ao grupo Taquinha e Laura, aprendiz de viola e tipe, Karina Coelho e Carolina Iarosz, ambas pesquisadoras, a primeira na assistência da tripulação e a segunda fotografando e colhendo dados que viriam a compor o novo RAIPI/APPA, então em fase de elaboração.

Por mais de uma vez, durante a noite, ou durante o café (intiruma) que precedia a alvorada, conversávamos sobre formas de melhorar aspectos estéticos das toadas (chegadas e despedidas), manutenção de pulso, intensidades durante o canto e intermezzos instrumentais, detalhes de harmonia, encordoamento dos instrumentos, afinações. Digo afinações porque elas eram modificadas ao longo do dia. Nas alvoradas, por exemplo, o centro tonal variava entre fá e fá sustenido, subindo para sol no decorrer do dia, pois a voz ainda estava fria nas primeiras visitas, pela manhã, e, para mantê-la até a noite, procuramos poupá-la.

\footnotetext{
${ }^{112} \mathrm{O}$ alferes ajuda na organização logística e cuida das roupas dos foliões, do incensário e dos óleos de unguento, dos tecidos que envolvem as bandeiras depois do encerro, do corte das fitas a serem colocadas nas cachopas de flores que enfeitam as bandeiras e também recolhe as ofertas destinadas à romaria.
} 
Retomando a memória, tento recriar esse dia, que me fez refletir sobre a ideia de "tempo fora do tempo", do tempo mitológico de maias e astecas, em que se implica esse lapso, metáfora do que transita de maneira cíclica, significados impressos da história que se repete muitas e muitas vezes.

Após sofrer uma fratura e retornar do atendimento em Guaraqueçaba, "Dona” Belmira, fervorosa devota do Divino, teve nova queda ao desembarcar do barco e fraturou a região da bacia. Isso aconteceu há alguns anos, e ela vive acamada desde então. A visita à casa de "Dona" Belmira foi intensa, com versos em que se pediam saúde, amparo e redenção. Passado o momento da chegada, Aorélio se dirige ao quarto da senhora e se põe em oração; com uma vela e um copo d'água ao lado, põe as mãos sobre o corpo debilitado, o que parecia lhe dar algum conforto, a julgar pelo afeto e pela emoção que aflorava em seu semblante.

Acompanhando do lado de fora da casa, comecei uma conversa com Cleiton do Prado, mestre fandangueiro de credo religioso kardecista. Falamos longamente sobre espiritualidade e fé e sobre os tantos sentidos de nossa efêmera existência frente aos mistérios do universo, sobre o tempo distendido nos planetas superiores povoados pelos deuses hindus, cuja passagem de um único dia supera o tempo que transcorre em uma de nossas eras, em que se somam anos na ordem das centenas de milhões.

Tanto na literatura védica quanto na helênico-judaico-cristã, o som é elo fundante, gerador de materialidade. $\mathrm{O}$ verbo que se faz carne, o pranava (vibração fundamental), que, junto aos três Vyahritis (os três mundos), representa a causa do universo, personificada em Brahman. Divindades, crenças, tempo, luz, cor e som.

Depois de os moradores terem ouvido atentamente algumas orientações de Aorélio sobre a necessidade de estar próximos, levar "Dona" Belmira para tomar banho de sol e beber muita água, nos despedimos. Tanto os familiares quanto o pessoal que acompanhava a romaria se puseram novamente em marcha, seguindo as Bandeiras.

Fomos em frente, pois não é de bom alvitre voltar no itinerário com as bandeiras em punho. Sempre em frente. As bandeiras sempre na frente. Nem instrumentistas, nem romeiros, nem moradores - quem dita o passo são os devotos que levam as bandeiras. 
Figura 5.6 - Devotas levando as bandeiras (Pontal do Leste, Ilha do Cardoso, 2017)

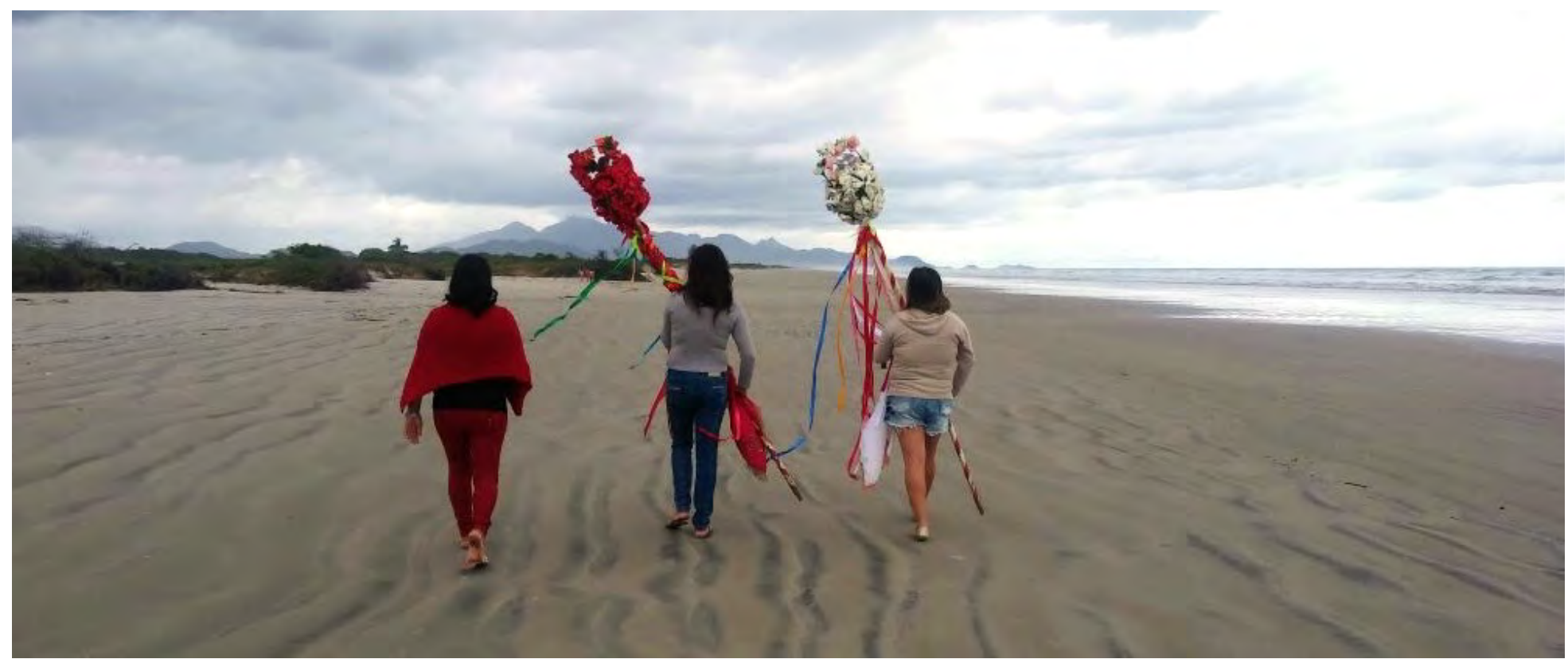

Fonte: Acervo Pessoal

Nesses dois anos em que acompanhei a folia como instrumentista, venho aprendendo a me comportar durante a peregrinação. Minha dificuldade inicial foi justamente controlar os movimentos, indicando involuntariamente os tempos fortes acompanhando a rítmica de despedidas e encerros com pequenos meneios. Ao observar meus movimentos em breves gravações, comecei a perceber o problema que o mestre já pontuara. A regra é ser comedido: movimentos desnecessários desviam a atenção tanto dos músicos como da audiência.

Nesse dia, tive outro entendimento, ainda mais significativo, e que me aproximou dos experimentos de controle emocional de atores e performers experientes em cena. Além do movimento corporal, o controle das emoções, ou ao menos da forma como as expressamos durante as atividades da bandeira, são muito importantes para manter em curso as experiências de fluxo.

Em Beyond boredom and anxiety - estudo sociológico sobre a experiência do fluir que reúne depoimentos de alpinistas, dançarinos, compositores, jogadores de basquete, enxadristas, cirurgiões e professores -, Mihaly Csikszentmihalyi diz: "Em estado de fluxo, ações sucedem-se de acordo com uma lógica interna que parece dispensar intervenções conscientes do agente. $\mathrm{O}$ agente experimenta a ação como um fluxo contínuo de momentos em que exerce controle absoluto da situação e no qual há apenas uma pequena distinção entre self e meio, entre estímulo e resposta, entre passado, presente e futuro" (CSIKSZENTMIHALYI, 1975, p. 36).

De acordo com o autor, o estado de fluidez é um estado alterado de consciência, ou seja, um comportamento fora dos padrões cotidianos de conduta, provocado pela realização de uma ação que envolve o agente de forma total. Aqui, "controlar a situação" é lançar-se com precisão. O autor 
contrapõe a ações automatizadas, dispersas e desatentas ao mundo, relações des-automatizadas, íntegras e engajadas de perceber, gerir e gerar o real. (FABIÃO, 2010, p. 321-322)

Neste ponto, abro um breve parêntese. Soa-me plausível estabelecer aqui um paralelo com o processo que vivi na companhia CiaSenhas de Teatro durante a montagem do espetáculo Circo negro, texto do dramaturgo argentino Daniel Veronese, com direção de Sueli Araújo. Na montagem, as mazelas do cotidiano de uma trupe circense, seus conflitos, pulsões e virtudes são escancarados à audiência por um jogo em que as personagens transitam entre narradores, personagens, atores encenando os atores que interpretam tais personagens e ainda o ator como pessoa. É um jogo de camadas referenciais sobrepostas que instiga e confunde a platéia, que pode se compadecer ou se irritar com determinada situação, inclusive interagindo em momentos pontuais da encenação.

Lembro-me de um dos exercícios propostos aos atuadores por Sueli Araujo, quando as lágrimas brotavam efusivamente, e a emoção não estava na lágrima derramada, mas no quase choro, na capacidade de regular a intensidade da emoção posta, no fato se ter o domínio da cena.

Sempre me lembrava disso nos momentos mais comoventes da romaria. Devotos mais velhos, um filho distante, um acidente grave, a morte de algum parente ou conhecido. A estreita relação dos tripulantes com as comunidades presentifica o instante que agrega referenciais múltiplos. Jairo viveu a infância naquelas redondezas, ${ }^{113}$ Aorélio e Poro ajudaram mestre Gabriel a levantar novamente a romaria, há mais de vinte anos. A romaria passa ano após ano e é ansiosamente esperada nas comunidades.

Como aprendiz, tento me integrar às condutas, inclusive às subjetivas. Segurar o choro é como segurar a força interior quando fumamos pety na casa de reza mbyá guarani, é prezar pela manutenção e continuidade do rito, é sinal do respeito pela tripulação, pelos devotos e pela divindade. É interação comunicativa que guarda subjetividades, memórias-lembrança $e$ memórias-contração.

Mais algumas casas, e chegamos à de Márcio e Nica (Rose Santana). Não me lembro exatamente dos versos disparadores. Confesso que me emociono facilmente e com certa frequência. Durante a romaria, tenho em mente a necessidade de regular a emoção, controlar o choro. Percebi também em outros foliões algo parecido. Concluída a chegada, retirei-me da sala

\footnotetext{
${ }^{113}$ Nosso mestre caixeiro que tira voz de tenor e de tipe, faz verso, faz piada e anima a audiência e os foliões. Ele é o mais antigo da tripulação, conhece todo mundo e todos os lugares, baixios, pesqueiros e toda sorte de conhecimentos que se pode ter em relação àquelas redondezas.
} 
para o fundo da casa e dali para um canto do quintal onde estivesse longe de qualquer observador. Chorei compulsivamente. Contemplei o mar por alguns minutos, lavei o rosto e desfrutei com satisfação o café gordo servido pelo anfitrião.

Na casa seguinte, "Seu” Rubens Muniz e Hilda Pires. Alguma coisa estava fora de lugar. Já na chegada, ao receber a bandeira, "Dona" Hilda passa das lágrimas ao choro torrencial. Alguém acudiu a bandeira, pois ela não conseguiu se manter na guarda. A essa altura, "Seu" Rubens já chorava também. Todos com lágrimas nos olhos, audiência e foliões, quando me dou conta de que Aorélio, Jairo, Ana e Cleiton estavam igualmente tomados pelo fluxo catártico que envolvia o instante, mantenho-me ainda íntegro por alguns momentos antes de finalizarmos a chegada, cujos últimos acordes se deram em meio às lágrimas. Abraços fraternos, sinceros, peculiares. Naquele momento, não havia estratificações, não havia diferenças. Todos ali reviviam o sentimento da perda do filho recém-falecido, da casa construída que não seria ocupada, da devoção consoladora no Divino Espírito Santo e na Santíssima Trindade.

Passados os instantes de comoção generalizada, tomamos assento para o café. Como de costume, quando a romaria passa pela casa de fandangueiros, é comum que eles peguem a viola e aconteçam pequenas violadas, com os fandangueiros cantando suas modas de apreço e mostrando suas habilidades em tanger o instrumento. Mesmo em meio à comoção ainda vívida, não foi diferente no caso de "Seu" Rubens, mas a carga emotiva do momento foi novamente compartilhada com a audiência. "Seu" Rubens na viola, Cleiton no machete, plano em que se deram os seguintes versos de uma chamarrita inominada:

\author{
Quando nasci neste mundo \\ Nascemos quatro num dia \\ Moreninha, nascemos quatro num dia \\ Ai neste mundo, nascemos quatro num dia \\ Nascemos quatro num dia \\ Nasci eu, nasceu saudade \\ Moreninha, tristeza, malencolia \\ Nasceu saudade, tristeza, malencolia ${ }^{114}$ \\ Esta casa tá bem feita, \\ Por dentro, por fora não...
}

\footnotetext{
${ }^{114}$ Em gravações realizadas com mestre Moacir Santos nos anos 1990, encontramos o verso com a seguinte terminação: "Nascemos quatro num dia / Nasci eu, nasceu saudade / Nasceu João, Nasceu Maria". Já mestre Zeca canta o verso terminando assim: "Nascemos quatro num dia / Nasci eu, nasceu saudade / Tristeza e alegria". Nesse sentido, a apropriação do verso e sua modificação parecem responder a um momento peculiar, fazendo-o consonar com o momento vivido por "Seu” Rubens.
} 
O verso não terminou. Mais uma vez, tomam lugar o pranto, as memórias, a tristeza, a saudade e a melancolia explicitamente citadas no verso. ${ }^{115}$ Inesperada e não intencionalmente, a moda e os pés de verso cantados canalizaram a carga emotiva que se dispersa no choro, comunicaram sentimentos íntimos, expressão de aspectos que, mesmo inconscientemente, tomam assento no instante singular de interação propiciado pela romaria em peregrinação.

Ainda da Barra, outra memória conta de "Seu" Antônio Muniz e do dia em que Aorélio lhe pediu que cantasse o Bendito da Paixão. (Até onde sei, quem cantava o terço e as ladainhas em latim era o falecido João Busa, e se imaginava que os versos e os cantos se haviam perdido quando ele morreu). Combinamos com "Seu" Antônio visitá-lo no dia seguinte ao pequeno baile que fizemos na Barra para entregar dois dos instrumentos do projeto Artesanias Caiçaras que não haviam sido distribuídos em Paranaguá no mês anterior (agosto de 2017). Assim foi. Nos dirigimos a sua casa, Aorélio, Poro, eu, Hely, Cirilo Charros (Flávio Rocha) e Leo Cardoso. Água fervendo e cheiro de café. Um de nossos camaradas teve um desarranjo na noite anterior, logo, na leiteira ferviam algumas folhas de goiaba, que, segundo "Seu" Antônio, resolviam qualquer mal-estar gastrointestinal. Café e chá de goiaba nas devidas xícaras, "Seu” Antônio vai até o quarto e volta com quatro folhas de caderno dobradas, onde estavam manuscritos os dezessete versos que narram o tormento de Jesus Cristo nos momentos que precederam a crucificação.

Organizamos o pequeno set de filmagem e começamos a gravar. Como não havia ninguém habilitado para fazer a segunda voz e Aorélio mostrou grande interesse nos aspectos melódicos da performance, sugeri que gravássemos "Seu” Antônio Muniz em overdub, ou seja, a segunda voz sobreposta à primeira, ambas cantadas por ele. Nunca havia usado o aplicativo nativo do celular para esse tipo de gravação (multipista). Enquanto Cirilo monta o tripé da câmara de vídeo, faço pequenos testes com "Seu” Antônio, para que se familiarize com o fone de ouvido, e damos início à sessão.

\footnotetext{
115 “Assim, uma palavra ou uma imagem é simbólica quando implica alguma coisa além do seu significado manifesto e imediato. Esta palavra ou esta imagem tem um aspecto 'inconsciente' mais amplo, que nunca é precisamente definido ou de todo explicado. E nem podemos ter esperanças de defini-la ou explicá-la. Quando a mente explora um símbolo, é conduzida a ideias que estão fora do alcance” (JUNG, 1969, p. 20).
} 
Figura 5.7 - Manuscrito do Benedito da Paixão, de "Seu” Antônio Muniz, 2017

Bendito da Paiscaó 10

Bendita lovado reja a paixcaó do Bom yesus para nós livirar do inferno padeden morte na crery 20

Descle o harto até o Calvario Posto em tropél de mil dores sofren todos os tarmentos Por a mor dos pecadores 30

Foi preso foi a cusado no tribunal coino réu Sendo rentror da ver clade troxe a lug dos altos céns.

Sopur ínjurias a a trozes De espintros foi coroado Carregan sobres rens onbros a crus em 5 que fai pregado

Os acaites que the deram faram einco mil e tantos que the rasgaram a earre

Fonte: Acervo Pessoal

236 
Movimentos vocais melismáticos, em que soavam quartas justas e terças menores paralelas, portamentos e glissandos que às vezes invertiam as funções das vozes, com um atravessamento bastante peculiar das energias sonoras (circulado na figura 5.8). Lembro desse tipo de movimento na gravação de algumas faixas do disco Amanhece, em cuja edição e mixagem não entendíamos qual era primeira e qual era a segunda voz. Perguntei a Cleiton e Aorélio: “- Como é isso?” Resposta: “-É assim mesmo”. E nós todos rimos.

Figura 5.8 - Sonograma de fragmento do Bendito da Paixão, executado a duas vozes por Antônio Muniz (Barra do Ararapira, 2017)

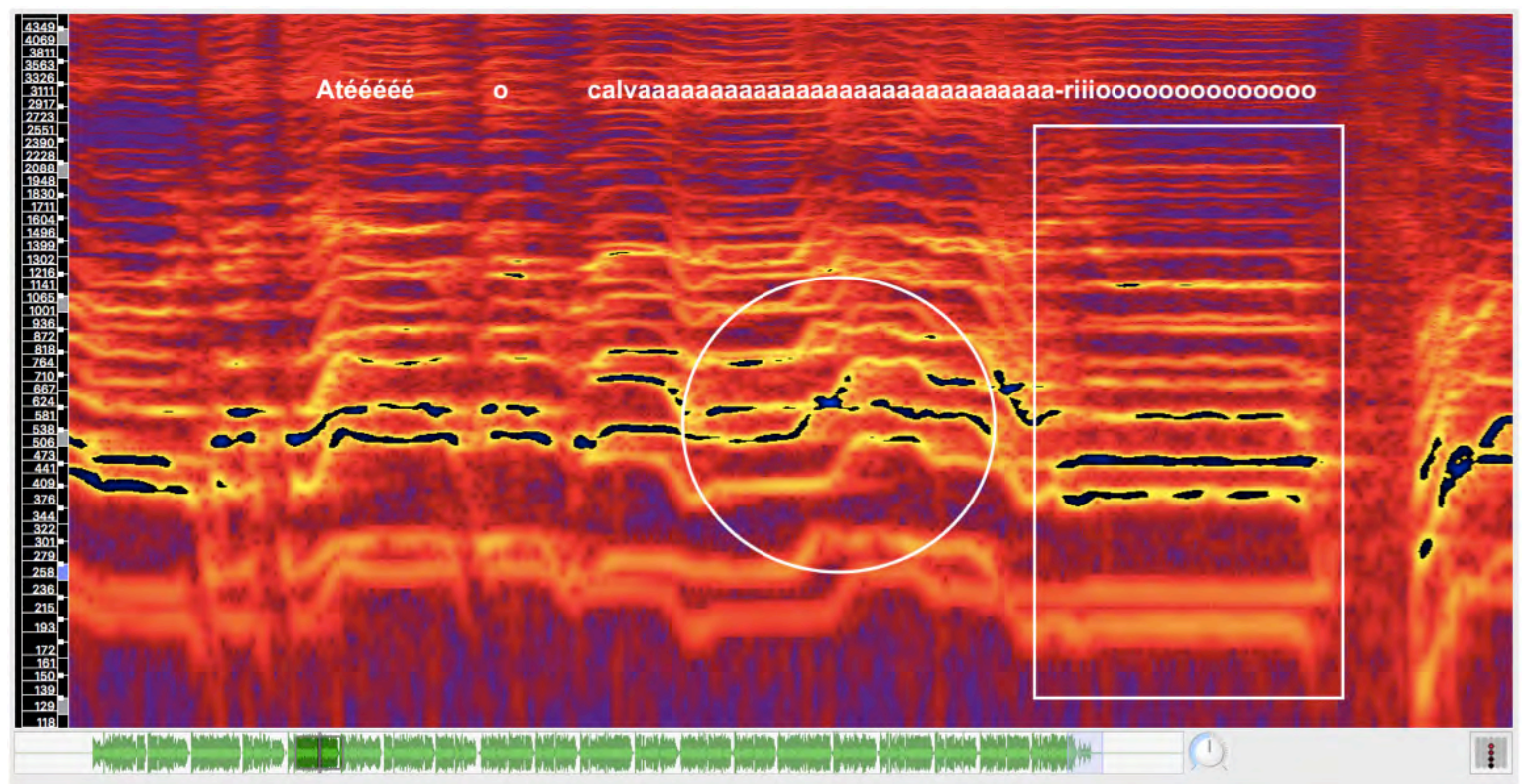

Fonte: Arquivo pessoal extraído em Sonic Visualizer

Vimos e ouvimos efetivamente os harmônicos superiores e inferiores, assinalados pela marcação retangular na figura 5.8, onde se vê o acorde de sol menor (D6, D5, Bb4, G4) ${ }^{116}$ na sustentação das últimas notas do verso, graficamente apresentado por uma tríade, mesmo que de fato o bendito esteja sendo executado a duas vozes. Sensações inerentes à sobreposição de harmônicos reforçada pela condução e pela "timbragem" das vozes. No fim do take, valeu o comentário de "Seu” Antônio: “- Agora saiu bem certinho!”. Assim como nossa percepção, a imagem sugere outras frequências fundamentais, superposição e sequências de sons complexos que nos levam a compreender o que denominamos música. Nos perguntamos o que do real de fato percebemos, que carga etológica carrega esse pequeno lapso temporal capaz de nos

${ }^{116}$ Do agudo para o grave: 2336,35Hz (D7-10c), 2131,79Hz (C7+32c), 1937,99Hz (B6-32c), 1862,62Hz (Bb62c), 1617,91Hz (Ab6 - 41c), 1559,42 Hz (G6-9c), 1399,76Hz (F6+4c), 1167,24Hz (D6-11c), 985, 369Hz (B54c), 931,276 Hz (Bb5-2c), 788,101Hz (G5+9c), 705,678Hz (F5+18c), 592,806Hz (D5+16c), 469,495Hz (Bb4+12c), 395,369Hz (G4+15c), 236,865Hz (Bb+28c), 193,799Hz (G3-20c). 
transportar para lugares nunca visitados, mas tão familiares? Fendas temporais, singularidades sonoras medievalescas, compaixão pelo sofrimento expresso nas palavras do canto. Propagamse fônons ${ }^{117}$ cuja precipitação vibracional percorre planos tipo tempo, tipo espaço, tipo luz ${ }^{118}$.

Figura 5.9 - Superespaço vetorial de $\mathbf{R}_{1}{ }^{\mathrm{n}+1}$

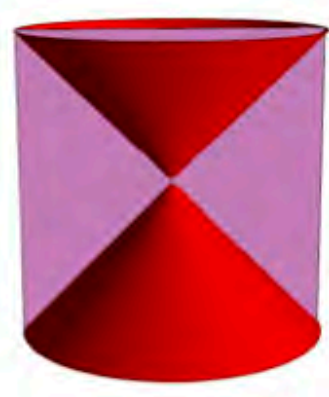

(i) Plano tipo tempo

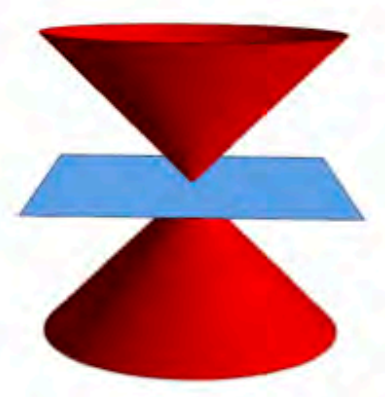

(ii) Plano tipo espaço

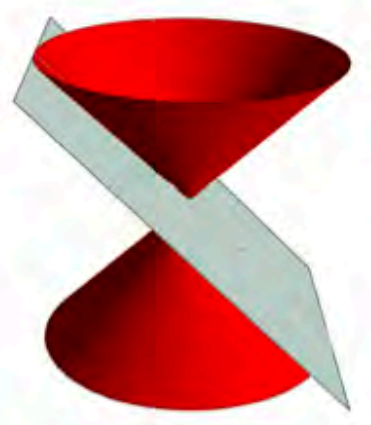

(iii) Plano tipo luz

Fonte: (SACRAMENTO, 2015, p. 6)

\title{
LÂMINA 11
}

Fitas das bandeiras na capela do Divino

Fonte: Acervo Pessoal

\begin{abstract}
117 "De forma análoga à quantização das oscilações eletromagnéticas (fótons), as vibrações elásticas da rede [cristalina] podem ser quantizadas dando origem aos fônons" (OLIVEIRA; DE JESUS, 2005, p. 165). Em suma, um fônon é um quantum de um modo normal de vibração, ou uma unidade de vibração capaz de descrever o som em escalas muito pequenas, notadamente no universo dos superfluidos. A novidade é que constatações teóricas e experimentais publicadas em 2018 informam que o fônon tem uma massa negativa muito pequena, indicando que, diferentemente das partículas e subpartículas afetadas pela gravidade, a trajetória das ondas sonoras tende para cima. Ou seja, a (minúscula) massa gravitacional efetiva do fônon gera um (minúsculo) campo gravitacional. E a fonte desse campo gravitacional viaja com o fônon. Assim, num sentido muito físico, o fônon tem massa (negativa). Além disso, isso não se deve à equivalência usual entre massa e energia na relatividade: o efeito sobrevive no limite não relativístico. E, finalmente, não é um efeito quântico, porque o formalismo [da equação dada] aplica-se inalterado aos pacotes de onda clássicos. [...]. Nós mostramos que, ao contrário da crença comum, as ondas sonoras carregam massa gravitacional, num sentido newtoniano padrão: elas são afetadas pela gravidade, mas também geram gravidade. Nossos resultados mostram que esse efeito anda de mãos dadas com as interações não lineares do som, e isso é verdade para superfluidos, fluidos comuns e sólidos. Em particular, para todos esses meios, no limite não relativista, a massa transportada por uma onda sonora é proporcional a sua energia multiplicada por um coeficiente que depende apenas da equação de estado do meio (ESPOSITO et al., 2018, p. $1 / 5$, tradução nossa).

118 "Para um vetor não nulo $v \in R^{n+1}$ e um número real c, definimos um hiperplano com pseudo-normal $v$, como $P(v, c)=\left\{x \in R^{n+1} \mid\langle x, v\rangle=c\right\} . P(v, c)$ é dito hiperplano tipo espaço, hiperplano tipo tempo ou hiperplano tipo luz se v é tipo tempo, tipo espaço ou tipo luz, respectivamente." (SACRAMENTO, 2015, p. 7)
\end{abstract}




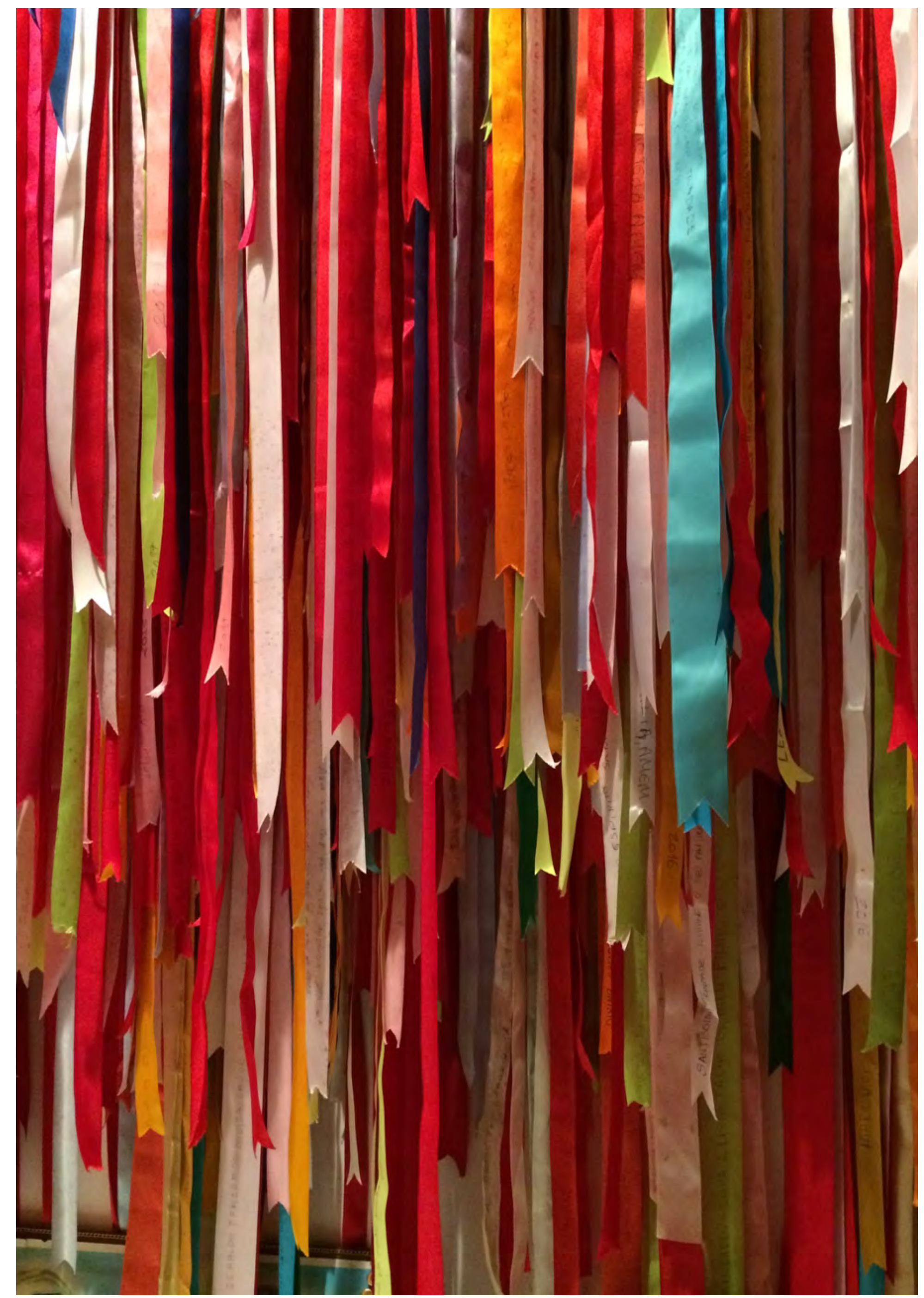




\title{
6 O FANDANGO NA ERA FONOGRÁFICA
}

\begin{abstract}
Isso pra sair pra fora foi quase um sonho, realizado um sonho que jamais você diria ver. Conhecer São Paulo, conhecer Curitiba, você nunca iria pensar em outra idéia. "Viemos aqui, vir pra chamar vocês pra nós gravar". Fiquei meio tremendão, aí não teve coisa, disse: "Como? Gravar, gravar o quê?" Gravar, aquilo a gente grava, mas sabe lá, a gente ia pra gravadora, sei lá o que é essa tal gravadora. Fomos pra lá. Chegamos lá, e se apronta e vai, entra pra dentro lá. [...] Pra falar era só por aceno pros outros. Começamos a gravar, uma, duas modas, descansa um pouquinho, vamos ver o que é que valeu. Disse: "Está valendo!" E se está valendo, então, vamos até o fim com uma gravação dessas. Nós nunca chegamos aqui e já está valendo. Não estamos errando, então, vou dar de tudo. [...] Daqui a esperança de mais ainda, mais gravação, porque depois a gente morre e fica aí menos história pra escutar..." (Leonildo Pereira) (MUSEU VIVO DO FANDANGO, 2006, p. 11).
\end{abstract}

Mais uma das apropriações tecnológicas que atravessam o fandango, ao menos desde a década de 1940 (RODERJAN, 1998, p. 9), são os diferentes registros fonográficos produzidos, sendo que, a partir da década de 1990, há um crescente aumento na produção específica de CDs tanto no litoral do Paraná quanto no de São Paulo. Assim, o disco emerge também como mediador que possibilita aos fandangueiros se constituírem como artistas, construindo uma imagem pública de uma sonoridade peculiar e conquistando o reconhecimento coletivo. Os discos podem ser entendidos como índices musicais, elementos que se mostraram atuantes no processo de construção de artistas (e grupos) e de determinada ideia de "artisticidade", considerando que o próprio espaço de vida e as referências estéticas caiçaras experimentam sobreposições de usos e ambiguidades de sentido derivadas da multiplicação de contextos em que esses objetos passam a circular.

Repensando a noção de comunidade, abrem-se oportunidades, em primeiro lugar, para explorar a transmissão musical e o desempenho não apenas como expressões ou símbolos de um determinado grupo social, mas como parte integrante de processos que podem em diferentes momentos ajudar a gerar, moldar e sustentar novas coletividades. (SHELEMAY, 2011, p. 349)

A discussão proposta pela autora visa tanto reavaliar estudos comunitários em bagagem musical quanto deslocar o foco para o papel da música na formação da comunidade. Tanto Shelemay quanto Thomas Turino concordam que o paradigma etnomusicológico deve ultrapassar as fronteiras geográficas, incluindo-se aí as formas de transmissão das novas 
tecnologias. Turino (2008, p. 94) propõe que a etnomusicologia dialogue com as "interações dialéticas em curso entre indivíduos e seus ambientes sociais e físicos realizados por meio de práticas observáveis", sugerindo que qualquer teoria geral sobre processos artísticos ou expressivos da cultura de determinada população deveria tomar como ponto de partida a concepção do self e da identidade individual, indicando que, em última análise, é na vida, nos indivíduos ativos que residem a cultura e o significado musical.

Talvez aí esteja o desvio epistemológico da ação, e, nesse sentido, a participação do pesquisador de índole folclorista, daquele que institucionalmente, com fins de catalogação, acabou sedimentando as bases das vertentes artísticas e espetaculares do folguedo na atualidade.

Para ampliar este debate, podemos tomar o ano de 1936 como marco histórico, quando Mário de Andrade elaborou o anteprojeto de proteção ao patrimônio artístico nacional. $\mathrm{O}$ documento foi elaborado a partir da solicitação do então ministro da Educação e Saúde, Gustavo Capanema, subsidiou o texto do Decreto-Lei n. 25/1937 e, mais tarde, orientou a Constituição de 1988, mais especificamente, os artigos 214 e 215 (SILVA, 2002). Essa legislação que vai de encontro ao anseio de Mário de Andrade de catalogar e divulgar elementos da cultura popular tanto em São Paulo como em outros rincões do país, registros que acabaram sendo efetivados de maneira ampla pelo Departamento de Assuntos Culturais do Ministério da Educação e Cultura por meio da Fundação Nacional de Arte (FUNARTE), pela Comissão de Defesa do Folclore Brasileiro (CDBF), e, no caso do fandango caiçara, pela Comissão Paranaense de Folclore, que foi responsável pela gravação do disco de vinil intitulado Fandango do Paraná, na série Documentário Sonoro do Folclore Brasileiro n. 15. ${ }^{119}$

Foi José Ramos Tinhorão quem sugeriu, no Jornal do Brasil de 15 de junho de 1974, que o ministro da Educação e Cultura, Ney Braga, tornasse Marcus Pereira um parceiro da Campanha de Defesa do Folclore Brasileiro. Pereira era assumidamente um empresário que concentrou seus interesses na cultura dita "popular", explorando seu potencial em função da relação dos projetos com a "alta cultura" e com a "contemporaneidade". Sua participação no projeto Documentário

\footnotetext{
119 "A questão política e a dimensão campo/cidade aparecem nas falas dos entrevistados que trabalharam na gravadora (Discos Marcus Pereira). Marcus Vinicius Andrade, seu diretor musical entre o fim da década de 1970 e o começo da de 1980, chegou a dar entrevistas a jornais da época criticando o "esmagamento de culturas locais do sertão" como um "erro de modo desenvolvimentista de um país que recebeu o desenvolvimento pelo litoral". Em entrevista para este trabalho, ele afirmou: "Era um momento em que o país estava saindo de uma estrutura arcaica, agrária, começando a viver os primeiros movimentos da cultura de massa. O desafio era: como entro nisso aí para fazer uma coisa brasileira? A sedução da cultura de massa falava do 'grande Brasil' de Médici. Tudo que revelasse a raiz brasileira era visto como fora de moda e até subversivo". É interessante notar que essa raiz brasileira "subversiva" estava contemplada em um projeto do Ministério da Educação e Cultura (MEC): o Documentário Sonoro do Folclore Brasileiro" (ARAGÃO, 2011, p. 43).
} 
Sonoro do Folclore Brasileiro foi haver obtido um ponto de equilíbrio entre o atrativo comercial dos discos e seu indispensável rigor documental (MILLARCH, 1974).

\begin{abstract}
O governo era lembrado pela imagem de "Grande Brasil" forjada pela ditadura, como observou Carolina Andrade, que coordenou as coleções de Sul e Norte: A gente procurou mostrar um Brasil verdadeiro. A ditadura estava sufocando o Brasil, tinha aquele espírito da Copa de 70, do Médici, aquela coisa de "Meu Brasil, eu te amo". Tinha um patriotismo, uma coisa urbana que era totalmente falsificada. Mas, ao mesmo tempo, tinha um Brasil sendo mostrado pelo Chico Buarque, pelo Caetano Veloso, tinha um movimento da música popular muito bonito, muito sério. Mas o folclore estava quase esquecido, e fomos buscar um pouco dele. (ARAGÃO, 2011, p. 43)
\end{abstract}

O disco n. 15 foi gravado nos estúdios da TV Iguaçu, canal 4, em Curitiba, em 1968, sendo lançado em novembro de 1976. Disco EP com três faixas: lado A: (1) Andorinha (marca batida) - 4’21", e (2) Vilão de lenço (marca bailada) - 1’22”; e lado B: (1) Mantiquira [Marinheiro] (marca batida) - 4'09".

A interpretação das faixas ficou a cargo de mestre Manequinho da Viola e Celestino (violas e canto), Ercílio (rabeca) e Doca (adufo). Danças, palmeado e sapateados, pelo grupo de Fandango, da Ilha dos Valadares (10 pares). ${ }^{120}$

Parece-nos que as primeiras gravações do gênero caiçara, ao menos na forma corrente em fins das primeiras décadas do século XX, foram realizadas por Fernando Corrêa de Azevedo, empreitada levada a cabo em fins da década de 1940.

É notório o desenvolvimento da tecnologia de áudio, que passa por inúmeras fases, do fonoautógrafo de Leon Scott, do tin-foil de Edson, dos cilindros de cera, dos discos planos de Berliner fabricados em vulcanite (que giravam de 76 a 78 vezes por minuto), do disco de microssulcos e do advento do policloreto de vinila (PVC) às fitas magnéticas e depois à linguagem binária da era do som digital, cujos suportes também seguem em desenvolvimento, do compact disc aos núcleos de silício.

Nosso intento aqui é indicar a variedade das nuances performáticas e estruturais do folguedo nos diferentes lugares do universo caiçara a partir das interações com essas tecnologias, marcadamente o advento da radiodifusão e do disco plano, a que se seguiram o desenvolvimento da indústria fonográfica e a influência que sofreu (e ainda sofre) do modelo da cultura de massa ditado pela indústria do entretenimento estadunidense e europeia.

\footnotetext{
${ }^{120}$ Informações extraídas da contracapa do disco (RODERJAN, 1968).
} 


\section{Fandangos caiçaras, facetas das regionalidades}

Nas oportunidades que tive de acompanhar apresentações da ciranda caiçara, cultura pulsante do litoral sul fluminense, ou de conviver com detentores e atores culturais dessas localidades, notei elementos do choro na condução dos baixos em violas e violões, assim como nas frases de machete, bandolim e cavaquinho (instrumentos de presença marcante nessas formações). Durante a II Festa do Fandango em Ubatuba, circulei nos bastidores e no pátio do Casarão do Porto e presenciei momentos vívidos de performances de chorões e sambistas experientes tocando em sua roda como tocariam nos mais distintos botecos da boemia. Os repertórios transitavam por Waldir Azevedo, Pixinguinha, Martinho da Vila, Clara Nunes, Paulinho da Viola, Nélson Gonçalves e Raphael Rabello, Ernesto Nazareth e Zequinha de Abreu.

A Ciranda de Paraty e o Chiba ${ }^{121}$ ubatubano compõem o mosaico cultural do universo fandangueiro. Apesar da discussão corrente que se vem construindo nas esferas deliberativas (como no caso do Comitê de Salvaguarda do Fandango Caiçara, que discute qual seria a melhor maneira de inserir essas manifestações no registro de bens imateriais brasileiros), o fato é que tanto historicamente como a forma dessas manifestações na atualidade indicam tratar-se de manifestações congêneres ao fandango caiçara. As semelhanças formais, estéticas, organológicas, métricas, poéticas e coreográficas com o que hoje denominamos fandango caiçara não devem ser relegadas.

No caso da ciranda caiçara, além das denominações de marcas e formas coreográficas que ecoam em estudos folclóricos, encontramos relatos de sua prática na baixada santista, em Bertioga, na década de 1960:

O Fandango do litoral, que não se deve confundir com o palmeado e sapateado de mesmo nome existente no interior sul, é nome genérico para o que os caiçaras chamam mais comumente de Batepé, Ciranda, Caranguejo, Tira-o-Chapéu, Tontinha, Panela-de-Arroz-Queimou, Marrafa e outras. Algumas dessas danças de coreografia ligeira são marcadas pelo sapateado dos homens em certos momentos, enquanto outras são valseadas (com esta denominação o caiçara quer significar: mais lenta). Durante uma função ou fonção é hábito intercalar um tipo e outro, havendo também as cantorias que não precisam ter dança correspondente; por exemplo, um pasquim ou uma

${ }^{121} \mathrm{Na}$ literatura corrente, encontra-se também a grafia "Xiba". 
moda qualquer. Em Bertioga, o Instituto Histórico e Geográfico GuarujáBertioga tem procurado às vezes incentivar a continuidade de certas festas, como, por exemplo, a de Sto. Antônio, quando se podem encontrar cantadores de "Reis" e semelhantes, procissão, violeiros que sabem rasquear o instrumento num Chiba ou numa Cana-verde, numa Tontinha ou numa Ciranda, além da presença também da Quadrilha típica do ciclo joanino (que, aliás, ocorre em todo o estado, no ciclo de festas de junho) - e igualmente o baile comum. (PELLEGRINI FILHO, 1975, p. 24)

Por ocasião da reunião de grupos de Fandango, Ciranda e Chiba durante a II Festa do Fandango de Ubatuba em 2017, uma das atividades inicialmente destinada ao repasse de coreografias da Ciranda de Paraty acabou se transformando numa produtiva discussão sobre a intersecção e o parentesco das três manifestações, onde os participantes mais velhos, assim como Pellegrini Filho (1975), indicam o nome genérico "função" para designar o evento coletivo festivo onde se dançavam e tocavam diferentes marcas, umas bailadas (valsadas), outras batidas (sapateadas).

O meu vizinho, Davi Vieira, comentou que não tinha nem nome de fandango, Mario Gato fala isso também, não tinha fandango nem era ciranda, ele dizia baile, função! (Melina Spoto, Ubatuba)

Bem antigamente, no baile, tinha o fandango. Eu conheci. Tenho 63 anos de idade e aprendi com vários mestres. Eu vou falar pra vocês: eu sou mestre da folia hoje em Ubatuba, e tô vendo se consigo fazer mais um mestre, porque a gente não dura muito. Eu acho que o fandango existiu. Existiu, sim, mas com meu avô. Meu avô é que foi mestre. Ele me falou na época, eu era criancinha de 7 anos. Comecei na folia com 10 anos de idade, por isso, hoje a turma fala que eu sou mestre. Não sei se sou mestre. Eu quero aprender mais, coisas que não sei. Quero aprender a novidade, a coisa que passou despercebida, que eu não vi. Mas eu toquei muito em baile de fandango - era o baile-função. Porque era o conjunto de danças, o conjunto de músicas, e ainda hoje a gente tá fazendo isso: é Chiba, é São Gonçalo, é uma função, é uma dança, tem a promesseira que está com o santo ali. (Pedro Victor dos Santos, Ubatuba - transcrição nossa)

Enumerando a diversidade das cirandas em território brasileiro, Campana (2011, p. 50) reconhece diferenças marcantes nas derivações que há nos diversos pontos do país: "Nas regiões interioranas do estado de São Paulo, ocorrem diferenças coreográficas das Cirandas em relação aos estados de Pernambuco e Rio de Janeiro, especificamente Paraty". Além da performance coreográfica, devemos observar a conformação poética, métrica e organológica. Se, por um lado, a ciranda guarda aspectos poéticos inerentes ao estado da arte no período colonial, de forte influência ibérica, por outro, a ciranda caiçara convive com a cultura litorânea e toma forma nesse contexto específico, adotando traços típicos das populações locais.

Nesse cenário, ressaltam-se hábitos culturais comuns que unem as diversas comunidades do universo caiçara que vai pelo litoral sul do Rio de 
Janeiro ao norte do Paraná. Dentre eles, as danças e músicas típicas, que recebem nomes diferentes de acordo com a região, mas possuem características semelhantes. Destacam-se os nomes fandango e ciranda, que na verdade se desdobram em outras danças, como as chamarritas e os dandãos, no caso do fandango, e o arara, a canoa e o caranguejo, no caso da ciranda, entre muitos outros (INSTITUTO COLIBRI, 2012).

Somadas à experiência de campo, tais constatações demonstram a proximidade epistemológica entre fandango caiçara e ciranda caiçara, sentido que se afasta diametralmente das cirandas amazonenses, pernambucanas e paraibanas ou do sarandi goiano, inclusive na instrumentação e no formato dos folguedos, tendo em vista, por exemplo, que em Tefé, no Amazonas, converte-se em auto cênico.

Na contracapa do disco Ciranda de Paraty, ${ }^{122}$ gravado no Museu de Folclore da CDFB em 6 de dezembro de 1975, Maria de Cássia Nascimento Frade nos mostra similaridades tanto funcionais como na denominação das marcas:

Em Tarituba, $2^{\circ}$ distrito de Paraty, o baile, denominado Ciranda e funcionando como animação para as noites monótonas de uma aldeia de pescadores, obedece a um pequeno esquema: a abertura dada pela ChibaCateretê; as danças de figurações variadas denominadas "miudezas" - CanaVerde, Caranguejo, Marrafa, Flor do Mar, Canoa, Ciranda, Limão, Arara, Chapéu, Cabôco Véio, Zombador, Namorador, Mariquita, Choradinha, Despedida de Amor - e o "fecho" ou encerramento feito com a roda da tonta (grifos nossos).

Nesse documento, podemos observar a função determinada de cada marca durante o baile, como no caso da Chiba-Cateretê como abertura (marca batida), análoga ao Anu (marca batida), que tem a mesma função no fandango paranaense, assim como a Tonta, que figura como marca de encerramento de um baile, fato corroborado por detentores e folcloristas tanto no estado de São Paulo como no Paraná. ${ }^{123}$

Há outra constatação de cunho fonográfico na produção fandangueira contemporânea, tanto na ciranda executada pelo grupo Os Sete Unidos da Ilha das Cobras quanto na faixa 4 do disco Pixé de Manema, gravado em Iguape (SP) em 2011, em que figura a moda Cirindi, cuja cabeça de verso, qual jézel, denuncia os traços ibero-alandaluzes de sua descendência, cuja hibridação está imersa em aspectos musicais marcantes no território caiçara.

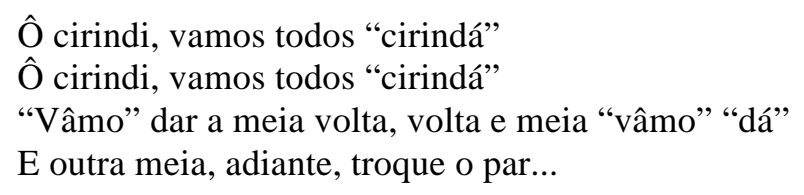

\footnotetext{
${ }^{122}$ Documentário Sonoro do Folclore Brasileiro no. 11 (ALENCAR PINTO e CORDOVA, 1975).

${ }^{123}$ Encontramos também menção ao "recortado" (colagem de diversas modas combinadas) como variante para encerrar a noite. (MUNIZ, 2017)
} 
Cirindi

Grupo Manema

.$=142$

Domínio Público

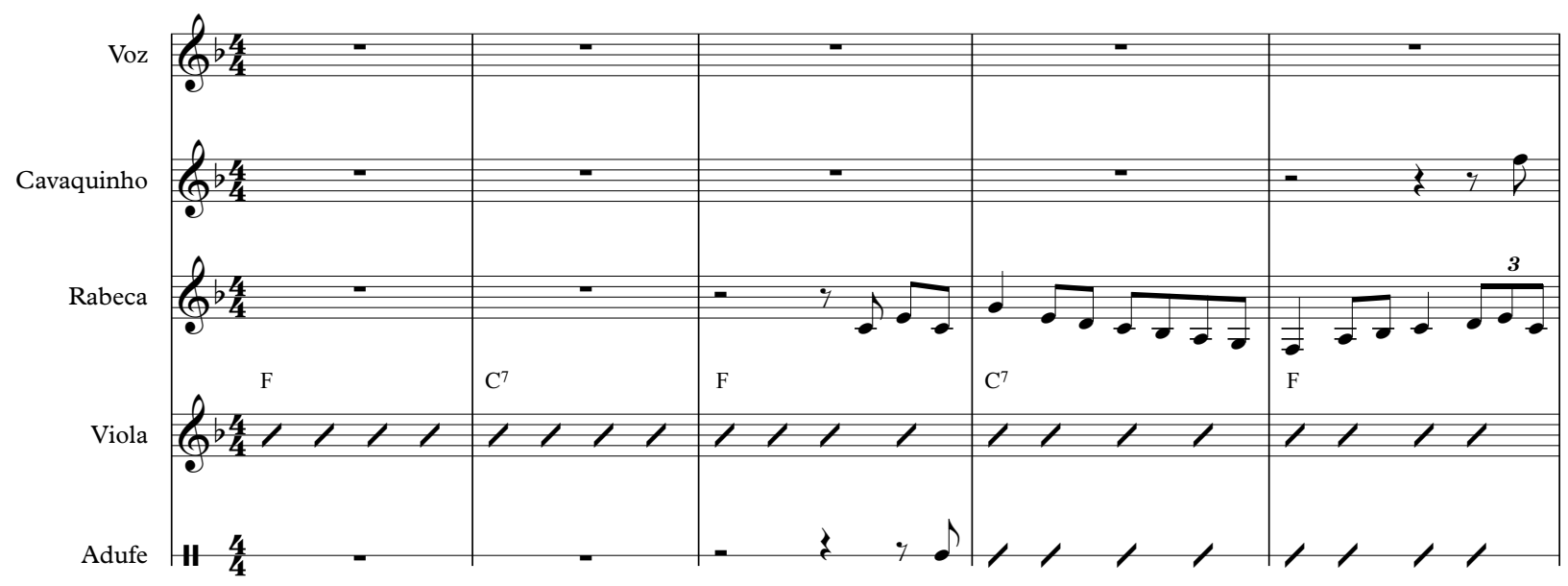

C.

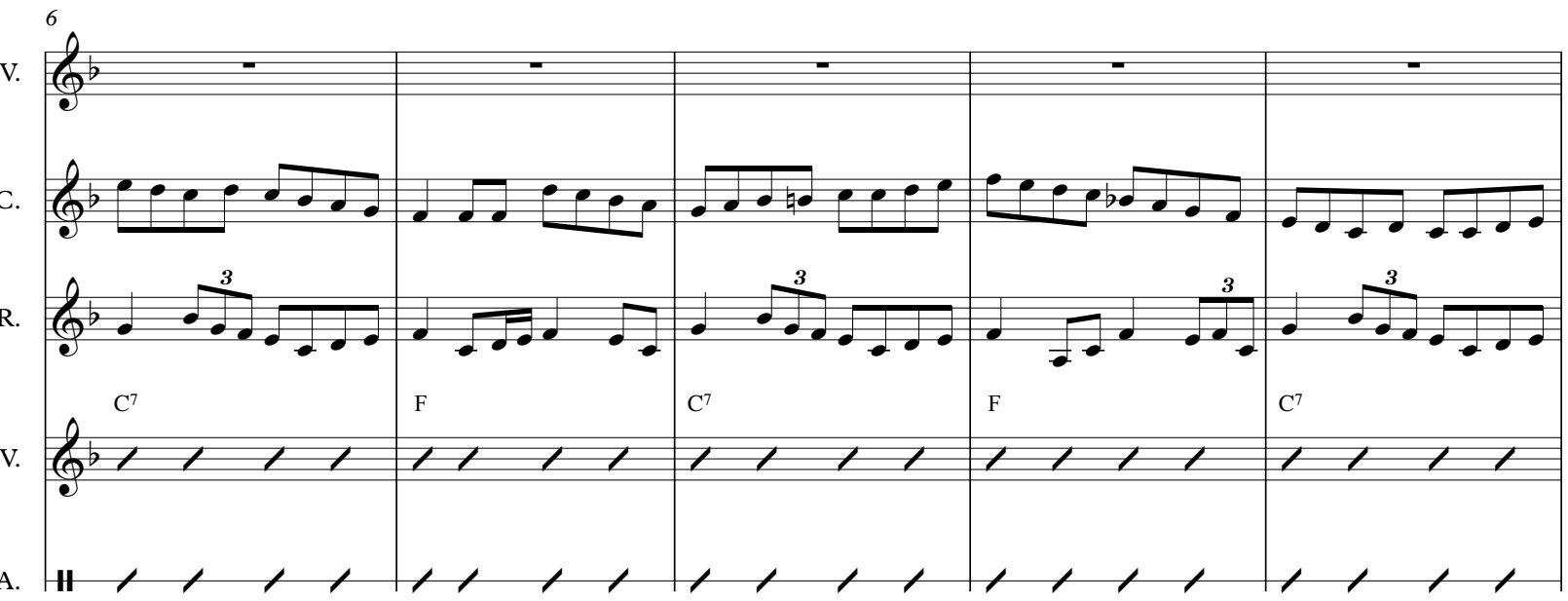

C.

R.

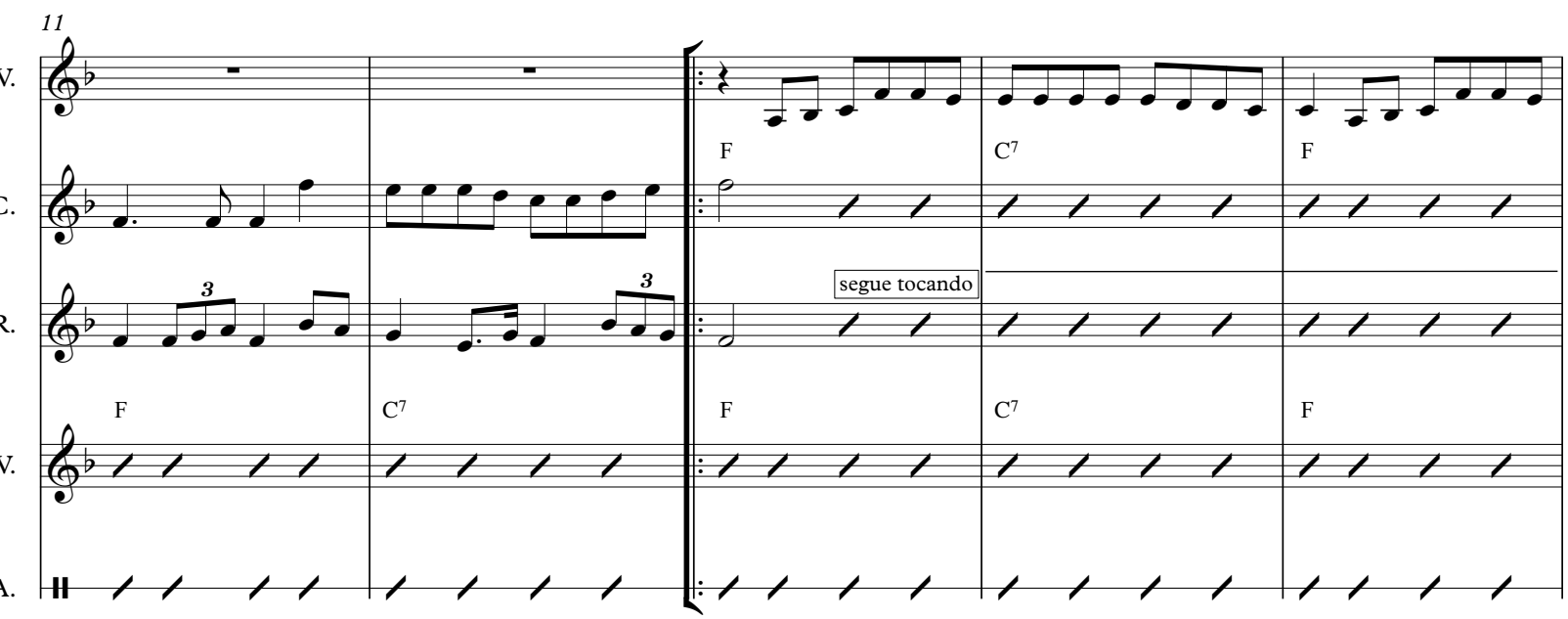

Figura 6.1A - Partitura da moda Cirindi - grupo Manema (Iguape/Peruíbe-SP)

246 
2

Cirindi
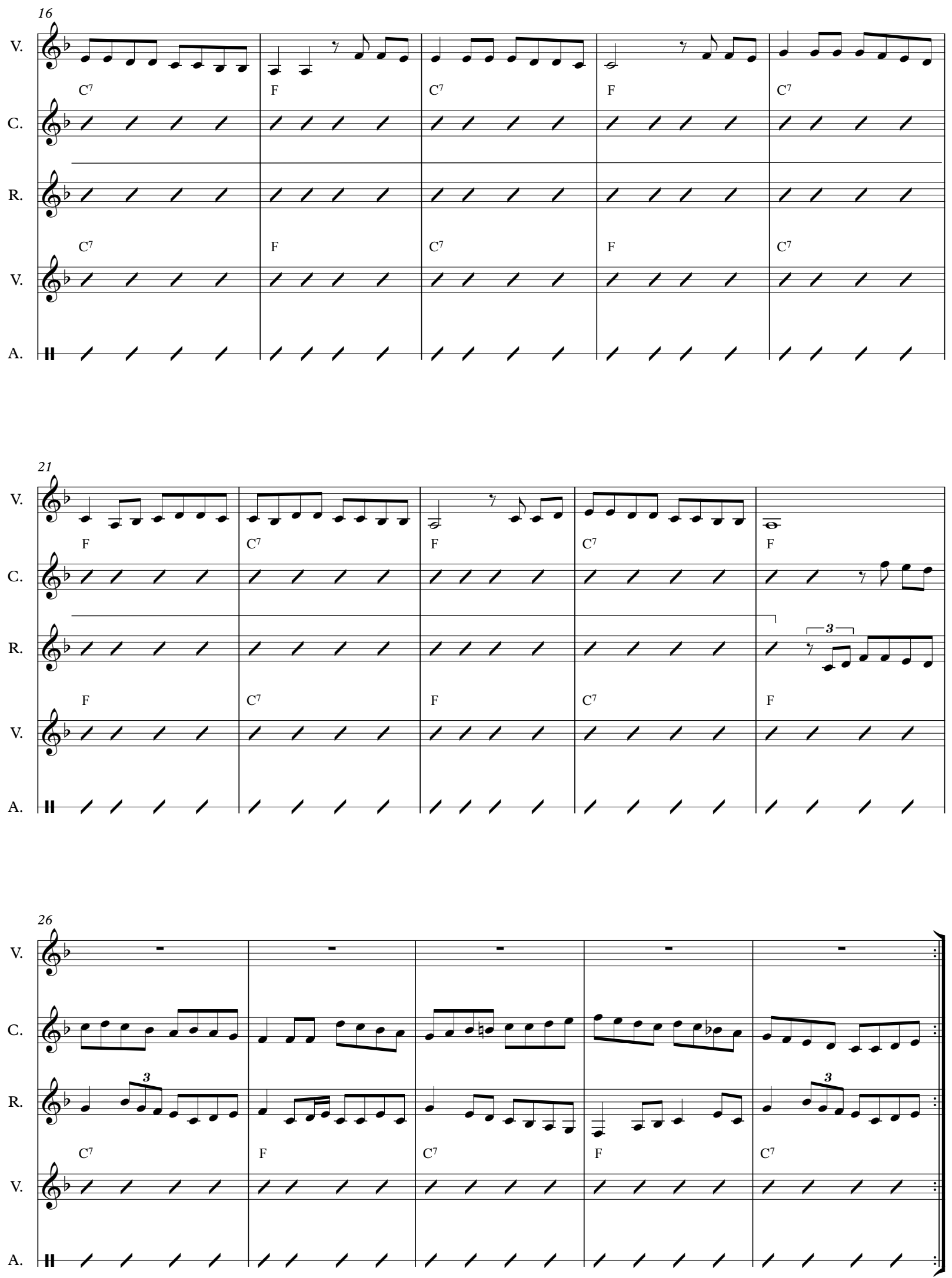

Figura 6.1B - Partitura da moda Cirindi - grupo Manema (Iguape/Peruíbe-SP)

247 
Ciranda

Grupo Os Sete Unidos da Ilha das Cobras

.$=130$

Domínio Público
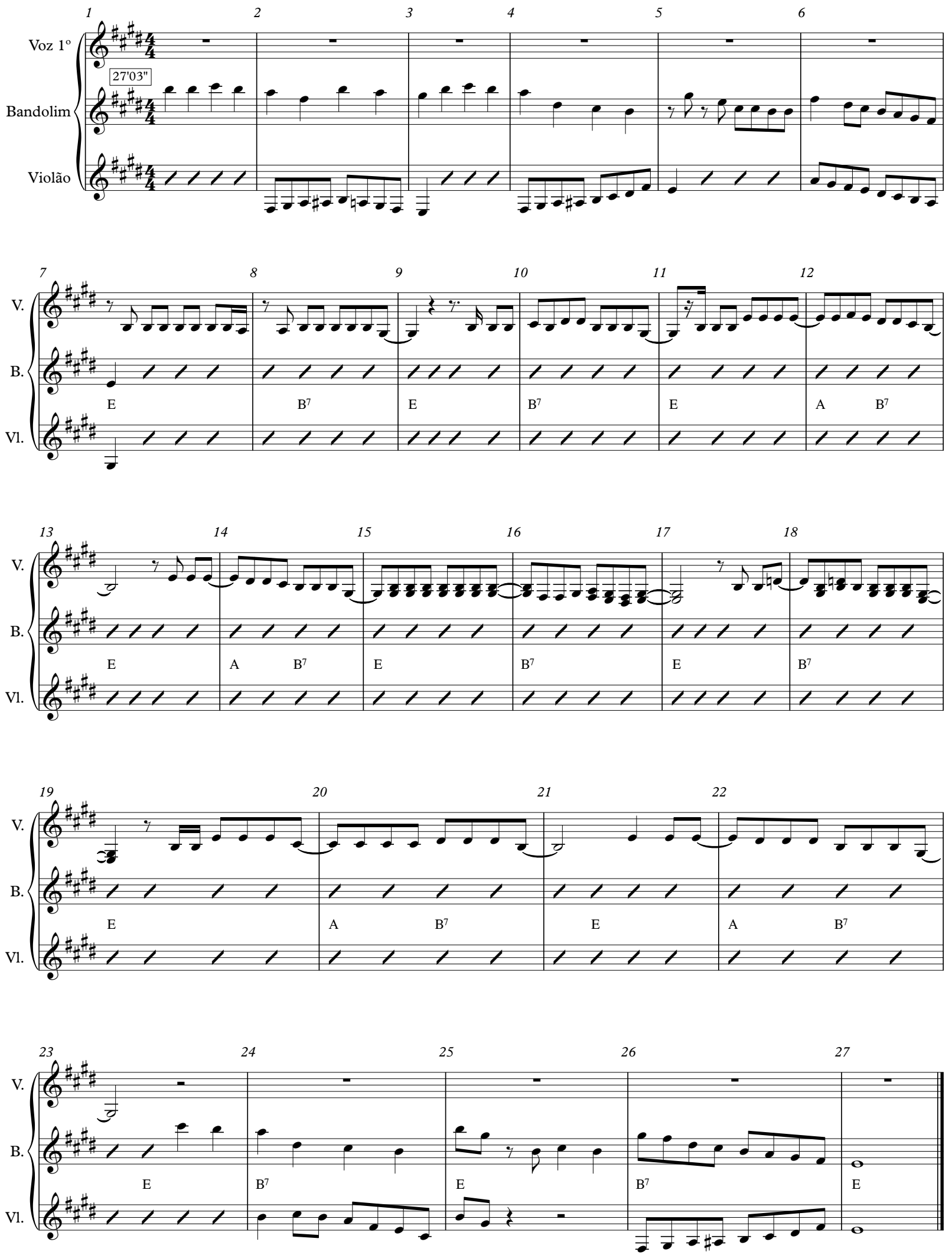

Figura 6.2 - Partitura da moda Ciranda - grupo Os Sete Unidos da Ilha das Cobras (Paraty-RJ)

248 
Essas conclusões não são novas. Já em 1954, Câmara Cascudo aventou o modo intrínseco como se inter-relacionam os folguedos descrevendo o verbete ciranda como "Samba rural no estado do Rio de Janeiro (Parati) [sic.] e também dança paulista de adultos, terminando o baile rural do fandango, em rodas concêntricas, homens por dentro e mulheres por fora" (CÂMARA CASCUDO, [s.d.], p. 285). Note-se ainda que, no verbete cirandinha, o autor indica "ver fandango".

$\mathrm{Na}$ ciranda, a parte da síntese epistemológica, uma das peculiaridades organológicas, além de violas, adufos, rabecas e mancados, ${ }^{124}$ tem bandolins, cavaquinhos e violões, fato que a aproxima dos conjuntos instrumentais de choro, cujos regionais foram fundamentais no desenvolvimento da indústria fonográfica brasileira, inclusive no universo caipira.

Posteriormente às primeiras gravações de Cornélio [Pires], as gravadoras passaram a exigir um padrão de interpretação que muitas vezes fugia do querer caipira por não fazer parte de seu campo de interesse. É o caso da limpeza sonora ao tocar [...]. Músicos da cidade muitas vezes passaram a ocupar esse espaço trazendo ao ambiente da música dos caipiras uma sonoridade já existente nos discos de choro e samba. Foi o caso de Raul Torres, antes cantor de emboladas nordestinas. Algumas de suas gravações com Florêncio têm como base instrumental o regional de choro por vezes acrescido de violinos, tuba e triângulo. [...] Nesse período [primeira fase], que vai até o início dos anos 1940, a sonoridade presente nos discos não é somente a de violão e viola. Aí encontramos a base instrumental da já pulsante música popular brasileira, que é a do choro. [...] O choro, tal como emprestara ao samba sua base instrumental, cede também, como "padrão sonoro brasileiro no disco" na época, sua sonoridade a algumas das primeiras gravações de música caipira. (VILELA, 2013, p. 100)

O universo da música caipira também influencia a musicalidade caiçara. Aproximandonos do pessoal de Iguape e de Peruíbe, percebemos outra vertente, mais próxima do caipira da paulistânia ${ }^{125}$ que do chorão ou do sambista carioca. Esse apontamento vem das atividades junto a grupos fandangueiros de Iguape, marcadamente dos integrantes do grupo Manema e dos fandangueiros do grupo formado pela associação Jovens da Jureia. O Manema conta com músicos de Iguape e de Peruíbe, todos com larga experiência para além do universo caiçara, por transitar em ambientes profissionais como bares, bandas de música sertaneja ou ainda rodas de samba.

\footnotetext{
${ }^{124}$ Caixote de madeira percutido por cepas de madeira (tamancos).

${ }^{125}$ Antonio Candido (1998) chamou paulistânia todo o eixo de expansão e difusão da cultura bandeirante, que engloba São Paulo, Goiás, Mato Grosso do Sul, o norte do Paraná, parte de Tocantins, parte do Mato Grosso e regiões como o sul de Minas e o Triângulo Mineiro, tendo na sonoridade da viola e nos toques do cururu e da catira (ou cateretê) suas principais vertentes de musicalidade.
} 
Experiências importantes para o argumento são a participação dos músicos em eventos do calendário fandangueiro como as festas do fandango de Paranaguá, Cananéia, Ubatuba e Iguape e as festas religiosas como a do Divino Espírito Santo, de Santo Antônio e de São Gonçalo.

Quando compareciam a esses eventos, os integrantes do Manema, durante a preparação para os bailes, sempre demonstraram dominar um vasto repertório de música sertaneja, desde a dita cultura caipira de raiz até o sertanejo romântico. Tocando quase ininterruptamente, fazem violadas e mesclam diferentes vertentes do repertório clássico de modas de viola: Zé Fortuna e Pitangueira, Lourenço e Lourival, Jacó e Jacozinho, Tonico e Tinoco, Vadico e Vidoco, Zico e Zeca, Liu e Léo, entre outros.

Outra peculiaridade do Prelado (Iguape) que notei em junho de 2017 foi a inclusão de repertório sertanejo/caipira nos fins de baile, tocado como fandango nos momentos que antecedem a alvorada, conformação estética sem precedentes no estado do Paraná.

Essas experiências apontam a influência das primeiras fases da música caipira nesses coletivos, aspectos escrutinados por Ivan Vilela ao discorrer sobre o desenvolvimento do gênero na discografia brasileira.

Segundo o autor, o ímpeto empreendedor de Cornélio Pires teve grande impacto na difusão da música caipira no estado de São Paulo e no Brasil: "Desde sua primeira aparição em público em 1910, Cornélio Pires passou a realizar o que foi chamado na época de 'Conferências Humorísticas"” (VILELA, 2013, p. 93). Vilela relata a trajetória desse caipira do Tietê, entusiasta da música e dos "causos" caipiras que acabou por ingressar no mercado fonográfico bancando do próprio bolso a gravação e a prensagem de mais de 25 mil discos, ${ }^{126}$ vendidos de mão em mão no interior de São Paulo. Contra o pessimismo do representante da Columbia do Brasil, Wallace Downey, os discos foram vendidos rapidamente, tornando-se sucessos e gerando pedidos para uma segunda tiragem.

O desastre comercial que Byington Jr.[contato de Cornélio Pires na Columbia do Brasil] esperava não ocorreu. Ao contrário. Cornélio Pires saiu em dois carros na direção de Bauru, fazendo do automóvel de trás uma verdadeira discoteca, tendo por intenção, antes, parar em Jaú. Ao chegar a essa cidade, todavia, já tinha vendido os vinte e cinco [trinta] mil discos que transportava consigo! Teve que telegrafar para Byington e pedir-lhe uma nova prensagem a ser distribuída em Bauru (FERRETE ${ }^{127}$ apud VILELA, 2013, p. 95).

\footnotetext{
${ }^{126}$ Outros autores indicam uma imprecisão no número de cópias prensadas na primeira tiragem e falam em até 30 mil.

${ }^{127}$ FERRETE, L. J. Capitão Furtado: viola caipira ou sertaneja? Rio de Janeiro: Funarte/Instituto Nacional de Música/Divisão de Música Popular, 1985.
} 
Na segunda fase, "uma constelação de duplas se formou no mercado. Aqui o filão se consagrou como um campeão de vendas. Cascatinha e Inhana, em 1951, venderam aproximadamente 2,5 milhões de cópias com a gravação de 'Índia'” (VILELA, 2005, p. 105). Nesse sentido, Vilella atenta para a aproximação entre o cantar caipira, a música caipira e o etnotexto, em que, além de se estabelecer como produto de entretenimento, a música ligada a essas populações agrega narrativas de sua sociabilidade, no contraste urbano versus rural e na estratificação dessa sociabilidade.

Não havendo movimentos dessa magnitude no território paranaense, o fandango e seus artífices apresentam modos peculiares de manter a manifestação, sem uma interação tão incisiva com outros universos musicais e artísticos no que tange à produção fonográfica e à indústria dos instrumentos musicais produzidos em série. É a partir da consolidação das redes fandangueiras nas últimas décadas que se percebem mudanças paramétricas no desenvolvimento posterior deste bem cultural em território paranaense.

A gente tá acostumado com este fandango daqui. E já é diferente lá do pessoal de Cananéia, de Iguape, que tem lugares que nem batem mais o tamanco: é só a violada, rabeca. E o tipo de toque também você percebe muito. [...] Até alguns anos atrás, eu achava que os fandangueiros só estavam por aqui, né? Foi até uma felicidade descobrir, depois que aquela coisa do Caburé, de fazer o Museu Vivo do Fandango, descobriu vários outros grupos e construtores de Cananéia e Iguape. Isso deixou a gente muito feliz (Poro de Jesus) (TRÂNSITOS CAIÇARAS, 2017, 27'46” - 28'40” - transcrição nossa).

Entusiastas e detentores das manifestações culturais caiçaras não medem esforços para manter viva a tradição fandangueira. Fortaleceu-se a rede de atores no litoral caiçara pelas políticas públicas da primeira década do milênio, conjugando anseios pessoais, modos alternativos de subsistência e a manutenção dos folguedos mencionados. Além de Aorélio Domingues e Cleiton do Prado, podemos citar alguns jovens fandangueiros que vêm tomando protagonismo na cena cultural caiçara: Leandro Diegues e José Muniz em Guaraqueçaba, Rodolfo Vidal em Cananéia, Mario Gato e Ostinho Garcez em Ubatuba e Fernando e Marcelo Alcântara em Paraty, no Rio de Janeiro. Todos esses jovens atores têm dedicado exaustivamente seu tempo e sua produção artística e intelectual ao Fandango, ao Chiba e à Ciranda Caiçara.

\section{LÂMINA 12}

Set de gravação do disco Amanhece, Curitiba, 2017

Fonte: Acervo Pessoal 


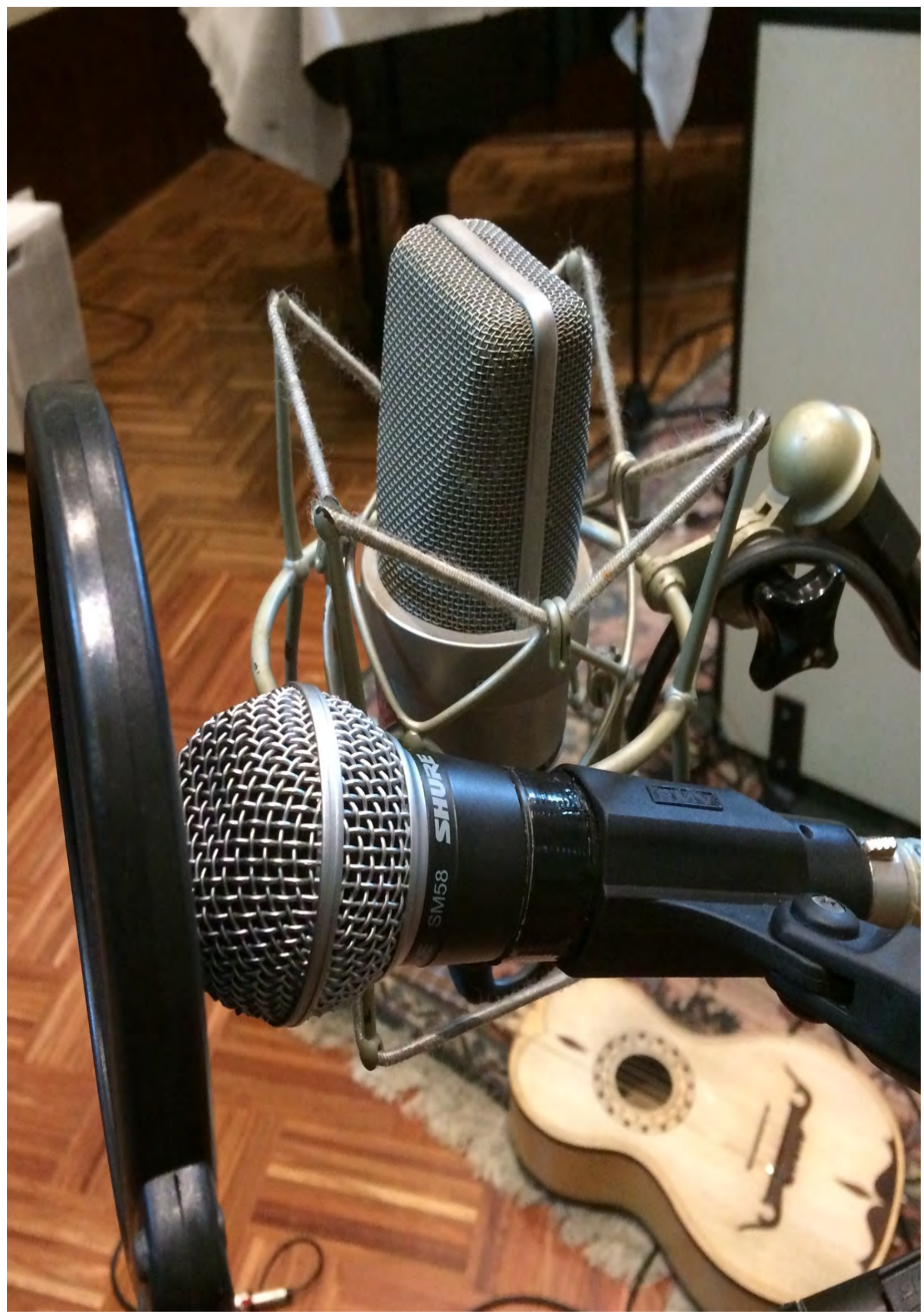




\section{Atenção: gravando!}

Em fevereiro de 2017, iniciei nova empreitada no universo caiçara, quando pude contribuir como produtor musical na gravação do disco Amanhece - Fandango Pancada. Iniciativa financiada pela Lei Municipal de Incentivo à Cultura de Curitiba, o disco traz a parceria de Aorélio Domingues e Cleiton do Prado. ${ }^{128}$ Mescla sonoramente influências do fandango paulista (como os ponteios de machete e os andamentos mais acelerados das marcas) e o caráter de protesto intrínseco a boa parte das composições que resultaram dessa parceria. A novidade materializada nas linhas melódicas do baixo elétrico (que acompanha a formação instrumental caiçara em todas as marcas bailadas que compõem o disco) reverbera os anseios de inovação e da recepção por novos públicos, com vistas às gerações mais jovens.

$\mathrm{O}$ ativismo político também tem espaço na proposta que retoma afinidades históricas visando a produção, divulgação e difusão da cultura caiçara.

O Fandango do litoral paulista é o que mais se afina com o Fandango paranaense. Autores paulistas fazem constantes referências ao Fandango do Paraná, citando que nossos caboclos iriam até as cidades e povoados do vizinho estado, nas romarias, para baterem o Fandango. Alceu Maynard Araújo escreve que, na afinação da viola, só os antigos gostavam de usar o ponteado do Paraná e que deixaram de usar porque era muito difícil de temperar. Essa e outras referências são evidências da interligação das danças do Fandango do litoral de São Paulo e do Paraná (RODERJAN, 1981, p. 30).

Tanto para Roderjan (1981, p. 30) como para os demais folcloristas paranaenses daquela época, articulados com a Comissão Nacional de Folclore, percebe-se que "há um interesse em preservar a delimitação de sua área específica de estudos", cujo foco é demarcado pelo fato folclórico.

"Conforme a perspectiva de Roderjan, o fandango do Paraná não se funde, entretanto, com o fandango paulista; estão no máximo correlacionados, como se a divisa entre os estados fosse algo concreto que demarcasse tradições distintas.” (CORRÊA, 2016, p. 426) Embora os folcloristas do Paraná tenham institucionalizado esse campo no estado articulados com a

\footnotetext{
${ }^{128}$ Violeiro, fandangueiro e luthier, vive no município de Iguape-SP e já há alguns anos vem desenvolvendo parceria artística e institucional com Aorélio Domingues, seja pelos laços de amizade e compadrio, seja pela inclinação associativista. Integra o grupo Manema e a Associação Jovens da Jureia, coletivo de detentores, agentes e mediadores culturais que atua no universo caiçara, sobretudo no litoral paulista.
} 
Comissão Nacional de Folclore e com um cenário intelectual e cultural mais amplo, percebemos que, naquele momento histórico, havia o já mencionado interesse em preservar a delimitação geopolítica de sua área específica de estudos. (ibid., p. 426)

Esses apontamentos nos afastam dos fluxos reais de comunicação estabelecidos por essas populações desde o período colonial, assim como da realidade hodierna. A difusão e divulgação do disco lançado em agosto de 2017 vem sendo percebida nas últimas atividades de campo: grupos de Iguape, Ubatuba e Paraty têm tocado modas do disco, assim como outros de Paranaguá, Guaraqueçaba e Superagui. Novamente, a transmissão e difusão não são uma via de mão única: a interação e o fortalecimento das redes têm possibilitado trocas de experiências entre as diversas localidades caiçara. "Seu” Nemésio, do grupo Pés de Ouro (Paranaguá), vinha ampliado seu repertório com músicas do Manema, e, no Mandicuera, temos tocado cirandas paratyanas durante violadas na sede da associação. Os fluxos de interação têm sido efervescentes.

Além das deliberações de engajamento e ativismo político, os encontros e as redes virtuais vêm intensificando também as trocas artísticas, parcerias em composições, técnicas de construção, uso de novas tecnologias e circulação de informações variadas.

Da experiência como produtor musical, passei a integrar o grupo Mandicuera, no qual tenho atuado como instrumentista e técnico de som (na medida do possível, combinando as duas funções em bailes e outras apresentações). O cotidiano do grupo é intenso: bailes no mercado do café, festas locais em Paranaguá, Guaraqueçaba, Cananéia, Iguape, Peruíbe e Ubatuba, espetáculos pelo interior do Paraná financiados pela Secretaria de Estado da Cultura ou integrando a orquestra Rabecônica do Brasil, projeto idealizado por Aorélio Domingues com a finalidade de recrutar tocadores e organizar didaticamente e por escrito as nuances do fandango caiçara, da folia do Divino, da dança do pau de fitas e do auto do Boi de Mamão.

O disco Amanhece foi gravado num estúdio considerado referência de qualidade, diferentemente da experiência que tive ao colaborar voluntariamente com os grupos de fandango de Paranaguá na gravação do disco Fandango - A Arte e Expressão Popular, quando questões básicas, como reguladores de tensão e descuido com os backups, acabaram pondo a perder dias de edição, ficando o resultado aquém do trabalho despendido. No último caso, a situação fugiu da alçada de uma contribuição voluntária, sem autonomia efetiva no processo.

Sabemos que hoje podemos "tirar leite de pedra" mesmo em estúdios caseiros. Com alguma sensibilidade, podem-se criar bons materiais de áudio a baixo custo; por outro lado, boas salas e bons equipamentos ajudam sobremaneira a alcançar melhores resultados. 
Figura 6.3 - Zeca Martins e Aorélio Domingues em sessão de gravação do disco Amanhece

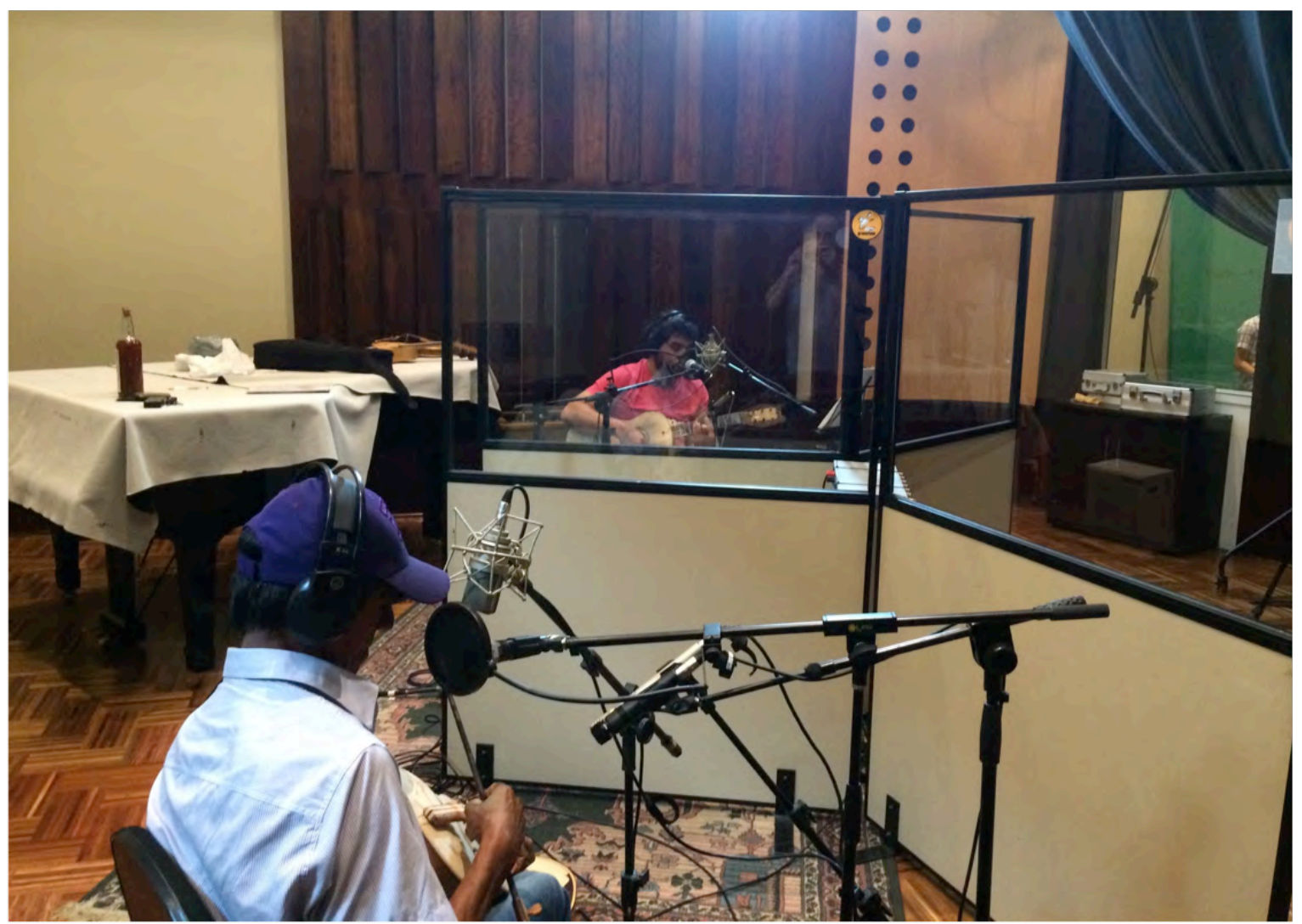

Fonte: Acervo pessoal

A captação foi um dos primeiros desafios, tendo em vista a necessidade de que os fonogramas mostrassem a vivacidade do bem imaterial, problema que havia enfrentado em 2006, na primeira experiência de gravar fandango em estúdio, quando assumi a produção musical do disco que acompanhava o material didático do projeto Fandango na Escola. Optei por gravar ao vivo violas, vozes, caixa, adufo, baixo e tamancos, sem o uso de metrônomo. ${ }^{129}$ O mais difícil foi captar as vozes tocadas ao mesmo tempo que as violas e a rabeca. Na sala principal de gravação, posicionei divisórias acústicas, mantendo as vozes juntas e com contato visual, fundamental para as entradas e nuances próprias das modas. Ora Aorélio e Cleiton (viola e viola), ora Aorélio e Zeca (viola e rabeca), os demais integrantes do conjunto instrumental usaram outras salas (o estúdio tinha três, além da principal).

\footnotetext{
${ }^{129}$ Mostrar as mudanças de andamento inerentes à performance ao vivo foi uma das questões que levaram a essa escolha. Nas modas batidas, por exemplo, a aceleração do beat é proposta pelos interlúdios de tamanqueado; já nas modas bailadas, a aceleração do andamento é orgânica, e o grupo convencionou acelerá-lo nos últimos versos para que, como nos bailes, a audiência se entusiasmasse com a expectativa de uma nova moda.
} 
Figura 6.4 - Jairo de Souza na capa do disco Amanhece

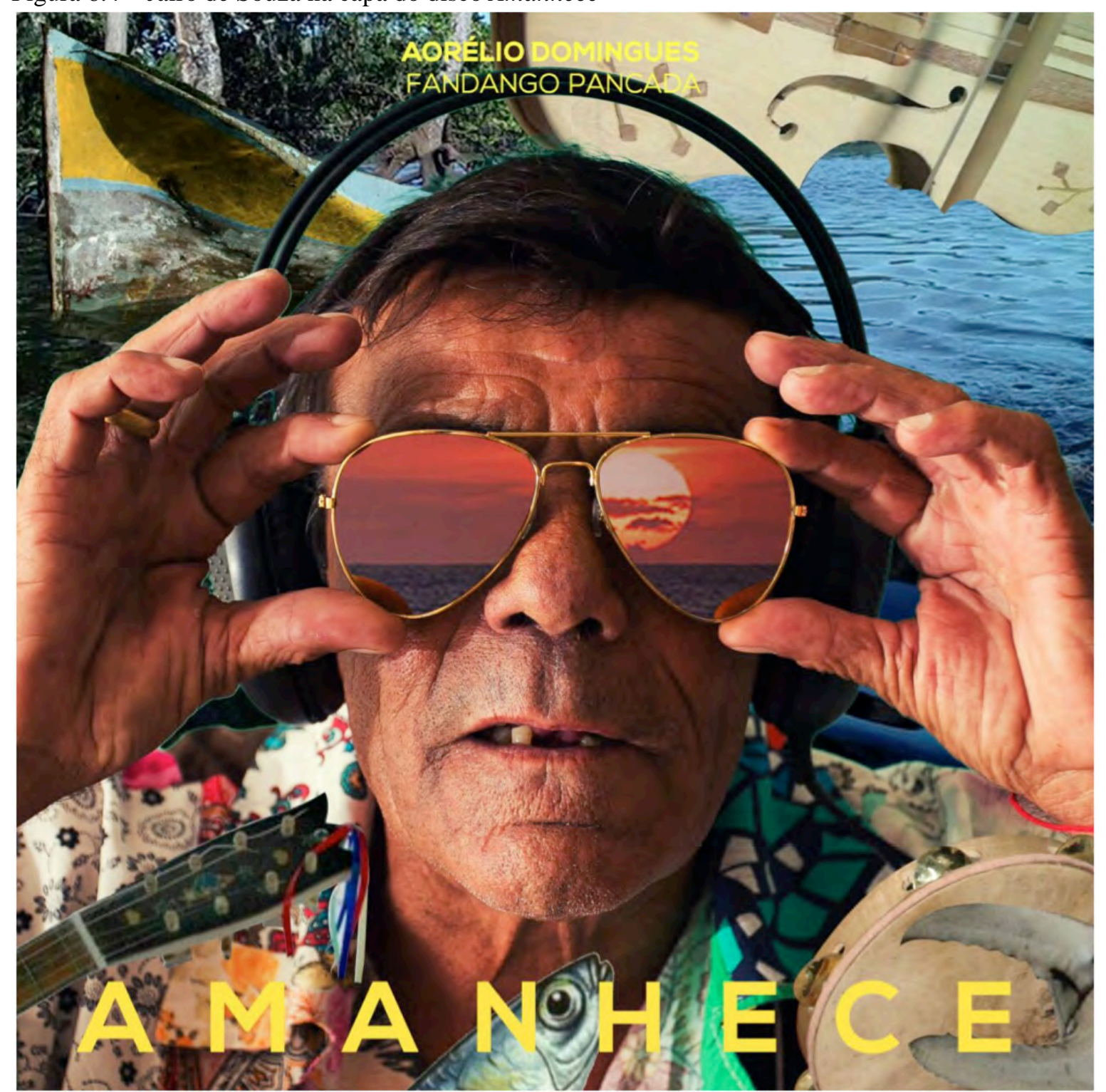

Fonte: Design gráfico de Gladson Targa

A oportunidade de isolar e captar com precisão os instrumentos e as vozes é pouco usual no registro discográfico do fandango, em geral produzido com fins etnográficos, sem a preocupação de atender às exigências da indústria fonográfica.

Ponto pacífico foi a necessidade de evidenciar as sonoridades graves. 


\section{Fandango Pancada, loudness e compressão}

O resultado dos fonogramas presentes em discos como Amanhece (Mandicuera) e Pixé de Manema (Manema) revela preocupações que dialogam com os modelos de produção da indústria fonográfica, inclusive com o conceito de loudness war, debate que toma forma no início do século e cujo desfecho incide no modo como as grandes empresas de streaming vêm delimitando nos últimos anos a intensidade dos fonogramas que suas plataformas disponibilizam ao público.

A evidência das frequências graves e a compressão visando maiores amplitudes sonoras dizem respeito tanto a práticas já balizadas no mercado fonográfico quanto ao "gosto" estético das localidades caiçaras. Ponto de interesse observado em campo foi a maneira como a juventude regula seus equipamentos de som em lugares como a Barra do Ararapira (PR) e o Pontal de Leste (SP), sempre com os potenciômetros de graves na capacidade máxima, "tochados no úrtimo". A ideia de evidenciar os graves atende a esses jovens que costumam ouvir funk, pop e outros gêneros em que estas frequências têm papel fundamental na massa sonora masterizada. A preocupação de que o fandango se apresente com uma massa sonora mais encorpada indica que modelos mais conservadores, em que se evidenciam as frequências médio-agudas, próprias de violas, rabecas, adufes e machetes, vêm sendo positivamente revistos.

A experiência de masterização do disco Amanhece foi surpreendente. Finalizados o processo de gravação e as edições preliminares, pusemo-nos em romaria, acompanhando a peregrinação da Bandeira do Divino pelo litoral paranaense e paulista. Durante a peregrinação, recebia os áudios pelo celular e ouvia as faixas premasterizadas nos mais diversos equipamentos disponíveis. A experiência pareceu produtiva, tendo em vista que o principal público do disco seriam justamente os moradores das localidades caiçaras. Às vezes, ao conectar o cabeamento, tivemos experiências frustrantes, percebendo a ineficácia de certos dispositivos, como no caso de uma audição que fizemos em Pontal de Leste (SP). Até perceber que as ligações do equipamento estavam erradas, gerando ruídos e distorcendo as frequências graves e subgraves, fiquei tenso, imaginando que poderia se tratar de um erro de masterização. Como um som com uma captação de tamanha qualidade podia se converter em ruídos desagradáveis (típicos de alto falantes "rachados")? A necessidade de se ouvir o bufo e de que fossem inteligíveis as linhas 
de baixo (acústico e elétrico) foram pontos discutidos à exaustão com Frederico Teixeira, responsável pela masterização do disco, cujas impressões tardias do processo se converteram em profícuo "dedo de prosa", do qual transcrevo aqui seu mais relevante fragmento. Profissional irretocável, fundamental na finalização do álbum, "Fred" nos traz comentários que contribuem substancialmente com as questões em debate:

Deixa eu ver do que me lembro agora; já faz dois anos, pelo menos. Já não está tão fresco na minha mente todo o processo. É disco atrás de disco, né?

Lembro um pouco que a gente teve a preocupação de fazer o disco soar pop, e não ser um registro fonográfico tradicionalista, com esse viés etnográfico. Lembro que a ideia era fazer um disco que competisse também com outras coisas que tocam no rádio, por exemplo. Lembro, não sei se foi você ou o Aorélio, comentando a questão dos festivais: quando iam tocar em festivais e tocava uma banda de rock, com espectro de som bem definido, e depois entrava o fandango e tinha uma pressão [sonora] muito menor. Lembro que havia essa preocupação durante o processo de finalização desse álbum. $O$ que determina um viés mais pop num disco? Na minha opinião, toda essa preocupação que existe na música clássica e no jazz, de haver uma reprodução fidedigna dos elementos, cai por terra. Então, hoje em dia, a música pop e o rock têm coisas que não soam como soariam acusticamente - é aquela coisa de realidade aumentada. Um professor meu no mestrado [Simon ZagorskiThomas] tinha uma teoria bem interessante: sonic cartoons, ${ }^{130}$ aquela coisa de pegar algo e deformar ou ampliar, deixar aquilo caricato. Na verdade, isso é prática comum no gênero pop. Lembro que a gente teve essa preocupação com o disco de fandango: deixar mais pop. E como que se faz isso? Que ferramentas se usam? No geral, você aplica a compressão de uma forma mais agressiva, pra limitar mais a dinâmica dos instrumentos. Quando um disco tem o objetivo de ser fidedigno, no jazz, na música clássica, você deixa a

\footnotetext{
130 "Numa abordagem ecológica da percepção, a teoria neural da linguagem e metáfora e cognição incorporadas usa a noção de Gibson de propriedades invariantes e affordances. Isso é baseado na ideia de que as estruturas de conhecimento da mente são fundadas na reencenação ou na simulação da experiência perceptiva e de que as expectativas (as affordances potenciais) de qualquer conjunto de experiências são destiladas até um dado conjunto de características - propriedades invariantes. Assim, por exemplo, minha experiência de som em diferentes tipos de espaço físico conectou um conjunto de propriedades invariantes como tempo de reverberação, pré-delay e acúmulo de frequências graves com affordances como potenciais perceptivos visuais e de movimento em espaços de tamanhos diferentes. Essas conexões terão associações culturais e emocionais, bem como as associações mais universais que se relacionam com a fisiologia do ser humano num ambiente semelhante à terra. Portanto, embora todos possamos reconhecer o som de um grande recinto com paredes de pedra, alguns de nós podemos fazer conexões culturais com igrejas e outros não - e cada um terá um conjunto diferente de possibilidades emocionais e affordances experienciais que nos sugerem significados" (BOURBON ZAGORSKI-THOMAS, 2016, p. 1).

No original: "Using the ecological approach to perception, the neural theory of language and metaphor and embodied cognition, this theoretical model utilizes Gibson's notion of invariant properties and affordances. This is based on the idea that the knowledge structures of the mind are founded on the re-enactment or simulation of perceptual experience and that expectations (the potential affordances) of any given set of experiences become distilled down to a given feature set - the invariant properties. Thus, for example, my experience of sound in different types of physical space has connected a set of invariant properties such as reverberation time, pre-delay and the accumulation of bass frequencies with affordances such as potential visual perception and movement in different sized spaces. These connections will have cultural and emotional associations as well as the more universal associations that relate to the physiology of being a human in an earth-like environment. So, while we are all likely to be able to recognize the sound of a large stone-walled enclosure, some of us may make cultural connections to churches and others may not - and each of us will have a different set of emotional and experiential affordances that suggest meaning to us".
} 
dinâmica bem livre, bem solta, pra reproduzir o que o músico fez. No caso do pop e desse disco, a gente pode ser mais agressivo ao usar essas ferramentas. Equalização também, a mesma coisa. Permite um uso mais agressivo de equalizadores.

Do ponto de vista musical, teve a entrada do baixo, que foi uma decisão de produção, mas que também representa essa preocupação e esse viés.

Sobre a discussão do loudness war: o que foi a loudness war? Todo mundo queria que seu disco soasse mais que o outro. Por quê? Nosso cérebro percebe uma coisa mais alta como sendo melhor, sempre. É psicoacústica! Então, todo mundo: “- Quero que soe mais alto, quero que soe mais alto!" Só que existe um limite físico e digital de quão alto pode ser. E, se você quer deixar alguma coisa excessivamente alta, tem que abusar mais desses compressores e limiters e precisa tirar mais as frequências graves. As coisas começam a ficar mais médias, que é a região onde a gente tem mais sensibilidade no ouvido: quanto mais médio, mais alto a gente percebe. Se a gente tiver um som no mesmo volume, um grave e outro médio agudo, podemos estar medindo a mesma coisa com um decibelímetro, mas vamos ouvir a médio-aguda como mais alta, porque o nosso cérebro percebe essa região como mais alta. Teve essa discussão muito forte ali no início dos anos 2000, 2010, por aí e um pouco depois. Mas o que aconteceu? O streaming virou a principal plataforma de veiculação no mundo: Spotify, Apple Music, Deezer e outros. E, com o passar do tempo, essas plataformas começaram a padronizar o volume. Eles têm hoje padrões de volume médio, que variam um pouco, mas estão lá: Spotify é $14 \mathrm{~dB}$ (RMS/lufs), YouTube também é $-14 \mathrm{~dB}$, Apple Music é - $16 \mathrm{~dB}$, mais baixo ainda. Então, se eu fizer uma máster muito agressiva pra ter um volume maior e fizer um upload no Spotify, se minha máster estiver em $-8 \mathrm{~dB}$, eles vão baixar 6dB. Eu perdi características sônicas importantes pra deixar mais alto, e vai ser baixado pra soar no mesmo volume das outras. Essa questão do decréscimo foi muito importante e se refere a loudness war. Em 2017, quando a gente fez esse álbum, essa preocupação ainda não era tão grande. Geralmente, os projetos que a gente tem feito miram nesse patamar de $-14 \mathrm{db}$, às vezes, um pouco mais, $-12 \mathrm{~dB},-13 \mathrm{db}$, para se ter uma margem. Você não precisa ter um decréscimo tão grande na qualidade do som para atingir volumes maiores.

Com relação à instrumentação, uma instrumentação clássica de fandango é o quê? Tamanco, rabeca, viola, voz, adufo e caixa. Que elemento desses tem um grave profundo? O adufe talvez um pouco, a caixa de folia pode ser mais grave. Mas, no geral, são elementos que tendem ao médio. A rabeca, e mesmo o tamanco, quando você escuta acusticamente, é o estalo do tamanco batendo na madeira. Eu não participei da captação, mas na mix já vieram os microfones [separados]. Você teve a preocupação de colocar microfones com cápsulas largas, como se usa pra capturar bumbo, kick, outras coisas do gênero colocadas embaixo do tablado: já é essa coisa de sonic cartoons. Você pega uma coisa que não necessariamente "existe" ali e realça. Eu lembro especialmente da questão dos tamancos, do uso dos microfones para capturar o grave, e a gente poder usar esse grave na mixagem. Fora isso, o baixo também, que foi inserido como um elemento grave. Se você pensar numa formação tradicional de pop ou de rock, por exemplo, os instrumentos possibilitam capturar uma gama maior de frequências. Você tem o kick e o baixo, que vão ficar responsáveis pelas frequências graves e subgraves; tem as guitarras, que são responsáveis pelos médio-graves, médio-agudos e agudos. Queira ou não, você tem esse espectro todo preenchido por conta da instrumentação. No fandango, se você insere um baixo, aí sim, esse espectro é preenchido também na parte grave. Mas, sem o baixo, você tem menos presença dessas frequências. Eu acho que essa experimentação foi legal, no 
sentido de aproximar um pouco a música do fandango à música mais popular, mais pop.

É um quebra cabeça, yin/yang: você tira grave de uma master, também pode perceber isso como um acréscimo de médio e agudo e vice-versa. Nosso cérebro percebe muito assim: uma coisa que você faz vai afetar a percepção geral. Então, eu diria que, em parte por conta da retirada de grave que a gente deu - porque eu lembro que a gente trabalhou isso e teve um momento em que a gente disse: "- Vamos voltar um pouco atrás 'play safe', vamos estar mais seguros no uso dos graves e subgraves". Isso pode ter gerado a percepção de acréscimo nos médios. E a outra coisa é que boa parte dos elementos tem essas características e esse espectro médio, preenchem esse espectro médio: violas, voz, platinelas do adufo (um pouco), machete e rabeca. Essa somatória de várias coisas que ocupam a região média pode criar essa ênfase [que nos fez rever o projeto da master final].

É normal. (Eu faço um monte de discos.) É normal que eventualmente você tome uma decisão e avalie com o cliente: “- É isso, ou é quase isso. Então, vamos voltar tal coisa..." Pra mim, foi normal [retomar a master], parte do processo. Eu lembro que foi complicado por conta da viagem. Você estava viajando muito [acompanhando a romaria do Divino Espírito Santo], e ficava difícil a audição. Às vezes, é difícil até você confiar no sistema que está ouvindo. Quando a gente finaliza um material qualquer, sempre temos o cuidado de fazer com que a master se traduza da melhor forma possível em diversos tipos de som, inclusive os mais "toscos". Mas é óbvio que, quanto melhor o equipamento, melhor vai ser a audição. E tem coisas que as pessoas fazem, como você comentou [que o pessoal nas ilhas usa regulagens com os graves no máximo], mesmo aqueles sons que têm o botão loudness ${ }^{131}$

Qual foi a intenção ao criar aquele botão? Essa coisa que te falei de o nosso cérebro ouvir se chama curva de Fletcher e Munson, que é essa coisa de que nosso cérebro escuta volumes diferentes em frequências diferentes. Então, quando a gente está escutando alguma coisa mais baixa em volume, volume menos intenso, o nosso cérebro automaticamente vai dar por eminência a região média e fazer com que a gente escute menos a região grave e aguda. Quando a gente escuta alto [intensidade], é o inverso: as extremidades soam mais altas, e escutamos menos médio. E qual era o objetivo do botão de loudness nesses aparelhos? É um botão que dá ênfase no grave e no agudo. Exatamente quando estiver escutando uma coisa baixa [intensidade], você liga o loudness, e ele compensa essa perda natural psicoacústica. Acentuar o grave e o agudo extremos: assim, estaríamos ouvindo o som de uma forma mais linear. Mas muita gente deixa o som superalto e liga o loudness: então, além do reforço psicoacústico que a gente tem, o equipamento dá esse reforço. A gente tenta tomar as melhores decisões para fazer com que o som viaje da melhor forma possível para outros lugares. Mas não controlamos o modo como as pessoas vão ouvir, as condições e tudo o mais.

\footnotetext{
${ }^{131}$ Loudness é um construto psicológico subjetivo com uma relação não linear com a energia sonora gerada. O volume percebido de um som depende principalmente dos níveis de pressão sonora (SPL) e do conteúdo de frequência. As curvas de Fletcher-Munson mostradas são o resultado de um grande número de experimentos psicoacústicos nos quais indivíduos são submetidos a eventos de tons puros binaurais. As curvas representam as médias dos dados obtidos com um grande número de sujeitos (indivíduos de 18 a 25 anos com audição regular) para regular o volume percebido de frequências incrementalmente crescentes (TURNER; JOHN; PRETLOVE, 1991). O nível de pressão do controle de referência é $2 \times 10^{-5} \mathrm{~N} / \mathrm{m}^{2}$, o que corresponde ao ponto zero na escala de volume a $0 \mathrm{~dB}$ (INTERNATIONAL STANDARDS ORGANIZATION, 1975).
} 
Figura 6.5 - Curva de Fletcher e Munson

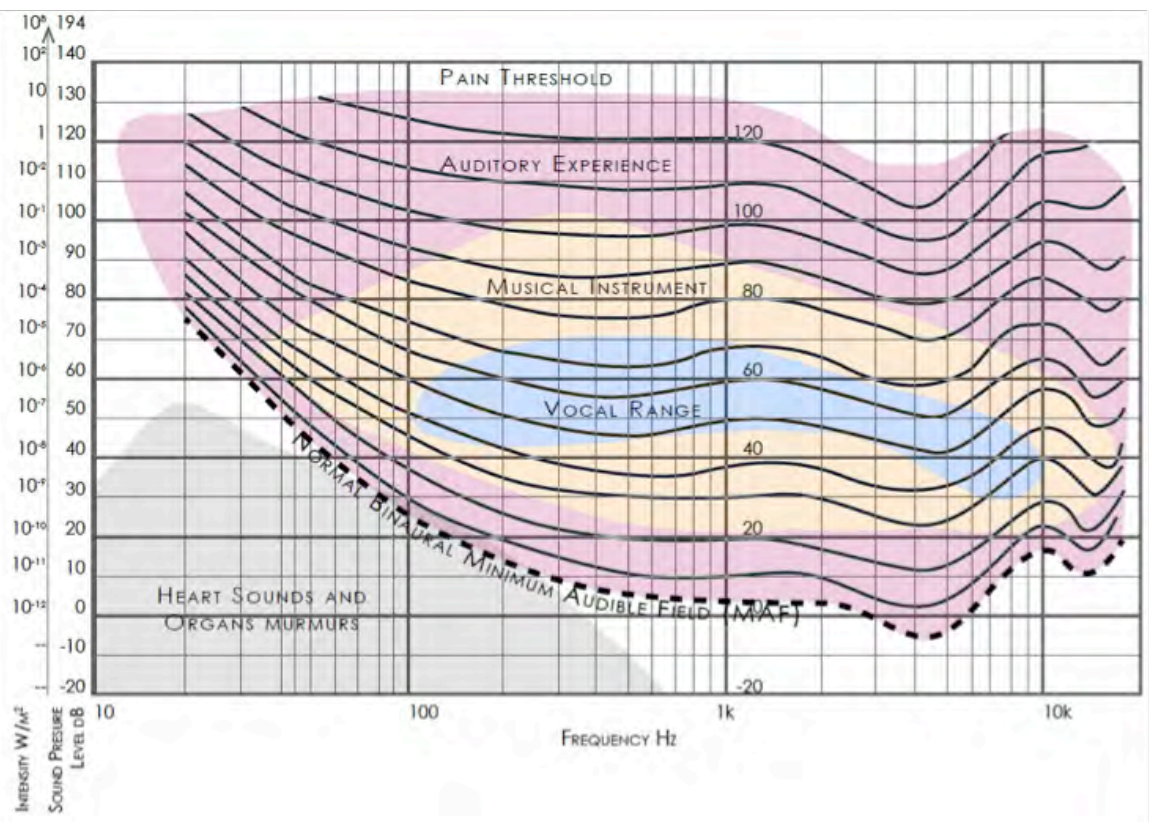

Fonte: Barakat (2016)

O que existe são os truques que a gente usa. Hoje em dia, é muito normal as pessoas ouvirem em fones, esses fones pequenininhos de celular. Muita gente escuta música assim. Tem várias músicas em que o grave soa bem; eles têm uma qualidade razoável de grave, embora o próprio alto-falante não reproduza tanto o grave. Temos alguns truques para as pessoas perceberem um grave que não necessariamente é reproduzido pelo alto-falante. Em geral, é assim: saturação harmônica, você excita os graves que não são fundamentais. Então, por exemplo, você tem um baixo que está em $60 \mathrm{~Hz}$ na frequência fundamental e vai enfatizar os harmônicos, $120 \mathrm{~Hz}, 180 \mathrm{~Hz}$. Isso vai fazer com que a pessoa perceba aquele grave, embora o alto-falante não esteja reproduzindo aquela fundamental. São truques para que se perceba o grave mesmo que não seja reproduzido de forma tão fidedigna.

De hardware, eu costumo usar tudo em todas as mixagens. O que eu tenho aqui a gente chama de estúdio híbrido, que junta uma plataforma digital com hardwares analógicos. Os hardwares são as ferramentas mais usadas em mixagem: compressores e equalizadores. Vários hardwares desses têm uma coisa legal nesse sentido: valorizam harmônicos e saturação harmônica para você não precisar ter a fundamental tão presente; são elementos que saturam. Muitas vezes, os hardwares têm saturação harmônica também. Por exemplo, o Drawmer [1968 MKII Vacuum Tube Compressor] tem duas válvulas no estágio de saída; quanto maior o estágio de saída, mais alto o estágio de saída, mais ele vai saturar as válvulas. O Avalon [Vt 747sp Vacuum Tube] tem quatro válvulas, que podem ser usadas exatamente com o intuito de gerar essa saturação harmônica e enfatizar os harmônicos do som. Mas é controlável: você controla a quantidade de saturação que insere no sinal de acordo com o volume de entrada e saída do hardware. E o Neve [AMS 8801] também é um channel strip que não tem válvula - é com transistores -, mas pode inserir bastante saturação harmônica no sinal. Ainda na mixagem, eu escolho alguns elementos da mixagem ou grupos de elementos da mixagem para passar por esses hardwares. Por exemplo, tinha duas violas. Em geral, uma está no canal esquerdo e outra no direito. Então, muitas vezes, eu pego esse grupo das violas, jogo num hardware - no Avalon, por exemplo - e ali comprimo e 
equalizo e volto isso para o Pro Tools. Outro grupo - a voz, por exemplo -, eu jogo no Neve, que funciona como um plugin na minha sessão.

Figura 6.6 - Periféricos utilizados na masterização do disco Amanhece

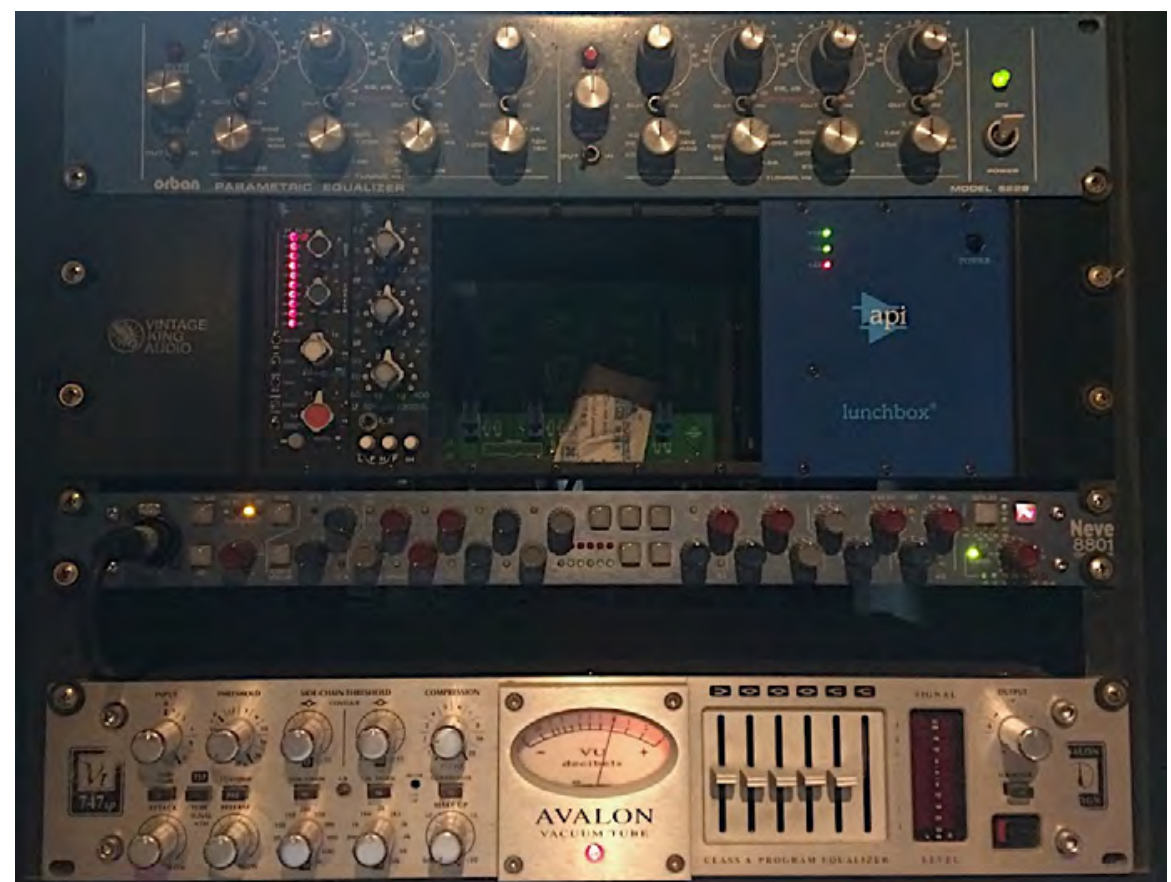

Fonte: Acervo pessoal

Do mesmo jeito que eu ligo um equalizador no canal [ProTools], vou mandá-lo para o hardware; ele vai e volta. Mas eu mexo aqui no hardware manualmente, ao invés de usar o mouse no plugin. Terminado esse processo da mix, depois que foi aprovado e que fizemos os ajustes todos, tem a masterização. Na master, novamente eu passo pelos hardwares, mas é um número menor de intervenções: equalização, às vezes compressão, limiter e um ou outro ajuste de timbre, como a gente fez também quando uma faixa está soando diferente das outras. Quando está mixando, você está focado naquela canção, você trabalha a canção.

Figura 6.7 - Periféricos utilizados na masterização do disco Amanhece

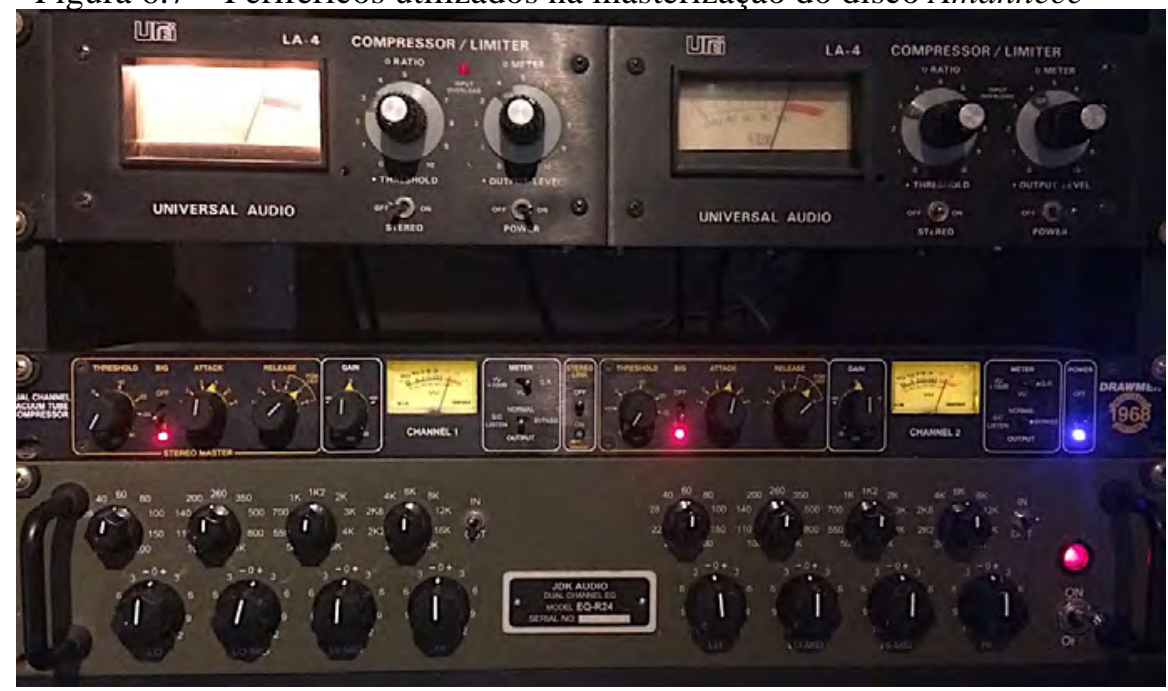

Fonte: Acervo pessoal 
Um cuidado comum que qualquer mixador tem diz respeito à inteligibilidade. O primeiro passo de qualquer música que você vai mixar: tem que estar inteligível. O pop tem essa questão do volume da voz na frente, por questões que eu considero originalmente relacionadas à mídia. Quando alguma coisa vai tocar no rádio, ele tem processos bem agressivos de limiter, dessa compressão mais pesada que evita que o som ultrapasse determinado volume. Se tudo estivesse muito próximo, esse limiter poderia empurrar a voz para dentro da mixagem e dificultar essa inteligibilidade. Então, começou-se a mixar com as vozes mais altas, e muitos artistas fazem até hoje rádio versions, versões específicas para rádio, que têm a voz mais alta do que a que vai para o disco. Nós tivemos também a preocupação de manter a voz num plano mais alto por conta dessa estética mais pop que a gente buscou, e a outra, pela questão da inteligibilidade. Até porque, muitas vezes, o sotaque [caiçara] é difícil de entender, na minha opinião. Então, às vezes, você ter um pouquinho mais de volume ajuda a entender a letra.

Voltando à questão de a gente exagerar em alguns elementos, é como a ideia do cartoon sonoro. Aquilo não condiz com a realidade, como um cartoon: o cara vai exagerar nos traços. É a mesma coisa na mixagem: você escuta uma bateria de pop, de rock no disco, e não tem nada a ver com o cara tocando bateria. O kick é bem mais alto, tem bem mais subgrave. Isso já faz parte da nossa percepção, já virou parte da estética (Entrevista com Frederico Teixeira, 20 fev. 2019, transcrição nossa).

O desenvolvimento dos diferentes processos e tecnologias de gravação que vêm sendo utilizados também para o registro do fandango caiçara guarda nos fonogramas uma gama de informações como espectro de frequências, saturação harmônica, variações de intensidade e contornos das estruturas melódicas, rítmicas e temporais, que atualmente podem ser observadas por ferramentas relativamente simples e de fácil acesso e operação como o software Sonic Visualizer, cujas principais funções se baseiam no suporte gráfico em formas de onda, faixas melódicas, picos de frequência e réguas de tempo destinados à análise de fonogramas de naturezas diversas.

A análise musical guiada por ferramentas computacionais já tem longo histórico de aplicação. Tido como pioneiro no trabalho de análise musical assistido por computadores, o livro Experimental music, de Lejaren Hiller e Leonard Isaacson (1959) tem foco na composição a partir de sistemas computacionais, transitando por temas como a análise musical e modelos de aplicação da teoria da informação. Temas como a otimização do estudo de dados e a necessidade de esforços integrados a perspectivas mais tradicionais de análise figuram em autores como Allen Forte (1967) e Nico Stephan Schuler (2000). Trabalhos mais recentes como os do Centro de Pesquisa para a História e Análise da Música Gravada (AHRC) ${ }^{132}$ exploram a

\footnotetext{
${ }^{132}$ The AHRC Research Centre for the History and Analysis of Recorded Music é uma parceria entre instituições como a Royal Holloway, da Universidade de Londres, o King's College (Londres) e a Universidade de Sheffield com o objetivo de promover o estudo musicológico de gravações, com uma ampla gama de abordagens que vão desde a análise computacional até a história dos negócios.
} 
utilidade de softwares gratuitos como Audacity e Sonic Visualizer no campo musicológico, incluídos aí artigos com esse fim específico, escritos em colaboração com especialistas da área como Cook e Leech-Wilkinson (2009) por exemplo, em que o texto se converte em tutorial de linguagem clara e acessível aos mais diversos públicos.

Os comentários de Fred Teixeira podem ser visualizados nos sonogramas das Figuras 6.8 a 6.10, onde constam duas versões da marca batida Marinheiro: a primeira gravada em 1968 pelo grupo do mestre Romão no disco Documentário Sonoro do Folclore Brasileiro, a segunda, faixa do disco Amanhece - Fandango Pancada. O espectro harmônico das duas imagens traz informações adicionais, mostrando, por exemplo, que se mantêm a estrutura métrica e a distribuição dos intermezzos batidos (assinalados em linhas verdes). Todavia, as faixas de frequência do espectro grave consolidam outra dinâmica referencial, que segue de modo continuado durante a faixa de áudio. A ferramenta permite visualizar o contexto melódico e harmônico e pode precisar a tonalidade utilizada: nesse exemplo, as tônicas em Dó 4 acrescido de 9 cents $(263,023 \mathrm{~Hz})$ na gravação de 1968 e em Ré 4 acrescido de 6 cents $(294,748$ Hz) na de 2017. Detalhes como ataques, decaimentos, a intensidade em dB, a minutagem e a fase da onda também podem ser consultados no fonograma, no quadro superior direito das imagens. Cabe salientar que, na amostra de áudio da gravação realizada por Inami Custódio Pinto, usei previamente filtros, equalizadores e compressores para reduzir os ruídos de fundo, evidenciar as frequências das vozes e minimizar o craquelamento resultante dos sulcos do disco.

Apesar de ferramentas desse tipo já figurarem em estudos musicológicos pelo mundo, ainda parecem subutilizadas no campo etnomusicológico, em vista da riqueza e da precisão dos dados que se poderiam extrair de suas interfaces. A transposição do som em imagem é análoga à imagem vibracional inerente ao movimento coclear. No comparativo exposto nas figuras abaixo, parece emergir das nuances dos harmônicos superiores a percepção do desenvolvimento da tecnologia de áudio, seus avanços exponenciais e em que isso nos toca. Não modificamos apenas o som, mas alteramos parametricamente sua imagem. 
Figura 6.8 - Sonograma comparativo entre Mantiquira e Marinheiro

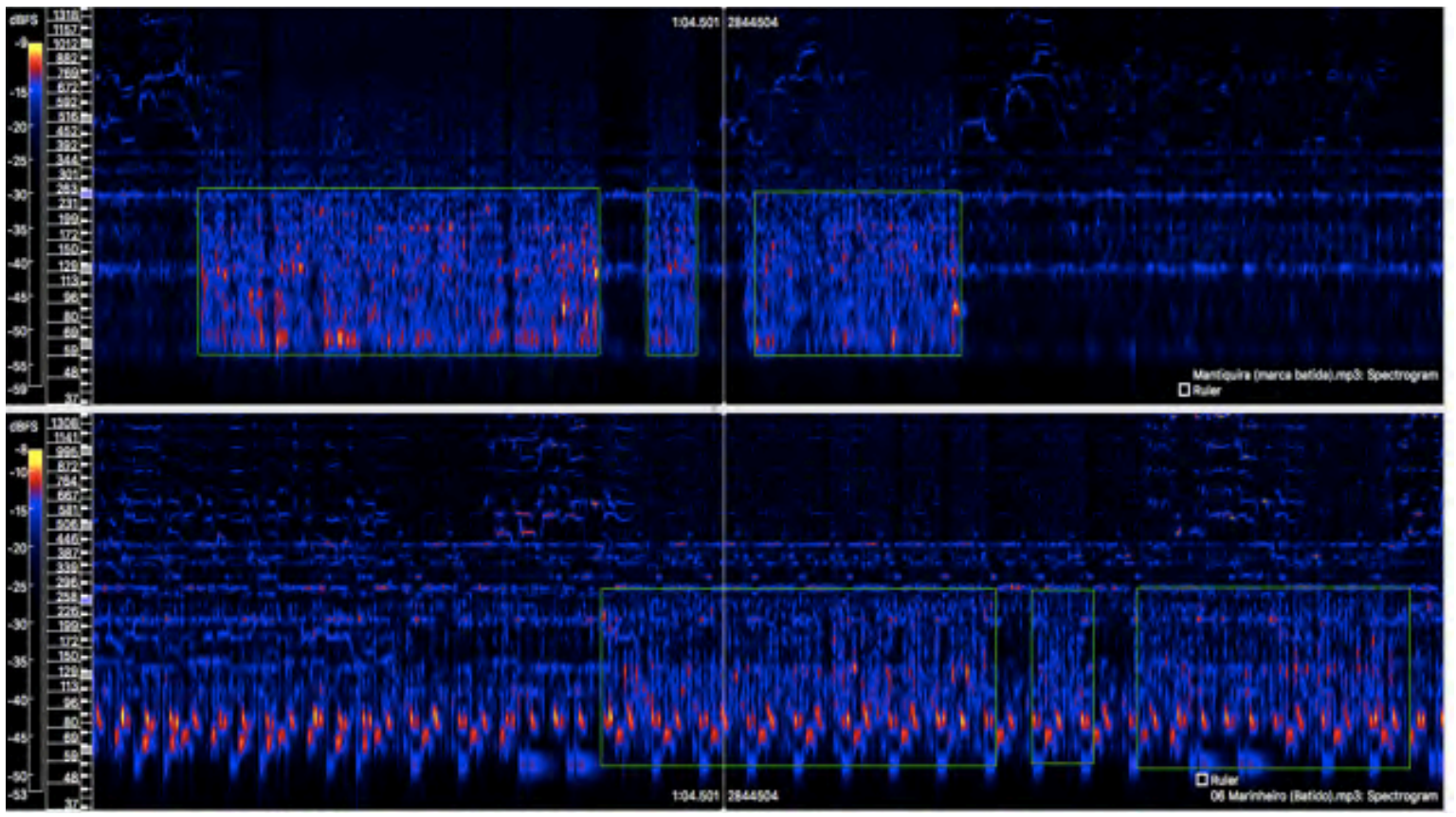

Fonte: o autor

Figura 6.9 - Indicação de frequências fundamentais - 1968

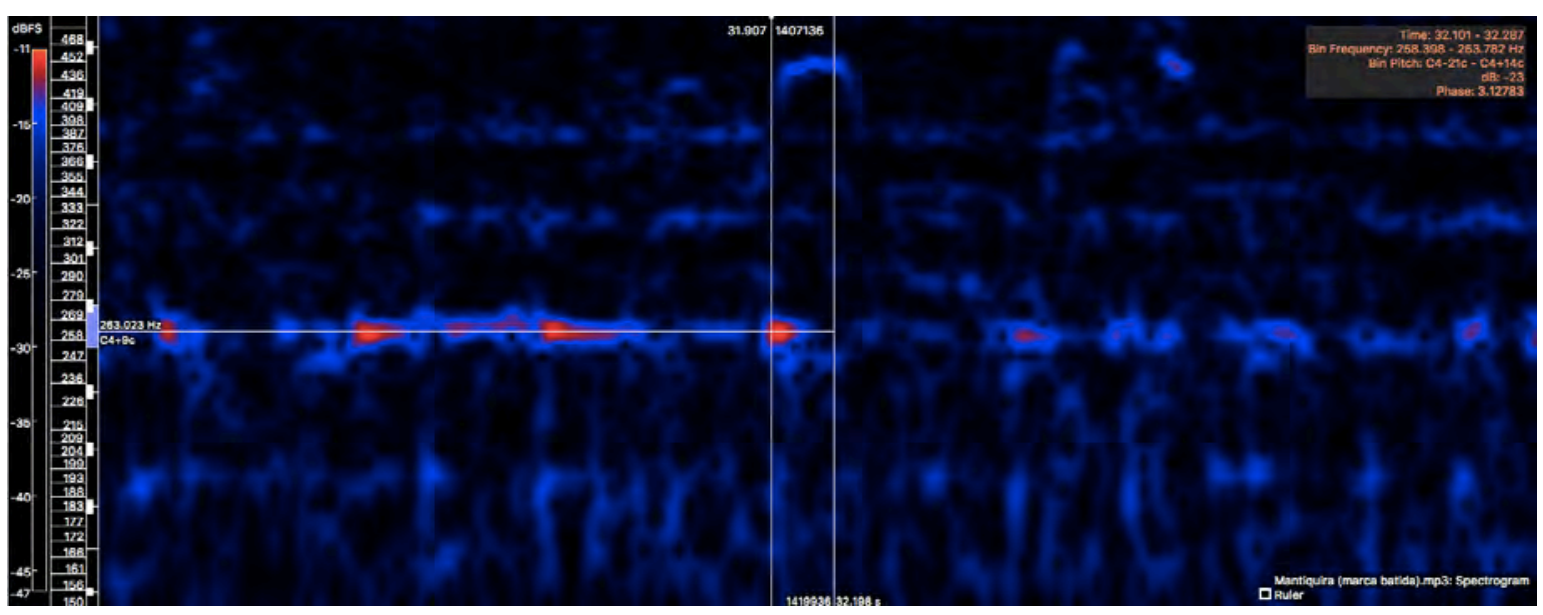

Fonte: o autor

Figura 6.10 - Indicação de frequências fundamentais - 2017

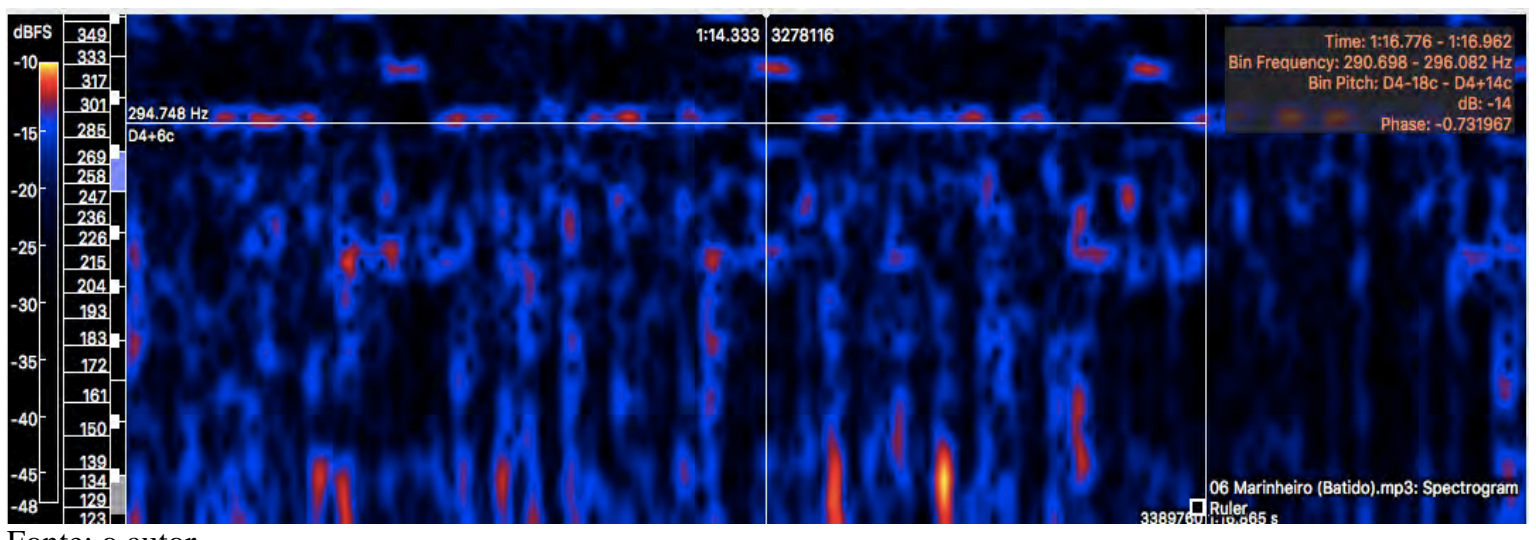

Fonte: o autor 


\title{
7 CIBERESPAÇO, FANDANGO CAIÇARA E REDES SOCIAIS
}

\author{
As pessoas já não acreditam nos fatos.
}

Noam Chomsky, $2018^{133}$

A consolidação de redes de interação para difusão, divulgação e promoção da cultura caiçara tem se ampliado exponencialmente nos últimos anos. Ferramentas como o Facebook e o WhatsApp modificaram sensivelmente esse cenário. Seguindo tendências globais de marketing, como se faz em muitos outros lugares da biosfera, atores e detentores culturais no território caiçara vêm adotando cada vez mais os dispositivos tecnológicos e suas potencialidades interativas.

Além de armazenar e transferir informação, essas ferramentas tecnológicas podem intermediar relações e mobilizar a atenção e a carga afetiva de seus usuários, e não é fácil mensurar fenômenos dessa magnitude. A transferência de conteúdos pode estimular o intelecto a ponto de desdobrar a realidade concreta, criando, entre coletivos interligados, realidades paralelas, seja no sentido participativo e colaborativo, seja pelos mais sórdidos recursos para a alienação de massas, sobretudo no espectro macropolítico. Em tempos de golpes jurídicomidiáticos espargidos pelo mundo contemporâneo, não é de espantar que máquinas maquinem nossa inculcação:

O Facebook está unindo o mundo. Tornou-se uma abrangente experiência cultural partilhada por pessoas em todo o planeta, especialmente jovens. Apesar de seu início modesto como um projeto de faculdade de um rapaz de 19 anos de idade, tornou-se uma potência tecnológica com influência sem precedentes sobre toda a vida moderna, tanto pública quanto privada. Sua composição inclui as mais diversas gerações, geografias, idiomas e classes sociais. Talvez seja, na realidade, a empresa de mais rápido crescimento de toda a história. O Facebook é ainda maior em países como o Chile e a Noruega do que nos Estados Unidos. Ele muda a forma como as pessoas se comunicam e interagem, como os comerciantes vendem seus produtos, como os governos chegam aos cidadãos e até como as empresas operam. Está alterando a natureza do ativismo político e, em alguns países, está começando a afetar o processo da própria democracia. Já não é apenas um brinquedo para estudantes universitários (KIRKPATRICK, 2011, p. 20).

\footnotetext{
133 “Já faz 40 anos que o neoliberalismo, liderado por Ronald Reagan e Margaret Thatcher, assaltou o mundo. E isso teve um efeito. A concentração aguda de riqueza em mãos privadas veio acompanhada de uma perda do poder da população em geral. As pessoas se sentem menos representadas e levam uma vida precária, com trabalhos cada vez piores. O resultado é uma mistura de aborrecimento, medo e escapismo. Já não se confia nem nos próprios fatos. Há quem chame isso de populismo, mas na verdade é descrédito das instituições", disse Noam Chomsky em entrevista a El País (GOMES, 2018, p. 1-2).
} 
De modo geral, a partir de experiências compartilhadas, atores, ativistas e detentores vêm estabelecendo comunicação instantânea e constante. Trocando informações sobre embates travados entre comunidades, poderes públicos e empreendimentos, traçando linhas de atuação que avaliam os prós e os contras de determinada situação, divulgando agendas culturais, festas, atividades artísticas, dicas profissionais, discussões sobre história, antropologia, política, piadas e mesmo conteúdos mais "picantes" em determinados grupos em que, entre outras pautas, há abertura para esse tipo de interação.

Inicialmente, os estudos preliminares para o registro do fandango caiçara, idealizado conjuntamente com membros da Associação Mandicuera e levados a cabo pela Associação Caburé (RJ), resultaram na publicação do livro Museu Vivo do Fandango (PIMENTEL et al., 2006) e culminaram nos encontros entre detentores e pesquisadores ocorridos em 2006 e 2008 no município de Guaraqueçaba. A proximidade e a identificação entre as comunidades vêm consolidando novas redes de troca e ativismo territorial e político e, é claro, gerando produtos artísticos e possibilitando a melhor integração entre agentes culturais em território caiçara, trânsito que pude observar mais de perto na execução do projeto Ô de Casa - Salvaguarda do Fandango Caiçara, citado no Capítulo 3. Entre as principais conquistas dessas ações, destaco o entendimento dos direitos adquiridos e a intensa troca de experiências.

Fragmentos da IX Festa do Fandango Caiçara de Paranaguá lançados na rede mostram a interação em tempo real. Esse tipo de atividade excita a rede. As conexões em trânsito no espaço-tempo individual tomam contornos híbridos, agregando aspectos emocionais e cognitivos, etológicos e eidológicos tanto virtual como pessoalmente, em todos os casos imersos em experiências de fluxo, em moldes próximos aos propostos por Csikszentmihalyi (1975) e Goleman (1995).

O fluxo é um estado sem estática emocional, a não ser por um sentimento compulsivo, altamente motivadores, de suave êxtase. Esse êxtase, parece ser um subproduto da concentração de atenção, que é um pré-requisito do fluxo. $\mathrm{Na}$ verdade, a literatura clássica das tradições contemplativas descreve estados de absorção que são sentidos como pura felicidade: fluxo induzido por nada mais que intensa concentração. [...] Quando as pessoas se acham empenhadas em atividades que prendem e mantêm, sem esforço sua atenção, seu cérebro se 'acalma', no sentido de que ocorre uma diminuição de estimulação cortical"' (GOLEMAN, 1995, p. 105).

É possível viver essa experiência em diferentes situações: compondo uma obra artística, ouvindo uma peça sinfônica, apreciando uma encenação performática e mesmo em ações cotidianas, quando as pessoas sentem que se superam em determinada atividade, sejam elas profissionais, didáticas ou de lazer, inclusive nas redes virtuais. 
O advento da web 2.0 permitiu que os softwares funcionassem pela internet e não apenas instalados em computadores locais, de modo que vários programas puderam se integrar formando uma grande plataforma, lembrando ainda que as mídias geradas pelo consumidor são usadas para descrever conteúdos criados e divulgados por ele mesmo, conceito denominado consumer-generated media (CGM). Para além do fluxo de informações gerais sobre a manifestação cultural, a propagação de verbetes na rede fornece dados sobre sua divulgação e difusão. Glocalmente, iniciativas como o Encontro de Fandango e Cultura Caiçara realizado em Guaraqueçaba reverberam mais amplamente no sistema global de salvaguarda proposto pela UNESCO.

O uso comercial da internet na década de 1990 amplia os limites da possibilidade de relacionamentos virtuais e chega a ter papel expressivo em dinâmicas políticas e sociais. A partir da world wide web $(w w w)$ e da possibilidade de acesso global a vários tipos de informação, a internet cresce exponencialmente, transbordando dos âmbitos militar e acadêmico para tornar-se uma ferramenta comercial já em 1994. Em 1995, o Ministério de Ciência e Tecnologia e o Ministério das Comunicações instituem o Comitê Gestor da Internet (CGI), constituído por representantes da academia, de empresas envolvidas nas conexões, provedores e usuários e então responsável pelo registro de nomes e domínios .br e pela distribuição dos números de IP (que identifica cada computador) (OLIVEIRA, 2011).

Essa revolução também reverbera no universo caiçara cada vez mais intensamente. Uma simples busca no Google (por meio de recursos como “" ou a inserção de site:URL) tomando como referência o mês de novembro de 2012, ano do registro do fandango caiçara, resultou no panorama apresentado na figura 7.1.

Figura 7.1 - Gráfico da busca no Google pelo verbete FANDANGO CAIÇARA

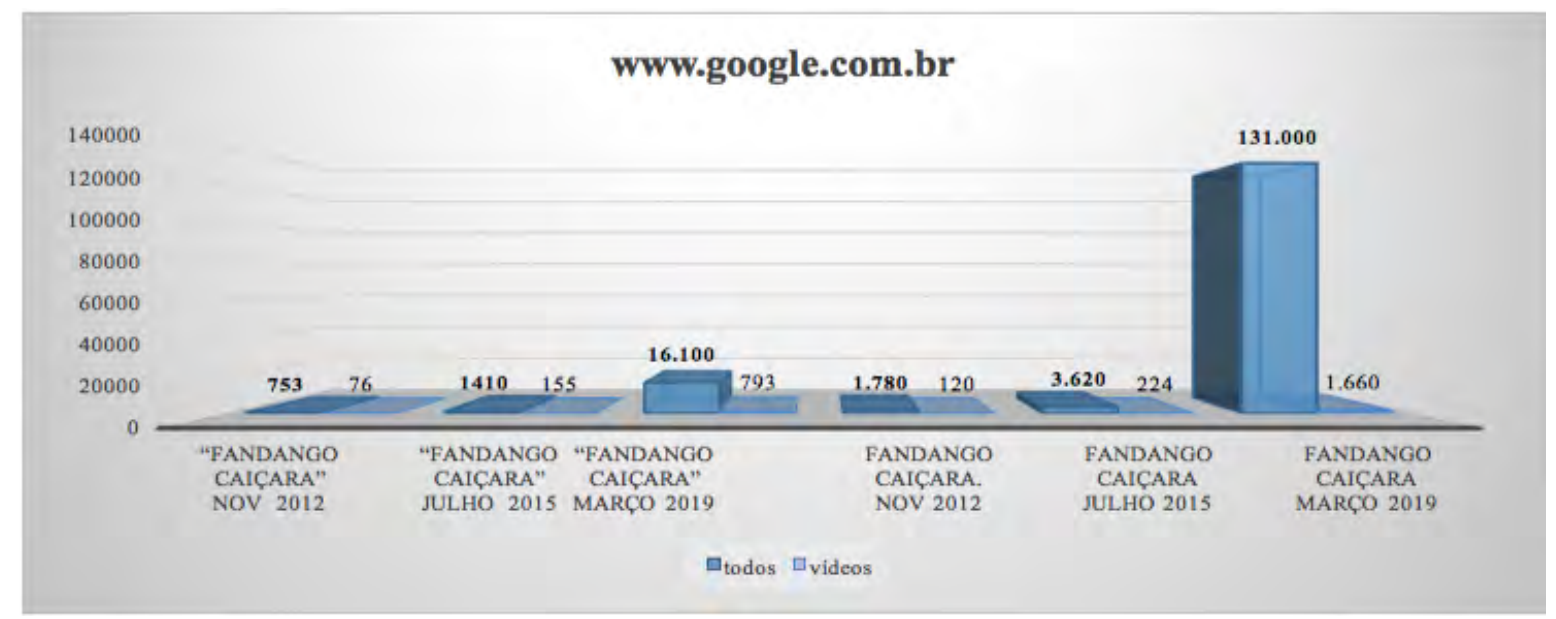

Fonte: $\mathrm{O}$ autor. 
Quando se busca o mesmo termo dentro do Facebook, constata-se o mesmo fenômeno.

Figura 7.2 - Gráfico da busca no Facebook (https://www.facebook.com/) pelos verbetes FANDANGO CAIÇARA E CAIÇARA

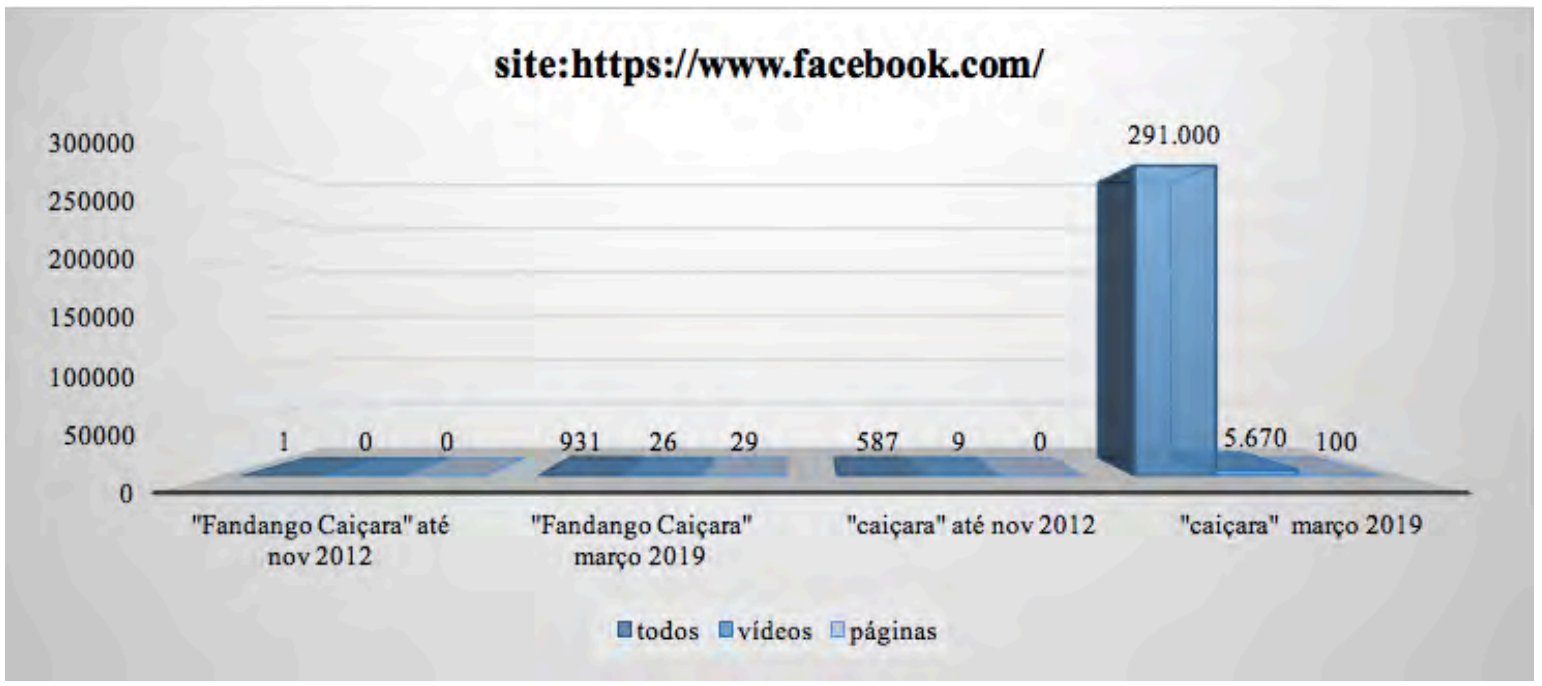

Fonte: $\mathrm{O}$ autor.

Há que considerar que esses dados são aproximados, mas ilustram o panorama atual. Além disso, deve-se ter em conta o também crescente uso da rede e da telefonia móvel nas duas últimas décadas. Mesmo nas regiões periféricas e mais distantes dos grandes centros urbanos, $\mathrm{o}$ acesso à rede vem crescendo vertiginosamente.

Figura 7.3 - Gráfico do crescimento do mercado de banda larga móvel no Brasil

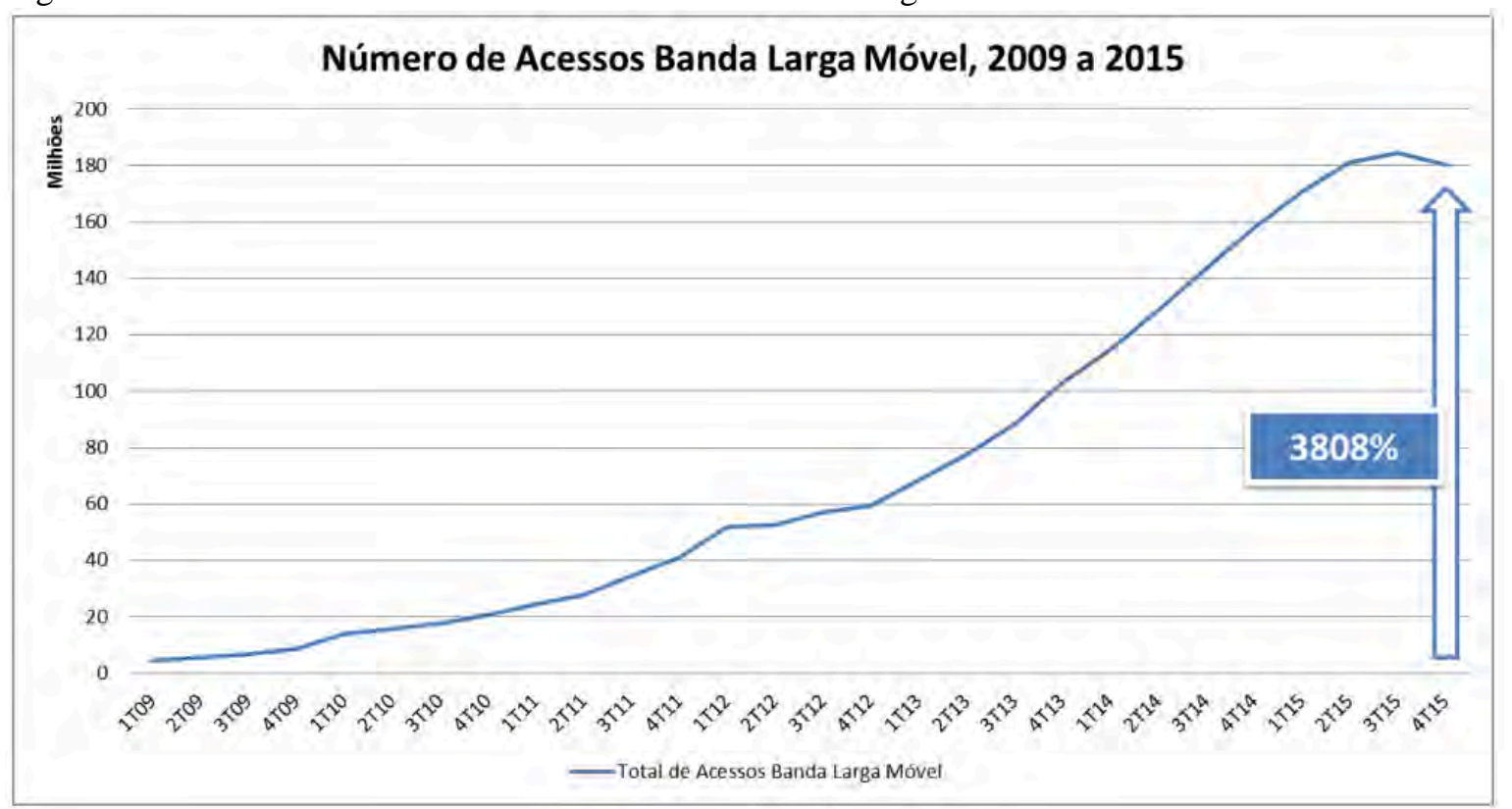

Fonte: Anatel (2016, p. 24) 
Em 2015, quando estive na Barra do Ararapira, ainda não havia nenhuma fonte de sinal de internet, mas os moradores criaram diferentes formas de se relacionar com as novas tecnologias. A grande disseminação de telefones celulares (mesmo sem sinal) servia a outros usos: câmera fotográfica, reprodutor de música ou central de jogos digitais. E era comum o compartilhamento de informações acessadas e armazenadas quando os moradores da Barra visitavam Cananéia, Ariri ou Paranaguá.

Em 2017, a situação havia mudado: três das pousadas na Barra já tinham sinal de internet via rádio, e, nos fins de tarde, a "piazada" se aglomerava num dos pontos de acesso e acabava imersa no mundo virtual, compartilhando dados e sobretudo verificando suas redes sociais.

Figura 7.4 - Criançada na sala de Márcio e Nica na boca da noite

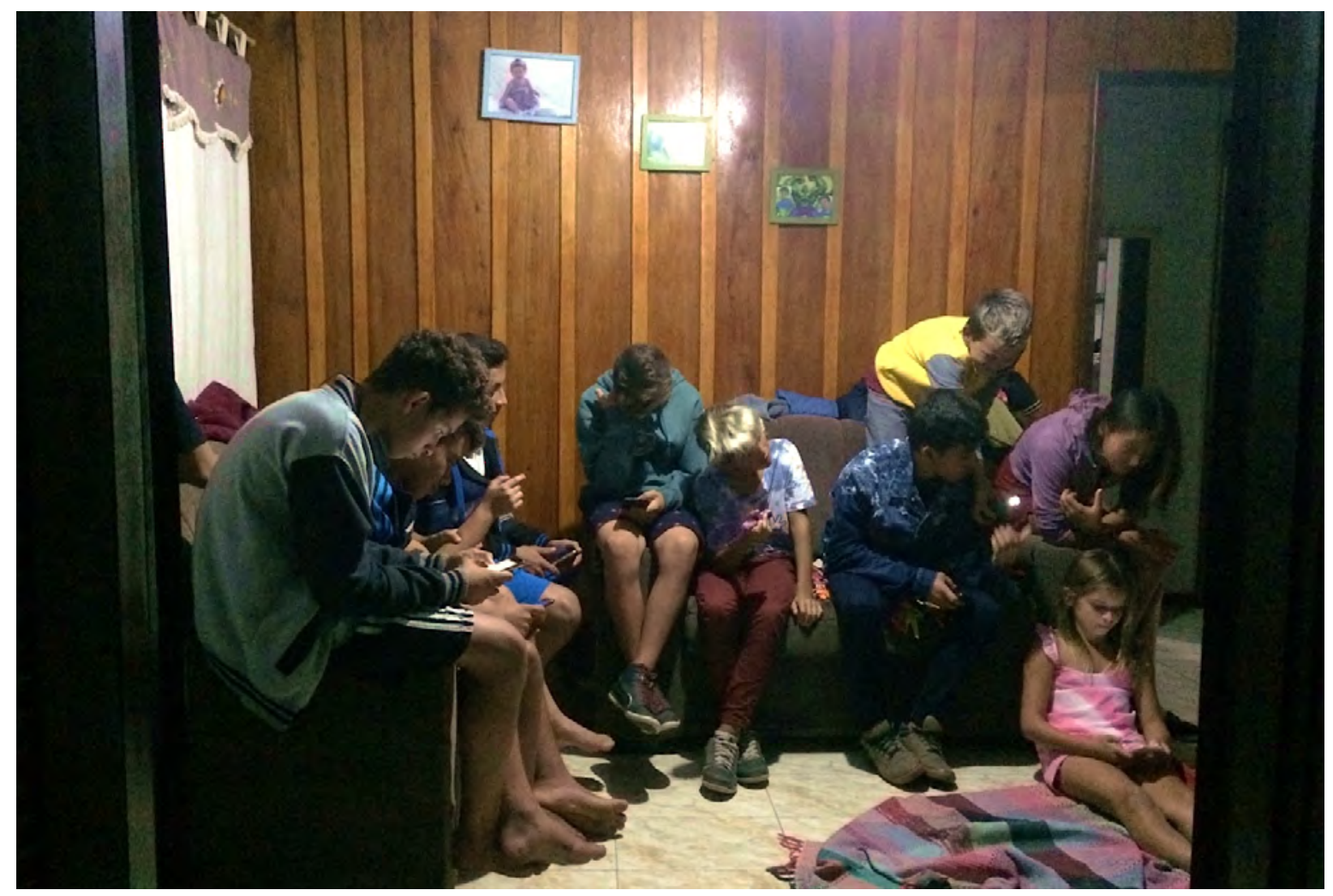

Fonte: Acervo pessoal 


\section{Comunicação instantânea, bolhas ideológicas e fake news}

Quando vai entardecendo

Acaba nossa alegria

Nosso povo está sofrendo

Com a falta de energia

Somos feito de cobaia

Para tecnologia

Única coisa que ascende

É a luzerna da ardentia

Pois a placa não carrega

Nem a luz da bateria

Aorélio Domingues e Cleiton do Prado,

"Moda da Placa Solar"

Como afirmam Connell e Gibson (2004, p. 351), a expansão da música do mundo ilustra a desterritorialização das culturas e mostra como o surgimento de uma mercadoria cultural particular (world music) "é essencialmente um fenômeno comercial, mas não poderia ter ocorrido sem a construção e contestação de discursos de lugar e alteridade”.

Os autores sustentam ainda que, de certo modo, a world music é muitas vezes uma busca pela autenticidade pré-capitalista, na qual os significantes de enraizamento são tidos como uma projeção de tela para as ansiedades e neuroses de uma maioria étnica ocidental. A tal respeito, vejamos o curioso depoimento do então jovem mestre fandangueiro Aorélio Domingues em sua página do Facebook:

Aí galera, pesquisadores, antropólogos, estudantes, professores, etc. Sempre me questionam se meu grupo de cultura popular tem rivalidade com outro grupo, me digam primeiro se existe algum grupo de teatro, dança, cinema, futebol, pesquisadores, etc, que não tem rivalidade com o outro? O Pessoal chega aqui e em umas poucas horas já querem fazer um diagnóstico da comunidade sentenciando quem é certo e quem é errado, péra lá. Por favor! E tem outra, chega de protecionismo babaca, se não daqui a pouco estaremos fazendo fandango, divino, etc, em uma redoma. E aqui vai uma lista das inovações da cultura popular: Viola com verniz; Fandango amplificado; Tocadores em pé; Fandangueiros com uniforme; Orquestra de Rabecas; Rabeca Gigante; Tamanco da Nike®; Clipe de fandango; Seriado caiçara; Suíte caiçara (música) rsrs ; Fandango com estatuto e alvará; Rabeca e viola elétrica; Afinação online; Blog e site de fandango; CD e DVD de fandango; Fandangueiros de figurino étnico e meia calça; Mestre curitibano; fandangueiro e romeiro de piercing; Afoxé e triângulo no fandango; e muitas outras coisas mais.... boa noite... (grifos nossos). ${ }^{134}$

${ }^{134}$ Postado por Aorélio Domingues em 4 de outubro de 2011. 
O uso de redes sociais para divulgar e difundir informações sugere pontos de alto rendimento analítico, como vimos no comentário postado por Aorélio Domingues. Discutemse conflitos vividos pelos núcleos artísticos, vínculos estatais e ações de protecionismo, bem como o desapego da "autenticidade cultural", que leva a "inovações da cultura popular" como a amplificação do folguedo, os tamancos personalizados e a veiculação de videoclipes no YouTube e em redes sociais, e ainda a institucionalização dos coletivos artísticos, a luteria contemporânea, com inserção de dispositivos elétricos de captação em instrumentos manufaturados artesanalmente, a possibilidade de fandangueiros não necessariamente morarem no litoral, além da relação inconstante entre atores culturais, pesquisadores e acadêmicos.

O depoimento também nos aproxima do conceito de glocalidade, tal como proposto por

Levitt, designando as estratégias de grandes multinacionais para expandirem seus negócios:

Levitt, que tem sido historicamente creditado entre os acadêmicos de negócios como o próprio inventor da "globalização", traduziu a internacionalização em padronização. Argumentou que esta implicaria economias de escala e faria daquela uma oportunidade de negócio lucrativa. Durante algum tempo, parecia que essa era de fato a lógica econômica apropriada para empresas transnacionais e multinacionais (MNC). No entanto, no devido tempo - pelo confronto prático com a realidade de diferenças culturais -, ficou claro que tal estratégia não era necessariamente um guia igual para todas as empresas e que também poderia não ser uma estratégia adequada para corporações transnacionais e multinacionais. Em vez disso, as empresas optaram por glocalizar seu marketing, o que foi documentado por meio de análises das estratégias comerciais da Coca-Cola, McDonalds, Procter \& Gamble (SINCLAIR; WILKEN, 2009) ${ }^{135}$ Starbucks (MAGUIRE; HU, 2013) ${ }^{136}$ e Nike (KOBAYASHI, 2012). ${ }^{137}$ Essa glocalização corporativa é particularmente pronunciada na Ásia, refletindo tanto a importância global da região quanto a necessidade de adaptação a contextos culturais específicos. $^{138}$

135 SINCLAIR, J.; WILKEN, R. Strategic regionalization in marketing campaigns: Beyond the standardization/glocalization debate. Continuum - Journal of Media \& Cultural Studies, v. 23, n. 2, p. 147-157, April 2009.

${ }^{136}$ MAGUIRE, J. S.; HU, D. Not a simple coffee shop: local, global and glocal dimensions of the consumption of Starbucks in China. Social Identities - Journal for the Study of Race, Nation and Culture, v. 19, n. 5, 16 Sept. 2013.

${ }^{137}$ KOBAYASHI, K. Globalization, corporate nationalism and Japanese cultural intermediaries: Representation of bukatsu through Nike advertising at the global-local nexus. Social Identities - Journal for the Study of Race, Nation and Culture, v. 47, n. 6, p. 724-742, 1 Dec. 2012.

${ }^{138}$ Levitt, who historically has been credited among business' scholars as the very inventor of "globalization", translated internationalization into standardization; he argued that the latter would bring forth economies of scale and make the former a lucrative business opportunity. For a period of time, it seemed that this was indeed the appropriate economic logic for TNCs (transnational companies) and MNCs (multinational companies). However, in due course of time - through the practical confrontation with the realities of cultural differences - it became evident that such a strategy was not necessarily a uniform guide for all firms but also might not be a suitable strategy for TNCs and MNCs. Instead, firms chose to glocalize their marketing, and that has been documented through analyses of the commercial strategies of Coca-Cola, McDonalds, Procter \& Gamble (Sinclair and Wilken, 2009), Starbucks (Maguire and Hu, 2013) and Nike (Kobayashi, 2012). This corporate glocalization is particularly 
Alguns abusos da parte de funcionários de instituições que usam a proteção de áreas de preservação ambiental $^{139}$ - já que, ordinariamente no Brasil, elas se sobrepõem a territórios ocupados por populações tradicionais como caiçaras, indígenas e quilombolas - como pretexto para sujeição do componente humano, e em outras frentes, a extração desenfreada de recursos naturais, delineiam um quadro já bastente complexo e que vem se intensificando em progressões geométricas nos primeiros meses de 2019. Tomemos como exemplo o recente caso de truculência contra populações caiçara no Mosaico da Juréia-Itatins ${ }^{140}$, ou ainda da invasão massiva de garimpeiros que vêm sofrendo as populações Yanomami em seus territórios ${ }^{141}$. Em ambos os casos, situações que vêm sendo cada vez mais publicizadas nas redes sociais.

Apesar de operar em novas mídias comunicacionais, como as já citadas iniciativas do MOPEAR e do Programa Cultura Viva (Capítulo 2), agentes e militantes dos direitos territoriais e socioculturais dessas parcelas periféricas da população nacional seguem buscando seu lugar de reconhecimento e de fala. Esses espaços vêm sendo ampliados pelas novas ferramentas de comunicação, sobretudo no aspecto micropolítico, onde se consolidam redes de interação e potencializam agenciamentos coletivos de insurgência frente ao colonialismo capitalístico, insurgência norteada pelo divertimento, compartilhamento de experiências e pulsão de vida.

Altamente algoritmizadas, as redes virtuais tendem a encapsular os sujeitos que nelas interagem, fato claramente observável na intensa polarização ideológica e político-partidária aguçada por seu uso. Apesar de indicar, um tanto "contraintuitivamente" que as redes sociais ensejam uma maior exposição a perspectivas opostas e tendo em vista limitações patentes na coleta de dados (universo de 50.000 usuários, com Bing Toolbar necessariamente instalado e amostras restritas a usuários de desktop), as conclusões de Flaxman e demais autores do estudo

pronounced in Asia, reflecting both the global importance of the region as well as the necessity for tailoring into specific cultural contexts (ROUDEMETOF, 2015, p. 12).

${ }^{139}$ As atuações de instituições diversas é deveras complexo. No caso do ICMBio por exemplo, a regionalização de suas ações (por vezes até mesmo distanciandas de sua principal missão), propiciou fortes embates com as populações caiçaras paranaenses, sobretudo aquelas que habitam o Parque Nacional do Superaguí e suas imediações, situação que vem se alterando nos últimos anos com a renovação de seus quadros diretivos. Já com órgãos como a Fundação Florestal - SP (como ilustrado na matéria abaixo), contrário aos avanços nos diálogos junto às comunidades caiçaras em prol das políticas ambientais e socioculturais das quais deveriam, em tese, ser consignatários, parecem aderir ao mote da truculência e do descaso ao desconsiderar instrumentos legais como a OIT 169 e o texto da Constituição Federal (1988) ao tratar com essas populações.

${ }^{140}$ INSTITUTO SOCIOAMBIENTAL. Nota sobre os fatos ocorridos na comunidade tradicional caiçara Rio Verde e Grajaúna. 12/08/2019. Disponível em: <https://www.socioambiental.org/pt-br/blog/blog-do-vale-doribeira/nota-sobre-os-fatos-ocorridos-na-comunidade-tradicional-caicara-rio-verde-egrajauna?fbclid=IwAR3osIifld3s Y0uf4WBXor5Ix-P2Fd6YRi2hJD6QJKHJ2jt9E2prgG4B0UI>

${ }^{141}$ SASSINE, Vinicius. Garimpo, cobiça e pobreza: extração de ouro em reserva indígena deixa rastro de destruição. O Globo Brasil, 04/08/2019. Disponível em: <https://oglobo.globo.com/brasil/garimpo-cobicapobreza-extracao-de-ouro-em-reserva-indigena-deixa-rastro-de-destruicao-

23853666?fbclid=IwAR2zR1212HmMvlx7vnFc2kPcuyF949yyCzaHyD-a7gVmyEnEh0OVlkL8DIw> 
conduzido no Departamento de Estatística da Universidade de Oxford, levantam pontos que nos interessam:

\begin{abstract}
Assim, autores como Sunstein (2009) ${ }^{142}$ previram o surgimento de "câmaras de eco", onde os indivíduos são amplamente expostos a opiniões conformes. De fato, em experimentos controlados, os sujeitos tendem a escolher artigos de notícias de canais alinhados com suas opiniões políticas (GARRETT, 2009; ${ }^{143}$ IYENGAR; HAHN, 2009; ${ }^{144}$ MUNSON; RESNICK, 2010). ${ }^{145}$ Além disso, mecanismos de busca, agregadores de notícias e redes sociais estão cada vez mais personalizando conteúdo por meio de modelos de aprendizado de máquina (AGICHTEIN; BRILL; DUMAIS, 2006; ${ }^{146}$ DAS et al. 2007; ${ }^{147}$ HANNAK et al. 2013), ${ }^{148}$ criando potencialmente "bolhas de filtro" (PARISER, 2011) ) $^{149}$ em que os algoritmos, inadvertidamente, amplificam a segregação ideológica, recomendando automaticamente conteúdos com os quais um indivíduo provavelmente concordará. [...] Resumindo nossos achados sobre isolamento ideológico, descobrimos que os indivíduos geralmente leem publicações que são ideologicamente bastante semelhantes e, além disso, leem regularmente artigos partidários expostos quase exclusivamente a apenas um lado do espectro político (FLAXMAN; GOEL; RAO, 2016, p. 299/316). ${ }^{150}$
\end{abstract}

Outro estudo realizado na Faculdade de Artes, Humanidades e Ciências Sociais da Universidade Estadual da Dakota do Norte, nos EUA, investigou os motivos que estudantes universitários identificaram para o uso de quatro dispositivos tecnológicos - telefones celulares,

${ }^{142}$ SUNSTEIN, C. R. Republic.com 2.0. Princeton, NJ: Princeton University Press, 2009.

${ }^{143}$ GARRETT, R. K. Echo Chambers Online? Politically Motivated Selective Exposure among Internet News Users. Journal of Computer-Mediated Communication, v. 14, p. 265-285, 2009.

${ }^{144}$ IYENGAR, S.; HAHN, K. S. Red Media, Blue Media: Evidence of Ideological Selectivity in Media Use. Journal of Communication, v. 59, p. 19-39, 2009.

${ }^{145}$ MUNSON, S. A.; RESNICK, P. Presenting Diverse Political Opinions: How and How Much. Proceedings of the Sigchi Conference on Human Factors in Computing Systems, ACM, p. 1457-1466, 2010.

${ }^{146}$ AGICHTEIN, E.; BRILL, E.; DUMAIS, S., 2006. Improving Web Search Ranking by Incorporating User Behavior Information. Sigir Conference on Research and Development in Information Retrieval, ACM, p. 19-26.

147 DAS, A. S.; DATAR, M.; GARG, A.; RAJARAM, S. Google News Personalization: Scalable Online Collaborative Filtering. Proceedings of the 16th International Conference on World Wide Web, ACM, p. 271-280, 2007.

${ }^{148}$ HANNAK, A.; SAPIEZYNSKI, P.; KAKHKI, A. M.; KRISHNAMURTHY, B.; LAZER, D.; MISLOVE, A.; WILSON, C. 2013. Measuring Personalization of Web Search. Proceedings of the 22nd International Conference on World Wide Web, p. 527-538, 2013.

${ }^{149}$ PARISER, E. The Filter Bubble: What the Internet is Hiding from You. London: Penguin UK, 2011.

${ }^{150}$ Commentators such as Sunstein (2009) have thus predicted the rise of "echo chambers", in which individuals are largely exposed to conforming opinions. Indeed, in controlled experiments, subjects tend to choose news articles from outlets aligned with their political opinions (Garrett, 2009; Iyengar; Hahn, 2009; Munson; Resnick, 2010). Additionally, search engines, news aggregators, and social networks are increasingly personalizing content through machine-learning models (Agichtein; Dumais, 2006; Das et al., 2007; Hannak et al., 2013), potentially creating "filter bubbles" (Pariser, 2011) in which algorithms inadvertently amplify ideological segregation by automatically recommend- ing content an individual is likely to agree with. [...] Summarizing our results on ideological isolation, we find that individuals generally read publications that are ideologically quite similar, and moreover, users that regularly read partisan articles are almost exclusively exposed to only one side of the political spectrum (FLAXMAN; GOEL; RAO, 2016, p. 299/316). 
televisores, computadores e aparelhos de MP3 -, determinando concomitantemente a relação entre esses motivos e a percepção dos alunos sobre solidão e pertencimento. Apoiados na noção de pertencimento, construída a partir da teoria do self, de Kohut (1984), Lee e Robbins (1995), distinguem a adequação de conceitos correlatos como solidão, apego e apoio social percebido:

Eles apresentam a pertença como uma característica pessoal que surge do desenvolvimento do self, contrastando-o com a solidão, que é em grande parte experimental e pode ser crônica ou aguda. A pertença tem duas dimensões: conectividade social e segurança social. A conexão social é definida como "receber empatia e compreensão de seus pares ou da sociedade" (Lee; Robbins, 1995, p. 236). ${ }^{151}$ Amadurecendo de adolescentes para adultos, os indivíduos passam a ter sentimentos de conexão social à medida que mantêm amizades e se sentem mais à vontade com amigos e familiares em situações sociais. A conectividade social é a distância emocional que se sente entre si e os outros, inclusive família, amigos, colegas, comunidade e sociedade (Lee; Robbins, 1995). A conexão social proporciona aos indivíduos não só um sentimento de seu lugar na sociedade, mas também uma identidade pessoal (Miller, 1992), ${ }^{152}$ que é essencial para atuar com êxito em ambientes sociais. A segurança social é a segunda dimensão do pertencimento (Lee; Robbins, 1995). Paralelamente ao conceito de conexão social, a segurança social inclui sentimentos de empatia e aceitação dos outros, mas em relacionamentos mais interpessoais (ou seja, com indivíduos e pares importantes). O fracasso no desenvolvimento da segurança social impede que os indivíduos atuem como indivíduos independentes na sociedade (PEARSON et al., 2009, p. 47, tradução nossa). ${ }^{153}$

Esses elementos são marcantes também nas novas formas de se construir a sociabilidade caiçara presente no cotidiano das redes fandangueiras: na impossibilidade de se encontrar concretamente, as pessoas se valem de dispositivos como aparelhos celulares ou computadores para manter relações artísticas, de amizade ou de militância social e política.

${ }^{151}$ LEE, R. M.; ROBBINS, S. B. Measuring belongingness: The Social Connectedness and the Social Assurance Scales. Journal of Counseling Psychology, v. 42, p. 232-241, 1995

${ }^{152}$ MILLER, I. J. Interpersonal vulnerability and narcissism: a conceptual continuum for understanding and treating narcissistic psychopathology. Psychotherapy, v. 29, p. 216-224, 1992.

153 "Building from Kohut's (1984) theory of self, Lee and Robbins (1995) distinguish belongingness from related concepts such as loneliness, attachment and perceived social support. They present belongingness as a personality characteristic arising from the development of self, contrasting it with loneliness, which is largely experiential and may be chronic or acute. Belongingness has two dimensions: social connectedness and social assurance. Social connectedness. Social connectedness is de ned as 'receiving appropriate empathy and understanding from peers or society' (Lee; Robbins, 1995, p. 236). As individuals mature from adolescents to adults, they begin to have feelings of social connectedness as they maintain friendships and feel more comfortable with friends and family in social situations. Social connectedness is the emotional distance one feels between self and others, including family, friends, col- leagues, community, and society (Lee; Robbins, 1995). Social connectedness not only provides individuals with a feeling of their place in society, but it also provides them with a personal identity (Miller, 1992), which is essential to operate successfully in social settings. [...] Social assurance. Social assurance is the second dimension of belongingness (Lee; Robbins, 1995). Parallel to the concept of social connectedness, social assurance addresses feelings of empathy and acceptance from others, but it addresses them in more interpersonal relationships (i.e., with important individuals and peers). Failure to develop social assurance deters individuals from functioning as independent individuals in society" (PEARSON et al., 2009, p. 47). 
Um dos resultados a que chegam Pearson et al. (2009, p. 51 - tradução nossa) é que os sentimentos de conectividade social dos alunos também estão positivamente correlacionados com o uso de telefones celulares: "Assim, sugerindo que, quanto mais os alunos usassem seus celulares para fins de interação, maior a probabilidade de se sentirem socialmente conectados”. Mesmo imersos em realidades muito díspares, as experiências de campo constatam relações similares com essas tecnologias, marcadamente televisores e celulares, que também fazem as vezes de tocadores de MP3 e câmeras fotográficas (embora esta última função não figure no estudo citado).

O jogo político combina dimensões como a conectividade e a segurança social gerando ainda outros vieses de interação em que agenciamentos externos procuram modelar realidades paralelas para atender a interesses oportunistas e/ou capitalistas.

O caderno de tecnologia na sucursal brasileira da Reuters noticiou, em 21 de janeiro de 2019, que a agência de proteção de dados da França multou a Google em $€ 50$ milhões por violação de regras de privacidade da União Europeia: "a maior penalidade do tipo imposta contra uma companhia de tecnologia dos Estados Unidos” (ROSEMAIN, 2019).

O órgão regulador francês afirmou que a Google não é transparente ou clara na maneira como informa usuários sobre seu trato com dados pessoais e que não obteve o devido consentimento dos usuários para lhes enviar anúncios publicitários personalizados.

A reportagem informa ainda que a Regulação Sobre Proteção Geral de Dados (GDPR) da UE passa pela maior reforma das leis de privacidade de dados em mais de duas décadas. A legislação entrou em vigor em maio do ano passado, permitindo aos usuários um melhor controle sobre seus dados pessoais e dando às autoridades o poder de impor multas de até $4 \%$ da receita global das empresas em casos de violação: "O montante decidido e a publicidade da multa são justificados pela gravidade das infrações observadas”, disse a agência francesa (ROSEMAIN, 2019).

Apesar dos evidentes avanços no acesso à informação, o planeta como um todo tem sofrido um grande revés a partir do uso indevido de tais tecnologias, e a exploração comercial de perfis psicológicos não é ficção: desde o fim da chamada Guerra Fria, amplamente intensificado pela implementação da www e por todos os seus desdobramentos. Como exemplos, podemos citar o caso de Rodrigo Duterte, presidente das Filipinas, que tirou proveito de seus seguidores mais fanáticos no Facebook para desacreditar jornalistas e ativistas; como os artifícios utilizados para persuadir eleitores em relação ao Brexit, plebiscito que decidiu a saída do Reino Unido da União Europeia; ou como no escândalo envolvendo a Cambridge Analytica nas eleições estadunidenses de 2016, quando a empresa, que trabalhou na campanha 
de Donald Trump, extraiu dados de 87 milhões de pessoas no Facebook. Em entrevista à BBC Brasil, Evgeny Morozov ${ }^{154}$ (ROSSI, 2018) comenta:

Se a democracia está em perigo - e eu acredito que esteja - é porque suas infraestruturas mais importantes, incluindo as que são usadas no debate público, estão completamente sincronizadas com a lógica de negócios das empresas de tecnologia. Ocasionalmente, isso pode criar oportunidades. Por exemplo, movimentos sociais de todos os tipos podem espalhar suas mensagens a custos muito baixos. Mas também há um custo invisível. E nós estamos começando a pagar por ele agora, já que sofremos com as consequências, como a manipulação eleitoral. [...] Se você analisa como Facebook, Google, YouTube e Twitter operam, fica claro que eles têm um objetivo principal: reunir dados dos usuários, seja para aumentar a venda de anúncios ou para criar serviços de inteligência artificial. A necessidade de reunir dados - que eu chamo de "extrativismo de dados" - prejudica o debate público em geral. Nessas empresas, há centenas de pessoas que trabalham para criar formas de nos viciar nos botões de atualizar ou postar. Quanto mais provocativo for um post, mais ele vai gerar interação do usuário. E é essa interação que permite às empresas coletarem mais dados sobre nós. [...] $\mathrm{O}$ impacto de curto prazo tem a ver com a deterioração do debate e da comunicação política. Em comparação com dez anos atrás, as coisas ficaram muito piores. Também podemos medir essa deterioração em comparação com uma configuração perfeita inatingível - [Jürgen] Habermas (o filósofo e sociólogo alemão) costumava chamá-la de "situação de fala ideal". Nessa configuração perfeita, é fácil para as pessoas exercitarem o pensamento crítico, raciocinarem sobre causas e efeitos e expressarem opiniões que não são apenas o subproduto das campanhas de medo dirigidas a elas por meio de uma extensa coleta de informações sobre os seus temores e ansiedades.

O uso de informações falsas para ancorar fundamentalismos, ideologias e vantagens econômicas não é novo, mas a velocidade da disseminação e as ferramentas disponíveis hoje delineiam novas formas operativas, inimagináveis antes da virada de século.

Em editorial do jornal $O$ Globo, Gisele Barros cita exemplos dessas mazelas em território brasileiro anteriores ao advento da internet, cujo impacto se fez sentir no esporte, na política, na defesa civil ou na segurança pública. Sobre um dos casos mencionados, ela conta:

Em 1936, o mercado de café foi alvo de notícias falsas que geraram especulações negativas e reduziram as cotações do produto brasileiro. Segundo reportagem do jornal publicada em 25 de junho de 1936, um dos boatos dizia que o Departamento Nacional do Café havia entregue uma grande quantidade do produto ao porto de Santos, em São Paulo, para que fosse vendida em Nova York. Além da informação, espalhou-se que a "quota de equilíbrio", que definia taxas entre a produção e o consumo do café, seria radicalmente modificada em consequência de reclamações dos produtores. Em apenas um dia, a mercadoria teve baixa de mais de 20 pontos no preço de venda.

\footnotetext{
${ }^{154}$ Morozov concluiu seu PhD em Harvard e foi professor visitante em Stanford. É autor do livro Net Delusion (2011), que critica o que chama de ciberutopia, ou a crença utópica de que o acesso à internet fortaleceria a democracia, mostrando que a tecnologia também pode servir ao autoritarismo.
} 
É notório que o uso e divulgação de informações falsas visando interesses econômicos já data de décadas, mas, na atualidade, vêm a baila expressões como conexão social e segurança social e atravessam outras esferas de interação humana, em que afecções e afetos se somam a interesses de grandes empresas e corporações da tecnologia da informação que a cada dia exercem mais influência em setores políticos e midiáticos, local e globalmente.

O psicanalista Marcos Donizetti de Almeida (2018) é assertivo: "Vivemos uma crise política e social, uma crise que é também e principalmente dos afetos e das relações". Na conjuntura política ímpar criada pelas eleições de 2018 no Brasil, percebemos uma movimentação à deriva, onde todos os pontos mencionados tomam forma concreta e passam a afetar o cotidiano da população brasileira, inclusive caiçaras.

Tudo isso tem sido discutido à exaustão com integrantes da romaria do Divino Espírito Santo de Paranaguá, por exemplo. Colegas que fazem pesquisas continuadas junto às comunidades por onde passa a romaria, romeiros que moram nas comunidades e os foliões que compõem a tripulação têm dado depoimentos preocupantes sobre a disseminação de notícias falsas nesses lugares, e, em boa medida, paira um temor de que afetem de algum modo o período de peregrinação. É ponto pacífico entre estudiosos do fandango caiçara (BONA, 2016; PIMENTEL; GRAMANI; ORTIGÃO, 2011; CUSTÓDIO PINTO, 2010) o fato de que a disseminação de igrejas neopentecostais pelo litoral causou um declínio efetivo na manutenção de manifestações culturais como o fandango caiçara e a romaria do Divino, sobretudo nas últimas décadas do século XX, como explica Helena de Moura Aragão (2011, p. 64):

Inami acaba seu texto com a constatação de que "o fandango hoje está morrendo, vítima do rádio de pilha, do iê-iê-iê, da cultura de massa, do empobrecimento da região e, até mesmo, da proliferação de certas seitas religiosas que proíbem o canto e a dança por pecaminosos". Carolina explicou em entrevista que soube que havia estrangeiros que passavam de barco pelas ilhas oferecendo tratamento dentário e dizendo que dançar fandango era pecado, o que teria prejudicado a tradição.

Cabe salientar o caráter ecumênico presente na conformação da tripulação parnanguara. Durante os giros da folia, pude conviver com foliões de diversos credos religiosos: kardecistas, umbandistas e daimistas; em todos os casos, devotos fervorosos do Divino Espírito Santo e da Santíssima Trindade. Em localidades como na Vila de Superaguí, ou na Ilha da Peças, percebese o distanciamento da comunidade evangélica em relação às atividades da romaria, ainda havendo outras comunidades, como a do Canudal (Ilha de Superaguí), em que a quase 
totalidade dos moradores é de credo religioso pentecostal e neopentecostal, e que, via de regra, não é visitada pela romaria.

No fandango, com relação à influência dessas orientações religiosas, é recorrente o afastamento de fandangueiros, tanto dos jovens quanto daqueles de mais idade. Milton Pinheiro (Paranaguá), João Cordeiro (Paranaguá), Felício Pereira (Guaraqueçaba) são alguns exemplos. "Vaca" (Edvaldo Oliveira), jovem fandangueiro e já antigo parceiro desde as primeiras empreitadas junto ao coletivo Mandicuera, ficou por três anos distanciado das atividades da associação. Depois de vivenciar algumas desilusões quanto a amizades e ideais junto a uma congregação pentecostal, achou por bem retomar as atividades culturais e artísticas. Apesar de seguir em outra igreja, também pentecostal, atualmente participa laboriosamente das ações festivas e devocionais levadas a cabo pelos membros da associação, sobretudo visando à manutenção das amizades e do divertimento que o fandango lhe proporciona.

Quando eu estava no fandango, a amizade era melhor de que quando eu estava na igreja, eu tava mais feliz. Não que eu seja contra o que eles pregam e o que eles falam, por opção minha! Hoje eu sou evangélico ainda, pentecostal, mas com algumas ressalvas, entendeu? E voltei para o fandango por causa desse círculo de amizades. Essa comunhão da turma, essa amizade, que é muito boa, né? Uma troca de amizade, de companheirismo, muito legal, que está se fortalecendo. Por isso eu voltei, não vejo maldade nem nada. Acho que não agride o meu conceito sobre Deus. É mais ou menos isso. (Edvaldo Oliveira, comunicação pessoal, 20/08/2019 - transcrição nossa)

Mesmo que determinados credos religiosos refutem folias, ajuntórios e violadas, percebe-se que o fandango caiçara e seus detentores de um modo geral não sinalizam quaisquer sectarismos de vertente dogmática, sendo sua prática aberta a todos aqueles que tenham interesse em participar.

A discussão acima mencionada, sobre a disseminação de notícias falsas nas localidades visitadas pela romaria, também se desenvolveu no grupo da tripulação, em 2019, depois que diversos canais de informação como o jornal O Estado de São Paulo, a revista Isto É e o canal Brasil 247 noticiaram um alerta sobre a Agência Brasileira de Inteligência (ABIN) e os comandos militares, publicizando-se atos de espionagem relativos aos recentes encontros entre cardeais brasileiros e o Papa Francisco no Vaticano para discutir a realização do Sínodo sobre a Amazônia. Previsto para outubro de 2019, o encontro reuniria em Roma bispos de todos os continentes para discutir a situação de povos indígenas, mudanças climáticas provocadas por desmatamento e questões ligadas a quilombolas e comunidades tradicionais amazônicas, temas secundários na agenda da gestão que se instalou no Brasil em 2016, sinalizando retrocessos nas esferas do meio ambiente, das políticas públicas para cultura e do desenvolvimento social, que 
incidem diretamente no cotidiano das populações caiçaras e na manutenção de suas práticas e modos de vida.

Entendemos que o diálogo com as comunidades visitadas pela romaria é fundamental, mas também que, devido à conjuntura, pode ser problemático. Perguntamo-nos qual seria a melhor maneira de se abordar tais assuntos quando surgem durante a peregrinação, sobretudo tentando entender o contexto micropolítico de nossos agenciamentos, sem depreciar nossos interlocutores. Como denunciar argumentos falaciosos sem usar termos amplamente difundidos pela grande mídia? Como desmistificar mentiras ditas e repetidas à náusea, como as "mamadeiras de piroca" ou o famigerado "Kit Gay"? ${ }^{155}$ Esses completos disparates se converteram em "verdades" pela repetição incessante, recuperando a conhecida máxima de Joseph Goebbels, ministro da propaganda na Alemanha nazista: "uma mentira contada mil vezes torna-se verdade".

Nas eleições de 2018, a expressão fake news entrou definitivamente no vocabulário brasileiro, quando se divulgaram à exaustão informações falsas, criadas deliberadamente para atingir um fim político.

Ainda sobre nossa discussão sobre condutas a esgrimir durante o período de romaria, retomo o "pequeno manual" proposto por Marcos Donizetti de Almeida (2018) sobre a crise política e social que reverbera em nossos afetos e nossas relações:

\begin{abstract}
A angústia, porém, pode ser combustível da ação, e cabe o questionamento a respeito do que pode ser feito para lidar com esse estado de coisas tentando permanecer minimamente saudável. O resultado dessa inquietação minha é o que chamo de pequeno manual de conduta e resistência a essa estratégia de controle do discurso e da libido tão facilmente identificável nas ações de quem investe nesse cenário de crise, insegurança e confronto generalizados. Não raro, vemos declarações de pessoas próximas ao presidente eleito falando em "guerra cultural", e não surpreende que a gestão da comunicação do novo governo, desde a campanha, tenha elementos de estratégia militar, de "guerra híbrida", o assim chamado firehosing. A atuação se dá em duas frentes: num primeiro nível, declarações cada vez mais estapafúrdias e revoltantes, sem nenhum compromisso com fatos ou lógica, com frequentes idas e vindas, com avanços aparentes e desistências. O objetivo aí é o controle da pauta. É uma maneira de controlar não só a imprensa, e essa tem sido a estratégia de Trump desde o início de seu mandato, como também os temas das conversas nas ruas, bares e condomínios. O uso das postagens em massa impulsionadas no WhatsApp de maneira supostamente ilegal é o dado novo e até o momento um grande diferencial do firehosing à brasileira. [...] Quando eu compartilho uma fala do presidente dizendo "olha o absurdo que ele está falando", minha
\end{abstract}

\footnotetext{
${ }^{155}$ Essas talvez tenham sido as mais absurdas mentiras veiculadas durante o período eleitoral e que tomaram feições de verdade depois de sua reprodução massiva. Os termos dão conta de supostas mamadeiras com bico em formato de pênis que estariam sendo distribuídas em creches, assim como de um kit destinado a crianças do ensino básico cujo conteúdo principal seria a apologia da homoafetividade.
} 
indignação implica direcionamento de energia para esse fato, um consumo de libido, e consigo até mesmo algum gozo, uma satisfação secreta e mesmo inconsciente, na captura também da indignação do meu grupo, garantida pelo algoritmo no caso das redes sociais. Há uma sensação de pertencimento mesmo nos afetos negativos vivenciados coletivamente.

Tais questões geram tensionamentos e rupturas de interação pelo viés político e ideológico. É corrente excluir das redes sociais perfis com pontos de vista divergentes, o que estreita ainda mais o contato com espectros próximos a nossas próprias ideias, incidindo na conectividade social e na segurança social nos termos de Pearson et. al. (2009).

O trânsito de mercadorias diversas no âmbito internacional afeta o cotidiano caiçara de diferentes formas: a introdução de capital estrangeiro, como aconteceu recentemente na compra de ações de grandes managers do transporte transatlântico para a aquisição do Terminal de Conteineres de Paranaguá por acionistas chineses, é apenas um exemplo. A ampliação de berços de atracamento e o consequente aumento do fluxo de caminhões são outra pequena parte do projeto de ampliação do setor portuário em curso no litoral do Paraná. Tanto detentores do patrimônio imaterial quanto a população em geral sofrem consequências nem sempre bem mensuradas. A suspensão de material particulado no ar, epidemias de doenças causadas por insetos e roedores e o declínio da qualidade de vida das populações que vivem essa realidade é sentido no drástico aumento de problemas respiratórios, no recente surto de dengue, Zika e Chikungunya, além de alarmantes índices de violência, tráfico de drogas e prostituição, ambiente propício para o aumento da criminalidade em cidades portuárias.

\footnotetext{
Eles prendem malha cinco

E prendem meu gerival

Não deixam mais dar um cerco

Não deixam cortar um pau

Liberam a pesca lá fora

Dizendo que não faz mal ${ }^{156}$
}

Apesar do chiste nessa moda, a realidade aguça a melancolia; diminui a oferta pesqueira, e a pesca artesanal é cerceada, enquanto grandes embarcações internacionais beiram nossa costa e, sem maiores entraves, extraem peixes na ordem das toneladas, valendo-se de tecnologia de ponta e redes de arrasto e sob as atribuições legislativas que os salvaguardam, sabendo-se que menos de $1 \%$ das águas internacionais estão protegidas atualmente.

156 “Moda da força verde”, composição de Aorélio Domingues e Ivo Costa. 
Segundo o ecologista marinho Enric Sala, cinco países capturam três quartos de toda a pesca feita em águas internacionais: China, Taiwan, Coreia do Sul, Japão e Espanha. Com pesquisas bem fundamentadas, ele esclarece:

Se a pesca fosse fechada em todas as águas internacionais, todos os peixes que seriam produzidos a mais e que migrariam para as regiões econômicas exclusivas dos países beneficiariam muito mais países. Apenas alguns têm frotas de longa distância. E essas frotas pescam peixes que não entrarão nas águas dos países pobres (ANSEDE, 2017).

Na mesma entrevista, Enric Sala comenta diversos aspectos da pesca predatória em âmbito internacional, do trágico e insustentável modelo de produção do camarão no sudeste asiático e da corrupção instalada nos órgãos internacionais de controle, assim como da política superexploradora inaugurada pelo governo de Donald Trump nos EUA, que sugere a abertura de áreas de proteção ambiental e santuários marinhos para exploração petrolífera para proveito de especuladores dessa commoditiy “à custa desses ecossistemas incríveis". Encerra-se a entrevista nos seguintes termos:

Continuamos com o mesmo problema: não pagamos o verdadeiro custo das coisas, o custo ambiental. As pessoas que estão pagando gasolina barato nos EUA não estão pagando o custo dessa gasolina. O custo é pago pela criança que vai morrer de asma devido à poluição na cidade em que vive. $\mathrm{O}$ que fazemos é terceirizar os custos. Se todo mundo, incluindo as grandes empresas petroleiras, tivessem de pagar o custo do uso dos recursos naturais, o mercado teria solucionado os problemas. Teríamos inovado rapidamente para reduzir as emissões (ANSEDE, 2017).

Além das já mencionadas ampliações de portos e construção de estradas que ferem um dos mais ricos resquícios de Mata Atlântica e da biodiversidade marinha do planeta, segue em fluxo, alinhada com o neoliberalismo monetizado, a implementação de políticas que flexibilizam leis ambientais e desconsideram aspectos étnicos e culturais das populações que vivem nessas localidades. As guerras híbridas e o firehosing à brasileira têm demonstrado eficácia nesse desastre, difundindo desinformação e posicionamentos levianamente polarizados, em que discussões estapafúrdias mascaram os reais interesses de corporações e conglomerados transnacionais, interesses que fogem ao entendimento do cidadão comum mas que acabam por se refletir no cotidiano que os presentifica. Em nosso pequeno recorte, a crescente contaminação das baías e canais, a diminuição da oferta pesqueira na região estuarina e no lagamar, assim como o declínio da biodiversidade, têm impacto direto na vida cotidiana das populações caiçaras na atualidade. O "capitalismo global”, ou "capitalismo mundial integrado", ou ainda o interesse "capitalístico", vêm usurpando a pulsão de vida e subjugando 
as subjetividades a partir de todos os recursos que tem à mão. São tempos de hipervigilância (LIPOVETSKI, 2004): não só as “paredes têm ouvidos”, como também os gadgets que levamos no bolso.

\title{
O virtual como dimensão do concreto
}

\author{
Portanto, a transição do "possível" ao "real" ocorre \\ durante o ato de observação. \\ Heisenberg, 1981 \\ E quanto ao sujeito, como fazer para nos descolar dos \\ pontos de subjetivação que nos fixam, que nos pregam \\ numa realidade dominante? \\ Deleuze e Guattari, 2012
}

A distância que ora se antepõe entre a subjetividade da teorização filosófica e a experimentação materialista (objeto da física da matéria condensada e da física teórica), já não parece gerar tanto antagonismo, enunciado que nos convida a analogias e metáforas.

A descoberta do bóson de Higgs, ou melhor, de sua assinatura, rastros energéticos que emanam de sua efêmera precipitação antes que decaia em fótons ou léptons (elétrons e múons) no interior de um acelerador de partículas, revela outra ótica do concreto existencial. Entendemos que o campo de Higgs se comporta de modo análogo ao devir filosófico, no que tange à fundamentação empírica da materialidade, formam-se campos e redes onde o virtual apresenta potência subjetiva. "No ano de 2012, a última partícula que completa o Modelo Padrão de Partículas Elementares, a teoria mais sofisticada sobre a natureza na história da humanidade, foi descoberta" (GELMINI, 2014, p. 1).

Fora de seus círculos mais restritos, o desenvolvimento tecnológico não raro suscita estranhamento, como se buracos negros e estrelas de nêutrons fossem conceitos imaginários que emergem de um conto ou de um romance ficcional, como se a relatividade restrita e geral fossem teorias distantes de nossa realidade, como se aparelhos celulares e gadgets de localização não sincronizassem seus relógios com os dispositivos atômicos instalados nos satélites que orbitam nosso planeta. 
Figura 7.5 - Modelo padrão da Física de Partículas

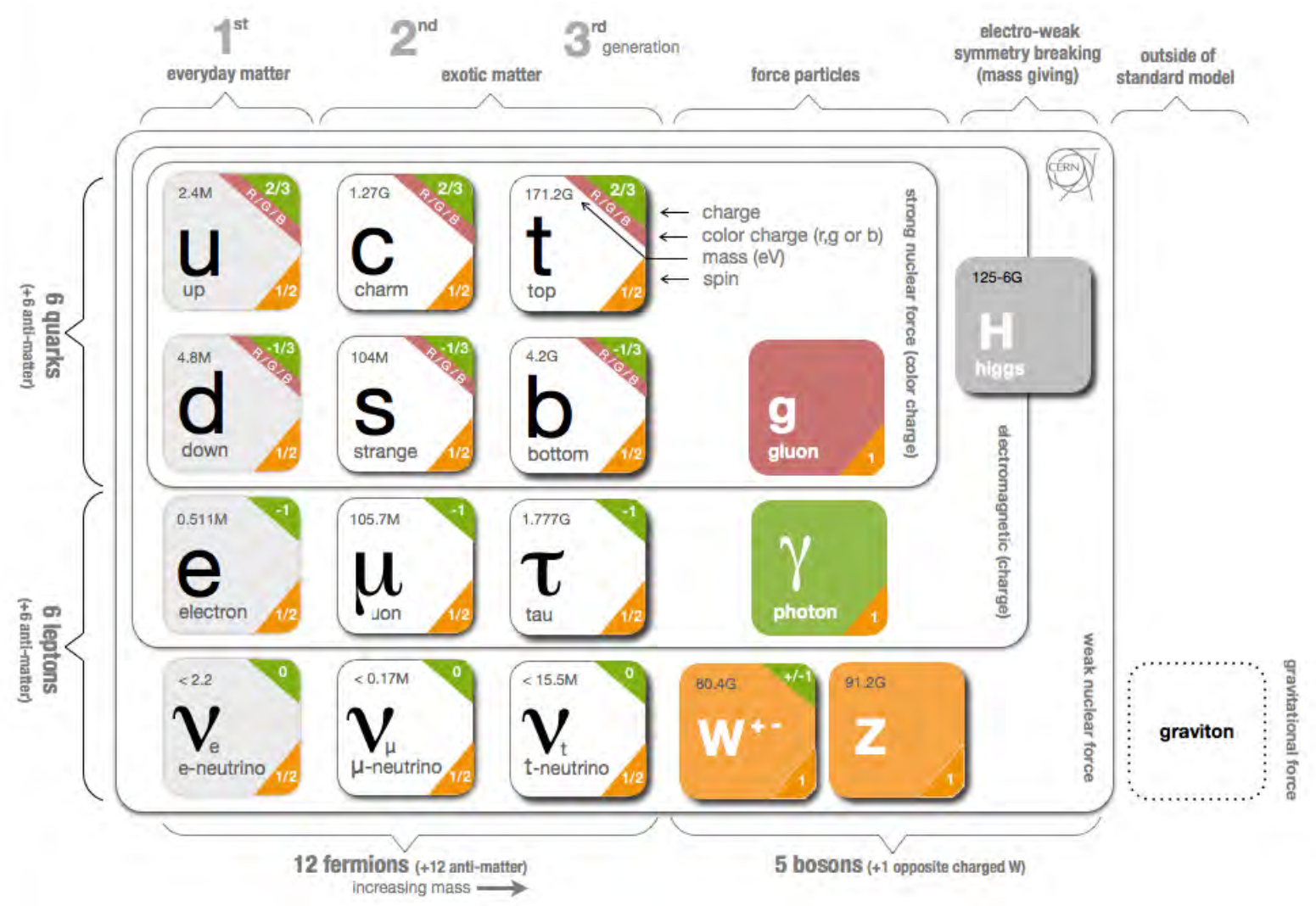

Fonte: CERN Bulletin. ${ }^{157}$

Desconstruir a distância epistemológica dessas realidades implica aproximar o público em geral daquilo que ele já vivencia cotidianamente. Mesmo que muitas vezes pareçam ininteligíveis a possibilidade da manipulação fotônica em feixes de laser, o ordenamento de emaranhados quânticos para o teletranspote ${ }^{158}$ de pacotes de informação ou a medição das oscilações de frequência nos precisos relógios de césio, talvez a fibra ótica, os tomógrafos computadorizados, os aparelhos de ressonância magnética e, em última análise, os aparelhos celulares nos aproximem desse turbilhão de informações e do uso indiscriminado de ferramentas cujo princípio básico é a manipulação eletromagnética e temporal. Os atores

157 O infográfico do modelo padrão foi desenvolvido no Webfest 2012 (CERN), onde alunos do Citizen Cyberscience Centre (CCC) e da Peer 2 Peer University desenvolveram o projeto para explicar o modelo padrão numa ordem intuitiva para pessoas com pouca familiaridade com física ou matemática, apresentando conceitos complexos de forma lúdica e interativa (CERN Bulletin, [2012]).

158 "Na verdade, não ocorre um teletransporte como vislumbrado por muitos escritores de ficção científica. Ou seja, o qbit de Alice não é "desmaterializado" e em seguida "materializado" onde Bob se encontra. A entidade que é teletransportada nesse processo é o estado quântico, ou, numa visão de teoria de informação, toda informação nele contida. [...] Podemos entender o processo como se toda informação de um qbit fosse separada em duas partes, uma clássica e outra quântica. A parte clássica é transmitida pelos dois bits enviados por Alice, e a parte quântica viaja pelo canal EPR [Einstein, Podolky e Rosen], consumindo um estado de Bell ou um ebit (entangled bit)" (RIGOLIN, 2005, p. 10). 
mencionados neste trabalho são usuários contumazes dessa ferramenta, mesmo aqueles de mais idade, e ainda outros que moram em localidades mais isoladas, e que, em todos os casos, recorrentemente expressam suas opiniões, anseios e vicissitudes pelos grupos de WhatsApp.

A manipulação e o controle do tempo mensurado se dão em relação à frequência e à energia, seara que aproxima nossa aventura crono-reflexiva caiçara do mundo subatômico. São aspectos de nossa realidade que podem ser mais atraentes às nossas conjecturas do que inicialmente poderíamos supor; metáforas do tempo presente na interação social, cultural e artística de atores diversos, incluídos aí os detentores do bem imaterial fandango caiçara. Eleonora Fabião (2010, p. 322) transpõe tais dilemas relativos ao tempo e à presença para a prática performática:

O fluxo abre uma dimensão temporal: o presente do presente. A capacidade de conhecer e habitar este presente dobrado determina a presença do ator. Perder-se nos arredores do instante - na ansiedade do futuro do presente ou na dispersão do passado do presente - faz com que o agente se ausente de sua presença. A qualidade de presença do ator está associada à sua capacidade de encarnar o presente do presente, tempo da atenção. O passado será evocado ou o futuro vislumbrado como formas do presente.

Embora soem como metáfora crono-reflexiva, essas questões são experimentalmente consideradas no âmbito da física da matéria condensada. Inaugurada por Niels Bohr em 1913, a mecânica quântica é mais bem formulada por Werner Heisenberg e Erwin Schrödinger em 1925 e 1926. As diferentes abordagens eram equivalentes e surgem da necessidade de explicar tanto a estabilidade dos átomos quanto as características de emissão e absorção da energia que só se dá em quantidades discretas.

A ideia revolucionária da mecânica quântica é que a posição de uma partícula não pode ser determinada com precisão, mas apenas por probabilidades de localização. O abandono do determinismo para escalas subatômicas teve consequências revolucionárias no pensamento científico e filosófico do início do século XX.

Mesmo que pareça inusitado o trânsito nos domínios da física, da psicologia e da filosofia no trabalho de cunho etnomusicológico, esses domínios vêm enriquecendo as discussões na área desde sua fase germinal. (BASTOS, 1995).

Como vincular ideias já consolidadas como símbolos arquetípicos, teorias políticas ou campos gravitacionais de baixa energia ao trabalho de campo e à reflexão etnomusicológica? A criação e disseminação de ferramentas computacionais parecem colaborar com o pleito levando-nos ao olho do furacão, onde a percepção subjetiva deixa rastros, assinaturas e resquícios mensuráveis. 
Ao aludirmos a um "conjunto infinito de energias sonoras", como propõe Benenzon (2008), poderíamos ainda acrescer e correlacionar aos aspectos acústicos e de movimento à informação táctil vibracional ou, em última análise, em termos estritamente materialistas e dependentes da causalidade, sondar informações inerentes à estrutura atômica e molecular do indivíduo, que retém informação em diferentes camadas, proporcionais às forças de interação no âmbito das forças nucleares forte e fraca, eletromagnética e gravitacional em que se dão as perturbações eletrobiofísicas no corpo humano. Experimentos no campo da percepção de ruídos, como em Vinnik, Itskov e Balaban (2011), por exemplo, demonstram que a suscetibilidade individual à descontinuidade ilusória de estímulos sonoros está correlacionada com a magnitude das respostas fisiológicas às explosões de ruído quando apresentadas com ou sem um tom concorrente (figura 7.6). Conclui-se que as diferenças de eletroencefalogramas relatadas em suas pesquisas refletiam a função dos processos neurais básicos que modulam a suscetibilidade à ilusão.

Os participantes muito suscetíveis a essa descontinuidade ilusória não perceberam a continuidade auditiva ilusória (na qual um som subjetivamente continua durante uma explosão de ruído de mascaramento) quando os ruídos eram curtos, mas o fizeram quando o ruído durava mais (VINNIK; ITSKOV; BALABAN, 2011, p. 11-12).

Figura 7.6 - ERP alinhado ao surgimento de rajadas de ruído

a

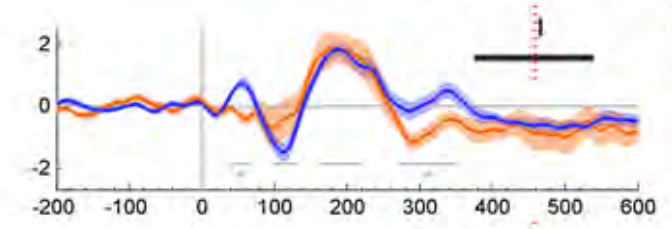

d
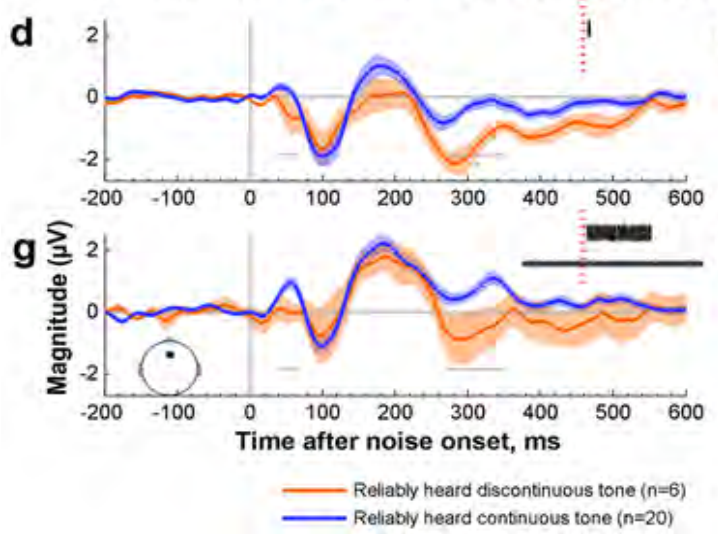

Fonte: (VINNIK; ITSKOV; BALABAN, 2011, p. 11) 159 b

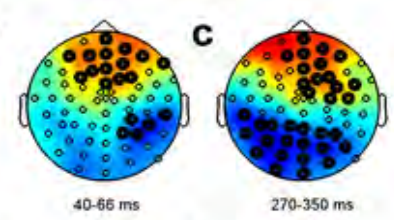

e

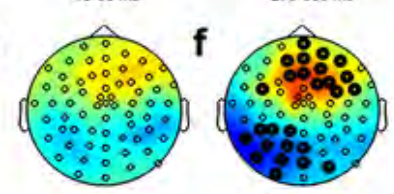

h

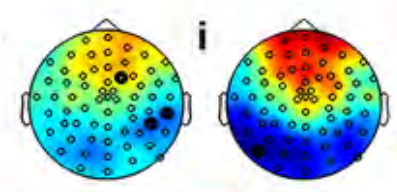

․

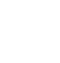


Indicando a segregação acústica ${ }^{160}$ como importante função psicoacústica de nosso aparato auditivo, no estudo, o uso da tecnologia computacional e de eletroencefalogramas fundamenta e apresenta na forma de imagens um conjunto de informações relativas à coleta de dados laboratoriais. Fatos tambéns constatados nas pesquisas de Sänger, Müller e Lindenberger (2012) indicando que oscilações síncronas dentro de e entre cérebros atuam de modo funcional no desempenho musical (figura 7.7).

Tais resultados foram obtidos a partir do monitoramento da performance de dois violonistas tocando repetidamente um dueto em duas vozes, que a partir de um modelo conjunto, interpessoalmente compartilhado, segundo os autores, podem ajudar a iniciar e manter a coordenação da ação interpessoal.

Essa coordenação da ação interpessoal durante a realização de fandangos pode ser visualizada corriqueiramente quando pares de fandangueiros se aprumam para iniciar a cantoria (configuração do andamento preparatório); apesar da estrutura fixa das toadas expressas nas linhas melódicas de modas bailadas e das marcas batidas, de modo geral, há um leve tensionamento entre os cantores ao início de cada verso. Se entendemos a execução da primeira voz como "líder" e da segunda voz como "seguidor", não seria de se espantar, que em meio à violadas fandangueiras, obtivéssemos resultados comparáveis aos gráficos apresentados na figura 7.7.

Diferente do estudo acima descrito, em que os músicos tinham prévio conhecimento da peça a ser executada (no caso um Rondó em Ré-Maior de C.G. Scheidler), os versos a serem executados por fandangueiros, em boa parte dos casos, refletem as memórias-contração e as memórias-lembrança expressas no instante presente e materializadas pelas emissões em terças das vozes.

\footnotetext{
ruído de $50 \mathrm{~ms}$ sozinho. $\mathrm{g}$, h, i ruídos de $1.000 \mathrm{~ms}$ juntamente com o tom. As linhas são médias de grupo e as áreas sombreadas são erros padrão. As linhas cinzas horizontais denotam janelas de tempo de interesse. Os asteriscos cinzentos próximos a elas indicam a correlação significativa entre magnitude e desempenho (VINNIK; ITSKOV; BALABAN, 2011, p. 11 - tradução nossa).

${ }^{160}$ A experiência baseada em padrões de frequência, timbre e comodulação permite que os ouvintes tratem sons que vêm de diferentes objetos como fontes auditivas dinamicamente separáveis (como a voz de uma única pessoa que emerge do ruído de fundo num coquetel ou linhas melódicas independentes) (VINNIK; ITSKOV; BALABAN, 2011, p. 11-12).
} 
Figura 7.7 - Diagramas de tempo-frequência (média do índice de bloqueio de fase) dos eletrodos frontais para líder (Leader) e seguidor (Folower) durante a configuração do andamento preparatório e em torno de ataques coordenados
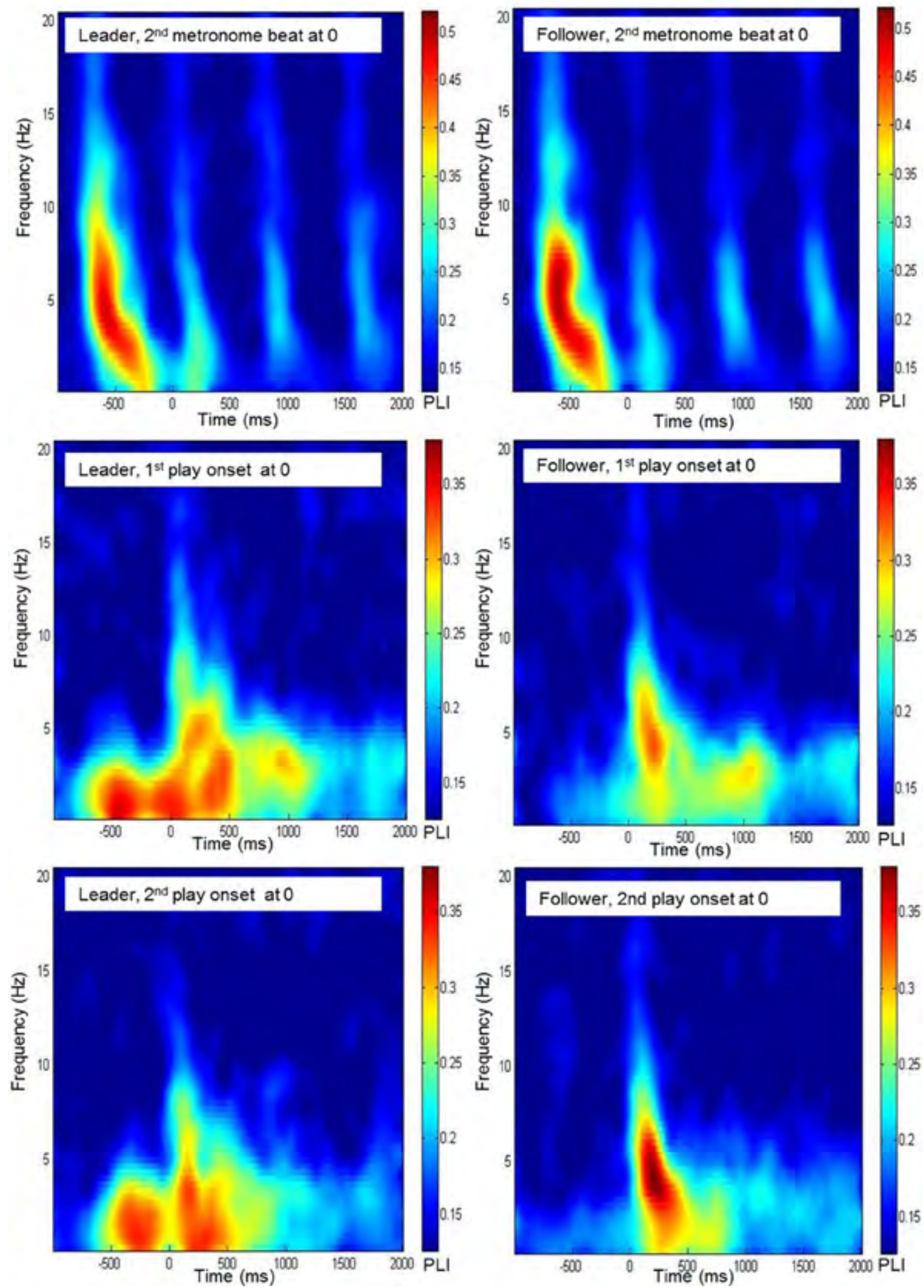

Fonte: Sänger, Müller e Lindenberger (2012, p 5) 
As frequências vibracionais e seus análogos visuais oferecem vasto conteúdo para análise, desde os eletroencefalogramas e espectrogramas de áudio aos mais sofisticados experimentos subatômicos levados a cabo por aceleradores de partículas.

A excitação de campo, no caso do bóson de Higgs, nos esclarece o conteúdo material como efêmera singularidade, e o emaranhamento quântico nos dá a possibilidade de compartilhar informação de modo instantâneo e a longa distância. A realidade, tal qual a vivenciamos, pode ser redimensionada consonante a tais desenvolvimentos.

Essa assertiva respinga em todas as áreas de nosso conhecimento, que desde tempos imemoriais vêm sendo gradativamente construídas quase sempre pela experiência, com seus padrões indeterminados de acerto e erro. De que tipo de redes de interação rizomáticas deleuzianas poderemos falar quando os campos de interação neural forem escrutinados de modo análogo aos emaranhados quânticos e às colisões de hádrons? Nossa epistemologia semiológica haverá de abarcar novos elementos para além do signo, do significado e do significante, atentando também para a singularidade probabilística.

Percebemos o campo quântico bosônico análogo ao campo de imanência do desejo, plano de consistência que figura na construção teórica do Corpo sem Órgãos [CsO] deleuziano: por um lado, a emergência da materialidade, por outro, a da subjetividade.

\begin{abstract}
O problema não é mais aquele do Uno e do Múltiplo, mas o da multiplicidade de fusão, que transborda efetivamente toda oposição do uno e do múltiplo. Multiplicidade formal dos atributos substanciais que constitui como tal a unidade ontológica da substância. Continuum de todos os atributos ou gêneros de intensidade sob uma mesma substância, e continuum das intensidades de um certo gênero sob um mesmo tipo ou atributo. Continuum de todas as substâncias em intensidades, mas também de todas as intensidades em substância. Continuum ininterrupto do CsO. O CsO imanência, limite imanente. Os drogados, os masoquistas, os esquizofrênicos, os amantes, todos os CsO prestam homenagem a Espinosa (DELEUZE; GUATTARI, 2012, p. 17).
\end{abstract}

Por estarmos imersos nesses campos, sejam bosônicos ou de consistência, experimentamos devires quânticos e ontológicos, onde ocasionalmente as energias que os constituem são transferidas por diferentes estados de excitação.

Nos relacionamos de modo integrado a esses campos para que se viabilize nossa experiência existencial como seres humanos. Tais postulados indicam a necessidade de reorganizar amplamente a própria concepção de existência no espaço-tempo, como entendemos a matéria e como interagimos no mundo, não apenas no que tange às relações humanas, mas para além daquilo que se pode mensurar em nosso momento histórico, em que comunicação e interação se revertem em energia, em que, além de expressar em ações e palavras suas pulsões 
e seus agenciamentos, o indivíduo transmite também informação a partir das perturbações eletromagnéticas que emanam continuamente de suas redes sinápticas. É uma superfície topológico-relacional nos termos de Rolnik (2018), em processo contínuo de composição, feita de toda espécie de corpos (humanos e não humanos) em conexões variadas e variáveis cujas duas faces indissociáveis se apresentam como forma e como força.

A compreensão do conceito de excitação em física da matéria condensada incide tanto na investigação de fônons em espalhamentos cristalinos quanto na teoria de campos. Assim como os indicativos da concretude das ondas gravitacionais, a comprovação do campo de Higgs inserem novos parâmetros no entendimento da realidade tida como material. A rede informacional artificial que se estende, não apenas pelo cabeamento ótico, mas pelo espaço que nos rodeia a partir de antenas de sinal, repetidores e satélites em órbita já cobre áreas consideráveis de aglomeração humana. Historicamente, essas emissões têm início a partir das tecnologias de radiofrequência previstas por Maxwell e geradas experimentalmente por Hertz em fins do século XIX; a partir daí, alcançam também localidades geograficamente isoladas. Desde então, têm sido utilizadas tanto para povoar imaginários humanos com sonoridades diversas, quanto para sujeitar sua realidade - em vista do papel que teve a radiodifusão tanto na consolidação e divulgação de musicalidades e sonoridades quanto na conjuntura belicista inerente aos dois grandes conflitos mundiais travados na primeira metade do século XX.

Aventamos a possibilidade de se desvelarem novos campos de interação no sentido quântico do termo, onde pulsão vital, pertencimento, macro e micropolítica alçam patamares energéticos de vórtex, excitados a partir da dinâmica das frequências individuais e coletivas que compõem as socialidades, as sociabilidades e as demais dimensões interacionais experimentadas pelo componente humano neste efêmero recorte espaço-temporal.

Sentada numa esquina do bairro paulistano de Higienópolis, atenta à complexidade da ocupação popular em lugares dominadas por padrões eletizados de consumo, Suely Rolnik sugere ponderações que podem corroborar o que hipoteticamente propõe nosso argumento:

A experiência é sempre uma experiência subjetiva, e essa experiência subjetiva tem muitas dimensões, mas tem duas dimensões fundamentais, que estão sempre em tensão, porque elas são totalmente distintas. A percepção que vê o concreto vê o que está ali, como volume, forma, textura, mas eu tenho uma outra experiência. Ela não é o que eu percebo visualmente ou auditivamente, como forma, volume, cor e tal, mas é do efeito que aquela presença produz em mim. Porque é uma presença viva, e eu sou um corpo vivo. Então, não é minha experiência estruturada segundo meu repertório cultural, que é muito importante para eu me situar socialmente e poder me comunicar, mas é a experiência do meu corpo vivo, do efeito que isso produz em mim. E aí não tem nada ver: "ai, que lindo ou que feio", "isso é verde"... 
É como se o olho tivesse a retina que se liga com o nosso repertório cultural, ao mesmo tempo, o olho é afetado por aquilo que ele vê, os ouvidos são afetados, nosso corpo é afetado por aquilo que vê. Aí, isso produz um estado distinto, um estado novo. Esse estado é como se a gente estivesse sendo fecundado pelas forças do corpo vivo do que está nos afetando. E isso nos fecunda e produz uma espécie de embrião de mundo. Embrião de futuro, de outra forma de ser, viver e existir. Os Guarani usam o termo Teko Porã, quer dizer bom, belo. Porque, para os Guarani, tudo o que é bom para a vida é belo. Tudo que é belo, é belo porque é bom para a vida. E a palavra "Teko vai" é feio e ruim. Tudo o que é ruim para a vida é feio, tudo o que é feio é feio porque é ruim para a vida. Então, desse ponto de vista, isto aqui não é apenas "Não vamos ter preconceito de classe". É o mínimo, alguém minimamente são. Não, tem uma outra coisa. Aqui, eu sinto Teko Porãa, nessa esquininha. E esse Teko Porã me traz muita alegria, que é diferente de felicidade. Me traz alegria, me traz algo que eu nem sei dizer o nome.

Pra conquistar espaços de Teko Porá, a gente quer poder conviver com tudo o que tá ali, porque a gente não se liga no outro por identificação, a gente se liga porque tem uma reverberação de frequência de afeto e de embrião de mundo (ESPAÇOS TEKO PORÃ, 2018, 0’03"' 7'09” - transcrição nossa).

Cabe considerar aqui aspectos menos usuais no nosso entendimento do meio biótico em que estamos inseridos. As interações se dão em muitas e diferentes camadas de subjetivação, aquelas eidológicas, outras etológicas e ainda aquelas quânticas, sem as quais não haveria substrato cognitivo ou emocional, ao menos na experiência vivencial quadridimensional na qual nos encontramos.

Bateson denomina platôs as regiões de intensidade contínua, que são constituídas de tal maneira que não se deixam interromper por uma terminação exterior, como também não se deixam ir em direção a um ponto culminante: são assim certos processos sexuais ou agressivos na cultura balinense. Um platô é um pedaço de imanência. Cada CsO [Corpo sem Órgãos] é feito de platôs. Cada CsO é ele mesmo um platô, que se comunica com os outros platôs sobre o plano de consistência. É um componente de passagem (DELEUZE; GUATTARI, 2012, p. 23).

Potencialmente, as redes virtuais digitais, tidas como dimensões concretas de aprendizado e interação, modelam reviravoltas paramétricas na construção e na desconstrução de estruturas culturais e, apesar de púberes - dado que o uso massivo da www só se consolidou nas últimas quatro décadas -, vêm afetando direta e indiretamente a macropolítica em âmbito global. Tomados como análogos à dimensão concreta exposta pelas redes virtuais, o constructo junguiano de inconsciente coletivo ou a ideia de inconsciente colonizado sugerida por Rolnik e Guattari nos aproximam dos campos de excitação da física subatômica, campos que, quando excitados, modelam a realidade concreta objetiva e subjetivamente, em todos os casos atravessados pela não linearidade da experiência espaço-temporal quadridimensional. 
Evidenciados os campos e os dispositivos de Higgs, se nos apresenta a ideia de que camadas, platôs ou campos com diferentes estruturas dimensionais podem ser mensurados e avaliados em laboratório, afastando-nos de antemão de premissas místicas ou daquelas que não encontram eco naquele mundo academicista norteado pela experiência positivista da realidade. Tekó porã, embrião de mundo, pulsão vital seriam apenas novas formas de dizer as velhas coisas.

Apesar de hoje a teoria parecer elegante, sobretudo pela descoberta do dispositivo de Higgs, críticos mais exigentes como Teller (1995) ou Seibt (2002) mostram que ainda há muitas lacunas a serem preenchidas, inclusive no sentido ontológico corpuscular que orienta a teoria quântica. E parecem estar justamente aí os componentes que nos aproximam dos axiomas deleuzianos mencionados acima.

Na minha opinião, a ontologia não é um luxo a que podem renunciar as teorias físicas que aspiram a um caráter fundamental. Portanto, os esforços envidados ao longo dos anos para dotar a física quântica de uma ontologia coerente não são ociosos, e suas armadilhas indicam apenas que talvez tenhamos que olhar em outra direção. Afinal, as noções de corpúsculo e campo estão ligadas ao nível macroscópico como uma idealização dos objetos de nossa experiência. E a teoria quântica de campos representa a tentativa de obter um híbrido fértil da união entre os dois. Mas o mundo quântico difere de nossas expectativas empíricas usuais, aponta para uma realidade diferente e, sem dúvida, precisa de novos objetos básicos para sua ontologia. Precisamos de um novo elemento fundamental - ou de vários -, cujas características nos permitam elaborar uma ontologia comum para o espaçotempo, a matéria e suas interações. As tentativas frustradas de reduzir a matéria às relações espaço-temporais e vice-versa sugerem fortemente que poderia haver um substrato subjacente, uma ontologia compartilhada de cuja riqueza fenomenológica as perplexidades quânticas são uma manifestação ${ }^{161}$ (BERENGUER, 2011, p. 40, tradução nossa).

Apesar dos avanços e do êxitos de fundamentar o modelo padrão indicando o "novo elemento fundamental" invocado por Berenguer, ainda estamos longe de uma teoria unificada que dê conta de conjugar a interação das forças forte e eletrofraca em consonância com a interação gravitacional, e tampouco se nos explicou a hierarquia das massas dos léptons e

\footnotetext{
161 “A mi juicio, la ontología no es un lujo del cual puedan prescindir las teorías físicas que aspiran a un carácter fundamental. No son ociosos, pues, los esfuerzos realizados a lo largo de los años por dotar a la física cuántica con una ontología coherente, y sus escollos tan solo indican que quizás debamos buscar en otra dirección. Al fin y al cabo las nociones de corpúsculo y campo vienen ligadas al nivel macroscópico como idealización de los objetos de nuestra experiencia. Y la teoría cuántica de campos representa la tentativa de obtener un híbrido fértil de la unión entre ambas. Pero el mundo cuántico diferente de nuestras expectativas empíricas usuales, apunta a una realidad distinta y sin duda precisa nuevos objetos básicos para su ontología. Necesitamos un nuevo elemento fundamental - o varios - cuyas características permitan elaborar una ontología común para el espacio-tiempo, la materia y sus interacciones. Los fracasados intentos de reducir la materia a relaciones espacio-temporales y viceversa, sugieren poderosamente que podría existir un sustrato subyacente, una ontología compartida de cuya riqueza fenomenológica las perplejidades cuánticas son una manifestación” (BERENGUER, 2011, p. 40).
} 
quarks, seja sua repetição em três gerações, seja a hierarquia dentro de cada geração, ou ainda uma explicação da carga relativa do elétron e dos quarks, fato que assegura que os átomos tenham carga elétrica neutra, e nem o porquê de a matéria atômica estável no universo ser feita apenas de átomos, e não de antiátomos (GELMINI, 2014, p. 18). Mais do que isso:

Finalmente, o tipo de matéria composta de átomos constitui menos de 5\% do conteúdo do Universo. $23 \%$ do conteúdo estão na forma de "matéria escura", um tipo de matéria que não absorve nem emite luz de nenhum tipo e para a qual não há candidatos no modelo padrão, e os $72 \%$ restantes são de forma mais exótica ainda, a "energia escura", que, ao contrário da matéria, tem interações gravitacionais repulsivas e para as quais ainda não existe um modelo teórico (tradução nossa). ${ }^{162}$

Assim como os grandes esforços destinados à melhor compreensão de campos tão inexplorados quanto o da composição dos elementos que compõem o cosmos que nos rodeia, também encontramos ainda inúmeras lacunas nos estudos que tentam escrutinar as estruturas, o funcionamento e as funções do cérebro humano. Emissões neurais sinápticas norteiam os impulsos de frequência que indicam estados de vigília ou de sono, estados em que se podem acessar reminiscências, significadas de formas análogas por diferentes indivíduos e que guardam em si elementos universais, arquetípicos:

Quanto mais pesquisamos as origens de uma "imagem coletiva" (ou, para nos expressarmos em linguagem eclesiástica, de um dogma), mais vamos descobrindo uma teia de esquemas de arquétipos aparentemente interminável que, antes dos tempos modernos, nunca haviam sido objeto de qualquer reflexão mais séria. Assim, paradoxalmente, sabemos mais a respeito de símbolos mitológicos que qualquer uma das gerações que nos precederam. A verdade é que os homens do passado não pensavam em seus símbolos. Viviam-nos e eram inconscientemente estimulados por seu significado (JUNG, 1969, p. 81).

O corpo vibrátil é capaz de significar imagens e símbolos acessados inconscientemente, emite e recebe sinais das mais variadas fontes, interagindo continuamente com o ambiente e com os demais indivíduos que o cercam, tanto virtualmente como face a face, percebendo e decodificando diferentes gamas de frequências, sejam elas sonoras, luminosas ou térmicas. "A energia dos arquétipos pode ser concentrada (através de ritos e outros apelos à emoção das massas) com o objetivo de levar as pessoas a ações coletivas". A novidade é a velocidade do

\footnotetext{
162 "Finalmente, el tipo de materia compuesta por átomos constituye sólo menos del $5 \%$ del contenido del Universo. Un $23 \%$ del contenido está en la forma de "materia oscura", un tipo de materia que no absorbe ni emite luz de ningún tipo y para la cual no hay candidatos en el ME, y el 72\% restante está en una forma más exótica todavía, la "energía oscura", que, contrariamente a la materia, tiene interacciones gravitacionales repulsivas y para la cual no hay ningún modelo teórico todavía” (GELMINI, 2014, p. 18).
} 
fluxo de informação. Movimentos autoritários, fascistas ou xenófobos, como o nazista, não apenas tinham ciência do poder imanente de tais energias como "utilizavam diversas versões de mitos teutônicos para arregimentar o povo para a sua causa" (JUNG, 1969, p. 79).

A percepção antigravitacional do fônon coloca o fenômeno sonoro vibracional (em âmbito subatômico) em correlação com o efeito onda corpuscular da luz. Os desenvolvimentos posteriores à validação teórica da mecânica quântica, da incerteza e da relatividade seguem sendo atualizados continuamente, modificando parametricamente a experiência humana desde o início do século XX.

O éter platônico foi atualizado e sobrescrito empiricamente pelas subpartículas, quasepartículas, antipartículas, ondas eletromagnéticas e gravitacionais; somos continuamente atravessados por formas diversas de energia e com elas mantemos interações. O devir, ente tão caro à filosofia contemporânea, pode ser observado de modo análogo à iminência do salto quântico, em que campos de bósons tomam formas materiais palpáveis estruturando simetrias cristalinas de onde emergem as materialidades minerais e orgânicas que tocam a percepção humana em seus aspectos eidológicos (cognitivos) e etológicos (afetivos emocionais).

Seriam os agenciamentos caiçaras, suas festas e peregrinações devocionais fendas espaço-temporais?

O ajuntório de agentes diversos delimitado por interesses comuns, afetos, afectos e ideais estabelecidos e compartilhados por coletivos de atores caiçaras desde a idealização dos encontros, da interação necessária à produção das festas, das articulações locais e regionais, do deslocamento, da logística e a experiência compartilhada proporcionam, aos presentes, picos de excitação de campo.

As memórias, os afetos e as experiências catárticas que se somam às demais transduções neurobioeletroquímicas geram e armazenam informação perceptiva análoga aos princípios do entrelaçamento quântico, assim como a metonímia de Merleu-Ponty mencionada por Eleonora Fabião (203, p. 29) ao presentificar a interação na ação cênica:

O corpo vibrátil tende ao "entrelaçamento". O copo cênico conhece e se dá a conhecer por entrelaçamento. O espectador não é vidente e eu visível; somos ambos videntes e visíveis, tocantes e tocáveis, atores e expectadores. Vista do palco, a plateia é um espetáculo de estranha beleza. O entrelaçamento é justamente a condição que todo participante do evento teatral tem de, simultaneamente, ver-se vendo, ver-se sendo visto, ser visto vendo, ser visto vendo-se.

Percebemos os fluxos de interação humana como possibilidades concretas de excitação de campo no sentido quântico do termo. O escrutínio das redes neurais, dos novos componentes 
do modelo padrão e das interações gravitacionais repulsivas, próprias dos domínios da matéria e da energia escura, ainda farão com que se gaste muita tinta antes que cheguemos a conclusões plausíveis sobre o tema, questões das quais por hora nos evadimos.

Foi Anaxágoras que, mais de quatrocentos anos antes de Cristo, formulou a hipótese de que uma forma de energia ilimitada e autônoma ordenaria e constituiria o mundo sensível a partir da atividade intelectiva. Parece razoável o entendimento de nous como campo de consistência, em vista de que "o universo de Anaxágoras é posto em movimento não por amor e conflito, conforme pensava Empédocles, mas sim por nous, que podemos traduzir como "espírito", isto é, a intuição intelectual" (HEISENBERG, 1981, p. 33). O nous, atualizado e percebido como campo, sugere fissuras na dualidade filosófica de Anaxágoras, e nos aproximaria do mutualismo entre as experiências material e espiritual.

Experiências compartilhadas entre foliões do Divino Espírito Santo devido à rotina diária instaurada nos dias de peregrinação, podem nos servir de ilustração: a equalização do horário para despertar e preparar o Alvorada é orgânica. Inicialmente movidos por despertadores de aparelhos celulares, com o passar dos dias, sincronizam-se os relógios biológicos dos foliões. Mesmo retomadas as atividades cotidianas e tendo voltado os foliões às suas localidades de origem, seguem por dias o hábito de despertar para a Alvorada. Isso acabou inspirando uma brincadeira: os foliões postam determinados horários no grupo de WhatsApp quando por acaso percebem-na em seu aparelho celular. Seguiram-se postagens que temos denominado "hora cheia": 05h05, 13h13, 02h20, $01 \mathrm{~h} 11$ e assim por diante. Essa experiência vem gerando "coincidências" interessantes: postagens simultâneas e marcações sincrônicas, muitas vezes envolvendo peculiaridades e motivações dos envolvidos, acreditando haver algum sentido na prática autodirecionada à percepção e à modelagem do tempo, lapsos sincrônicos que permeiam fortes laços de afeto e amizade, já ilustrados anteriormente pela figura 1.2.

Além dos eventos de sincronicidade temporal compartilhada, a brincadeira acabou mantendo o grupo em constante diálogo, alimentado pela experiência da "hora cheia", que mais de uma vez rendeu conversas variadas e que ultimamente têm extrapolado o ambiente da tripulação cósmica e envolvido outros grupos comuns: amigos e familiares dos integrantes.

Efetivamente, as conversas nos grupos de WhatsApp e pelo Facebook se intensificam nos períodos de festa, sejam encontros de fandango, atividades do comitê de salvaguarda ou peregrinações religiosas. Tanto organizadores como participantes e convidados articulam agenciamentos que atingem seus picos durante os eventos e nos dias subsequentes, havendo acréscimos exponenciais no compartilhamento de fotos, vídeos, agradecimentos e discussões. Nesse sentido, parece haver um lapso espaço-temporal em que os agenciamentos e a força de 
trabalho se somam às atividades físicas e emocionais catárticas que beiram a exaustão, sobretudo para os organizadores e fandangueiros.

De modo mais amplo, desvinculado de modismos ou de procedimentos capitalísticos, que a partir de "guerras híbridas" manipulam e sujeitam as massas, sugerimos aqui vislumbrar um ponto de vista que privilegia a interatividade e a manutenção identitária de grupos e sociabilidades periféricas. A metáfora aqui delineada transfigura a intuição intelectual - nous em excitação de campo, de forma análoga às interações fundamentais da mecânica quântica, como processos empíricos que venham um dia tratar das interações fundamentiais de sociabilidade.

Para usar as palavras de Eleonora Fabião (2003, p. 26):

Imaginar transforma a matéria 


\section{CONSIDERAÇÕES FINAIS}

Nada de novo, nada. Lavoisier teve suas razões...

O autor

Ultimando a redação deste texto, retomo as questões iniciais que figuram no introito: que papel fazemos neste ínterim, lapso efêmero de interação com o outro e com o mundo? Procuro reorganizar as ideias como sugere Aorélio Domingues: "Não foram feitas inovações, foram feitas adaptações de ferramentas das necessidades. Nós não criamos nada: só adaptamos ferramentas". Cismogênese, inconsciente coletivo, inconsciente colonizado-capitalístico, campos de imanência e de consistência, identidade sonora, campos de interação bosônica, ontologia corpuscular - eis algumas das ferramentas passíveis de adaptação.

Das mais remotas memórias, inclusive as de fora da experiência cognitiva, encontramos reminiscências pulsantes de períodos diacronicamente remotos. Moaxajas, zegéis, rabecas e violas, estruturas, padrões, metapadrões e formas. A ideia de refrão e das métricas poéticas balizadas em quadras, décimas e sextilhas não só configura e sustenta a musicalidade caiçara, suas alterações e dinâmicas de divulgação e difusão, como pode ser observada em um semnúmero de ramos da música popular na atualidade, do lundu ao samba-funk, do romance ao tecnobrega, ao pop, ao rock, à world music. Não é à toa que se toca e dança o fandango, e que os bailes lotam e perduram até o amanhecer.

A subjetividade que envolve este bem cultural o torna efusivo, presente e dinâmico. Mesmo que a informação que antes dependia da oralidade para se difundir venha sendo transladada aos núcleos de silício, mesmo que o neoliberalismo monetarizado avance sobre direitos fundamentais ou sobre quaisquer outros ímpetos progressistas, não nos deixamos abater pela melancolia. Entendemos e sabemos que os movimentos cíclicos e circulares que inscrevem avanços e retrocessos como dinâmicas autorreguladoras - em última análise, feedbacks negativos, na acepção cibernética do termo - sustentam a vida em sociedade.

Perceber na riqueza de nossas mais caras tradições a iminência da pulsão de vida, da subjetividade que gera alteridades, nos alenta frente ao cotidiano desgastado pela ignomínia política inerente à conjuntura que se instaura. 
Perceber-se como sujeito que percebe é um aspecto basilar da alteridade que nos põe em movimento contínuo. Nos termos da cismogênese batesoniana, se nos impõe o "reconhecimento implícito de que o sistema contém uma ordem extra de complexidade, devida à combinação da aprendizagem com a interação das pessoas” (BATESON, 2008, p. 325), princípio que fundamentou a cibernética como ramo promissor da investigação científica. Ao enunciar o desenrolar dos acontecimentos, colocamo-nos em fluxo, inseridos em sólidas redes de criação e manutenção de subjetividades, percebendo a singularidade individual e as energias dispersas pelas sinapses neurais, ponto nevrálgico da interação e, consequentemente, da construção de subjetividades compartilhadas pelos princípios de sociabilidade instaurados pela estrutura cultural.

Padrões organológicos e poéticos árabes se conectam aos al-andaluzos, novos padrões são formulados e consolidados no novo mundo: padrões organológicos, poéticos e coreográficos fluminenses, paulistas e paranaenses se inter-relacionam configurando o fandango na contemporaneidade. Padrões sólidos que ocupam e modelam campos de imanência e de consistência, metapadrões que se deslocam analogamente aos novos paradigmas estruturais do modelo padrão e das críticas que se lhe dirigem, podem ser hipoteticamente percebidos como potência virtual que estrutura a percepção cognitiva e emocional de seus atores.

Ao traçar novas trajetórias e outras óticas sobre os mesmos temas, bens imateriais, agenciamentos de ordens múltiplas e atravessamentos micro e macropolíticos, ampliamos os mapas de influência e nominamos agentes e agências antes pouco considerados no cômputo da configuração caiçara: guaranis, jesuítas, mediadores culturais, guerras híbridas e os trânsitos comunicacionais de múltiplas vias. Componentes al-andaluzos, ibéricos, indígenas e africanos presentificam-se diacronicamente, muitas vezes ameaçados pela ótica de uma constituição macropolítica que se pretende hegemônica e que historicamente abomina vertentes outras que não as escritas e contadas pelos protagonistas de dominação. Não se trata de ignorar esses pontos de vista; pelo contrário, esses agentes afetam diretamente a conformação de nossa identidade, sobrepostos, incrustados numa miríade de outras camadas subjetivas, inconscientes, campos de imanência.

A opção pela transdisciplinaridade como norte tem seus contratempos: a angústia ao lidar com o tempo e várias vezes se contentar com a superficialidade no tratamento de certos tópicos. Perceber em cada tema proposto um universo à parte tanto pode frustrar como instigar a novas investigações. Tempo - grandeza tão cara a estes seres que habitam a pós-verdade hipermoderna. Transitar por enunciados da percepção cognitiva ao modelo probabilístico, visitando contextos historiográficos, etnográficos e autobiográficos junto a populações tão 
singulares aguça o sentido do pertencimento e nos aproxima do agir comunicativo, em que a interação é propositiva.

A eletrificação do fandango, assim como a consolidação das redes de interação virtuais, induz desenvolvimentos paramétricos dos produtos e da subjetivação dos atores que mantêm vivo o fandango caiçara - aspectos cognitivos e emocionais, eidológicos e etológicos. $\mathrm{O}$ exercício intelectual de enquadrar a experiência (sempre subjetiva) em molduras teóricas e conceituais enseja a alteração paramétrica do sujeito (pesquisador) e é capaz não apenas de alterar a percepção individual da realidade, mas de modificar a própria realidade.

Na moldura cismogênica, podemos constatar que, simetricamente, a glocalização e a globalização afetam o fandango caiçara por meio de conflitos de ordem internacional, seja pelos interesses políticos neoliberais, que procuram solapar seu território e suas subjetividades, seja pela exploração desenfreada dos recursos naturais, como no caso da proliferação de grandes empreendimentos transnacionais em áreas do território caiçara, seja pela indústria pesqueira em águas internacionais, que, subtrae a oferta de peixes e, assim, modifica processos de subsistência dessas populações. Complementarmente à luta de classes, os movimentos institucionalizados e a autoconsciência cultural desses atores orientam processos de retroalimentação necessários à preservação de suas práticas.

A organização das redes de interação fortalecidas e ampliadas pela comunicação instantânea insere detentores, pesquisadores e entusiastas em campos macropolíticos cujos resultados se refletem na instauração de legislações específicas para salvaguardar bens imateriais, e, micropoliticamente, alimenta os atores que seguem realizando seus agenciamentos, cada vez mais atentos a questões de gênero, geração e alteridade, mobilizando forças pulsionais para desconstruir o contexto colonial captalístico em que estão inseridos.

Assim, entendemos que, apesar das adversidades, o fandango caiçara se apresenta hoje como potência de interação comunicativa, firmado num amplo sistema sociocultural onde territorialidade, identidade e política incidem nos agenciamentos e nas pulsões de vida e de mundo de seus atores. Atores que, em última análise, almejam o divertimento, a alegria e a felicidade - que, a meu ver, deveriam ser os objetivos inapeláveis de todos os seres humanos que habitam o planeta.

Segue o baile! 


\section{REFERÊNCIAS}

A BÍBLIA SAGRADA: ANTIGO E NOVO TESTAMENTO. Trad. João Ferreira de Almeida. Ed. rev. e atual. no Brasil. Brasília: Sociedade Bíblia do Brasil, 2017.

ALMEIDA, A. W. B. Terras tradicionalmente ocupadas: processos de territorialização e movimentos sociais. Revista Brasileira de Estudos Urbanos e Regionais, Rio de Janeiro, v. 6, n. 1, p. 9-32, maio 2004.

ALMEIDA, M. D. Pequeno manual de conduta e resistência ao controle do discurso e da libido. Le Monde Diplomatique, 30 nov. 2018. Diponível em: <https://diplomatique.org.br/pequeno-manual-de-condutae-resistencia-ao-controle-do-discurso-e-da-libido/>. Acesso em: 3 abr. 2019.

ANDRADE, M. Remate de Males. In: Obras Completas de Mário de Andrade. São Paulo: Martins, 1955. v. 2: Poesias Completas.

ANSEDE, M. As águas internacionais são o Velho Oeste: ecologista marinho denuncia a expansão "predadora" da China pelos oceanos do mundo. El País, Viña del Mar, CL, 20 set. 2017.

APPADURAI, A. The Production of Locality, In: Modernity at Large. Cultural Dimensions of Globalization. Minneapolis/London: University of Minnesota Press, 1996.

ARAGÃO, H. M. Mapeamentos musicais no Brasil: três experiências em busca da diversidade. Rio de Janeiro: FGV, 2011

ARAÚJO, A. M. Fandango. In: Folclore nacional: danças, recreação e música. São Paulo: Martins Fontes, 2004. v. II.

APPADURAI, Arjun. The Production of Locality, In: Modernity at Large. Cultural Dimensions of Globalization. Minneapolis/London: University of Minnesota Press, 1996.

ASSIS, V. S. Dádiva, mercadoria e pessoa: as trocas na constituição do mundo social Mbyá-Guarani. Tese (Doutorado em Antropologia Social) - Instituto de Filosofia e Ciências Humanas, Universidade Federal do Rio Grande do Sul, Porto Alegre, 2006.

AZEVEDO, F. C. Fandango do Paraná. Cadernos de Folclore, Rio de Janeiro: Funarte, n. 23, 1978.

AZEVEDO, F. C. Aspectos folclóricos do Paraná. Cadernos de Artes e Tradições Populares, Curitiba: MAAP-UFPR, v. 1, p. 57-101, 1973.

BARAKAT, M. A. Musicology concepts and spatial awareness. 16 fev. 2016. Disponível em: <http://www.meratebarakat.com/research-blog?category=Human+Aural+Response>. Acesso em: 3 abr. 2019.

BARRETO FILHO, H. T. Utopias tecnológicas, distopias ecológicas e contrapontos românticos: "populações tradicionais" e áreas protegidas nos trópicos. Revista Sexta-Feira, n. 6, p. 139-151, 2001.

BARROS, G. Marca da era Trump e do Brexit, "fake news" abalaram café do Brasil nos anos 30. O Globo, Rio de Janeiro, 18 out. 2017. Disponível em: <https://acervo.oglobo.globo.com/em-destaque/marca-da-eratrump-do-brexit-fake-news-abalaram-cafe-do-brasil-nos-anos-30-21761730>. Acesso em: 3 abr. 2019.

BATESON, G. Mente e natureza. Trad. Cláudia Gerpe. Rio de Janeiro: Francisco Alves, 1986.

BATESON, G. Naven. São Paulo: Edusp, 2008.

BATESON, G. Vers une écologie de l'esprit. Trad. Perial Drisso, Laurencine Lot e Eugène Simion. Paris: Seuil, 1977.

BENENZON, R. La nueva musicoterapia. 2a ed. Buenos Aires: Lumen, 2008.

BERENGUER, R. A. A. El significado filosófico de la teoría cuántica de campos. Contrastes - Revista Internacional de Filosofía, Málaga: Universidad de Málaga, v. XVI, 2011[2010].

BERGMANN FILHO, J. Artífices, artifícios e artefatos: narrativas e trajetórias no processo de construção da rabeca brasileira. Tese (Doutorado em Design) - Setor de Artes, Comunicação e Design, Universidade Federal do Paraná, Curitiba, 2016.

BERLANGA, M. A. The Fandangos of Southern Spain in the Context of Other Spanish and American Fandangos. Música Oral Del Sur, Granada: Centro de Documentación Musical de Andalucía, n. 12, 2015.

BERTOLO, G. Narrativas do espólio: uma etnografia sobre o fandango e a "perda" cultural caiçara (CananéiaSP). Dissertação (Mestrado em Antropologia Social) - Centro de Educação e Ciências Humanas, Universidade Federal de São Carlos, São Carlos, 2015.

BEY, H. Taz: zona autônoma temporária. Trad. Patrícia Decia e Renato Resende. [S.1.]: Coletivo Sabotagem, [s.d.]. 
BLACKING, J. Música, cultura e experiência. Cadernos de Campo, São Paulo, v. 16, n. 16, 2007. Disponível em: <http://www.revistas.usp.br/cadernosdecampo/article/view/50064>. Acesso em: 3. abr. 2019.

BLACKING, J. How Musical is Man? London: University of Washington, 1974.

BOLETIM da Comissão Paranaense de Folclore, Curitiba: Funarte/INF, v. 4, n. 4. Curitiba, 1980.

BOLLO-PANADERO, M. D. La "transversalidad" de la Moaxaja en el proceso de formación cultural. Hispanófila, n. 165, p. 3-13, 2012.

BONA, B. F. Solo da rabeca: território e patrimônio cultural, o caso do fandango caiçara. Trabalho de Conclusão de Curso (Bacharelado em Geografia) - Faculdade de Filosofia, Letras e Ciências Humanas, Universidade de São Paulo, São Paulo, 2016

BOURBON, A.; ZAGORSKI-THOMAS, S. Sonic Cartoons and Semantic Audio Processing: Using Invariant Properties to Create Schematic Representations of Acoustic Phenomena. London: 2nd AES Workshop on Intelligent Music Production, 2016.

BUDASZ, R. Teatro e música na América portuguesa: convenções, repertório, raça, gênero e poder. Curitiba: DeArtes-UFPR, 2008.

BUDASZ, R. O cancioneiro ibérico em José de Anchieta: um enfoque musicológico. Dissertação (Mestrado em Musicologia) - Escola de Comunicação e Artes, Universidade de São Paulo, São Paulo, 1996a.

BUDASZ, R. Uma tablatura para saltério do século XIX. Revista Eletrônica de Musicologia, Curitiba: Departamento de Artes da UFPR, v. 1, n. 1, set. 1996b. Disponível em: <http://www.rem.ufpr.br/_REM/REMv1.1/vol1.1/saltport.html>. Acesso em: 2 fev. 2019.

BUDASZ, R. A presença do cancioneiro ibérico na lírica de José de Anchieta. In: ENCONTRO DE MUSICOLOGIA HISTÓRICA, 1., 1994, Juiz de Fora. Anais... Juiz de Fora: Centro Cultural PróMúsica, Universidade Federal de Juiz de Fora, 1994.

BULHOES NETTO, P. J.; NASCIMENTO, A.; BULHÕES, S. F. Vamos indo na ciranda: Mestre Chiquinho de Tarituba - de bailes e histórias. Rio de Janeiro: DP\&A, 2004.

BURKE, P. Cultura popular na Idade Moderna. São Paulo: Companhia das Letras, 1999.

CAESAR, R. A forma do utensílio: acaso ou analogia? In: CONGRESSO DA ASSOCIAÇÃO NACIONAL DE PESQUISA E PÓS-GRADUAÇÃO EM MÚSICA, 21., 2011, Uberlândia. Anais... Uberlândia: ANP, 2011.

CAMACHO, R.; TORRES, J. Instrumentos musicais da tradição popular madeirense. Folclore - 48 Horas a Bailar, Santana: Casa do Povo de Santana, n. 16, p. 8-9, 2006.

CÂMARA CASCUDO, L. Dicionário do Folclore Brasileiro. 10 a ed. Rio de Janeiro: Ediouro, [s.d.].

CÂMARA MUNICIPAL DE CASTELO BRANCO E ASSOCIAÇÃO RECREATIVA E CULTURAL VIOLA BEIROA. A viola beiroa: caderno de especificações técnicas. Castelo Branco, 2016.

CANCLINI, N. G. Culturas híbridas: estratégias para entrar e sair da modernidade. Trad. Heloísa P. Cintrão e Ana Regina Lessa. 2a ed. São Paulo: Edusp, 2013.

CANDIDO, A. Parceiros do Rio Bonito. 8a ed. São Paulo: Duas Cidades. 1998.

CARDOSO, A. C. V. Reflexões sobre o desenvolvimento auditivo. Verba Volant, Pelotas: UFPEL, v. 4, n. 1, p. 104-116, 2013.

CARNEIRO DA CUNHA, M. Cultura com aspas e outros ensaios. São Paulo: Cosac Naify, 2009.

CARNEIRO DA CUNHA, M. (Org.). História dos índios do Brasil. São Paulo: Companhia das Letras/Secretaria Municipal de Cultura/FAPESP, 1992.

CARVALHO, J. J. Culturas populares: contra a pirâmide de prestígios e por ações afirmativas. In: SEMINÁRIO NACIONAL DE POLÍTICAS PÚBLICAS PARA AS CULTURAS POPULARES. São Paulo/Brasília: Instituto Polis/Ministério da Cultura, 2005.

CARVALHO, J. J. O lugar da cultura tradicional na sociedade moderna. Rio de Janeiro: Funarte, 1992. (Série Encontros e Estudos, n. 1.)

CARVALHO, M. C. F.; SCHMITT, A. Laudo histórico e antropológico. Relatório técnico-científico para identificação de famílias tradicionais presentes na Estação Ecológica da Jureia-Itatins. São Paulo: Secretaria Estadual do Meio Ambiente, 2010.

CASTAGNA, P. A música como instrumento de catequese no Brasil dos séculos XVI e XVII. D. O. Leitura, São Paulo, v. 12, n. 43, p. 6-9, abr. 1994.

CASTELO-BRANCO, S. E.-S.; BRANCO, J. F. Folclorização em Portugal: uma perspectiva. Lisboa: Etnográfica, 2003.

CAVALCANTI, R. O retorno do sagrado: a reconciliação entre ciência e espiritualidade. São Paulo: Cultrix, 2000.

CERN Bulletin. [2012]. Disponível em: <https://cds.cern.ch/record/1473657/files/SMinfographic_image.png?subformat=>. Acesso em: 3 abr. 2019.

CHAMORRO, G. A espiritualidade guarani: uma teologia ameríndia da palavra. São Leopoldo, RS: Sinodal, 1998. 
CHAMORRO, G. Kurusu Ñe'ëngatu: palabras que la historia no podría olvidar. São Leopoldo, RS: IEPG/COMIN, 1995.

CHION, M. Le son: traité d'acoulogie. Paris: A. Colin, 2010.

CHION, M. Guide des objets sonores: Pierre Schaeffer et la recherche musicale. Paris: Buchet/Chastel. 1983.

COELHO, K. S. Bandeiras, pessoas e causos em circulação: notas sobre o movimento e o território durante a Folia do Divino. In: REUNIÃO BRASILEIRA DE ANTROPOLOGIA, 31., 2018, Brasília, DF. Anais... Brasília, DF, 2018.

COHEN, R. Performance como linguagem. São Paulo: Perspectiva, 2009.

CONNELL, J.; GIBSON, C. World music: deterritorializing place and identity. Progress in Human Geography, Sydney, v. 28, n. 3, p. 342-361, jun. 2004.

CORRÊA, J. R. O. A construção social do fandango como expressão cultural popular e tema de estudos de folclore. Sociologia \& Atropologia, Rio de janeiro, v. 6, n. 2, p. 407- 445, ago. 2016.

CRIVILLÉ I BARGALLÓ, J. M. Historia de la música española. Madrid: Alianza, 1988.

CSIKSZENTMIHALYI, M. Beyond boredom and anxiety. San Francisco: Jossey-Bass, 1975.

CUSTÓDIO PINTO, I. Folclore do Paraná. 2a ed. Curitiba: SEED-PR, 2010.

CUSTÓDIO PINTO, I. O fandango na ilha de Valadares. In: BRITO, M. L. (Org.). Fandango de Mutirão. Curitiba: [s.e.], 2003.

CUSTÓDIO PINTO, I. Manual do folclore. In: SOUZA NETO, M. J. (Org.). A [des]construção da música na cultura paranaense. Curitiba: Quatro Ventos, 2004. p. 436-487.

CUSTÓDIO PINTO, I. Fandango do Paraná. Curitiba: Ed. UFPR, 1992.

CUSTÓDIO PINTO, I. Curso de Introdução aos Estudos de Folclore. Curitiba: Museu Paranaense/Secretaria de Estado da Cultura e do Esporte, 1983. Apostila.

DAMAZIO, R. Cultura sem fronteiras. Cadernos de Leitura, São Paulo: Edusp, [s.d.]. Entrevista com Néstor García Canclini. Disponível em: 〈https://www.edusp.com.br/cadleitura/cadleitura_0802_8.asp>. Acesso em: 12 jan. 2019.

DELEUZE, G. Bergsonismo. Trad. Luiz B. L. Orlandi. São Paulo: Editora 34, 1999.

DELEUZE, G.; GUATTARI, F. Mil platôs: capitalismo e esquizofrenia.Trad. Aurélio Guerra Neto et al. Rio de Janeiro: Editora 34, 2012. v. 3.

ELEUZE, G \& GUATTARI, F. Rizoma. In: Mil Platôs: capitalismo e esquizofrenia. São Paulo: Editora 34, 2000 [1980]. V.1

DIEGUES, A. C. (Org.). Enciclopédia Caiçara. São Paulo: Hucitec/Nupaub/CEC-USP, 2006. v. 5: Festas, lendas e mitos caiçaras.

DONNADIEU, G. et all. L'approche systémique: de quoi s'agit-il?. Synthèse des travaux du Groupe AFSCET. Paris, 2003.

DUFOURCQ, N. La musique des origines a nous jours. Paris: Larousse, 1946.

ENCONTRO NACIONAL DE COMUNIDADES TRADICIONAIS, 1., 2005, Luziânia, DF: NUPAUB. Disponível em: <http://nupaub.fflch.usp.br/sites/nupaub.fflch.usp.br/files/PDF\%20$\% 20 \mathrm{I} \% 20$ Encontro\%20Nacional\%20de\%20Comunidades\%20Tradicionais.pdf $>$. Acesso em: 23 abr. 2018.

ESPOSITO, A.; KRICHEVSKY, R.; NICOLIS, A. The mass of sound. New York: Columbia University, 2018.

FABIÃO, E. Corpo cênico, estado cênico. Contrapontos, v. 10, n. 3, p. 321-326, set./dez. 2010.

FANDANGO NA ESCOLA. Material Didático. Curitiba: SEED/PR, 2010[2007].

FARIAS, D. S. E.; ALVES, L.; GUIMARÃES, G. M.; DEMATHE, A.; COSTA, O. S. (Org.). Projeto de avaliação de impacto ao patrimônio arqueológico e educação patrimonial na área de ampliação do terminal de contêineres de Paranaguá. Tubarão, SC: Sapienza, 2016.

FERRAZ, S. Deleuze, música, tempo e forças não sonoras. Ouro Preto : Artefilosofia, , n.9. 2010.

FERREIRA, M. P. Emulação e hibridismo na Península Ibérica: antecedentes medievais. Revista Portuguesa de Musicologia, Lisboa, v. 1, n. 2, p. 135-150, 2015

FERRERO, C. B. Na trilha da viola branca: aspectos sócio-culturais e técnico-musiciais do seu uso no fandango de Iguape e Cananéia, SP. São Paulo: [s.e.], 2007.

FLAXMAN, S.; GOEL, S.; RAO, J. M. Filter bubbles, echo chambers, and online news consumption. Public Opinion Quarterly, v. 80, p. 298-320, 2016. Special Issue

FONSECA, S. T.; FARIA, C. D. C. M.; OCARINO, J. M.; MANCINI, M. C. Abordagem ecológica à percepção e ação: fundamentação para o comportamento motor. Brazilian Journal of Motor Behavior, v. 2, n. 1 , p. 1-10, 2007.

FORTE, A. Music and Computing: The Present Situation. Computers and the Humanities, v. 2, n. 1, p. 32-35, 1967.

FREITAS, C. D. S.; NEDEL, L.; GALANTE, R.; LAMB, L. C. Extração do conhecimento e análise visual de redes sociais. In: CONGRESSO DA SBC, 28., 2008, Belém do Pará. Anais... Belém do Pará, 2008. p. 106-120. 
FREYRE, G. Casa Grande \& Senzala: formação da família brasileira sob o regime da economia patriarcal. 29a ed. Rio de Janeiro: Record, 1994 [1933].

FREYRE, G. Casa Grande \& Senzala. 16 ed. São Paulo: José Olympo, 1973.

FUGANTI, L. Fuganti - Agenciamento. Escola Nômade, Rio de Janeiro: Laboratório de Política e Pensamento, 2016. Disponível em: <http://escolanomade.org/2016/02/24/agenciamento/>. Acesso em: 3 abr. 2019.

GARCÍA DE LEÓN, A. El mar de los deseos, el Caribe hispano musical: historia y contrapunto. México: Siglo XXI, 2002.

GARLET, I. Mobilidade Mbyá: história e significação. Dissertação (Mestrado em História) - Pontifícia Universidade Católica do Rio Grande do Sul, Porto Alegre, 1997.

GELMINI, G. B. El bosón de Higgs. Ciencia e Investigación de la Asociación Argentina para el Progreso de las Ciências, v. 64, n. 3, p. 5-22, 2014, jun. 2014. Disponível em: <http://www.aargentinapciencias.org/2/images/RevistasCeI/tomo64-3/Paginas5-22desdeRevista643.pdf>. Acesso em; 1 fev. 2019.

GIBSON, J. J. Ecological Approach to Visual Perception. Hillsdate, MI: Lawrence Erlbaum, 1986[1979].

GIORDANI, A. Une installation pour la mémoire. In:. Pratiques de la voix sur scène: Incertains Regards HS2, Cahiers Dramaturgiques. Aix-en-Provence: Presses Universitaires de Provence, 2018.

GIORDANI, A. Mbaraka: metonímia musical mbya. Dissertação (Mestrado em Música) - setor de Humanas, Letras e Artes, Universidade Federal do Paraná, Curitiba, 2009.

GIOVANNONI, D. Phonautograms-Édouard-Léon Scott de Martinville (c. 1853-1861). USA: Library of Congress, 2010. Disponível em: <https://www.loc.gov/programs/static/national-recording-preservationboard/documents/phonautograms.pdf $>$. Acesso em: 3 abr. 2019.

GOLEMAN, D. A inteligência emocional: a teoria revolucionária que redefine o que é ser inteligente. Rio de Janeiro: Objetiva, 1995.

GONÇALVES, A. Mba' Erei Rei Ra Anga: as esculturas de madeira e seus aprendizados. Trabalho de Conclusão de Curso (Licenciatura Intercultural Indígena) - Universidade Federal de Santa Catarina, Florianópolis, 2015.

GRAMANI, D. C. O aprendizado e a prática da rabeca no fandango caiçara: estudo de caso com os rabequistas da família Pereira da comunidade do Ariri Dissertação (Mestrado em Música) - Setor de Ciências Humanas, Letras e Artes, Universidade Federal do Paraná, Curitiba, 2009.

GRAN ENCICLOPÈDIA DE LA MÚSICA. Bandúrria. Disponível em: <https://www.enciclopedia.cat/ECGEM-181.xml>. Acesso em: 12 dez. 2018.

GUATTARI, F. e ROLNIK, S. Micropolítica: Cartografias do Desejo. Petrópolis: Vozes, 1996.

HABERMAS, J. The theory of communicative action. Boston: Beacon, 1987. v. 2: Lifeworld and sistem: a critique of functionalist reason.

HEISENBERG, W. Física e filosofia. Brasília, DF: Ed. UnB, 1981.

HOLANDA, S. B. Raízes do Brasil. 26a ed. São Paulo: Companhia das Letras. 1995[1936].

iFit:Models. Phonons - Lattice dynamics. 2018. Disponível em: <http://ifit.mccode.org/Models_Phonons_Tutorial.html. Acesso em: 3 abr. 2019.

IBGE. Catálogo . 2017. Disponível em: <https://biblioteca.ibge.gov.br/bibliotecacatalogo.html?id=34114\&view=detalhes>

IKEDA, A. T. Folia de Reis, sambas do povo. São José dos Campos, SP: CECP/FCCR, 2011. (Cadernos de Folclore, v. 21.)

INGOLD, T. Making: anthropology, archaeology, art and architecture. London/New York: Routledge, 2013.

INSTITUTO COLIBRI. A Ciranda Caiçara de Paraty: Projeto de gravação, lançamento e distribuição do CD Ciranda Caiçara de Paraty. 2012. Disponível em < https://cirandacaicaradeparaty.wordpress.com/about/> Acesso em $21 \mathrm{dez} 2018$.

IPHAN. Dossiê de Registro do Fandango Caiçara. Brasília, DF: IPHAN, 2011.

IPHAN. Inventário nacional de referências culturais: manual de aplicação. Apres. Célia Maria Corsino. Intr. Antônio Augusto Arantes Neto. Brasília, DF, 2000.

IPHAN. Revista do Serviço do Patrimônio Histórico e Artístico Nacional, Rio de Janeiro: Ministério da Educação e Saúde, n. 4, 1940. Disponível em: <http://docvirt.com/docreader.net/DocReader.aspx?bib=reviphan\&pagfis=5028>. Acesso em: 12 nov. 2018.

JACKSON, J. L. Jr. Thin Description : Ethnography and the African Hebrew Israelites of Jerusalem. Harvard University Press, 2013.

JORNAL MARTIM-PESCADOR, v. 15, n. 156, nov./dez. 2018. Disponível em:<https://issuu.com/belacarrari/docs/martim_156_9_/1?ff>. Acesso em: 24 mar. 2019.

JUNG, C. G. et al. O homem e seus símbolos. Trad. Maria Lúcia Pinho. 5a ed. Rio de Janeiro: Nova Fronteira, 1969. 
LADEIRA, Maria Inês. Espaço Geográfico Guarani Mbya: significado, constituição e uso. Tese (Doutorado) São Paulo: Faculdade de Filosofia, Letras e Ciências Humanas da Universidade de São Paulo, 2001

LANGE, F. C. El Estrañamiento de la Compañiade Jseús del Rio de La Plata (1767) Los bienes musicales y la constância de su existência a través de los inventarios praticados $1^{\mathrm{a}}$ parte. In: Revista Musical Chilena 165 (XL), 1986

LANGER, P. P. Violinistas Kaiowá/Guarani: dados etnográficos e históricos sobre os violinos de procedência missioneira no atual Mato Grosso do Sul. In: LANGER, Protasio Paulo; CHAMORRO, Candida Graciela. (Org.). Missões, Militância Indigenista e Protagonismo Indígena. 1ed.São Bernardo do Campo / SP: Nhanduti, 2012, v. , p. 317-338.

LARA, L. F. A Música Instrumento: O Padre Antônio Sepp, S.J., e as práticas musicais nas reduções jesuíticas (1691-1733) (Disertação de Mestrado) FFLCH. São Paulo, 2015.

LIPOVETSKI, G. Os Tempos Hipermodernos. São Paulo: Editora Barcarolla, 2004.

LOPES, R. M. C. O villancico na capela real portuguesa (1640-1716): o testemunho das fontes textuais. (tese doutoral) Évora: Universidade de Évora, 2006.

MACEDO, F. R. A. A Conquista Pacífica de Guarapuava. Grupo Editor Renascimento do Paraná - GERPA, 1951.

MAESTRI FILHO, M. Jesuítas e Tupinambás: A Catequese Impossível. In: AZEVEDO, F.L.; MONTEIRO, J. M. (Orgs) Confronto de Culturas: Conquista, Resistência, Transformação. Rio de Janeiro: Expressão e Cultura; São Paulo: EDUSP, 1997.

MARCOJE. L.M. Os Viâncicos e a Restauração Portuguesa: uma breve história. In: Anais do XVI encontro regional de história da Apuh-Rio: Saberes e práticas científicas. Rio de Janeiro: ANPUH-Rio, 2014.

MARTINS, A. R. História do Paraná. $3^{\mathrm{a}}$ Ed. Curitiba: Edição Guaíra, s.d.

MARTINS, P. Pelas cordas da viola, nas curvas da rabeca: uma etnografia dos movimentos de fazer musical caiçara. Tese (Doutorado em Antropologia Social) - Centro de Filosofia e Ciências Humanas, Florianópolis, 2018.

MARTINS, Patrícia. Modernidade, Cultura e Entretenimento. O Fandango em Valadares: entre o Sítio e a Cidade. In: $30^{\circ}$ Encontro Anual da ANPOCS 24 a 28 de outubro de 2006. Caxambu, 2006a.

MARTINS, P. Sobre tamancos e violas: uma descrição do fandango na ilha dos Valadares. in: Enciclopédia Caiçara: festas, lendas e mitos caiçaras. Antonio Carlos Diegues (org.) vol.V. São Paulo: Hucitec: USP, Nupaub/CEC, 2006b.

MCCARTHY, T. Introdução à obra The Theory of communicative action: Vol 1. de J. Habermas. Boston: Beacon Press, 1984.

MELÍA, B. El “modo de ser” guarani en la primera documentación jesuítica (1594-1639). Revista de Antropologia, v. 24, p. 1-24, 1981.

MELlo, F. C. Aata Tape Rupy, seguindo pela estrada: uma investigação dos deslocamentos territoriais de famílias mbyá-guarani no sul do Brasil. Dissertação (Mestrado em Antropologia Social) - Centro de Filosofia e Ciências Humanas, Universidade Federal de Santa Catarina, Florianópolis, 2001.

MIGUEZ, R. T. A música da Folia do Divino no litoral paranaense: estudo dos elementos musicais e extramusicais característicos. Dissertação (Mestrado em Música) - Setor de Comunicação, Artes e Design, Universidade Federal do Paraná, Curitiba, 2017.

MIGUEZ, R. T. A música da folia do Divino paranaense: estudo sobre a prática musical das comunidades caiçaras de Guaratuba e Ilha dos Valadares (2012-2014). Trabalho de Conclusão de Curso (Bacharelado em Produção Sonora) - Setor de Artes Comunicação e Design, Universidade Federal do Paraná, Curitiba, 2014.

MIKANOWSKI, J. New sounds, old voices. The New Yorker, New York, FEB. 2014. Disponível em: <https://www.newyorker.com/tech/annals-of-technology/new-sounds-old-voices>. Acesso em: 3 abr. 2019.

MONTEIRO, A. R. A. Depois do meio ambiente: mudança social em uma unidade de conservação ambiental. Dissertação (Mestrado em Antropologia Social) - Instituto de Filosofia e Ciências Humanas, Universidade Estadual de Campinas, 2002.

MONTEIRO, J. M. Negros da terra: índios e bandeirantes nas origens de São Paulo. São Paulo: Companhia das Letras, 2005.

MONTEIRO, J. M. Os Guarani e a história do Brasil meridional: séculos XVI-XVII. In: CARNEIRO DA CUNHA, M. (Org.). História dos índios do Brasil. São Paulo: Companhia das Letras/Secretaria Municipal de Cultura/FAPESP, 1992.

MONTOYA, A. R. Tesoro de la lengua guaraní. Madrid: Iuan Sanchez,1639.

MONTOYA, A. R. Vocabulario e tesoro de la língua guarani, ó mas bien tupi. Viena/Paris: Visconde de Porto Seguro/Faesy y Frick/Maisonneuve, 1876.

MUNIZ, J. C. "O meu pai não me deu mestre, minha mãe não me ensinô, não sei por quem eu puxei, violeiro e cantadô": memórias de um caiçara fandangueiro de Guaraqueçaba-PR. Dissertação (Mestrado em 
Desenvolvimento Territorial Sustentável) - Setor Litoral, Universidade Federal do Paraná, Matinhos, 2017.

OLIVEIRA, I. S.; JESUS, V. L. B. Introdução à física do estado sólido. São Paulo: Editora Livraria da Física, 2005.

OLIVEIRA, M. Primórdios da rede. Pesquisa Fapesp, São Paulo, n. 180, fev. 2011. Disponível em: <2011.http://revistapesquisa.fapesp.br/2011/02/18/prim\%C3\%B3rdios-da-rede_/>. Acesso em: 3 abr. 2019.

ORNELLAS, M. Gaúchos e beduínos. São Paulo: José Olympo/MEC, 1976.

OUTHWAITE, W.; BOTTOMORE, T. Dicionário do Pensamento Social do Século XX. Rio de Janeiro: Jorge Zahar, 1996.

PEARSON, Judy C. et al. Motives for Communication: Why the Millennial Generation Uses Electronic Devices. In: Journal of the Communication, Speech \& Theatre Association of North Dakota. Published by the C. S. \& T. A. of North Dakota, 2009/2010

PELLEGRINI FILHO, A. Calendário e documentário do folclore paulista. São Paulo: Cortez, 1985.

PEREIRA, M. R. de M. A Desinvenção da Tradição; ou de como as elites locais reprimiram o fandango e outras manifestações de gauchismo no Paraná do Século XIX. In: NETO, M. J. de Souza. A [des]Construção da Música na Cultura Paranaense. Curitiba: Ed. Aos Quatro Ventos, 2004.

PEREIRA, P. P. G. Limites, traduções e afetos: profissionais de saúde em contextos indígenas. Mana, Rio de Janeiro, v. 18, n. 3, p. 511-538, dez. 2012.

PETROBRAS. Projeto de monitoramento de cetáceos na Bacia de Santos, PMC-BS. Projeto Executivo. Santos, SP: Petrobras, 2015.

PIMENTEL, A.; GRAMANI, D.; CORRÊA, J. (Org.). Museu Vivo do Fandango. Rio de Janeiro: Associação Cultural Caburé, 2006.

PIMENTEL, A.; PEREIRA, E.; CORRÊA, J. Museu Vivo do Fandango: aproximações entre cultura, patrimônio e território. In: ENCONTRO ANUAL DA ANPOCS GT19 "Memória social, museus e patrimônios", 35., 2011, Caxambu. Anais... Caxambu, MG, 2011. p. 1-20.

PINTO, C. R. J. Uma história do feminismo no Brasil. São Paulo: Ed. Fundação Perseu Abramo, 2003.

PINTO, J. M. R. A teoria da ação comunicativa de Jürgen Habermas: conceitos básicos e possibilidades de aplicação à administração escolar. Ribeirão Preto, SP: FFCLRP, 1995.

PORTAL BRASIL. Conheça as principais lutas e conquistas das mulheres. Brasília, DF: Governo Federal, 2017. Disponível em: <http://www.brasil.gov.br/cidadania-e-justica/2017/03/conheca-as-principais-lutas-econquistas-das-mulheres>. Acesso em: 3 abr. 2019.

PRECIADO, P. B. La Izquierda Bajo la Piel: um prólogo para Suely Rolnik. In: ROLNIK, S. Esferas da insurreição: notas para uma vida não cafetinada. São Paulo: n-1 Edições, 2018.

RAIPI. Relatório De Avaliação De Impactos Aos Bens Registrados. Ampliação do Terminal de Contêineres de Paranaguá-PR - TCP. Paranaguá: ContextoBR, 2016.

RAIPI. Relatório De Avaliação De Impactos Aos Bens Registrados. Obras de Ampliação do Cais de Acostagem do Porto Paranaguá. Administração do Porto de Paranaguá e Antonina - APPA. Paranaguá: PLANAVE SA, 2018.

REGISTRO. Prefeitura Municipal. Secretaria de Cultura. Ciclo de Estudos sobre Cultura Tradicional e Contemporaneidade será realizado em Registro nos dias 28 e 29/09. 2018. Disponível em: $<$ http://www.registro.sp.gov.br/n/ciclo-de-estudos-sobre-cultura-tradicional-e-contemporaneidade-serarealizado-em-registro-nos-dias-28-e-29-09>. Acesso em: 8 nov. 2018.

REVIRAVOLTA na telefonia. Advon - Aplicativo de Negócios e Serviços. Teresina, 30 mar. 2016. Disponível em: <http://advon.com.br/banda-larga-deve-ser-novo-foco-das-telecomunicacoes-no-brasil/>. Acesso em: 3 abr. 2019.

REY, P. Cordophones pincés et styles musicaux dans la Péninsule Ibérique (1200-1500). In : RAULT, C. (Org.). Instruments à cordes du Moyen Age. Grane, FR: Créaphis, 1999.

REYNER, I. R. Pierre Schaeffer e sua teoria da escuta. Opus, Porto Alegre, v. 17, n. 2, p. 77-106, dez. 2011.

RIBEIRO, D. O povo brasileiro: a formação e o sentido do Brasil. São Paulo: Companhia das Letras, 2006.

RIGOLIN, G. G. Estados quânticos emaranhados. Tese (Doutorado em Física) - Instituto de Física Gleb Wataghin, Universidade Estadual de Campinas, Campinas, 2005.

ROBERTSON, R. Globalisation: social theory and global culture. London: Sage, 1992.

ROCHAT, P. Object manipulation and exploration in 2 to 5 month old infants. Developmental Psychology, v. 25, p. 871-874, 1989.

RODERJAN, R. V. As origens do fandango paranaense. In: SEMANA DE ESTUDOS SOBRE A CULTURA PARANAENSE, 1979, Curitiba. Apostila do Curso de Folclore. Curitiba: Secretaria do Estado da Cultura e do Esporte, 1979. p. 50-55.

RODERJAN, R. V. Folclore brasileiro: Paraná. Rio de Janeiro: MEC/SEC/FUNARTE/INF, 1981. 
RODRIGUES, R. A.; AFONSO, M. C. Um olhar etnoarqueológico para a ocupação guarani no estado de São Paulo. Horizontes Antropológicos, Porto Alegre, v. 8, n. 18, p. 155-173, dez. 2002.

ROEDERER, J. G. Introdução a física e psicofísica da música. Trad. Alberto Luis da Cunha. 1a ed. 1a reimpr. São Paulo: Edusp, 2002.

ROLNIK, S. Esferas da insurreição: notas para uma vida não cafetinada. São Paulo: n-1 Edições, 2018.

ROMERO, S. Cantos populares do Brasil. Rio de Janeiro: Francisco Alves, 1897.

ROSEMAIN, M. França multa Google em 50 milhões de euros por violação de lei de privacidade da UE. Reuters, 21 jan. 2019. Disponível em: <https://br.reuters.com/article/internetNews/idBRKCN1PF217OBRIN>. Acesso em: 10 fev. 2019.

ROSSI, A. Empresas que permitem disseminação de fake news devem ser multadas, diz um dos principais teóricos sobre a relação entre política e tecnologia. BBC News Brasil, São Paulo, 3 nov. 2018. Disponível em: <https://www.bbc.com/portuguese/geral-46067403>. Acesso em: 3 abr. 2019.

ROUDEMETOF, V. Mapping the glocal turn: literature streams, scholarship clusters and debates. Glocalism Journal of Culture, Politics and Innovation, n. 3, p. 1-12, 2015.

SACRAMENTO, A. J. Curvas no espaço de Minkowski. Tese (Doutorado em Matemática) - Instituto de Ciências Matemáticas e de Computação, Universidade de São Paulo, São Carlos, 2015.

SAHLINS, M. O pessimismo sentimental e a experiência etnográfica: por que a cultura não é um objeto em extinção. Mana, Rio de Janeiro, v. 3, n. 1, p. 41-74, 1997; v. 3, n. 2, p. 103-150, 1997.

SAHLINS, M. Cosmologias do capitalismo: o setor Trans-Pacífico do "Sistema Mundial”. In: REUNIÃO BRASILEIRA DE ANTROPOLOGIA, 16., 1998, Campinas, SP. Anais... Campinas, SP, 1988. p. 47 106.

SAINT-HILAIRE, A. Viagem à comarca de Curitiba: Costa Pereira. São Paulo: Companhia Editora Nacional, 1964[1851].

SALTURI, L. A. O movimento paranista e a revista Illustração paranaense. Temáticas, Campinas, v. 22, n. 43, p. 127-158, fev./jun. 2014.

SANDRONI, C. Circuito de difusão de mercado: contra ou a favor? In: Seminário de Políticas Públicas para as Culturas Populares. São Paulo/Brasília, DF: Instituto Polis/Minc, 2005.

SCHAEFFER, P. Ensaio Sobre o Rádio e o Cinema: Estética e Técnica das Artes-Relé 1941-1942.Belo Horizonte: Editora da UFMG, 2010.

SCHAFER, M. A afinação do mundo. São Paulo: Ed. Unesp, 2001.

SCHULER, N. S. Methods of computer-assisted music analysis: history, classification, and evaluation. Thesis (Doctorate) - School of Music, Michigan State University, East Lansing, 2000.

SEEGER, A. Etnografia da música. Cadernos de Campo, São Paulo, n. 17, p. 237-260, 2008.

SEIBT, J. The matrix of ontological thinking: Heuristic preliminaries for an ontology of QFT. In: KUHLMANN, M.; LYRE, H.; WAYNE, A. (Ed.). Ontological Aspects of Quantum Field Theory. Singapore/London/Hackensack, NJ: World Scientific Publishing Company, 2002. p. 53-97.

SETTI, K. Questões relativas à autoctonia nas culturas musicais indígenas da atualidade, consideradas no exemplo mbyá-guarani. Brasil-Europa: Correspondência Euro-Brasileira, n. 21, 1993.

SETTI, K. Ubatuba nos cantos das praias: estudo caiçara paulista e de sua produção musical. São Paulo: Ática, 1985.

SHELEMAY, K. K. Musical communities: rethinking the collective in music. Oakland: University of California Press/American Musicological Society, 2011.

SIEMSSEN, D. The Semiclassical Einstein Equation on Cosmological Spacetimes. Thesis (Ph. D.) Dipartimento di Matemática, Università degli Studi di Genova, Genova, 2015.

SILVA, F. F. Mário e o patrimônio: um anteprojeto ainda atual. Revista do Patrimônio Histórico e Artístico Nacional, Org. Marta Rossetti Batista, Brasília, DF: IPHAN, n. 30, 2002.

SILVEIRA, C. E. Fandangueiros, folcloristas e produtores culturais: reflexões sobre a produção do fandango caiçara. In: Reunião Brasileira de Antropologia, 29., 2014, Nartal. Anais... Natal, 2014.

SOARES, D. Espaço e espaço-tempo nas teorias relativistas. Belo Horizonte, 2013. Disponível em : <http://lilith.fisica.ufmg.br/dsoares/esptmp/esptmp.htm>. Acesso em: 3 abr. 2019.

SOLER, L. Origens àrabes no folclore do sertão brasileiro. Florianópolis: Ed. UFSC, 1995.

SOUZA, J. Gilberto Freyre e a singularidade cultural brasileira. Tempo Social, São Paulo, v. 12, n. 1, p. 69-100, maio 2000.

SPRÉA, N. E. Comentários Sobre a Capacitação dos Monitores: Projeto Fandango na Escola. Paranaguá: Associação Mandicuéra e Secretaria Estadual de Educação do Estado do Paraná - SEED/PR, 2007. (Publicação restrita).

STEILL, C. A.; MOURA CARVALHO, I. C. Epistemologias ecológicas: delimitando um conceito. Mana, Rio de Janeiro: PPGAS-Museu Nacional, v. 20, n. 1, 2014.

STERnE, J. The Audible Past: Cultural Origins Of Sound Reproduction. Durham/London: Duke University Press, 2003. 
TAVARES DE LIMA, R. et al. O folclore do litoral norte de São Paulo. Rio de Janeiro/São Paulo: MEC/SEAC/Funarte/INF, 1981.

TEIXEIRA, F. J.; TONETTI, E. L. Poluição sonora na área urbana de Paranaguá, Paraná. In: SIMPÓSIO PARANAENSE DE PÓS-GRADUAÇÃO EM GEOGRAFIA, 3., 2008, Ponta Grossa. Anais... Ponta Grossa, 2008. v. 1. p. 1-21.

TELLER, P. An Interpretive Introduction to Quantum Field Theory. Princeton: Princeton University Press, 1995.

TOFFOLO, R. B. G.; OLIVEIRA, L. F.; ZAMPRONHA, E. S. Paisagem sonora: uma proposta de análise. 2003. Disponível em: <http://cogprints.org/3000/1/TOFFOLO_OLIVEIRA_ZAMPRA2003.pdf〉. Acesso em: 3 abr. 2019.

TURINO, T. Music as Social Life, The Politics of Participation. Chicago: University of Chicago Press, 2008.

UPANISHADS. Tradução em português de Krishna Yajur Veda. Rio de Janeiro, The Theosophical Publishing House, 2009.

VIANNA, L. Patrimônio imaterial: a experiência do Projeto Celebrações e Saberes da Cultura Popular. Rio de Janeiro: Funarte, 2005. (Série Encontros e Estudos, n. 5.)

VILELA, I. Cantando a própria história: música caipira e enraizamento. São Paulo: EDUSP, 2013.

VIVEIROS DE CASTRO, E. A inconstância da alma selvagem e outros ensaios de antropologia. São Paulo: Cosac Naify, 2002.

VINNIK, E.; ITSKOV, P. M.; BALABAN, E. Individual Differences in Sound-in-Noise Perception Are Related to the Strength of Short-Latency Neural Responses to Noise. PLoS ONE, v. 6, n. 2, 28 Feb. 2011. Disponível em: <https://doi.org/10.1371/journal.pone.0017266>. Acesso em: 4 mar. 2019.

WERNER, L. A. Issues in human auditory development. Journal of Communication Disorders, Bethesda, v. 40, n. 4, p. 275-283, 2007. Disponível em: <https://www.ncbi.nlm.nih.gov/pmc/articles/PMC1975821/>. Acesso em: 2 ago. 2018.

WITHAGEN, R.; MICHAELS, C. F. On ecological conceptualizations of perceptual systems and action systems. Theory \& Psychology, v. 15, n. 5, p. 603-620, 2005

ZUMTHOR, P. La letra y la voz de la "literatura" medieval. Madrid: Cátedra, 1989.

\section{Material audiovisual}

ALENCAR PINTO, A.; CORDOVA, H. (Orgs.). Documentário Sonoro do Folclore Brasileiro - no 11. Ciranda de Paraty. Rio de Janeiro: Ministério da Educação e Cultura/FUNARTE, 1975. (EP 7")

BARREADO, FAMÍlIA, RABECÔNICA. Sou Fandango. FuturaPlay, 2018. 1 vídeo (22 min.). Disponível em: <http://www.futuraplay.org/video/barreado-familia-rabeconica/454394/>. Acesso em: 1 jan. 2019.

DOMINGUES, A. Amanhece. Curitiba: Gramofone, 2017. 1 CD.

ESPAÇOS TEKO PORÃ. Suely Rolnik. 3 out. 2018. Disponível em: <https://www.youtube.com/watch?v=_0iDKO8I-f8>. Acesso em: 3 abr. 2019.

GRUPOS DE FANDANGO DE PARANAGUÁ. Fandango - A Arte e Expressão Popular. Paranaguá: FUMCUL, 2015. 1 CD.

MARCHI, L. Aula de Fandango. Projeto Registros de Toques de Mestres de Fandango. Waldemar Barbosa Cordeiro - Viola, 2016a. Disponível em: 〈https://www.youtube.com/watch?v=oLWlQxSNYLc〉. Acesso em: 1 maio 2018.

MARCH, L. Aula de Fandango. Projeto Registros de Toques de Mestres de Fandango. José Martins Filho Rabeca. 2016b. Disponível em: <https://www.youtube.com/watch?v=K-pecpJnqXw\&t=167s>. Acesso em: 1 maio 2018.

NA TERRA E NO MAR: NÓS VAMOS LUTAR. Vídeo documentário. Bico de Ciri. 2014. Disponível em: <https://www.youtube.com/watch?v=XHHN0e6SHCI>. Acesso em: 15 jun. 2018.

O DIVINO, o popular e o erudito (Fandango do Paraná). Diretor de cena: Juliano de Paula Santos. Produtores executivos: Juliano de Paula Santos e Gehad Ismail Hajar. 2017. Disponível em: <https://www.youtube.com/watch?v=G115Kaenzhs\&feature=youtu.be>. Acesso em: $11 \mathrm{dez} .2018$.

RIBANA. Caiçaras cap. 6. Ponto de Cultura Casa Mandicuera. Direção e edição: Mariana Zanette. Ministério da Cultura, Programa Cultura Viva. 2011. Disponível em: <https://www.youtube.com/watch?v=ekmaNhAmzRI>. Acesso em: 21 abr. 2017.

ROCHA, F. Artesanias Caiçaras: A sustentabilidade do Fandango através da Construção de Instrumentos Musicais. 2016. Disponível em: <https://www.facebook.com/artesaniascaicaras/videos/293922857637113/>. Acesso em: 22 dez. 2018.

RODERJAN, R.V (Org.). Documentário Sonoro do Folclore Brasileiro - n⿳0 15. Fandango do Paraná. Curitiba: Ministério da Educação e Cultura/FUNARTE, 1968. (EP 7”) 
TRÂNSITOS CAIÇARAS: em redes fandangueiras. Direção: Flávio Rocha. Produção gráfica: Brenda Maria. [entre 2010 e 2017]. Disponível em: <https://www.youtube.com/watch?v=rfUQpFlVcIU>. Acesso em: 20 nov. 2018.

UNESCO. Museu Vivo do Fandango - 15 min. 2013. Disponível em: <https://www.youtube.com/watch?v=Tnr533vszGs\&index=2\&list=PL9oO9cO9I9f5qZdqAZQGq1DFR _Pu6ooNH\&t=717s>. Acesso em. 20 out. 2017. 
ANEXOS 


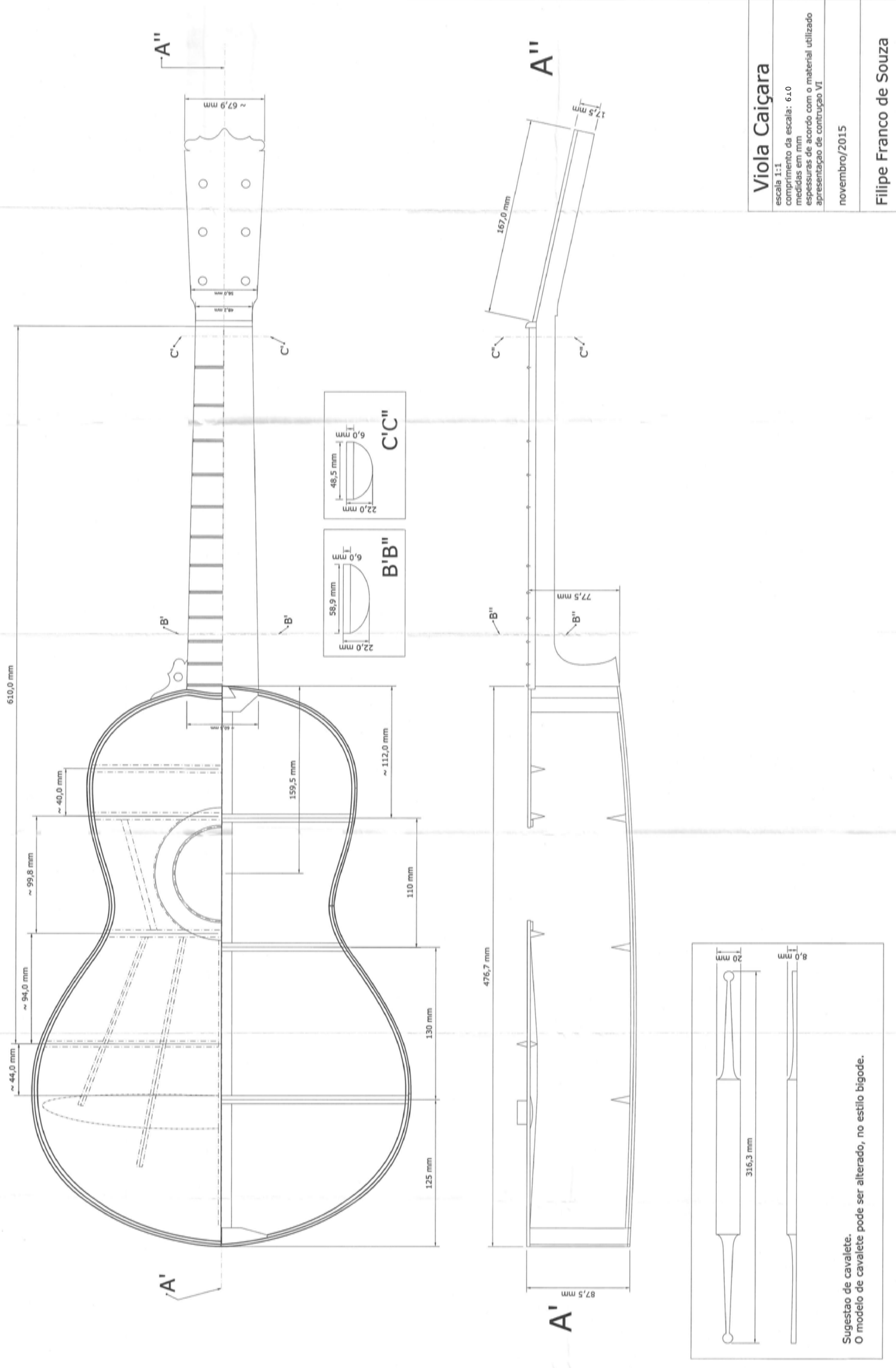


OFICINA

DE VIOLA

BRANCA 


\section{Introdução:}

\section{A Viola}

A viola é um instrumento musical muito usado no meio rural de todo território brasileiro e em várias culturas. Sua origem é portuguesa e espanhola, mas ao se expandir para o Brasil sofreu varias modificações em sua anatomia e, principalmente, no número de cordas. Em cada região usa-se um respectivo numero de cordas e, quando não, uma afinação diferente.

Como vamos trabalhar com um modelo específico de viola, exemplifico algumas de suas particularidades: a viola branca, usada desde o litoral norte de São Paulo até o litoral sul do Paraná, tem de cinco a dez cordas dependendo da região ou até da cidade.

É usada para encordoar a viola branca uma combinação do encordoamento do violão e da viola sertaneja (caipira).

\section{Afinação:}

Não existe uma altura ou tonalidade especificas para a afinação da viola branca. $\mathrm{O}$ intervalo da afinação é semelhante ao do violão, só que com oitavas diferentes. Algumas violas (dependendo da localidade, como as de Cananéia por exemplo) possuem uma corda que vai até o começo do braço chamado Turina ou Piriquita. Chamada também de cantadeira é ela que dita a altura (tom) que o violeiro deve cantar.

\section{Utilização :}

A viola branca é usada no Fandango para embalar cantorias nas festas tradicionais e nos mutirões. É acompanhada, geralmente, de um machete (espécie de cavaquinho), adufe (espécie de pandeiro) e rabeca.

Nas músicas religiosas, como Folias de Bandeira e de Reis, ela é acompanhada também de uma caixa de folia.

\section{Construção}

A madeira usada para a construção do corpo da viola branca é a caxeta (Tabebuia Cassinoides). O braço geralmente é feito de cedro e a escala, o cavalete e as cravelhas são de canela. Os trastes são feitos de arame batido ou coloca-se o industrializado

Para construir a viola usamos um utensílio chamado de forma (molde).

\section{$A$ viola desmontada}

A viola é composta das seguintes peças:

Tampo: parte frontal do corpo da viola

Fundo: parte traseira do corpo da viola

Aro: parte lateral da viola (geralmente moldada) (espelho)

Braço: extensão do corpo onde se situam a escala e o conjunto de cravelhas

Cavalete: peça onde se fixa as cordas

Cravelha: usada para afinar as cordas

Rastilho e pestana: onde as cordas ficam apoiadas

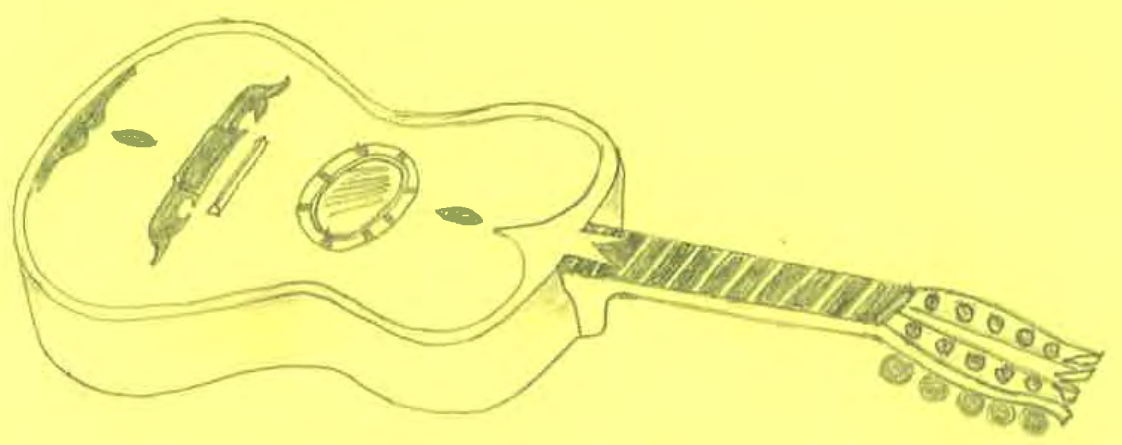


$1^{\circ}$ passo: escultura do braço

O braço é uma peça feita totalmente esculpida, sem emendas, com madeira que tenha, ao mesmo tempo, uma certa flexibilidade e rigidez. Para isso usamos o cedro que também é fácil de esculpir.

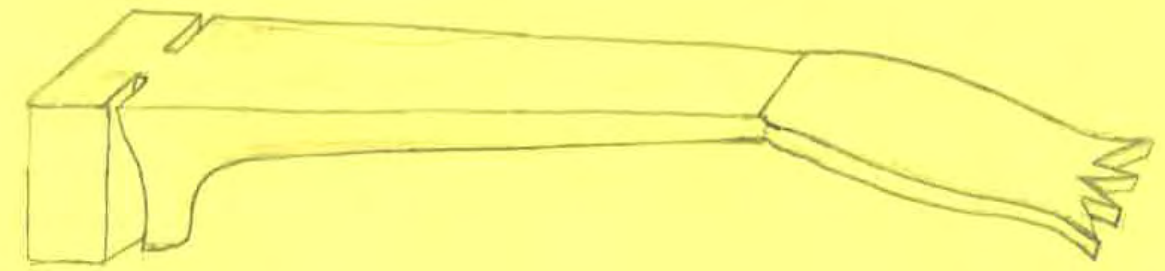

$2^{0}$ passo: construção do aro

Tiramos duas tábuas bem finas, normalmente com $65 \mathrm{~cm}$ de comprimento, $2 \mathrm{~mm}$ de espessura, $7,5 \mathrm{~cm}$ de largura na extremidade mais estreita e $8,5 \mathrm{~cm}$ de largura na parte mais larga.
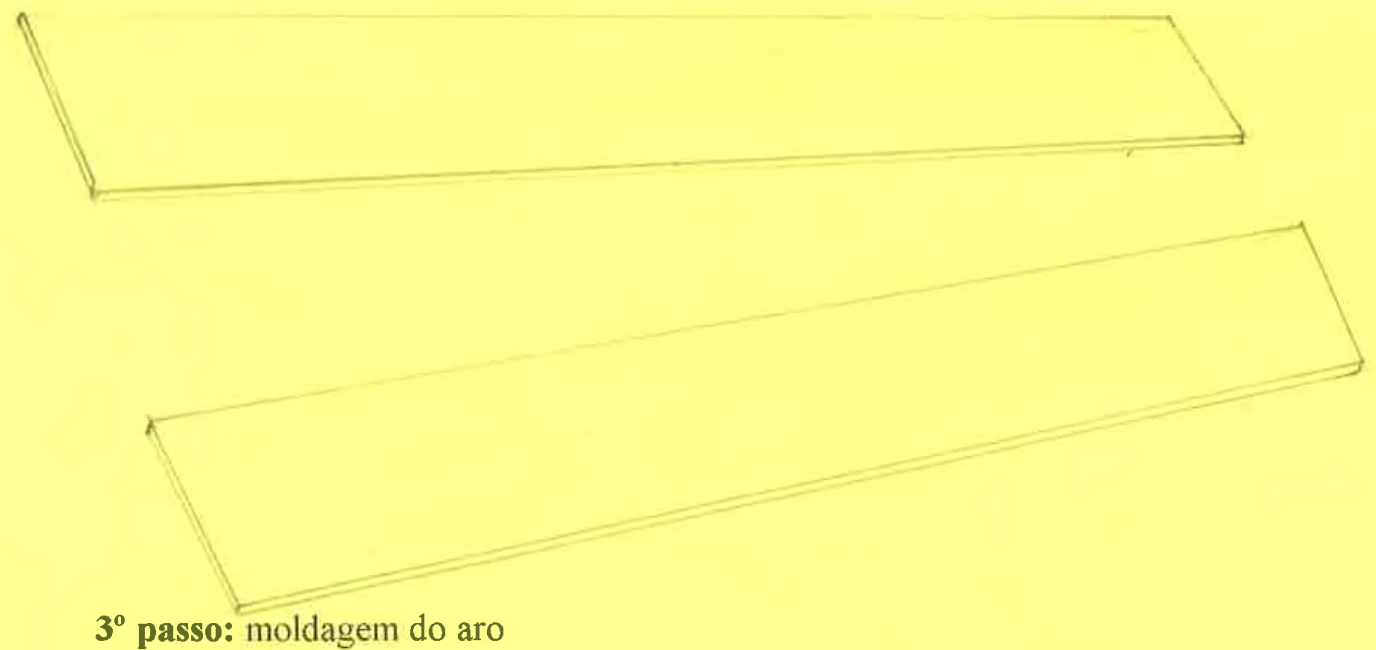

$3^{\circ}$ passo: moldagem do aro

As extremidades mais estreitas das tábuas são encaixadas num corte feito na parte inferior do braço. Depois de encaixadas e coladas as três peças vão para a forma e começa a etapa de moldagem.

Entortamos as duas partes do aro até o meio da forma, formando a chamada cintura e colocamos uma cunha de madeira em um furo na base da forma, para fixar o aro. Após esse procedimento entortamos o resto do aro acompanhando a forma e fazendo com as duas partes se cruzem, ficando uma em cima da outra e as fixamos com outra cunha de madeira. 

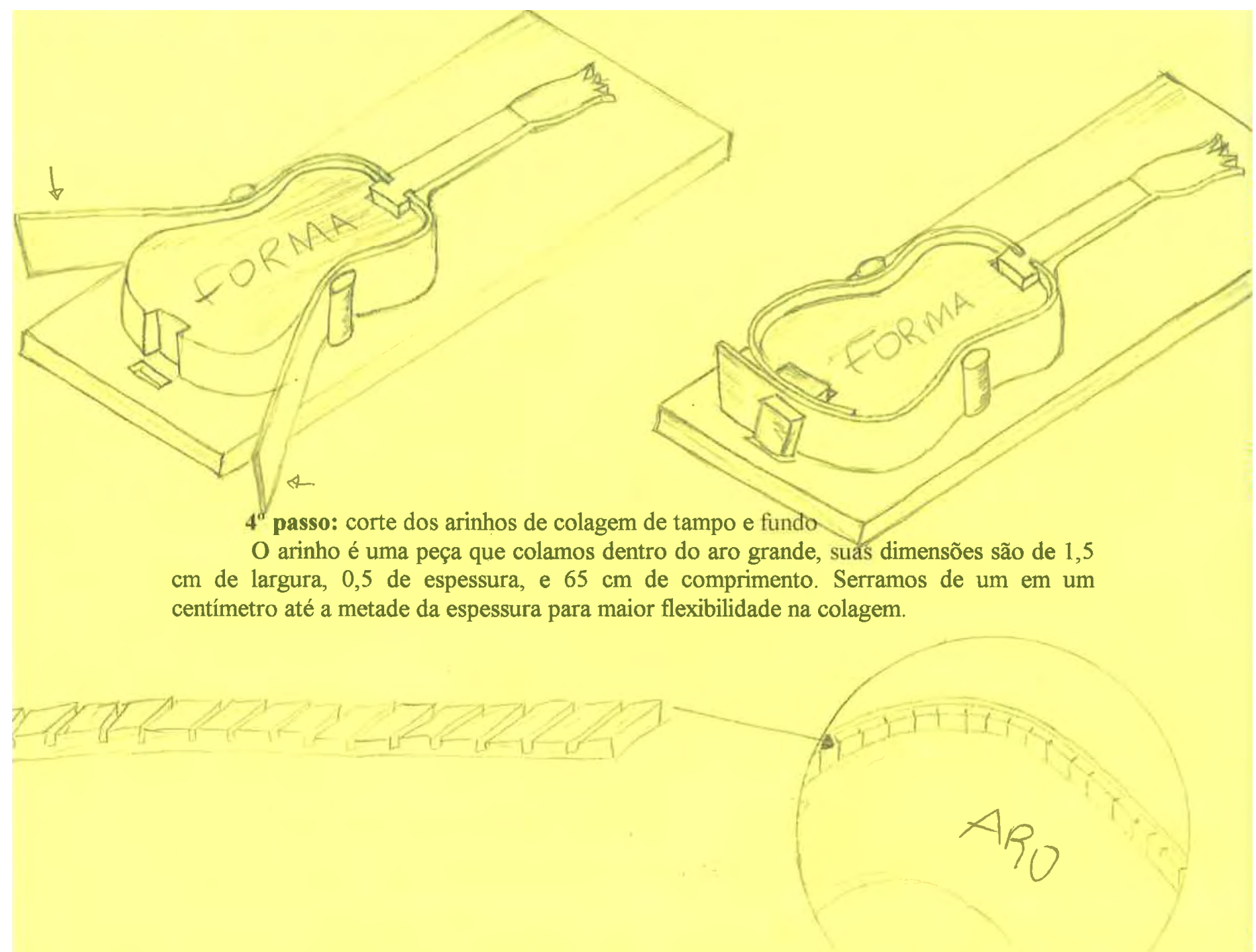

$5^{\circ}$ passo: construção de tampo e fundo

A construção dessas peças é mais ou menos semelhante. São feitos com duas tábuas de $30 \mathrm{~cm}$ de largura, $4 \mathrm{~mm}$ de espessura e $50 \mathrm{~cm}$ de comprimento. Desenha-se o tampo e o fundo, contornando as curvas do aro.

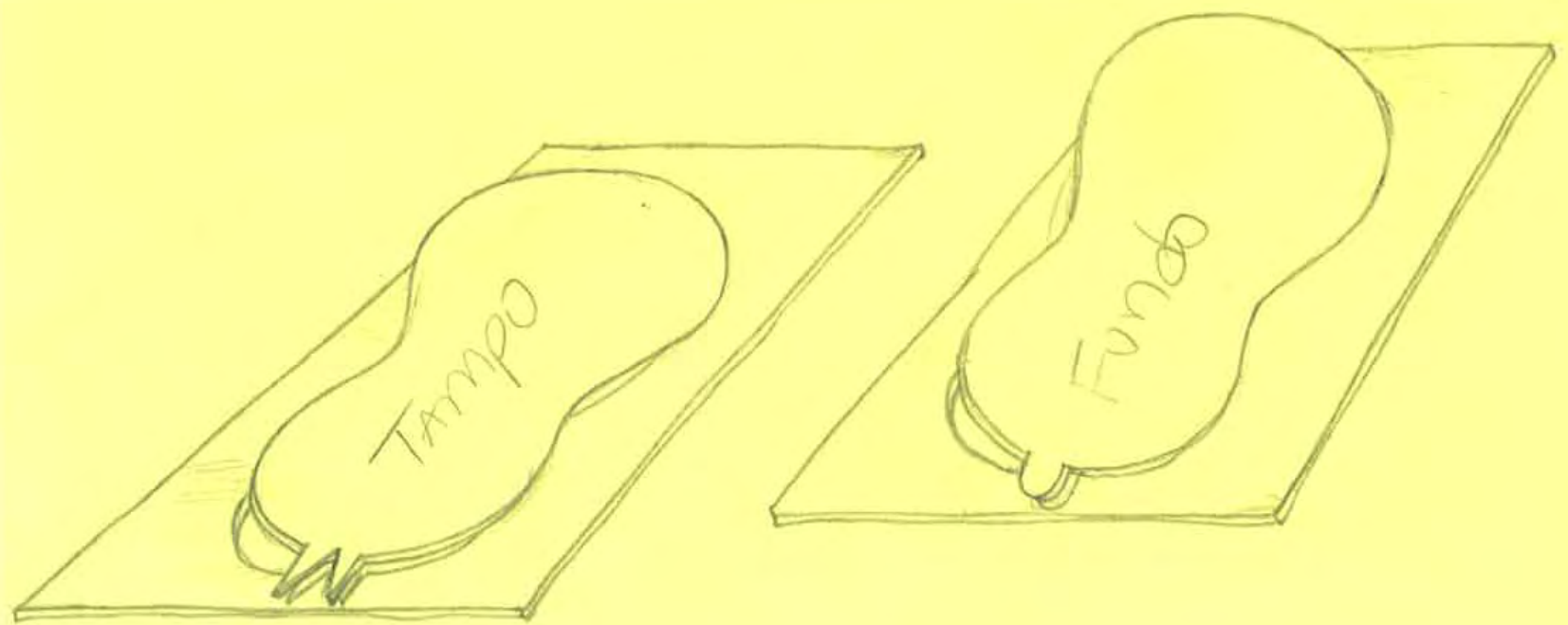


$6^{\circ}$ passo: escultura das cravelhas

Cortamos uma tábua de $1 \mathrm{~cm}$ de espessura, $6 \mathrm{~cm}$ de largura e $25 \mathrm{~cm}$ de comprimento. Desenhamos as dez cravelhas que têm $5 \mathrm{~cm}$ de comprimento por $2,5 \mathrm{~cm}$ de largura cada. Depois a esculpimos com uma extremidade cônica e outra redonda e achatada.

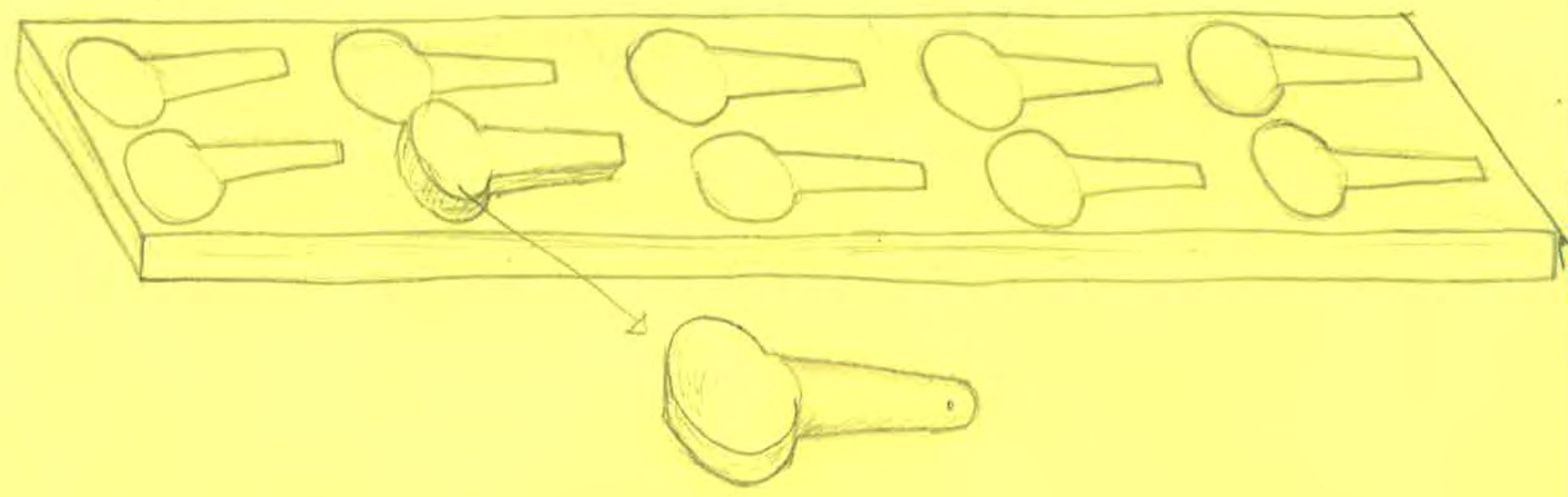

$7^{\circ}$ passo: construção da escala

A escala é construída na mesma largura do braço,com espessura de $0,5 \mathrm{~cm}$. Após a colagem ela é serrada para a colocação dos trastes. Começam os encaixes com $1,5 \mathrm{~cm}$ de distancia, aumentando com intervalos de $1 \mathrm{~mm}$ a cada corte.

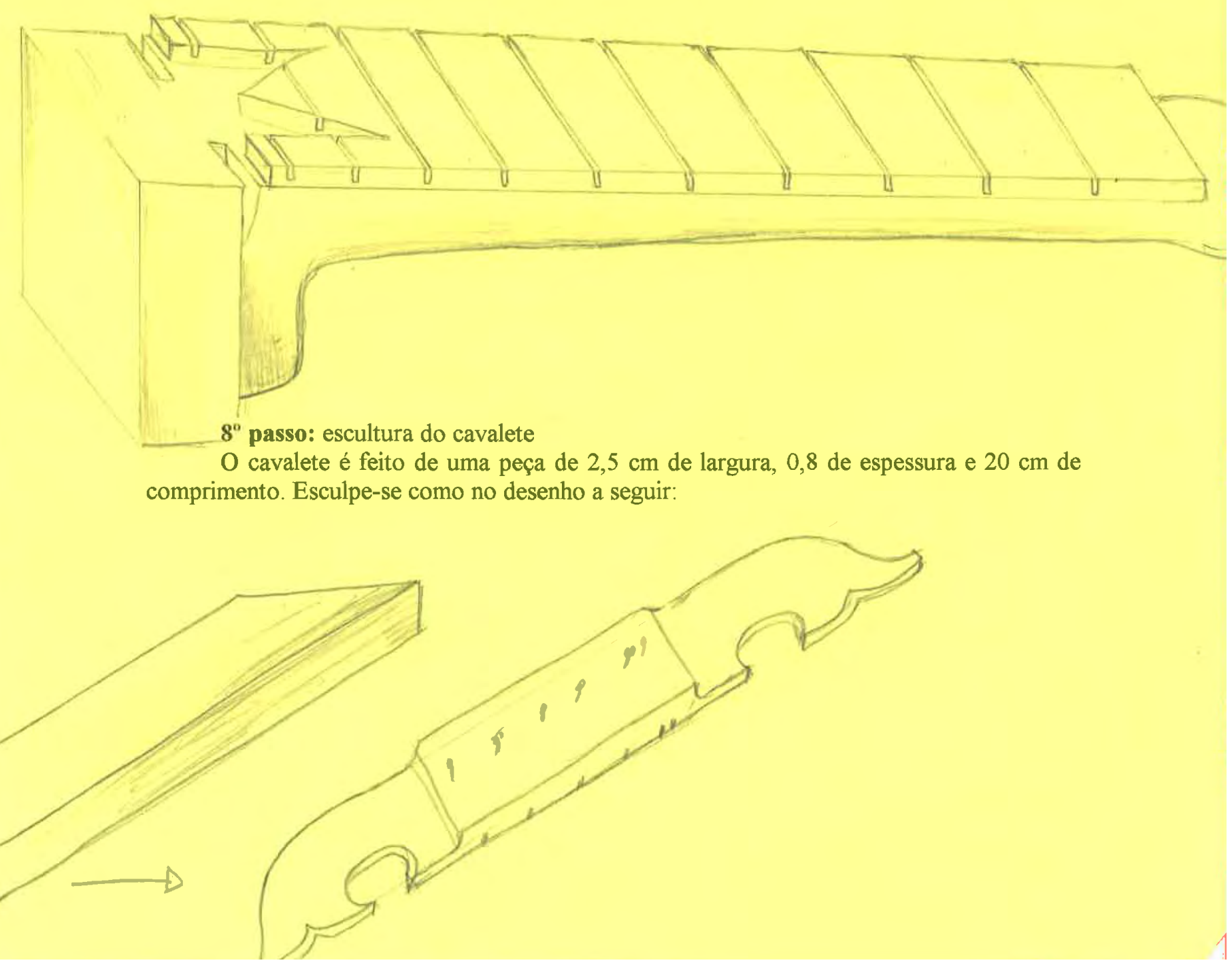




\section{1}

$9^{\circ}$ passo: machetaria e enfeite

A machetaria é uma técnica que consiste no encaixe de uma madeira, com um determinado desenho, dentro de uma fenda feita na outra, de uma cor diferente. Colando e lixando depois.

Todos os enfeites da viola e da rabeca são feitos com essa técnica, inclusive o mosaico da boca da viola

Esses enfeites são feitos com canela e piaçava.

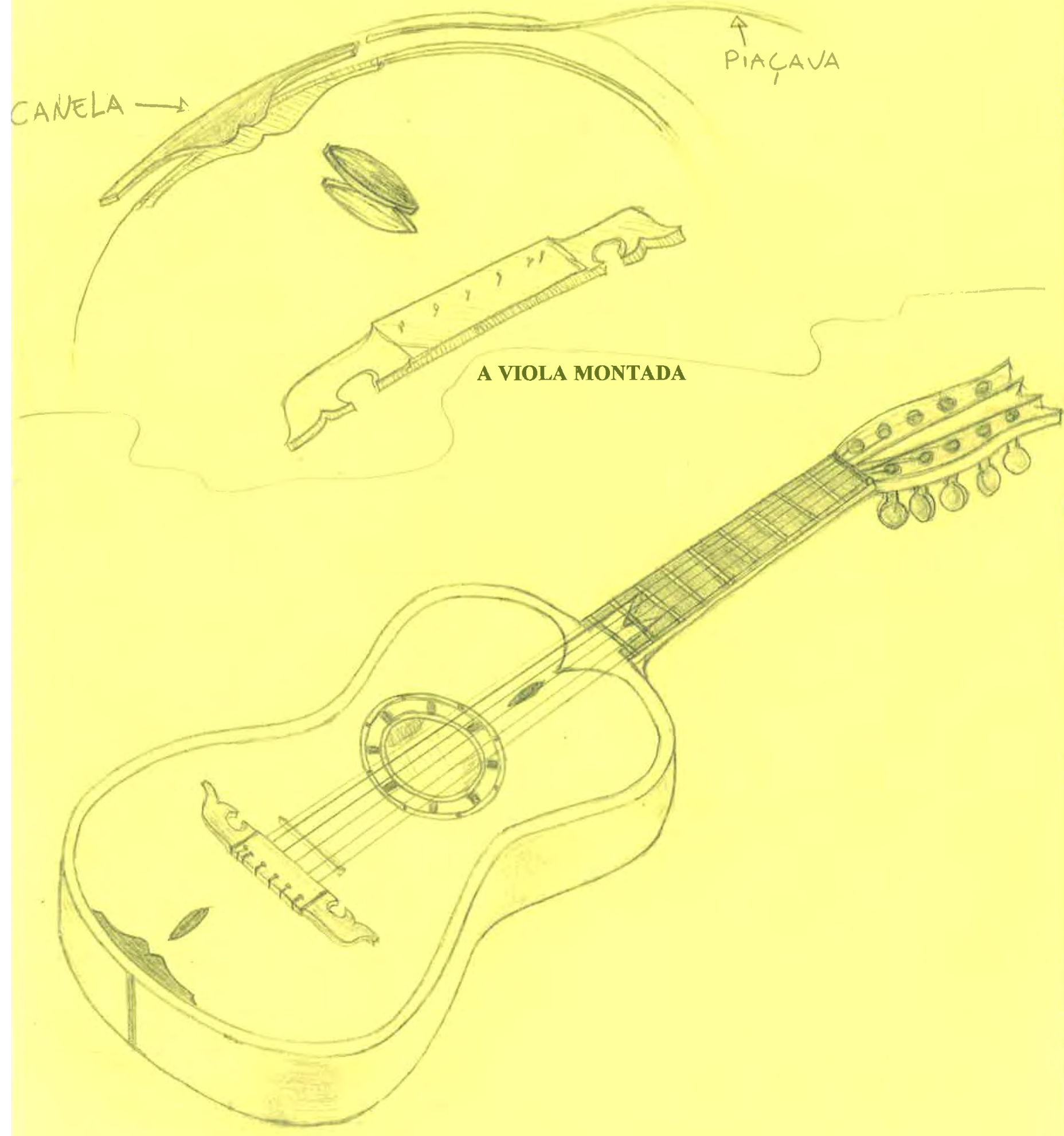


OFICINA

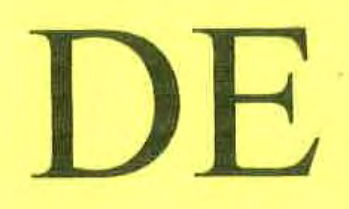

RABECA 


\section{Introducão:}

\section{Rabeca}

A rabeca é um instrumento musical pouco conhecido na musica popular, o que não ocorre nas manifestações folclóricas. Sua ocorrência é nacional, em cada região brasileira tem sua particularidade, como a afinação, espessura das cordas, seu formato e maneira de construção.

$\mathrm{Na}$ cultura caiçara a rabeca é usada como um dos principais instrumentos para o ritmo do fandango e também para folia de bandeira e reiada (reisado), geralmente ela tem como instrumentos acompanhantes viola branca, machete e adufo; nas musicas religiosas, a caixa do Divino ou de Folia.

A madeira usada para a construção do corpo desse instrumento é a caixeta (tabebuia cassinoides) e para a construção das partes que exigem mais esforço são usados o cedro e a canela.

Suas peças principais podem ser feitas de várias formas, por exemplo, em alguns lugares a rabeca é feita de cocho, ou seja, o aro, o fundo e o braço são feitos da mesma peça, apenas o tampo é esculpido separadamente.

No caso dessa oficina as rabecas são formadas por quatro peças, ou seja, o tampo, o fundo, o aro e o braço são esculpidos separadamente. 


\section{Instrucão para construcão de rabecas}

$1^{\circ}$ passo: escultura do tampo e do fundo

Primeiro esculpe-se a parte de dentro de forma côncava e a parte de fora de forma convexa.

Obs. O mesmo sistema aplica-se à escultura do fundo, só que de forma que a parte côncava atinja ao máximo das extremidades.
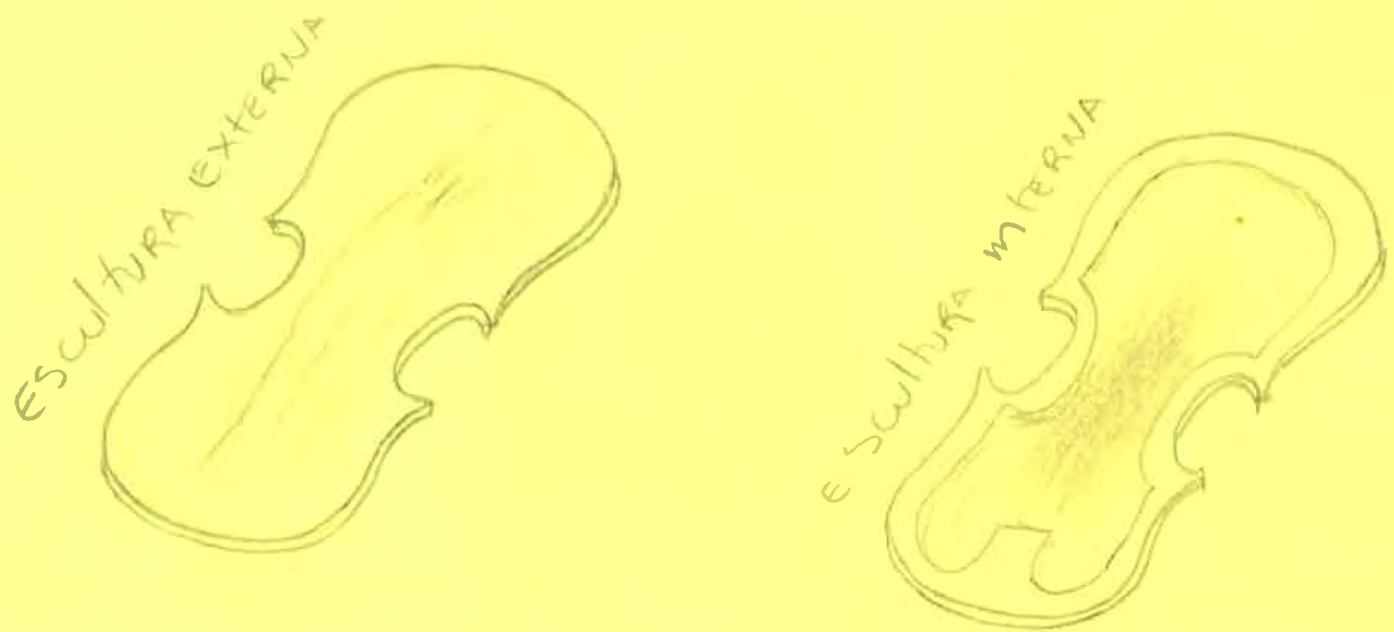

$\mathbf{2}^{\circ}$ passo: o corte do aro

$\mathrm{O}$ aro é cortado por dentro e por fora, deixando um espaço de $0,5 \mathrm{~cm}$ de madeira e ô encaixe para o braço

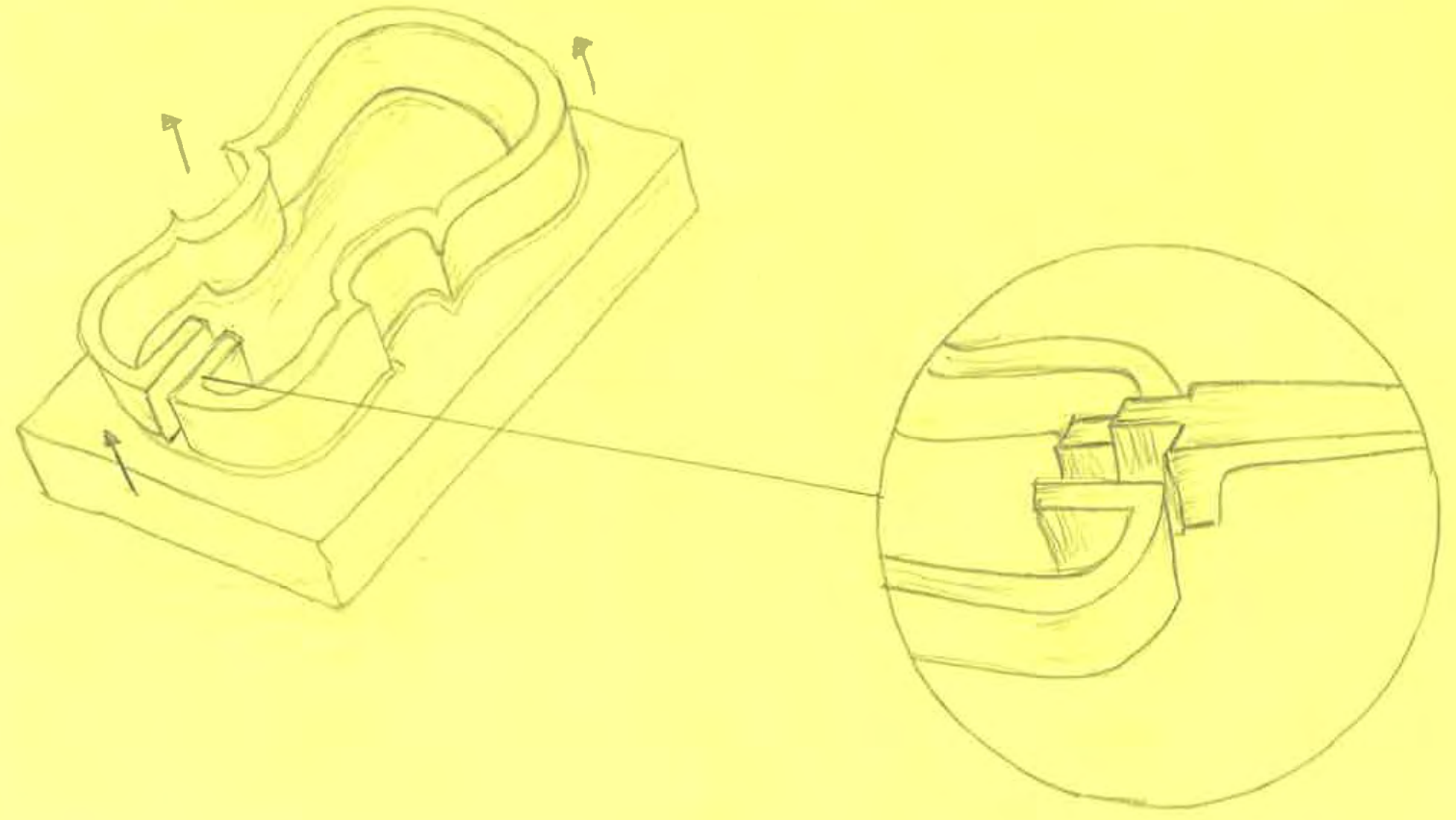


$\mathbf{3}^{\circ}$ passo: escultura do braço

A escultura do braço é feita de forma que a parte debaixo do braço seja roliçada e a parte de cima plana, para que sirva de apoio para o sobre-braço (escala). O espaço para as cravelhas tem aproximadamente $8 \mathrm{~cm}$ de comprimento por $2 \mathrm{~cm}$ de largura, sua altura varia de $4 \mathrm{~cm}$ a $2,5 \mathrm{~cm}$, à medida que se aproxima do caramujo (voluta). Esse espaço tem mais da metade de sua altura escavado, para a entrada das cordas.

O caramujo é esculpido de forma simétrica, ou seja, igual dos dois lados, começando do final do espaço das cravelhas e percorrendo três voltas em torno do seu próprio eixo, em direção ao centro, formando uma espécie de caracol de ambos os lados.

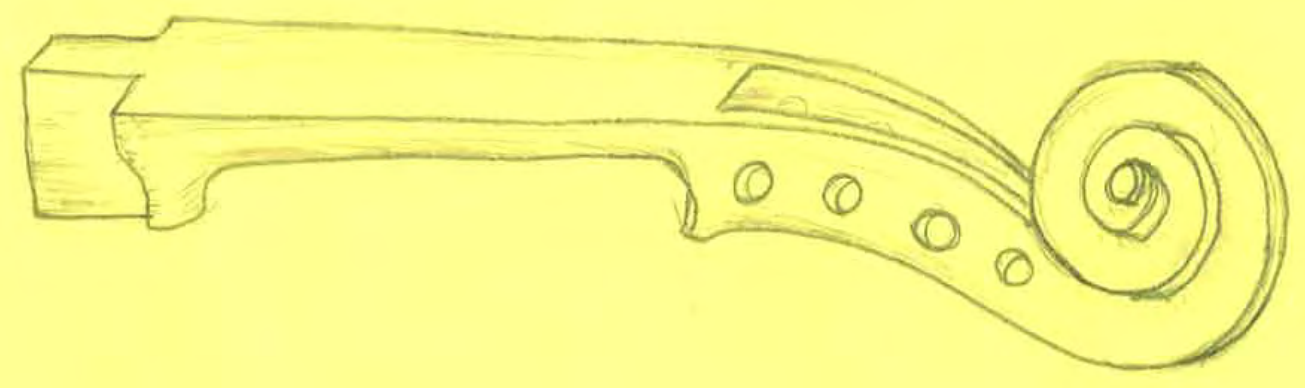

$4^{\circ}$ passo: construção do sobre-braço (escala)

A construção do sobre-braço é feita em uma peça que varia de $2 \mathrm{~cm}$ numa extremidade e $3,5 \mathrm{~cm}$ na outra, com $2 \mathrm{~cm}$ de espessura, escavando-se a parte de dentro e arroliçando-se a parte de fora, para que as cordas fiquem distribuídas em níveis diferentes evitando que o arco raspe em duas cordas ao mesmo tempo.

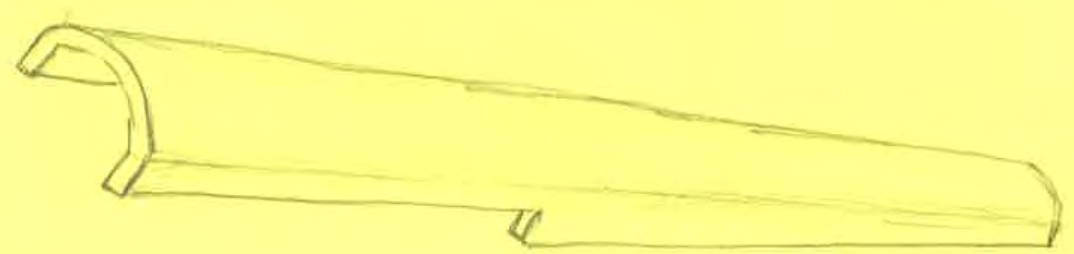


$\mathbf{5}^{\circ}$ passo: rabequinho (estandarte)

Essa peça serve para segurar as cordas, deve ser roliça por fora e escavada por dentro, deve-se colocar um pedaço de madeira de sentido contrário na parte côncava para que sirva de suporte para as cordas.

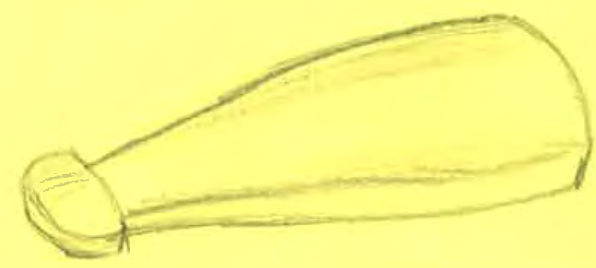

$6^{\circ}$ passo: cavalete

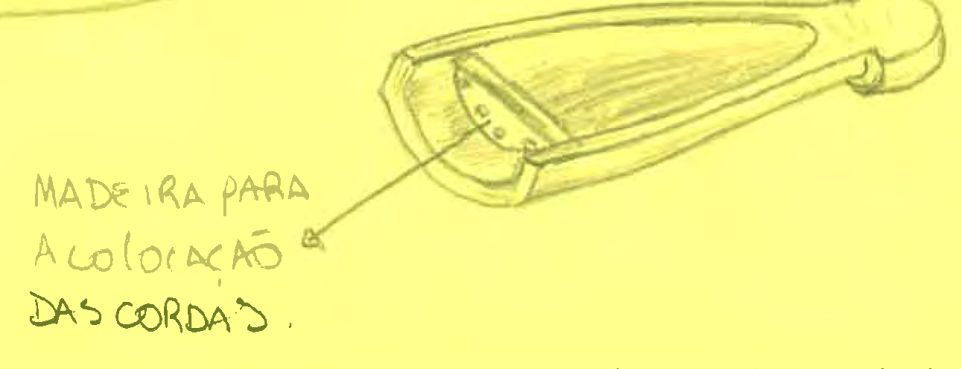

O cavalete é a peça que serve como sustentação para as cordas, sua altura varia de acordo com a angulação do sobre-braço, e a largura é de $4 \mathrm{~cm}$ e sua espessura é de $5 \mathrm{~mm}$.

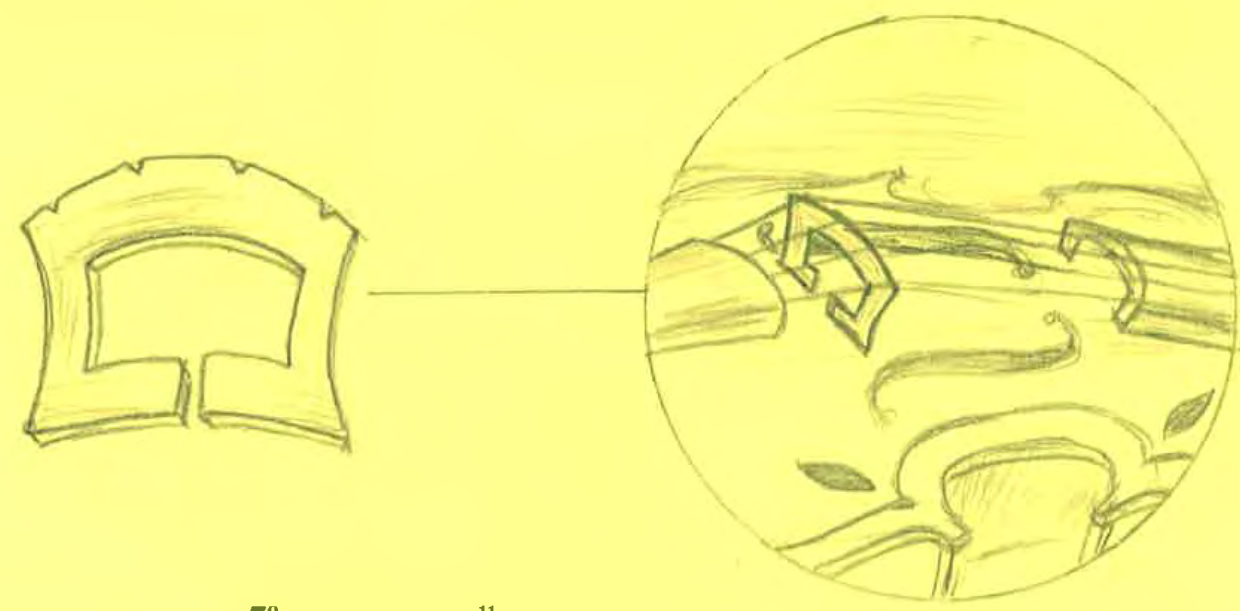

$7^{\circ}$ passo: cravelha

As cravelhas são usadas para o esticamento das cordas, ou seja, para afinar a rabeca. Uma extremidade tem forma cônica e a outra achatada.

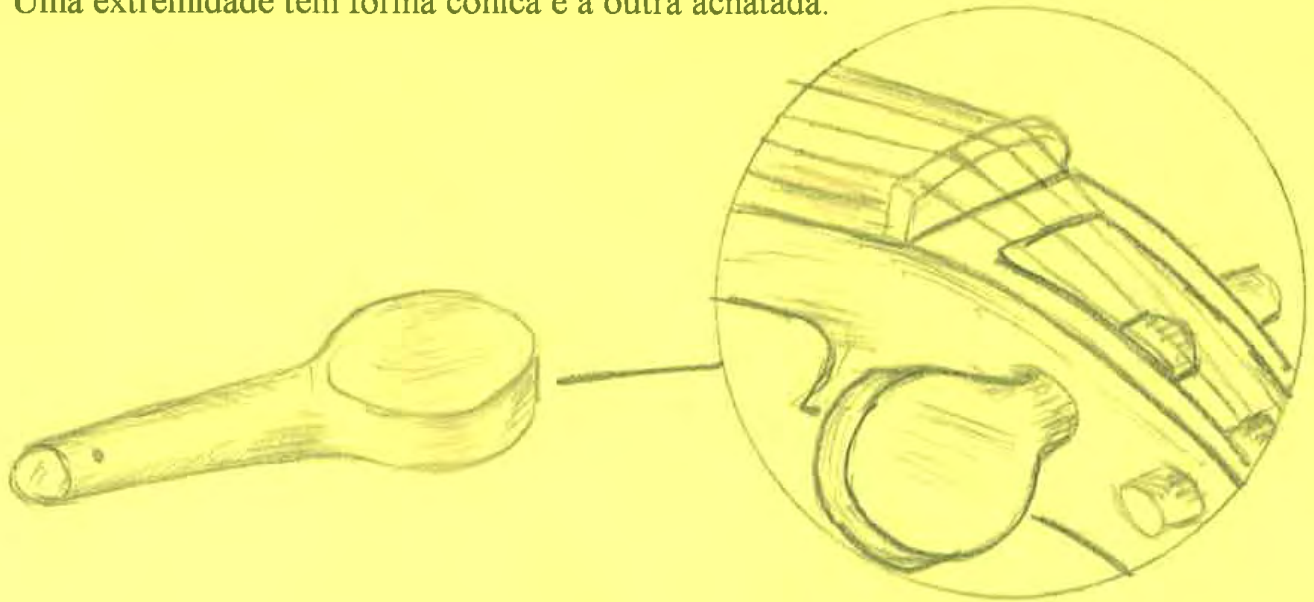




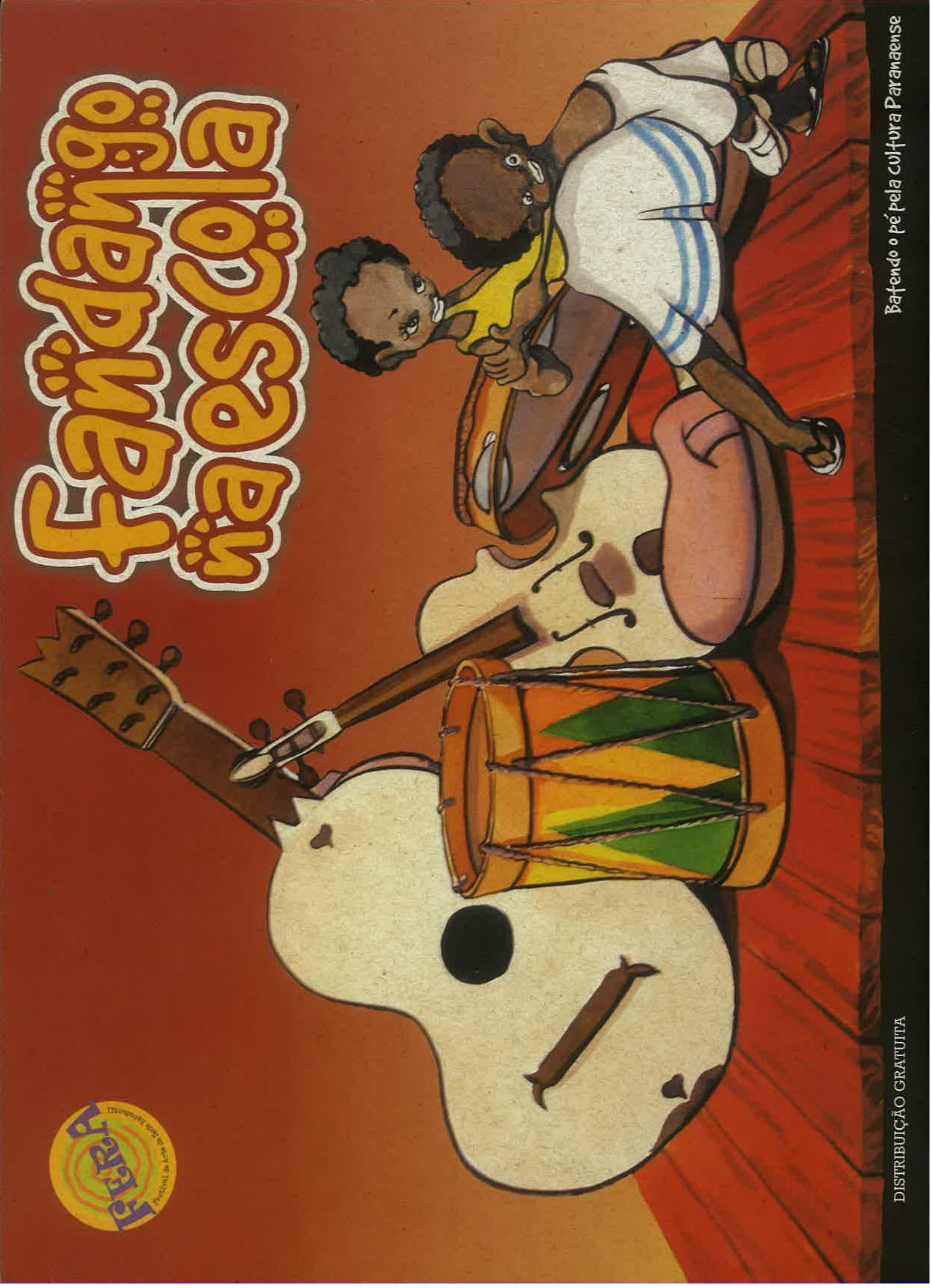




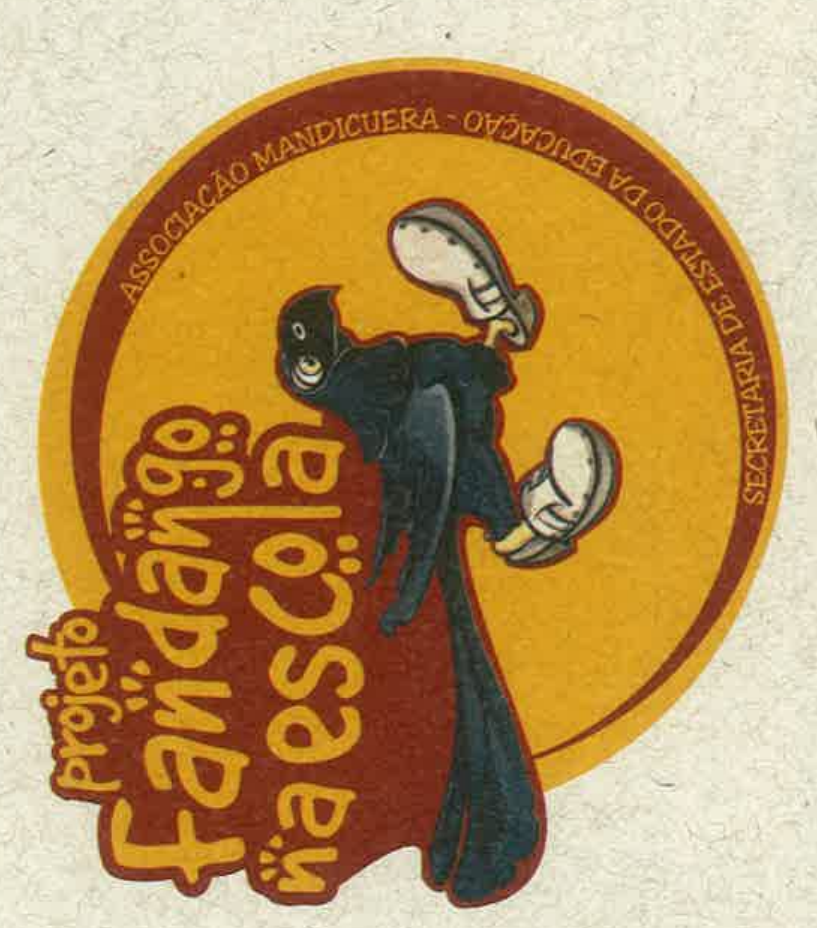




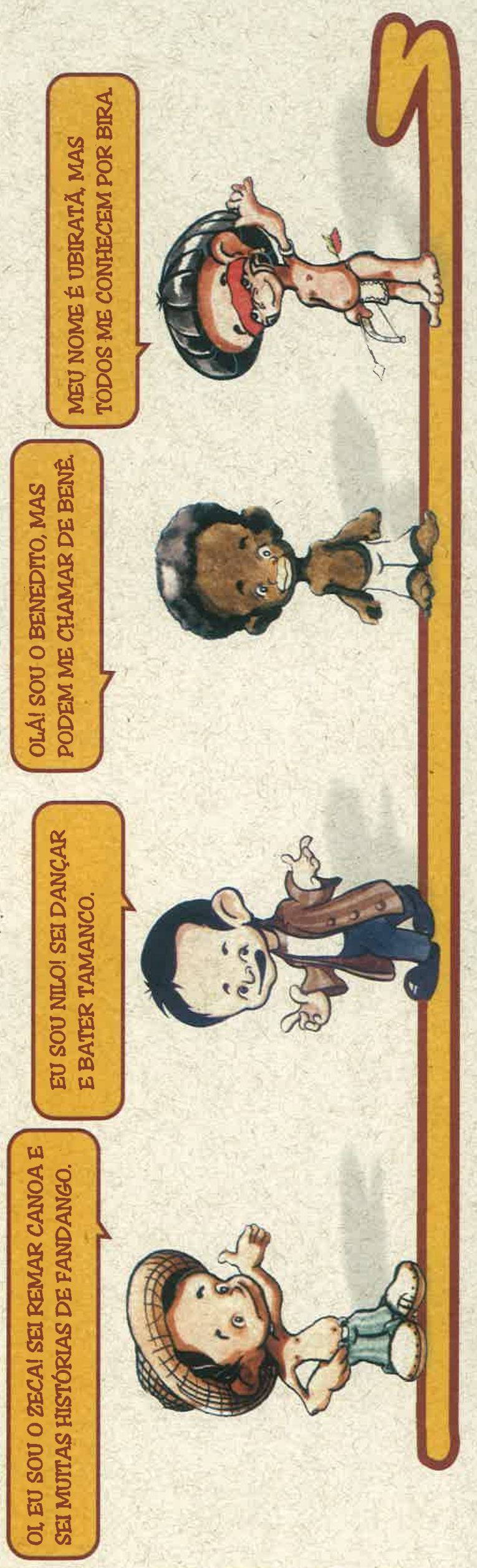




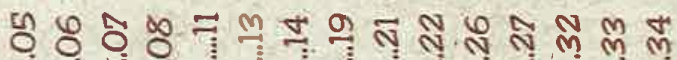

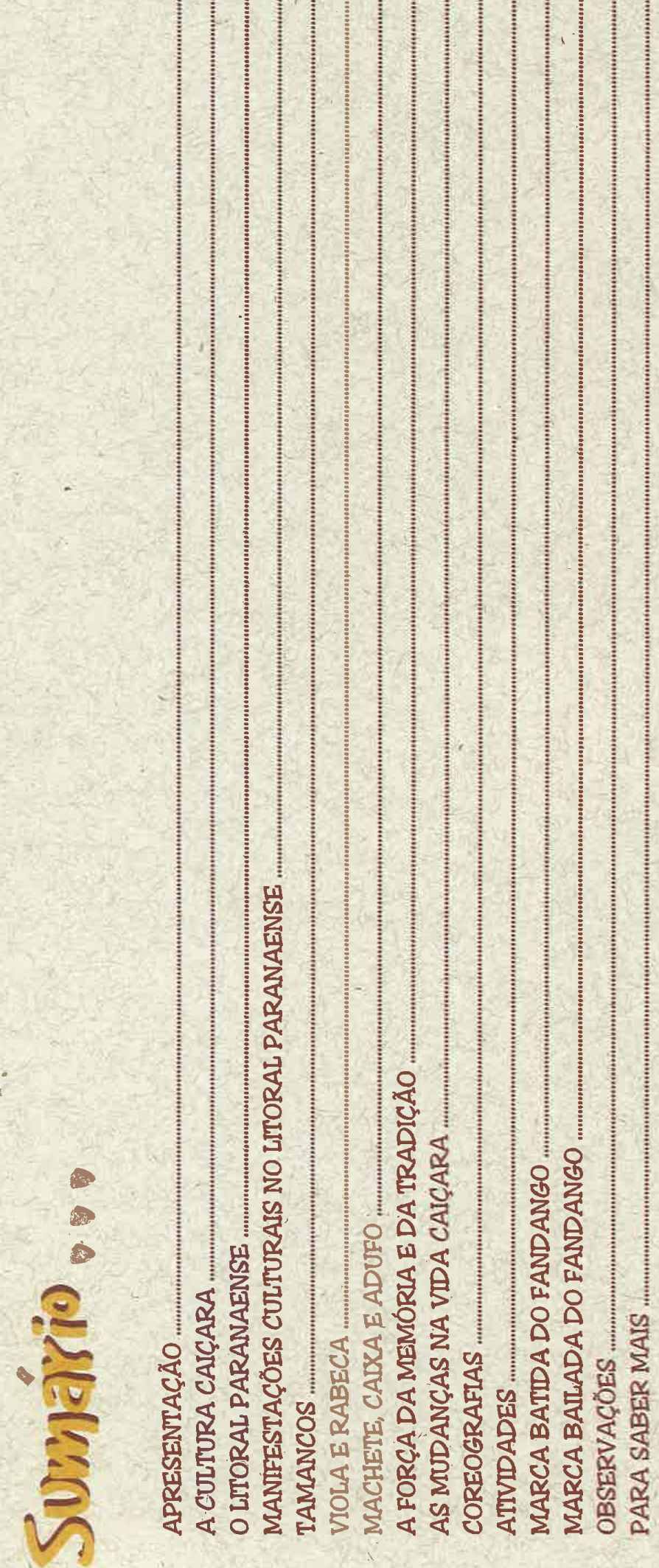




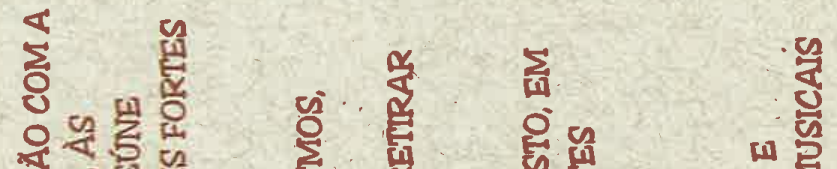

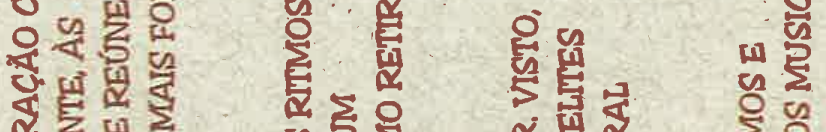

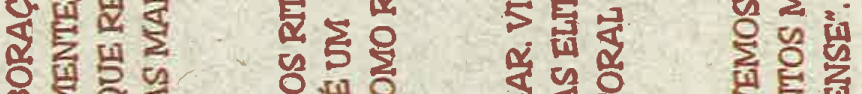

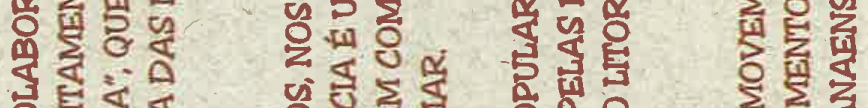

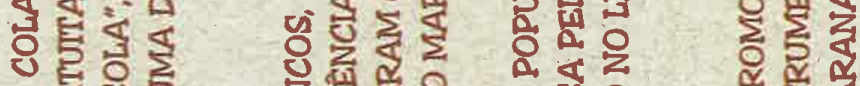

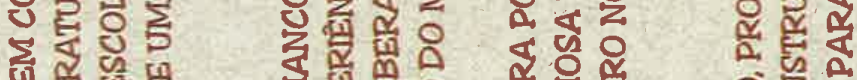

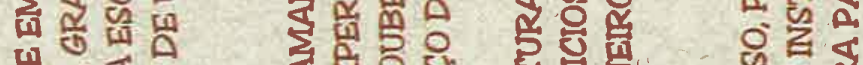

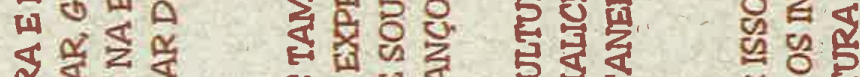

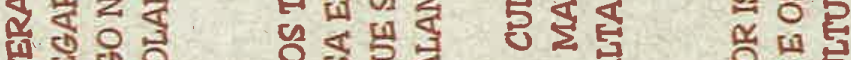

4

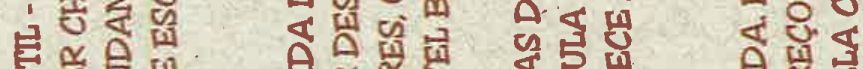

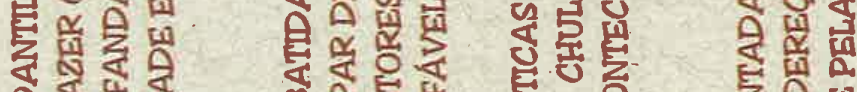

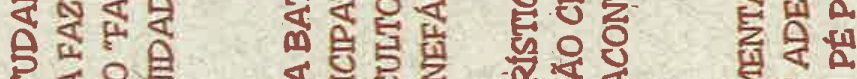

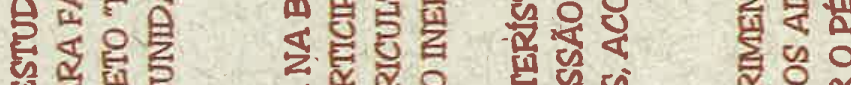

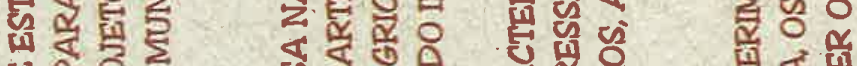

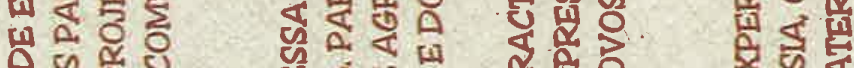

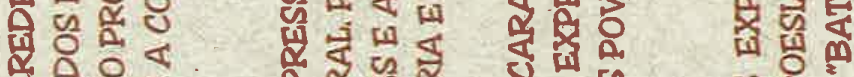

से우

ธิ

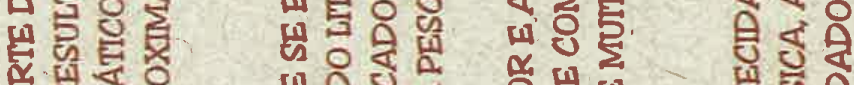

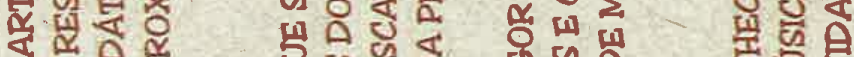

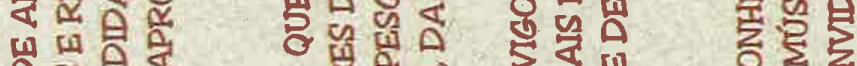

मै

सेष्ठ

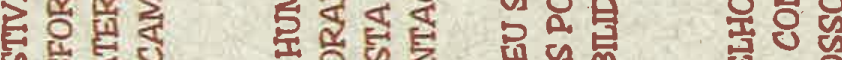

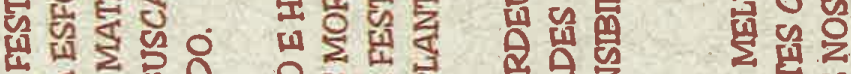

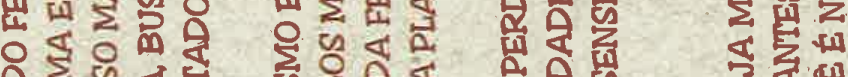

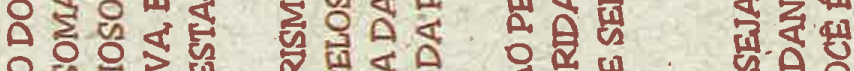

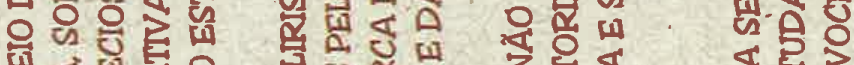

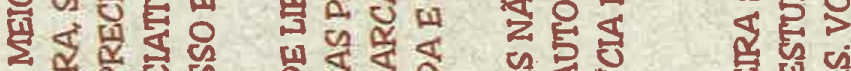

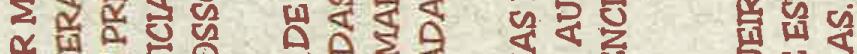

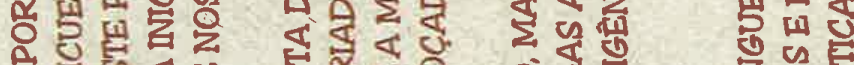

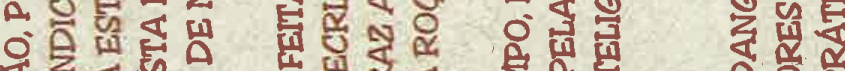

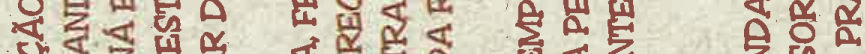

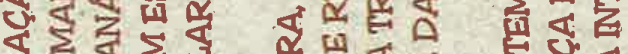

才ै

$\frac{2}{3}$

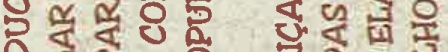
जि

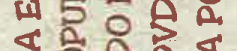

पे दे

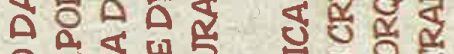

$\circ$ 过

से

ई द्धि

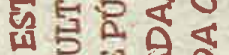

दे

जड जा दे

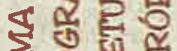

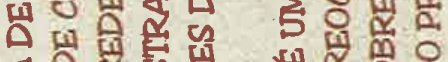

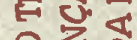

8 帘

잉용

원

곱

연

放家

实是

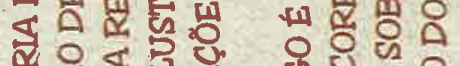

歪

究是

出落

우원

든

डे

운

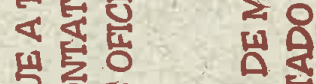

«

8 요요

00 z

这角

in 0 i

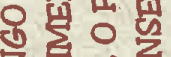

봉요

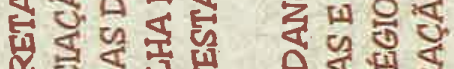

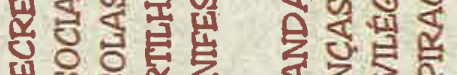

学得

要专要

为帘家

罂

《皆它

空要

点

䟧出
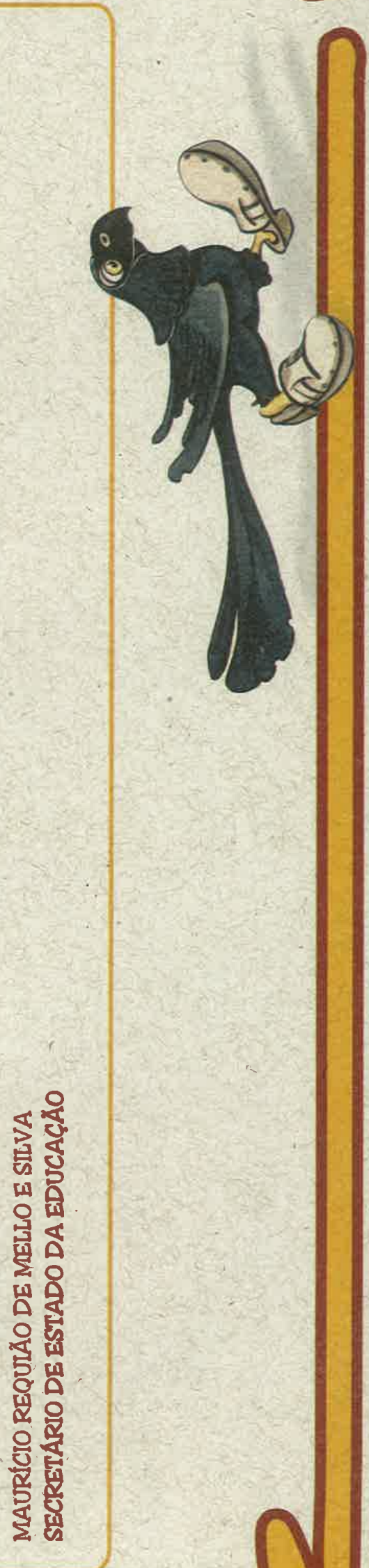
ङ

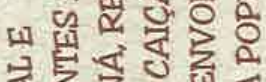

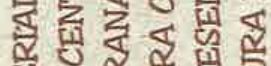

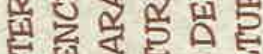

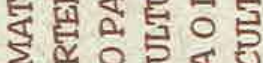

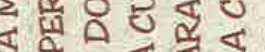

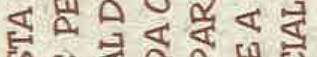

的数的

(1)

s

i 을 의

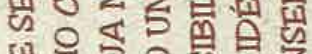

wo 을

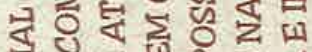

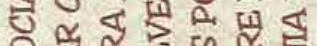

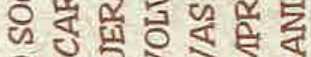

들

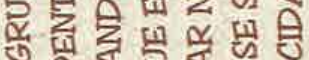

政的

no

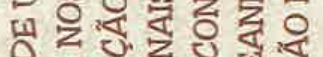

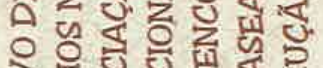

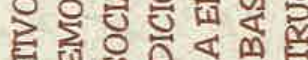

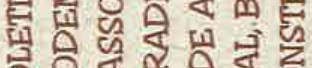

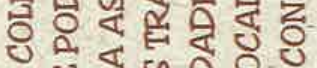

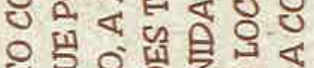

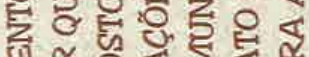

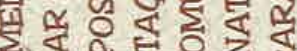

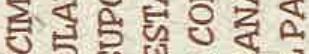

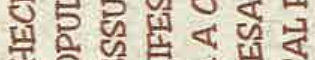

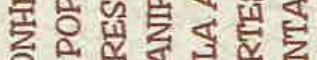

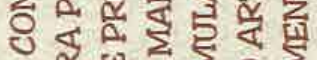

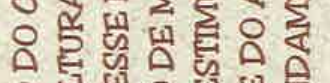

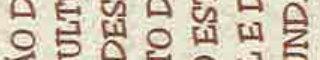

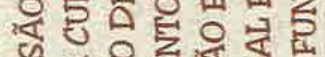

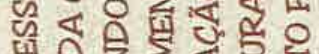

采。

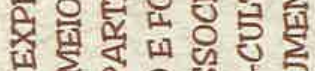

4 这然

w告

业出出氞

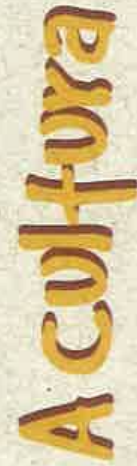

娄 0

ठै 仓ो

\$ㅇำ

育祭

500

« ठํ

为。

을

舜密

5 넨은

孚

a药

대용

最

우란

究

का 2

००

5 ज्ञ

0 \& \&

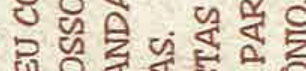

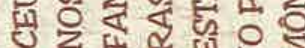

के 0 宛

คㅇำ 늘

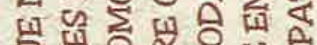

누ㅇㅝㅛ $\mu$

运的

인.

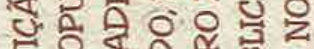

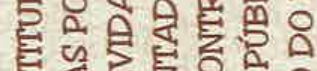

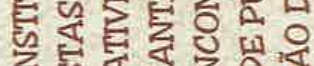

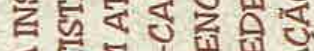

इ

डद प्रषष

的面少焉

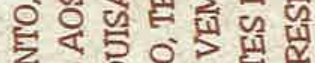

द जि क्ष है

जि क्षे

ठิ

실

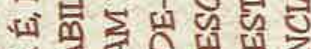

यद

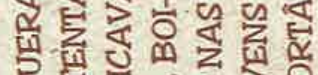

ट्रे

它资

दें द्षे

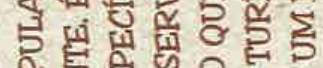

施离亩出

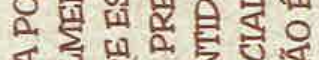

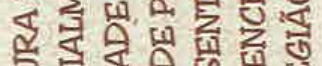

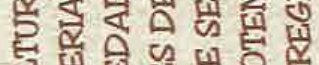

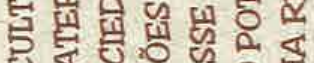

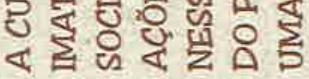

5

यदि

ชै문

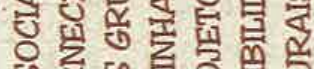

要曾 0

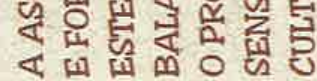

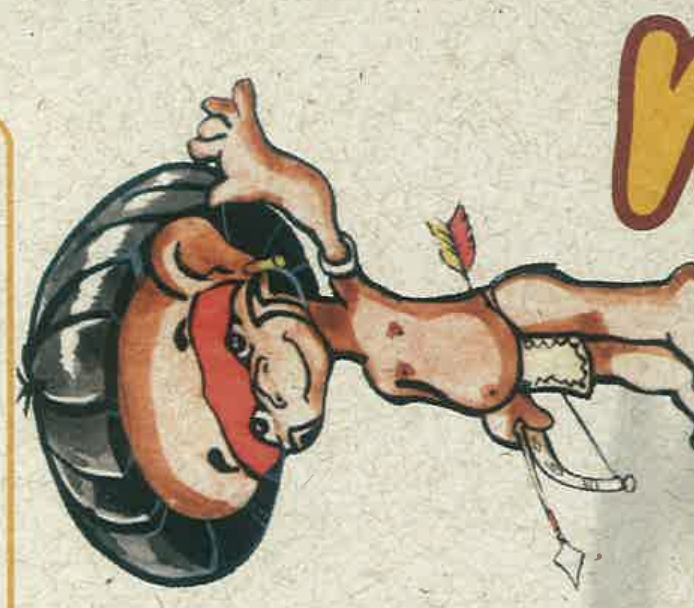




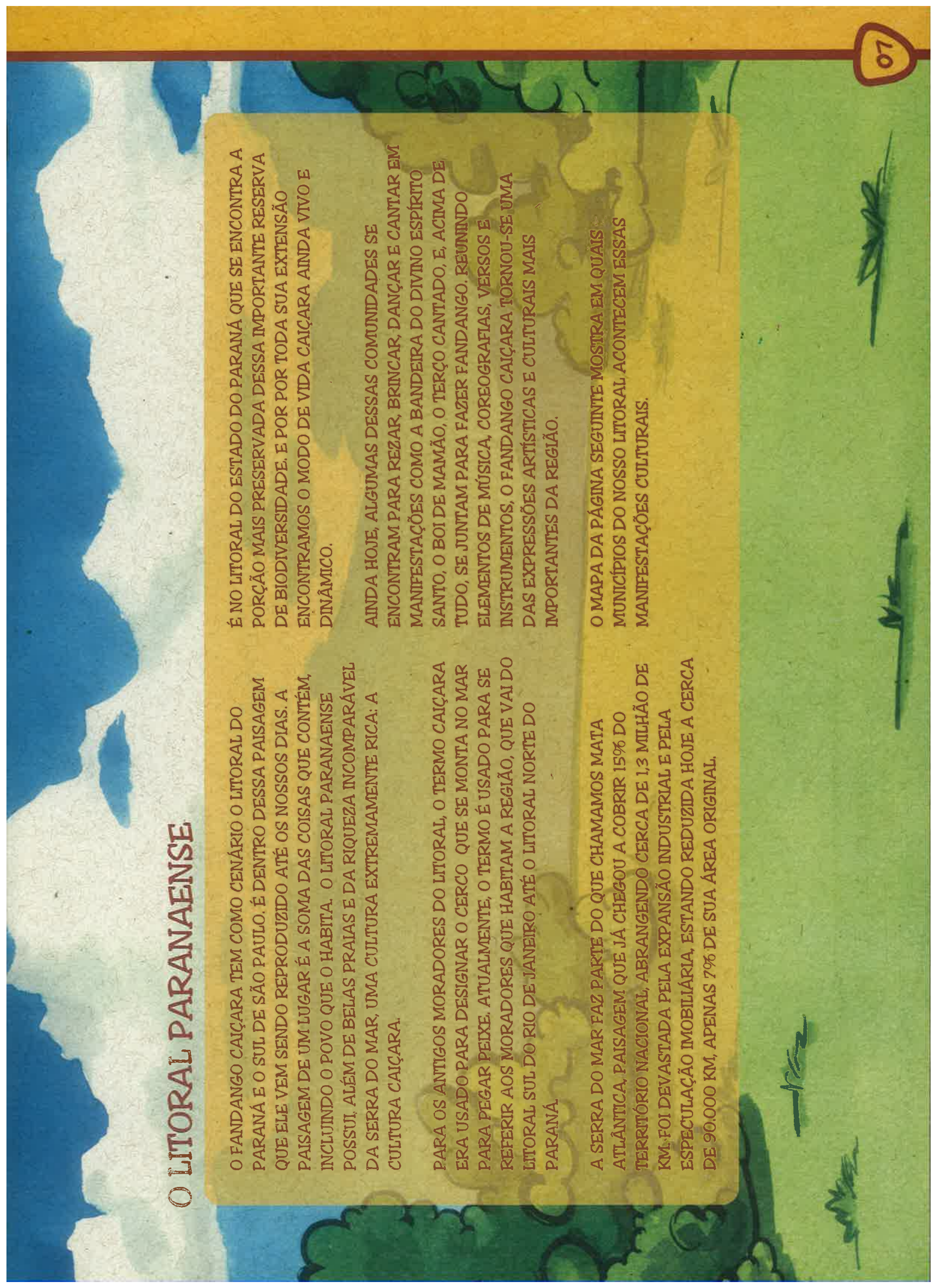




\section{MANIFESTAÇÕES CULTURAIS NO LITORAL PARANAENSE}
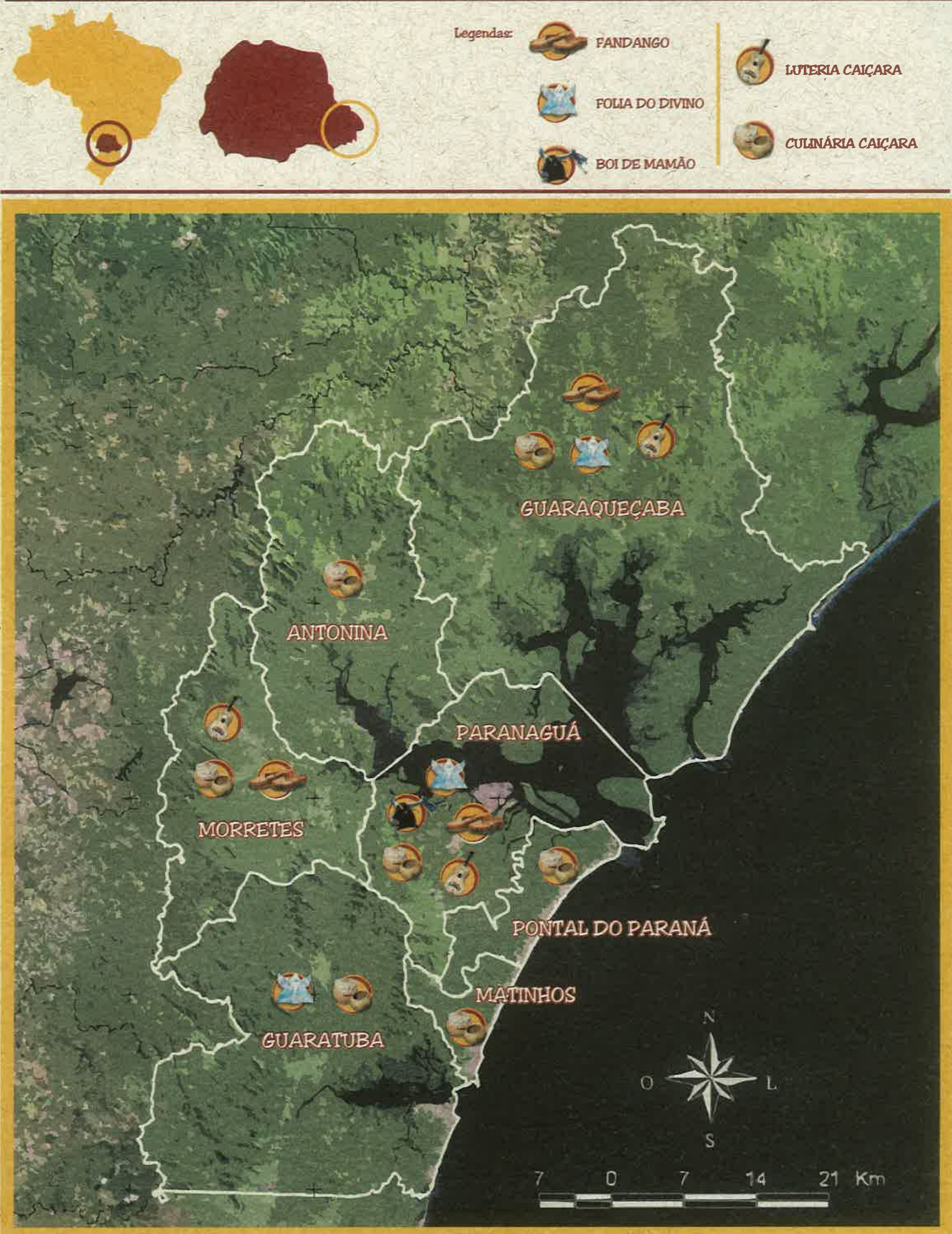


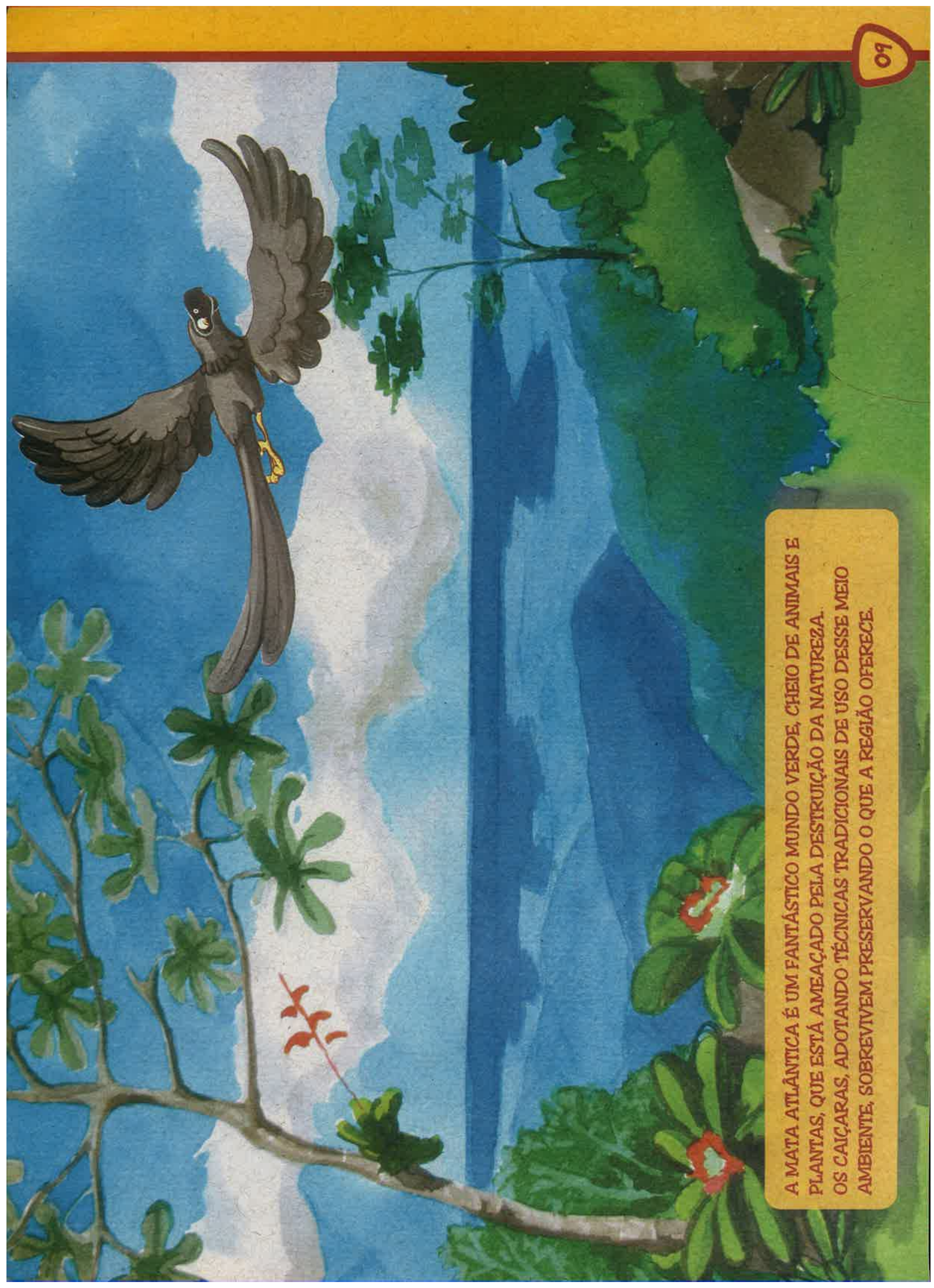




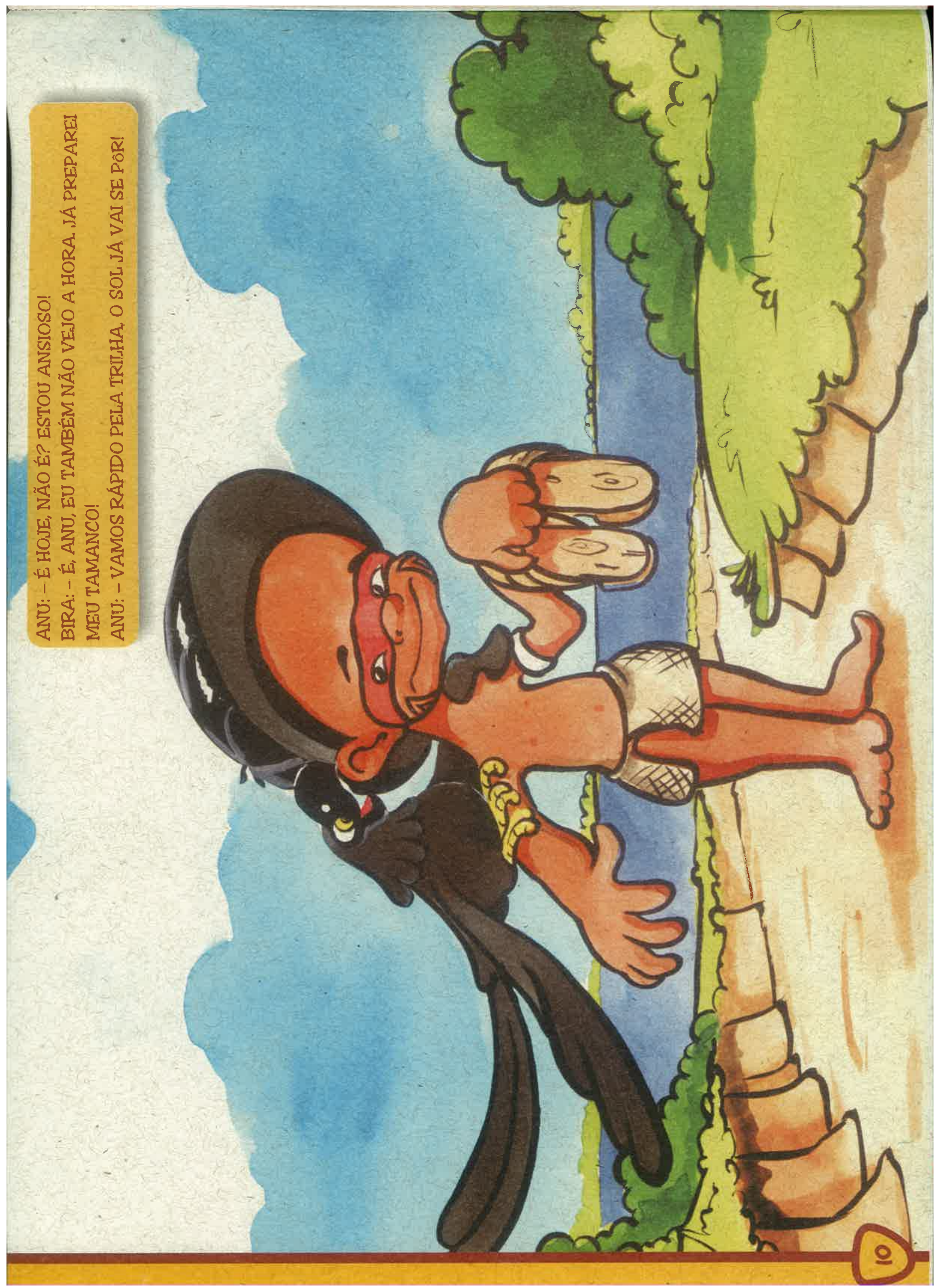




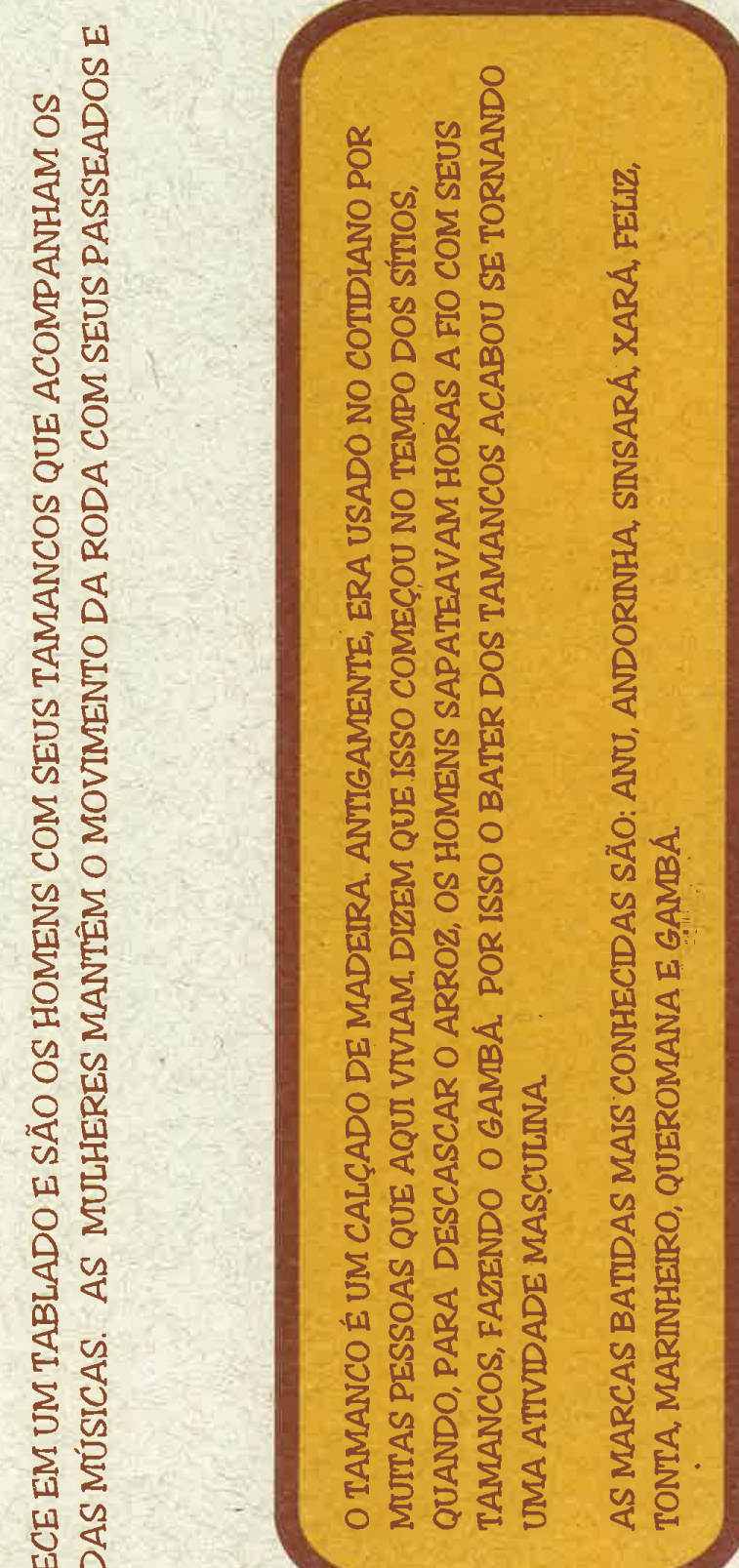




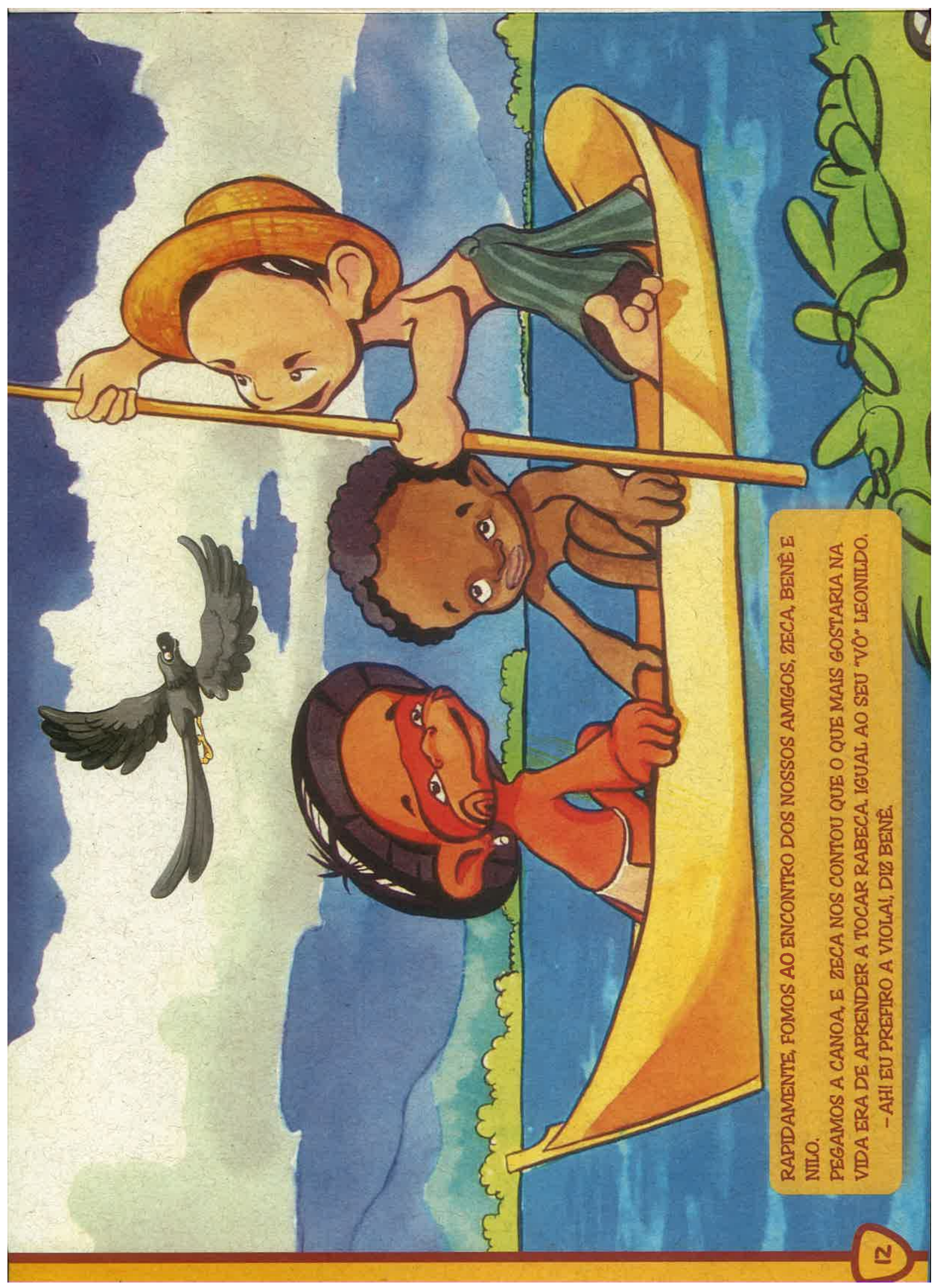




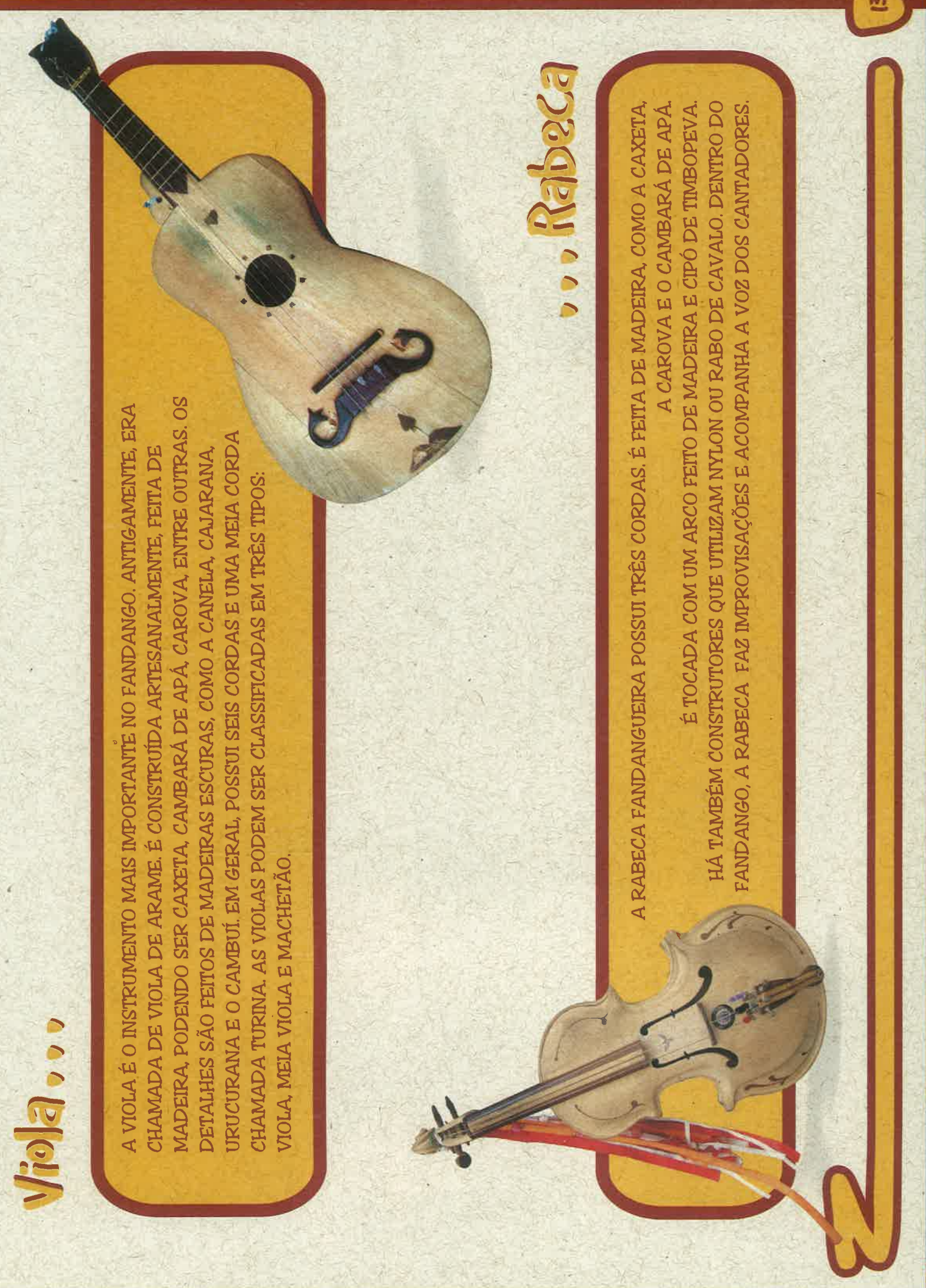




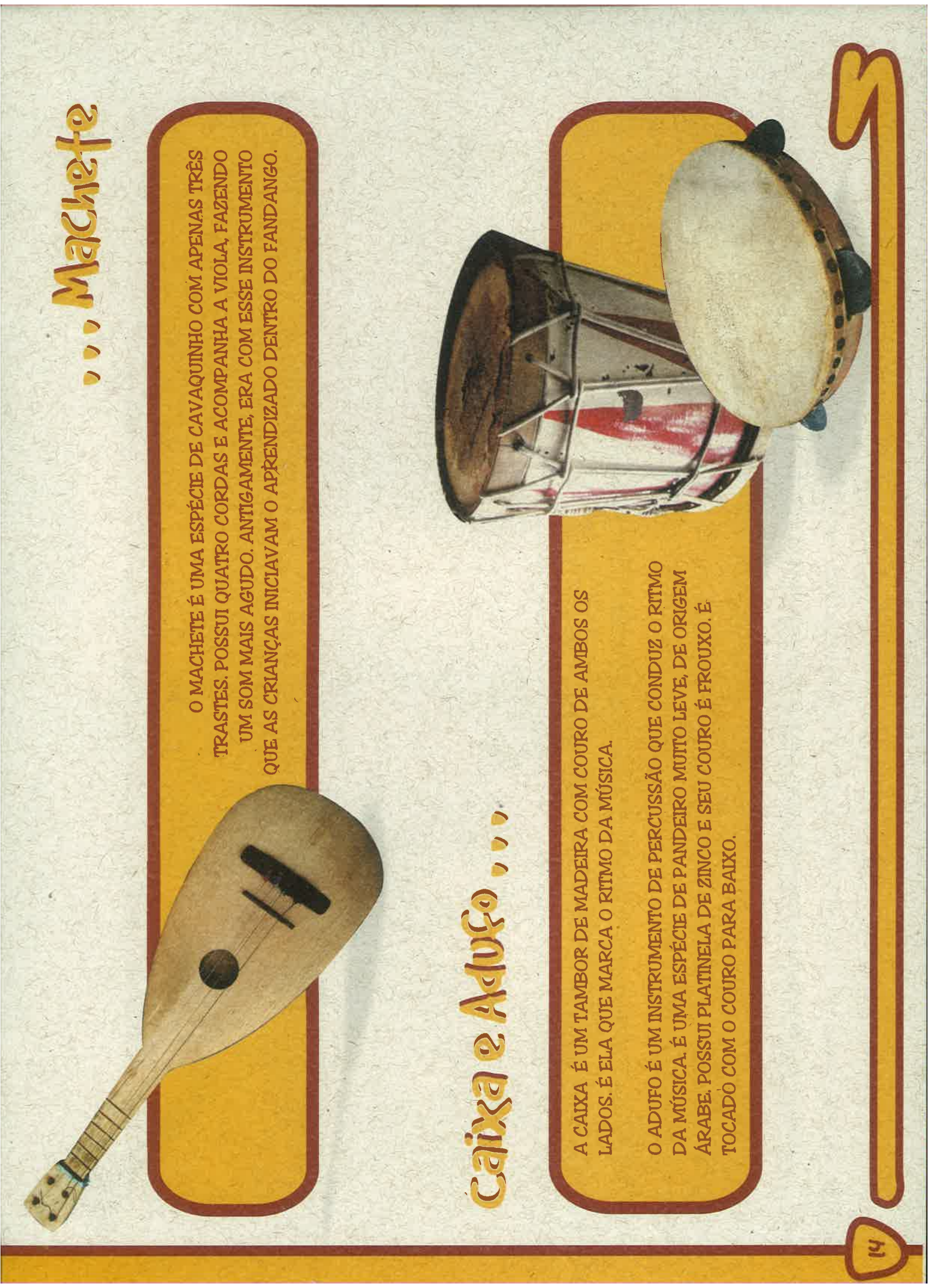




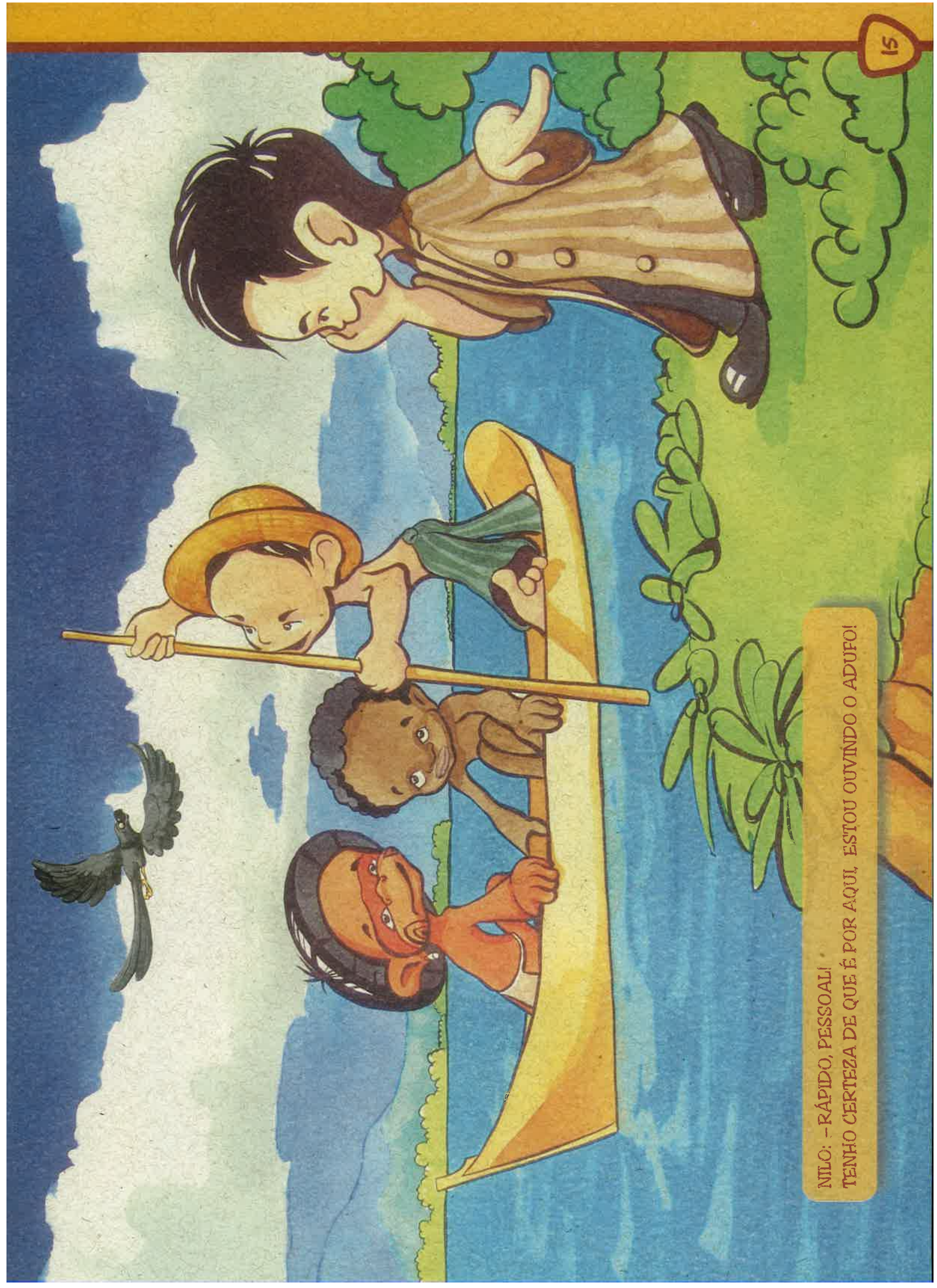




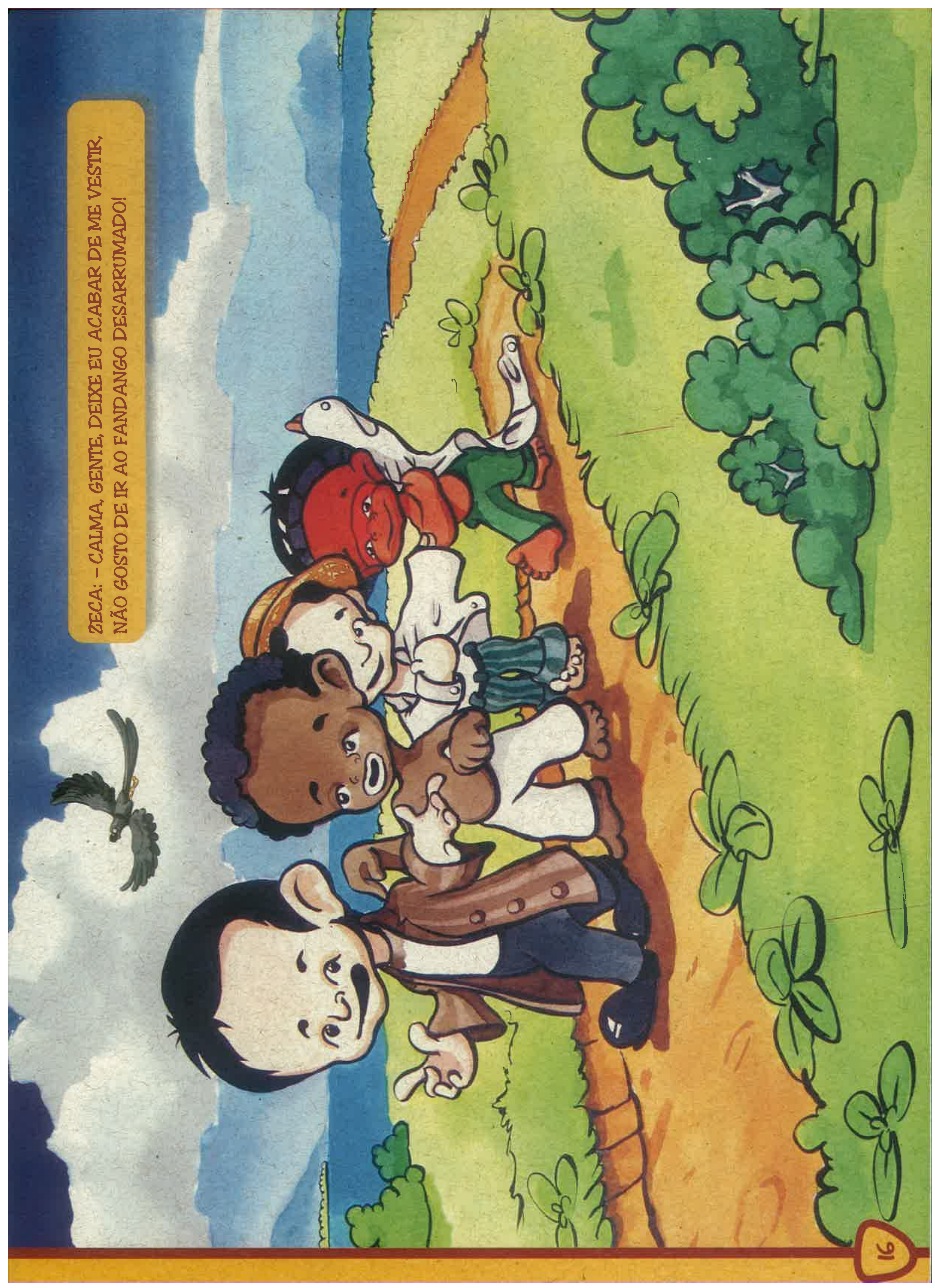




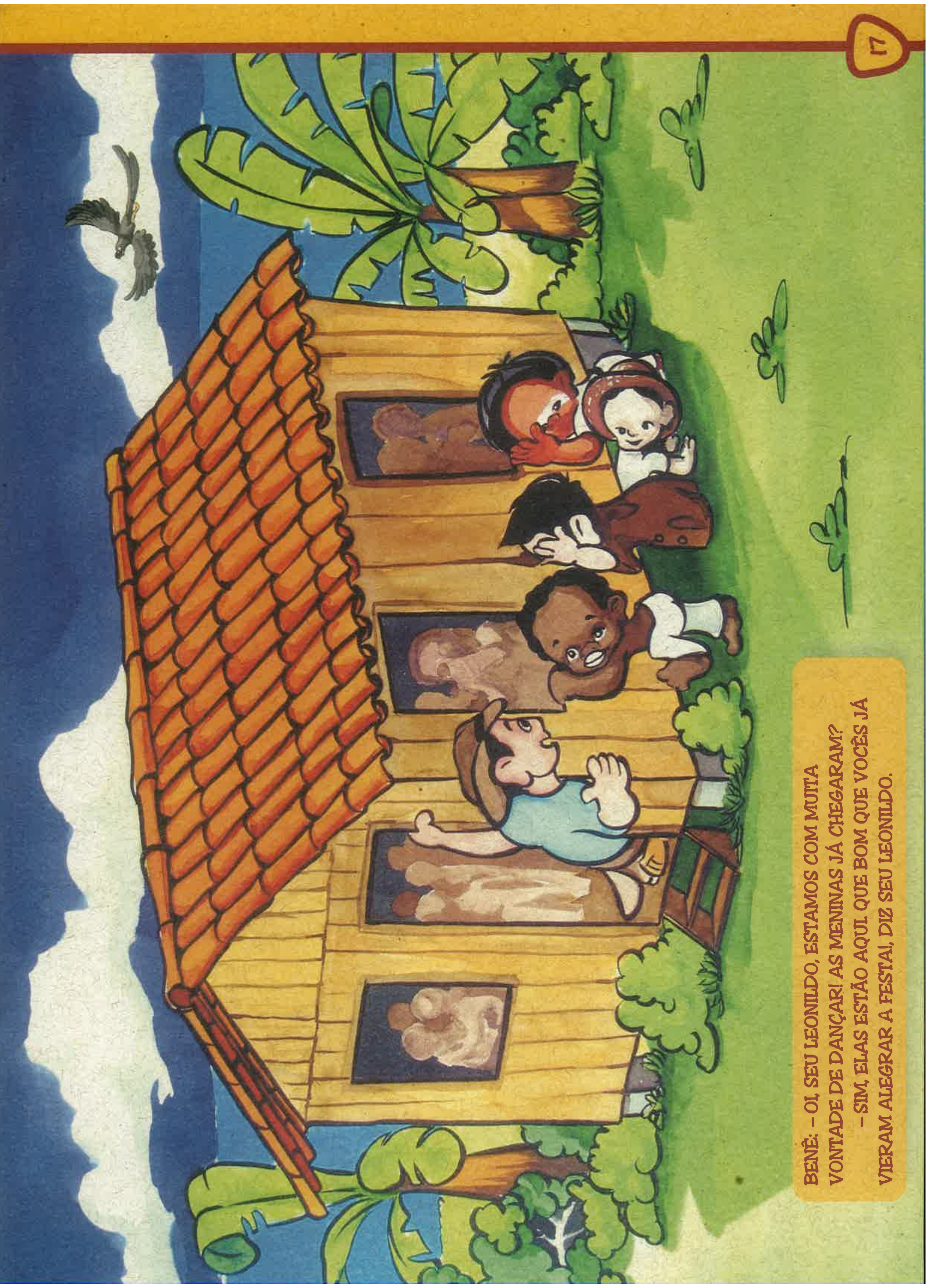




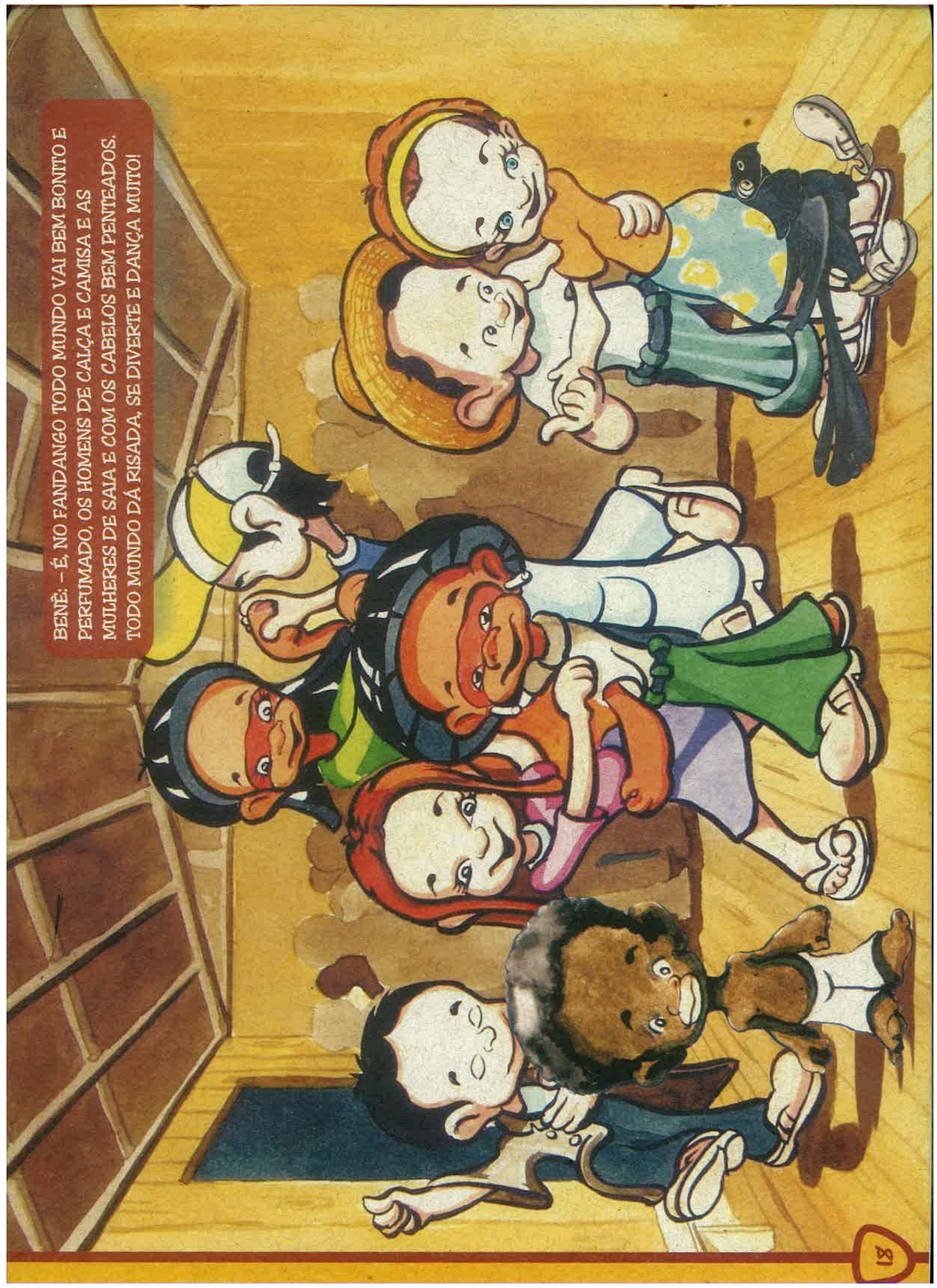




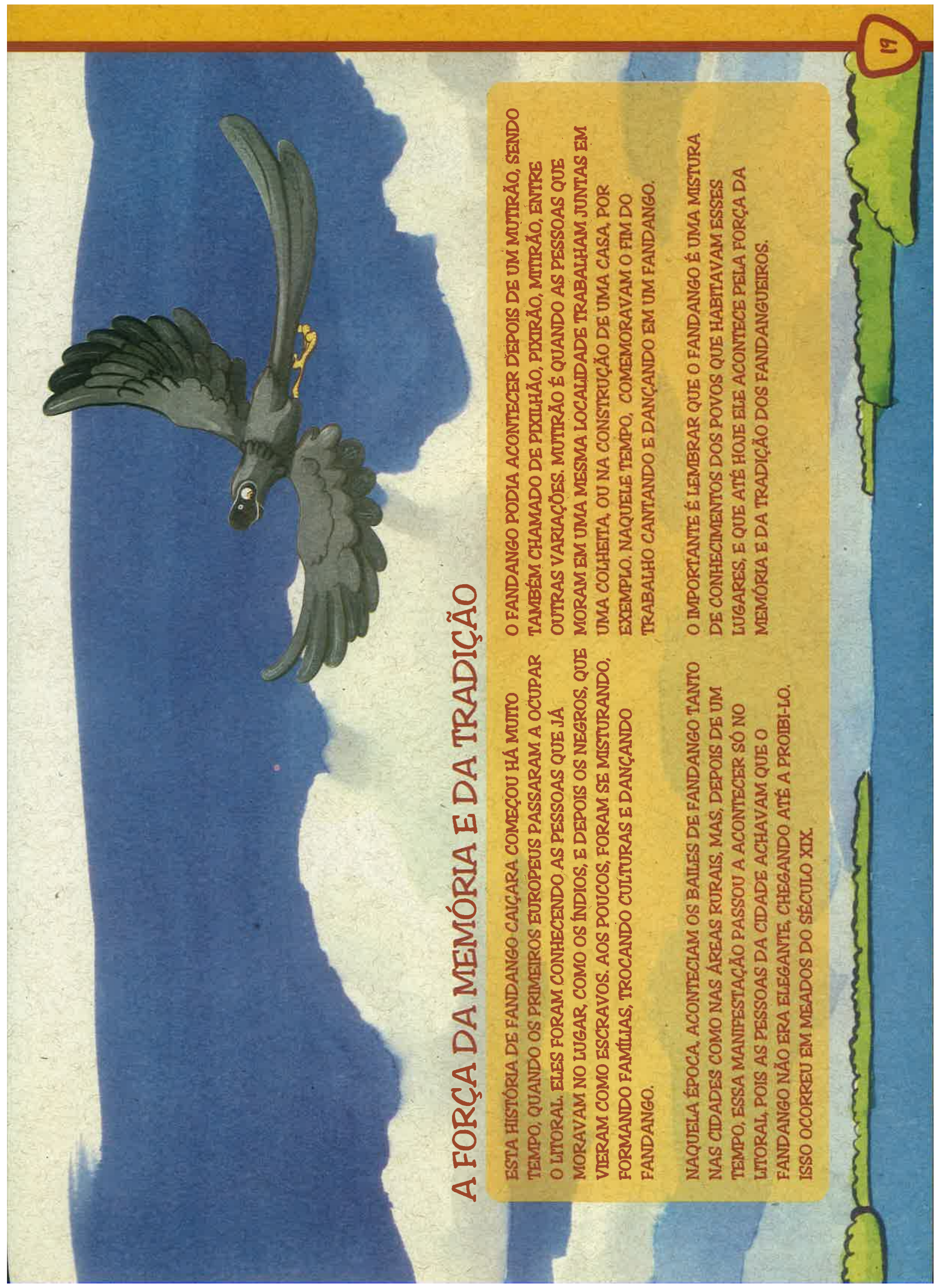




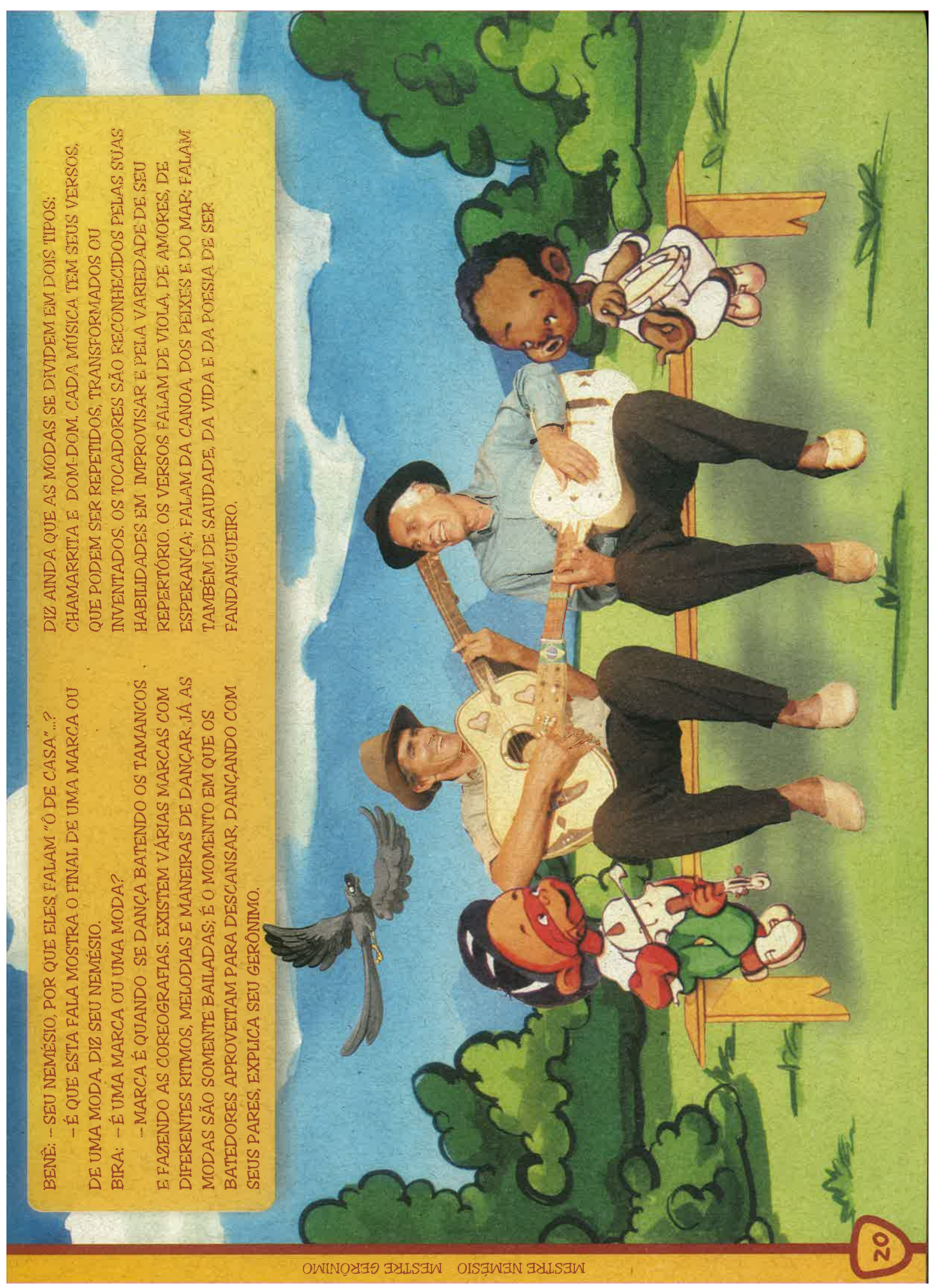


\%

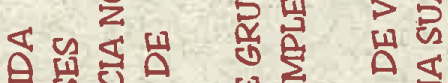

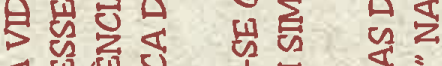

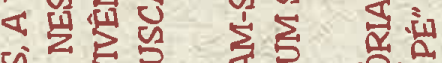

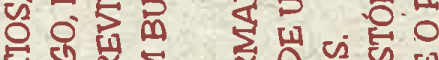

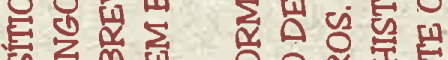

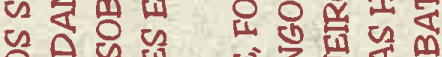

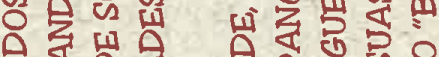

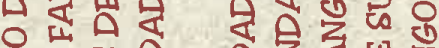

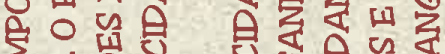

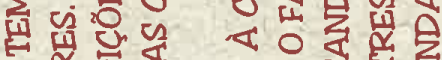

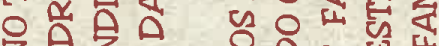

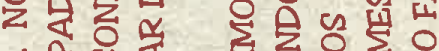

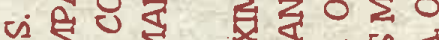

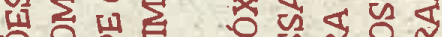
ชᄋํㅇ

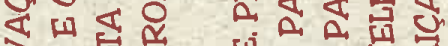

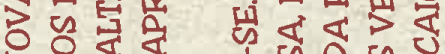

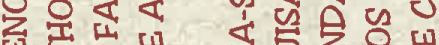

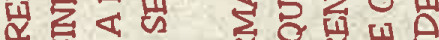
ज次

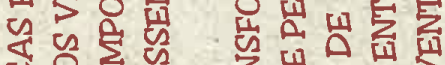

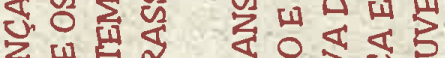

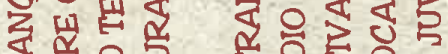
ค它昌

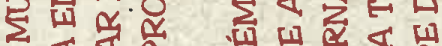

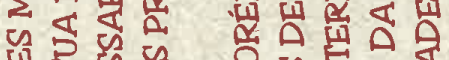

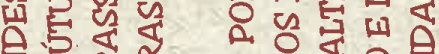
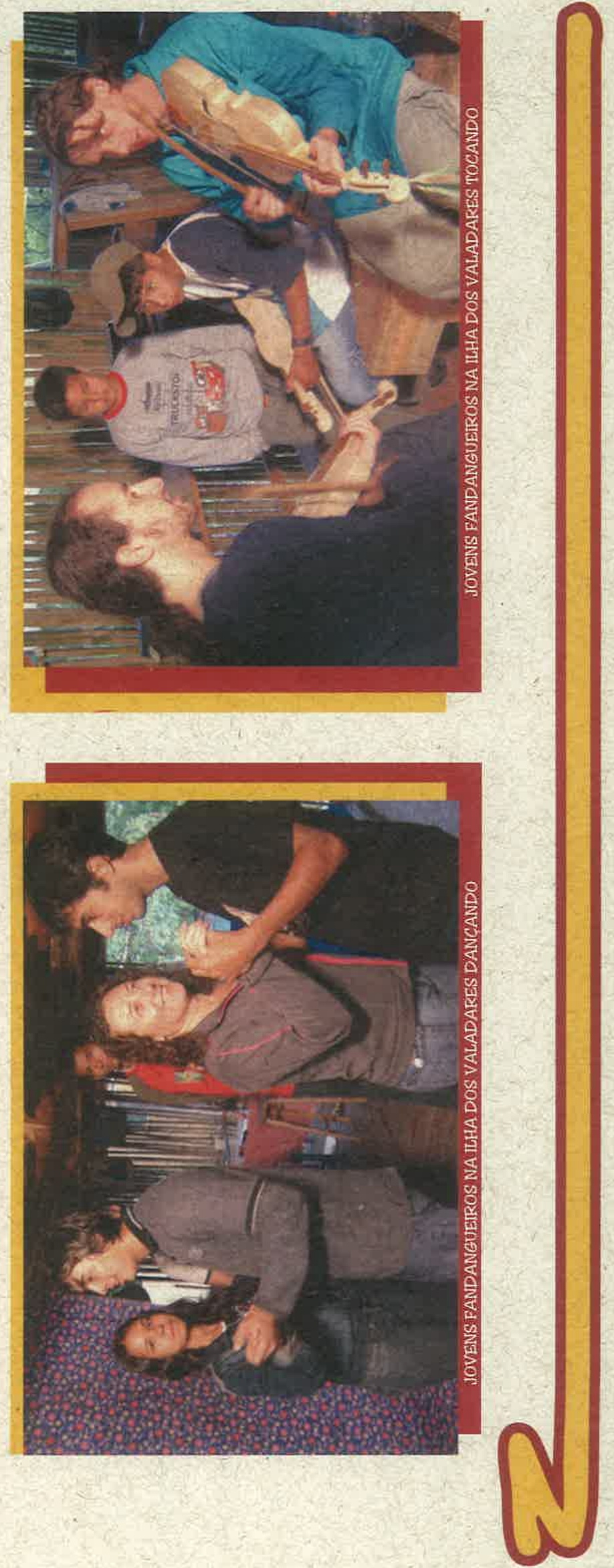

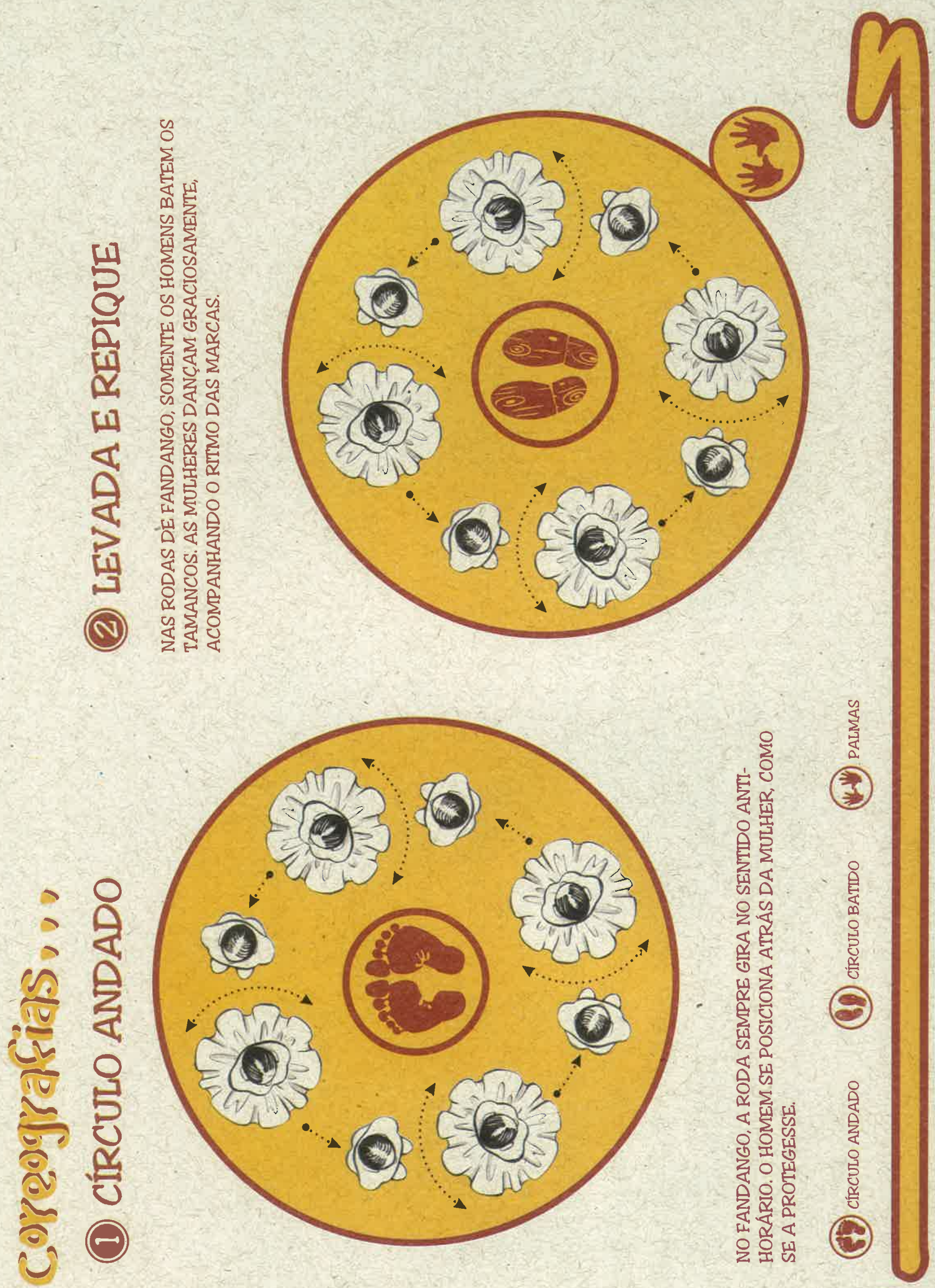

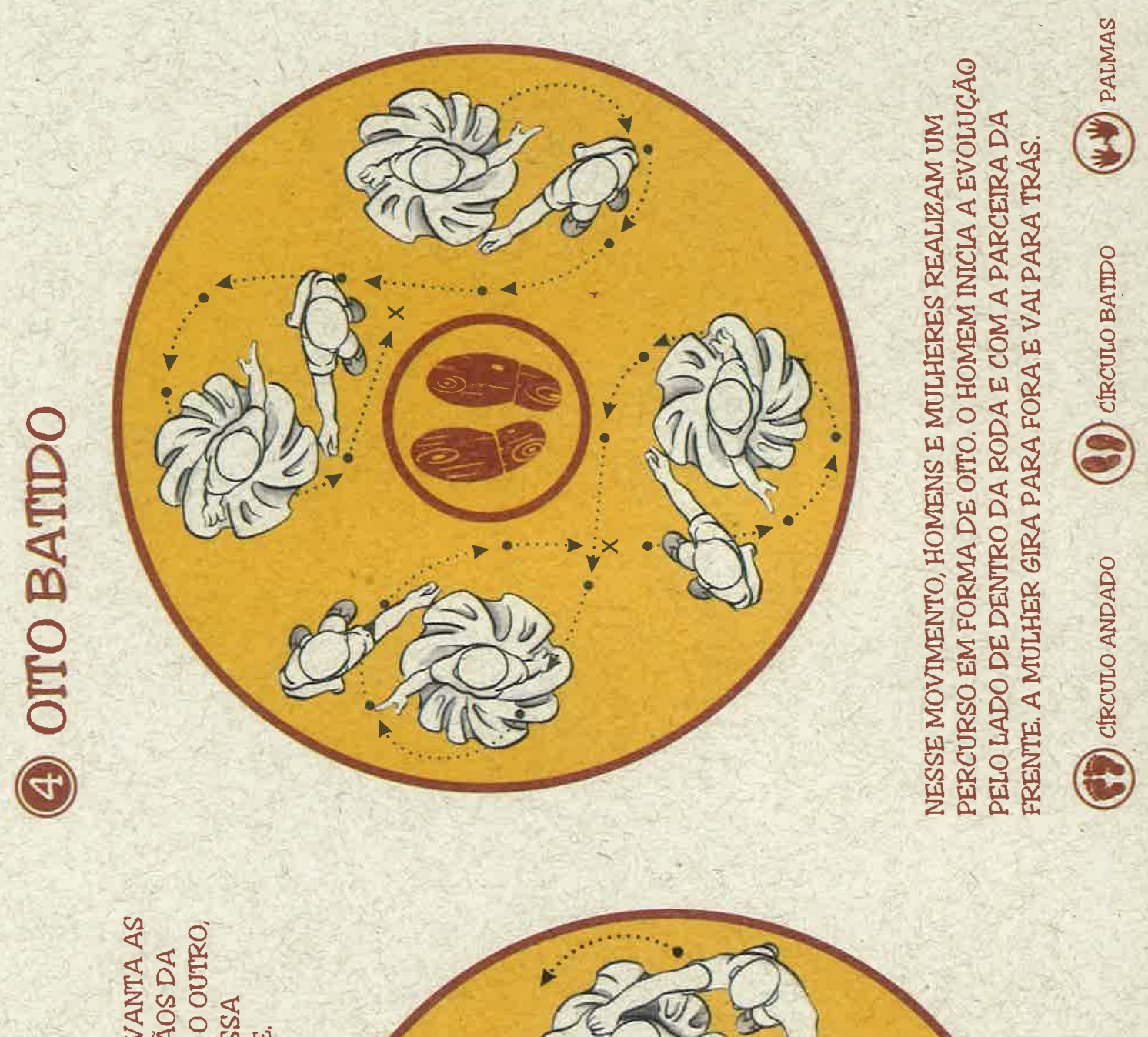
$\leq 20$ 岃之业崖 분정 $\sum<0$ 어

- $\quad \sum_{0}^{2} \frac{\alpha}{\alpha}$

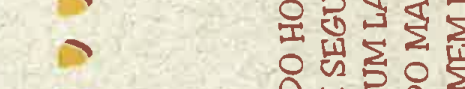

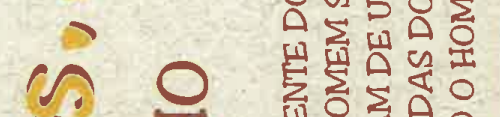

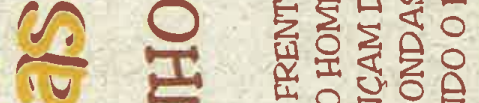
12 《

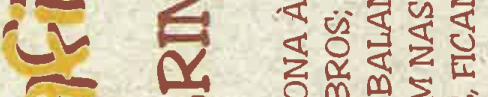

IV U1 1 H छ ㄱ 욜 尺 \

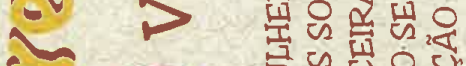

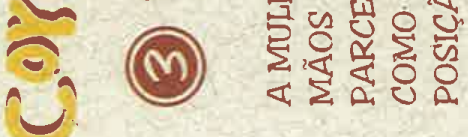

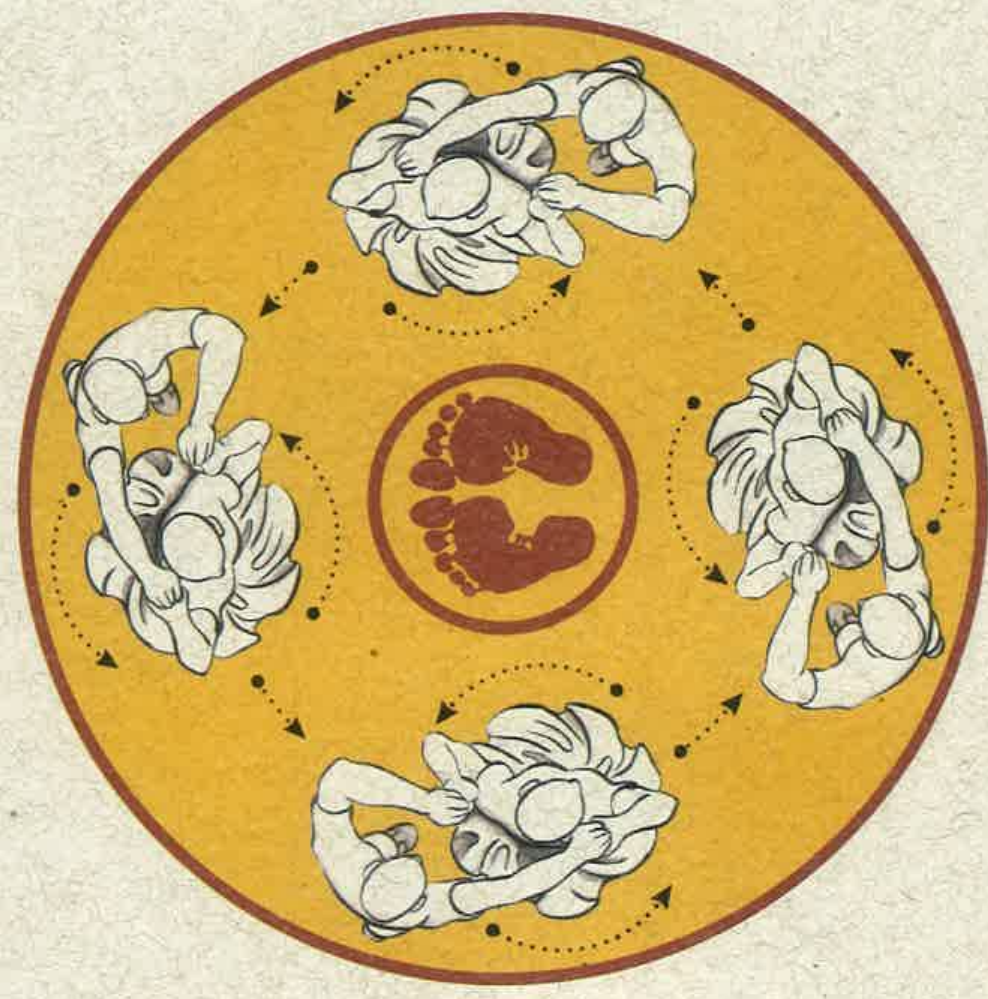



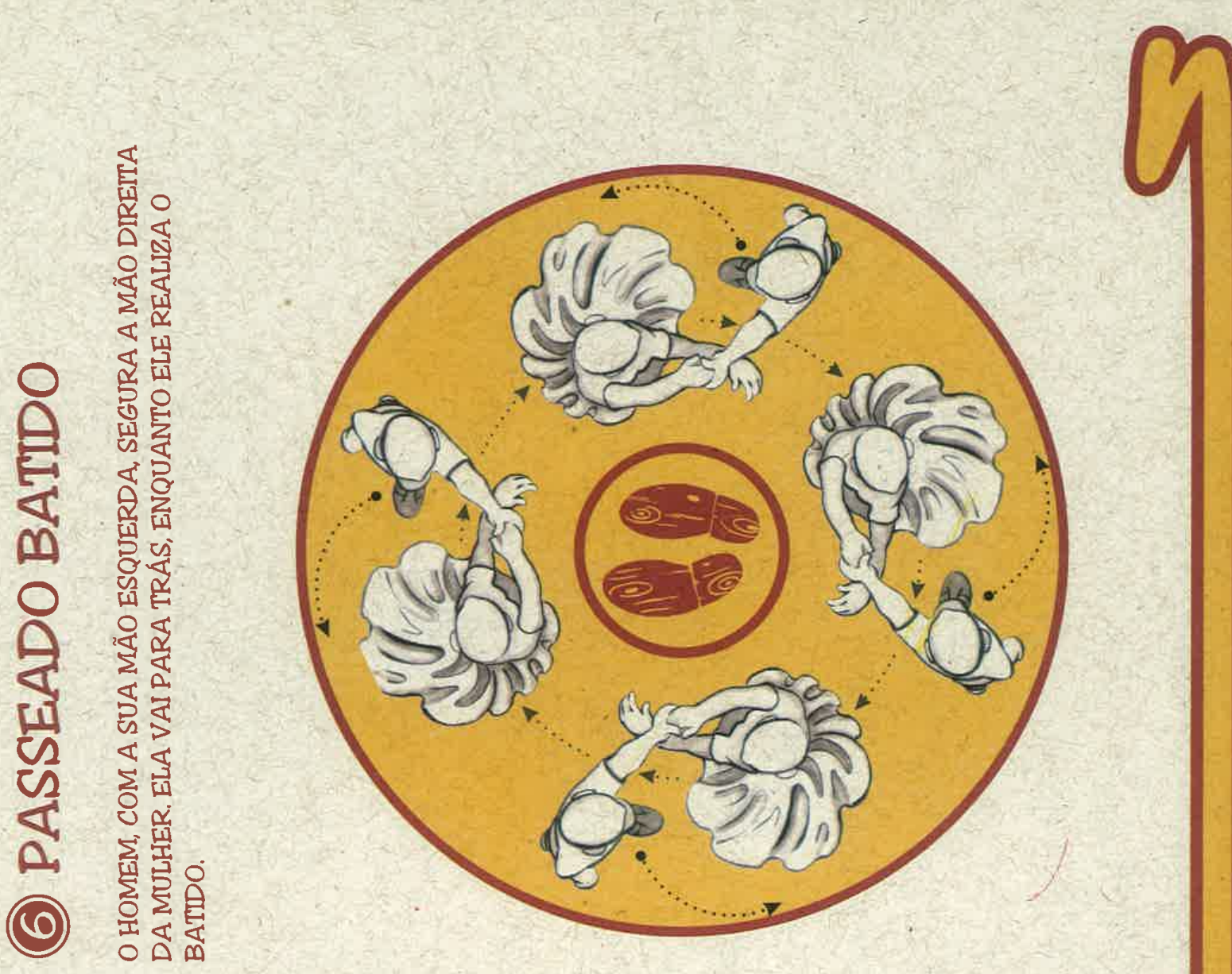

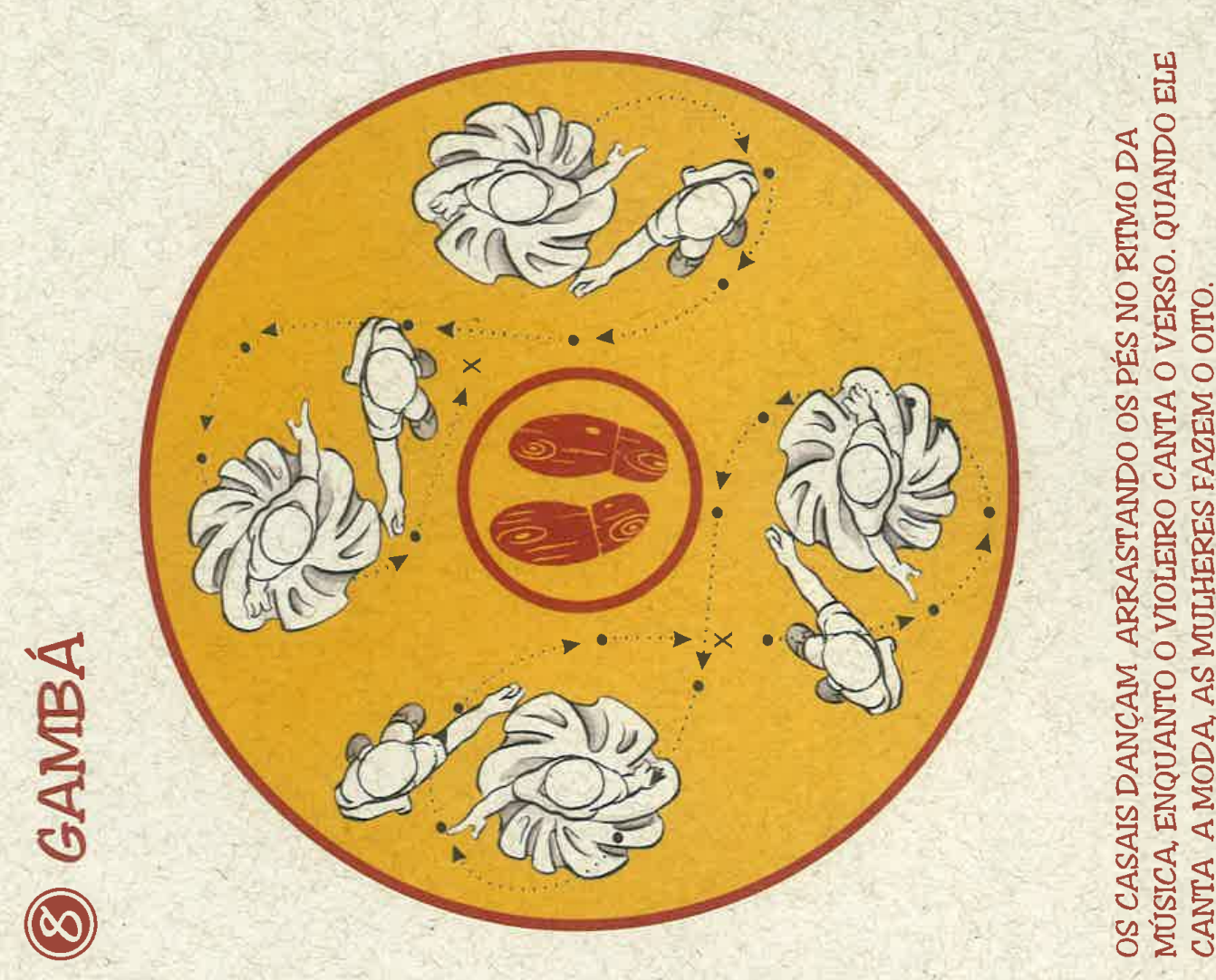

3)

盾

2 을

ᄂ

운

\&

究

出志

咒全台

¿

䆓点䆓

足完品

올을

- $\quad \sum_{0}$

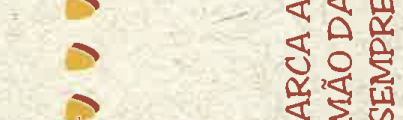

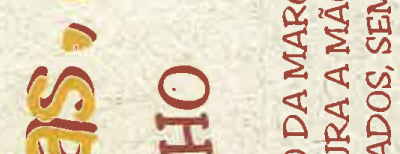

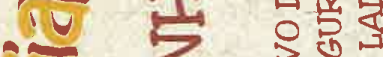

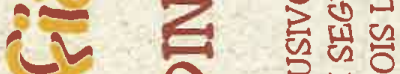

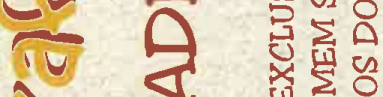

$\therefore<$ w出

- U 인저

․ 1 인

- $A$ 它豈

ง (D)

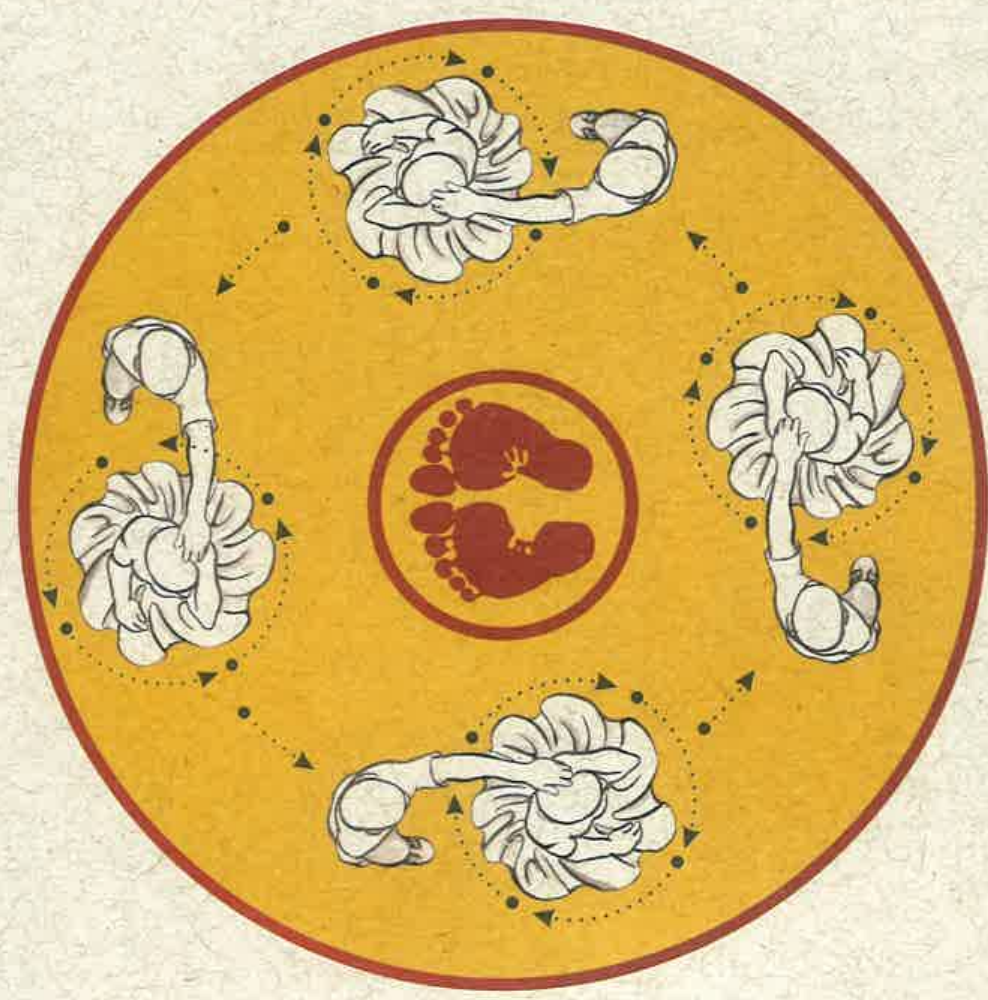

W 

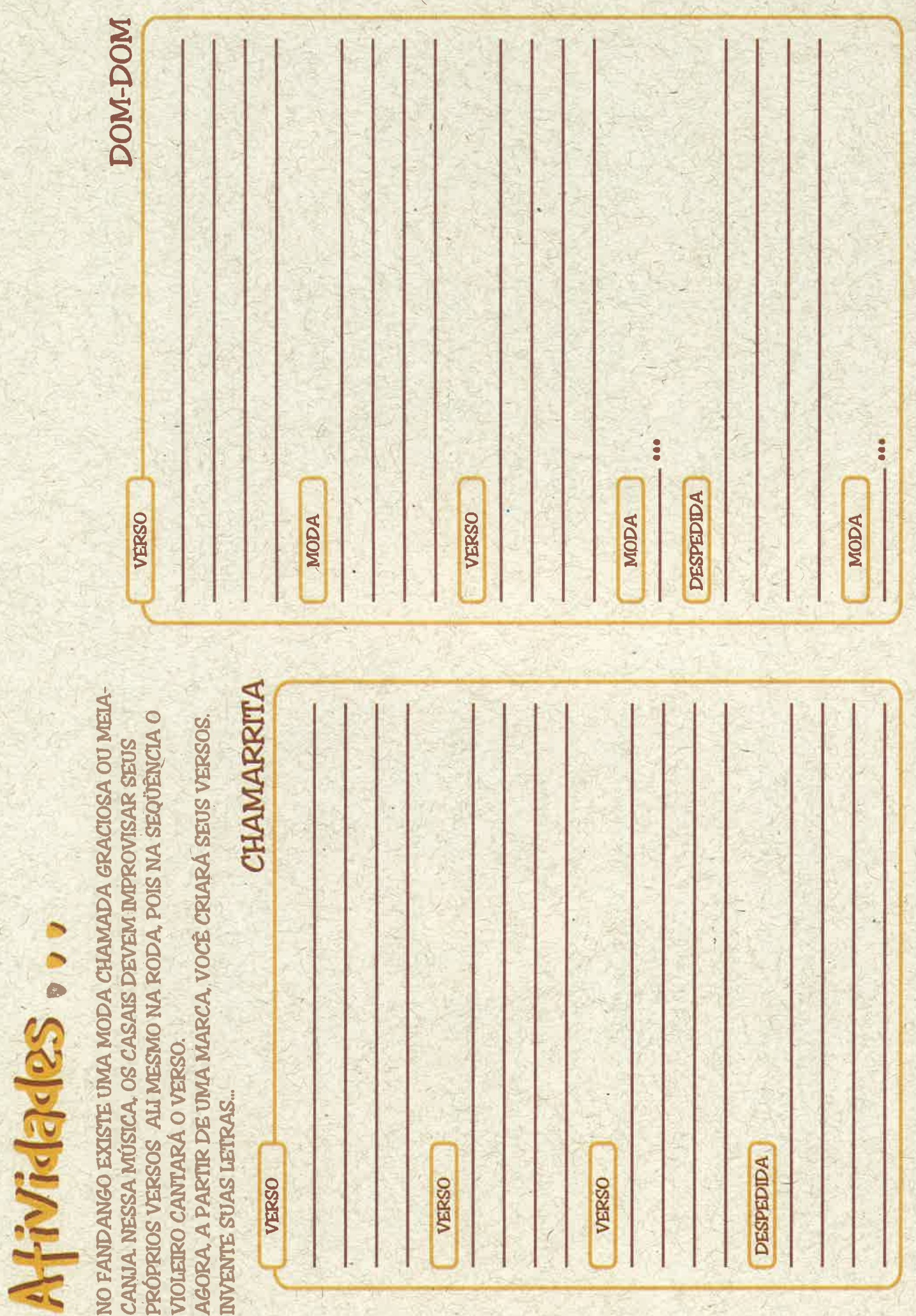

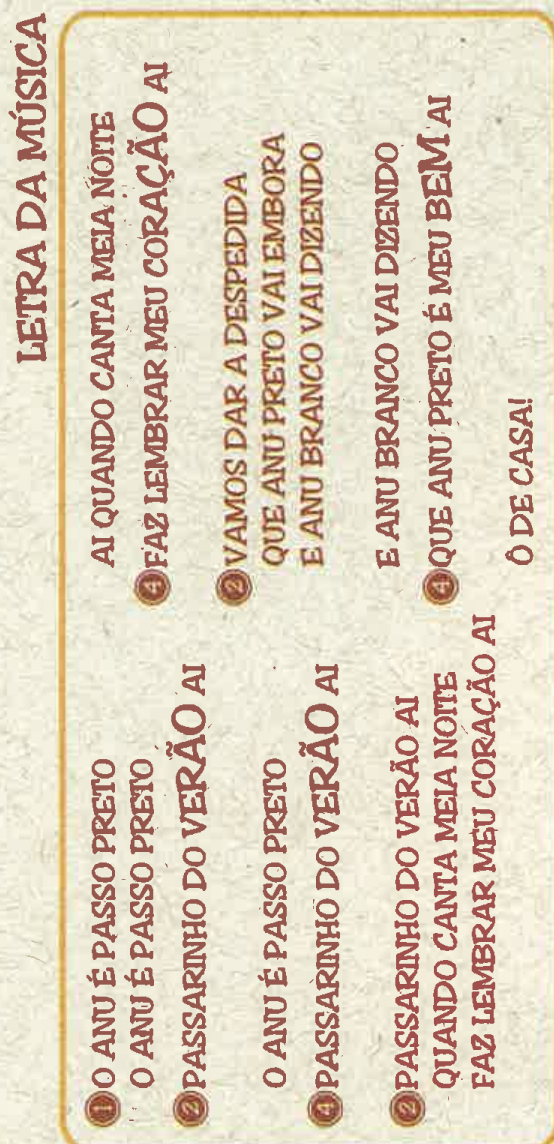

님

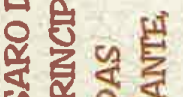

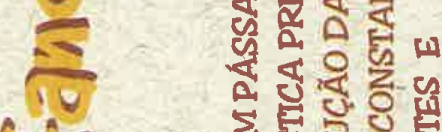

L S

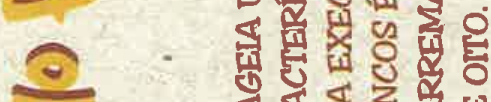

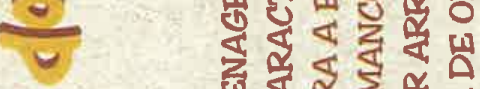

IV

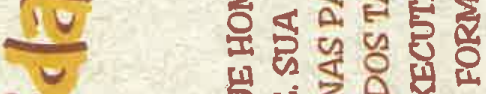

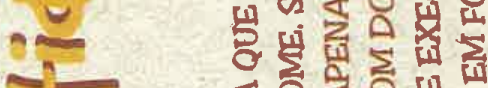

ㄴ)

IV

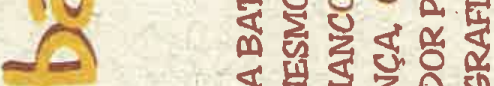

I0 S

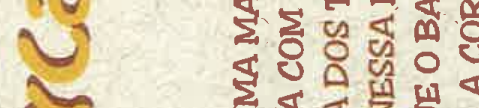

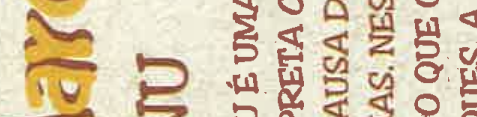

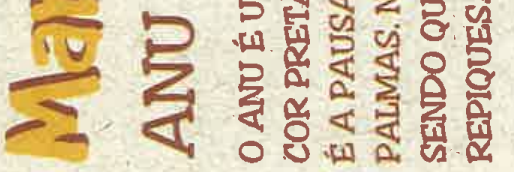

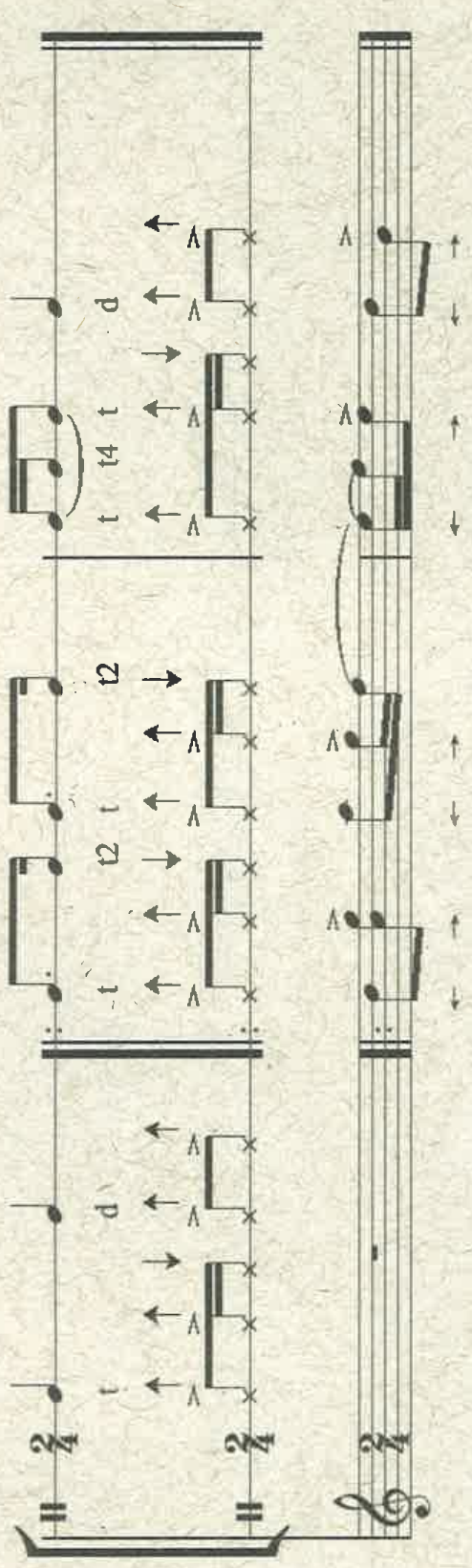

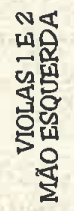

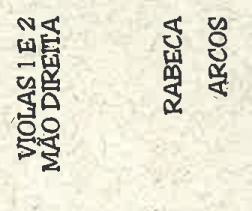



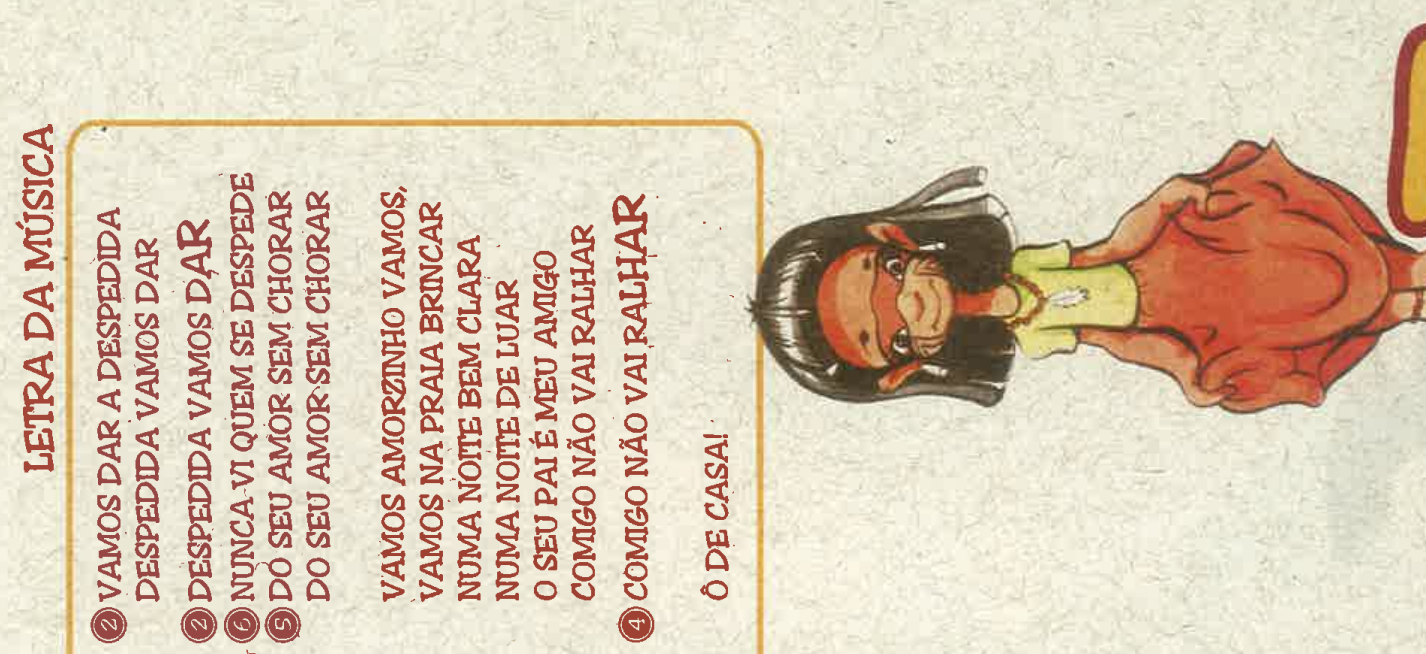

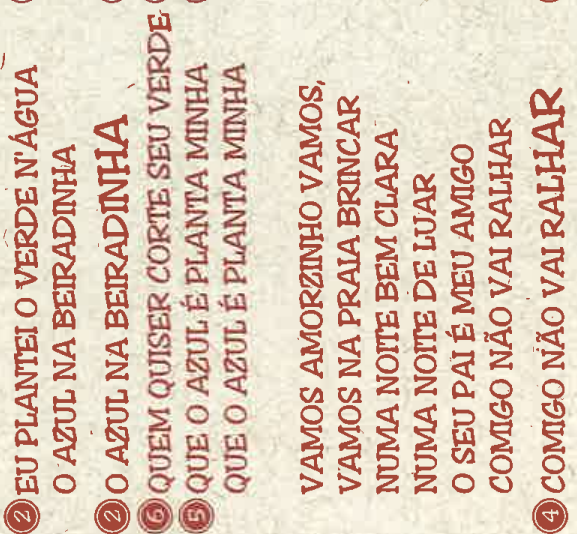
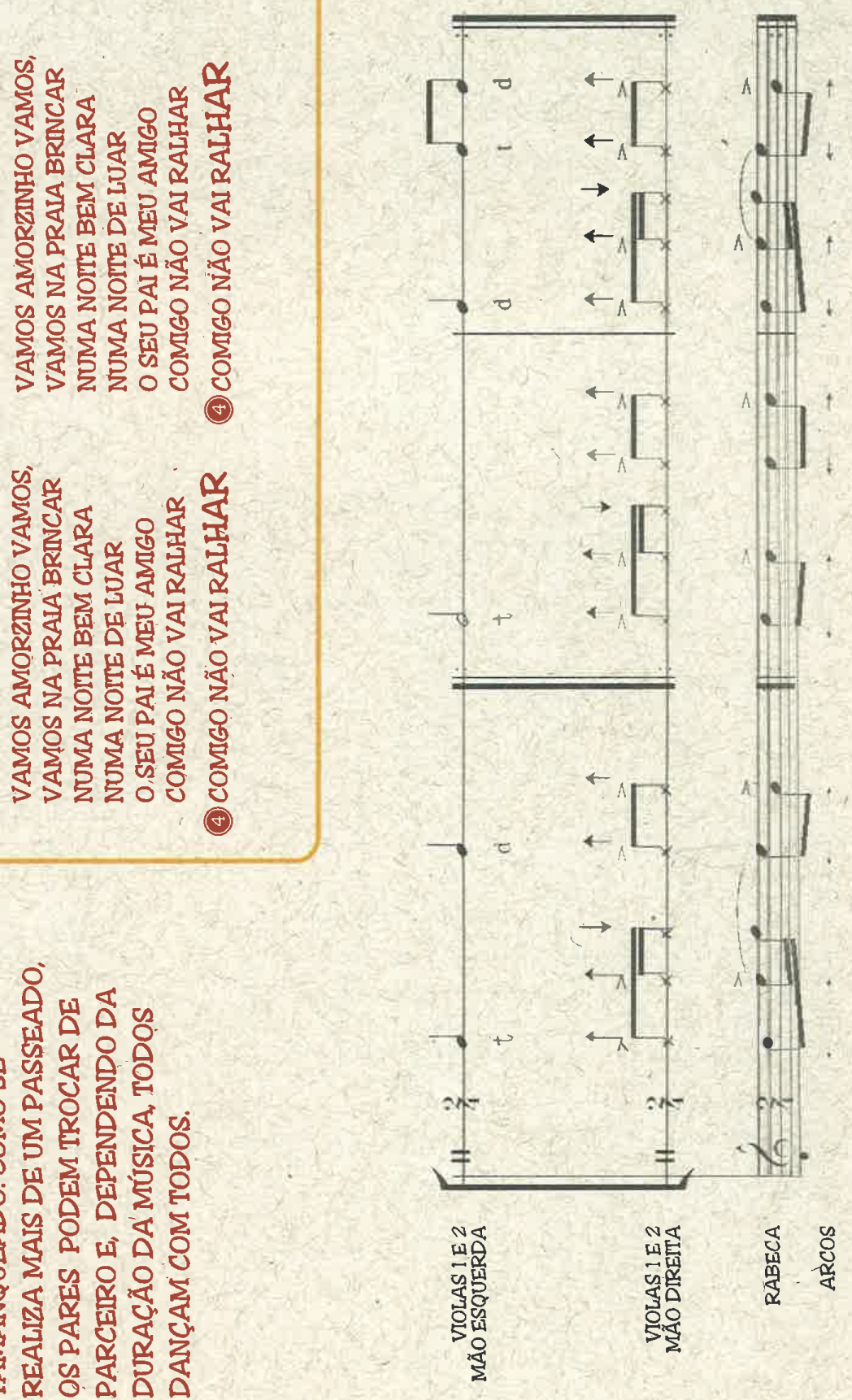


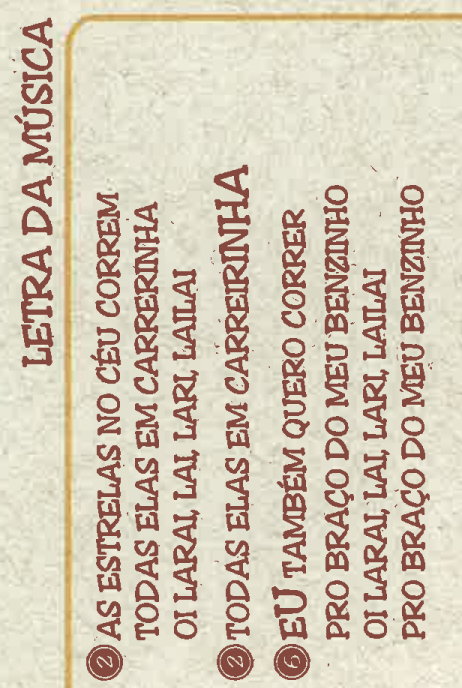

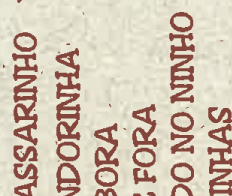

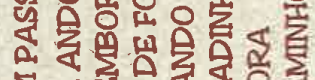

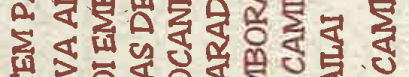

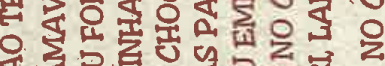

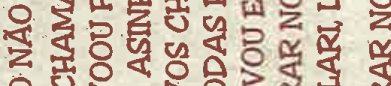

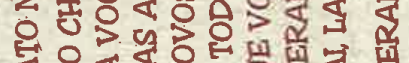

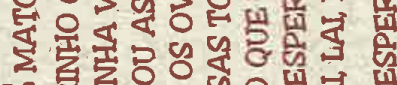

田.

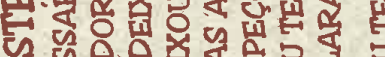

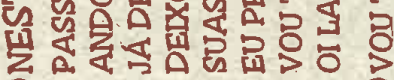

(ล)

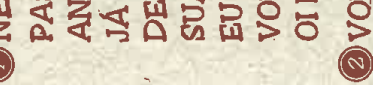

울 울

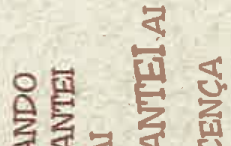

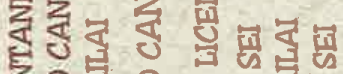

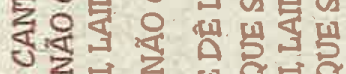

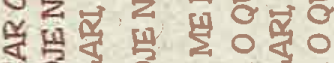

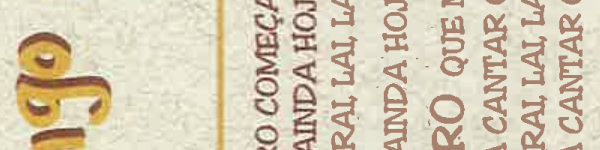

०द्ध

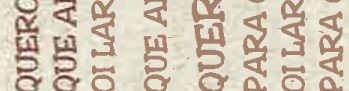

(e) (a) ()

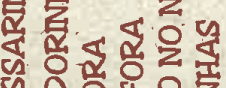

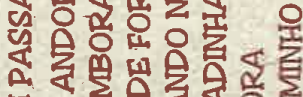

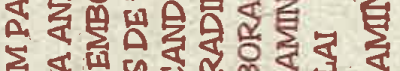

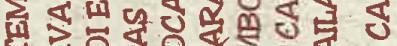

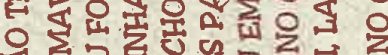

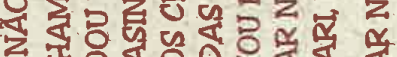

엉요의

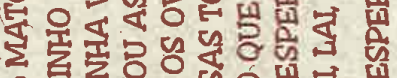

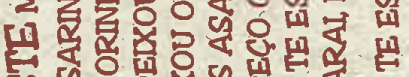

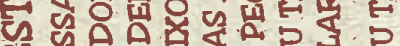

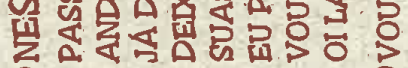

(c)

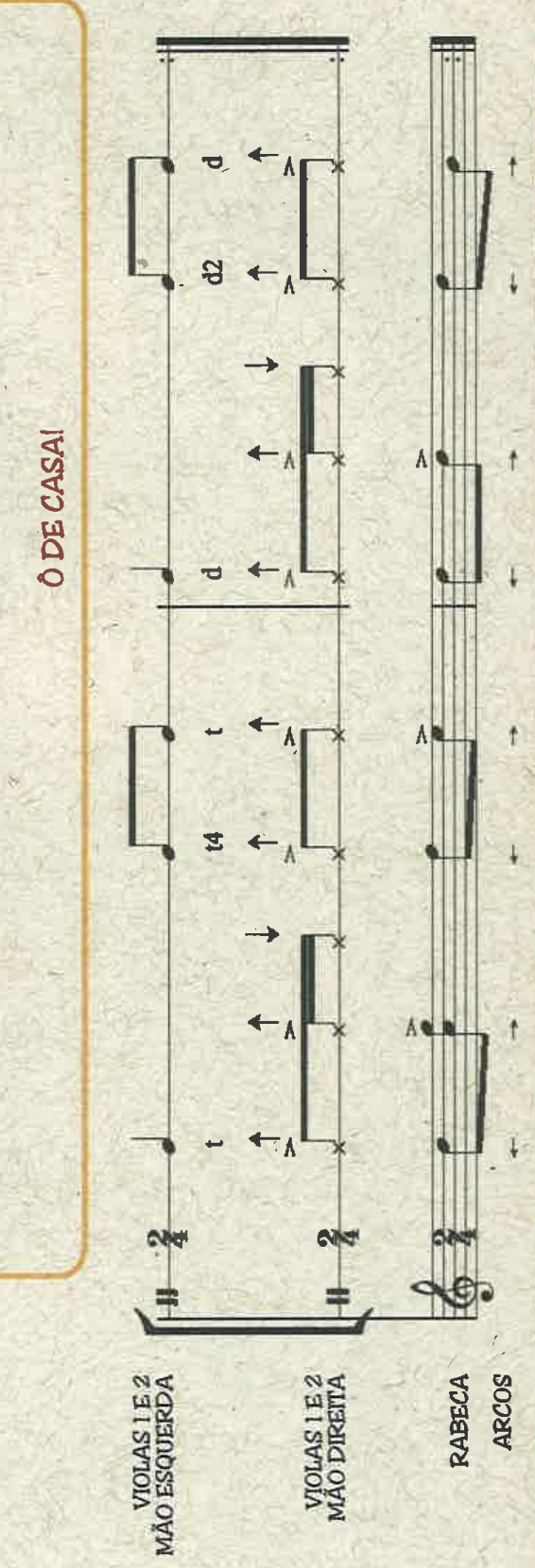

उ্

㟧

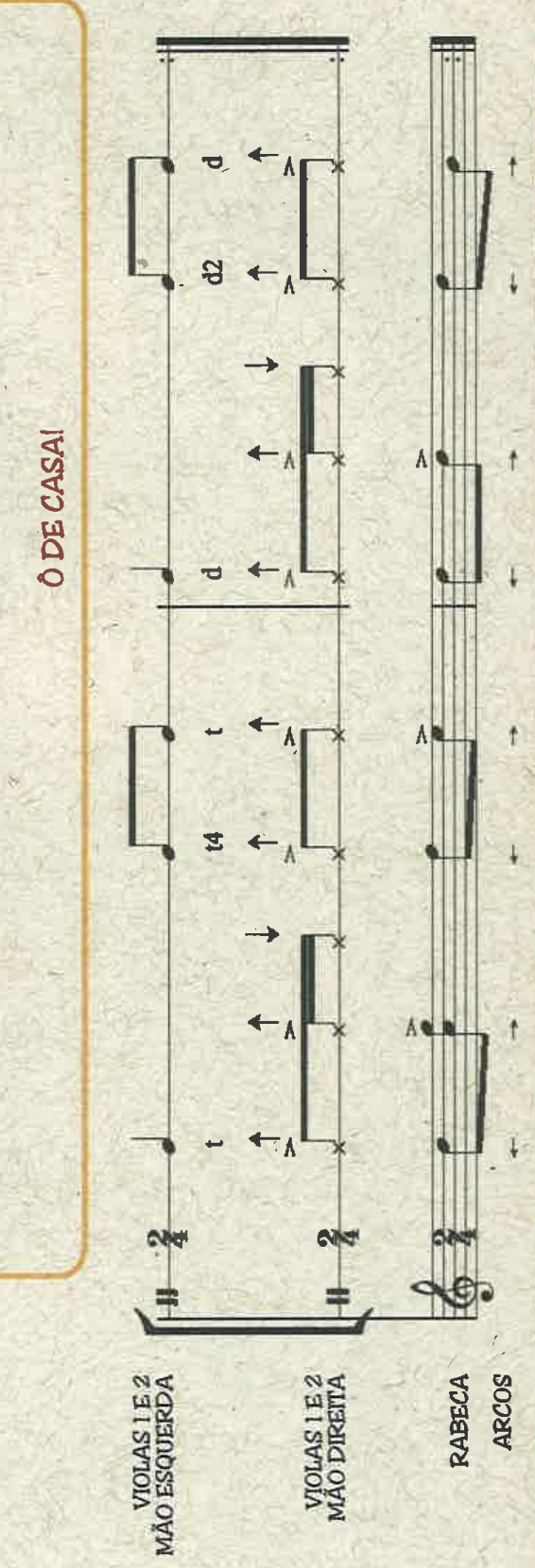

2

(c)

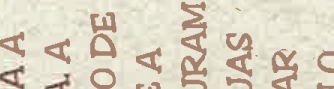

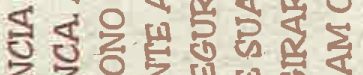

संद्ये

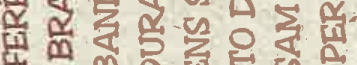

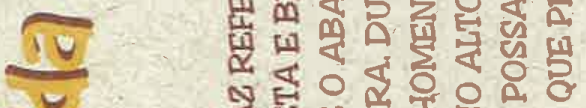

2 क्षा

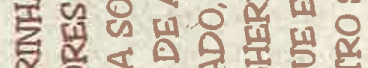

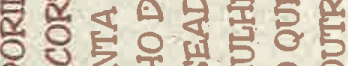

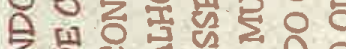

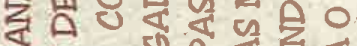

$40 \leqslant 5$

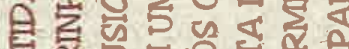

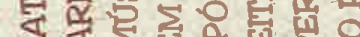

m दे

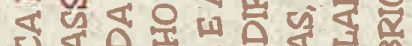

a 40 \%

ड 422 出

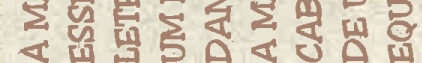

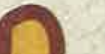



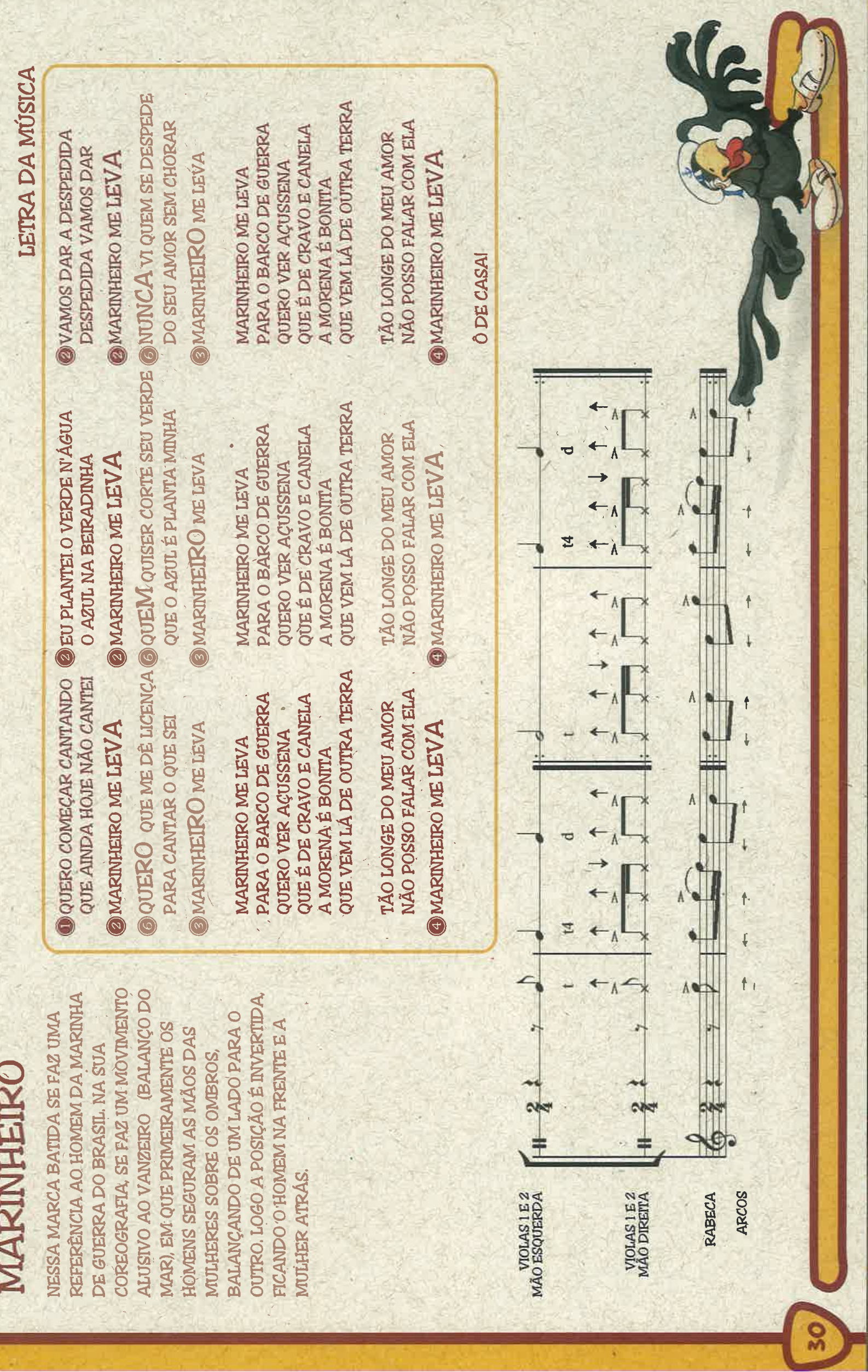

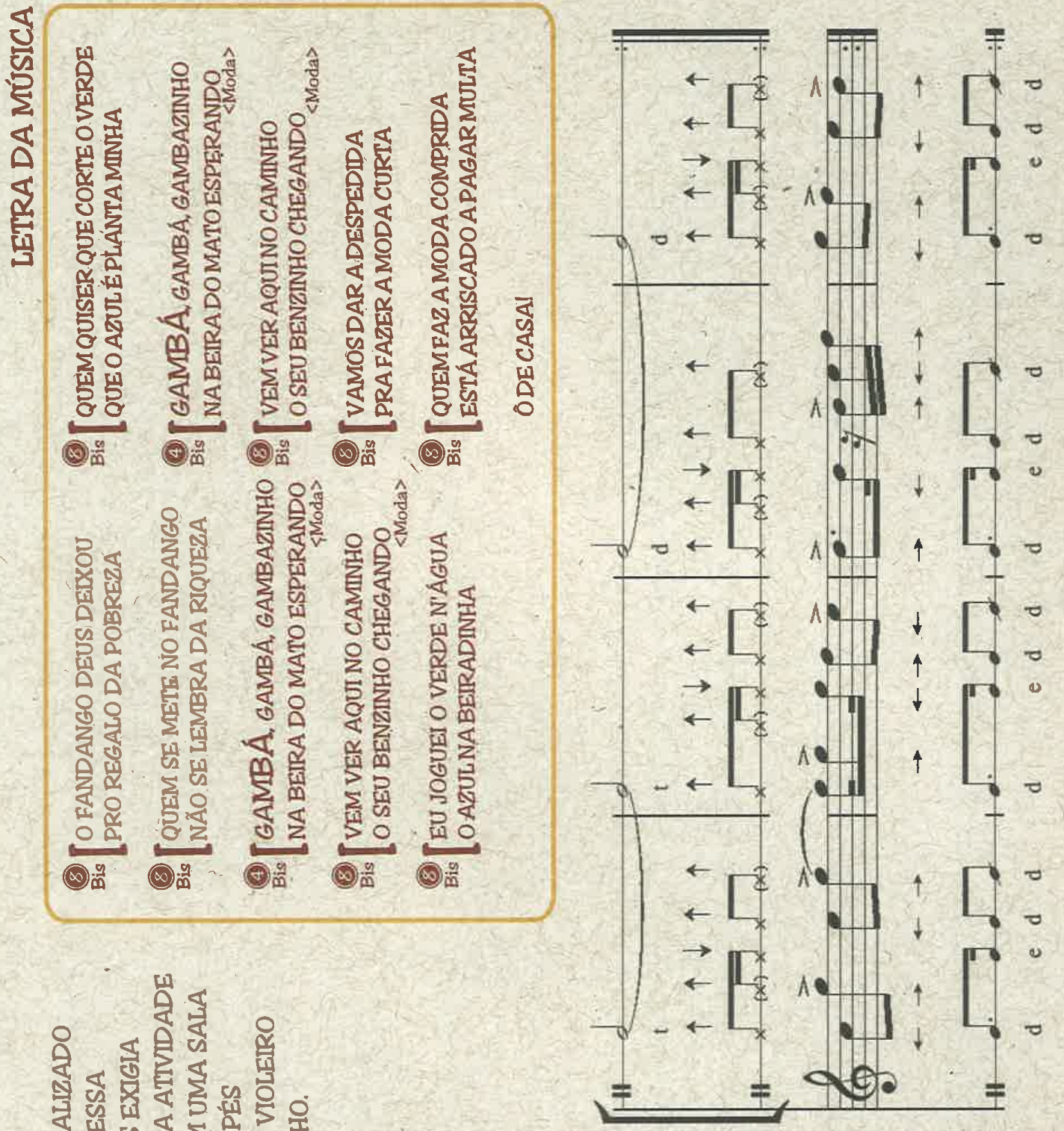

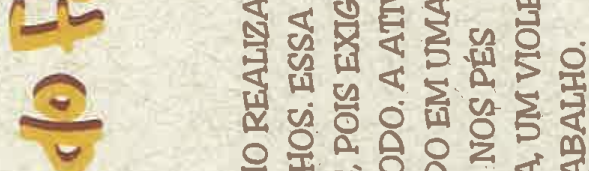

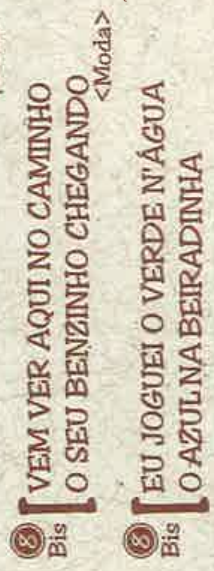

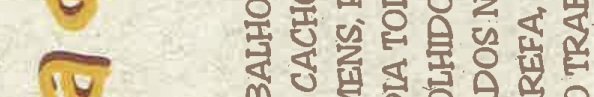

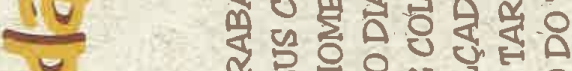

는

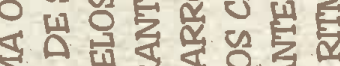

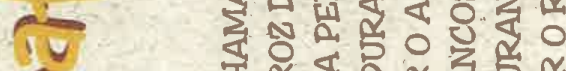

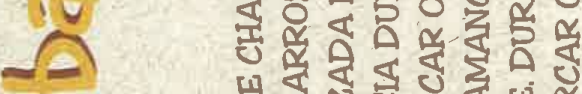

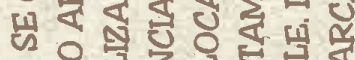

एु

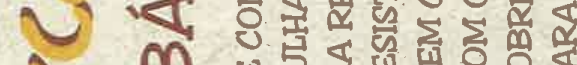

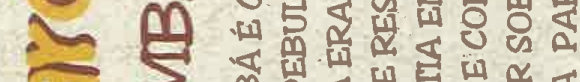

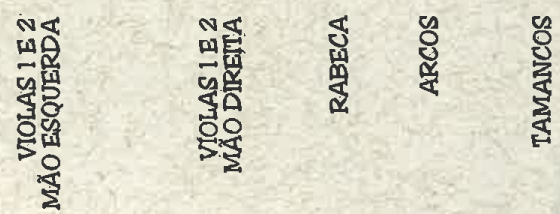

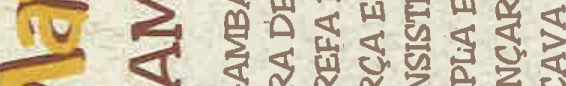

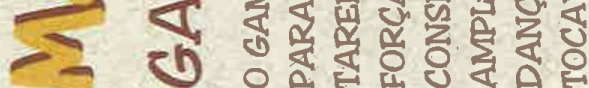

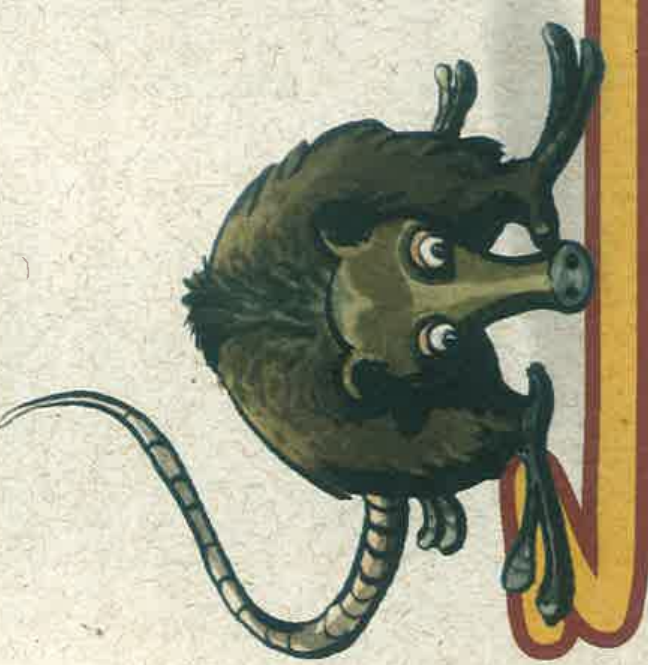




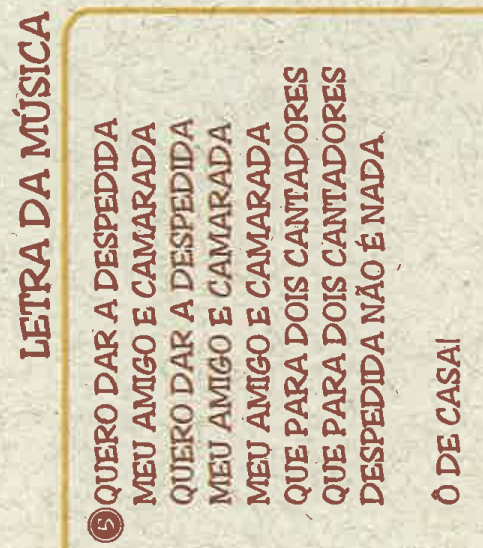

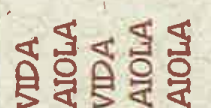

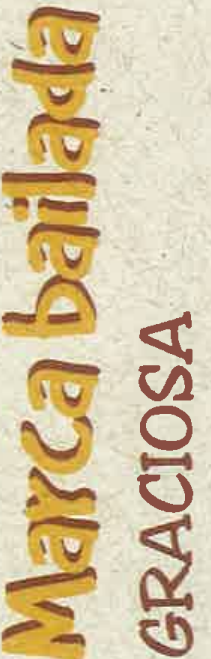

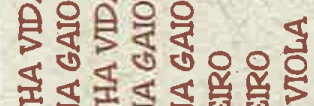

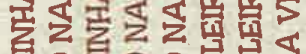

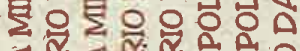

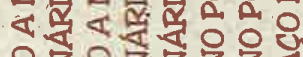
일열 过过芯芯

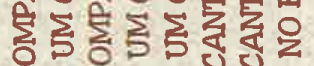
858 논

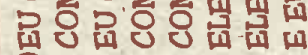
(4)

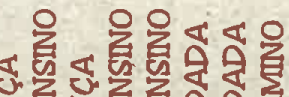

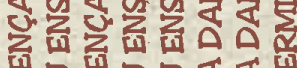

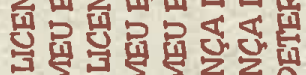
O

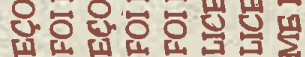

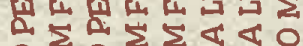

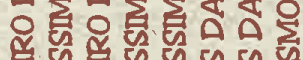

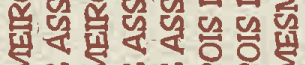

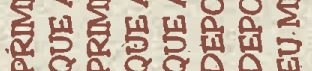
(a)



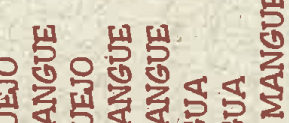

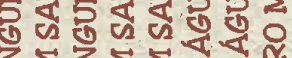
等 2及然。

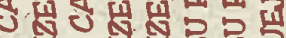

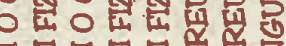

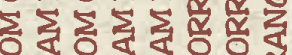
¿ 82802

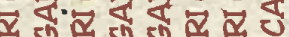

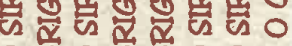
(i) 品

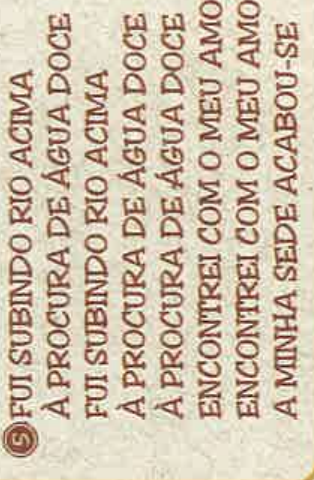

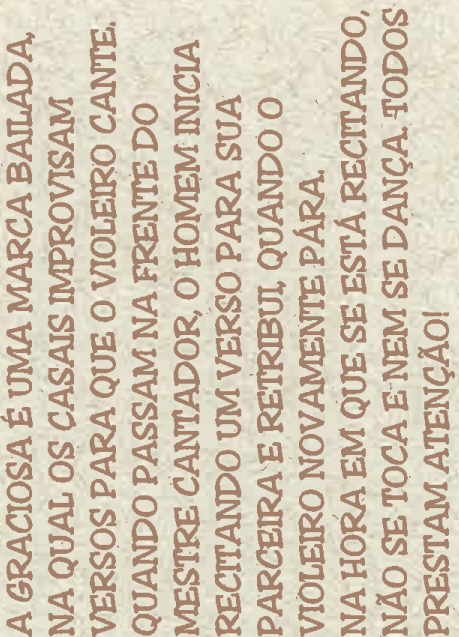
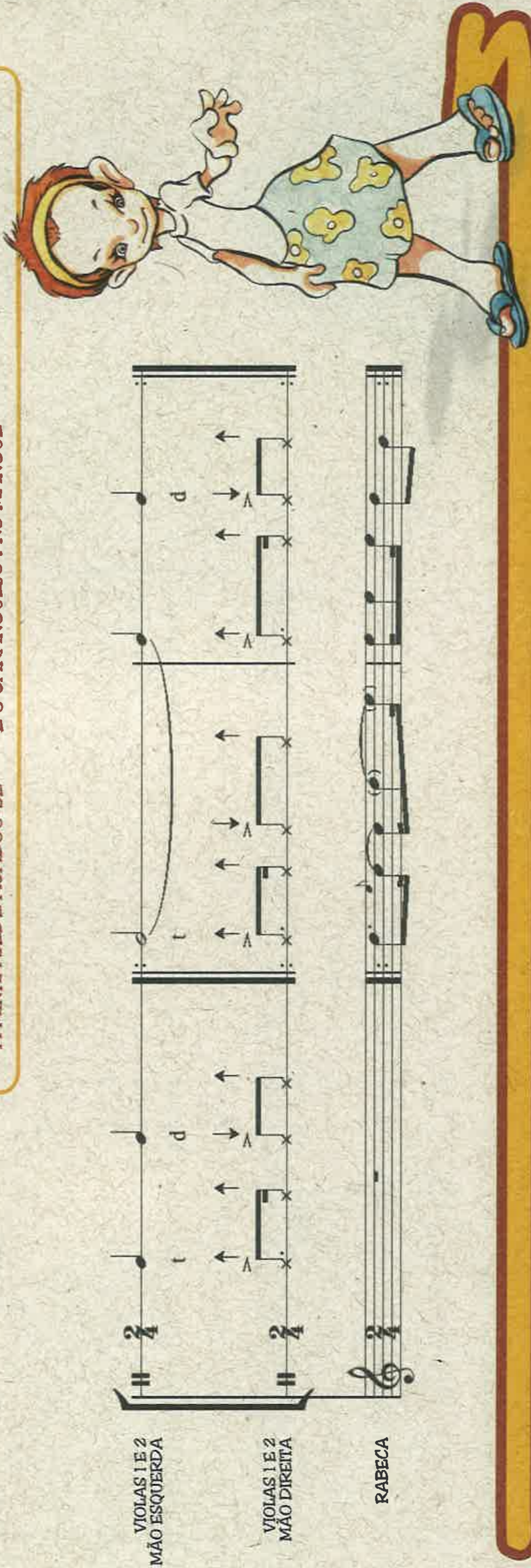

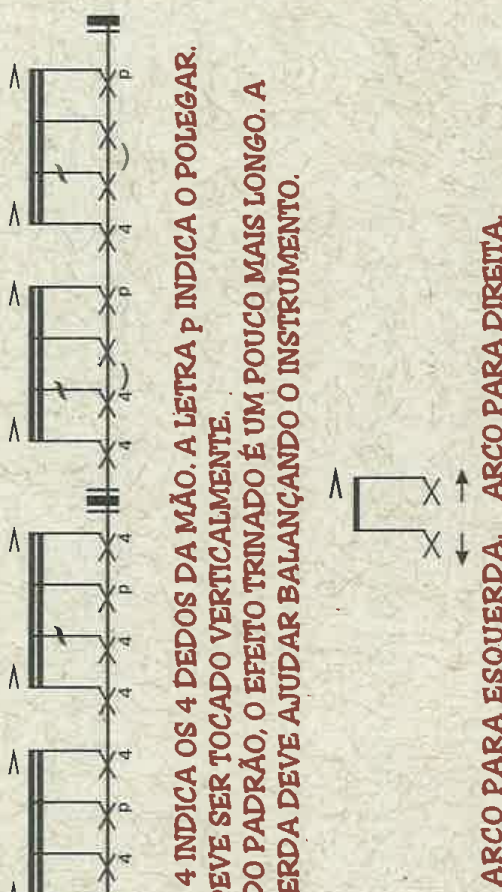

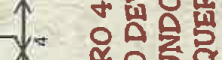

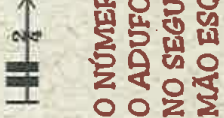

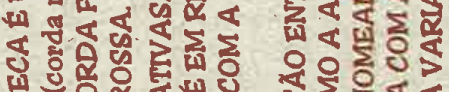

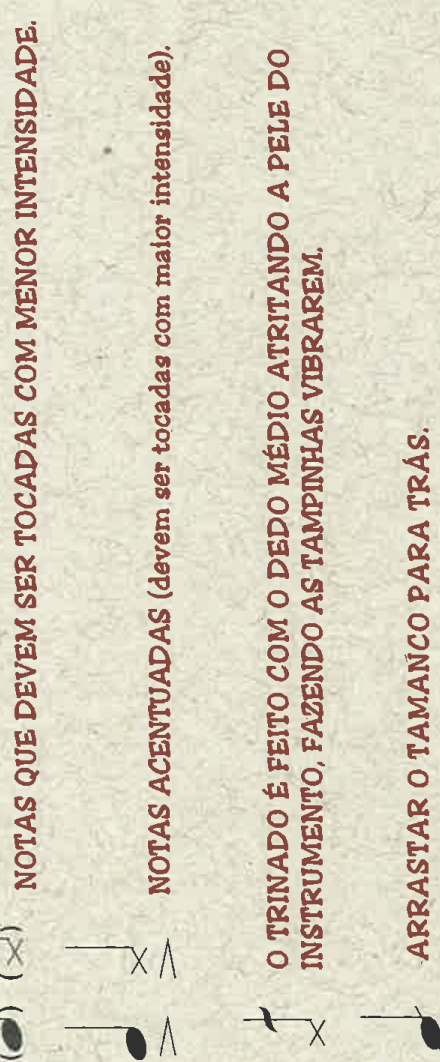

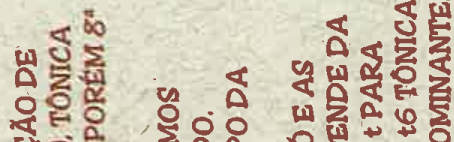

तें

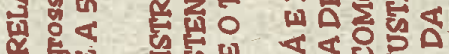

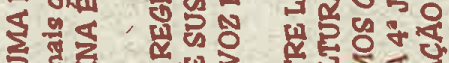

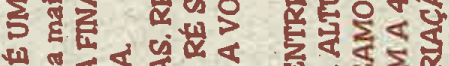

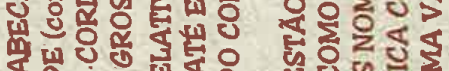

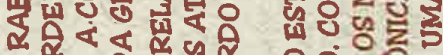

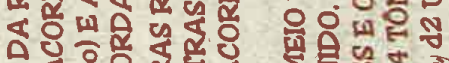

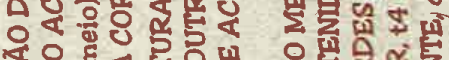

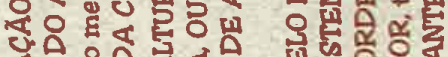

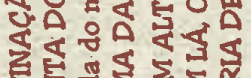

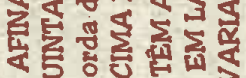
$<0,00$

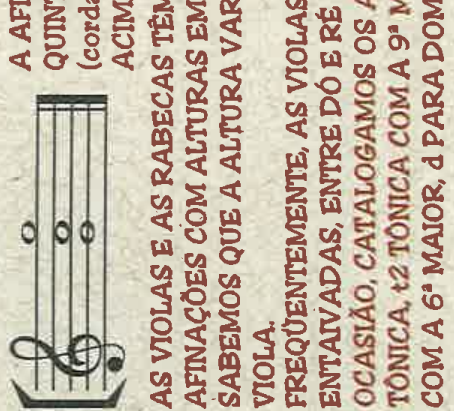

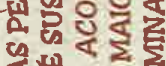
专路

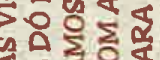
4. 要起骂

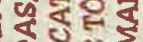
这

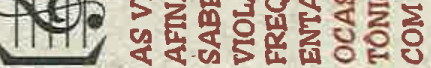

号

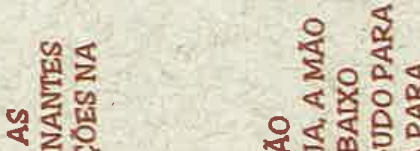

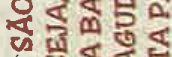
的袺能 O요

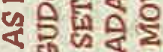

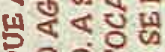
व००ᄋ:

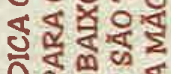

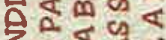
जूई

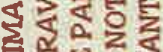
행⿶ㅐㄹ ₹웅

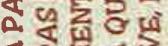
तिड़ 融

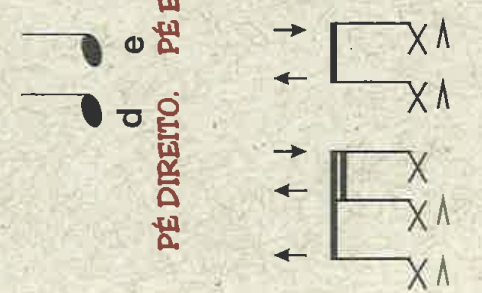

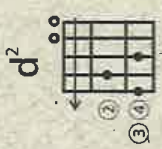
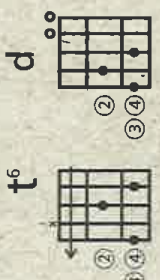

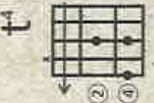
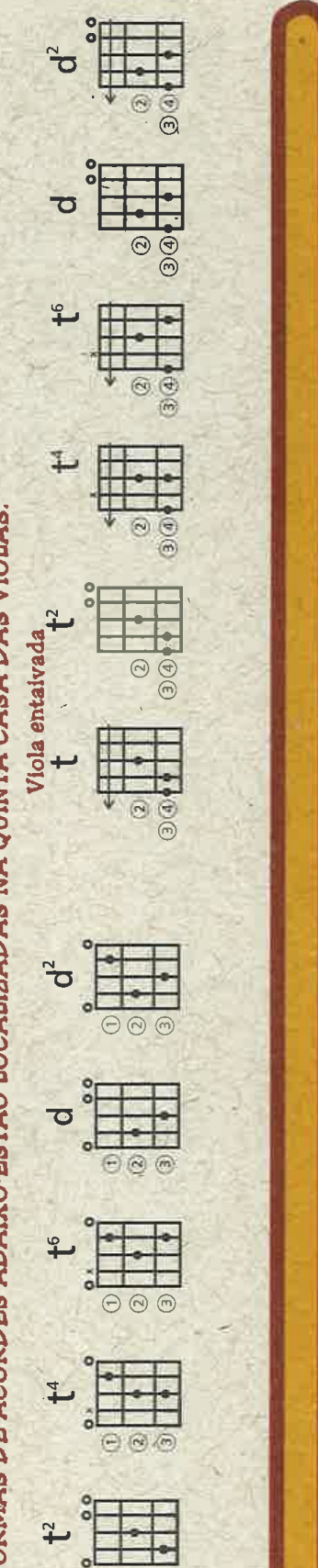

究
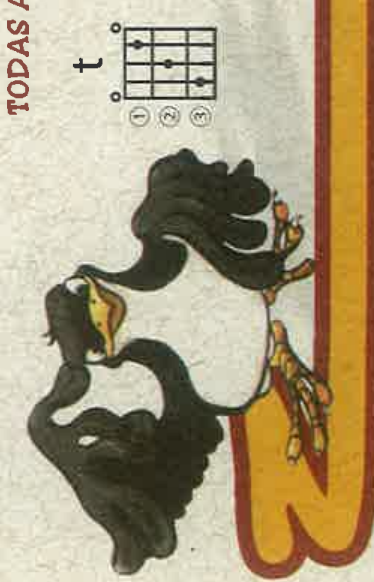


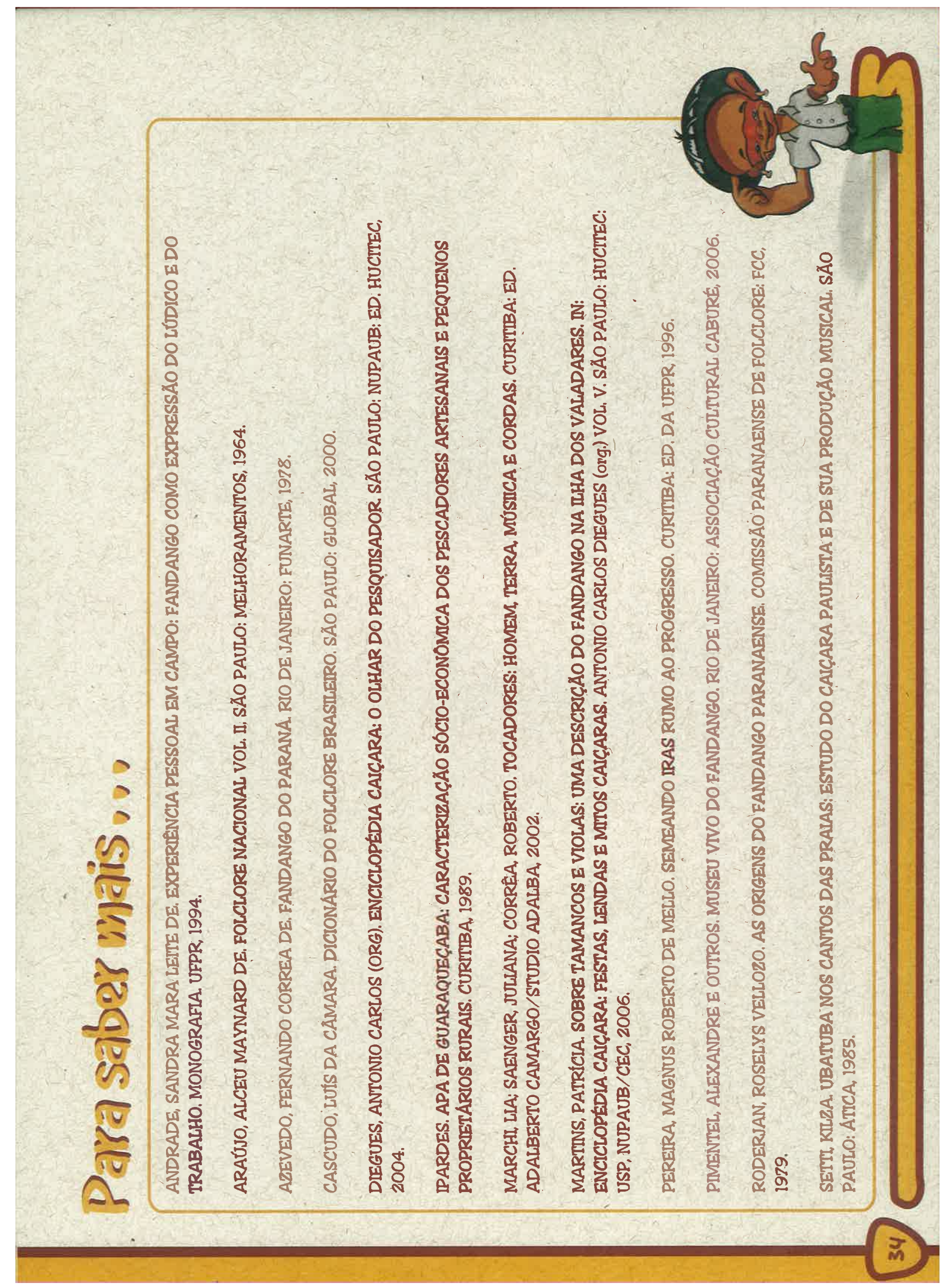


《 \&

E

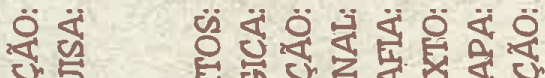

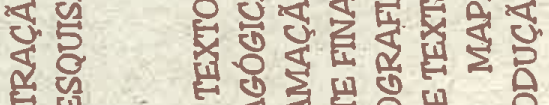

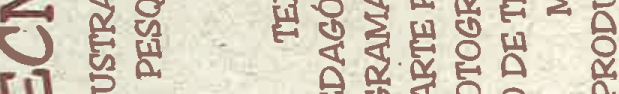

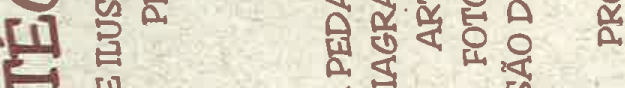

ए 退

एद

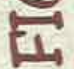

寒 


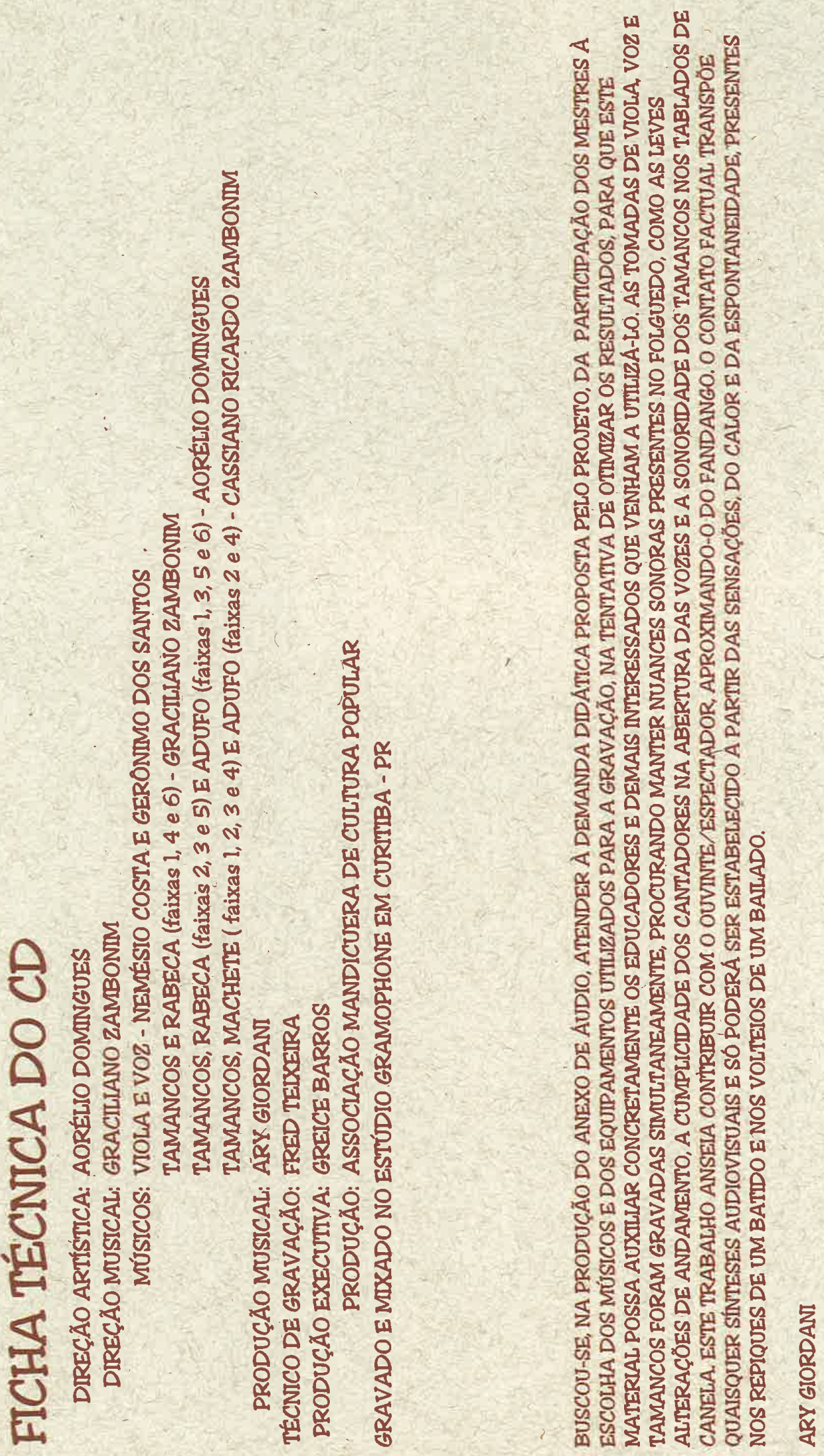



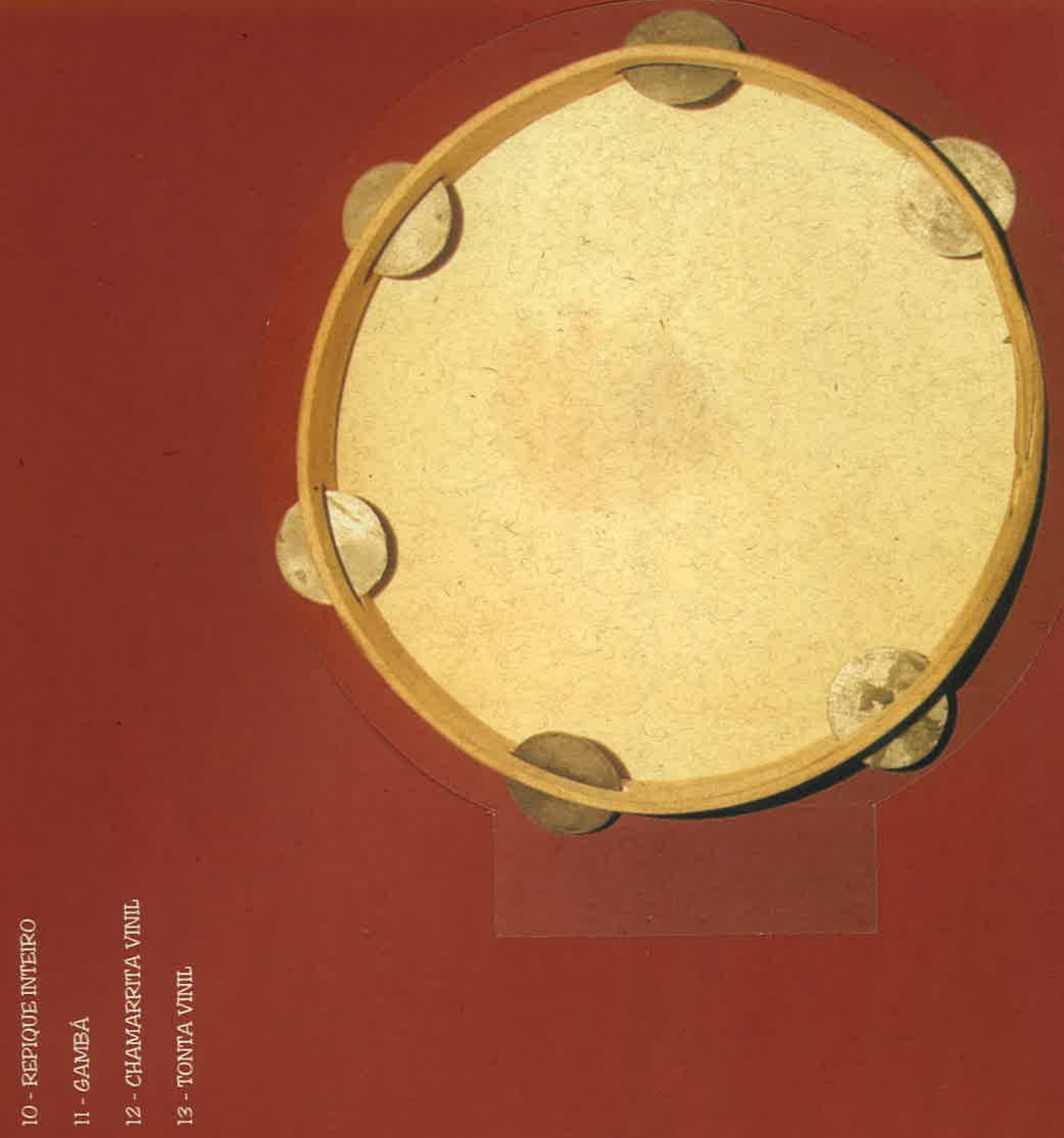

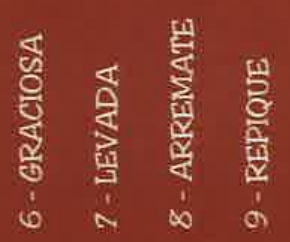

ए人 